Nevada

Environmental

Restoration

Project

\title{
Closure Report for Corrective Action Unit 408: Bomblet Target Area Tonopah Test Range (TTR), Nevada
}

Controlled Copy No.:

Revision No.: 0

September 2010

Approved for public release; further dissemination unlimited.

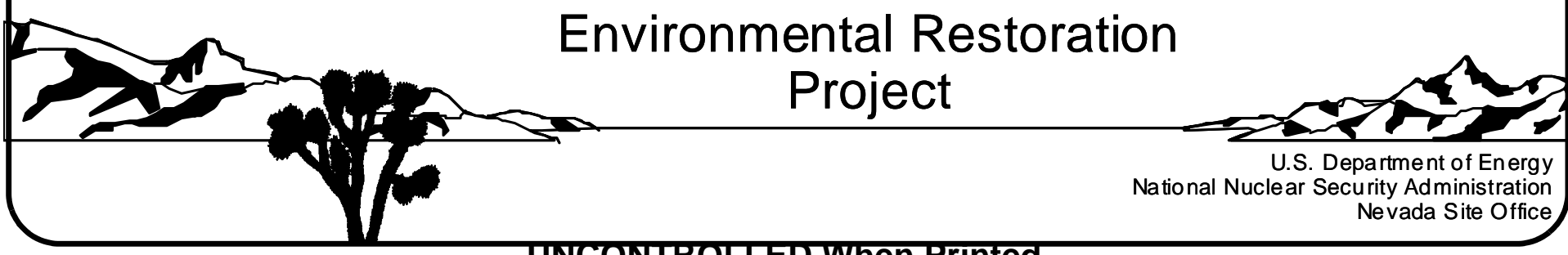


Available for sale to the public from:

U.S. Department of Commerce

National Technical Information Service

5301 Shawnee Road

Alexandria, VA 22312

Telephone: 800.553.6847

Fax: 703.605.6900

E-mail: orders@ntis.gov

Online Ordering: $\underline{h t t p: / / w w w . n t i s . g o v / h e l p / o r d e r m e t h o d s . a s p x ~}$

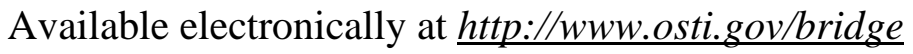

Available for a processing fee to U.S. Department of Energy and its contractors, in paper, from:

U.S. Department of Energy

Office of Scientific and Technical Information

P.O. Box 62

Oak Ridge, TN 37831-0062

Phone: 865.576.8401

Fax: 865.576.5728

Email: reports@adonis.osti.gov

Reference herein to any specific commercial product, process, or service by trade name, trademark, manufacturer, or otherwise, does not necessarily constitute or imply its endorsement, recommendation, or favoring by the United States Government or any agency thereof or its contractors or subcontractors. 


\title{
CLOSURE REPORT FOR CORRECTIVE ACTION UNIT 408: BOMBLET TARGET AREA TONOPAH TEST RANGE (TTR), NEVADA
}

\author{
U.S. Department of Energy \\ National Nuclear Security Administration \\ Nevada Site Office \\ Las Vegas, Nevada
}

Controlled Copy No.:

Revision No:: 0

September 2010

Approved for public release; further dissemination unlimited.

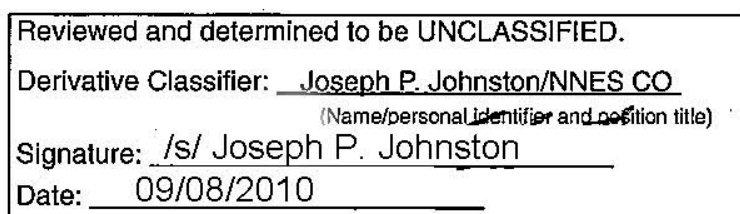




\section{CLOSURE REPORT FOR \\ CORRECTIVE ACTION UNIT 408: \\ BOMBLET TARGET AREA \\ TONOPAH TEST RANGE (TTR), NEVADA}

Approved by:_/s/ Kevin J. Cabble

Date: $09 / 07 / 2010$

Kevin J. Cabble

Federal Sub-Project Director

Industrial Sites Sub-Project

Approved by: $\begin{aligned} & \text { /S/ Robert F. Boehlecke Dabert F. Boehlecke } \\ & \begin{array}{l}\text { Federal Project Director } \\ \text { Environmental Restoration Project }\end{array}\end{aligned}$ Dag/07/2010 


\section{Table of Contents}

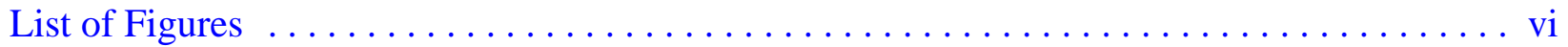

List of Tables $\ldots \ldots \ldots \ldots \ldots \ldots \ldots \ldots \ldots \ldots \ldots \ldots \ldots \ldots \ldots \ldots \ldots$ viii

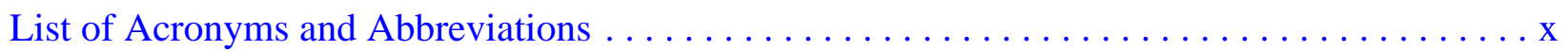

Executive Summary . . . . . . . . . . . . . . . . . . . . . . . . . ES-1

$1.0 \quad$ Introduction. . . . . . . . . . . . . . . . . . . . . . . . . . . 1

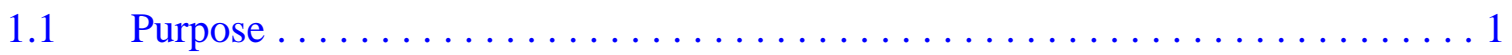

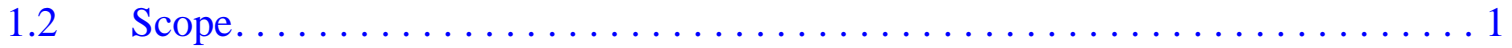

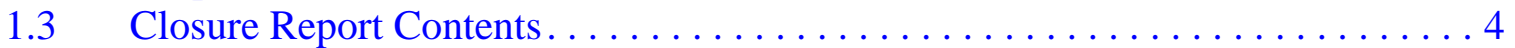

1.3.1 Applicable Programmatic Plans and Documents ............. 5

1.3.2 Data Quality Objectives ...................... 5

1.3.3 Data Quality Assessment Summary .................... 6

$2.0 \quad$ Closure Activities . . . . . . . . . . . . . . . . . . . . . . . . . . 8

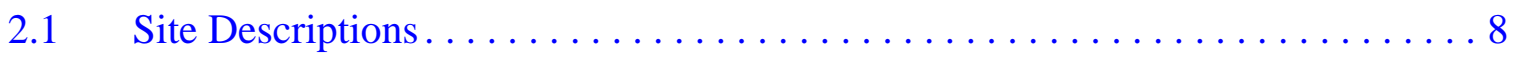

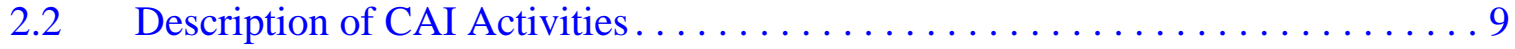

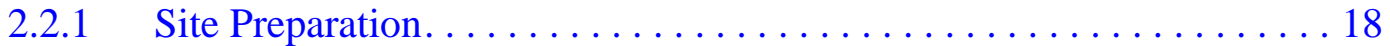

2.2.2 Disposal Pit Investigation and Remediation. . . . . . . . . . . . . 18

$2.2 .3 \quad$ MEC Surface Clearance . . . . . . . . . . . . . . . . . 21

2.2 .4 Buffer Zone Visual Sweep . . . . . . . . . . . . . . . . . . . . 28

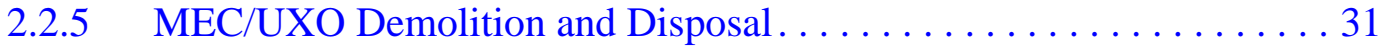

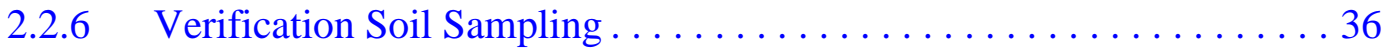

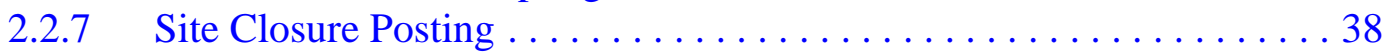

2.3 Deviations from SAFER Plan as Approved . . . . . . . . . . . . 38

2.4 Corrective Action Schedule as Completed . . . . . . . . . . . . . . . . . 38

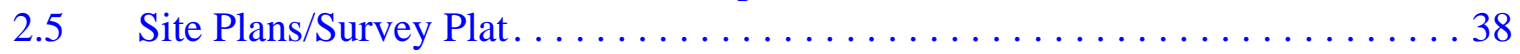

$3.0 \quad$ Waste Disposition . . . . . . . . . . . . . . . . . . . . 39

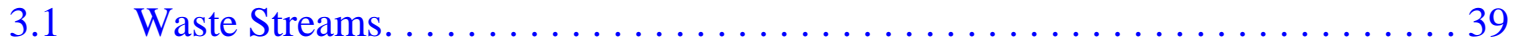

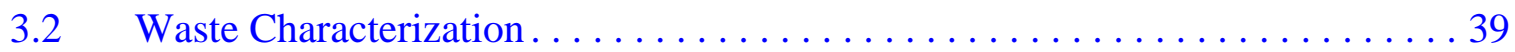

3.3 Waste Disposal . . . . . . . . . . . . . . . . . . . 40

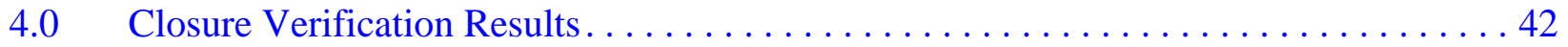

4.1 Surface Clearance Verification. ..................... 42

4.2 Disposal Pit Investigation and Remediation. . . . . . . . . . . . . 44

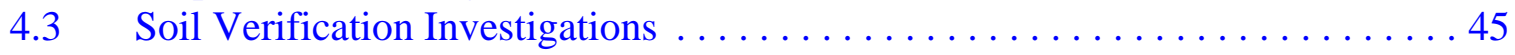

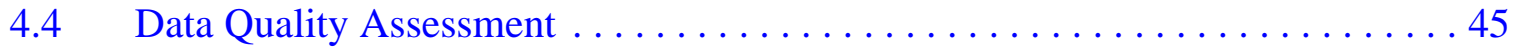

4.4.1 Review DQOs and Sampling Design . . . . . . . . . . . . . 46

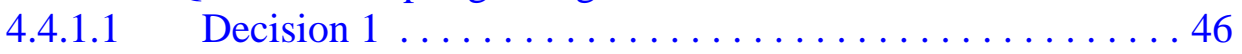

4.4.1.1.1 DQO Provisions To Limit

False Negative Decision Error ......... 47 


\section{Table of Contents (Continued)}

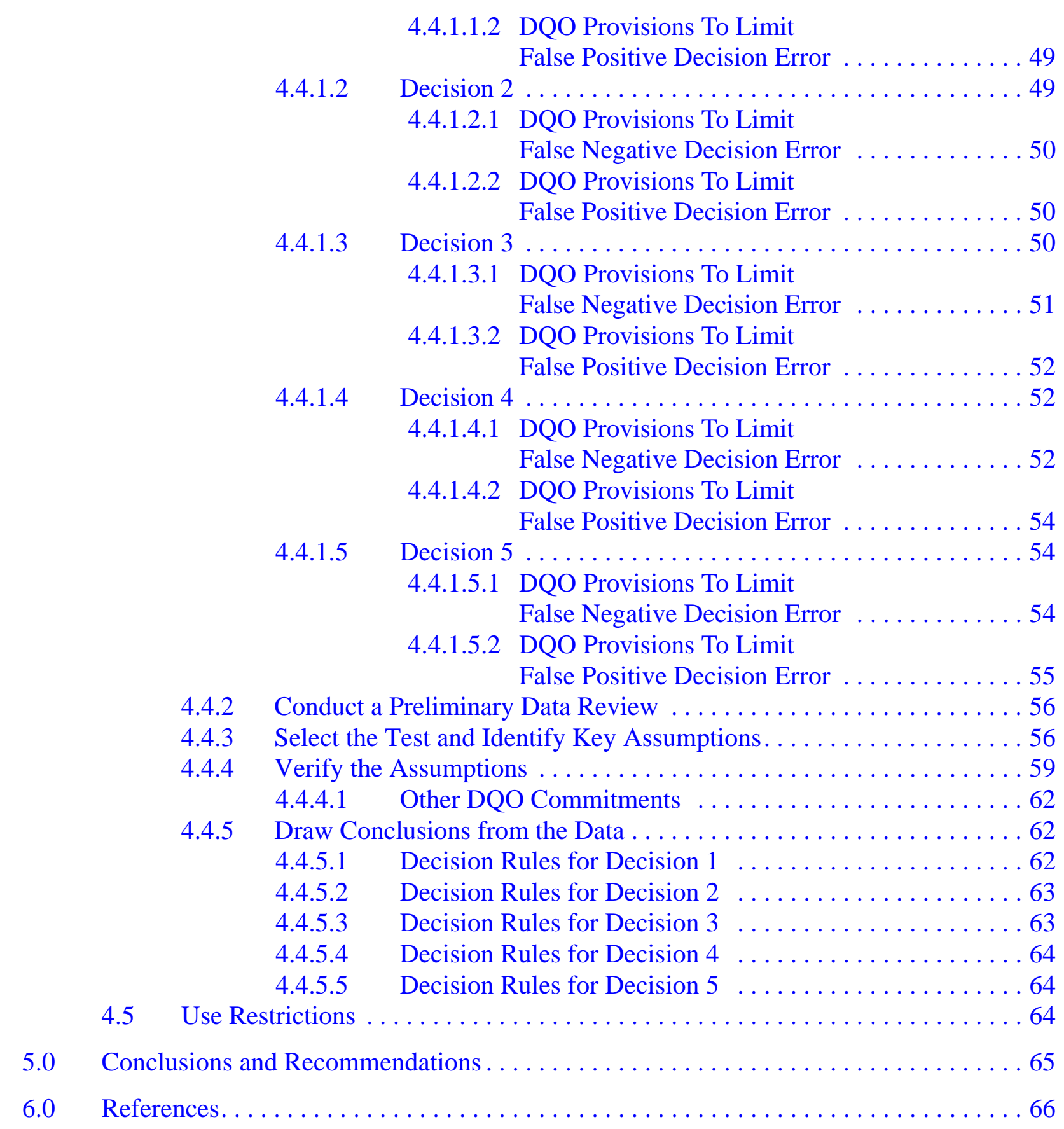




\section{Table of Contents (Continued)}

Appendix A - Data Quality Objectives as Developed in the SAFER Plan

Appendix B - MEC Closure Activities

B.1.0 MEC Closure Activities . B-1

Attachment 1 - Final After-Action Report: Munitions and Explosives of Concern (MEC) Disposal Pit Investigation and Sub-Munition Clearance Corrective Action Unit 408 Tonopah Test Range Prepared by Weston Solutions, Inc.

Attachment 2 - Excerpts from After-Action Report for the Corrective Action Unit (CAU) 408 Bomblet Target Area Munitions and Explosives of Concern Surface Clearance Tonopah Test Range, Nevada Prepared by EOD Technology, Inc.

\section{Appendix C - Confirmation Sampling Test Results}

C.1.0 Introduction. . . . . . . . . . . . . . . .

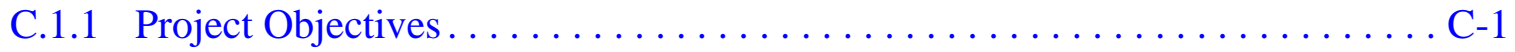

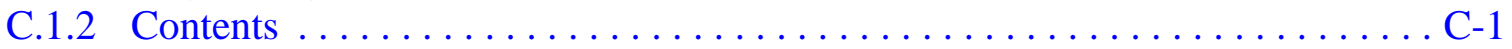

C.2.0 Investigation Overview $\ldots \ldots \ldots \ldots \ldots \ldots \ldots \ldots \ldots \ldots \ldots \ldots \ldots \ldots \ldots \ldots$

C.2.1 Investigation Activities . . . . . . . . . . . . . . . . .

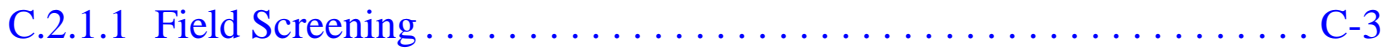

C.2.1.2 Verification Soil Sampling ..................... . 5

C.2.1.3 Waste Characterization Sampling. .................. C-5

C.2.2 Laboratory Analytical Information. . . . . . . . . . . . . . . C-6

C.2.3 Comparison to Action Levels . . . . . . . . . . . . . . . . . . . . C-7

C.3.0 CAS TA-55-002-TAB2, Bomblet Target Areas, Investigation Results . . . . . . . . . C-8

C.3.1 Verification Sampling Activities . . . . . . . . . . . . . . . . C-8

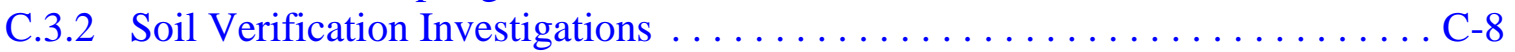

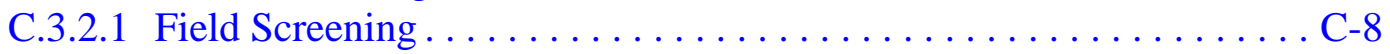

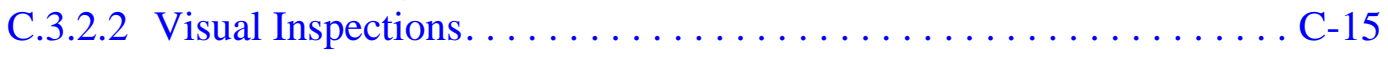

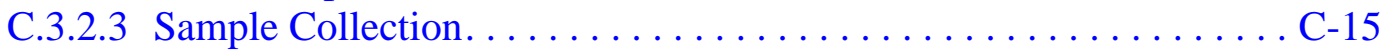

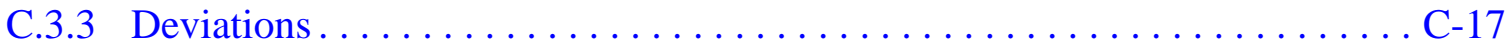

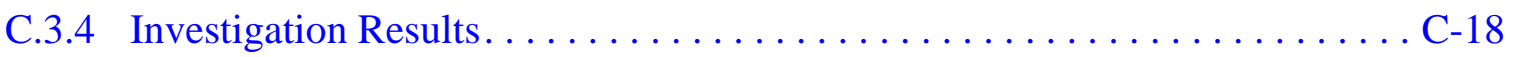

C.3.4.1 High Explosives . . . . . . . . . . . . . . . . . C-19

C.3.4.2 RCRA Metals and Beryllium ................... C-19

C.3.4.3 Gamma-Emitting Radionuclides . . . . . . . . . . . . . . . C-19

C.3.4.4 Uranium Isotopes . . . . . . . . . . . . . . . . . . C-28 


\section{Table of Contents (Continued)}

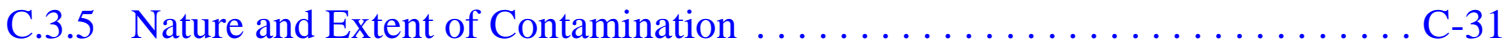

C.3.6 Revised Conceptual Site Model . . . . . . . . . . . . . . . . . . . . C-31

C.4.0 Waste Management. . . . . . . . . . . . . . . . . . . . . C-32

C.4.1 Waste Minimization . . . . . . . . . . . . . . . . . . . . C-32

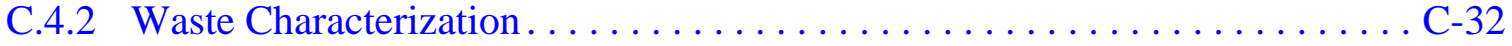

C.4.3 Sanitary Waste . . . . . . . . . . . . . . . . . . . . . C-32

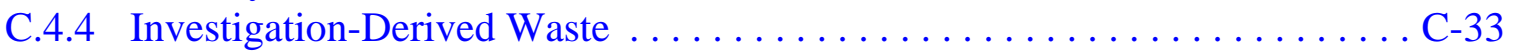

C.4.5 Remediation Waste. . . . . . . . . . . . . . . . . . . C-33

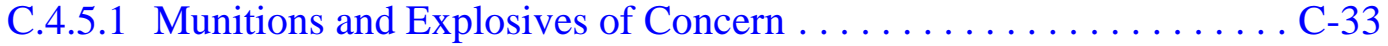

C.4.5.2 Munitions Debris . . . . . . . . . . . . . . . . . . . . . . C-35

C.4.5.3 Remediated Soil Waste. . . . . . . . . . . . . . . . . C-35

C.4.5.4 Recycled Lead. ......................... C-36

C.5.0 Quality Assurance..................................

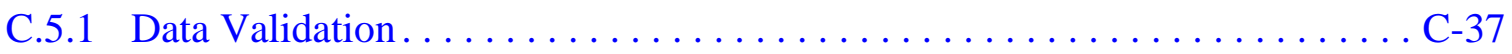

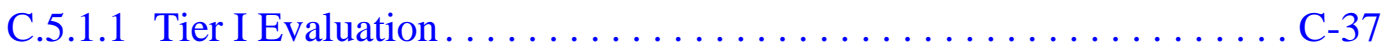

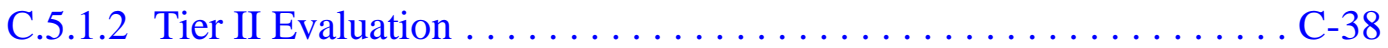

C.5.1.3 Tier III Evaluation $\ldots \ldots \ldots \ldots \ldots \ldots \ldots \ldots \ldots \ldots \ldots \ldots \ldots \ldots$

C.5.2 Field QC Samples. . . . . . . . . . . . . . . . . . . . . . . .

C.5.2.1 Laboratory QC Samples ....................... C-41

C.5.3 Field Nonconformances . . . . . . . . . . . . . . . . . . C-42

C.5.4 Laboratory Nonconformances . . . . . . . . . . . . . . . . C-42

C.6.0 Summary $\ldots \ldots \ldots \ldots \ldots \ldots \ldots \ldots \ldots \ldots \ldots \ldots \ldots \ldots \ldots \ldots \ldots \ldots$

C.7.0 References................................. C-44

\section{Appendix D - Waste Disposition Documentation}

\section{Appendix E - Risk Evaluation}

E.1.0 Risk Assessment . . . . . . . . . . . . . . . . . . . . . . . E-1

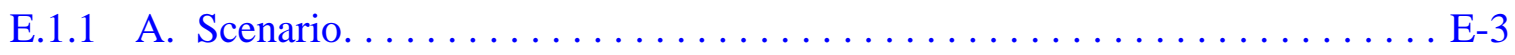

E.1.2 B. Site Assessment. . . . . . . . . . . . . . . . . . E

E.1.3 C. Site Classification and Initial Response Action . . . . . . . . . . . E-5

E.1.4 D. Development of Tier 1 Lookup Table of RBSLs . . . . . . . . . . . . E-5

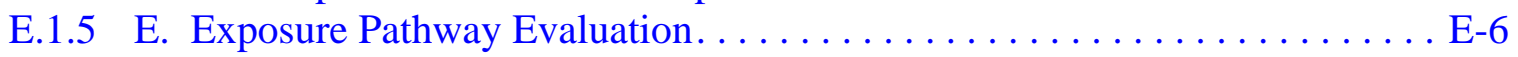

E.1.6 F. Comparison of Site Conditions with Tier 1 RBSLs $\ldots \ldots \ldots \ldots \ldots \ldots$. . . E-7

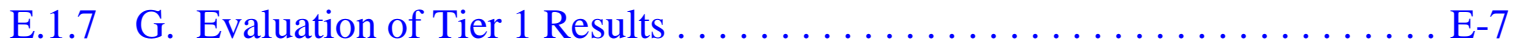

E.1.8 H. Tier 1 Remedial Action Evaluation . . . . . . . . . . . . . . . . . . . . E E-7 


\section{Table of Contents (Continued)}

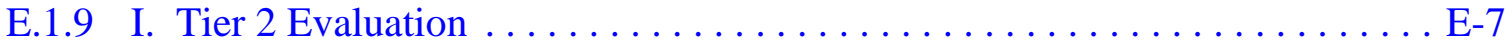

E.1.10 J. Development of Tier 2 SSTLs ......................... E-8

E.1.11 K. Comparison of Site Conditions with Tier 2 SSTLs . . . . . . . . . E-9

E.1.12 L. Tier 2 Remedial Action Evaluation. . . . . . . . . . . . . . . . . . . . E-9

E.2.0 Recommendations................................... E-10

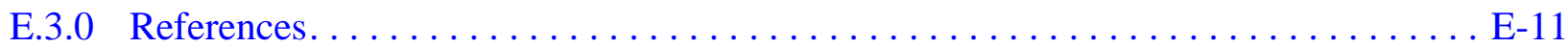

Appendix F - Nevada Division of Environmental Protection Comment Responses 


\section{List of Figures}

Number

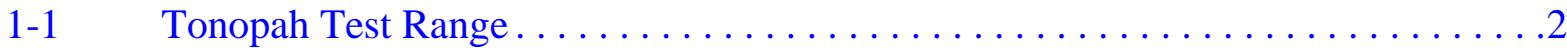

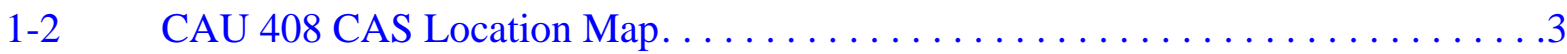

2-1 Mid Target Grid Inspection Layout $\ldots \ldots \ldots \ldots \ldots \ldots \ldots \ldots \ldots \ldots \ldots \ldots \ldots \ldots$

2-2 Flightline Grid Inspection Layout. ..........................

2-3 SAC Targets 1 and 2 Grid Inspection Layout......................

2-4 South Antelope Lake Grid Inspection Layout .....................13

2-5 Tomahawk Target 1 Grid Inspection Layout $\ldots \ldots \ldots \ldots \ldots \ldots \ldots \ldots \ldots \ldots$

2-6 Tomahawk Target 2 Grid Inspection Layout $\ldots \ldots \ldots \ldots \ldots \ldots \ldots \ldots \ldots \ldots$

2-7 Geophysical Anomalies, South Antelope Lake, Tonopah Test Range. . . . . . . . 16

2-8 Pre-excavation Photograph of Point \# 1 at Anomaly B083_32 on South Antelope Lake ................................. 19

2-9 Exploratory Pit at Anomaly B114_122 on South Antelope Lake ............20

2-10 Excavation at Anomaly 156_95 on South Antelope Lake ................20

2-11 Radiological and UXO Screening of Soil in Excavation at Anomaly G104_008..........................22

2-12 Grizzly Operation at Anomaly G156_95 on South Antelope Lake ............22

2-13 BLU-97 Submunition Located on Surface in Mid Target ................23

2-14 BLU-26 Submunition Found near Anomaly D058_01

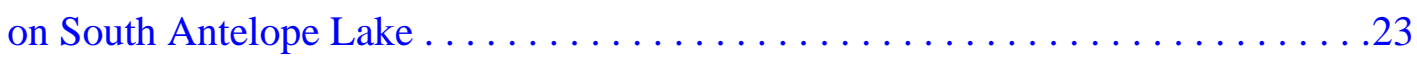

2-15 UXO Crew Performing Mag and Dig Survey on South Antelope Lake .......24

2-16 UXO Crew Performing Mag and Dig Survey at Tomahawk Target ..........24

2-17 Inert Zuni Rocket in Grid 73/733 at SAC Target $1 \ldots \ldots \ldots \ldots \ldots \ldots \ldots \ldots$

2-18 Small Fragment of DU Alloy Found in Grid 94/695 on South Antelope Lake .................................29 


\section{List of Figures (Continued)}

Number

Title

Page

2-19 Visual Inspection of Buffer Zone at Tomahawk Target $2 \ldots \ldots \ldots \ldots \ldots \ldots$

2-20 DU-Contaminated Soil Pile in Bunker near NEDS Lake................ 30

2-21 Closeup View of Oxidized DU Contamination in Soil Pile . . . . . . . . . . . . . . 31

2-22 M117A1 (750-lb bomb) Uncovered in Grid 53/816 at Mid Target . . . . . . . . . . 32

2-23 BLU-63 Submunitions Staged for Relocation before Demilitarization . . . . . . . . 32

2-24 BLU-63s (513) Staged for Demilitarization at Flightline Target . . . . . . . . . . 33

2-25 Typical Demolition Setup for BLU-63s at Mid Target $\ldots \ldots \ldots \ldots \ldots \ldots \ldots$

2-26 Before: Soil Mound in Grid 71/729 at SAC

Target 2 before Inspection . . . . . . . . . . . . . . . . . . . . . . 37

2-27 After: QC Inspection of Flattened Soil Mound with Magnetometer at Grid 71/729 at SAC Target $2 \ldots \ldots \ldots \ldots \ldots \ldots \ldots . \ldots . \ldots . \ldots$

3-1 Construction Debris Pile from Anomaly G156_95 ....................40

C.2-1 South Antelope Lake Covered with Snow $\ldots \ldots \ldots \ldots \ldots \ldots \ldots \ldots$ C-4

C.2-2 South Antelope Lake after Heavy Rainfall. .....................

C.3-1 Sample Locations at CAS TA-55-002-TAB2, Bomblet Target Areas ..........C-14

C.3-2 Disposal Pit G156_95 Soil Sampling ......................

C.3-3 Disposal Pit D006_002 Sampled Trench .........................-16

C.3-4 Grid 94/701 Post-excavation and Remediation ....................-17

C.3-5 SAC Target, Grid 71/729 Soil Mound after MEC Inspection . . . . . . . . . . .C-18

C.4-1 RCRA-Regulated MEC inside an SAA in South Antelope Lake.............C-34

C.4-2 Example of Non-RCRA-Regulated MEC before Treatment . . . . . . . . . . . .C-34

E.1-1 Risk-Based Corrective Action Decision Process ................... E-2 


\section{List of Tables}

Number

Title

Page

2-1 CAI Activities Conducted To Meet Clean Closure for CAU $408 \ldots \ldots \ldots \ldots$. . . 17

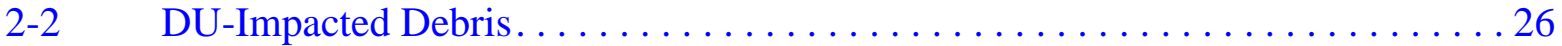

2-3 Treatment Event Table . . . . . . . . . . . . . . . . . . 34

3-1 Waste Summary Table for CAS TA-55-002-TAB2 $\ldots \ldots \ldots \ldots \ldots \ldots \ldots \ldots$

4-1 Key Assumptions for MEC Clearance $\ldots \ldots \ldots \ldots \ldots \ldots \ldots \ldots \ldots$

4-2 Key Assumptions for Soil Verification Sampling Design . . . . . . . . . . . 58

4-3 CAU 408 Analyses Performed $\ldots \ldots \ldots \ldots \ldots \ldots \ldots \ldots \ldots \ldots \ldots \ldots \ldots \ldots \ldots \ldots \ldots$

4-4 Accuracy Measurements. .........................61

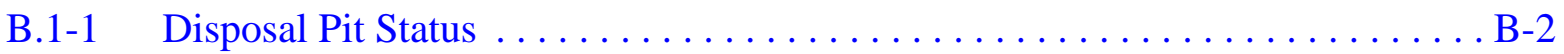

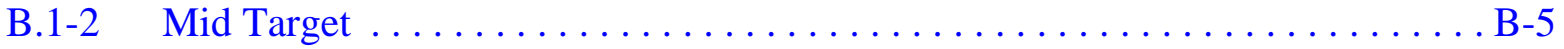

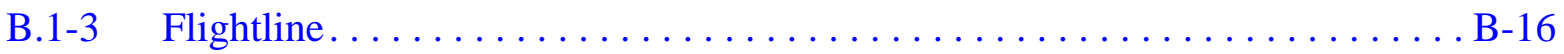

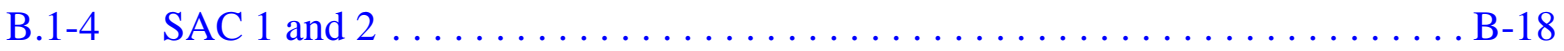

B.1-5 South Antelope Lake.$\ldots \ldots \ldots \ldots \ldots \ldots \ldots \ldots \ldots \ldots \ldots \ldots \ldots \ldots \ldots \ldots \ldots \ldots \ldots$

B.1-6 Tomahawk $1 \ldots \ldots \ldots \ldots \ldots \ldots \ldots \ldots \ldots \ldots \ldots \ldots \ldots \ldots \ldots \ldots$

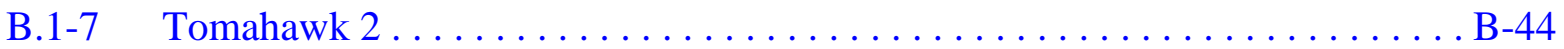

C.2-1 Laboratory Analyses and Methods, CAU 408 Investigation Samples . . . . . . . C-6

C.3-1 Samples Collected at CAS TA-55-002-TAB2, Bomblet Target Areas ....... C-9

C.3-2 Sample Results for Metals Detected above MDCs

at CAS TA-55-002-TAB2, Bomblet Target Areas . . . . . . . . . . . . . . . . C-20 


\section{List of Tables (Continued)}

Number

Title

Page

C.3-3 Sample Results for Gamma-Emitting Radionuclides Detected above MDCs at CAS TA-55-002-TAB2, Bomblet Target Areas .......... C-25

C.3-4 Sample Results for Isotopic U Detected above MDCs at CAS TA-55-002-TAB2, Bomblet Target Areas . ............. C-28

C.4-1 Waste Characterization Results Detected at CAS TA-55-002-TAB2, Bomblet Target Areas ................ C-35

E.1-1 Maximum Concentration of Detected Contaminants for CAS TA-55-002-TAB2, Bomblet Target Areas .................. E-4

E.1-2 COPCs Detected above PALs $(\mathrm{mg} / \mathrm{kg}) \ldots \ldots \ldots \ldots \ldots \ldots \ldots \ldots \ldots \ldots \ldots$ 


\section{List of Acronyms and Abbreviations}

Ac

ALM

ASTM

bgs

BLU

BMP

BOL

CAI

CAS

CAU

$\mathrm{CD}$

CDC

CLP

COC

COPC

CR

Cs

CSM

DOE

$\mathrm{dpm} / 100 \mathrm{~cm}^{2}$

DQA

DQI

DQO

DU

EML

EOD
Actinium

Adult Lead Methodology

American Society for Testing and Materials

Below ground surface

Bomb live unit

Best management practice

Bill of lading

Corrective action investigation

Corrective action site

Corrective action unit

Construction debris

Centers for Disease Control and Prevention

Contract Laboratory Program

Contaminant of concern

Contaminant of potential concern

Closure report

Cesium

Conceptual site model

U.S. Department of Energy

Disintegrations per minute per 100 square centimeters

Data quality assessment

Data quality indicator

Data quality objective

Depleted uranium

Environmental Measurements Laboratory

Explosive Ordnance Disposal 


\section{List of Acronyms and Abbreviations (Continued)}

\begin{tabular}{|c|c|}
\hline EPA & U.S. Environmental Protection Agency \\
\hline FAL & Final action level \\
\hline FD & Field duplicate \\
\hline FFACO & Federal Facility Agreement and Consent Order \\
\hline FSL & Field-screening level \\
\hline FSR & Field-screening result \\
\hline $\mathrm{ft}$ & Foot \\
\hline gal & Gallon \\
\hline GIS & Geographic Information Systems \\
\hline GPS & Global Positioning System \\
\hline HASL & Health and Safety Laboratory \\
\hline ID & Identification \\
\hline IDW & Investigation-derived waste \\
\hline in. & Inch \\
\hline $\mathrm{lb}$ & Pound \\
\hline LCS & Laboratory control sample \\
\hline LVF & Load verification form \\
\hline $\mathrm{m}$ & Meter \\
\hline $\mathrm{MD}$ & Munitions debris \\
\hline MDC & Minimum detectable concentration \\
\hline MEC & Munitions of explosive concern \\
\hline $\mathrm{mg} / \mathrm{kg}$ & Milligrams per kilogram \\
\hline $\mathrm{mg} / \mathrm{L}$ & Milligrams per liter \\
\hline $\mathrm{mi}$ & Mile \\
\hline $\mathrm{mi}^{2}$ & Square mile \\
\hline $\mathrm{mm}$ & Millimeter \\
\hline MS & Matrix spike \\
\hline
\end{tabular}




\section{List of Acronyms and Abbreviations (Continued)}

\begin{tabular}{|c|c|}
\hline MSD & Matrix spike duplicate \\
\hline N/A & Not applicable \\
\hline NAC & Nevada Administrative Code \\
\hline NAD & North American Datum \\
\hline NCRP & National Council on Radiation Protection and Measurements \\
\hline NDEP & Nevada Division of Environmental Protection \\
\hline NIOSH & National Institute for Occupational Safety and Health \\
\hline NIST & National Institute of Standards and Technology \\
\hline NNES & Navarro Nevada Environmental Services, LLC \\
\hline NNSA/NSO & $\begin{array}{l}\text { U.S. Department of Energy, National Nuclear Security Administration } \\
\text { Nevada Site Office }\end{array}$ \\
\hline NTS & Nevada Test Site \\
\hline PAL & Preliminary action level \\
\hline PB & Preparation blank \\
\hline $\mathrm{PbB}$ & Blood lead concentration \\
\hline PCB & Polychlorinated biphenyl \\
\hline $\mathrm{pCi} / \mathrm{g}$ & Picocuries per gram \\
\hline POC & Performance objective criteria \\
\hline PPE & Personal protective equipment \\
\hline PRG & Preliminary Remediation Goal \\
\hline PSDR & Package storage and disposal request \\
\hline QA & Quality assurance \\
\hline QAPP & Quality Assurance Project Plan \\
\hline QC & Quality control \\
\hline RBCA & Risk-based corrective action \\
\hline RBSL & Risk-based screening level \\
\hline RCRA & Resource Conservation and Recovery Act \\
\hline
\end{tabular}




\section{List of Acronyms and Abbreviations (Continued)}

\begin{tabular}{|c|c|}
\hline RCT & Radiological control technician \\
\hline RfD & Reference dose \\
\hline RMA & Radioactive material area \\
\hline RPD & Relative percent difference \\
\hline RWMC & Radioactive Waste Management Complex \\
\hline SAA & Satellite accumulation area \\
\hline SAC & Strategic Air Command \\
\hline SAFER & Streamlined Approach for Environmental Restoration \\
\hline SDG & Sample delivery group \\
\hline SNJV & Stoller-Navarro Joint Venture \\
\hline SSTL & Site-specific target level \\
\hline SUXOS & Senior Unexploded Ordnance Supervisor \\
\hline TBD & To be determined \\
\hline TCLP & Toxicity Characteristic Leaching Procedure \\
\hline Th & Thorium \\
\hline $\mathrm{TP}$ & Target practice \\
\hline TPT & Target practice tracer \\
\hline TTR & Tonopah Test Range \\
\hline $\mathrm{U}$ & Uranium \\
\hline USAF & U.S. Air Force \\
\hline UTM & Universal Transverse Mercator \\
\hline UXO & Unexploded ordnance \\
\hline UXOSO/QC & Unexploded Ordnance Safety Officer/Quality Control Specialist \\
\hline $\mathrm{yd}^{3}$ & Cubic yard \\
\hline$\mu \mathrm{g} / \mathrm{dL}$ & Micrograms per deciliter \\
\hline$\mu g / \mathrm{kg}$ & Micrograms per kilogram \\
\hline$\% \mathrm{R}$ & Percent recovery \\
\hline
\end{tabular}




\section{Executive Summary}

This Closure Report (CR) presents information supporting the closure of Corrective Action Unit (CAU) 408: Bomblet Target Area (TTR), Tonopah Test Range, Nevada. This CR complies with the requirements of the Federal Facility Agreement and Consent Order that was agreed to by the State of Nevada; U.S. Department of Energy (DOE), Environmental Management; U.S. Department of Defense; and DOE, Legacy Management. Corrective Action Unit 408 is located at the Tonopah Test Range, Nevada, and consists of Corrective Action Site (CAS) TA-55-002-TAB2, Bomblet Target Areas. This CAS includes the following seven target areas:

- Mid Target

- Flightline Bomblet Location

- Strategic Air Command (SAC) Target Location 1

- SAC Target Location 2

- South Antelope Lake

- Tomahawk Location 1

- Tomahawk Location 2

The purpose of this CR is to provide documentation supporting the completed corrective actions and data confirming that the closure objectives for the CAS within CAU 408 were met. To achieve this, the following actions were performed:

- Review the current site conditions, including the concentration and extent of contamination.

- Implement any corrective actions necessary to protect human health and the environment.

- Properly dispose of corrective action and investigation wastes.

- Document Notice of Completion and closure of CAU 408 issued by the Nevada Division of Environmental Protection.

From July 2009 through August 2010, closure activities were performed as set forth in the Streamlined Approach for Environmental Restoration Plan for CAU 408: Bomblet Target Area, Tonopah Test Range (TTR), Nevada. The purposes of the activities as defined during the data quality objectives process were as follows:

- Identify and remove munitions of explosive concern (MEC) associated with DOE activities. 
- Investigate potential disposal pit locations.

- Remove depleted uranium-contaminated fragments and soil.

- Determine whether contaminants of concern (COCs) are present.

- If COCs are present, determine their nature and extent, implement appropriate corrective actions, and properly dispose of wastes.

Analytes detected during the closure activities were evaluated against final action levels to determine COCs for CAU 408. Assessment of the data indicated COCs are not present at CAS TA-55-002-TAB2; therefore, no corrective action is necessary.

No use restrictions are required to be placed on this CAU because the investigation showed no evidence of remaining soil contamination or remaining debris/waste upon completion of all investigation activities. The MEC was successfully removed and dispositioned as planned using current best available technologies. As MEC guidance and general MEC standards acknowledge that MEC response actions cannot determine with 100 percent certainty that all MEC and unexploded ordnance (UXO) are removed, the clean closure of CAU 408 will implement a best management practice of posting UXO hazard warning signs near the seven target areas. The signs will warn future land users of the potential for encountering residual UXO hazards.

The DOE, National Nuclear Security Administration Nevada Site Office, provides the following recommendations:

- A Notice of Completion to the DOE, National Nuclear Security Administration Nevada Site Office, is requested from the Nevada Division of Environmental Protection for closure of CAU 408.

- Corrective Action Unit 408 should be moved from Appendix III to Appendix IV of the Federal Facility Agreement and Consent Order. 


\subsection{Introduction}

This Closure Report (CR) presents information supporting closure of Corrective Action Unit (CAU) 408: Bomblet Target Area (TTR), Tonopah Test Range, Nevada. This complies with the requirements of the Federal Facility Agreement and Consent Order (FFACO) that was agreed to by the State of Nevada; U.S. Department of Energy (DOE), Environmental Management; U.S. Department of Defense; and DOE, Legacy Management (FFACO, 1996; as amended March 2010). Corrective Action Unit 408 is located at the Tonopah Test Range (TTR), which is approximately 235 miles (mi) northwest of Las Vegas, Nevada (Figure 1-1).

Corrective Action Unit 408 is composed of Corrective Action Site (CAS) TA-55-002-TAB2, Bomblet Target Areas (Figure 1-2).

\subsection{Purpose}

This CR provides documentation and justification for the closure of CAU 408 without further corrective action. This justification is based on process knowledge, implementation of corrective actions, and the results of the investigative activities conducted in accordance with the Streamlined Approach for Environmental Restoration (SAFER) Plan for Corrective Action Unit 408: Bomblet Target Area, Tonopah Test Range (TTR), Nevada, Revision 1 (NNSA/NSO, 2010). The SAFER Plan provides information relating to site history as well as the scope and planning of the investigation.

\subsection{Scope}

The corrective action of clean closure was accomplished by removal of munitions of explosive concern (MEC) within seven target areas and potential disposal pits (see Section 2.1). Clean closure was also demonstrated through verification sample analytical results collected after disposal pit remediation that contaminants of concern (COCs) do not exist within the CAS. Activities used to implement these corrective actions included the following:

- Clearing bomblet target areas within the study area.

- Identifying and remediating disposal pits.

- Removing depleted uranium (DU)-contaminated fragments and soil.

- Performing visual survey/inspection of the buffer zone.

- Collecting verification samples for laboratory analysis. 


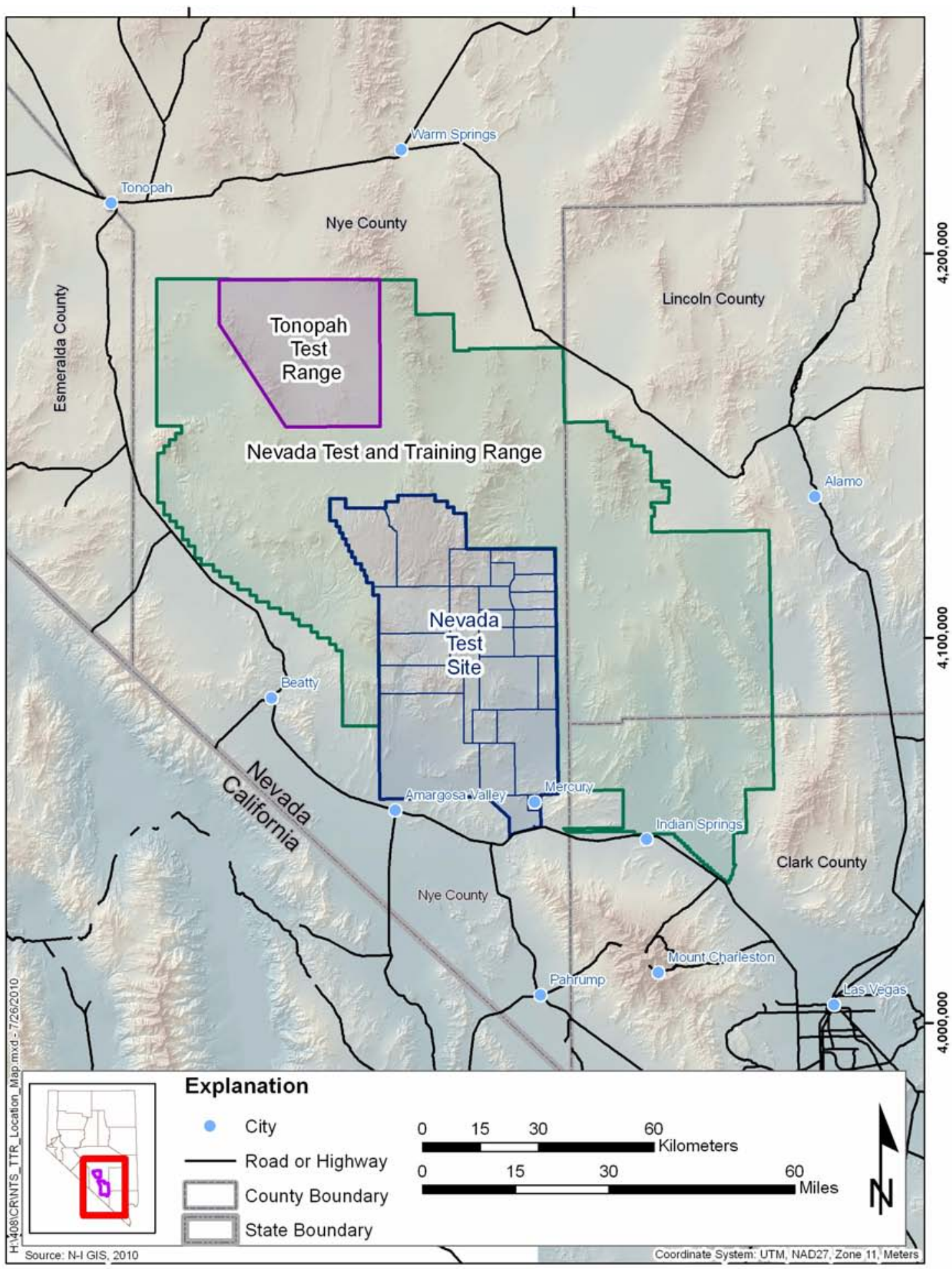

Figure 1-1

Tonopah Test Range 


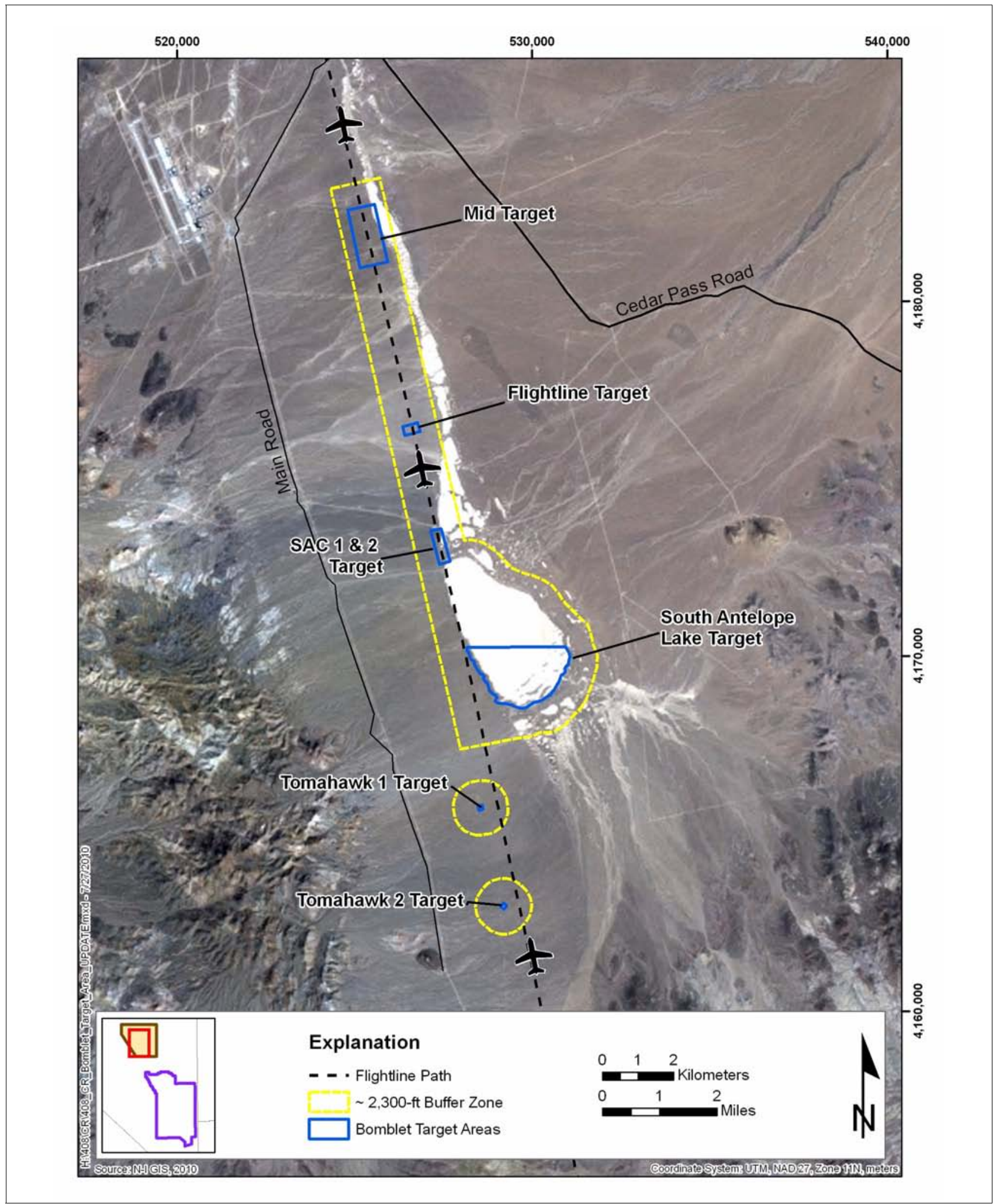

Figure 1-2

CAU 408 CAS Location Map 
- Performing radiological screening of soil and debris.

- Collecting waste management samples.

- $\quad$ Performing best management practices (BMPs).

- Documenting Notice of Completion and closure of CAU 408.

\subsection{Closure Report Contents}

This CR is divided into the following sections and appendices:

Section 1.0, "Introduction," summarizes the purpose, scope, and contents of this CR.

Section 2.0, "Closure Activities, summarizes the closure activities, deviations from the SAFER Plan, the actual schedule, and the site conditions following completion of corrective actions.

Section 3.0, "Waste Disposition," discusses the wastes generated and entered into an approved waste management system as a result of the corrective action.

Section 4.0, “Closure Verification Results,” describes verification activities and results.

Section 5.0, “Conclusions and Recommendations,” provides the conclusions and recommendations along with the rationale for their determination.

Section 6.0, "References,” provides a list of all referenced documents used in the preparation of this CR.

Appendix A, Data Quality Objectives (DQOs) as Developed in the SAFER Plan, provides the DQOs as presented in Section 3.0 of the CAU 408 SAFER Plan.

Appendix B, MEC Closure Activities, describes the investigation of disposal pits and Mag and Dig clearance surveys within the seven target areas. Includes Attachment 1, "Final After-Action Report: Munitions and Explosives of Concern (MEC) Disposal Pit Investigation and Sub-Munition Clearance” prepared by Weston Solutions, Inc.; and Attachment 2, “After-Action Report for the Corrective Action Unit (CAU) 408 Bomblet Target Area Munitions and Explosives of Concern, Surface Clearance” (excerpts), prepared by EOD Technology, Inc. 
Appendix C, Confirmation Sampling Test Results, provides a description of the project objectives, field closure and sampling activities, and closure results.

Appendix D, Waste Disposition Documentation, documents disposal of items removed during closure activities.

Appendix E, Risk Evaluation, provides established final action levels (FALs) and risk-based recommendations.

Appendix F, Nevada Division of Environmental Protection (NDEP) Comments, contains NDEP comments on the draft version of this document.

\subsubsection{Applicable Programmatic Plans and Documents}

To ensure all project objectives, health and safety requirements, and quality control (QC) procedures were adhered to, all closure activities were performed in accordance with the following documents:

- $\quad$ Streamlined Approach for Environmental Restoration Plan for CAU 408: Bomblet Target Area, Tonopah Test Range (TTR), Nevada, Revision 1 (NNSA/NSO, 2010)

- $\quad$ Industrial Sites Quality Assurance Project Plan (QAPP) (NNSA/NV, 2002)

- Federal Facility Agreement and Consent Order (1996, as amended March 2010)

- $\quad$ MEC Work Plans (Weston, 2009; EODT, 2010)

- Approved standard operating procedures

\subsubsection{Data Quality Objectives}

This section contains a summary of the DQO process that is presented in Appendix A. The DQOs were developed to identify data needs, clearly define the intended use of the environmental data, and design a data collection program that will satisfy these purposes.

The problem statement for CAU 408 is as follows: “Corrective Action Unit 408 is being investigated and closed because potential and known explosive hazards due to the presence of MEC/unexploded ordnance (UXO) and potential soil contamination related to DOE submunitions testing exist at 
locations within CAU 408 target areas.” To address this problem, the resolution of five decision statements is required:

- Decision 1: “Have all disposal pits been identified?” If all of the potential disposal pit locations have been excavated and all of the potential disposal pit locations identified during the surface clearance operations have been verified, then it will be decided that all disposal pits have been identified. If this criterion has not been met, then additional excavations will be performed at the identified geophysical anomalies. Visual observations will determine whether the material excavated represents a location where debris has been buried.

- Decision 2: "Have all hazardous materials in disposal pits been removed?” If only native soil remains on the sides and bottom of a disposal pit excavation (i.e., no additional debris observed) and verification sample results do not contain contamination at concentrations exceeding FALs, then it will be decided that all hazardous materials have been removed from the disposal pit.

- Decision 3: "Have all areas impacted by submunitions (i.e., bomblets) been identified and delineated? If predefined target areas (including a 200-foot [ft] radius surrounding the last item observed or identified) and the visual inspection of buffer zones surrounding each target area are clear of submunitions debris, then it will be decided that the extent of the target area has been delineated. If this criterion has not been met, the boundary of the target area will be extended, and a surface clearance will be conducted over the extended area.

- Decision 4: “Have 100 percent of all areas impacted by submunitions been surface cleared of DOE-related submunitions?” If the areas covered by surface clearance traverses are adjacent and extend to the edges of the target area, then it will be decided that 100 percent of the target area has been surface cleared. If this criterion has not been met, additional surface clearance will be conducted.

- Decision 5: “Have all COCs (if present in soil) been removed?” If all analytical result concentrations from all verification samples are less than their corresponding FALs, then it will be decided that no COCs remain in the target area. If this criterion has not been met, soils containing COCs will be removed for disposal.

\subsubsection{Data Quality Assessment Summary}

The data quality assessment (DQA) presented in Section 4.4 includes an evaluation of the data quality indicators (DQIs) to determine the degree of acceptability and usability of the reported data in the decision-making process. The DQO process ensures that the right type, quality, and quantity of data will be available to support the resolution of those decisions at an appropriate level of confidence. Using both the DQO and DQA processes help to ensure that DQO decisions are sound and defensible. 
The DQA process, as presented in Section 4.4, is composed of the following steps:

- Step 1: Review DQOs and Sampling Design.

- Step 2: Conduct a Preliminary Data Review.

- Step 3: Select the Test.

- Step 4: Verify the Assumptions.

- Step 5: Draw Conclusions from the Data.

Based on the results of the DQA presented in Section 4.4, the information generated during the investigation supports the conceptual site model (CSM) assumptions, and the data collected meet the DQOs and support their intended use in the decision-making process. 


\subsection{Closure Activities}

The following sections summarize the CAU 408 closure activities and any deviations from the original scope of work. Detailed descriptions of the CAU 408 MEC clearance surveys and disposal pit investigations performed and results of this work are presented in the After-Action Reports found in Appendix B. Results of verification soil sampling at identified disposal pits are presented in Appendix C.

\subsection{Site Descriptions}

Corrective Action Unit 408 was originally identified as an approximately 19-square-mile (mi ${ }^{2}$ ) area extending from Mid Target to the middle of Antelope Lake (DOE/NV, 1994 and 1996; SNL, 1992; Swaton, 1994). Records research of U.S. Air Force (USAF) Armament Laboratory Reports at Sandia Albuquerque, Eglin Air Force Base, and Maxwell Air Force Base; interviews with personnel; site visits; and geophysical surveys redefined the investigation area to the following seven discrete target areas (Cabble, 2007) where bomblet testing occurred:

- $\quad$ Mid Target

- Flightline Target

- $\quad$ Strategic Air Command (SAC) Target 1

- SAC Target 2

- South Antelope Lake Target

- Tomahawk Target 1

- $\quad$ Tomahawk Target 2

The lateral dispersion of bomblets around the target areas was expected to be minimal and mainly concentrated along the flightline axis. The aircraft dropping the submunitions ordnance on targets were directed by aircraft controllers on the ground who carefully positioned the aircraft such that the cameras and telemetry used to record the tests were safe from damage and in the correct position to record the data (BN, 2004). However, to account for possible inaccuracies in hitting the intended targets and to be conservative in estimating the lateral extent of bomblets, the CAU 408 corrective action investigation (CAI) included a 2,300-ft buffer zone. The 2,300-ft buffer distance was calculated as twice the distance of the farthest known bomblet drop location from the center of the target. The farthest documented bomblet drop from the center of a target was calculated to be approximately 1,150 ft at Mid Target based upon USAF Armament Laboratory Reports. The 2,300-ft 
buffer zone was defined as a width of 2,300 ft on either side of the flightline and a length of 2,300 ft north of the predefined Mid Target boundary extending to 2,300 ft south of the South Antelope Lake target area boundary. Because the Tomahawk targets and the South Antelope Lake target were located off the axis of the flightline, a 2,300-ft buffer zone surrounding each Tomahawk target area and the entire extent of South Antelope Lake also was applied. Therefore, the CAU 408 boundary was defined to include the specific target areas, including the 2,300-ft buffer zones. Figure 1-2 shows the bomblet target areas that were investigated and the expanded CAU 408 boundary (buffer zone). Figures 2-1 through 2-6 show the investigation area associated with each individual target area.

Existing digital geophysical mapping, multispectral photographs, and surface radiological survey data were used to identify 25 geophysical anomalies that had the potential to represent disposal pits (NNSA/NSO, 2006). Geophysical surveys on 10-meter (m) transects were conducted on portions of Mid Target and SAC Target as well as the southwestern boundary of Antelope Lake to provide a 10 percent coverage of each of the target areas. A more comprehensive survey with 100 percent coverage was conducted of the Antelope Lake dry lake bed. No subsurface anomalies were identified at Mid Target, while one subsurface anomaly was identified at SAC Target 1. The geophysical data for Antelope Lake indicated 24 subsurface anomalies (Zapata, 2007). See Figure 2-7 for locations of the 25 subsurface anomalies identified on Antelope Lake and SAC Target 1.

The scope of CAU 408 was limited to submunitions (on the surface and in disposal pits) released from DOE activities and potentially contaminated soil from those activities.

\subsection{Description of CAI Activities}

The CAI activities were conducted in accordance with the requirements set forth in the CAU 408 SAFER Plan (NNSA/NSO, 2010). Table 2-1 lists the CAI activities that were conducted at each of the target areas and buffer zone. Descriptions of the activities performed to achieve closure of CAU 408 are presented in the following sections.

Personnel qualifications were in accordance with the U.S. Department of Defense Explosives Safety Board Technical Paper 16 (DoD, 2005). The initial composition of each UXO team consisted of a Senior Unexploded Ordnance Supervisor (SUXOS), UXO Safety Officer/QC Specialist (UXOSO/QC), UXO Technician III (Team Lead), and five UXO Technician II personnel. The UXO 


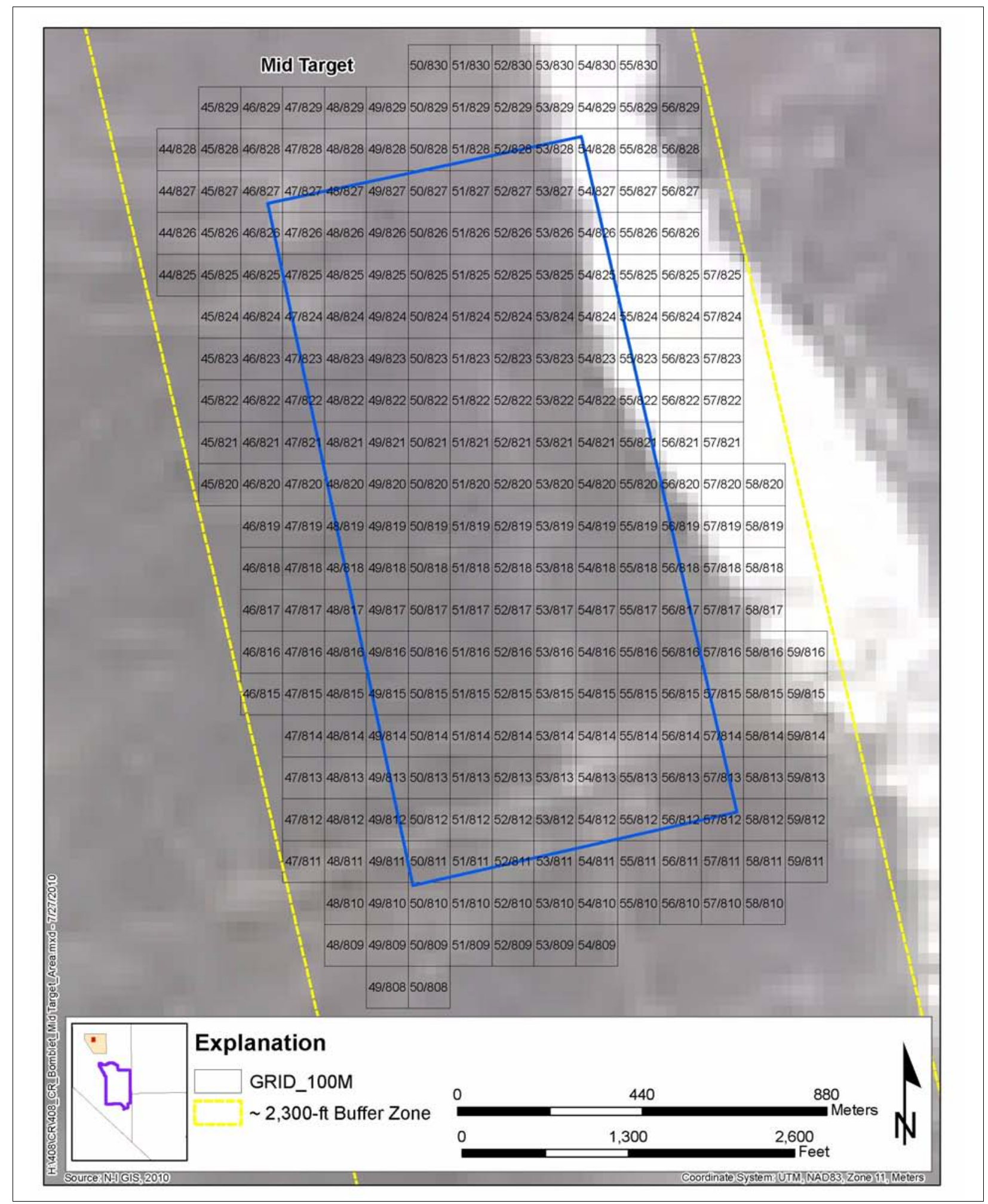

Figure 2-1

Mid Target Grid Inspection Layout 


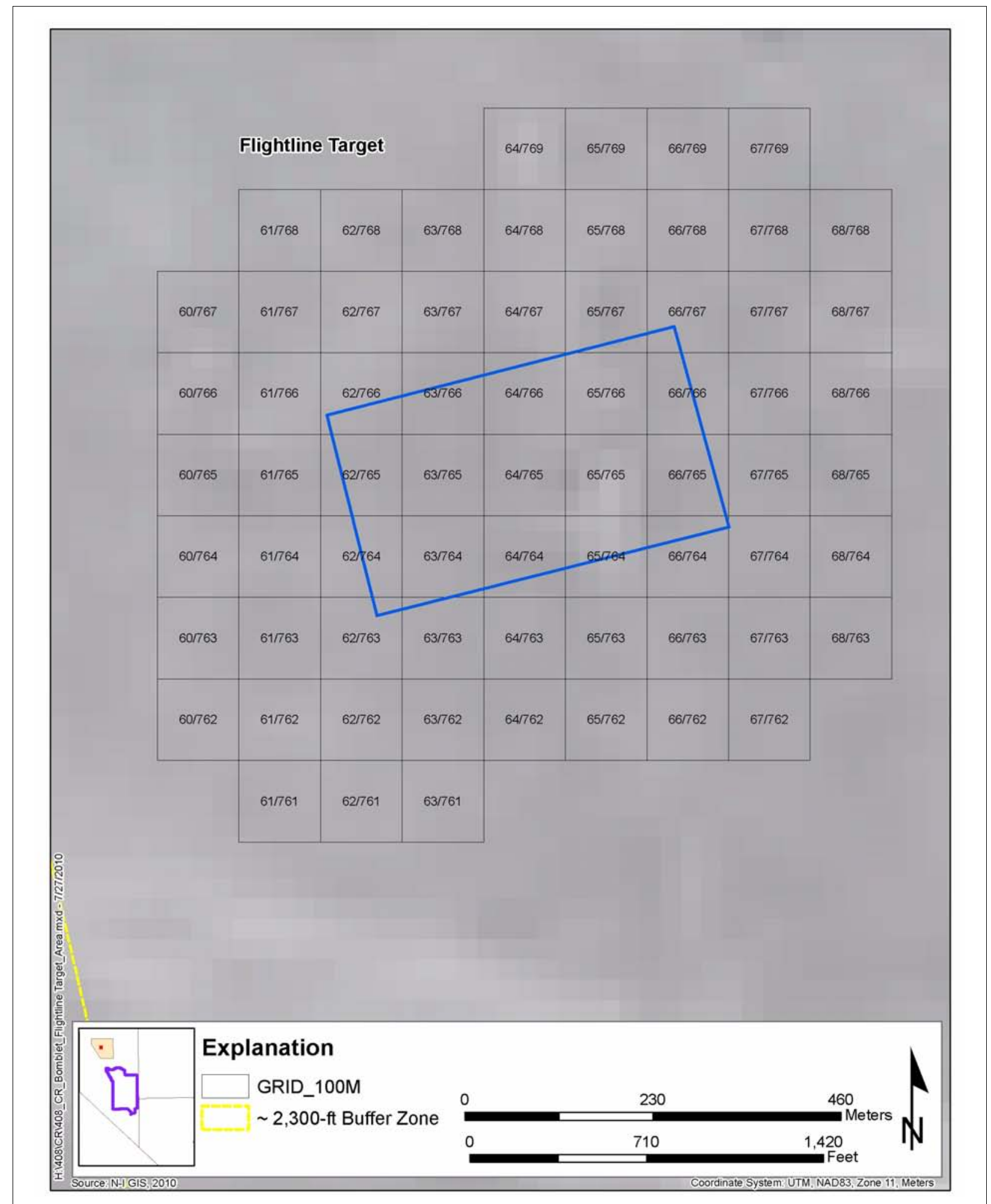

Figure 2-2

Flightline Grid Inspection Layout 


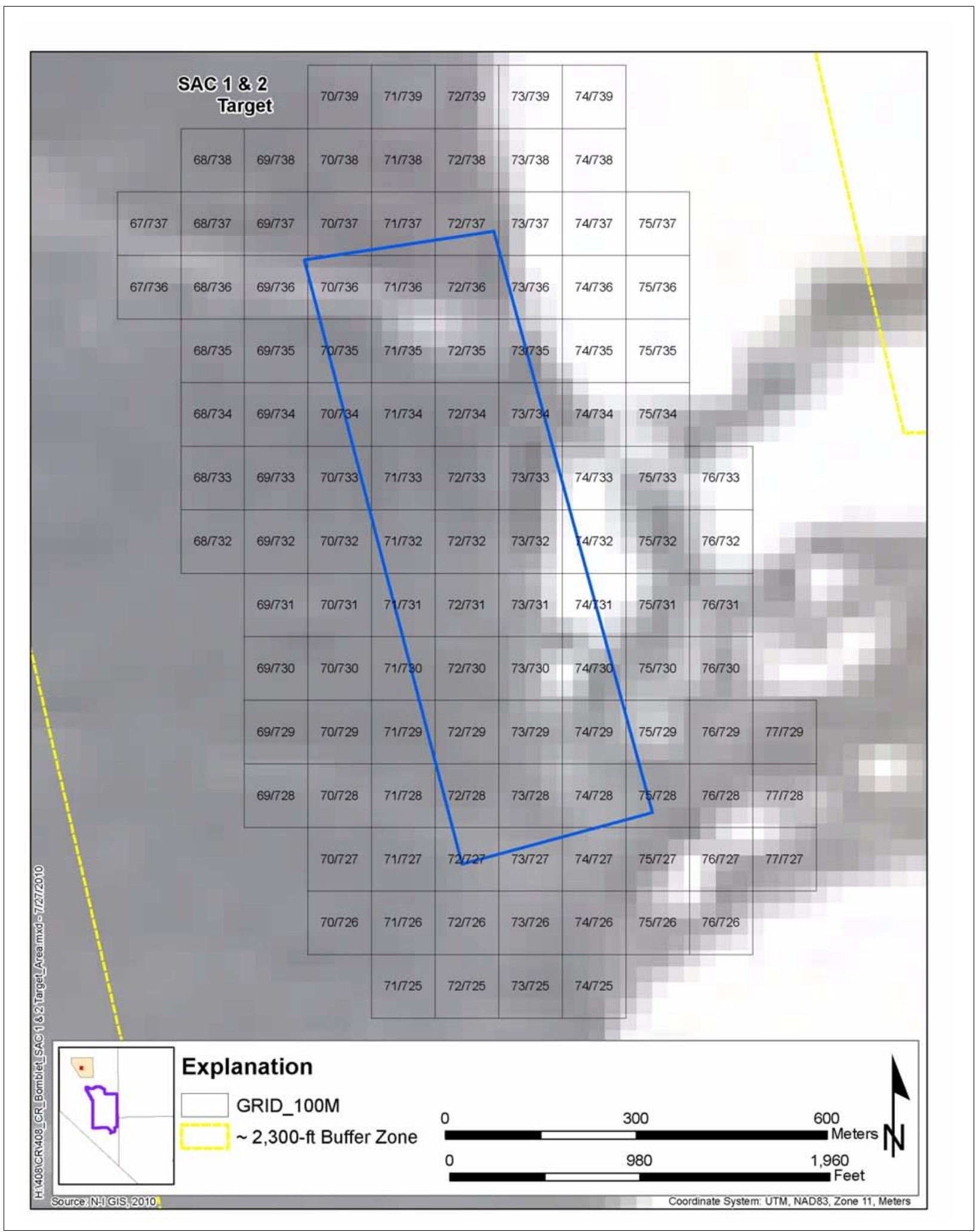

Figure 2-3

SAC Targets 1 and 2 Grid Inspection Layout 


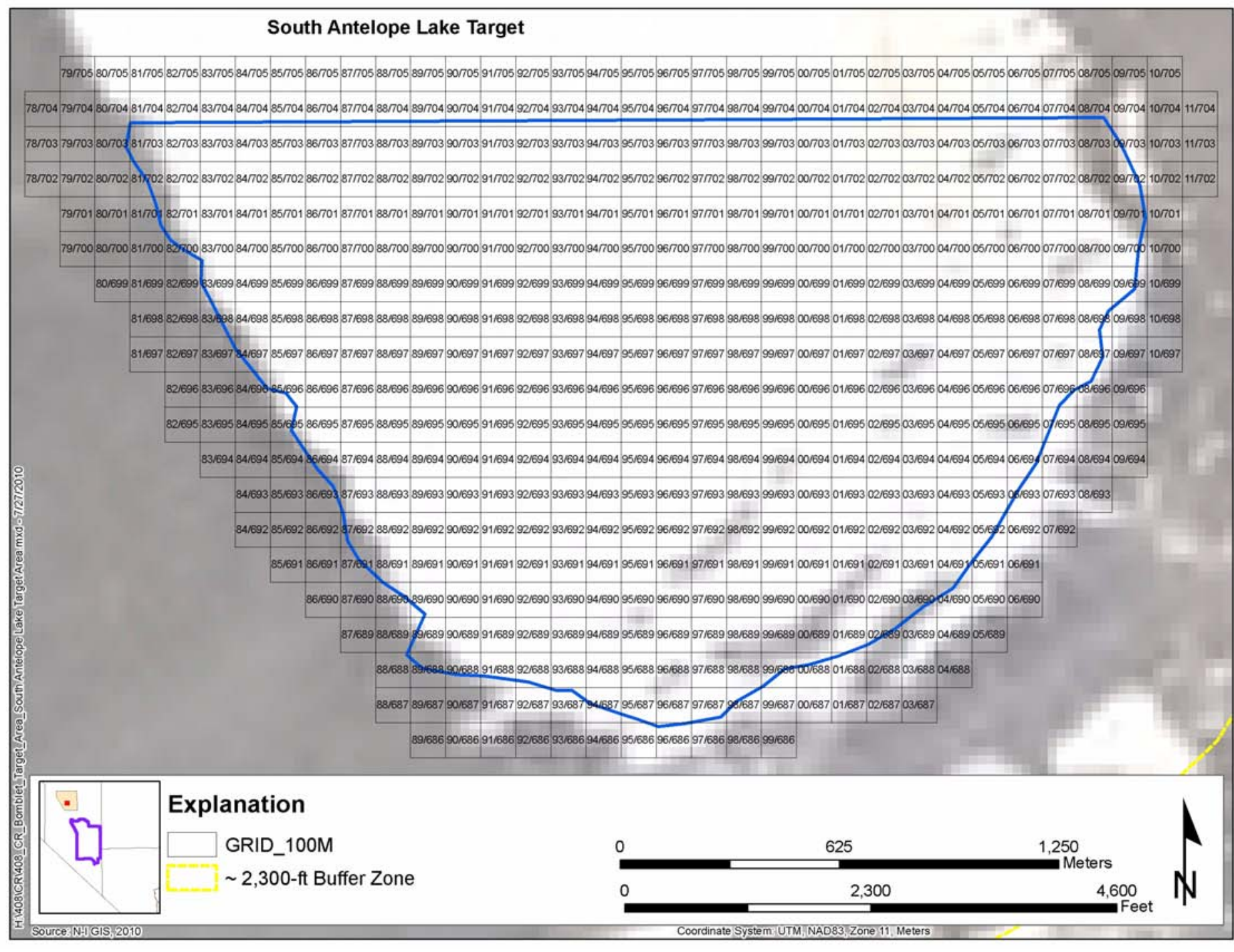

Figure 2-4

South Antelope Lake Grid Inspection Layout

\section{UNCONTROLLED When Printed}




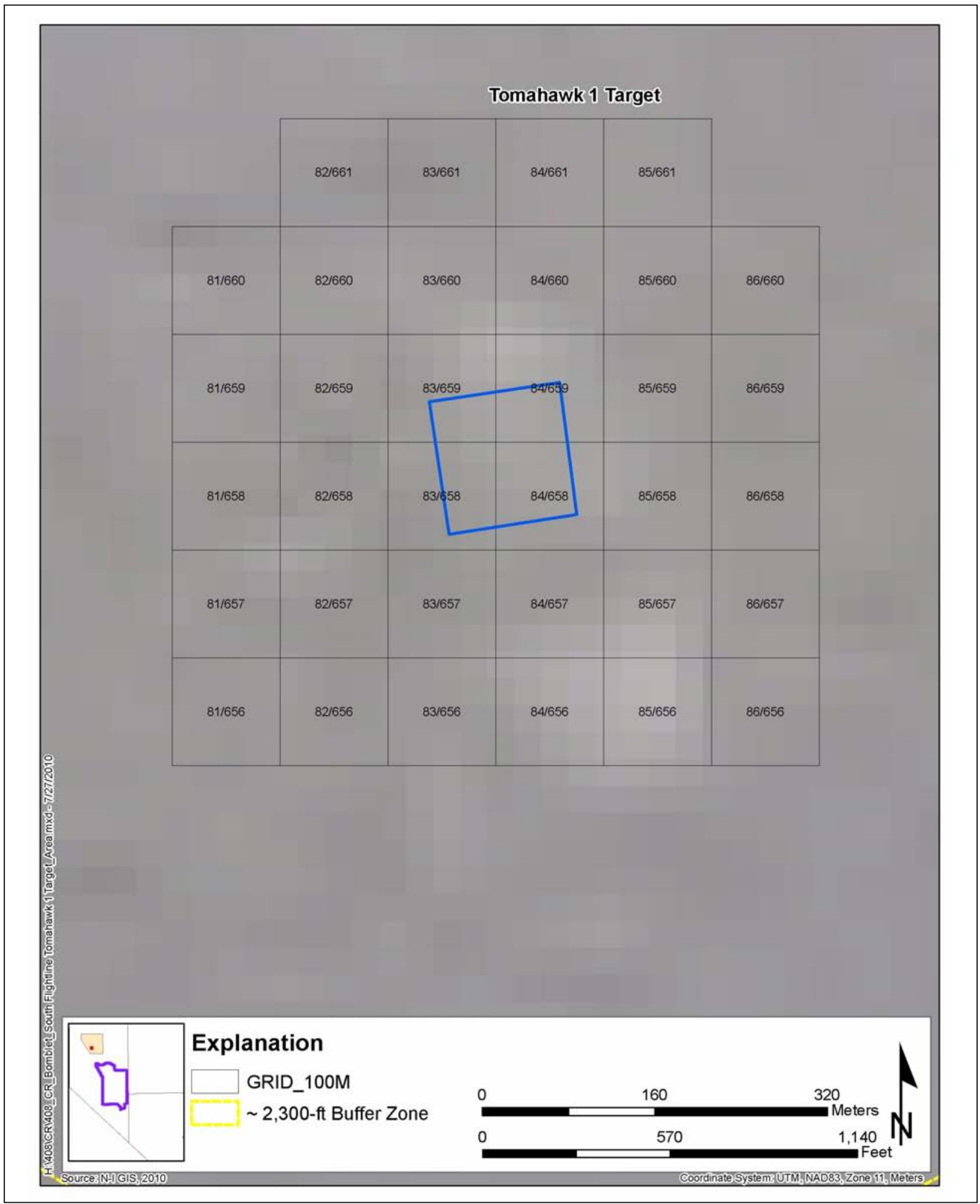

Figure 2-5

Tomahawk Target 1 Grid Inspection Layout 


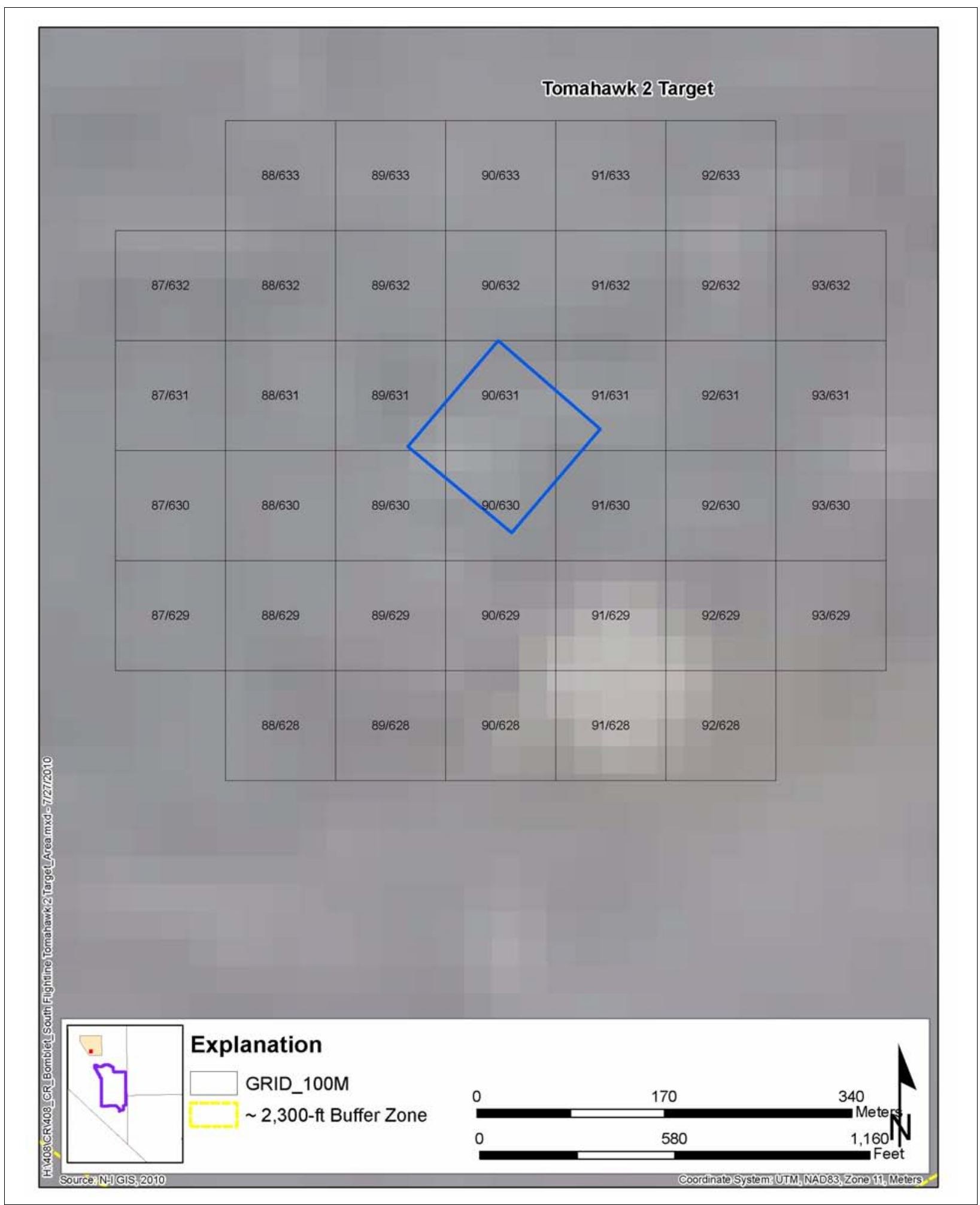

Figure 2-6

Tomahawk Target 2 Grid Inspection Layout 


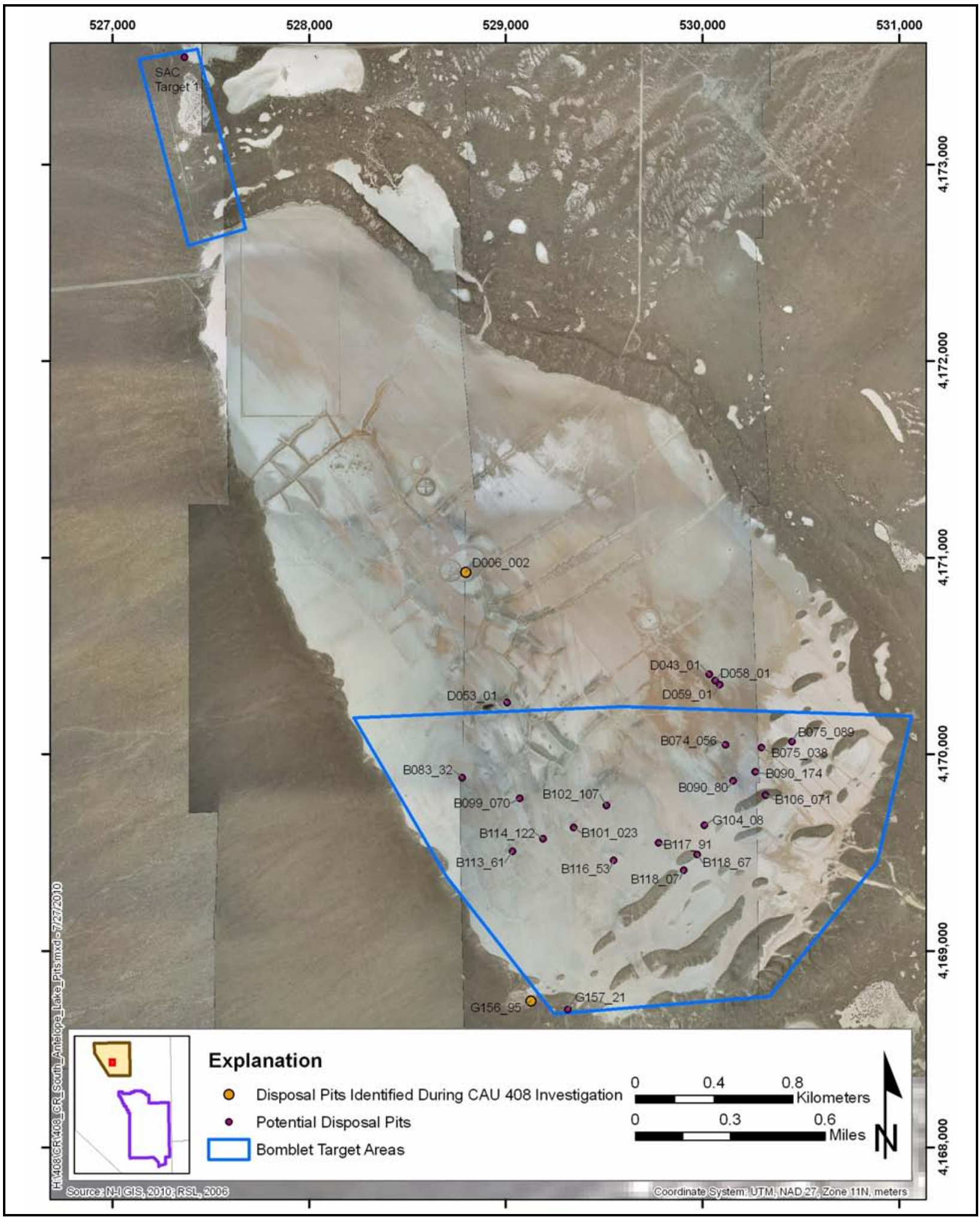

Figure 2-7

Geophysical Anomalies, South Antelope Lake, Tonopah Test Range 
Table 2-1

CAI Activities Conducted To Meet Clean Closure for CAU 408

\begin{tabular}{|c|c|}
\hline Investigation Area ${ }^{a}$ & CAl Activities \\
\hline Mid Target Area & $\begin{array}{l}\text { - Performed Mag and Dig survey of } 158 \text { 100-by-100-m grids (approximately } 390 \text { acres). } \\
\text { - Performed } 10 \% \text { QC survey of each grid, including seeding program. } \\
\text { - Removed and dispositioned } 130 \mathrm{lb} \text { of sanitary construction debris. } \\
\text { - Removed and dispositioned } 4,882 \mathrm{lb} \text { of MD. } \\
\text { - Removed and dispositioned/demolished } 1,867 \mathrm{MEC} \text { items. } \\
\text { - } \text { Collected } 27 \text { verification samples. }\end{array}$ \\
\hline Flightline Target Area & $\begin{array}{l}\text { - Performed Mag and Dig survey of } 19 \text { 100-by-100-m grids (approximately } 47 \text { acres). } \\
\text { - Performed } 10 \% \text { QC survey of each grid, including seeding program. } \\
\text { - Removed and dispositioned } 38 \mathrm{lb} \text { of sanitary construction debris. } \\
\text { - Removed and dispositioned } 19 \mathrm{lb} \text { of MD. } \\
\text { - Removed and dispositioned/demolished } 513 \text { MEC items (BLU-63s). }\end{array}$ \\
\hline $\begin{array}{c}\text { SAC } 1 \\
\text { and } 2 \text { Target Areas }\end{array}$ & $\begin{array}{l}\text { - Investigated potential disposal pit within SAC Target } 1 . \\
\text { - } \text { Collected } 1 \text { biased verification sample. } \\
\text { - } \text { Performed Mag and Dig survey of } 45100-\text {-by-100-m grids (approximately } 111 \text { acres). } \\
\text { - Performed } 10 \% \text { QC survey of each grid, including seeding program. } \\
\text { - Removed and dispositioned } 350 \mathrm{lb} \text { of sanitary construction debris. } \\
\text { - Removed and dispositioned } 617 \mathrm{lb} \text { of MD. } \\
\text { - Removed and dispositioned/demolished } 1 \mathrm{MEC} \text { item (.50-caliber round). }\end{array}$ \\
\hline $\begin{array}{c}\text { South Antelope Lake } \\
\text { Target Area }\end{array}$ & $\begin{array}{l}\text { - Performed Mag and Dig survey of } 357 \text { 100-by-100-m grids (approximately } 882 \text { acres). } \\
\text { - Performed } 10 \% \text { QC survey of each grid, including seeding program. } \\
\text { - Removed and dispositioned DU-impacted debris and fragments. } \\
\text { - Removed and dispositioned 1,156.5 lb of sanitary construction debris. } \\
\text { - Removed and dispositioned 3,713 lb of MD. } \\
\text { - Removed and dispositioned/demolished } 22 \text { MEC items. }\end{array}$ \\
\hline $\begin{array}{l}\text { Tomahawk } 1 \\
\text { Target Area }\end{array}$ & $\begin{array}{l}\text { - Performed Mag and Dig survey of } 4 \text { 100-by-100-m grids (approximately } 10 \text { acres). } \\
\text { - Performed } 10 \% \text { QC survey of each grid, including seeding program. } \\
\text { - Removed and dispositioned } 0.5 \mathrm{lb} \text { of sanitary construction debris. } \\
\text { - Removed and dispositioned } 0.5 \mathrm{lb} \text { of MD. } \\
\text { - Discovered no MEC items. }\end{array}$ \\
\hline $\begin{array}{l}\text { Tomahawk } 2 \\
\text { Target Area }\end{array}$ & $\begin{array}{l}\text { - Performed Mag and Dig survey of } 6100-b y-100-m \text { grids (approximately } 15 \text { acres). } \\
\text { - Performed } 10 \% \text { QC survey of each grid, including seeding program. } \\
\text { - Removed and dispositioned } 0.5 \mathrm{lb} \text { of sanitary construction debris. } \\
\text { - Recovered no MD. } \\
\text { - Discovered no MEC items. }\end{array}$ \\
\hline Antelope Lake & $\begin{array}{l}\text { - Investigated } 24 \text { potential disposal pits. } \\
\text { - Discovered and remediated } 2 \text { disposal pits. } \\
\text { - Performed Mag and Dig survey of South Antelope Lake Target Area. } \\
\text { - Performed visual survey of North Antelope Lake Area for MEC/radiologically impacted debris. } \\
\text { - Collected } 37 \text { verification samples. }\end{array}$ \\
\hline Buffer Zone & $\begin{array}{l}\text { - Performed visual sweep of 8,660-acre area. } \\
\text { - Performed Mag and Dig survey of approximately } 200 \text { acres for step-out surveys. } \\
\text { - Performed QC oversight during visual sweep activities. } \\
\text { - Removed and dispositioned approximately 5,000 lb of sanitary construction debris. } \\
\text { - Removed and dispositioned approximately } 25,000 \mathrm{lb} \text { of MD. } \\
\text { - Removed and dispositioned/demolished approximately } 500 \mathrm{MEC} \text { items. } \\
\text { - Removed and dispositioned DU-impacted debris and fragments. }\end{array}$ \\
\hline
\end{tabular}

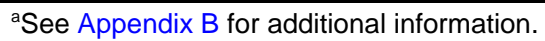

$\mathrm{lb}=$ Pound

$\mathrm{MD}=$ Munitions debris 
Technicians were typically Explosive Ordnance Disposal (EOD) School trained with at least five years military EOD and/or civilian experience. This requirement provided a team of well-trained and experienced UXO personnel for the TTR project.

\subsubsection{Site Preparation}

Layout, survey and staking of previously identified geophysical anomalies, target boundaries, target grid systems, and buffer zone boundaries was completed to prepare the site for CAI activities. Survey and staking of the investigation site provided the following:

- A means for tracking progress of the Mag and Dig surveys

- Defined boundaries for each clearance area

- A means of navigation for the UXO team

- Site survey control for data management and anomaly classification

Identification and staking of the 25 geophysical anomalies investigated as potential disposal pits consisted of marking one to several points within each anomaly with wooden stakes (Figure 2-8). Each stake was labeled with the unique anomaly number and the individual point to be excavated and investigated.

Survey and staking at each of the seven target areas was completed to identify and demarcate the target boundaries, and to layout the grid system for Mag and Dig clearance surveys (see Figures 2-1 through 2-6). The grid system consisted of 100-by-100-m grids placed over each target area and integrated with a Geographic Information Systems (GIS) database. The grid system was set up at each target area using a Global Positioning System (GPS) unit and staking each grid corner with a 48-inch (in.) wooden stake, labelled with grid number, and flagged.

Staking for the buffer zone visual inspection included identifying and staking the buffer zone. Buffer zone perimeter stakes were placed at 200-m intervals in the north-south direction, and 300-m intervals in the east-west direction.

\subsubsection{Disposal Pit Investigation and Remediation}

All 25 potential disposal pit locations identified in Section 3.1.7 of the SAFER Plan (NNSA/NSO, 2010) were investigated. Twenty-four of the potential disposal pits were located 


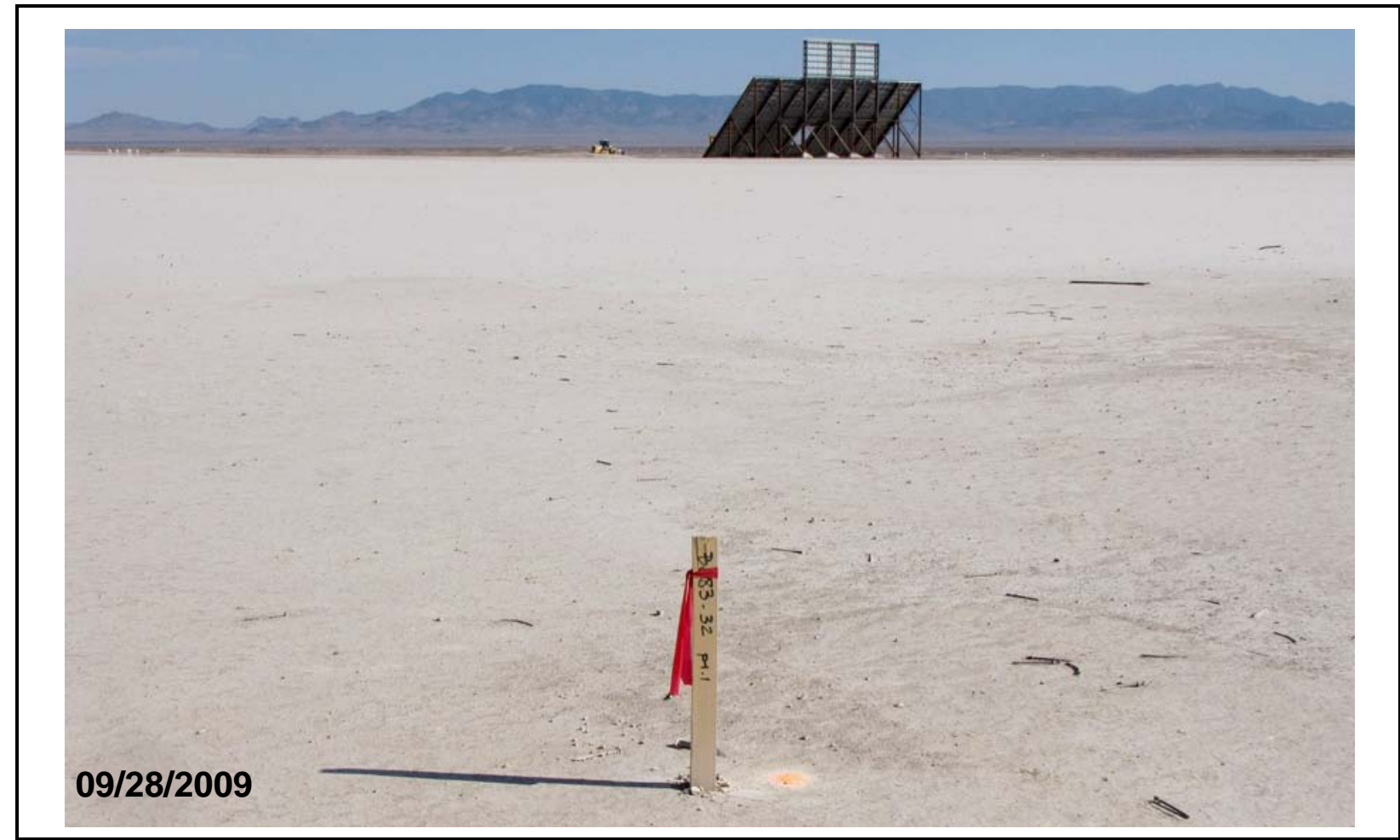

Figure 2-8

Pre-excavation Photograph of Point \# 1 at Anomaly B083_32 on South Antelope Lake on Antelope Lake, and one was located in SAC Target 1 (Figure 2-7). The disposal pit locations were investigated by excavating a pothole at the center of the anomaly and/or selected geophysical points within the anomaly footprint (Figure 2-9) representing locations of the highest probability of encountering waste. Appendix B presents information on the location of disposal pits, completion dates, and results of each anomaly excavation. Excavation activities resulted in the identification of two disposal pits containing buried MEC and debris at Antelope Lake. The disposal pits were identified during investigation at anomaly locations G156_95 (Figure 2-10) and D006_002. Each anomaly was excavated to native soil/disturbed soil interface, and was cleared of all MEC and debris.

Six additional locations were identified as disposal pits during Mag and Dig surveys, with one location on South Antelope Lake Target within grid 94/701 (Figure 2-4), and five locations on Mid Target within grids 53/815, 53/814, and 52/817 (Figure 2-1). For CAU 408, a disposal pit was defined as a man-made pit or trench in which MEC or munitions-related debris was intentionally buried in the ground. The six additional locations were conservatively identified as disposal pits due to the depth, and mixture of debris and MEC within the excavation. In each case, the excavation was 


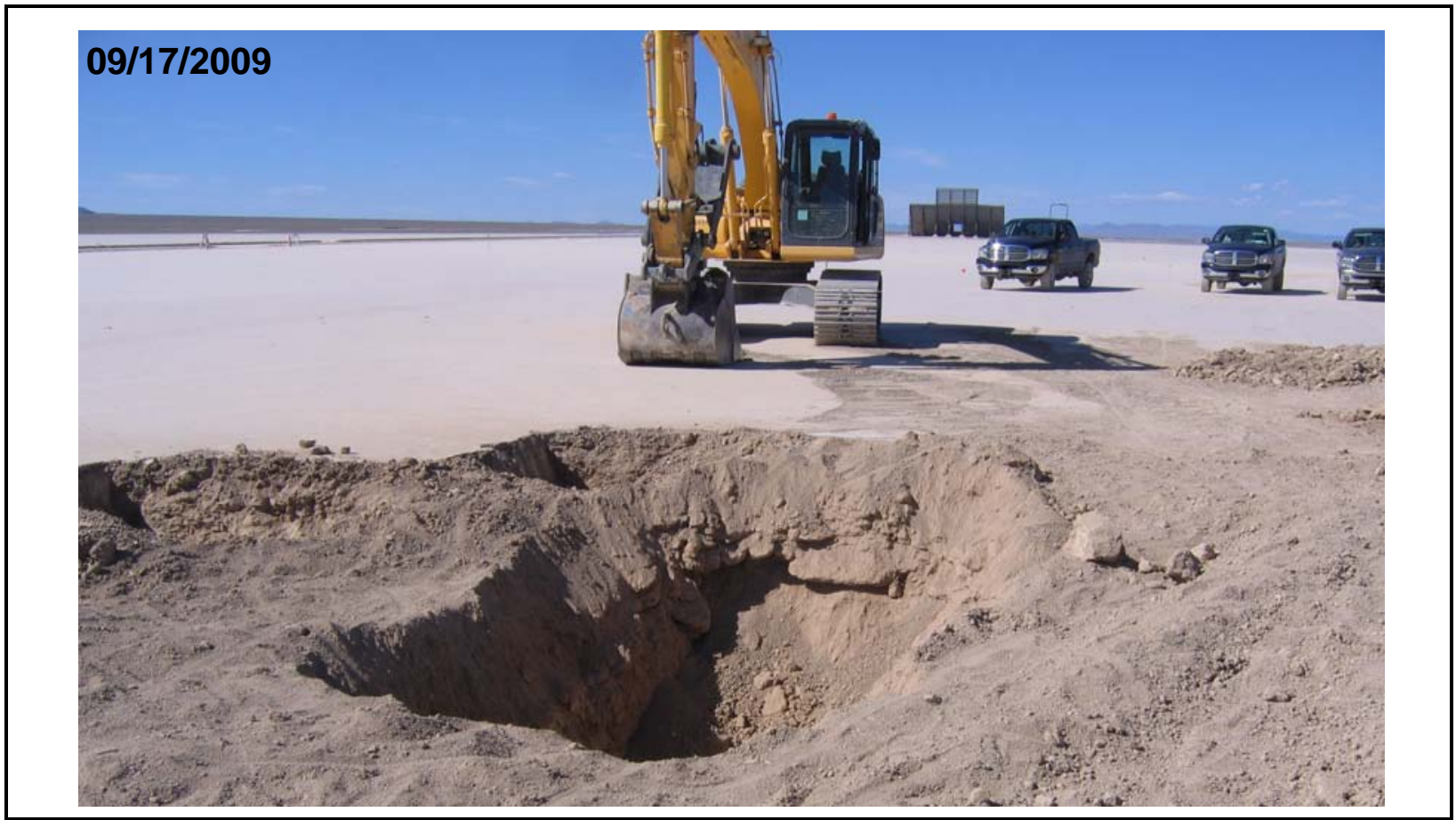

Figure 2-9

Exploratory Pit at Anomaly B114_122 on South Antelope Lake

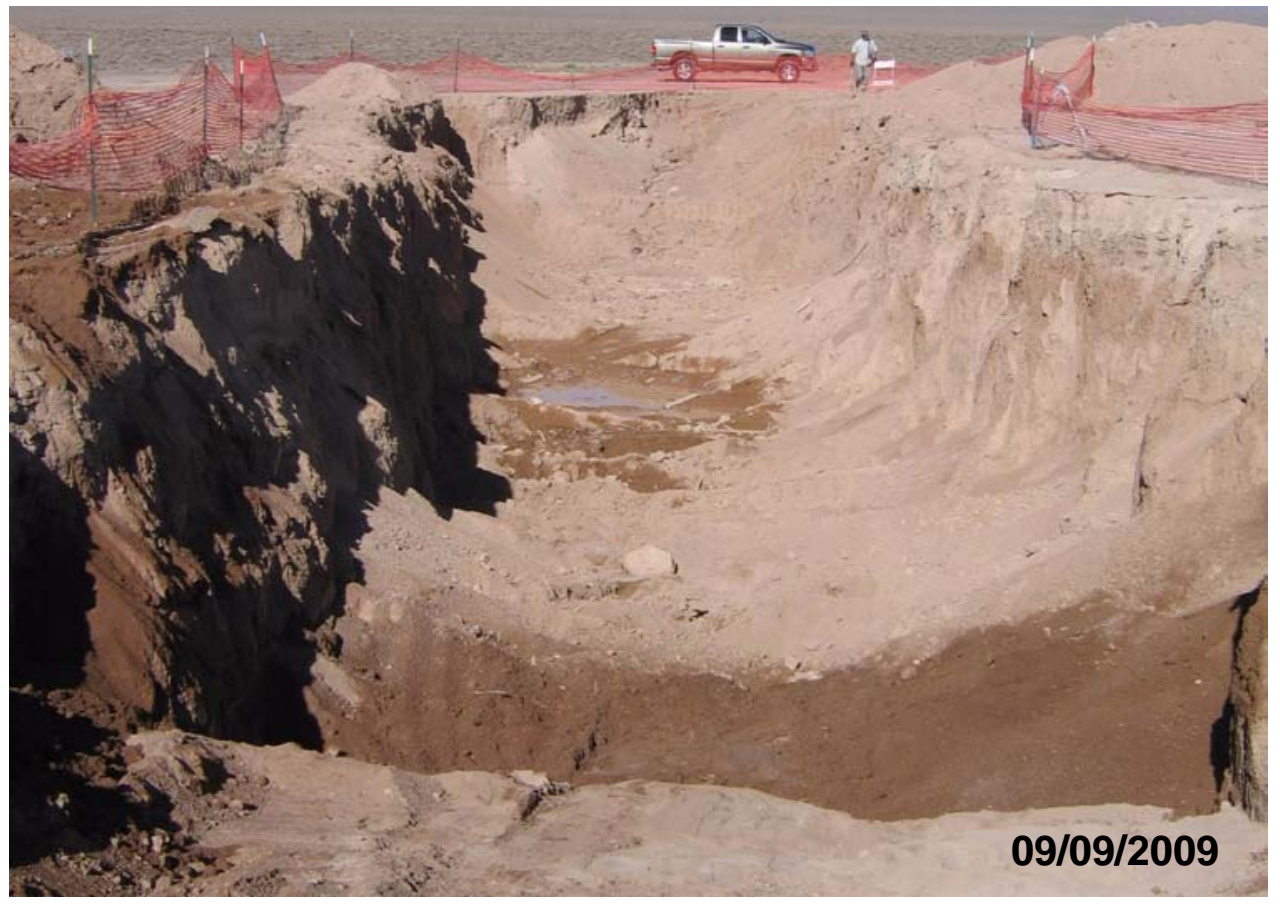

Figure 2-10

Excavation at Anomaly 156_95 on South Antelope Lake 
cleared of MEC and waste (debris) until the sides and bottom of the excavation were composed of native soil.

For all suspect disposal pits, all wastes were removed; MEC/MD was segregated from other types of debris (e.g., nails, wood); and verification samples were collected for analysis to confirm no COCs were present. All wastes, including MD and sanitary debris, were loaded into end-dumps and disposed of at the Nevada Test Site (NTS) and/or TTR landfills as sanitary waste. Details of the waste disposal are presented in Section 3.0.

All spoils from disposal pit excavation activities were screened for radiological contamination using a Ludlum Model 2221 scaler with a Model 4421 beta and low-energy gamma detector, and for MEC/UXO using analog magnetometers (Figure 2-11). Excavation spoils were spread out onto the ground in a thin layer (4 to 6 in.) with a wheel loader and then walked over by the Radiological Control Technician (RCT) and UXO technicians using the appropriate instrumentation. In the case of the large anomaly (156_95) located on southwestern Antelope Lake, the spoils were screened using a 3/4-in. grizzly to locate MEC/UXO items (Figure 2-12). The 3/4-in. mesh screen on the grizzly was sized appropriately to segregate the smallest anticipated submunition (BLU-26). The MEC/UXO items were sorted from sanitary debris and MD.

\subsubsection{MEC Surface Clearance}

The Mag and Dig survey technique involves using handheld analog magnetometers capable of detecting the types of MEC expected at CAU 408 to a depth of $1.0 \mathrm{ft}$ below ground surface (bgs) (Figures 2-13 and 2-14). Mag and Dig clearance surveys were performed by UXO personnel using grid systems and walking evenly spaced clearance lanes to ensure full coverage of the clearance area (Figures 2-15 and 2-16). Excavation was performed at several locations to assist in locating anomalies deeper than $1.0 \mathrm{ft}$ bgs and/or to clear large concentrations of surface debris (Figure 2-17). All anomalies identified were excavated/investigated to extinction (no further instrument response).

One location in grid 94/701 on South Antelope Lake, and five locations in three grids (53/815, 53/814, and 52/817) at Mid Target were identified as disposal pits, so verification samples were collected following removal of MD to confirm no COCs were present. The small soil mound in 


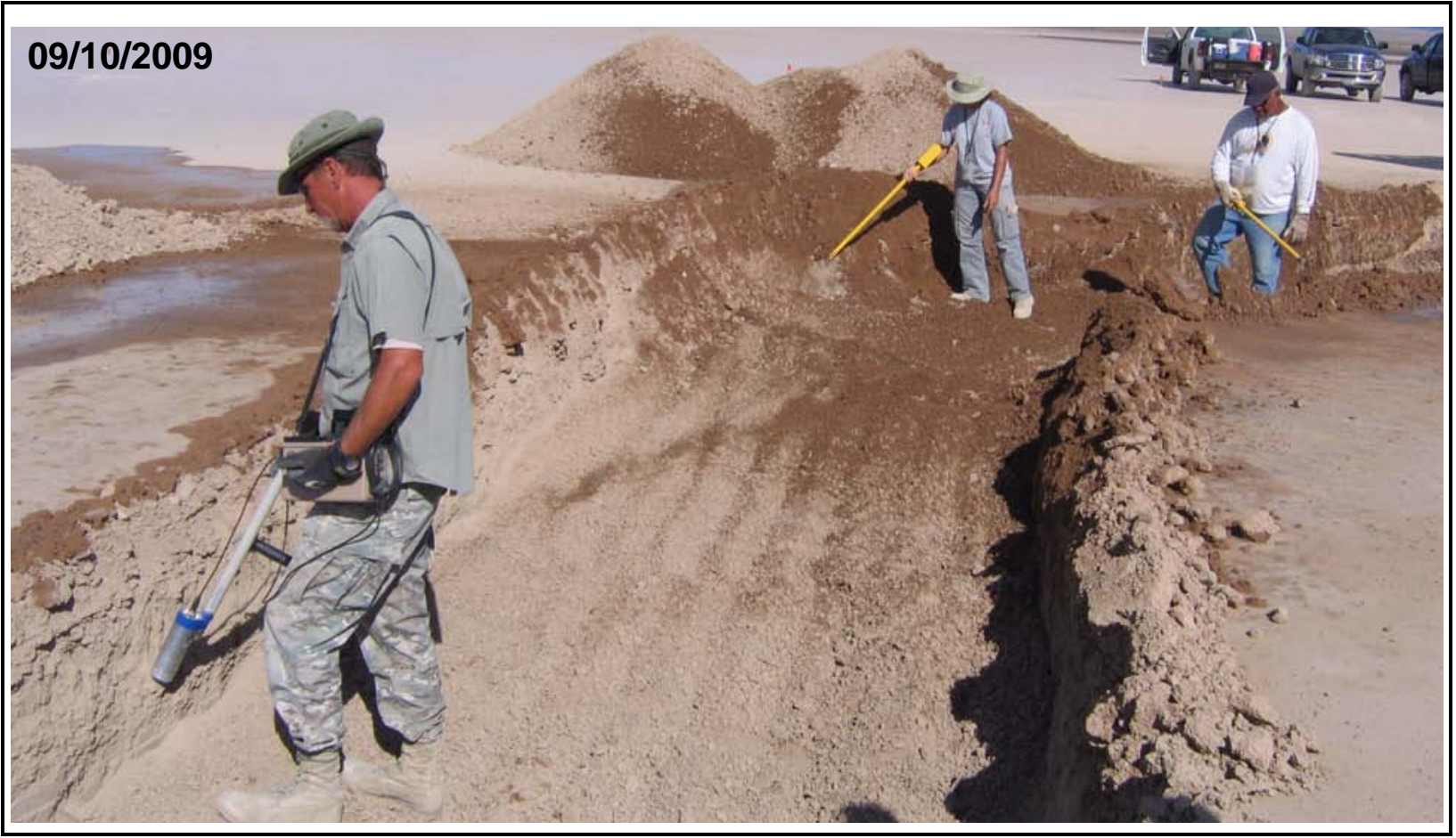

Figure 2-11

Radiological and UXO Screening of Soil in Excavation at Anomaly G104_008

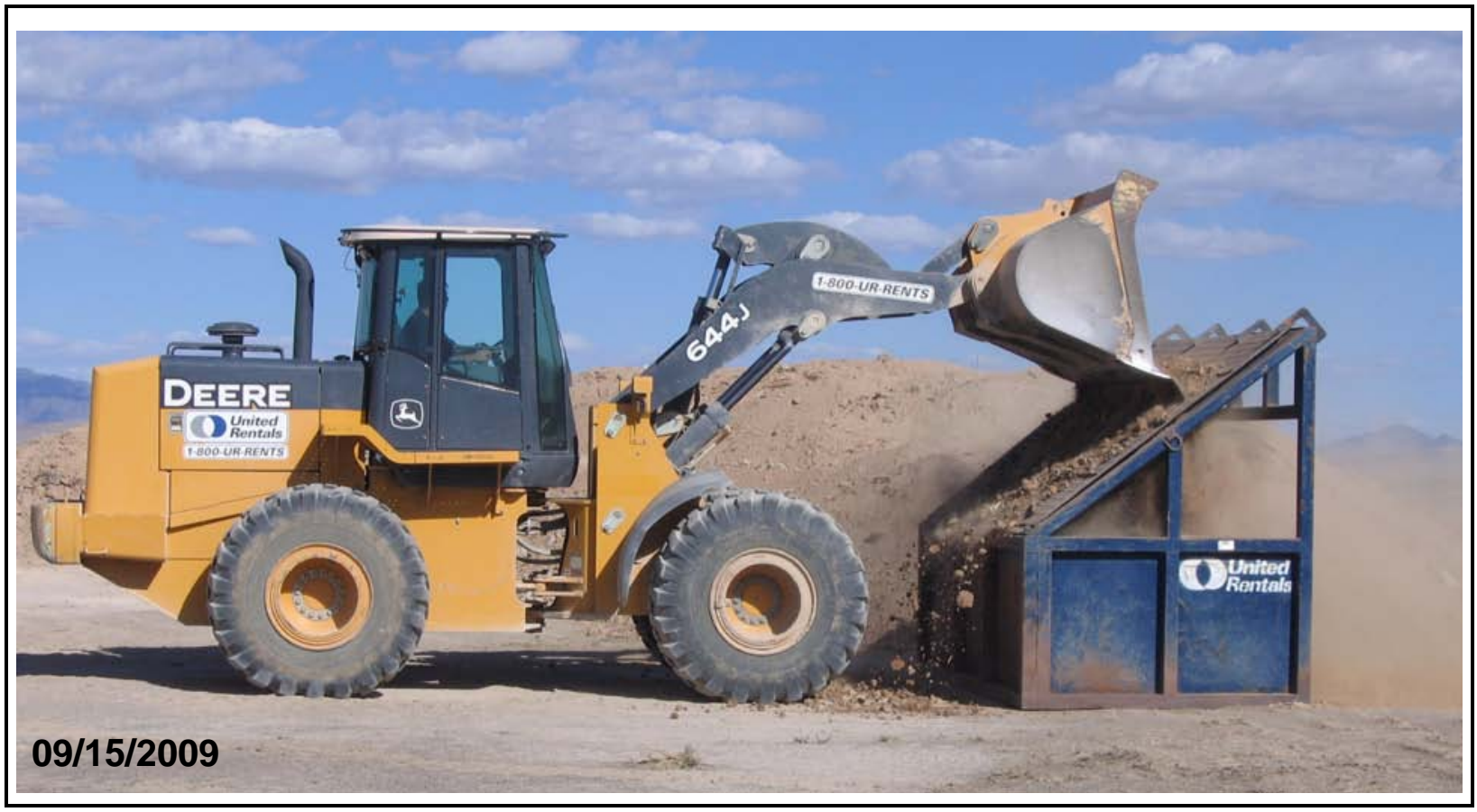

Figure 2-12

Grizzly Operation at Anomaly G156_95 on South Antelope Lake 


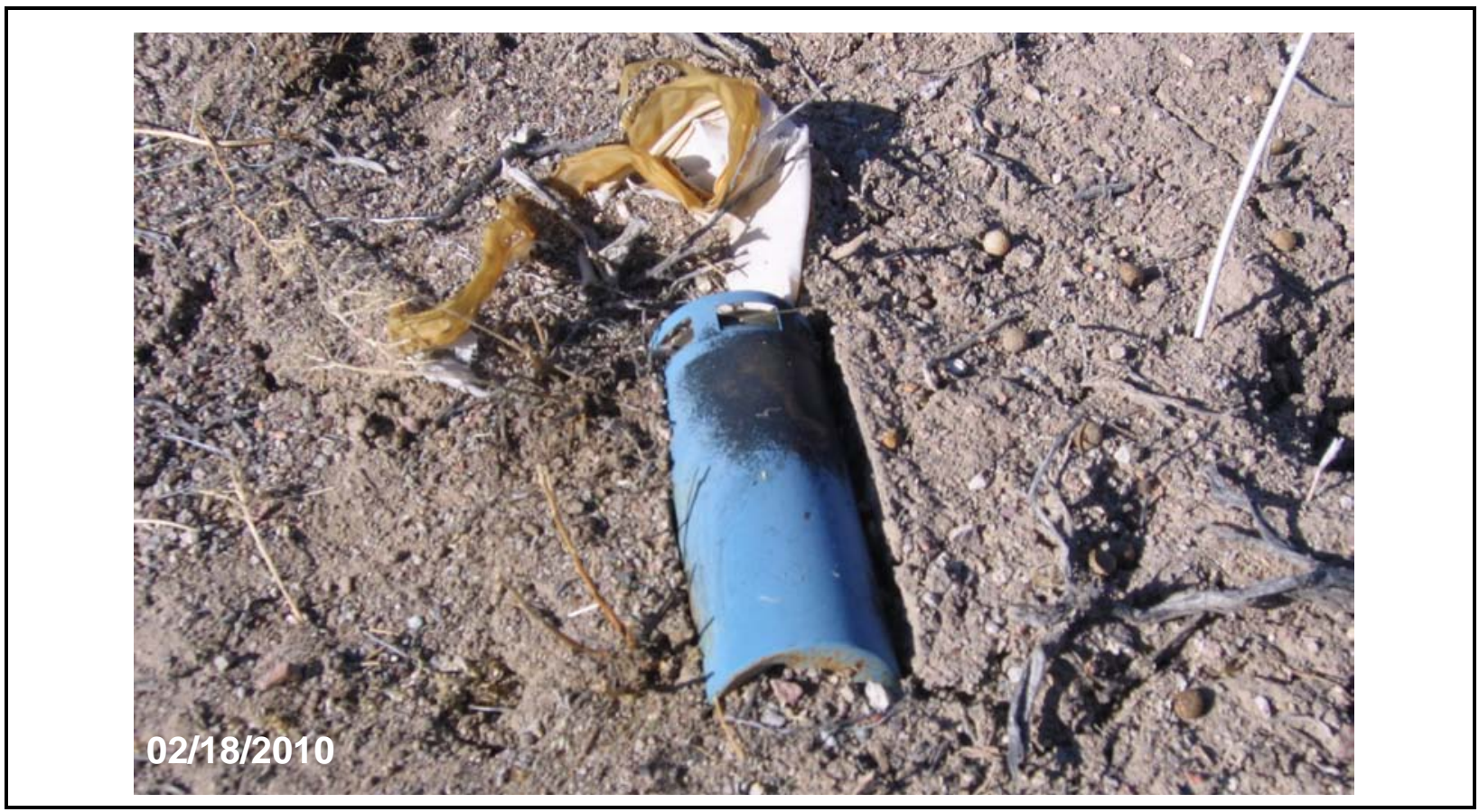

Figure 2-13

\section{BLU-97 Submunition Located on Surface in Mid Target}

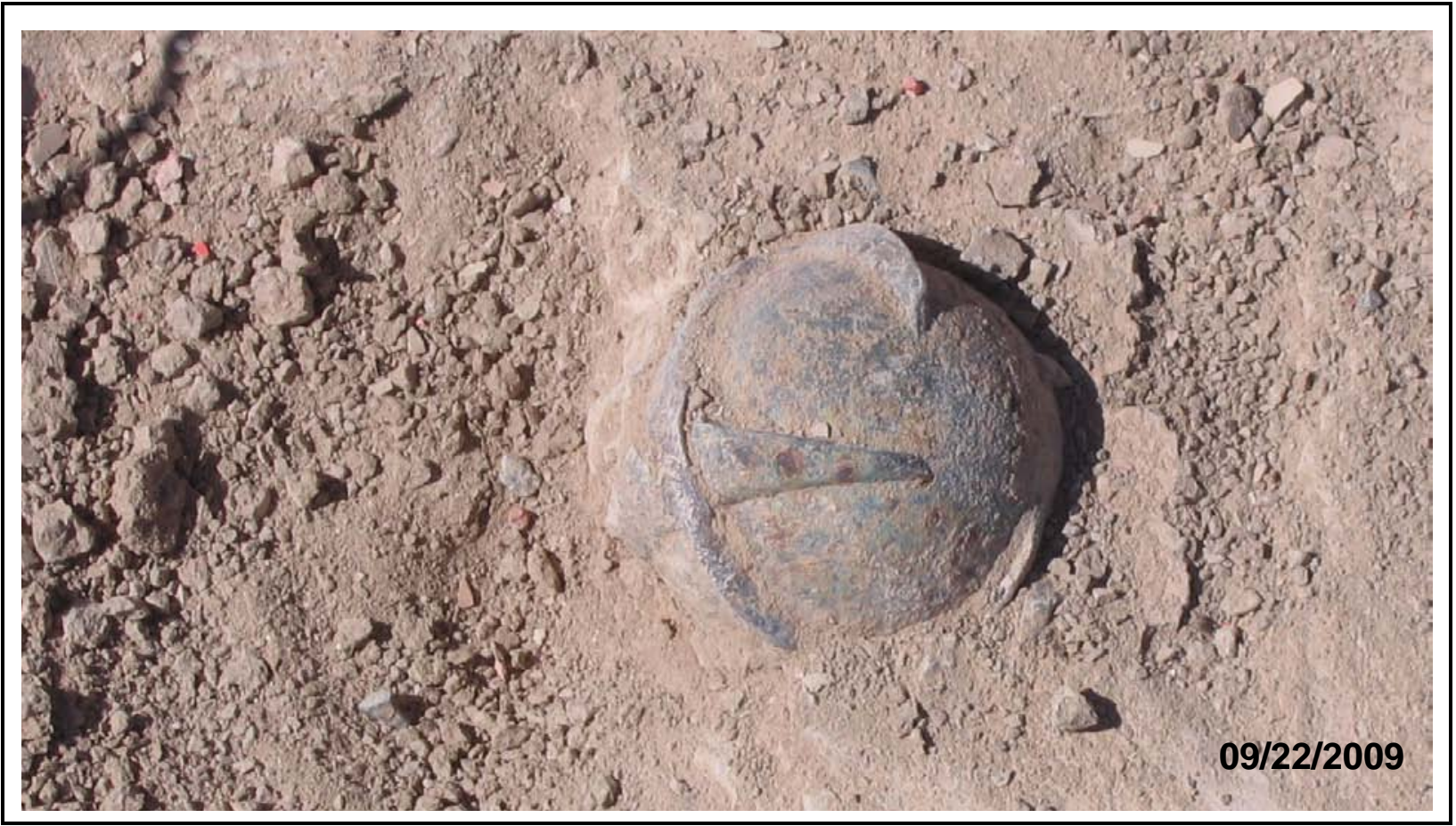

Figure 2-14

BLU-26 Submunition Found near Anomaly D058_01 on South Antelope Lake 


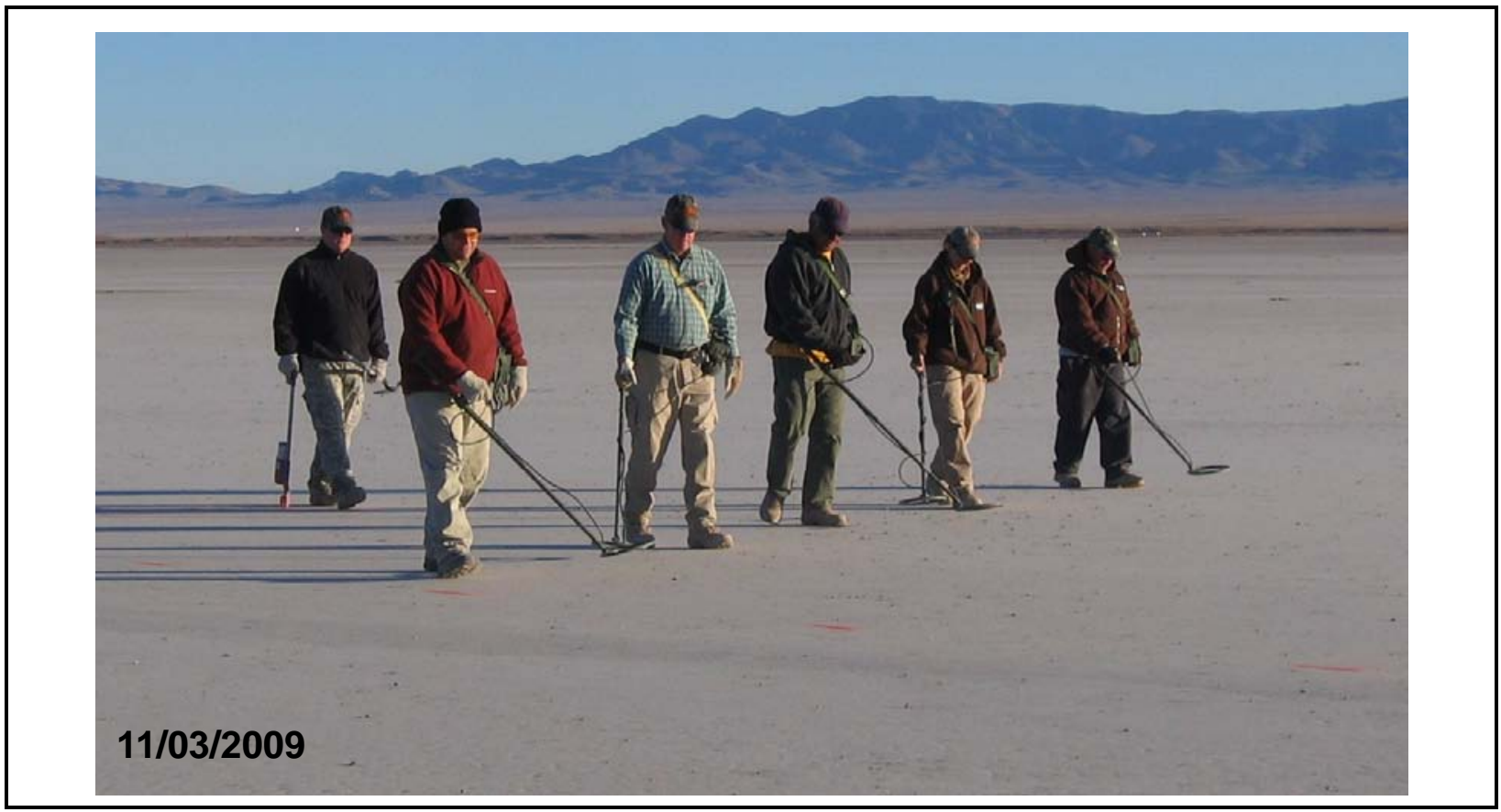

Figure 2-15

UXO Crew Performing Mag and Dig Survey on South Antelope Lake

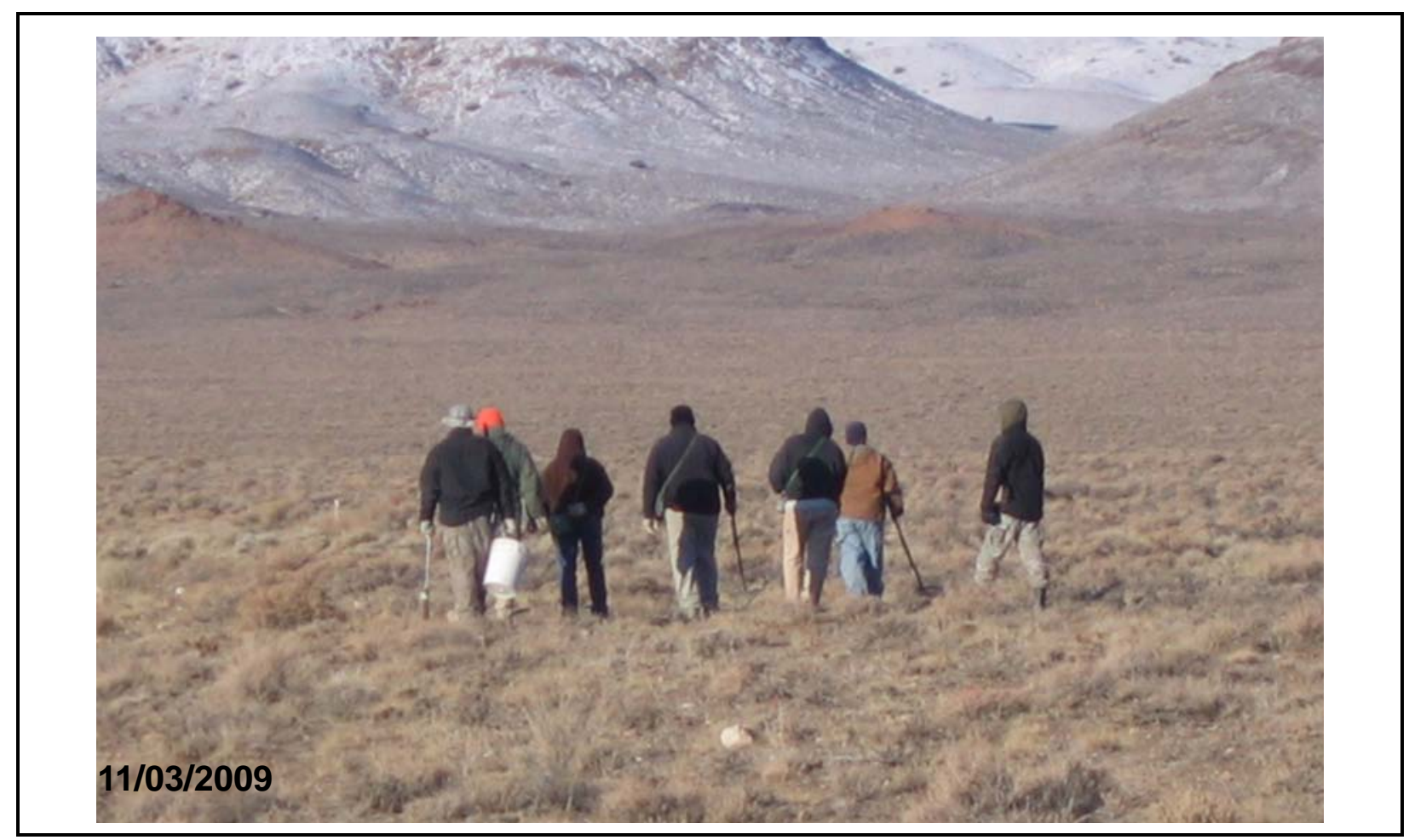

Figure 2-16

UXO Crew Performing Mag and Dig Survey at Tomahawk Target 


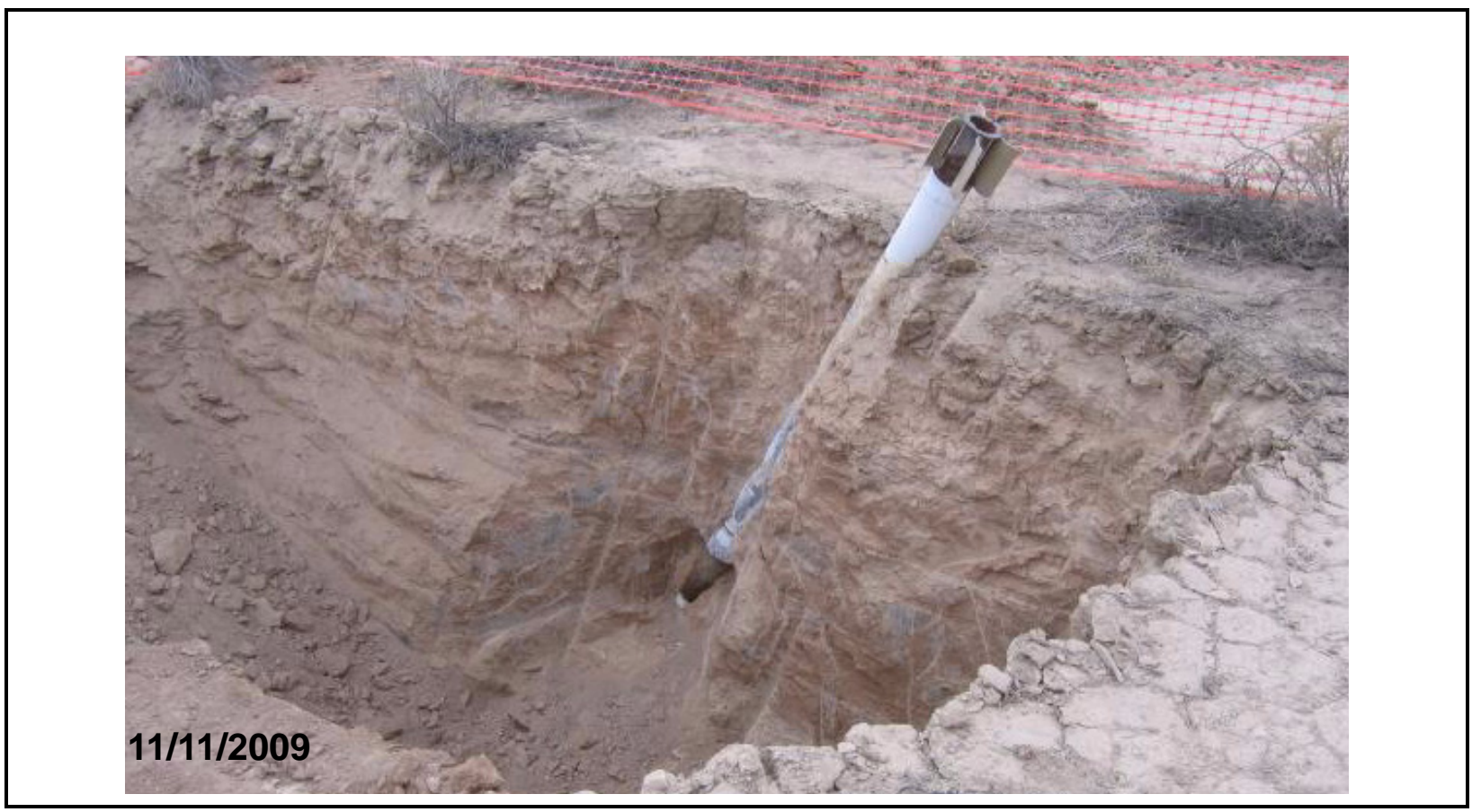

Figure 2-17

\section{Inert Zuni Rocket in Grid 73/733 at SAC Target 1}

grid 71/729 at SAC Target 2 (Figure 2-3) was excavated to assist in removal of a large concentration of MD with one biased soil sample collected. See Section C.3.0 for further details and sample results.

During MEC clearance activities, RCTs were present to perform field screening on debris recovered due to the known and suspected presence of DU. Several pieces of metal debris were identified as being impacted with DU and were removed for disposal. Table 2-2 presents an accounting of the DU-impacted contaminated metal fragments and debris identified and removed during investigation activities.

All pieces of DU-impacted metal and debris (Figure 2-18) discovered during CAU 408 CAI activities were discrete fragments found on the surface and are likely associated with non-DOE-related submunition testing. The walkover surveys performed as part of the CAU 408 project allowed a thorough investigation of the area and identification of additional DU-impacted metal and debris. 
Table 2-2

\section{DU-Impacted Debris}

(Page 1 of 3)

\begin{tabular}{|c|c|c|c|}
\hline Date & Description & Grid & Grid Coordinates \\
\hline $11 / 18 / 2009$ & $\begin{array}{l}\text { One small piece of DU-impacted debris, limited to one } \\
\text { face of the metal, about } 1 \text { by } 1 \text { in. found on grid } 90 / 703 \\
\text { exhibiting } 600 \mathrm{dpm} / 100 \mathrm{~cm}^{2} \text { alpha fixed and } \\
17,000 \mathrm{dpm} / 100 \mathrm{~cm}^{2} \text { beta/gamma fixed. }\end{array}$ & $\begin{array}{l}\text { South Antelope Lake } \\
90 / 703\end{array}$ & $\begin{array}{l}\text { UTM83N, UTM83E } \\
4170344,529158 \\
4170344,529058 \\
4170444,529058 \\
4170444,529158\end{array}$ \\
\hline $11 / 18 / 2009$ & $\begin{array}{l}\text { One small piece of DU-impacted debris, limited to one } \\
\text { face of the metal, about } 1 \text { by } 1 \text { in. found on grid } 92 / 702 \\
\text { exhibiting } 100 \mathrm{dpm} / 100 \mathrm{~cm}^{2} \text { alpha fixed and } \\
13,600 \mathrm{dpm} / 100 \mathrm{~cm}^{2} \text { beta/gamma fixed. }\end{array}$ & $\begin{array}{l}\text { South Antelope Lake } \\
\qquad 92 / 702\end{array}$ & $\begin{array}{l}\text { UTM83N, UTM83E } \\
4170244,529258 \\
4170344,529258 \\
4170244,529358 \\
4170344,529358\end{array}$ \\
\hline $11 / 19 / 2009$ & $\begin{array}{l}\text { Two small pieces of DU-impacted debris about } \\
1 \text { by } 1 \text { in. found on grid } 91 / 702 \text { exhibiting } \\
600 \mathrm{dpm} / 100 \mathrm{~cm}^{2} \text { alpha fixed and } 17,000 \mathrm{dpm} / 100 \mathrm{~cm}^{2} \\
\text { beta/gamma fixed, and } 600 \mathrm{dpm} / 100 \mathrm{~cm}^{2} \text { alpha fixed } \\
\text { and } 21,000 \mathrm{dpm} / 100 \mathrm{~cm}^{2} \text { beta/gamma fixed. }\end{array}$ & $\begin{array}{l}\text { South Antelope Lake } \\
\qquad 91 / 702\end{array}$ & $\begin{array}{l}\text { UTM83N, UTM83E } \\
4170244,529258 \\
4170244,529158 \\
4170344,529158 \\
4170344,529258\end{array}$ \\
\hline $11 / 20 / 2009$ & $\begin{array}{l}\text { One piece of DU-impacted debris } 1 \text { by } 1 \text { in. found on } \\
\text { grid } 93 / 702 \text { exhibiting } 250 \mathrm{dpm} / 100 \mathrm{~cm}^{2} \text { alpha fixed and } \\
15,000 \mathrm{dpm} / 100 \mathrm{~cm}^{2} \text { beta/gamma fixed. }\end{array}$ & $\begin{array}{l}\text { South Antelope Lake } \\
\qquad 93 / 702\end{array}$ & $\begin{array}{l}\text { UTM83N, UTM83E } \\
4170244,529358 \\
4170344,529358 \\
4170244,529458 \\
4170344,529458\end{array}$ \\
\hline $12 / 16 / 2009$ & $\begin{array}{l}\text { One piece of DU frag } 1 \text { by } 2 \text { in. found on grid 93/696 } \\
\text { exhibiting } 200 \mathrm{dpm} / 100 \mathrm{~cm}^{2} \text { alpha fixed and } \\
56,000 \mathrm{dpm} / 100 \mathrm{~cm}^{2} \text { beta/gamma fixed. }\end{array}$ & $\begin{array}{l}\text { South Antelope Lake } \\
\qquad 93 / 696\end{array}$ & $\begin{array}{l}\text { UTM83N, UTM83E } \\
4169644,529458 \\
4169644,529358 \\
4169744,529358 \\
4169744,529458\end{array}$ \\
\hline 01/04/2010 & $\begin{array}{l}\text { One piece of DU frag approximately } 1 \mathrm{ft} \text { square found } \\
\text { on grid } 89 / 697 \text { exhibiting } 14,000 \mathrm{dpm} / 100 \mathrm{~cm}^{2} \text { alpha } \\
\text { fixed and } 1,000,000 \mathrm{dpm} / 100 \mathrm{~cm}^{2} \text { beta/gamma fixed. }\end{array}$ & $\begin{array}{l}\text { South Antelope Lake } \\
\qquad 89 / 697\end{array}$ & $\begin{array}{l}\text { UTM83N, UTM83E } \\
4169744,529058 \\
4169744,528958 \\
4169844,528958 \\
4169844,529058\end{array}$ \\
\hline 01/14/2010 & $\begin{array}{l}\text { One piece of DU frag } 1.5 \text { by } 2 \text { in. found on grid } 93 / 693 \\
\text { exhibiting } 250 \mathrm{dpm} / 100 \mathrm{~cm}^{2} \text { alpha and } \\
75,000 \mathrm{dpm} / 100 \mathrm{~cm}^{2} \text { beta/gamma. }\end{array}$ & $\begin{array}{l}\text { South Antelope Lake } \\
\qquad 93 / 693\end{array}$ & $\begin{array}{l}\text { UTM83N, UTM83E } \\
4169344,529458 \\
4169344,529358 \\
4169444,529358 \\
4169444,529458\end{array}$ \\
\hline 01/15/2010 & $\begin{array}{l}\text { One piece of DU alloy found on grid 94/695 exhibiting } \\
13,000 \mathrm{dpm} / 100 \mathrm{~cm}^{2} \text { alpha fixed and } \\
1,500,000 \mathrm{dpm} / 100 \mathrm{~cm}^{2} \text { beta/gamma fixed. }\end{array}$ & $\begin{array}{l}\text { South Antelope Lake } \\
\qquad 94 / 695\end{array}$ & $\begin{array}{l}\text { UTM83N, UTM83E } \\
4169544,529558 \\
4169544,529458 \\
4169644,529458 \\
4169644,529558\end{array}$ \\
\hline 01/19/2010 & $\begin{array}{l}\text { One piece of DU frag } 1 \text { by } 2 \text { in. found on grid 93/689 } \\
\text { exhibiting } 150 \mathrm{dpm} / 100 \mathrm{~cm}^{2} \text { alpha fixed and } \\
8,000 \mathrm{dpm} / 100 \mathrm{~cm}^{2} \text { beta/gamma fixed. }\end{array}$ & $\begin{array}{l}\text { South Antelope Lake } \\
93 / 689\end{array}$ & $\begin{array}{l}\text { UTM83N, UTM83E } \\
4168944,529358 \\
4168944,529458 \\
4169044,529358 \\
4169044,529458\end{array}$ \\
\hline
\end{tabular}


Table 2-2

\section{DU-Impacted Debris}

(Page 2 of 3)

\begin{tabular}{|c|c|c|c|}
\hline Date & Description & Grid & Grid Coordinates \\
\hline 01/20/2010 & $\begin{array}{l}\text { One piece of DU frag } 2 \text { by } 2 \text { in. found on grid 92/688 } \\
\text { exhibiting } 125 \mathrm{dpm} / 100 \mathrm{~cm}^{2} \text { alpha fixed and } \\
11,000 \mathrm{dpm} / 100 \mathrm{~cm}^{2} \text { beta/gamma fixed. }\end{array}$ & $\begin{array}{l}\text { South Antelope Lake } \\
92 / 688\end{array}$ & $\begin{array}{l}\text { UTM83N, UTM83E } \\
4168844,529258 \\
4168944,529258 \\
4168844,529358 \\
4168944,529358\end{array}$ \\
\hline $01 / 21 / 2010$ & $\begin{array}{l}\text { One piece of DU alloy } 1.5 \text { by } 1.5 \mathrm{in} \text {. found on } \\
\text { grid } 91 / 688 \text { exhibiting } 3,200 \mathrm{dpm} / 100 \mathrm{~cm}^{2} \text { alpha fixed, } \\
\text { and } 902,000 \mathrm{dpm} / 100 \mathrm{~cm}^{2} \text { on beta/gamma fixed. }\end{array}$ & $\begin{array}{l}\text { South Antelope Lake } \\
\qquad 91 / 688\end{array}$ & $\begin{array}{l}\text { UTM83N, UTM83E } \\
4168844,529258 \\
4168844,529158 \\
4168944,529158 \\
4168944,529258\end{array}$ \\
\hline 01/21/2010 & $\begin{array}{l}\text { One piece of DU alloy } 0.5 \text { by } 0.75 \text { in. found on } \\
\text { grid } 91 / 691 \text { exhibiting } 2,000 \mathrm{dpm} / 100 \mathrm{~cm}^{2} \text { alpha fixed } \\
\text { and } 316,000 \mathrm{dpm} / 100 \mathrm{~cm}^{2} \text { beta/gamma fixed. }\end{array}$ & $\begin{array}{l}\text { South Antelope Lake } \\
\qquad 91 / 691\end{array}$ & $\begin{array}{l}\text { UTM83N, UTM83E } \\
4169144,529158 \\
4169144,529258 \\
4169244,529158 \\
4169244,529258\end{array}$ \\
\hline $01 / 21 / 2010$ & $\begin{array}{l}\text { One piece of DU alloy } 1 \text { by } 2 \text { in. found on grid 91/690 } \\
\text { exhibiting } 15,000 \mathrm{dpm} / 100 \mathrm{~cm}^{2} \text { alpha fixed and } \\
1,300,000 \mathrm{dpm} / 100 \mathrm{~cm}^{2} \text { beta/gamma fixed. }\end{array}$ & $\begin{array}{l}\text { South Antelope Lake } \\
\qquad 91 / 690\end{array}$ & $\begin{array}{l}\text { UTM83N, UTM83E } \\
4169044,529158 \\
4169144,529158 \\
4169044,529258 \\
4169144,529258\end{array}$ \\
\hline $01 / 21 / 2010$ & $\begin{array}{l}\text { One piece of DU alloy } 1 \text { by } 0.5 \text { in. found on grid } 90 / 690 \\
\text { exhibiting } 750 \mathrm{dpm} / 100 \mathrm{~cm}^{2} \text { alpha fixed and } \\
547,000 \mathrm{dpm} / 100 \mathrm{~cm}^{2} \text { beta/gamma fixed. }\end{array}$ & $\begin{array}{l}\text { South Antelope Lake } \\
\qquad 90 / 690\end{array}$ & $\begin{array}{l}\text { UTM83N, UTM83E } \\
4169044,529158 \\
4169044,529058 \\
4169144,529058 \\
4169144,529158\end{array}$ \\
\hline 02/24/2010 & $\begin{array}{l}\text { One piece of DU alloy } 1 \text { by } 5 \text { in. found South Antelope } \\
\text { Lake exhibiting } 276 \mathrm{dpm} / 100 \mathrm{~cm}^{2} \text { alpha fixed and } \\
1,067,000 \mathrm{dpm} / 100 \mathrm{~cm}^{2} \text { beta/gamma fixed in grid } \\
97 / 688 .\end{array}$ & $\begin{array}{l}\text { South Antelope Lake } \\
97 / 688\end{array}$ & $\begin{array}{l}\text { UTM83N, UTM83E } \\
4168844,529858 \\
4168844,529758 \\
4168944,529758 \\
4168944,529858\end{array}$ \\
\hline 03/12/2010 & $\begin{array}{l}\text { Two pieces of DU frag, } 1 \text { by } 1.5 \mathrm{in} \text {. found at south end } \\
\text { of Antelope Lake exhibiting } 200 \mathrm{dpm} / 100 \mathrm{~cm}^{2} \text { alpha } \\
\text { fixed and } 5,000 \mathrm{dpm} / 100 \mathrm{~cm}^{2} \text { beta/gamma fixed. }\end{array}$ & $\begin{array}{l}\text { South Antelope Lake } \\
\text { South Boundary }\end{array}$ & $\begin{array}{c}\text { No coordinates } \\
\text { available }\end{array}$ \\
\hline 04/07/2010 & $\begin{array}{l}\text { Two pieces of DU frag found at grid 00/702 exhibiting } \\
124 \mathrm{dpm} / 100 \mathrm{~cm}^{2} \text { alpha fixed, 35,000 beta/gamma, } \\
\text { and } 74 \mathrm{dpm} / 100 \mathrm{~cm}^{2} \text { alpha, } 95,000 \text { beta/gamma } \\
\text { fixed, respectively. }\end{array}$ & $\begin{array}{l}\text { South Antelope Lake } \\
\text { 00/702 }\end{array}$ & $\begin{array}{l}\text { UTM83N, UTM83E } \\
4170244,530158 \\
4170244,530058 \\
4170344,530058 \\
4170344,530158\end{array}$ \\
\hline 04/26/2010 & $\begin{array}{l}\text { One } 1.5 \text { by } 1.5 \mathrm{in.} \text { of DU alloy in grid } 96 / 692 \\
\text { exhibiting } 2,800 \mathrm{dpm} / 100 \mathrm{~cm}^{2} \text { alpha fixed and } \\
885,000 \mathrm{dpm} / 100 \mathrm{~cm}^{2} \text { beta/gamma fixed. }\end{array}$ & $\begin{array}{l}\text { South Antelope Lake } \\
\qquad 96 / 692\end{array}$ & $\begin{array}{l}\text { UTM83N, UTM83E } \\
4169244,529758 \\
4169244,529658 \\
4169344,529658 \\
4169344,529758\end{array}$ \\
\hline
\end{tabular}


Table 2-2

\section{DU-Impacted Debris}

(Page 3 of 3 )

\begin{tabular}{|c|c|c|c|}
\hline Date & Description & Grid & Grid Coordinates \\
\hline 04/28/2010 & $\begin{array}{l}\text { One } 1 \text { by } 2 \text { in. DU alloy frag found on grid } 94 / 688 \\
\text { exhibiting } 15,000 \mathrm{dpm} / 100 \mathrm{~cm}^{2} \text { alpha fixed and } \\
1,800,000 \mathrm{dpm} / 100 \mathrm{~cm}^{2} \text { beta/gamma fixed. }\end{array}$ & $\begin{array}{l}\text { South Antelope Lake } \\
94 / 688\end{array}$ & $\begin{array}{l}\text { UTM83N, UTM83E } \\
4168844,529558 \\
4168844,529458 \\
4168944,529458 \\
4168944,529558\end{array}$ \\
\hline 05/20/2010 & $\begin{array}{l}\text { One 6-by-14-in. piece of DU-impacted debris found } \\
500 \mathrm{~m} \text { from the south end of NEDS Lake in the buffer } \\
\text { zone exhibiting } 3,000 \mathrm{dpm} / 100 \mathrm{~cm}^{2} \text { alpha fixed and } \\
170,000 \mathrm{dpm} / 100 \mathrm{~cm}^{2} \text { beta/gamma. A second piece } \\
\text { of DU metal } 2 \text { by } 1 \mathrm{in} \text {. found on the southwest corner } \\
\text { of NEDS Lake just outside the buffer zone } \\
\text { exhibiting } 649 \mathrm{dpm} / 100 \mathrm{~cm}^{2} \text { alpha fixed and } \\
2,409,000 \mathrm{dpm} / 100 \mathrm{~cm}^{2} \text { beta/gamma fixed. }\end{array}$ & $\begin{array}{l}\text { Southwest corner } \\
\text { NEDS Lake and } \\
500 \text { m south of } \\
\text { NEDS Lake }\end{array}$ & $\begin{array}{c}\text { No coordinates } \\
\text { available }\end{array}$ \\
\hline 05/24/2010 & $\begin{array}{l}\text { One DU-impacted piece of debris found in scrub area } \\
\text { west of NEDS Lake/DU Bunker area exhibiting } \\
132 \mathrm{dpm} / 100 \mathrm{~cm}^{2} \text { alpha fixed and } 210,000 \mathrm{dpm} / 100 \mathrm{~cm}^{2} \\
\text { beta/gamma fixed. A second piece of DU-impacted } \\
\text { debris found exhibiting } 112 \mathrm{dpm} / 100 \mathrm{~cm}^{2} \text { alpha fixed } \\
\text { and } 274,000 \mathrm{dpm} / 100 \mathrm{~cm}^{2} \text { beta/gamma fixed in the } \\
\text { same general area as the location of the first piece. }\end{array}$ & $\begin{array}{l}\text { Buffer Zone - north of } \\
\text { Flightline and west of } \\
\text { NEDS Lake }\end{array}$ & $\begin{array}{c}\text { No coordinates } \\
\text { available }\end{array}$ \\
\hline 06/21/2010 & $\begin{array}{l}\text { One piece of DU-impacted metal frag approximately } \\
6 \text { by } 6 \text { in. in size. Radiological readings on the item } \\
\text { exhibiting } 115 \mathrm{dpm} / 100 \mathrm{~cm}^{2} \text { alpha fixed and } \\
17,000 \mathrm{dpm} / 100 \mathrm{~cm}^{2} \text { beta/gamma fixed. }\end{array}$ & $\begin{array}{l}\text { Buffer Zone on the } \\
\text { east side of Flightline } \\
\text { Road, between } \\
\text { Flightline and Mid } \\
\text { Targets }\end{array}$ & $\begin{array}{c}\text { No coordinates } \\
\text { available }\end{array}$ \\
\hline
\end{tabular}

$\mathrm{dpm} / 100 \mathrm{~cm}^{2}=$ Disintegrations per minute per 100 square centimeters

UTM = Universal Transverse Mercator

\subsubsection{Buffer Zone Visual Sweep}

Inspections of the buffer zone consisted of UXO personnel walking and/or driving an all-terrain utility vehicle along evenly spaced lanes (personnel spaced 15 to $20 \mathrm{ft}$ apart) within each buffer zone grid to visually identify MEC items present outside of identified target areas (Figure 2-19). A total of approximately 8,660 acres were inspected for MEC within the buffer zone.

In addition to MEC identification and removal during the buffer zone visual sweeps, several pieces of metal debris were identified as being impacted with DU and were removed for disposal. Table 2-2 summarizes the locations and radiological readings for the DU-impacted debris discovered during the investigation. All pieces of DU-impacted metal and debris discovered during CAU 408 CAI activities were discrete fragments found on the surface (Section 2.2.3). 


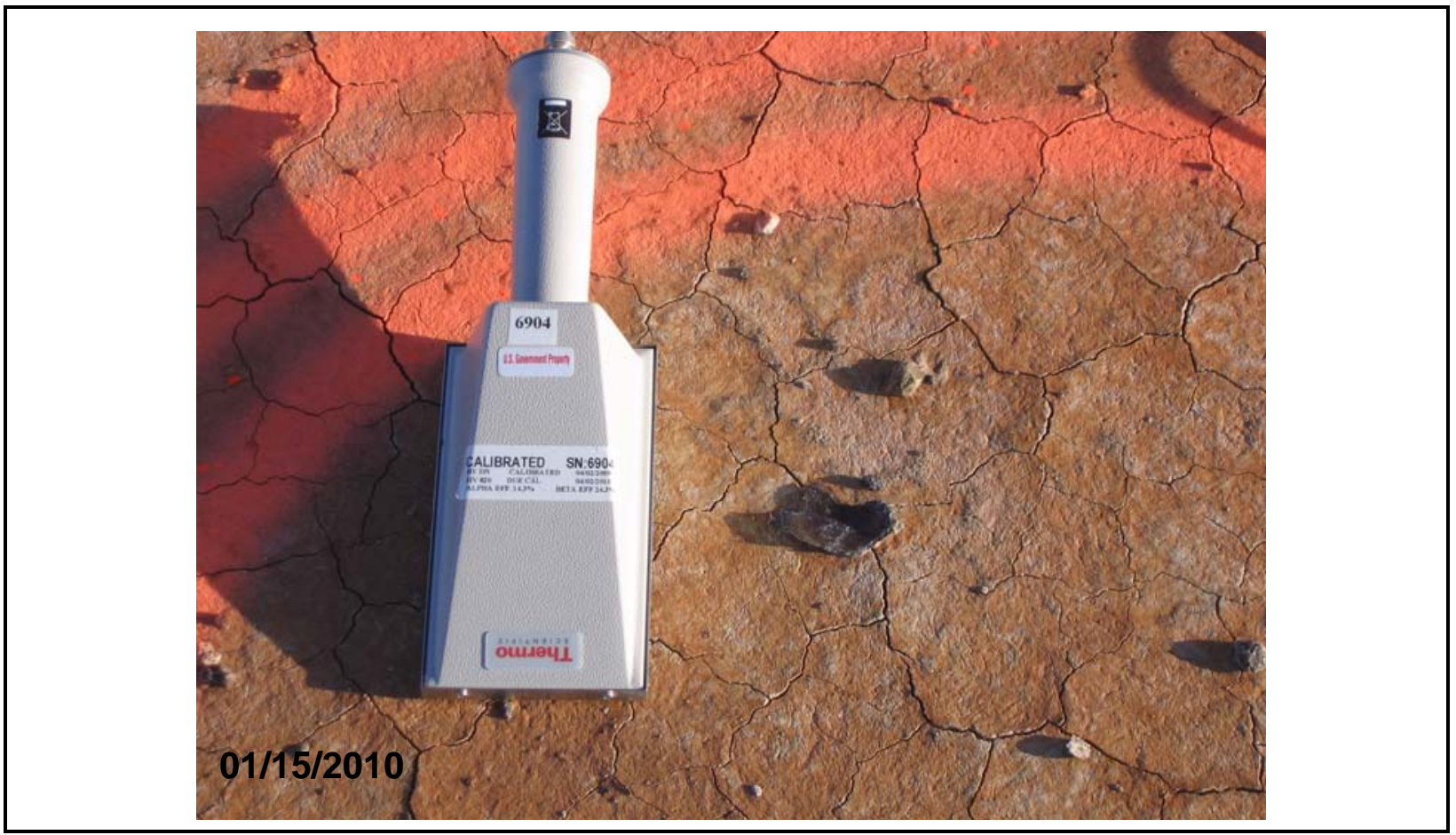

Figure 2-18

Small Fragment of DU Alloy Found in Grid 94/695 on South Antelope Lake

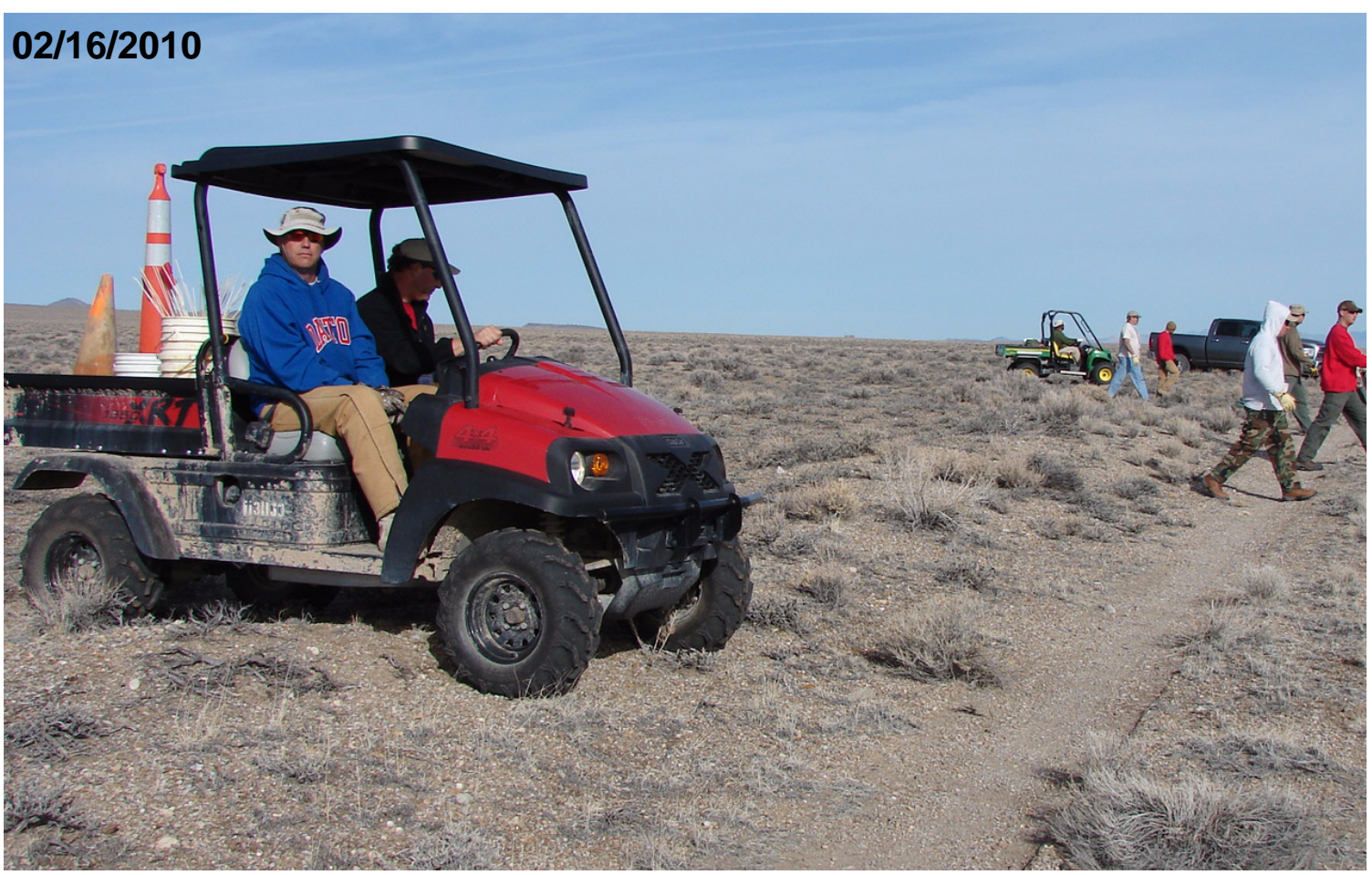

Figure 2-19

Visual Inspection of Buffer Zone at Tomahawk Target 2 
During visual sweep of the eastern boundary of the buffer zone near Mid Target, several intact bomblets and MD were identified in and around the CAU 400 Bomblet Pit. As a BMP, the CAU 408 investigation area was extended to encompass the CAU 400 Bomblet Pit. A grid system was established around the CAU 400 fence line. Mag and Dig surveys were performed within the fence line and within the 15 grids established outside the fence line. An additional visual sweep was conducted extending $100 \mathrm{~m}$ beyond the 15 grids. See Appendix B for additional details.

Personnel also identified a mound of soil (approximately 5 cubic feet) impacted with DU inside a concrete bunker near NEDS Lake (Figures 2-20 and 2-21). The origin of the DU-contaminated soil is unknown and not likely CAU 408 related; however, the soil mound was removed and containerized for disposal. Following removal of the DU-contaminated soil, the soil underneath the mound and surrounding area was surveyed using all NE Electra with DP6BD probe, and determined to be indistinguishable from background.

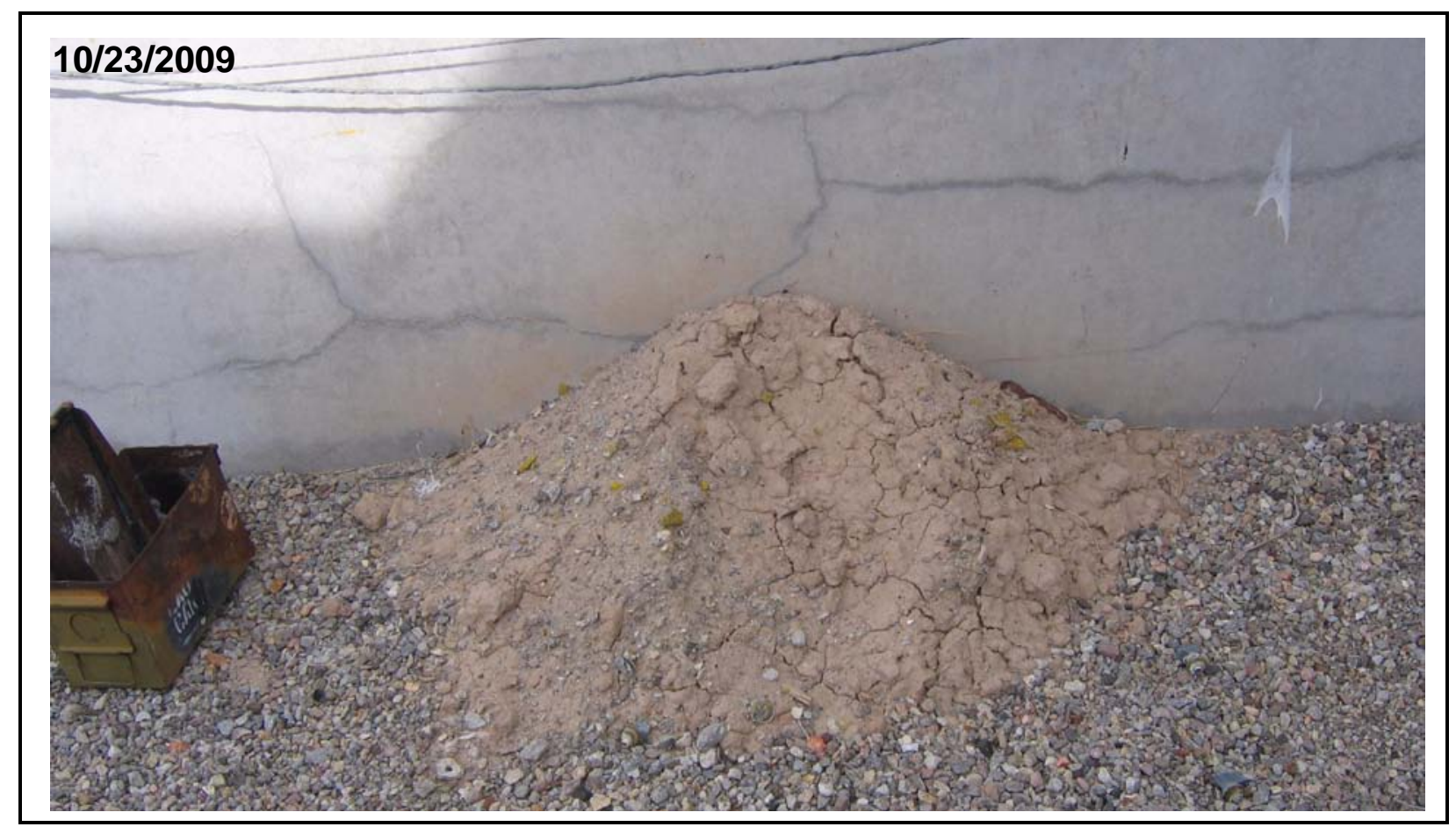

Figure 2-20

DU-Contaminated Soil Pile in Bunker near NEDS Lake 


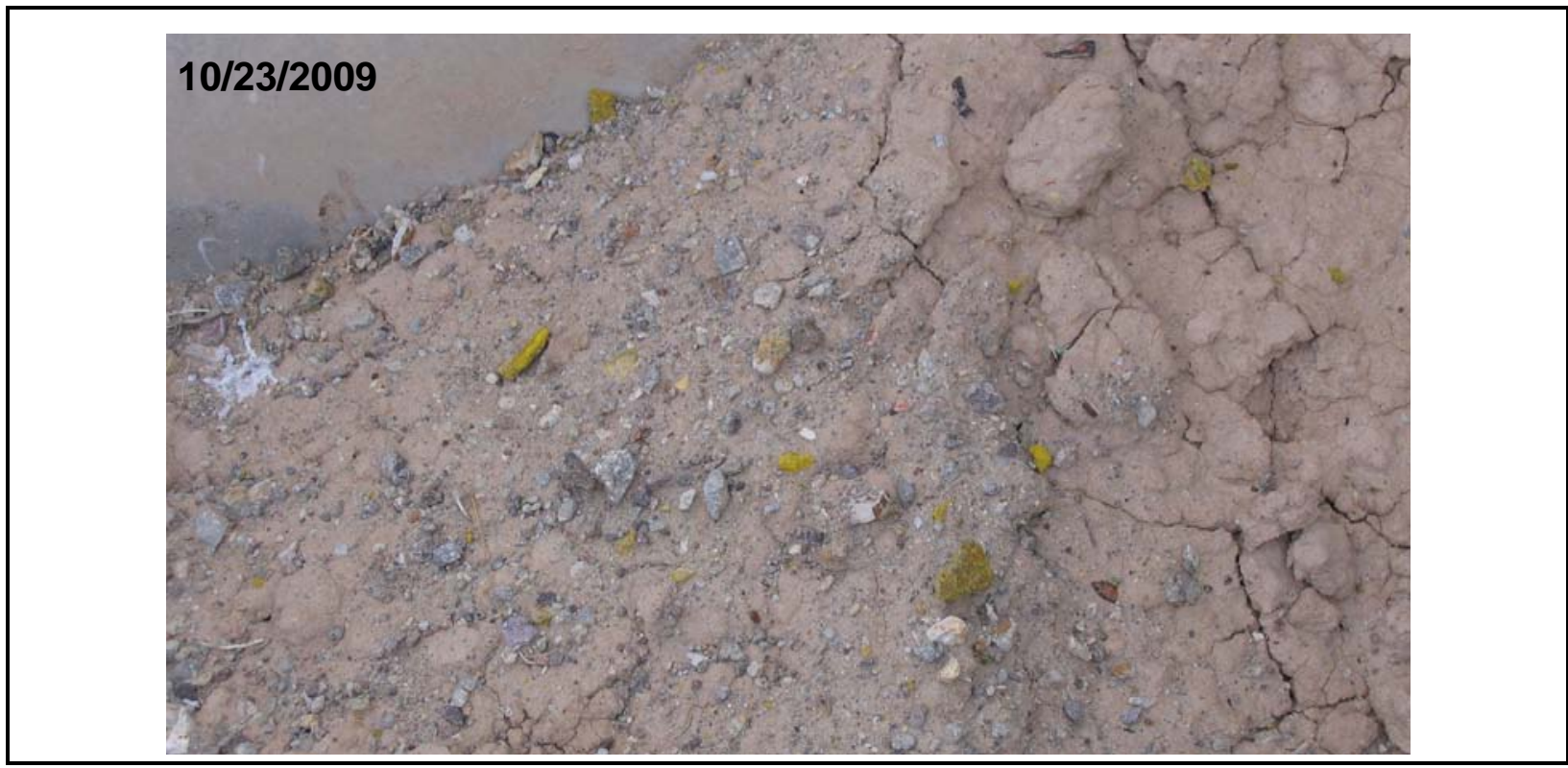

Figure 2-21

Closeup View of Oxidized DU Contamination in Soil Pile

\subsubsection{MEC/UXO Demolition and Disposal}

All MEC/UXO identified by UXO personnel was either blown in place (Figure 2-22) or, if deemed safe to move, consolidated to a centralized location for demolition (Figures 2-23 and 2-24). The MEC recovered from disposal pits were demilitarized under an approved NDEP Emergency Resource Conservation and Recovery Act (RCRA) Permit (Murphy, 2009 and 2010) (see Section 3.0 for details). The MEC recovered during surface clearance surveys were demilitarized under the Military Munitions Rule (CFR, 2010). Recovery and destruction of MEC during range clearance activities is not a solid waste, and is therefore exempt from RCRA as a hazardous waste under the Military Munitions Rule.

Five demolition events (Figure 2-25) were conducted to render all MEC inert between February and August 2010. The first three events included MEC treated under the NDEP Emergency Treatment Permit (Murphy, 2009 and 2010), the last two events included remaining MEC recovered under the Military Munitions Rule (CFR, 2010). Table 2-3 summarizes the demolition events, including detonation times, donor explosives, and treatment locations. Inspection of the demolition site by qualified UXO personnel was completed following each detonation. Inspection of the site included visual and magnetometer sweep of the area for removal of remaining fragments and debris. Visual inspection confirmed the absence of any remaining explosive residues. 


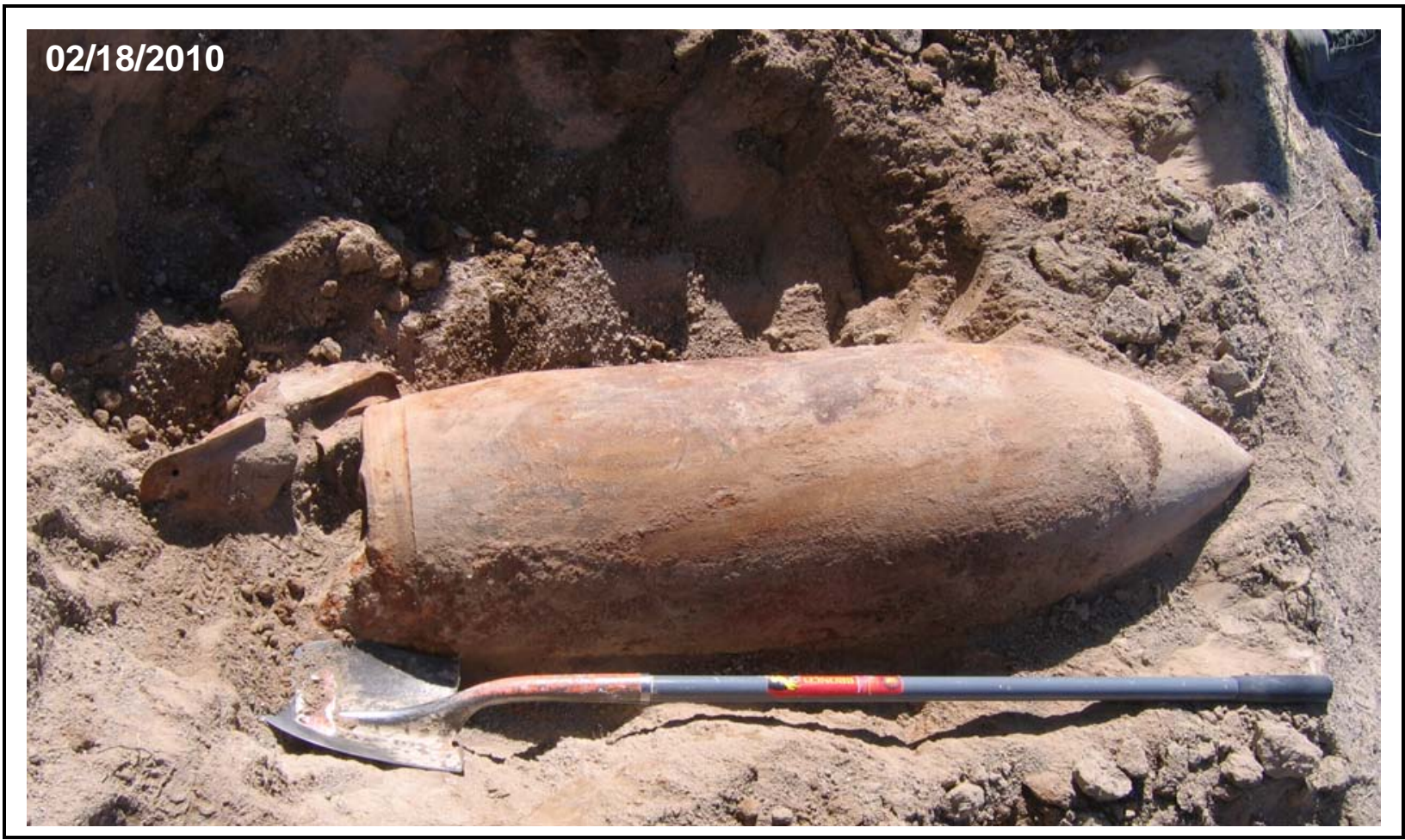

Figure 2-22

M117A1 (750-lb bomb) Uncovered in Grid 53/816 at Mid Target

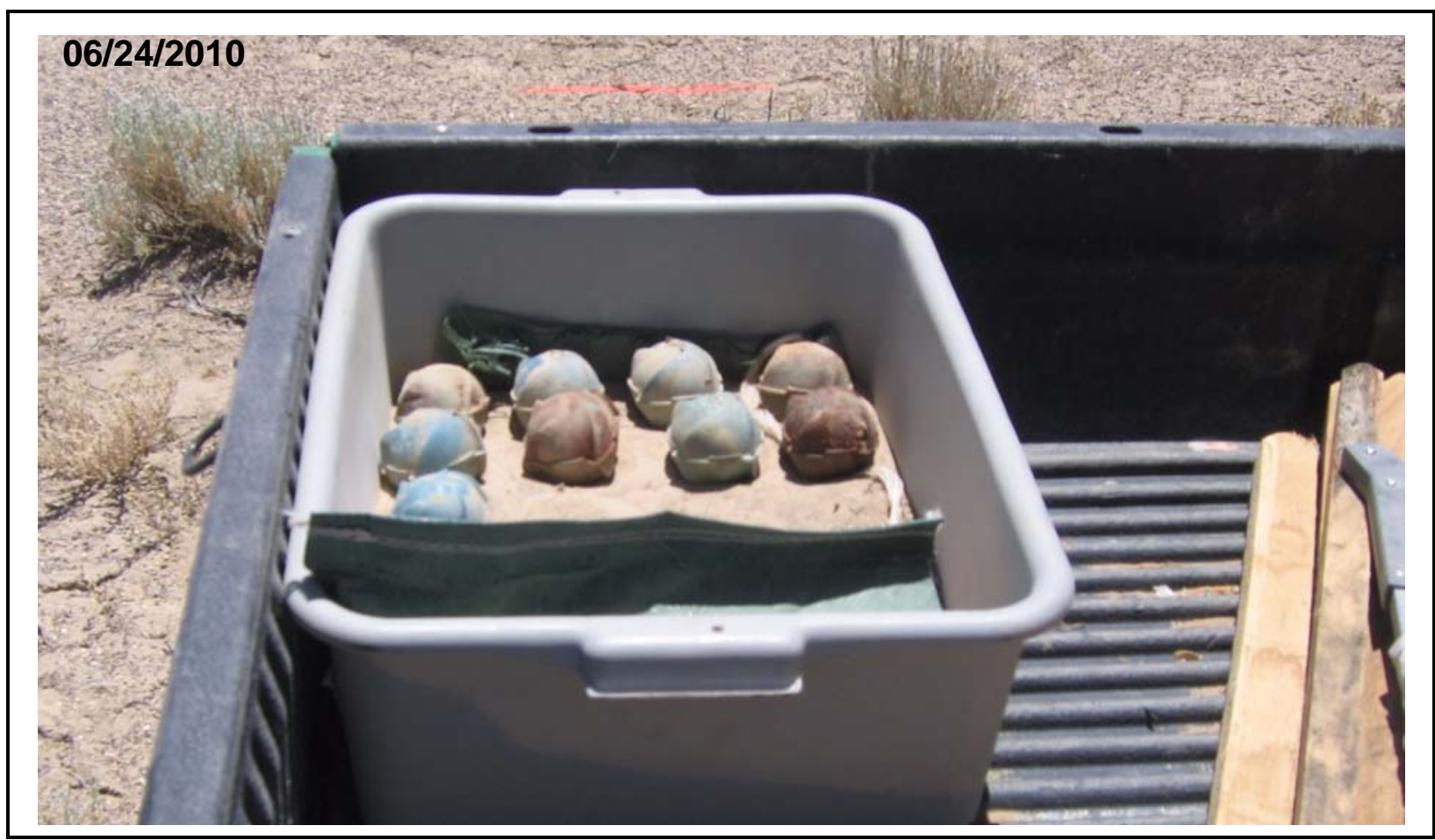

Figure 2-23

BLU-63 Submunitions Staged for Relocation before Demilitarization 


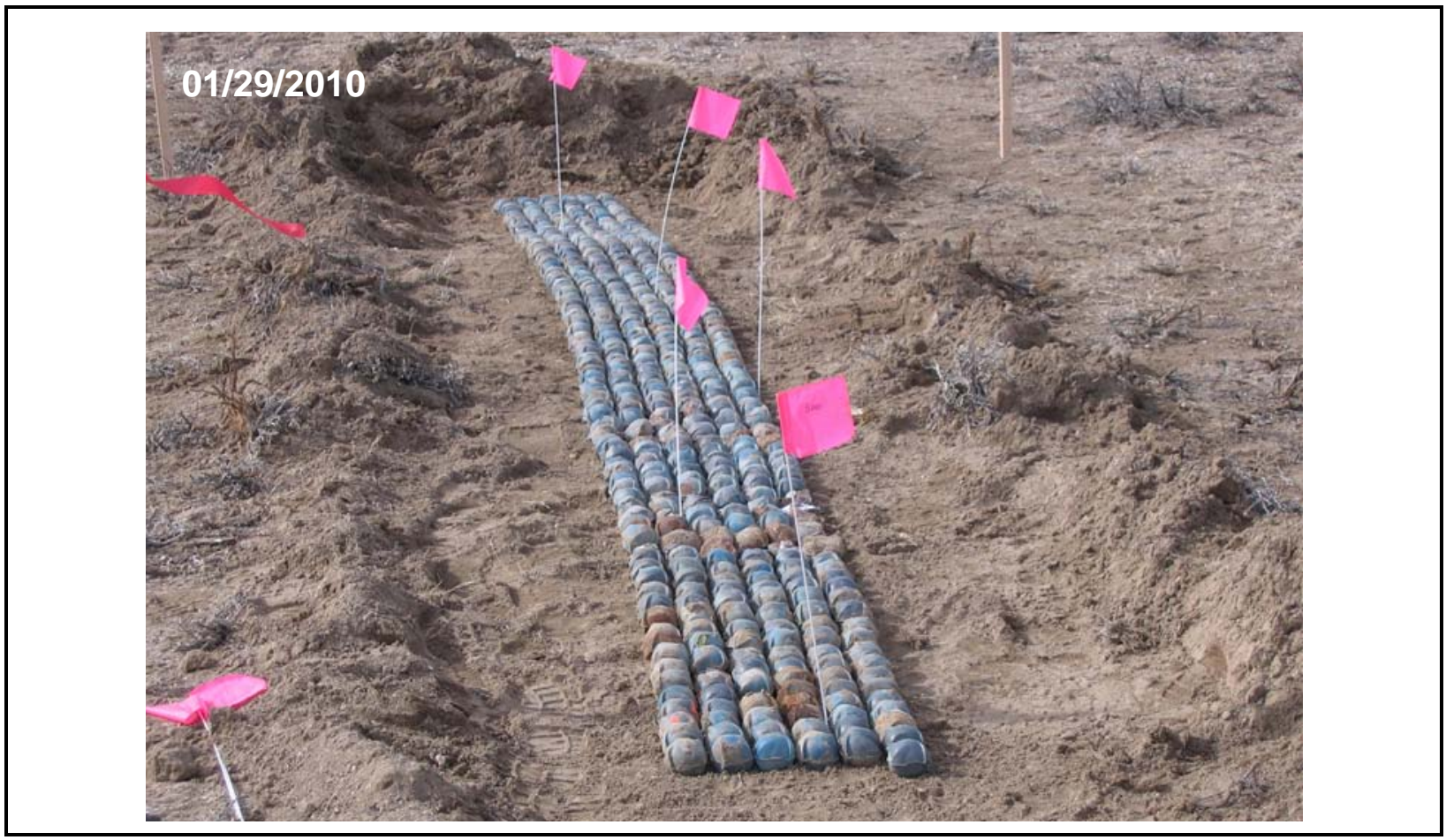

Figure 2-24

BLU-63s (513) Staged for Demilitarization at Flightline Target

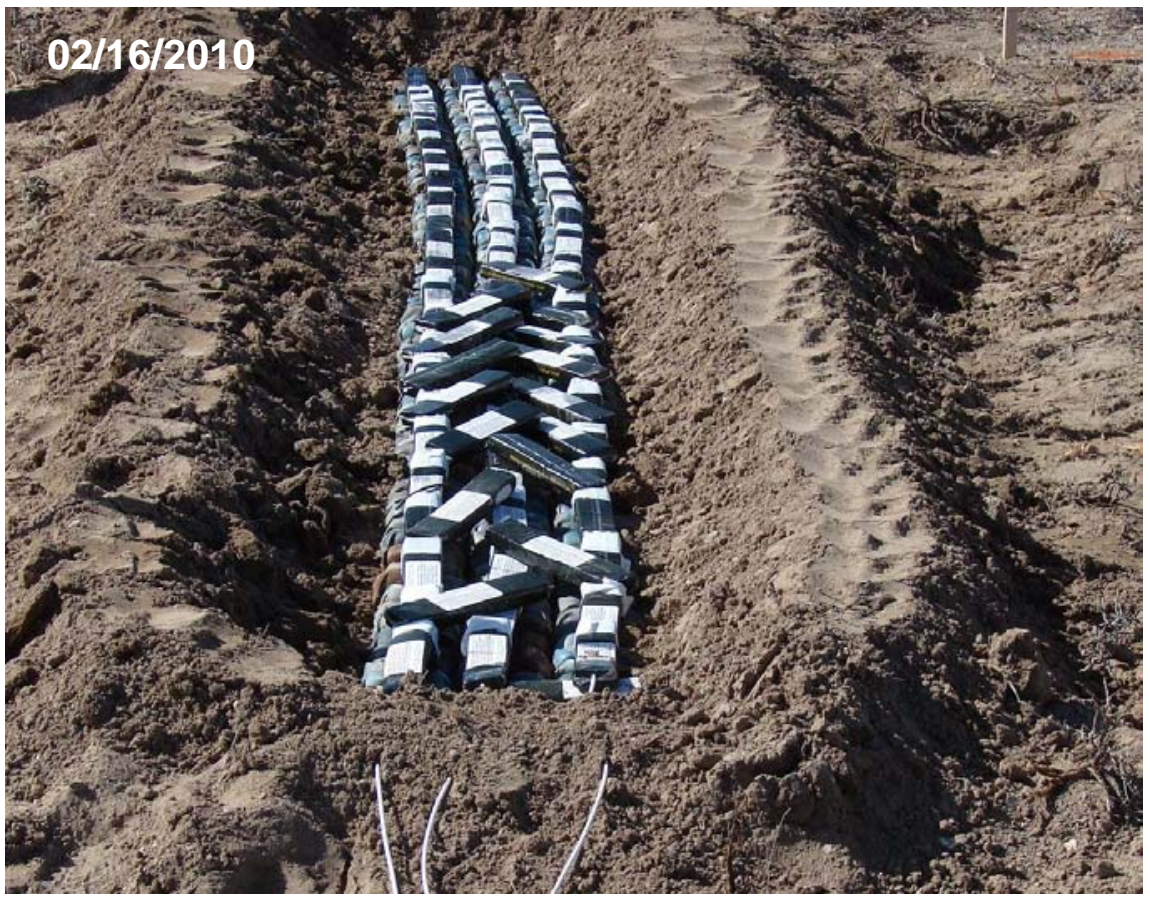

Figure 2-25

Typical Demolition Setup for BLU-63s at Mid Target

Note: C-4 donor explosive charges on top of BLU-63s. 
Table 2-3

Treatment Event Table

(Page 1 of 3)

\begin{tabular}{|c|c|c|c|c|}
\hline $\begin{array}{l}\text { Date of } \\
\text { Event }\end{array}$ & $\begin{array}{l}\text { Detonation } \\
\text { Time }\end{array}$ & Demolition Location & MEC Items & Donor Explosives \\
\hline $\begin{array}{l}\text { 02/15/2010 } \\
\text { Location } 1\end{array}$ & 1322 hours & $\begin{array}{l}\text { South Antelope Lake } \\
\text { Lat. } 37^{\circ} 40^{\prime} 22.75^{\prime \prime} \mathrm{N} \\
\text { Long. - } 116^{\circ} 39^{\prime} 53.98^{\prime \prime} \mathrm{W}\end{array}$ & $\begin{array}{l}1 \text { M424A1 spotting round } \\
7 \text { BLU-49 bomblets } \\
3 \text { BLU-26 bomblets } \\
1 \text {.50-caliber round } \\
1 \text { 20-mm TPT } \\
3 \text { 155-mm rounds } \\
3 \text { 8-in. projectiles } \\
1 \text { 5-in. Zuni dummy warhead } \\
1 \text { unknown canister }\end{array}$ & $\begin{array}{l}3 \text { non-electric blasting caps } \\
80 \text {-ft detonating cord } \\
7.5 \text {-lb C- } 4 \text { explosives } \\
2 \text { electric blasting caps } \\
6 \text { jet perforators }\end{array}$ \\
\hline $\begin{array}{l}\text { 02/15/2010 } \\
\text { Location } 2\end{array}$ & 1337 hours & $\begin{array}{l}\text { Flightline Target } \\
\text { Lat. } 37^{\circ} 44^{\prime} 8.765^{\prime \prime} \mathrm{N} \\
\text { Long. - } 116^{\circ} 41^{\prime} 58.848^{\prime \prime} \mathrm{W}\end{array}$ & 513 BLU-63s & $\begin{array}{l}5 \text { non-electric blasting caps } \\
80-f t \text { detonating cord } \\
117.5-\text {-lb C- } 4 \text { explosives } \\
32-f t \text { time fuse } \\
10 \text { igniters }\end{array}$ \\
\hline $\begin{array}{l}\text { 03/08/2010 } \\
\text { Location } 1\end{array}$ & $\begin{array}{l}1130 \text { hours } \\
1152 \text { hours }\end{array}$ & $\begin{array}{l}\text { Mid Target } \\
\text { Lat. } 37^{\circ} 46^{\prime} 56.33^{\prime \prime} \mathrm{N} \\
\text { Long. }-116^{\circ} 42^{\prime} 32.39^{\prime \prime} \mathrm{W}\end{array}$ & 1 M424A1 spotting round ${ }^{b}$ & $\begin{array}{l}2 \text { non-electric blasting caps } \\
4 \text { electric blasting caps } \\
20 \text {-ft detonating cord } \\
5 \text {-lb C-4 explosives } \\
5 \text { jet perforators }\end{array}$ \\
\hline $\begin{array}{l}\text { 04/28/2010 } \\
\text { Location } 1\end{array}$ & 0853 hours & Mid Target, Grid 50/825 & $\begin{array}{l}1 \text { each MK-83 } \\
80 \text { each BLU-63s }\end{array}$ & $\begin{array}{l}6 \text { each non-electric blasting caps } \\
25-f t \text { detonating cord } \\
25-f t \text { time fuse } \\
10-\text {-lb C- } 4 \\
3 \text { each igniters }\end{array}$ \\
\hline $\begin{array}{l}04 / 28 / 2010 \\
\text { Location } 2\end{array}$ & 0854 hours & $\begin{array}{l}\text { Mid Target, Grid 53/816 } \\
\text { Lat. } 37^{\circ} 47^{\prime} \mathrm{N} \\
\text { Long. }-116^{\circ} 42.5^{\prime} \mathrm{W}\end{array}$ & $\begin{array}{l}14 \text { each bomblet fuses } \\
8 \text { each BLU-26s } \\
41 \text { each BLU-61s } \\
967 \text { each BLU-63s } \\
1 \text { each M117A1 } \\
4 \text { each } 40-m m \text { TPT } \\
3 \text { each MK118 (Rockeye) }\end{array}$ & $\begin{array}{l}\text { 18-ft detonating cord } \\
67.5-\text {-lb C- } 4 \text { explosives } \\
3 \text { non-electric blasting caps } \\
25 \text {-ft time fuse } \\
2 \text { each igniters }\end{array}$ \\
\hline $\begin{array}{l}\text { 04/28/2010 } \\
\text { Location } 3\end{array}$ & 0857 hours & Mid Target, Grid 52/821 & 715 each BLU-63s & $\begin{array}{l}2 \text { each non-electric blasting caps } \\
20 \text {-ft time fuse } \\
2 \text { each igniters } \\
40 \text {-lb C- } 4 \text { explosives }\end{array}$ \\
\hline $\begin{array}{l}\text { 05/15/2010 } \\
\text { Location } 1\end{array}$ & $\begin{array}{l}1206 \text { hours } \\
1207 \text { hours } \\
1208 \text { hours }\end{array}$ & $\begin{array}{l}\text { Mid Target } \\
\text { Lat. } 37^{\circ} 46^{\prime} 45^{\prime \prime} \mathrm{N} \\
\text { Long. }-116^{\circ} 42^{\prime} 40^{\prime \prime} \mathrm{W}\end{array}$ & $\begin{array}{l}23 \text { BLU-97s } \\
88 \text { BLU-63s } \\
2 \text { 40-mm grenades } \\
2 \text { M38 (100-lb bombs) }\end{array}$ & $\begin{array}{l}15 \mathrm{ft} \text { of time fuse } \\
20 \text { non-electric blasting caps } \\
6 \text { igniters } \\
25 \text {-lb C- } 4 \text { explosives } \\
200 \text {-ft detonating cord }\end{array}$ \\
\hline $\begin{array}{l}\text { 05/15/2010 } \\
\text { Location } 2\end{array}$ & 1231 hours & $\begin{array}{l}\text { Buffer Zone } \\
\text { Lat. } 37^{\circ} 45^{\prime} 19^{\prime \prime} \mathrm{N} \\
\text { Long. - } 116^{\circ} 42^{\prime} 31^{\prime \prime} \mathrm{W}\end{array}$ & $69 \mathrm{M} 42 \mathrm{~s}$ grenades & $\begin{array}{l}15 \mathrm{ft} \text { of time fuse } \\
20 \text { non-electric blasting caps } \\
6 \text { igniters } \\
25 \text {-lb C- } 4 \text { explosives } \\
200 \text {-ft detonating cord }\end{array}$ \\
\hline
\end{tabular}


Table 2-3

Treatment Event Table

(Page 2 of 3 )

\begin{tabular}{|c|c|c|c|c|c|}
\hline $\begin{array}{l}\text { Date of } \\
\text { Event }\end{array}$ & $\begin{array}{c}\text { Detonation } \\
\text { Time }\end{array}$ & Demolition Location & MEC Items & \multicolumn{2}{|c|}{ Donor Explosives } \\
\hline $\begin{array}{l}\text { 05/15/2010 } \\
\text { Location } 3\end{array}$ & 1256 hours & $\begin{array}{l}\text { South Antelope Lake } \\
\text { Lat. } 37^{\circ} 41^{\prime} 29^{\prime \prime} \mathrm{N} \\
\text { Long. }-116^{\circ} 41^{\prime} 11^{\prime \prime} \mathrm{W}\end{array}$ & $\begin{array}{l}\text { CAU } 408 \text { items } \\
3 \text { BDU-33s } \\
11 \text { BLU-26s } \\
59.50-\text { caliber rounds } \\
1 \text { 100-lb sand filled bomb spotting } \\
\text { charge } \\
1 \text { flare } \\
240-m m \text { grenades } \\
\text { Non-CAU } 408 \text { items }^{c} \\
120 \text { BLU-97s } \\
8 \text { BDU 50A/Bs } \\
8 \text { MK76s }\end{array}$ & $\begin{array}{l}\text { Detonating cord: } \\
\text { C-4 explosives: } \\
\text { Non-electric blasting caps: } \\
\text { Electric blasting caps: } \\
\text { Jet perforators: } \\
\text { Time fuse: } \\
\text { Igniters: }\end{array}$ & $\begin{array}{l}1,482 \mathrm{ft} \\
117 \mathrm{lb} \\
449 \text { each } \\
194 \text { each } \\
189 \text { each } \\
368 \mathrm{ft} \\
177 \text { each }\end{array}$ \\
\hline $\begin{array}{l}\text { 08/16/2010 } \\
\text { Location } 1\end{array}$ & 1330 hours & $\begin{array}{l}\text { Antelope Lake } \\
\text { Lat. } 37^{\circ} 40^{\prime} 13.74^{\prime \prime} \mathrm{N} \\
\text { Long. - } 116^{\circ} 40^{\prime} 31.8^{\prime \prime} \mathrm{W}\end{array}$ & $\begin{array}{l}7 \text { each } 155 \text {-mm projectiles } \\
6 \text { each } 8 \text {-in. projectiles } \\
303 \text { BLU-63s } \\
3 \text { each M451 MLRS fuses } \\
6 \text { each MK-118 fuses } \\
1 \text { each M219E1 fuse } \\
80 \text { each .50-caliber rounds } \\
1 \text { M-206 flare } \\
2 \text { MJU-7 flares } \\
2 \text { BDU-33s } \\
1 \text { M38 100-lb practice bomb }\end{array}$ & $\begin{array}{l}1,000 \text {-ft shock tube } \\
4 \text { non-electric blasting caps } \\
20 \text {-ft time fuse } \\
3 \text { fuse igniters } \\
10 \text { each } 80 \text {-ft shock tube } \\
36 \text { jet perforators } \\
63-\text { lb C-4 explosives } \\
50 \text {-ft detonating cord }\end{array}$ & \\
\hline $\begin{array}{l}\text { 08/16/2010 } \\
\text { Location } 2\end{array}$ & 1340 hours & $\begin{array}{l}\text { Antelope Lake } \\
\text { Lat. } 37^{\circ} 41^{\prime} 4.62^{\prime \prime} \mathrm{N} \\
\text { Long. - } 116^{\circ} 38^{\prime} 56.1^{\prime \prime} \mathrm{W}\end{array}$ & $1 \mathrm{MJU}-23$ flare & $\begin{array}{l}1,000 \text {-ft shock tube } \\
2 \text { non-electric blasting caps } \\
20 \text {-ft time fuse } \\
3 \text { fuse igniters } \\
2 \text { each } 80 \text {-ft shock tube } \\
4 \text {-lb C- } 4 \text { explosives }\end{array}$ & \\
\hline $\begin{array}{l}\text { 08/16/2010 } \\
\text { Location } 3\end{array}$ & 1352 hours & $\begin{array}{l}\text { Antelope Lake } \\
\text { Lat. } 37^{\circ} 40^{\prime} 45.84^{\prime \prime} \mathrm{N} \\
\text { Long. - } 116^{\circ} 40^{\prime} 50.1^{\prime \prime} \mathrm{W}\end{array}$ & $1 \mathrm{MJU}-23$ flare & $\begin{array}{l}1,000-f t \text { shock tube } \\
2 \text { non-electric blasting caps } \\
20 \text {-ft time fuse } \\
3 \text { fuse igniters } \\
2 \text { each } 80 \text {-ft shock tube } \\
4 \text {-lb C- } 4 \text { explosives }\end{array}$ & \\
\hline $\begin{array}{l}\text { 08/16/2010 } \\
\text { Location } 4\end{array}$ & 1407 hours & $\begin{array}{l}\text { Antelope Lake } \\
\text { Lat. } 37^{\circ} 40^{\prime} 45.84^{\prime \prime} \mathrm{N} \\
\text { Long. }-116^{\circ} 40^{\prime} 50.1^{\prime \prime} \mathrm{W} \\
\text { and } \\
\text { Lat. } 37^{\circ} 42^{\prime} 16.14^{\prime \prime} \mathrm{N} \\
\text { Long. - } 116^{\circ} 40^{\prime} 25.02^{\prime \prime} \mathrm{W}\end{array}$ & $\begin{array}{l}1 \text { MK-41 5-in. projectile } \\
2 \text { MK-82 bombs (inert) } \\
1 \text { MK-84 bomb (inert) } \\
1 \text { MK-40 Mod } 0 \text { BullPup C warhead }\end{array}$ & $\begin{array}{l}4 \text { each } 1,000 \text {-ft shock tube } \\
1 \text { each } 500 \text {-ft shock tube } \\
4 \text { non-electric blasting caps } \\
20 \text {-ft time fuse } \\
3 \text { fuse igniters } \\
4 \text { each } 80 \text {-ft shock tube } \\
2 \text { jet perforators } \\
10 \text {-lb C- } 4 \text { explosives } \\
100 \text {-ft detonating cord }\end{array}$ & \\
\hline
\end{tabular}


Table 2-3

\section{Treatment Event Table}

(Page 3 of 3 )

\begin{tabular}{|c|c|c|c|c|}
\hline $\begin{array}{l}\text { Date of } \\
\text { Event }\end{array}$ & $\begin{array}{c}\text { Detonation } \\
\text { Time }\end{array}$ & Demolition Location & MEC Items & Donor Explosives \\
\hline $\begin{array}{l}\text { 08/16/2010 } \\
\text { Location } 5\end{array}$ & 1424 hours & $\begin{array}{l}\text { Antelope Lake } \\
\text { Lat. } 37^{\circ} 43^{\prime} 17.34^{\prime \prime} \mathrm{N} \\
\text { Long. - } 116^{\circ} 41^{\prime} 13.14^{\prime \prime} \mathrm{W}\end{array}$ & 1 each 2.75-in. Rocket warhead & $\begin{array}{l}1,000 \text {-ft shock tube } \\
2 \text { non-electric blasting caps } \\
20 \text {-ft time fuse } \\
3 \text { fuse igniters } \\
2 \text { each } 80 \text {-ft shock tube } \\
4 \text {-lb C- } 4 \text { explosives }\end{array}$ \\
\hline $\begin{array}{l}\text { 08/16/2010 } \\
\text { Location } 1\end{array}$ & 1510 hours & $\begin{array}{l}\text { Antelope Lake } \\
\text { Lat. } 37^{\circ} 40^{\prime} 13.74 " \mathrm{~N} \\
\text { Long. }-116^{\circ} 40^{\prime} 31.8^{\prime \prime} \mathrm{W}\end{array}$ & Final cleanup shot & $\begin{array}{l}8 \text { each } 1,000-f t \text { shock tube } \\
15 \text { each } 500-f t \text { shock tube } \\
36 \text { non-electric blasting caps } \\
2,900 \text {-ft time fuse } \\
5 \text { fuse igniters } \\
25 \text { each } 80 \text {-ft shock tube } \\
2 \text { jet perforators } \\
35 \text {-lb C- } 4 \text { explosives } \\
2,350 \text {-ft detonating cord }\end{array}$ \\
\hline
\end{tabular}

${ }^{a}$ Complete treatment (demilitarization) of the M424A1 spotting round was not achieved. This item was placed back into the SAA (TTR-09-03) until another treatment event was scheduled.

${ }^{\mathrm{b}}$ Shot \#1 perforated and cracked the casing of the M424A1 projectile. Shot \#2 was necessary to open the casing in order to verify the absence of high explosives. Inspection of the M424A1 round following the treatment events indicated the body of the projectile was constructed of solid steel and does not contain any high explosives.

${ }^{c}$ The detonation event at location 3 on 05/15/2010 included several non-CAU 408 items. The additional MEC items were identified by Sandia National Laboratories personnel and managed at CAU 408 as a BMP.

$\mathrm{mm}=$ Millimeter

SAA $=$ Satellite accumulation area

\subsubsection{Verification Soil Sampling}

Closure verification samples were collected from the bottom and sides of eight identified disposal pits and from one soil mound, and are presented in Appendix D. Subsurface soil samples collected from disposal pits were collected using a tracked excavator. Surface soil samples were collected by hand excavation. Soil samples were field screened for alpha and beta/gamma radiation. Verification samples were shipped to offsite laboratories to be analyzed for appropriate chemical and radiological parameters.

Verification sample analytical results from the SAC Target 2 soil mound (grid 71/729) showed lead concentrations above the preliminary action level (PAL) (Figures 2-26 and 2-27), but below the FALS (see Appendix E). 


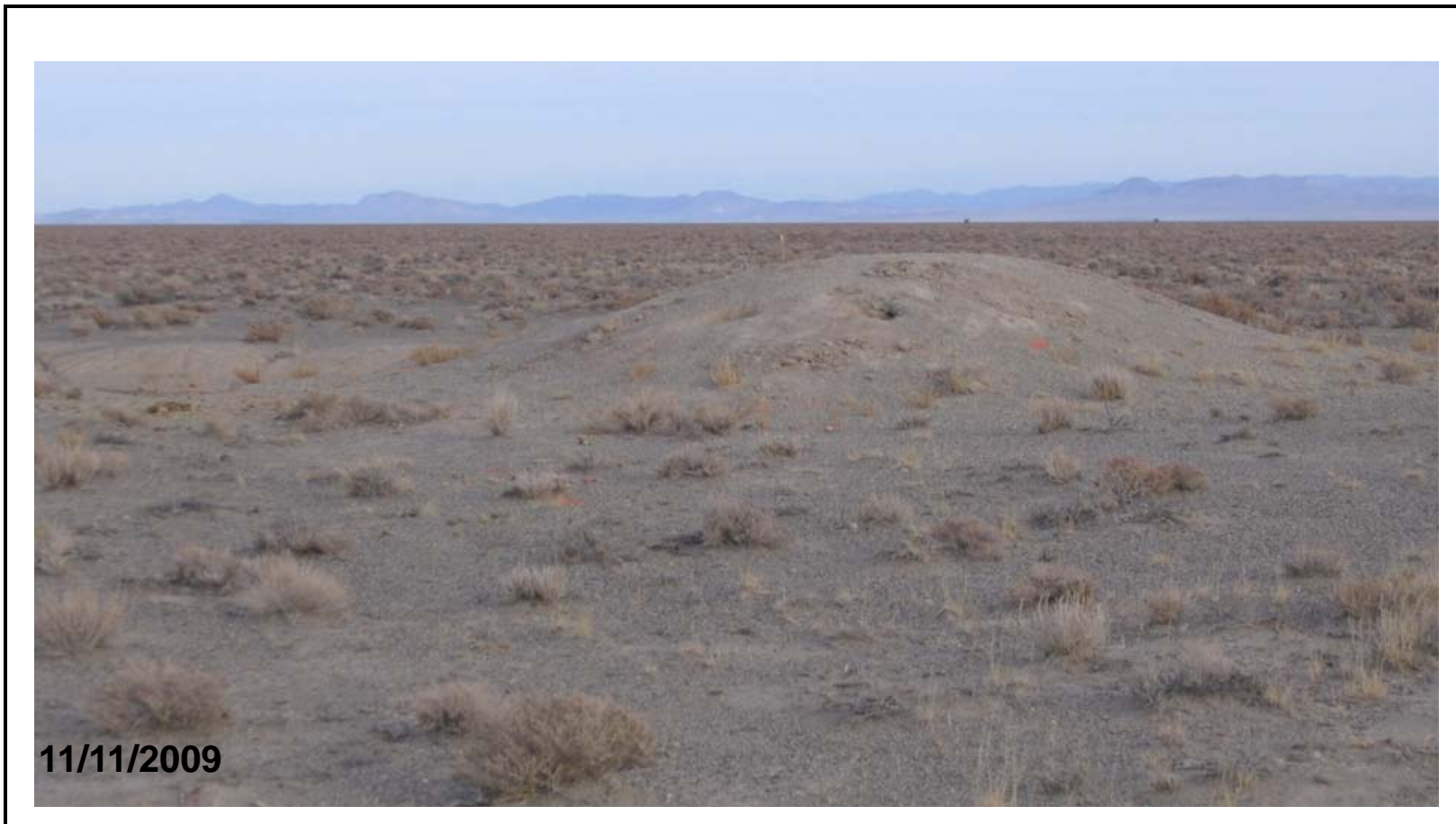

Figure 2-26

Before: Soil Mound in Grid 71/729 at SAC Target 2 before Inspection

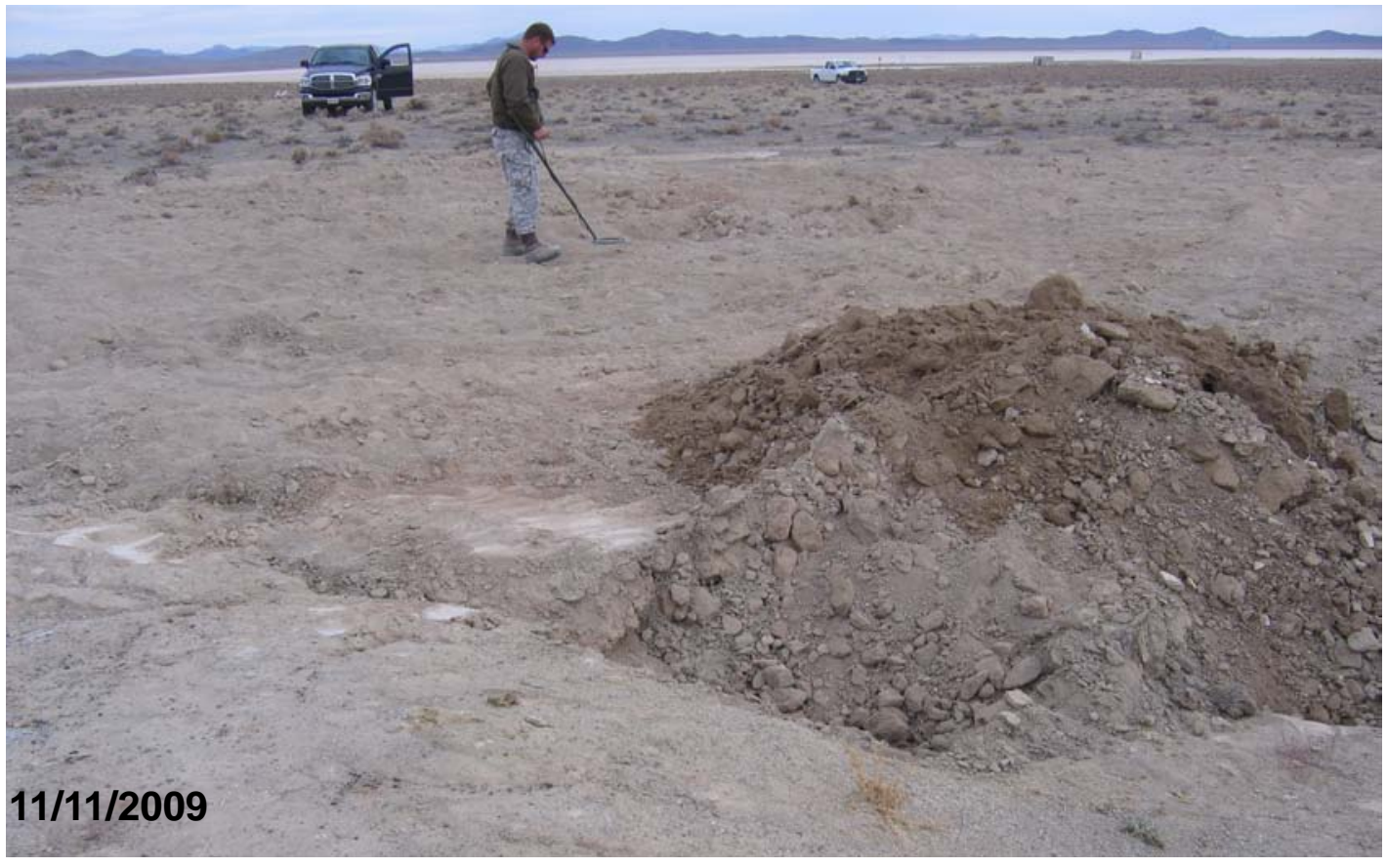

Figure 2-27

After: QC Inspection of Flattened Soil Mound with Magnetometer at Grid 71/729 at SAC Target 2 
Verification sample analytical results from the disposal pit at Anomaly G156_95 at South Antelope Lake showed that arsenic is present above the PAL. It was determined that the elevated concentrations of arsenic are not attributable to DOE activities, but from native mineralogy and natural processes that concentrate soluble salts (see Appendix E).

\subsubsection{Site Closure Posting}

Although the corrective action of MEC clearance was successfully completed, MEC guidance (DoD, 2008; EPA, 2005) and general MEC standards acknowledge that MEC response actions cannot determine with 100 percent certainty that all MEC/UXO are removed. Therefore, the BMP of posting UXO-hazard warning signs near the seven target areas was implemented. These signs will inform land users of the potential for encountering residual UXO hazards.

\subsection{Deviations from SAFER Plan as Approved}

There were no significant deviations to the SAFER Plan requirements (NNSA/NSO, 2010) at this CAS.

\subsection{Corrective Action Schedule as Completed}

Mobilization and site preparation occurred from July 22 through July 29, 2009. The CAU 408 closure activities, which consisted of both disposal pit investigations and Mag and Dig clearance surveys to identify and remove MEC, took place from July 22, 2009, through July 6, 2010. Final demilitarization of MEC and final waste management activities concluded September 7, 2010. Table B.1-1 in Appendix B presents a summary of the disposal pit investigation completion schedule. Table B.1-2 in Appendix B presents a summary of the MEC surface clearance progress and completion schedule for the seven target areas and buffer zone grids.

\subsection{Site Plans/Survey Plat}

See the After-Action reports in Appendix B for figures of target area and buffer zone grid layout. Sample locations are shown in Figure C.3-1 in Appendix C. 


\subsection{Waste Disposition}

Wastes generated during the CAI field activities include disposable personnel protective equipment (PPE) and sampling equipment, contaminated soil, recyclable lead debris, non-hazardous construction debris, and MD. The types, amounts, and disposal of the wastes are detailed in the following subsections. Newly generated wastes such as the DU-impacted soil removed from the buffer zone area near NEDS Lake have been characterized based on the associated soil samples and knowledge of the waste generating process. Waste containers that were not sampled directly were characterized based on process knowledge, radiological screening and swipes, and analytical results of the corresponding soil samples. Site controls were in place to prevent the introduction of hazardous constituents to these waste streams.

\subsection{Waste Streams}

The waste generated by site closure activities at CAU 408 was segregated into the following waste streams:

- Sanitary waste composed of PPE, disposable sampling equipment, plastic sheeting, glass/plastic sample jars, and aluminum foil

- Sanitary construction and debris remediation waste

- Munitions debris waste

- $\quad$ Radioactive (DU-impacted) remediation waste

- Recyclable lead waste

\subsection{Waste Characterization}

Waste determinations were made using process knowledge and media sample association. Direct sampling was performed only on the 55-gallon (gal) drum of DU-impacted soil to confirm the regulatory status of this remediation waste. All analytical data and radiological surveys were reviewed to determine a waste disposal path for the waste streams present (i.e., construction debris and $\mathrm{MD})$. 


\subsection{Waste Disposal}

Figure 3-1 is a photograph of the construction debris removed from anomaly G156_95 staged for pickup and disposal on Antelope Lake at the TTR. Table 3-1 summarizes the types, amounts, and disposal paths of all remediation wastes generated during the CAU 408 closure activities. All load verification forms are presented in Appendix D including the MEC-free declaration forms provided by the SUXOS.

Office waste and lunch trash were disposed of in designated sanitary waste bins allocated for disposal at the TTR sanitary landfill. Sanitary industrial waste was inspected and disposed of in designated sanitary waste bins located in Area 3 of the TTR.

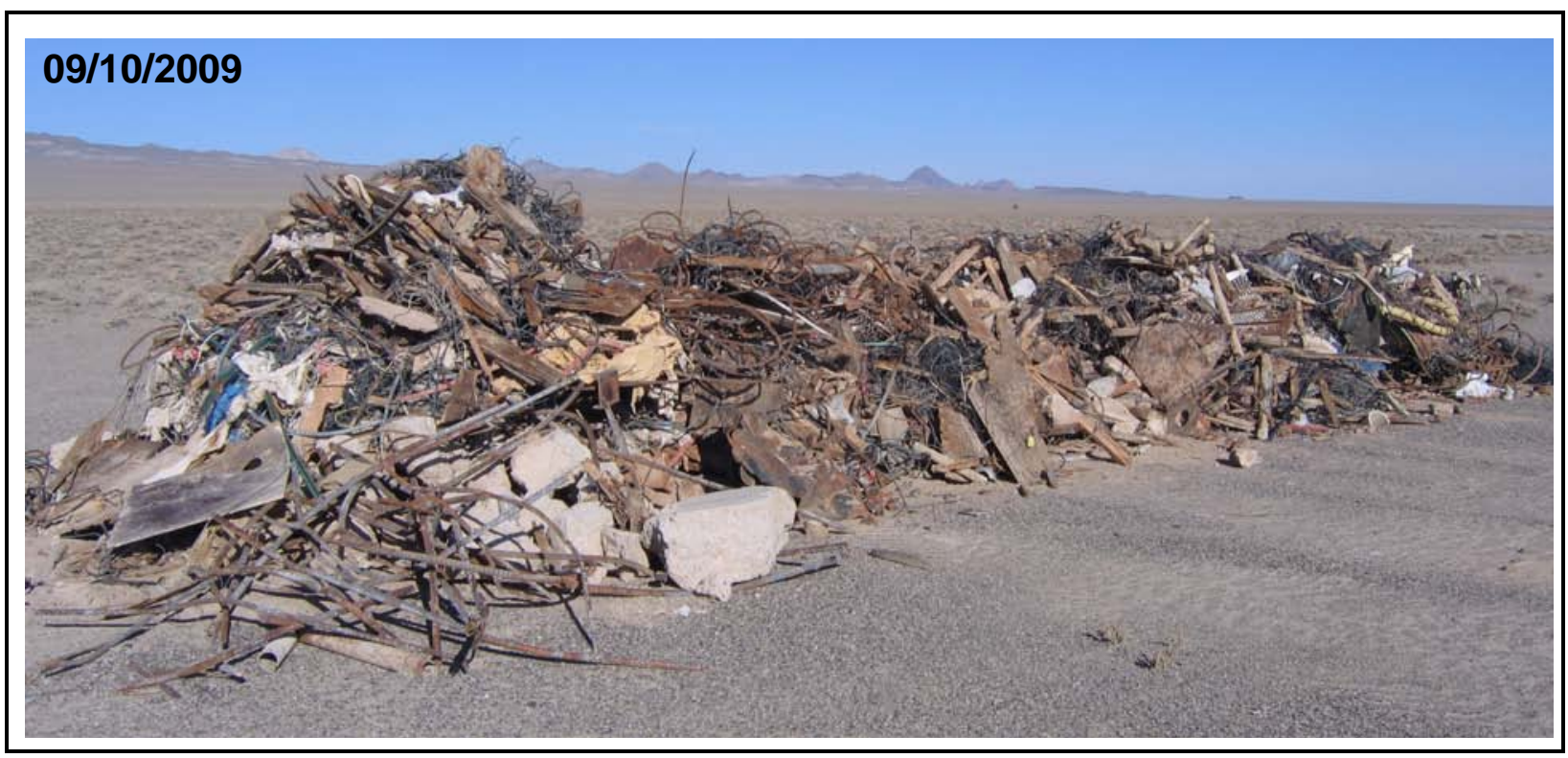

Figure 3-1

Construction Debris Pile from Anomaly G156_95 
Table 3-1

Page 41 of 68

Waste Summary Table for CAS TA-55-002-TAB2

\begin{tabular}{|c|c|c|c|c|c|c|c|c|c|}
\hline \multirow{2}{*}{$\begin{array}{c}\text { Container } \\
\text { Number }\end{array}$} & \multirow{2}{*}{ Waste Items } & \multicolumn{4}{|c|}{ Waste Characterization } & \multicolumn{4}{|c|}{ Waste Disposition } \\
\hline & & Hazardous & Hydrocarbon & PCBs & Radioactive & Disposal Facility & $\begin{array}{l}\text { Waste } \\
\text { Mass }\end{array}$ & $\begin{array}{l}\text { Disposal } \\
\text { Date }\end{array}$ & $\begin{array}{c}\text { Disposal } \\
\text { Document }^{\mathrm{a}}\end{array}$ \\
\hline 408A01 & $\begin{array}{c}\text { Recyclable lead } \\
\text { 408A01 }\end{array}$ & No & No & No & No & N/A & $50 \mathrm{lb}$ & N/A & BOL \\
\hline 408A02 & $\begin{array}{l}\text { Debris-printed } \\
\text { circuit boards, } \\
\text { and batteries }\end{array}$ & Yes & No & No & No & $\begin{array}{l}\text { Waste consumed } \\
\text { during } \\
\text { characterization } \\
\text { sampling }\end{array}$ & $0.25 \mathrm{lb}$ & N/A & N/A \\
\hline 408A03 & $\begin{array}{l}\text { DU-contaminated } \\
\text { debris and } \\
\text { fragments }\end{array}$ & No & No & No & Yes & $\begin{array}{c}\text { Contents of } 408 \mathrm{~A} 03 \\
\text { consolidated into } \\
\text { 408A06 }\end{array}$ & 70 & 09/07/2010 & PSDR \\
\hline 408A04 & $\begin{array}{l}\text { Debris - metal, } \\
\text { wood, plastic, } \\
\text { concrete }\end{array}$ & No & No & No & No & $\begin{array}{l}\text { PEOT Landfill } \\
\text { (TTR) }\end{array}$ & $59,920 \mathrm{lb}$ & 03/03/2010 & LVF \\
\hline 408A05 & Inert MD & No & No & No & No & $\begin{array}{c}\text { Area } 9-\text { U } 10 C \\
\text { (NTS) }\end{array}$ & $32,680 \mathrm{lb}$ & 05/18/2010 & LVF \\
\hline 408A06 & $\begin{array}{l}\text { DU-contaminated } \\
\text { soil and } \\
\text { fragments }\end{array}$ & No & No & No & Yes & $\begin{array}{c}\text { NTS } \\
\text { Area } 5 \text { - RWMC }\end{array}$ & $420 \mathrm{lb}$ & 09/07/2010 & PSDR \\
\hline
\end{tabular}

${ }^{\mathrm{a} C}$ Copies of waste disposal documents are located in Appendix D.

$\mathrm{BOL}=$ Bill of lading

LVF $=$ Load verification form

$\mathrm{N} / \mathrm{A}=$ Not applicable

$\mathrm{PCB}=$ Polychlorinated biphenyl

PSDR = Package storage and disposal request

RWMC $=$ Radioactive Waste Management Complex

$\mathrm{TBD}=$ To be determined 


\subsection{Closure Verification Results}

Closure verification results consist of the information necessary to satisfy the closure criteria for each of the DQO decision statements described below and presented in Section 3.0 of the CAU 408 SAFER Plan (NNA/NSO, 2010):

- $\quad$ Have all disposal pits been identified?

- Have all hazardous materials in disposal pits been removed?

- Have all areas impacted by submunitions (i.e., bomblets) been identified and delineated?

- Have 100 percent of all areas impacted by submunitions been surface cleared of DOE-related submunitions?

- Have all COCs (if present in soil) been removed?

For the corrective action of clean closure, verification results demonstrate that submunitions within the CAU boundary were identified and removed through the MEC response action consisting of surface clearance surveys, visual inspections, and disposal pit excavations. Verification soil sample results demonstrate that no COCs exist within the CAS.

The CAU 408 SAFER Plan (NNSA/NSO, 2010) identified that the right type, quality, and quantity of data are needed to resolve the DQO decision statements. To verify that the soil sample analytical dataset obtained as a result of this investigation supports the DQO decisions, a DQA was conducted. Section 4.4 provides a summary of the DQA, and Section 4.5 summarizes any use restrictions for the CAS.

This section provides a summary of verification data from the closure activities performed at CAS TA-55-002-TAB2, Bomblet Target Areas, as detailed in Appendices B and C.

\subsection{Surface Clearance Verification}

The information necessary to satisfy the closure criteria for the surface clearance was generated by fully delineating submunitions debris and/or MD encountered at each target area and within the buffer zone through visual inspections and Mag and Dig surveys. Mag and Dig surveys were performed by 
qualified UXO personnel using handheld analog geophysical instruments on 100 percent of all target areas (approximately 1,455 acres) to detect and identify anomalies to a depth of approximately $1.0 \mathrm{ft}$ bgs. All anomalies were investigated, and the item (MEC or debris) creating the instrument response was removed. The area was rechecked to ensure the area was clear. If additional anomalies were detected, investigation/excavation continued until there was no additional instrument response.

Visual inspection was performed on the buffer zone area surrounding the seven targets, consisting of approximately 8,660 acres. To ensure target area boundaries were fully delineated, site boundaries were adjusted accordingly (to maintain a minimum 200-ft munitions-free area) for any submunition discovered during surface clearance or visual inspection. Additional Mag and Dig surveys were conducted on approximately 200 acres of the buffer zone due to discovery of submunitions on the surface. The additional Mag and Dig surveys included step-out surveys around the perimeter of the South Antelope Lake Target, Mid Target, and Flightline Target, and three areas in the buffer zone located between Mid Target and Flightline targets (see After-Action Reports in Appendix B).

The following QC measures were among those used to ensure surface clearance activities were performed correctly:

- Daily magnetometer function testing

- Blind seeding

- $\quad$ Grid inspections

Daily function testing of all magnetometers was performed each day before Mag and Dig operations. Simulated items (similar in size and shape to the smallest expected ordnance) were buried in a test grid. Each magnetometer to be used that day was required to be able to detect all items; failure to detect the buried items indicated the instrument was not functioning correctly, and it was removed from service.

A blind-seeding program consisting of random placement of simulated items (inert submunition) at varying depths within each grid was implemented. Blind seeds were placed by the project UXOSO/QC officer at a rate of approximately one seed in every four consecutive grids within each target. Failure of the UXO team to detect a blind seed would require an analysis to determine an appropriate corrective action to ensure all grids meet the clearance quality standard. All blind seeds were recovered during CAU 408 CAI activities. 
Independent grid inspections were performed by the UXOSO/QC on each grid within each of the seven target areas. The independent clearance verification consisted of a second surface clearance over a portion of each grid using the same methodology as the initial clearance. The initial clearance verification was performed on 25 percent of each grid in four consecutive grids. If no submunitions were found by independent clearance verification in four consecutive grids, the independent clearance verification was reduced to 10 percent. If a submunition was found during the independent clearance verification, the independent inspection portion of each grid would revert back to 25 percent, and the SUXOS would determine whether corrective action was necessary.

Independent QC grid inspections were performed throughout the project on all seven targets. There were no instances of missed submunitions found during independent QC inspections; however, there was one instance of unidentified MD (metal debris) within grid 81/702 on South Antelope Lake. Grid 81/702 was one of the initial grids where Mag and Dig clearance was performed and thus required 25 percent independent clearance verification. To ensure clearance quality standards, an additional 25 percent of grid 81/702 was clearance verified, and the next four consecutive grids were independently inspected on 25 percent of each grid. Following four successful grid inspections, the rate of inspection was decreased to 10 percent.

\subsection{Disposal Pit Investigation and Remediation}

The information necessary to satisfy the closure criteria for the disposal pit investigation was generated by excavating all the potential disposal pit locations identified through geophysical surveys and Mag and Dig survey to determine the presence or absence of buried submunitions waste. Thirty-one locations were investigated as potential disposal pits by excavating a pothole at the center of the anomaly and/or selected geophysical points within the anomaly footprint representing locations of the highest probability of encountering waste. Eight disposal pits were identified and remediated to meet clean closure by removing waste and MEC until all sides and the bottom of the excavation were composed of native soil. Appendix B presents additional information on the location of disposal pits, and the types of waste identified and removed from each disposal pit remediated. 


\subsection{Soil Verification Investigations}

The information necessary to satisfy the closure criteria for verification sampling was generated at specific target areas and disposal pit locations by collecting and analyzing soil samples. Verification samples were collected from soil beneath and/or adjacent to areas indicating the potential for explosives and/or DU contamination. For disposal pit excavations, samples were collected from the bottom and sides of excavations after waste and MEC removal was conducted.

A total of 64 soil samples were collected from the eight disposal pits. The soil mound investigated at SAC Target 2 was sampled based on biasing factors (presence of MD in the mound).

Lead was detected above the PAL in a soil sample collected at the SAC target soil mound but did not exceed the Tier 2 risk-based corrective action (RBCA) criteria. Therefore, it is not considered a COC. Arsenic was detected above the PAL in soil samples collected from the excavation at anomaly G156_95, but concentrations are not attributable to DOE activities, but from native mineralogy and natural processes that concentrate soluble salts. Therefore, it is not considered a COC.

No COCs were identified at this CAS through sampling. No further action is recommended for this CAS based on soil analytical results.

\subsection{Data Quality Assessment}

The DQA process is the scientific evaluation of the actual investigation results to determine whether the DQO criteria for soil verification sampling established in the CAU 408 SAFER Plan (NNSA/NSO, 2010) were met and whether DQO decisions can be resolved at the desired level of confidence. The DQO process ensures that the right type, quality, and quantity of data will be available to support the resolution of those decisions at an appropriate level of confidence. Using both the DQO and DQA processes helps to ensure that DQO decisions are sound and defensible.

The DQA involves five steps that begin with a review of the DQOs and end with an answer to the DQO decisions. The five steps are briefly summarized as follows:

Step 1: Review DQOs and Sampling Design - Review the DQO process to provide context for analyzing the data. State the primary statistical hypotheses; confirm the limits on decision errors for 
committing false negative (Type I) or false positive (Type II) decision errors; and review any special features, potential problems, or any deviations to the sampling design.

Step 2: Conduct a Preliminary Data Review - A preliminary data review should be performed by reviewing quality assurance (QA) reports and inspecting the data both numerically and graphically, validating and verifying the data to ensure that the measurement systems performed in accordance with the criteria specified, and using the validated dataset to determine whether the quality of the data is satisfactory.

Step 3: Select the Test - Select the test based on the population of interest, population parameter, and hypotheses. Identify the key underlying assumptions that could cause a change in one of the DQO decisions.

Step 4: Verify the Assumptions - Perform tests of assumptions. If data are missing or censored, determine the impact on DQO decision error.

Step 5: Draw Conclusions from the Data - Perform the calculations required for the test.

\subsubsection{Review DQOs and Sampling Design}

This section contains a review of the DQO process presented in Appendix A. The DQO decisions are presented with the DQO provisions to limit false negative or false positive decision errors. Special features, potential problems, or any deviations to the sampling design are also presented.

\subsubsection{Decision 1}

The Decision 1 statement as presented in the CAU 408 SAFER Plan (NNSA/NSO, 2010) is as follows: "Have all disposal pits been identified”?

\section{Decision 1 Rules}

- If all of the potential disposal pit locations presented in Section 3.1.7 of the SAFER Plan have been excavated, and all of the potential disposal pit locations identified during surface clearance operations have been verified, then all disposal pits have been identified. 
Population Parameter: For investigation of the 25 anomalies identified in Section 3.1.7 of the SAFER Plan, the population parameter is the observation of buried MEC and/or debris. For potential disposal pits identified during surface clearance operations, the population parameter is the observation of buried MEC and/or debris.

\subsection{DQO Provisions To Limit False Negative Decision Error}

A false negative decision error (where consequences are more severe) was controlled by meeting the following criteria:

1. Completing excavation/investigation of all predefined potential disposal pit anomalies (identified in Section 3.1.7 of the SAFER Plan [NNSA/NSO, 2010]).

2. Performing surface clearance on 100 percent of the predefined target areas.

3. Having a high degree of confidence that activities were conducted with sufficient quality and completeness.

\section{Criterion 1}

The following methods (stipulated in the CAU 408 DQOs [NNSA/NSO, 2010]) were used to investigate all predefined disposal pit anomalies:

1. Identifying all potential disposal pit anomalies through the use of existing digital geophysical mapping, multispectral photographs, and surface radiological survey data.

2. Surveying and staking all potential disposal pit locations.

3. Excavating or potholing at potential disposal pit locations up to a depth of $10.0 \mathrm{ft}$ bgs or to undisturbed native soil.

4. Using visual observation to determine whether the material excavated represents a location where debris and or MEC has been buried.

\section{Criterion 2}

Surface clearance activities at each of the seven defined target areas was accomplished using Mag and Dig surveys. Each target area received a full coverage (100 percent) Mag and Dig surface clearance using handheld analog geophysical instruments (magnetometers). A grid system was established at each target area using a predetermined layout developed using a GIS database. The grid system was 
composed of 100-by-100-m grids set across each target area to provide a means of tracking progress and ensuring full coverage of the target. Each geophysical anomaly detected was investigated to determine whether it represented a disposal pit or MEC.

A blind-seeding program was also instituted and consisted of burying an item simulating a bomblet below the surface in a random location unknown to clearance personnel. Blind seeds were placed at a rate of at least one seed in every four consecutive grids. Failure to detect a blind seed required that an analysis be conducted to determine the appropriate corrective action to ensure that all grids met appropriate clearance quality standards.

\section{Criterion 3}

To satisfy the third criterion, each potential disposal pit was excavated, trenched, or potholed to determine the source of the geophysical anomaly up to a depth of $10.0 \mathrm{ft}$ bgs or to undisturbed native soil. If no waste was encountered within this depth, it was determined the anomaly did not represent a disposal pit. If waste was encountered, the disposal pit was remediated by removing the waste until all sides and the bottom of the excavation were composed of native soil. All excavation spoils were evaluated for radiological contamination and MEC/UXO. Screening for radiological contamination was performed using a Ludlum Model 2221 scaler with a Model 4421 beta and low-energy gamma detector. Spoils piles were spread out on the ground in 6- to 12-in. layers and surveyed with the field detector. The spoils pile was also surveyed for MEC/UXO using Mag and Dig survey techniques or onto the 3/4-in. grizzly. The 3/4-in. mesh screen on the grizzly was selected because the smallest submunition historically used within any of the seven target areas was a BLU-26, which is approximately 2-1/2-in. diameter.

All debris was sorted and segregated. The MEC/UXO was segregated and staged until demilitarization. Munitions debris was separated from sanitary construction debris. There were no elevated radiological readings in the soil or on any debris recovered from any of the disposal pit excavations. Verification soil samples were also collected from biased locations on the sidewalls and bottoms of each disposal pit. Soil samples were analyzed for explosives, metals, gamma-emitting radionuclides, and isotopic uranium (U). Spoils piles were returned to the excavation as backfill. 
Daily function testing was performed on all magnetometers each day before Mag and Dig operations. Simulated items the size of the smallest known ordnance items (BLU-26 and 40-mm grenade) were placed at depths below grade, and on the surface in a test grid. Each magnetometer to be used that day was required to be able to detect all items; failure to detect all items indicated that the instrument was not functioning properly, and it was removed from service until repaired or replaced.

\subsection{DQO Provisions To Limit False Positive Decision Error}

The false positive decision error was controlled by defining what constitutes a disposal pit and assessing that submunitions were placed for burial. A disposal pit is defined as a man-made pit or trench in which MEC or munitions-related debris was intentionally buried in the ground. In the case that intentionally buried debris was encountered within an anomalous area, the area was defined as a disposal pit. In addition to the original predefined 25 potential disposal pits, six additional locations discovered during Mag and Dig surface clearance were identified as potential disposal pits.

\subsubsection{Decision 2}

The Decision 2 statement as presented in the CAU 408 SAFER Plan (NNSA/NSO, 2010) is as follows: "Have all hazardous materials in the disposal pits been removed?"

\section{Decision 2 Rule}

If only native soil remains on the sides and bottom of a disposal pit excavation (i.e., no additional debris is observed) and verification sample results do not contain contamination at concentrations exceeding FALs, then it will be decided that all hazardous materials have been removed from the disposal pit.

Population Parameters: The population parameters are the visual observation of submunitions and debris, and analytical sample results for verification samples. 


\subsection{DQO Provisions To Limit False Negative Decision Error}

False negative decision error was controlled by meeting the following criteria:

1. Each disposal pit was excavated until all debris was cleared and native soil material was encountered on the disposal pit sidewalls and bottom.

\section{$\underline{\text { Criterion } 1}$}

The following methods were used to confirm the removal of all hazardous materials from disposal pits.

1. Using visual observation to determine that all MEC/debris was cleared from the disposal pit and native soil was encountered on the disposal pit sidewalls and bottoms.

2. Excavating, trenching, or potholing each potential disposal pit to determine the source of the geophysical anomaly up to a depth of $10.0 \mathrm{ft}$ bgs or to undisturbed native soil. If no waste was encountered within this depth, it was determined the anomaly did not represent a disposal pit. If waste was encountered, the disposal pit was remediated by removing the waste until all sides and the bottom of the excavation were composed of native soil. All excavation spoils were evaluated for radiological contamination and MEC/UXO. Screening for radiological contamination was performed using a Ludlum Model 2221 scaler with a Model 4421 beta and low-energy gamma detector. Spoils piles were spread-out on the ground in 6- to 12-in. layers and surveyed with the field detector. The spoils pile was also surveyed for MEC/UXO using Mag and Dig survey techniques or onto the 3/4-in. grizzly. The 3/4-in. mesh screen on the grizzly was selected because the smallest submunition historically used within any of the seven target areas was a BLU-26, which is approximately 2-1/2-in. diameter. Biased sampling of disposal pit sidewalls and bottom followed removal of debris and MEC. Verification soil samples were analyzed for explosives, metals, gamma-emitting radionuclides, and isotopic $\mathrm{U}$.

\subsection{DQO Provisions To Limit False Positive Decision Error}

There were no false positive decision error parameters established.

\subsubsection{Decision 3}

The Decision 3 statement is as follows: "Have all areas impacted by DOE submunitions (i.e., bomblets) been identified and delineated?” 


\section{Decision 3 Rule}

- If all of the predefined target areas (including a 200-ft radius surrounding the last item observed or identified) and the visual inspection of the buffer zones surrounding each target area are clear of submunitions debris, then it will be decided that the extent of the target area has been delineated.

Population Parameters: The population parameter for Mag and Dig surveys is the geophysical instrument results. The population parameter for visual sweeps conducted in the buffer zone is the observation of submunitions.

\subsection{DQO Provisions To Limit False Negative Decision Error}

A false negative decision error (where consequences are more severe) was controlled by meeting the following criteria:

1. Having a high degree of confidence that activities were conducted with sufficient quality and completeness (seeding, calibration and excavation proofing).

2. Performing surface clearance on 100 percent of the target areas.

3. Verifying that target boundaries are accurate (e.g., no additional submunitions are present within a 200-ft radius from the last observed submunition in target areas and in the buffer zone).

\section{$\underline{\text { Criterion } 1}$}

The following methods were used to ensure all activities were conducted with sufficient quality and completeness:

1. Identifying all potential disposal pit anomalies through the use of existing digital geophysical mapping, multispectral photographs, and surface radiological survey data.

2. Surveying and staking all target areas and the buffer zone.

\section{Criterion 2}

Surface clearance activities at each of the seven defined target areas was accomplished using Mag and Dig surveys. Each target area received a full coverage (100 percent) Mag and Dig surface clearance using handheld analog geophysical instruments (magnetometers). A grid system was established at each target area using a predetermined layout developed using a GIS database. The grid system was 
composed of 100-by-100-m grids set across each target area to provide a means of tracking progress and ensuring full coverage of the target. Each geophysical anomaly detected was investigated to determine whether it represented a disposal pit or MEC.

\section{$\underline{\text { Criterion } 3}$}

To satisfy the third criterion, the lateral boundaries of each target area and the buffer zone were extended as necessary to ensure the boundaries of all areas impacted by submunitions were at least $200 \mathrm{ft}$ beyond any identified submunition identified either by surface clearance or by visual survey in the buffer zone. This strategy was implemented in order to establish a cleared area at least $200 \mathrm{ft}$ beyond the last identified submunition.

\subsection{DQO Provisions To Limit False Positive Decision Error}

The false positive decision error was controlled by visual observations and magnetometer surveys that confirmed no submunitions were present within a $200-\mathrm{ft}$ radius of the last detected submunition.

\subsubsection{Decision 4}

The Decision 4 statement is as follows: "Have 100 percent of all areas impacted by submunitions been surface cleared of DOE-related submunitions?”

\section{Decision 4 Rule}

- If the areas covered by surface clearance traverses are adjacent and extend to the edges of the target area, then it will be decided that 100 percent of the target area has been surface cleared.

Population Parameters: The population parameter for surface clearance is the measurement/survey and layout of the target areas.

\subsection{DQO Provisions To Limit False Negative Decision Error}

A false negative decision error was controlled by meeting the following criteria:

1. Calibrating field instrumentation.

2. Laying out and surveying target areas and step-out distances. 


\section{$\underline{\text { Criterion } 1}$}

The following methods were used to ensure the calibration of field instrumentation.

1. The GPS data are derived via a GPS receiver's interpretation of signals broadcast from individual satellites which cumulatively comprise the existing GPS constellation. This constellation is maintained by the U.S. government, and each satellite is monitored daily for problems. The status and health of the constellation is broadcast to a GPS unit via what is known as an "ephemeris file." This file is collected by the GPS receiver and provides the mechanism by which the receiver selects only "healthy" satellites in calculating its position. The combination of the GPS system design and the user settings implemented during data collection ensures quality positional data.

2. Analog magnetometers were checked daily before being used in the field for Mag and Dig operations. A test grid was constructed using simulated items the size of the smallest known ordnance items (BLU-26 and 40-mm grenade). The inert ordnance items were placed at depths 0.5 to $1.0 \mathrm{ft}$ bgs, and on the surface, and were marked with a stake indicating the locations of the items. Each magnetometer to be used that day was required to be able to detect all items; failure to detect all items indicated that the instrument was not functioning properly, and it was not used for Mag and Dig clearance operations

\section{Criterion 2}

The layout and survey of target areas and step-outs were performed using GPS equipment. Target areas were defined using document reviews, personnel interviews, and past investigations, and were laid out based upon predetermined GPS coordinates. Step-outs surveys were laid out in the field using tape measures and verified using GPS equipment and input into the GPS database.

The lateral boundaries of each target area were extended as necessary to ensure the boundaries of all areas impacted by submunitions are at least $200 \mathrm{ft}$ beyond any identified submunition identified either by surface clearance or by visual survey in the buffer zone. This strategy was implemented in order to establish a cleared area at least $200 \mathrm{ft}$ beyond the last identified submunition. For example, if a submunition were discovered during the visual evaluation of a target buffer zone, an area extending $200 \mathrm{ft}$ surrounding the item would be surface cleared using Mag and Dig techniques. 


\subsection{DQO Provisions To Limit False Positive Decision Error}

False positive decision error was controlled by meeting the same criteria identified for false negative decision error as follows:

1. Calibrating field instrumentation.

2. Laying out and surveying target areas and step-out distances.

\subsubsection{Decision 5}

The Decision 5 statement is as follows: "Have all COCs (if present in soil) been removed?"

\section{Decision 5 Rule}

- If all analytical result concentrations from all verification samples are less than their corresponding FALs, then it will be decided that no COCs remain in the target area.

Population Parameters: The population parameter for Decision 5 is the analytical sample results.

\subsection{DQO Provisions To Limit False Negative Decision Error}

A false negative decision error (where consequences are more severe) is controlled by meeting the following criteria:

1. Having a high degree of confidence that the sample locations selected will identify the extent of the COCs.

2. Having a high degree of confidence that analyses conducted will be sufficient to detect any COCs present in the samples.

3. Having a high degree of confidence that the dataset is of sufficient quality and completeness.

\section{Criterion 1}

The information necessary to satisfy the closure criteria for verification sampling was generated at disposal pit locations by collecting and analyzing soil samples. Verification samples were collected from the bottom and sides of excavations, and spoils piles after waste and MEC removal was conducted. 
A total of 64 soil samples were collected from eight disposal pits. The soil mound investigated at SAC Target 2 was sampled based on biasing factors (presence of MD in the mound).

Lead was detected above the PAL in a soil sample collected at the SAC target soil mound but did not exceed the Tier 2 RBCA criteria. Therefore, it is not considered a COC. Arsenic was detected above the PAL in soil samples collected from the excavation at anomaly G156_95, but the concentrations are not attributable to DOE activities, but from native mineralogy and natural processes that concentrate soluble salts. Therefore, it is not considered a COC.

No COCs were identified at this CAS. No further action is recommended for this CAS based on soil analytical results.

\section{Criterion 2}

All samples were analyzed for the following COCs at CAS TA-55-002-TAB2, Bomblet Target Areas:

- Metals

- Explosives

- Gamma

- $\quad$ Isotopic U

The second criterion for extent (sensitivity) was accomplished for all analyses as demonstrated by all analytical detection limits being less than corresponding action levels.

\section{Criterion 3}

To satisfy the third criterion for extent, the entire dataset, as well as individual sample results, were assessed against the DQIs of precision, accuracy, representativeness, comparability, and completeness, as defined in the Industrial Sites QAPP (NNSA/NV, 2002). The DQI discussion is presented under Section 4.4.4.

\subsection{DQO Provisions To Limit False Positive Decision Error}

The false positive decision error was controlled by assessing the potential for false positive analytical results. Quality assurance/QC samples such as field blanks, laboratory control samples (LCSs), and method blanks were used to determine whether a false positive analytical result may have occurred. 
This provision is evaluated during the validation process, and appropriate qualifiers are assigned to the data when applicable.

Proper decontamination of sampling equipment, and the use of certified clean sampling equipment and containers also minimized the potential for cross contamination that could lead to a false positive analytical result.

\subsubsection{Conduct a Preliminary Data Review}

For Decisions 1 through 4, the preliminary data review consisted of reviewing daily field logs generated by the SUXOS, UXOSO/QC, and UXO Team Lead. Daily logs identified grid designations for Mag and Dig surveys, seeding and QC information, and function testing for instrumentation used during the day. All data received met contractual requirements, and no QA nonconformance reports were issued.

For Decision 5, a preliminary data review was conducted by reviewing QA reports and inspecting the data. The contract analytical laboratories generate a QA nonconformance report when data quality does not meet contractual requirements. All data received from the analytical laboratories met contractual requirements, and a QA nonconformance report was not generated. Data were validated and verified to ensure that the measurement systems performed in accordance with the criteria specified. The validated dataset quality was found to be satisfactory.

\subsubsection{Select the Test and Identify Key Assumptions}

The test for resolving DQO Decisions 1 through 4 was identifying seven target areas and potential disposal pits, and bounding those areas both laterally and vertically. The key assumptions that could impact DQO Decisions 1 through 4 (MEC remediation activities) are listed in Table 4-1.

The test for resolving DQO Decision 1 for the judgmental sampling design was comparing the maximum analyte result from each CAS to the corresponding FAL. The key assumptions regarding potential soil contamination with chemical and radiological contaminants of potential concern (COPCs) that could impact a DQO decision are listed in Table 4-2. 
Table 4-1

\section{Key Assumptions for MEC Clearance}

(Page 1 of 2)

\begin{tabular}{|c|c|}
\hline Exposure Scenario & $\begin{array}{l}\text { Site personnel are potentially exposed to submunitions ranging in size from } 2 \text { to } 4 \text { in. } \\
\text { at the seven bomblet target areas. Some submunitions may have contained DU. } \\
\text { Physical hazards from UXO are a concern. Exposure is limited to site workers, } \\
\text { remediation workers, and military personnel conducting training. } \\
\text { Submunition bomblets were designed to generate minimal terminal velocity to impact } \\
\text { surface targets and not penetrate the ground surface. Submunitions are assumed to } \\
\text { be present on the ground surface to a maximum depth of } 1 \mathrm{ft} \text { bgs, and potentially } \\
\text { intentionally buried in disposal pits. } \\
\text { The investigation results did not reveal any potential exposures other than those listed } \\
\text { in the CSM. }\end{array}$ \\
\hline Affected Media & $\begin{array}{l}\text { Surface soil, shallow subsurface and within potential disposal pits. } \\
\text { Submunition bomblets were designed to generate minimal terminal velocity to impact } \\
\text { surface targets and not penetrate the ground surface. Submunitions are assumed to } \\
\text { be present on the ground surface to a maximum depth of } 1 \mathrm{ft} \text { bgs, and potentially } \\
\text { intentionally buried in disposal pits. } \\
\text { The investigation results did not identify any affected media other than those identified } \\
\text { in the CSM. }\end{array}$ \\
\hline $\begin{array}{l}\text { Location of } \\
\text { Contamination/Release Points }\end{array}$ & $\begin{array}{l}\text { Release points are those identified in the SAFER Plan (disposal pits and seven } \\
\text { target areas). } \\
\text { The CSM assumes that upon detonation of the bomblets (high-order detonation), any } \\
\text { hazardous constituents (i.e., high explosives) would be spent and would not impact } \\
\text { the surrounding soil. } \\
\text { The investigation results did not reveal any locations of contamination or release } \\
\text { points other than identified in the SAFER Plan. }\end{array}$ \\
\hline Transport Mechanisms & $\begin{array}{l}\text { Surface transport of submunitions via natural environmental conditions is not } \\
\text { a concern. } \\
\text { The investigation results did not reveal any transport mechanisms other than identified } \\
\text { in the CSM. }\end{array}$ \\
\hline Preferential Pathways & $\begin{array}{l}\text { None. } \\
\text { The current results did not identify any preferential pathways. }\end{array}$ \\
\hline
\end{tabular}


Table 4-1

\section{Key Assumptions for MEC Clearance}

(Page 2 of 2)

\begin{tabular}{|c|c|}
\hline $\begin{array}{l}\text { Lateral and Vertical Extent of } \\
\text { Contamination }\end{array}$ & $\begin{array}{l}\text { Submunitions are expected to be concentrated around the individual target cluster } \\
\text { bomb unit grids with some longitudinal dispersion expected along the axis of the } \\
\text { aircraft travel. } \\
\text { Lateral dispersion of submunitions is expected to be minimal and concentrated along } \\
\text { the flightline axis, resulting in a distribution along the flight path to be skewed in the } \\
\text { long (late drop) direction, rather than symmetric about the target. } \\
\text { The lateral boundaries of each target area and the buffer zone were extended as } \\
\text { necessary to ensure the boundaries of all areas impacted by submunitions were at } \\
\text { least } 200 \text { ft beyond any identified submunition. } \\
\text { Submunition bomblets were designed to generate minimal terminal velocity to impact } \\
\text { surface targets and not penetrate the ground surface. Submunitions are assumed to } \\
\text { be present on the ground surface to a maximum depth of } 1 \mathrm{ft} \text { bgs, and potentially } \\
\text { intentionally buried in disposal pits. } \\
\text { The investigation results identified two areas with accumulations of submunitions } \\
\text { (M42s, BLU-63s) outside of the original seven target areas. The two areas are } \\
\text { potentially attributable to missed drops/pilot error. }\end{array}$ \\
\hline Groundwater Impacts & $\begin{array}{l}\text { None. } \\
\text { The investigation results did not identify any indicators that groundwater could } \\
\text { potentially be impacted. }\end{array}$ \\
\hline Future Land Use & $\begin{array}{l}\text { Nonresidential. } \\
\text { The investigation results did not reveal any future land uses other than nonresidential. }\end{array}$ \\
\hline Other DQO Assumptions & $\begin{array}{l}\text { Intentionally buried submunitions may exist in disposal pits. } \\
\text { The investigation results identified eight disposal pits. All anomalous areas were } \\
\text { excavated/investigated for subsurface MEC and cleared. }\end{array}$ \\
\hline
\end{tabular}

\section{Table 4-2}

\section{Key Assumptions for Soil Verification Sampling Design} (Page 1 of 2)

\begin{tabular}{||l|l||}
\hline \multirow{5}{*}{ Exposure Scenario } & $\begin{array}{l}\text { Site workers are only exposed to COCs through oral ingestion, inhalation, external } \\
\text { exposure to radiation, or dermal contact (by absorption) of COCs absorbed onto } \\
\text { the soils. } \\
\text { Exposure to contamination is limited to site workers, construction/remediation } \\
\text { workers, and military personnel conducting training. } \\
\text { The investigation results did not reveal any potential exposures than those identified in } \\
\text { the CSM. }\end{array}$ \\
\hline Affected Media & $\begin{array}{l}\text { Surface soil, shallow subsurface soil, and potentially perched (shallow) groundwater. } \\
\text { Deep groundwater contamination is not a concern. } \\
\text { Contaminants migrating to regional aquifers are not considered. } \\
\text { The investigation results did not reveal any affected media other than those identified } \\
\text { in the CSM. }\end{array}$ \\
\hline
\end{tabular}


Table 4-2

Key Assumptions for Soil Verification Sampling Design (Page 2 of 2)

\begin{tabular}{|c|c|}
\hline $\begin{array}{l}\text { Location of } \\
\text { Contamination/Release Points }\end{array}$ & $\begin{array}{l}\text { Release points are those identified in the SAFER Plan. } \\
\text { The investigation results did not reveal any locations of contamination or release } \\
\text { points other than those identified in the SAFER Plan. }\end{array}$ \\
\hline Transport Mechanisms & $\begin{array}{l}\text { Surface transport may occur as a result of a spill or stormwater runoff. } \\
\text { Surface transport beyond shallow substrate is not a concern. } \\
\text { The investigation results did not reveal any transport mechanisms other than those } \\
\text { identified in the CSM. }\end{array}$ \\
\hline Preferential Pathways & $\begin{array}{l}\text { None } \\
\text { The investigation results did not reveal any preferential pathways. }\end{array}$ \\
\hline $\begin{array}{l}\text { Lateral and Vertical Extent of } \\
\text { Contamination }\end{array}$ & $\begin{array}{l}\text { Subsurface contamination, if present, is contiguous and decreases with distance and } \\
\text { depth from the source. } \\
\text { Surface contamination may occur laterally as a result of a spill or stormwater runoff. } \\
\text { The area of contamination is contiguous. } \\
\text { The extent of COC concentration decreases away from the area of contamination. } \\
\text { The investigation results did not reveal any lateral and vertical extent of contamination } \\
\text { other than those identified in the CSM. }\end{array}$ \\
\hline Groundwater Impacts & $\begin{array}{l}\text { None. } \\
\text { The investigation results did not reveal any indicators that groundwater could be } \\
\text { potentially impacted. }\end{array}$ \\
\hline Future Land Use & $\begin{array}{l}\text { Nonresidential. } \\
\text { The investigation results did not reveal any future land uses other than nonresidential. }\end{array}$ \\
\hline Other DQO Assumptions & $\begin{array}{l}\text { Buried material may exist at CAS. } \\
\text { Contamination may be present in the soils adjacent to a feature due to runoff or } \\
\text { intended use (e.g., decontamination pad). } \\
\text { All detected contaminants were adjacent to features and decreased with distance. }\end{array}$ \\
\hline
\end{tabular}

\subsubsection{Verify the Assumptions}

The results of the MEC clearance (including investigation of the disposal pits and buffer zone) and soil verification sampling and design support the key assumptions identified in the CAU 408 DQOs and Tables 4-1 and 4-2, respectively.

All samples were analyzed using the analytical methods listed in Tables 7-2 and 7-3 of the SAFER Plan (NNSA/NSO, 2010). Table 4-3 provides a reconciliation of samples analyzed to the planned analytical program. 
Table 4-3

CAU 408 Analyses Performed

\begin{tabular}{|c|c|c|c|c|c|}
\hline CAS & Explosives & Gamma & Metals & TCLP Metals & Uranium \\
\hline \hline TA-55-002-TAB2 & RS & RS & RS & RS & RS \\
\hline
\end{tabular}

TCLP $=$ Toxicity Characteristic Leaching Procedure

RS = Required and submitted

\section{Sensitivity}

Sample results were assessed against the acceptance criterion for the DQI of sensitivity as defined in the Industrial Sites QAPP (NNSA/NV, 2002). The sensitivity acceptance criterion defined in the SAFER Plan (NNSA/NSO, 2010) is that analytical detection limits will be less than the corresponding action level. This criterion was achieved, as all sensitivity requirements were met for CAU 408.

\section{$\underline{\text { Precision }}$}

The analytical criteria for precision are evaluated using the relative percent difference (RPD) or normalized difference. Because all contaminants were within the acceptance criteria for precision established in the SAFER Plan (NNSA/NSO, 2010), the dataset is determined to be acceptable for the DQI of precision.

\section{$\underline{\text { Accuracy }}$}

Accuracy was evaluated as described in Section 7.3.2 of the SAFER Plan (NNSA/NSO, 2010). Table 4-4 provides the chemical accuracy analysis results for all contaminants qualified for accuracy. Accuracy rates are above the SAFER Plan criterion of 80 percent, except for barium and lead. No radiological data qualified for accuracy.

Of the 33 barium results qualified for accuracy, 13 were associated with matrix spike (MS) recoveries that exceeded the upper limits. This would indicated that the associated samples may have been reported at concentrations higher than actual, resulting in a false positive DQO decision error. This did not occur at CAU 408 because the highest reported barium result was 2,370 milligrams per kilogram (mg/kg) which is 80 times less than the FAL (190,000 mg/kg). For the remaining 20 barium results qualified for accuracy, bias could not be determined. 
Table 4-4

\section{Accuracy Measurements}

\begin{tabular}{||c|c|c|c|}
\hline Contaminant & $\begin{array}{c}\text { Number of } \\
\text { Measurements } \\
\text { Qualified }\end{array}$ & $\begin{array}{c}\text { Number of } \\
\text { Measurements } \\
\text { Performed }\end{array}$ & $\begin{array}{c}\text { Percent within } \\
\text { Criteria }\end{array}$ \\
\hline \hline 1,3,5-trinitrobenzene & 1 & 73 & 98.6 \\
\hline 2,4,6-trinitrotoluene & 1 & 73 & 98.6 \\
\hline 2-amino-4,6-dinitrotoluene & 1 & 73 & 98.6 \\
\hline 2-nitrotoluene & 1 & 73 & 98.6 \\
\hline 4-amino-2,6-dinitrotoluene & 1 & 73 & 98.6 \\
\hline 4-nitrotoluene & 1 & 73 & 98.6 \\
\hline HMX & 1 & 73 & 98.6 \\
\hline m-nitrotoluene & 1 & 73 & 98.6 \\
\hline RDX (cyclonite) & 1 & 73 & 98.6 \\
\hline Tetryl & 1 & 73 & 80.8 \\
\hline Arsenic & 19 & 73 & 74.0 \\
\hline Lead & 19 & 54.8 \\
\hline Barium & 19 & 73 & \\
\hline
\end{tabular}

For lead, all the results qualified were for failed MS recovery, while bias could not be determined; the highest qualified lead result was $9.95 \mathrm{mg} / \mathrm{kg}$, which is 80 times less than the FAL $(1,872 \mathrm{mg} / \mathrm{kg})$. In this case, there is negligible potential for false negative DQO decision error because the reported values are considerably less than the action level.

\section{Representativeness}

The DQO process as identified in Appendix A was used to address sampling and analytical requirements for CAU 408. During this process, appropriate locations were selected that enabled the samples collected to be representative of the population parameters identified in the DQO (the most likely locations to contain contamination and locations that verify no COCs exist). The sampling locations identified in the Criterion 1 discussion meet this criterion. Therefore, the analytical data acquired during the CAU $408 \mathrm{CAI}$ are considered representative of the population parameters. 


\section{Completeness}

The CAU 408 SAFER Plan (NNSA/NSO, 2010) defines acceptable criteria for completeness to be 80 percent of CAS-specific analytes identified in the SAFER Plan having valid results, and 100 percent of the requested analyses must be performed. Also, the dataset must be sufficiently complete to be able to make the DQO decisions. Although the data were rejected for one sample (surrogate recoveries exceeded control limits in one explosives sample), 100 percent of the analyses requested were performed, and 98.6 percent of the results were valid. Therefore, the analytical data acquired during CAU 408 verification sampling meet the DQO completeness requirements.

\section{Comparability}

Field sampling, as described in the CAU 408 SAFER Plan (NNSA/NSO, 2010), was performed and documented in accordance with approved procedures that are in conformance with standard industry practices. Analytical methods and procedures approved by DOE were used to analyze, report, and validate the data. These methods and procedures are in conformance with applicable methods used in industry and government practices. Therefore, project datasets are considered comparable to other datasets generated using standard industry procedures, thereby meeting DQO requirements.

\subsubsection{Other DQO Commitments}

The SAFER Plan (NNSA/NSO, 2010) made no other commitments for sampling.

\subsubsection{Draw Conclusions from the Data}

This section resolves the DQO decisions for CAU 408.

\subsubsection{Decision Rules for Decision 1}

Decision Rule: If all of the potential disposal pit locations presented in Section 3.1.7 of the SAFER Plan (NNSA/NSO, 2010) have been excavated, and all of the potential disposal pit locations identified during surface clearance operations have been verified, then all disposal pits have been identified.

Result: All 25 potential disposal pit locations identified in Section 3.1.7 of the SAFER Plan were investigated. Six additional disposal pits were identified during Mag and Dig activities. In each case, 
the excavation was cleared of all MEC and waste (debris) until the sides and bottom of the excavation were composed of native soil.

\subsubsection{Decision Rules for Decision 2}

Decision Rule: If only native soil remains on the sides and bottom of a disposal pit excavation (i.e., no additional debris is observed), and verification sample results do not contain contamination at concentrations exceeding FALs, then it will be decided that all hazardous materials have been removed from the disposal pit.

Result: Each disposal pit was excavated until all debris was cleared and native soil material was encountered on the disposal pit sidewalls and bottom. Visual inspection confirmed that the disposal pit was cleared and was composed of native soil on each sidewall and the bottom. Following removal of debris and MEC, verification samples from the disposal pit sidewalls and bottom were analyzed for explosives, metals, gamma-emitting radionuclides, and isotopic $\mathrm{U}$.

\subsubsection{Decision Rules for Decision 3}

Decision Rule: If all of the predefined target areas (including a 200-ft radius surrounding the last item observed or identified) and the visual inspection of the buffer zones surrounding each target area are clear of submunitions debris, then it will be decided that the extent of the target area has been delineated.

Result: Surface clearance activities at each of the seven defined target areas was accomplished using Mag and Dig surveys. Each target area received a full coverage (100 percent) Mag and Dig surface clearance using handheld analog geophysical instruments (magnetometers). A visual inspection covering 100 percent of the buffer zones was conducted outside the target boundaries to a distance determined to be twice the distance of the farthest known bomblet drop location from the center of the target. The farthest documented bomblet drop from the center of a target was calculated to be approximately 1,150 ft at Mid Target based upon USAF Armament Laboratory Reports. The 2,300-ft buffer zone was defined as a width of 2,300 ft on either side of the flightline and a length of 2,300 ft north of the predefined Mid Target boundary extending to 2,300 ft south of the South Antelope Lake target area boundary. The lateral boundaries of each target area were extended as necessary to ensure 
the boundaries of all areas impacted by submunitions are at least $200 \mathrm{ft}$ beyond any identified submunition identified either by surface clearance or by visual survey in the buffer zone. This strategy was implemented in order to establish a cleared area at least $200 \mathrm{ft}$ beyond the last identified submunition.

\subsubsection{Decision Rules for Decision 4}

Decision Rule: If the areas covered by surface clearance traverses are adjacent and extend to the edges of the target area, then it will be decided that 100 percent of the target area has been surface cleared.

Result: Target areas were defined using document reviews, personnel interviews, and past investigations, and were laid out based upon predetermined GPS coordinates. Each target area received a full coverage (100 percent) Mag and Dig surface clearance. The lateral boundaries of each target area were extended as necessary to ensure the boundaries of all areas impacted by submunitions are at least $200 \mathrm{ft}$ beyond any identified submunition identified either by surface clearance or by visual survey in the buffer zone.

\subsubsection{Decision Rules for Decision 5}

Decision Rule: If all analytical result concentrations from all verification samples are less than their corresponding FALs, then it will be decided that no COCs remain in the target area.

Result: Results of all verification samples from potential disposal pits were less than their corresponding FALs or were determined to be naturally occurring.

\subsection{Use Restrictions}

No use restrictions are required for CAU 408.

As MEC guidance (DoD, 2008; EPA, 2005) and general MEC standards acknowledge that MEC response actions cannot determine with 100 percent certainty that all MEC/UXO are removed, the clean closure alternative will implement a BMP of posting UXO-hazard warning signs near the seven target areas. These signs will inform land users of the potential for encountering residual UXO hazards. 


\subsection{Conclusions and Recommendations}

Based on the results of the closure activities, no further corrective actions are necessary for CAU 408.

The DOE, National Nuclear Security Administration Nevada Site Office (NNSA/NSO) provides the following recommendations:

- No further corrective action is required at CAS TA-55-0002-TAB2. Based on the MEC response action results and analytical results of the verification samples collected at this CAS, MEC has been adequately removed at a high degree of confidence, and no COCs have been released to the soil at this CAS. Therefore, additional corrective action is not required at this CAS.

- In the future, should the USAF determine that a proposed mission use would not comport with the proposed closure of CAU 408, or that there is a proposed transfer/relinquishment of all or part of the TTR that will impact CAU 408, then DOE will work with the USAF and NDEP to address and resolve cleanup issues associated with the proposed use or transfer/relinquishment. The DOE remains responsible for working with the regulators, as needed to revise or renegotiate any closure agreements, and remains liable for all costs associated with any future negotiation and/or remediation action for CAU 408, consistent with its responsibilities under applicable law.

- $\quad$ No Corrective Action Plan is required for CAU 408

- $\quad$ A Notice of Completion is requested from NDEP for the closure of CAU 408.

- $\quad$ Move CAU 408 from Appendix III to Appendix IV of the FFACO. 


\subsection{References}

BN, see Bechtel Nevada.

Bechtel Nevada. 2004. UXO Investigation Report for Antelope Lake on the Tonopah Test Range, Nevada Test Site, Nevada, Rev. 0. Prepared by Polestar Applied Technology, Inc.

CFR, see Code of Federal Regulations.

Cabble, K., U.S. Department of Energy, National Nuclear Security Administration Nevada Site Office. 2007. Memorandum to B.C. Kieffer (USAF), J.L. Holland (USAF), and R.D. Christensen (USAF) entitled “Air Force Meeting Summary,” 17 July. Las Vegas, NV.

Code of Federal Regulations. 2010. Title 40 CFR Part 266.202, “Definition of Solid Waste.” Washington, DC: U.S. Government Printing Office.

DoD, see U.S. Department of Defense.

DOE/NV, see U.S. Department of Energy, Nevada Operations Office.

EODT, see EOD Technology, Inc.

EPA, see U.S. Environmental Protection Agency.

EOD Technology, Inc. 2010. Corrective Action Unit (CAU) 408, Bomblet Target Area, Munitions and Explosives of Concern Surface Clearance, Tonopah Test Range, Nevada. February. Prepared for Navarro Nevada Environmental Services, LLC. Lenoir City, TN.

FFACO, see Federal Facility Agreement and Consent Order.

Federal Facility Agreement and Consent Order. 1996 (as amended March 2010). Agreed to by the State of Nevada; U.S. Department of Energy, Environmental Management; U.S. Department of Defense; and U.S. Department of Energy, Legacy Management.

Murphy, T., Bureau of Federal Facilities. 2009. Letter to K. Small (NNSA/NSO) entitled "Temporary Emergency Permits for Treatment of Unexploded Ordnance (UXO) Found During Remediation Activities for Corrective Action Unit (CAU) 484 on the Tonopah Test Range (TTR), while conducting a survey in the Cat Canyon area at the Nevada Test Site (NTS), and as accumulated during WSI activities on the NTS firing range,” 9 December. Las Vegas, NV.

Murphy, T., Bureau of Federal Facilities. 2010. Letter to K. Small (NNSA/NSO) entitled "Temporary Emergency Permit for Tonopah Test Range Unexploded Ordnance (UXO)," 16 April. Las Vegas, NV. 
N-I GIS, see Navarro-Intera Geographic Information Systems.

NNSA/NSO, see U.S. Department of Energy, National Nuclear Security Administration Nevada Site Office.

NNSA/NV, see U.S. Department of Energy, National Nuclear Security Administration Nevada Operations Office.

Navarro-Intera Geographic Information Systems. 2010. ESRI ArcGIS Software.

RSL, see Remote Sensing Laboratory.

Remote Sensing Laboratory. 2006. Tonopah Test Range Orthophotos, acquired 29 April. Las Vegas, NV.

SNL, see Sandia National Laboratories.

Sandia National Laboratories. 1992. As-built engineering drawing T60717 entitled "TTR Range Map,” 4 June.

Swaton, C., International Technology Corp. 1994. Written communication. Subject: "Record of Meeting Regarding ER Sites,” describing conversation between W. Lathrop (SNL-TTR) and K. Cabble (DOE/NV), R. Dubiskas (IT), and J. Enlow (SNL-TTR), 31 March. Las Vegas, NV.

U.S. Department of Defense. 2005. Methodologies for Calculating Primary Fragment Characteristics, Technical Paper 16, Rev. 2. Washington, DC: Department of Defense Explosives Safety Board.

U.S. Department of Defense. 2008. DOD Ammunition and Explosives Safety Standards, DoD 6055.09-STD. Washington, DC: Office of the Deputy Undersecretary of Defense (Installations and Environment).

U.S. Department of Energy, National Nuclear Security Administration Nevada Operations Office. 2002. Industrial Sites Quality Assurance Project Plan, Nevada Test Site, Nevada, Rev. 3, DOE/NV--372. Las Vegas, NV.

U.S. Department of Energy, National Nuclear Security Administration Nevada Site Office. 2006. Streamlined Approach for Environmental Restoration (SAFER) for Corrective Action Unit 408: Bomblet Target Area, Tonopah Test Range, Nevada, Rev. 0, DOE/NV--1171. Prepared by National Security Technologies, LLC. Las Vegas, NV.

U.S. Department of Energy, National Nuclear Security Administration Nevada Site Office. 2010. Streamlined Approach for Environmental Restoration for Corrective Action Unit 408: Bomblet Target Area, Tonopah Test Range (TTR), Nevada, Rev. 1, DOE/NV--1171-Rev. 1. Las Vegas, NV. 
U.S. Department of Energy, Nevada Operations Office. 1994. Written communication. Subject: Resource Conservation Recovery Act Facility Investigation Work Plan, U.S. Department of Energy Environmental Restoration Sites, Tonopah Test Range, Nevada, Volume 1. Las Vegas, NV.

U.S. Department of Energy, Nevada Operations Office. 1996. Corrective Action Unit Work Plan, Tonopah Test Range, Nevada, DOE/NV--443. Las Vegas, NV.

U.S. Environmental Protection Agency. 2005. Handbook on the Management of Munitions Response Actions, EPA 505-B-01-001. Washington, DC: Office of Solid Waste and Emergency Response.

Weston, see Weston Solutions, Inc.

Weston Solutions, Inc. 2009. Munitions and Explosives of Concern (MEC) Disposal Pit Investigation \& Submunition Clearance Work Plan, Corrective Action Unit 408, UXO Sites, Tonopah Test Range. June. Prepared for Stoller-Navarro Joint Venture. Huntsville, AL.

Zapata, see Zapata Engineering.

Zapata Engineering. 2007. Final Report, Geophysical Surveys, Tonopah Test Range, Tonopah Nevada. Prepared for National Security Technologies, LLC. Golden, CO. 


\title{
Appendix A
}

\section{Data Quality Objectives as Developed in the SAFER Plan}

\author{
(23 Pages) \\ Note: This appendix contains the DQOs presented in SAFER Plan and consists of \\ Section 3.0 of the SAFER Plan. Therefore, cross-references, page numbers, \\ and header information in this appendix refer to the original document.
}




\subsection{Data Quality Objectives}

The DQO process is a seven-step systematic planning method used to plan data collection and field investigation activities and provide the framework for corrective action decisions for CAU 408, Bomblet Target Area (TTR). The seven steps of the DQO process presented in this report were developed according to the U.S. Environmental Protection Agency (EPA) Guidance on Systematic Planning Using the Data Quality Objectives Process (EPA, 2006). The DQOs are designed to ensure that data collected will provide sufficient and reliable information to identify, evaluate, and technically defend the recommended corrective actions. Outputs from the DQO process will define: the objective of the data collection effort, the target population and CSM, the most appropriate type of data to collect, the closure standards, and the hold points where investigation findings will be reviewed with NDEP to obtain a consensus for a path forward.

During DQO discussions for CAU 408, data needed to resolve decision statements were identified, criteria for data collection and analysis were defined and agreed upon, and the appropriate QA/QC required for data collection activities were assigned. The individual QC measurements for the submunition removal activities and the analytical methods, reporting limits, and data quality indicators (DQIs) for laboratory analysis (e.g., precision and accuracy requirements) prescribed through the DQO process are provided in more detail in Section 7.0.

\subsection{Summary of DQO Analysis}

\subsubsection{State the Problem (Step 1)}

Step 1 of the DQO process describes the problem to be studied and develops a CSM to gain a sufficient understanding of the problem. The CSM for CAU 408 is defined in Section 3.2.5.

The problem statement for CAU 408 is: “Corrective Action Unit 408 is being investigated and closed because potential and known explosive hazards due to the presence of MEC/UXO and potential soil contamination related to DOE submunitions testing exist at locations within CAU 408 target areas.”

The objective of the study is to gather sufficient information during the implementation phase to resolve the decision statements listed in Section 3.1.2. Additional information is required to verify 
existing information, confirm the existence and extent of explosives hazards and/or soil contamination, and affirm the closure decision.

\subsubsection{Background Information}

The following sections present information on the physical setting, operational history, sources of potential contamination, and COPCs.

Physical Setting and Operational History - The CAU 408 target areas were used from the late 1960s to 1988 for the testing and development of improved submunition dispersion coverage and CBU accuracy (BN, 2004). Bomblet dispersion patterns were mapped at the target areas to provide input for engineering design and to document the accuracy of laser-guided CBU pods. Submunitions used for the testing consisted of various types of small spherical and cylindrical ordnance that ranged in size from 2 to 4 in. Dispersion testing included aerial drops of CBUs containing bomblets. After release from the aircraft, the CBUs would open and disperse the bomblets over the target areas. The bomblets used were mainly inert; however, at least one live test (containing high explosives) was also conducted (Karas et al., 1993).

The CAU 408 target areas are located in Cactus Flat and are relatively flat with no well-developed arroyos or erosional channels. The South Antelope Lake target area is located on a dry lake bed. Cactus Flat is an intermontane basin, typical of the Basin and Range Physiographic Province, surrounded by the Cactus Range to the southwest, the northern portion of Kawich Range to the east, and the Monitor Range to the north (DOE/NV, 1994). The central portion of Cactus Flat is underlain by thick sequences of valley-fill and/or lake and shoreline deposits. The surface is covered by deep thick soils that can range from poorly graded to well graded. The valley-fill material consists of poorly sorted sand, gravel and clay; whereas, the shoreline deposits are mainly composed of coarse to medium grained sand that is moderately well sorted. Total thickness of the alluvial deposits is unknown but may exceed $700 \mathrm{ft}$ (DOE/NV, 1994). A moderately thick soil layer on top of playa deposits underlies the Antelope Lake area. These deposits are rich in clay and may form large cracks during dry periods as they are subject to significant shrinking and swelling. The deposits are underlain by a thick sequence of valley-fill alluvium consisting of gravel and coarse sand (DOE/NV, 1994). 
The depth to alluvial groundwater near Antelope Lake is approximately $66 \mathrm{ft}$ below ground surface (bgs), and depth to alluvial groundwater below Mid Target is approximately 230 to $262 \mathrm{ft}$ bgs (DOE/NV, 1994). The depth to groundwater beneath Cactus Flat ranges from 90 to $600 \mathrm{ft}$ bgs. Groundwater flows northwest between Cactus Peak and Monitor Hills and then southwest into Stonewall Flat and Gold Flat and ultimately discharges into Death Valley (DOE/NV, 1994 and 1996c).

Sources of Potential Contamination and COPCs - The bomblets, which may contain high explosives, are the source of potential explosives hazards as well as soil contamination to the native surface/subsurface soil. In addition, bomblets on the South Antelope Lake target area may contain DU. Soil contamination is not expected at CAU 408; however, this will be confirmed by collecting and analyzing soil samples. Based on process knowledge, the only COPCs are high explosives (all bomblet areas), metals (i.e., lead and mercury; all bomblet areas), and DU (South Antelope Lake bomblet area and disposal pits).

\subsubsection{Identify the Goal of the Study (Step 2)}

Step 2 of the DQO process identifies the decision statements.

The goal of the study is to verify completion of surface clearance of each target area and remediation of disposal pits associated with CAU 408. The DQOs require identification of disposal pits and delineation of all submunition target areas.

The selected corrective action for CAU 408 is to clean close areas of submunition testing and disposal. This corrective action will be achieved by performing submunition removal activities and excavation of soil with COCs. Individual QC measurements for the submunitions removal and DQIs for laboratory analysis will be implemented to document that the procedures and acquired data can support the DQO for CAU 408. At the completion of CAU 408 closure activities, there will be a high degree of confidence that a comprehensive surface clearance of all areas of submunition target areas has been completed, and all disposal pits have been identified and remediated. 
Decision statements for CAU 408 are:

1. Have all disposal pits been identified?

2. Have all hazardous materials in disposal pits been removed?

3. Have all areas impacted by submunitions (i.e., bomblets) been identified and delineated?

4. Have 100 percent of all areas impacted by submunitions been surface cleared of DOE-related submunitions?

5. Have all COCs (if present in soil) been removed?

\subsubsection{Alternative Actions}

If it is determined that any of the above decision statements are negative, additional investigation and/or excavation will be conducted. If MEC or contamination still exists and additional remediation would violate the conditions of the SAFER, then work will stop and a consensus will be reached with NDEP on the path forward before continuing the affected SAFER activities.

\subsubsection{Identify Information Inputs (Step 3)}

Step 3 of the DQO process identifies the information needed, determines sources of information, and identifies sampling and analysis methods that will allow reliable comparisons with FALs. Table 3-1 provides a summary of the information needs and information sources for each of the CAU 408 decision statements.

\subsubsection{Information Needs}

To confirm the CSM and determine the nature and extent of MEC and contamination, data must be collected to provide the following:

- Information demonstrating that all disposal pits have been identified and remediated.

- Information demonstrating that no contamination exceeding FALs remains. 
Table 3-1

Data Quality Objective Decision Table

\begin{tabular}{|c|c|c|c|c|c|c|c|c|c|}
\hline DQO Decision & $\begin{array}{l}\text { Information } \\
\text { Needs }\end{array}$ & $\begin{array}{l}\text { Information } \\
\text { Sources }\end{array}$ & $\begin{array}{c}\text { Decision } \\
\text { Unit }\end{array}$ & $\begin{array}{c}\text { Target } \\
\text { Population }\end{array}$ & $\begin{array}{l}\text { Population } \\
\text { Parameter }\end{array}$ & $\begin{array}{l}\text { Action } \\
\text { Level }\end{array}$ & $\begin{array}{l}\text { Acceptance } \\
\text { Criteria }\end{array}$ & $\begin{array}{l}\text { False } \\
\text { Negative }\end{array}$ & $\begin{array}{l}\text { False } \\
\text { Positive }\end{array}$ \\
\hline $\begin{array}{l}\text { Have all disposal pits } \\
\text { been identified? }\end{array}$ & $\begin{array}{l}\text { Evidence that no } \\
\text { disposal pits remain }\end{array}$ & $\begin{array}{c}\text { Geophysical surveys } \\
\text { Mag and Diga }\end{array}$ & CAS & $\begin{array}{l}\text { Buried submunition } \\
\text { debris }\end{array}$ & $\begin{array}{l}\text { Observation of buried } \\
\text { submunition debris in } \\
\text { excavation or during } \\
\text { surface clearance }\end{array}$ & $\begin{array}{l}\text { Presence of buried } \\
\text { submunition debris }\end{array}$ & $\begin{array}{l}\text { Absence of buried } \\
\text { submunition debris }\end{array}$ & $\begin{array}{l}\text { All pre-defined potential } \\
\text { disposal pit anomalies } \\
\text { excavated } \\
\text { Perform surface } \\
\text { clearance on } 100 \% \text { of } \\
\text { target areas } \\
\text { Seeding, calibration, } \\
\text { and excavation proofing } \\
\text { (Section } 7.1)\end{array}$ & $\begin{array}{l}\text { Verify that subsurface } \\
\text { submunitions were } \\
\text { placed for burial }\end{array}$ \\
\hline $\begin{array}{l}\text { Have all hazardous } \\
\text { materials in the disposal } \\
\text { pits been removed? }\end{array}$ & $\begin{array}{l}\text { Evidence that no } \\
\text { submunitions or } \\
\text { contamination remains } \\
\text { exceeding FALs }\end{array}$ & $\begin{array}{l}\text { Observation } \\
\text { Analytical verification } \\
\text { samples }\end{array}$ & Each disposal pit & $\begin{array}{l}\text { Hazardous debris and } \\
\text { soil containing COCS }\end{array}$ & $\begin{array}{l}\text { Observation of } \\
\text { submunitions debris } \\
\text { Analytical sample } \\
\text { results }\end{array}$ & $\begin{array}{c}\text { Presence of } \\
\text { submunitions debris } \\
\text { FALs }\end{array}$ & $\begin{array}{l}\text { Absence of } \\
\text { submunitions debris } \\
\text { Analytical sample } \\
\text { results less than FALs }\end{array}$ & $\begin{array}{l}\text { Excavation will continue } \\
\text { until native materials are } \\
\text { encountered on each } \\
\text { side and below the } \\
\text { disposal pit }\end{array}$ & None \\
\hline $\begin{array}{l}\text { Have all areas impacted } \\
\text { by DOE submunitions } \\
\text { been identififed and } \\
\text { delineated? }\end{array}$ & $\begin{array}{l}\text { Evidence that all areas } \\
\text { impacted by } \\
\text { submunitions and } \\
\text { submunitions fragments } \\
\text { are contained within } \\
\text { study area }\end{array}$ & $\begin{array}{l}\text { Mag and } \mathrm{Dig}^{\mathrm{a}} \\
\text { Observation }\end{array}$ & CAS & $\begin{array}{l}\text { Areas impacted by } \\
\text { submunitions }\end{array}$ & $\begin{array}{l}\text { Geophysical instrument } \\
\text { results } \\
\text { Observation of } \\
\text { submunitions debris }\end{array}$ & $\begin{array}{c}\text { Presence of } \\
\text { submunitions debris }\end{array}$ & $\begin{array}{l}\text { Absence of } \\
\text { submunitions debris } \\
\text { observed in a radius of } \\
200 \text { ft from last } \\
\text { observed submunitions } \\
\text { debris and in the buffer } \\
\text { zone } \\
\text { Analytical sample } \\
\text { results less than FALs }\end{array}$ & $\begin{array}{l}\text { Seeding, calibration, } \\
\text { and excavation proofing } \\
\text { (Section 7.1) } \\
\text { Perform surface } \\
\text { clearance on } 100 \% \text { of } \\
\text { target areas } \\
\text { Verify that no } \\
\text { submunitions debris are } \\
\text { present within } 200 \text { ft of } \\
\text { last observed } \\
\text { submunitions debris or } \\
\text { in the buffer zone }\end{array}$ & $\begin{array}{l}\text { No submunitions debris } \\
\text { in a radius of } 200 \mathrm{ft} \text { from } \\
\text { last tobserved } \\
\text { submunitions debris will } \\
\text { stop clearance of } \\
\text { additional areas }\end{array}$ \\
\hline $\begin{array}{l}\text { Have all areas impacted } \\
\text { by DOE submunitions } \\
\text { been cleared? }\end{array}$ & $\begin{array}{l}\text { Evidence that surface } \\
\text { clearance has been } \\
\text { performed on } 100 \% \text { of } \\
\text { areas impacted by } \\
\text { submunitions and } \\
\text { submunitions fragments }\end{array}$ & GPS measurements & Each target area & $\begin{array}{l}\text { Areas delineated to } \\
\text { have been impacted by } \\
\text { submunitions }\end{array}$ & Measurements of area & $\begin{array}{l}100 \% \text { coverage of areas } \\
\text { delineated to have been } \\
\text { impacted by } \\
\text { submunitions }\end{array}$ & $\begin{array}{l}\text { Surface clearance has } \\
\text { been completed on } \\
100 \% \text { of areas } \\
\text { delineated to have been } \\
\text { impacted by } \\
\text { submunitions }\end{array}$ & $\begin{array}{l}\text { Calibration of GPS } \\
\text { Calculations of area }\end{array}$ & $\begin{array}{l}\text { Calibration of GPS } \\
\text { Calculations of area }\end{array}$ \\
\hline Do any COCs remain? & $\begin{array}{l}\text { Evidence that no } \\
\text { contamination remains } \\
\text { exceeding FALs }\end{array}$ & $\begin{array}{l}\text { Analytical verification } \\
\text { samples }\end{array}$ & $\begin{array}{l}\text { Each target area and } \\
\text { each disposal pit }\end{array}$ & Soil containing cOCs & $\begin{array}{l}\text { Analytical sample } \\
\text { results }\end{array}$ & FALS & $\begin{array}{l}\text { Analytical sample } \\
\text { results less than FALs }\end{array}$ & $\begin{array}{l}\text { Selection of sample } \\
\text { locations } \\
\text { MDCs less than FALs }\end{array}$ & $\begin{array}{c}\text { Prevention of } \\
\text { cross-contamination } \\
\text { QA protocols }\end{array}$ \\
\hline
\end{tabular}

${ }^{\mathrm{a}}$ See Section 3.1.3.2.

$\mathrm{MDC}=$ Minimum detectable concentration 
- Information demonstrating that all areas impacted by MEC and submunitions fragments are contained within the study area.

- Information demonstrating that surface clearance has been performed on 100 percent of the areas impacted by submunitions and submunitions fragments.

\subsubsection{Sources of Information}

Information needed to answer the study questions will be generated by conducting a field investigation and implementing corrective actions as required by DQO decision criteria. These activities will include:

- Excavating locations indicated by geophysical measurements to identify disposal pits and remove submunitions.

- Conducting a surface clearance of submunitions using appropriate detection and removal technologies (e.g., magnetometers).

- Collecting analytical samples based on the presence of disposal pits or indications of soil contamination (e.g., elevated radiological field-screening results or soil discoloration).

Existing digital geophysical mapping, multispectral photographs, and surface radiological survey data have been analyzed to identify a list of geophysical anomalies that have the potential to represent disposal pits at the South Antelope Lake target area and SAC Target 1. The basis for the selection of these geophysical anomalies as potential disposal pit locations is presented in Section 3.1.7. The presence of a disposal pit in any target area (including the South Antelope Lake target area) will be determined during the surface clearance of all target areas. This will be determined using the surface clearance instruments to locate geophysical anomalies representing potential disposal pits, and excavating these anomalies to determine whether a disposal pit is present. Although the surface clearance geophysical instruments (Schonstedt magnetometers or equivalent) are being used for their ability to find a single bomblet at a depth of $1 \mathrm{ft}$, they are also capable of detecting a larger mass of metallic debris (such as a disposal pit) down to the expected depths of the disposal pits. Single ferrous objects or large concentrations of ferrous debris (such as a disposal pit) can be identified at deeper depths depending upon the material and burial orientation of the items. Based upon the instrument's instruction manual (Schonstedt, 2003), the Schonstedt is capable of detecting an 18-in. length of $3 / 4$-in. pipe at depths up to $9 \mathrm{ft}$ bgs. The instrument may also detect a 55-gallon 
drum at depths up to $10 \mathrm{ft}$ bgs. Similar single items or concentrations of items exhibiting similar or more mass, like that in a disposal pit, would fall within the detection range of the Schonstedt.

Excavation or potholing of potential disposal pit locations will provide the information to decide whether the anomaly represents a disposal pit. Visual observations will determine whether the material excavated represents a location where debris has been buried.

"Mag and Dig” clearance surveys using handheld analog instrumentation (magnetometers) is the primary detection technology selected to detect, identify, and remove submunitions at CAU 408 submunition target areas and to detect bomblets up to $1 \mathrm{ft}$ bgs. For conducting the surface clearance at all seven target areas identified within CAU 408, the target response depth is determined to be $1 \mathrm{ft}$ bgs.

Mag and Dig surveys use grid systems and clearance lanes to provide and ensure full coverage of a survey area and to define lateral extent of the submunition test locations. Mag and Dig is a technology commonly used when MEC is not easily distinguishable from other metallic fragments and each anomaly must be investigated. When the instrument detects an anomaly, the operator will dig to identify the anomaly or place a small flag in the ground so the operator can return to dig and identify the anomaly. Advantages of analog geophysical surveys include:

- The ability of geophysical operator to use real-time field observations

- Determination of a precise anomaly location

- Anomalies that can be excavated immediately following and/or during the survey

- Operation with fewer vegetation and topographic constraints

Verification soil samples will be collected from biased locations. Samples will be collected from locations likely to be contaminated using appropriate sampling methods. The locations likely to be contaminated include areas with high concentrations of damaged or partially intact bomblets filled with high explosives, and areas where discrete pieces of DU are found. Soil samples collected from all bomblet areas will be analyzed for explosives and metals. In addition, soil samples collected from the South Antelope Lake area will be analyzed for isotopic uranium (U). Samples will be submitted to analytical laboratories meeting the quality criteria stipulated in the Industrial Sites QAPP (NNSA/NV, 2002). Validated data from analytical laboratories will be used to support DQO decisions. Sample collection and handling activities will follow standard procedures. 


\subsubsection{Define the Boundaries of the Study (Step 4)}

Step 4 of the DQO process defines the target population and characteristics of interest, specifies the spatial boundaries and time constraints of that population pertinent for decision-making, determines practical constraints on data collection, and defines units on which decisions will be made.

\subsubsection{Target Population}

The populations of interest are buried submunition debris (i.e., disposal pits), areas impacted by submunitions, and soil containing any COC. Table 3-1 provides a summary of the target populations for each of the DQO decision statements.

\subsubsection{Spatial Boundaries}

The vertical boundary for surface clearances is a depth of $2 \mathrm{ft}$ bgs, and for target area disposal pits the vertical spatial boundary is a depth of $20 \mathrm{ft}$ bgs. The lateral spatial boundary has been established at 23,000 ft north of the northern edge of Mid Target, 23,000 ft south of the southern edge of the Southern Flightline Tomahawk 2 Target, and 23,000 ft on both sides of the flightline axis. If bomblets and/or contamination are identified outside these boundaries, the CSM will be reviewed with NDEP, and a determination will be agreed upon as to how to proceed.

\subsubsection{Practical Constraints}

Other constraints that may affect the ability to implement the SAFER include the following:

- Approval of this revision of the SAFER Plan

- Access restrictions at the TTR (e.g., military exercises, threatened and endangered species)

\subsubsection{Define the Decision Units}

The scale of decision-making for each of the DQO decision statements is provided in Table 3-1. 


\subsubsection{Develop the Analytical Approach (Step 5)}

Step 5 of the DQO process defines the population parameters, develops the decision rules for drawing conclusions from findings, and specifies the action levels. Table 3-1 provides a summary of the population parameters and action levels for each of the DQO decision statements.

\subsubsection{Population Parameters}

The population parameter for the identification of disposal pits and areas impacted by submunitions is the observation of submunitions debris. The population parameter for determining whether all areas impacted by submunitions debris have been cleared of submunitions is the areal measurement of the cleared areas. The population parameter for COC contamination is each soil sample result that will be compared to the action levels.

\subsubsection{Decision Rules}

The decision rules are described in this section for each of the CAU 408 decision statements.

Decision Statement 1: Have all disposal pits been identified?

If all of the potential disposal pit locations presented in Section 3.1.7 have been excavated and all of the potential disposal pit locations identified during the surface clearance operations have been verified, then it will be decided that all disposal pits have been identified. If this criterion has not been met, then additional excavations will be performed at the identified geophysical anomalies. Visual observations will determine whether the material excavated represents a location where debris has been buried.

Decision Statement 2: Have all hazardous materials in disposal pits been removed?

If only native soil remains on the sides and bottom of a disposal pit excavation (i.e., no additional debris is observed) and verification sample results do not contain contamination at concentrations exceeding FALs, then it will be decided that all hazardous materials have been removed from the disposal pit. If this criterion has not been met, additional material will be excavated from the disposal pit. 
Decision Statement 3: Have all areas impacted by submunitions (i.e., bomblets) been identified and delineated?

If predefined target areas (including a 200 -ft radius surrounding the last item observed or identified) and the visual inspection of buffer zones surrounding each target area are clear of submunitions debris, then it will be decided that the extent of the target area has been delineated. If this criterion has not been met, the boundary of the target area will be extended, and a surface clearance will be conducted over the extended area.

Decision Statement 4: Have 100 percent of all areas impacted by submunitions been surface cleared of DOE-related submunitions?

If the areas covered by surface clearance traverses are adjacent and extend to the edges of the target area, then it will be decided that 100 percent of the target area has been surface cleared. If this criterion has not been met, additional surface clearance will be conducted.

Decision Statement 5: Have all COCs (if present in soil) been removed?

If all analytical result concentrations from all verification samples are less than their corresponding FALs, then it will be decided that no COCs remain in the target area. If this criterion has not been met, soils containing COCs will be removed for disposal.

\subsubsection{Action Level Determination and Basis}

The action levels for each of the DQO decision statements are summarized in Table 3-1. Derivation of the action levels for soil contamination (i.e., PALs and the process for establishing FALs) is presented in Section 3.2.1.

\subsubsection{Specify Performance or Acceptance Criteria (Step 6)}

Step 6 of the DQO process specifies controls against false rejection and false acceptance decision errors and examines the consequences of making incorrect decisions. Setting acceptable limits on the likelihood of making decision errors requires the planning team to weigh the relative effects of threat to human health and the environment, expenditure of resources, and the consequences of an incorrect decision. 
In general, confidence in DQO decisions will be established qualitatively by:

- Developing CSMs

- Testing the validity of the CSMs based on investigation results

- Evaluating the quality of the data based on performance criteria

\subsubsection{False Negative Decision Error}

This decision error would mean deciding that surface clearances are complete when they are not; all disposal pits have been remediated when they have not; or COCs are not present when they actually are. The potential consequence of a false negative decision error is an increased risk to human health and environment. The potential for a false negative decision error is reduced by meeting these criteria:

- Excavating at all potential disposal pit locations presented in Section 3.1.7 up to $10 \mathrm{ft}$ bgs or the undisturbed native soil interface (if less than $10 \mathrm{ft}$ bgs), and at all of the potential disposal pit locations identified during the surface clearance operations.

- Removing MEC and debris from disposal pits as verified by visual confirmation that native soil is present on all sides and the bottom of the excavation.

- Delineating target areas requiring surface clearance. The lateral boundaries of the areas impacted by submunitions will be defined by:

- Conducting a visual inspection of all buffer zones to identify surface submunition debris.

- Continuing the surface clearance beyond the target area boundary if necessary to establish a cleared area at least $200 \mathrm{ft}$ beyond the last identified submunition. For example, if MEC were discovered during the visual evaluation of a target buffer zone, an area extending $200 \mathrm{ft}$ surrounding the item would be surface cleared as described in Section 4.2.1.

- Completing the surface clearance of 100 percent of the areas impacted by submunitions, and investigating all potential submunition and potential disposal pit anomalies.

- Function-testing all handheld geophysical instruments at a geophysical system verification test strip daily (see Section 7.1.1) to ensure equipment is operating properly.

- Placing blind QC seeds (see Section 7.1.2) that consist of inert bomblets in each submunition test area to monitor anomaly detection performance during the submunition removal activities. 
- Performing QA verification of submunition removal during surface clearance operations (see Section 7.1.3).

- Selecting soil sample locations from areas most likely to be contaminated (e.g., highest radiation survey readings, staining).

- Assessing the analytical and field survey results to ensure that all sample analyses and instrumentation have detection limits less than or equal to the corresponding action levels.

- Assessing the data against the DQIs of precision, accuracy, comparability, sensitivity, and completeness, and collecting the appropriate QC samples as defined in the Industrial Sites QAPP (NNSA/NV, 2002).

\subsubsection{False Positive Decision Error}

This decision error would mean deciding that surface clearances are not complete when they actually are; disposal pits are present when they are not; MEC and debris remain in disposal pits when they actually do not; or COCs are present when they actually are not present. The potential consequence of a false positive decision error is increased costs and project duration. A false positive decision error in determining whether a disposal pit is present will be controlled by ensuring that subsurface debris is associated with a pit that was excavated and used to place submunition waste, and that it is not present due to other mechanical disturbance (i.e., grading) or from surface cracking of the dry lake bed. False positive decision errors in Mag and Dig surveys are commonly encountered due to the inability of the magnetometer to differentiate between ferrous MEC and ferrous-containing debris or rocks. Each anomaly detected will be investigated to determine whether MEC-related, debris, or geologic origin. False positive decision errors in soil sampling are typically attributed to laboratory and/or sampling errors that could cause cross-contamination. To control against cross-contamination, decontamination of sampling equipment will be conducted according to established and approved procedures, and only clean sample containers will be used. In addition, QC samples such as field blanks, trip blanks, laboratory control samples (LCSs), and method blanks will be collected to minimize the risk of a false acceptance analytical result. 


\subsubsection{Develop the Plan for Obtaining Data (Step 7)}

Results of the DQO analysis are used to develop the design of the sampling and analysis plan in Step 7 of the DQO process. The following summarizes the field activities to be conducted to meet the closure criteria.

All potential disposal pit locations identified in this section will be excavated to determine the presence or absence of buried submunitions waste (i.e., disposal pit). Each potential disposal pit location will be potholed at the center of the geophysical anomaly (i.e., the location of the highest probability of encountering waste) up to a depth of $10 \mathrm{ft}$ bgs or to undisturbed native soil. If no waste is encountered within this depth, it will be determined that the potential disposal pit anomaly does not represent a disposal pit. If waste is encountered, the disposal pit will be remediated by removing the waste until all sides and the bottom of the excavation are composed of native soil. The potential disposal pit anomalies were identified based upon an analysis of the geophysical data collected by Zapata Engineering (Zapata, 2007). A total of 25 anomalies (24 on Antelope Lake and 1 at SAC Target 1) have been identified as potential disposal pits. Figure 3-1 shows the location of the 24 disposal pits on Antelope Lake.

A visual inspection will be conducted over the entire area defined by the CAU boundary as described in Section 1.0 to identify any submunition debris. This includes the areas defined as buffer zones around the target areas as defined in Section 2.0.

Surface clearance activities to identify MEC at the seven defined target areas encompassing the known submunition test area(s) will be conducted using Mag and Dig surveys. Each target area will receive a full coverage (100 percent) Mag and Dig surface clearance using handheld analog geophysical instruments (i.e., magnetometers). Geophysical anomalies detected by UXO Technicians will be evaluated to determine whether they represent submunitions or disposal pits. If identified as submunitions, they will either be blown in place (BIP), or removed and demilitarized as appropriate. If identified as potential disposal pits, they will be excavated to determine the presence of buried submunitions waste. If a disposal pit is identified, the pit materials will be inspected, removed, and disposed to meet clean closure. If MEC is identified, it will either be BIP or, if safe, removed and demilitarized as appropriate. 


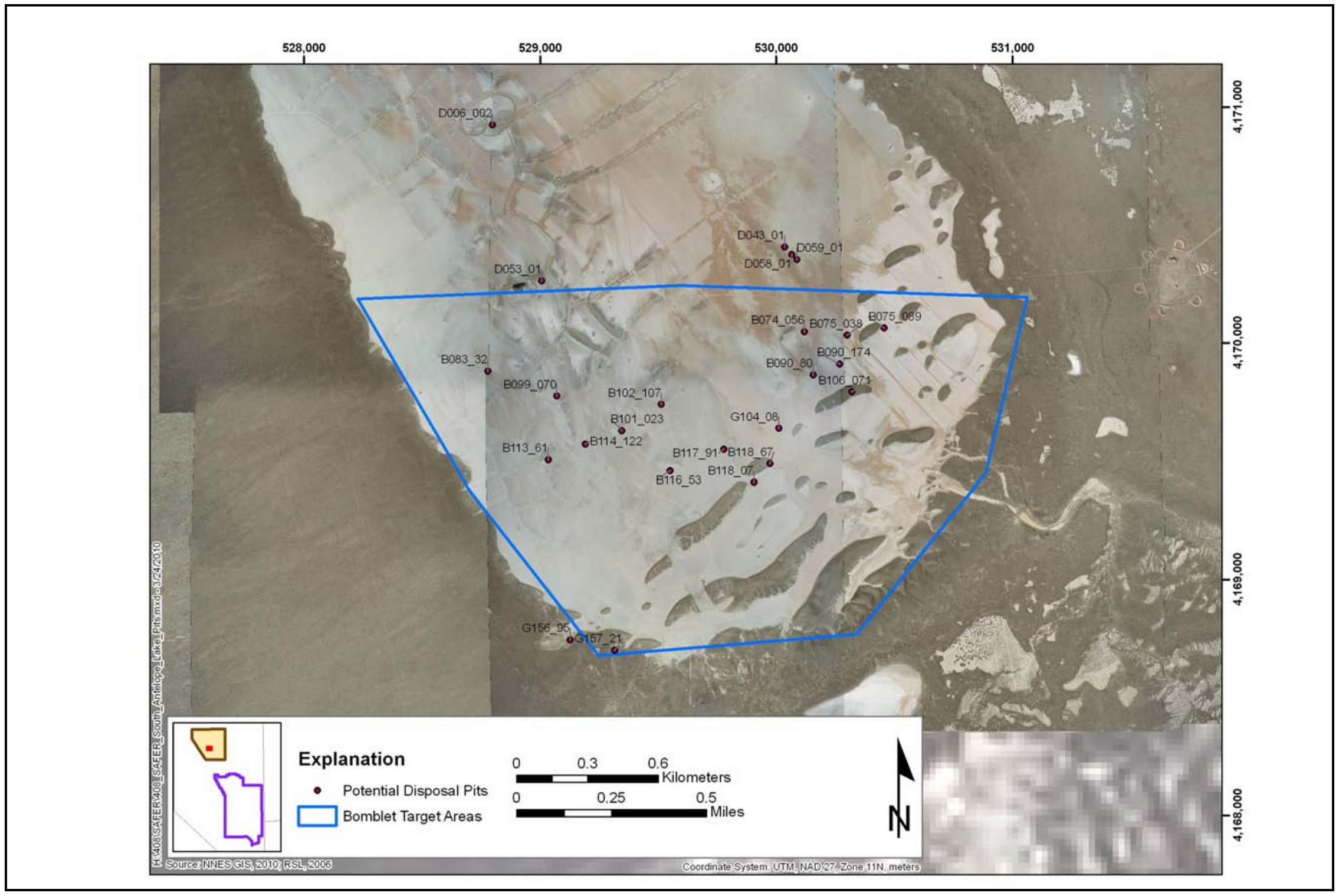

Figure 3-1

Geophysical Anomalies, South Antelope Lake, Tonopah Test Range 
The lateral boundaries of each target area will be extended as necessary to ensure the boundaries of all areas impacted by submunitions are at least $200 \mathrm{ft}$ beyond any identified submunition debris identified either by the surface clearance or the visual survey of the buffer zone.

After submunitions are removed or a disposal pit is remediated, soil verification samples will be collected as appropriate based on biasing factors, and analyzed for explosives, Resource Conservation and Recovery Act (RCRA) metals, and isotopic U (at South Antelope Lake). Biasing factors such as staining and radiation screening results will be used to determine the number and location of samples taken from disposal pits and surface areas. A minimum of three samples will be taken from each disposal pit. If contamination is found above action levels, the contaminated soil will be excavated and disposed.

\subsection{Results of the DQO Analysis}

\subsubsection{Action Level Determination and Basis}

The PALs presented in this section are to be used for site screening purposes. They are not necessarily intended to be used as cleanup action levels or FALs. However, they are useful in screening out contaminants that are not present in sufficient concentrations to warrant further evaluation, therefore streamlining the consideration of remedial alternatives. The risk-based corrective action (RBCA) process used to establish FALs is described in the Industrial Sites Project Establishment of Final Action Levels (NNSA/NSO, 2006a). This process conforms with Nevada Administrative Code (NAC) Section 445A.227, which lists the requirements for sites with soil contamination (NAC, 2008a). For the evaluation of corrective actions, NAC Section 445A.22705 (NAC, 2008b) requires the use of the American Society for Testing and Materials (ASTM) Method E1739 (ASTM, 1995) to "conduct an evaluation of the site, based on the risk it poses to public health and the environment, to determine the necessary remediation standards (i.e., FALs) or to establish that corrective action is not necessary."

This RBCA process, summarized in Figure 3-2, defines three tiers (or levels) of evaluation involving increasingly sophisticated analyses:

- Tier 1 evaluation - sample results from source areas (highest concentrations) are compared to action levels based on generic (non-site-specific) conditions (i.e., the PALs established in the 


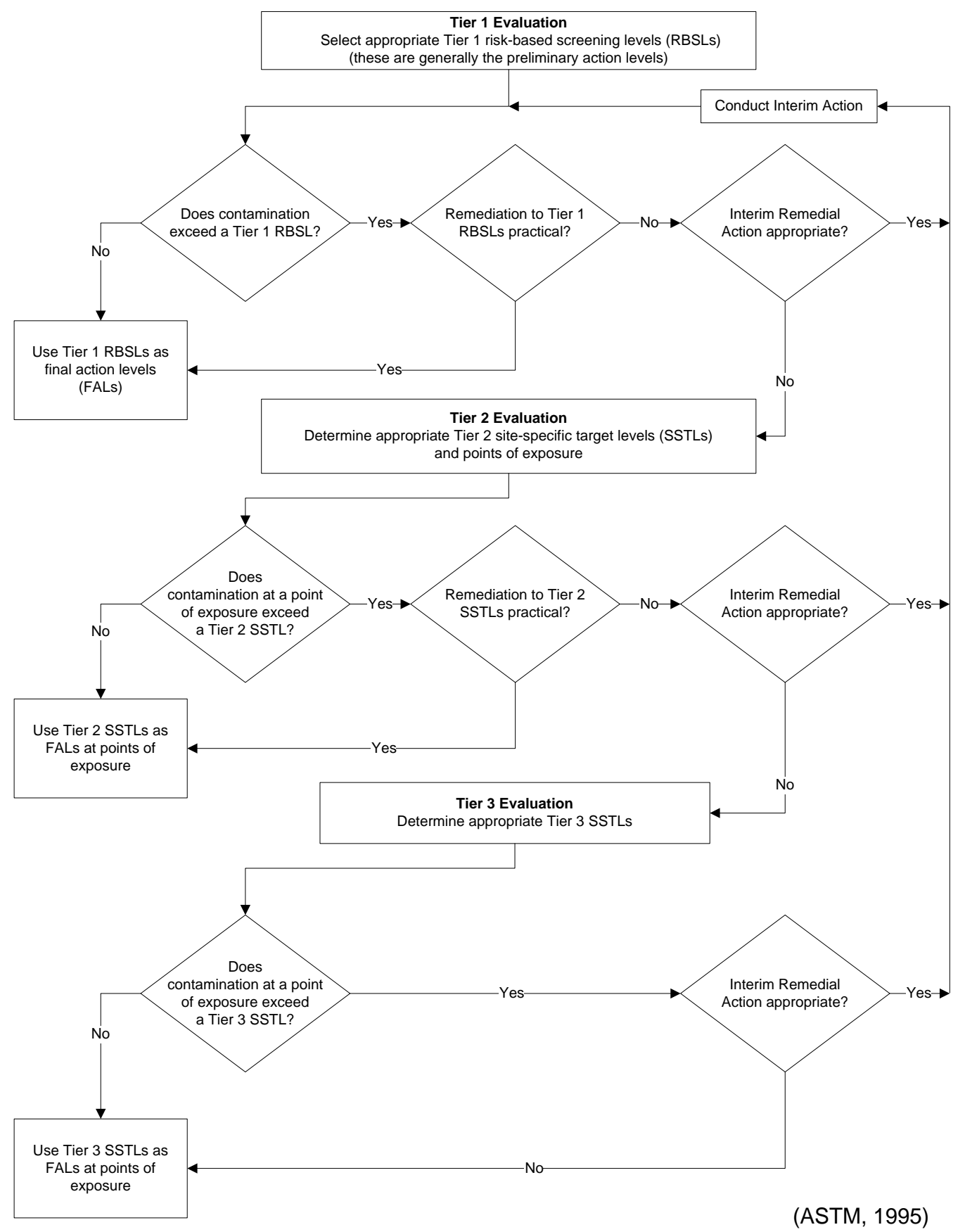

Figure 3-2

Risk-Based Corrective Action Decision Process 
SAFER). The FALs may then be established as the Tier 1 action levels, or the FALs may be calculated using a Tier 2 evaluation.

- Tier 2 evaluation - conducted by calculating Tier 2 site-specific target levels (SSTLs) using site-specific information as inputs to the same or similar methodology used to calculate Tier 1 action levels. The Tier 2 SSTLs are then compared to individual sample results from reasonable points of exposure (as opposed to the source areas as is done in Tier 1) on a point-by-point basis. Total TPH concentrations are not used for risk-based decisions under Tier 2 or Tier 3. Rather, the individual chemicals of concern are compared to the SSTLs.

- $\quad$ Tier 3 evaluation - conducted by calculating Tier 3 SSTLs on the basis of more sophisticated risk analyses using methodologies described in Method E1739 that consider site-, pathway-, and receptor-specific parameters.

Evaluation of DQO decisions will be based on conditions at the site following completion of any corrective actions. Any corrective actions conducted will be reported in the CR. The FALs (along with the basis for their selection) will be defined in the CR, where they will be compared to laboratory results in the evaluation of site closure.

\subsubsection{Chemical PALs}

Except as noted herein, the chemical PALs are defined as the EPA Region 9 Risk-Based Preliminary Remediation Goals (PRGs) for chemical contaminants in industrial soils (EPA, 2008a). Background concentrations for RCRA metals will be used instead of PRGs when natural background concentrations exceed the PRG. Background is considered the mean plus two standard deviations of the mean for sediment samples collected by the Nevada Bureau of Mines and Geology throughout the Nevada Test and Training Range (formerly the Nellis Air Force Range) (NBMG, 1998; Moore, 1999). For detected chemical COPCs without established PRGs, the protocol used by the EPA Region 9 in establishing PRGs (or similar) will be used to establish PALs (EPA, 2008a). If used, this process will be documented in the CR.

\subsubsection{Total Petroleum Hydrocarbon PALs}

The PAL for TPH is 100 parts per million as listed in NAC 445A.2272 (NAC, 2008c). 


\subsubsection{Radionuclide PALs}

The PALs for radiological contaminants (other than tritium) are based on the National Council on Radiation Protection and Measurement (NCRP) Report No. 129 recommended screening limits for construction, commercial, industrial land-use scenarios (NCRP, 1999) using a 25-millirem-per-year dose constraint (Murphy, 2004) and the generic guidelines for residual concentration of radionuclides in DOE Order 5400.5 (DOE, 1993). These PALs are based on the construction, commercial, and industrial land-use scenario provided in the guidance and are appropriate for the TTR based on future land uses.

\subsubsection{Hypothesis Test}

The baseline condition (i.e., null hypothesis) and alternative condition are:

- Baseline condition - closure objectives have not been met

- Alternative condition - closure objectives have been met

\subsubsection{Statistical Model}

A judgmental sampling design will be implemented to select sample locations and evaluate DQO decisions for CAS TA-55-002-TAB2.

\subsubsection{Design Description/Option}

Because individual sample results, rather than an average concentration, will be used to compare to FALs at the CAS, statistical methods to generate site characteristics will not be used. Adequate representativeness of the entire target population may not be a requirement to developing a sampling design. If good prior information is available on the target site of interest, then the sampling may be designed to collect samples only from areas known to have the highest concentration levels on the target site. If the observed concentrations from these samples are below the action level, then a decision can be made that the site does not contain unsafe levels of the contaminant without the samples being truly representative of the entire area (EPA, 2006).

All sample locations will be selected to satisfy the DQI of representativeness in that samples collected from selected locations will best represent the populations of interest. To meet this criterion for 
judgmentally sampled sites, a biased sampling strategy will be used for Decision I samples to target areas with the highest potential for contamination, if it is present anywhere in the CAS. Sample locations will be determined based on process knowledge, previously acquired data, or the field-screening and biasing factors. The Site Supervisor has the discretion to modify the judgmental sample locations, but only if the modified locations meet the decision needs and criteria stipulated in this DQO.

\subsubsection{Conceptual Site Model and Drawing}

The CSM is used to organize and communicate information about site characteristics. It reflects the best interpretation of available information and is based on historical documentation, personnel interviews, process knowledge, site visits, aerial photography, multispectral data, and preliminary geophysical surveys. The CSM describes the most probable scenario for current conditions at the site and defines the assumptions that are the basis for identifying appropriate data collection methods. Figure 3-3 graphically represents the CSM for CAU 408.

The primary CSM is considered the most probable scenario for current conditions at CAU 408. The CSM for CAU 408 assumes that submunition bomblets ranging in size from 2 to 4 in. that were dispensed from CBUs are present at the seven bomblet areas located on the TTR. Some previous cleanup of all submunition test areas is apparent but undocumented. An effective previous cleanup is assumed for the purposes of planning the surface clearance activities. While some miscellaneous debris (other than MEC) may be located and removed during CAU 408 field activities, it is not considered to be part of the closure scope. The primary CAU 408 closure scope is location and removal of MEC meeting CAU 408 MEC criteria within the identified targets.

The bomblets were designed to generate a minimal terminal velocity to impact surface targets and not to penetrate the ground surface. Therefore, they are assumed to be present on the ground surface to a maximum depth of $1 \mathrm{ft}$ bgs. Submunitions were constructed of ferrous metals and will be detectable by geophysical methods (e.g., magnetometry).

Submunitions tests were conducted at Mid Target to assess ordnance and delivery package design. Therefore, submunitions at Mid Target are expected to be concentrated around the CBU grid with some longitudinal dispersion expected along the axis of aircraft travel. Lateral dispersion is expected 


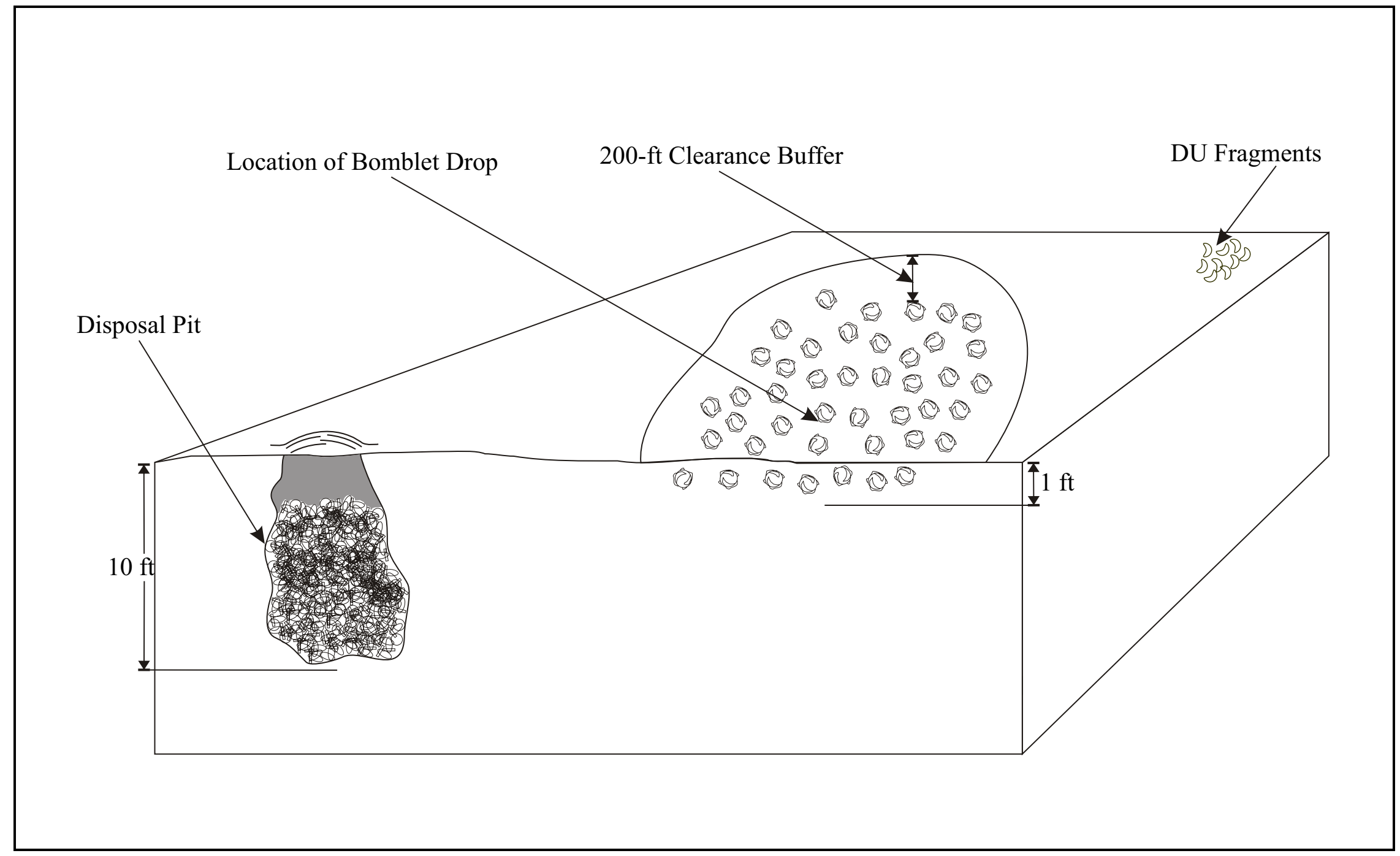

Figure 3-3

Conceptual Site Model Diagram for CAU 408

Source: Modified from NNSA/NSO, 2006b 
to be minimal and concentrated along the flightline axis, resulting in a distribution along the flight path to be skewed in the long (late drop) direction, rather than symmetric about the target.

Submunitions tests were conducted at South Antelope Lake to assess material effects. The tests were restricted to the southern half of the lake so that concurrent tests on the northern half of the lake could continue unaffected. Therefore, submunitions are not expected to be located above the midline of the lake.

Due to the lack of specific information regarding submunitions testing at the remaining five target areas, the CSM for these areas is assumed to be the same as for Mid Target.

Historical site knowledge and interviews indicate that there is potential for submunitions and debris to be present in disposal pits located within any target location. Results from preliminary geophysical surveys using EM-61 detection technology at the South Antelope Lake target area support the existence of several subsurface anomalies with features resembling disposal pits. For the CAU 408 investigation, a disposal pit is defined as a man-made trench or pit in which MEC or munitions-related debris (e.g., target construction materials) are intentionally buried in the ground. Previous subsurface investigations at TTR (e.g., CAU 410 and 484) indicate that if a disposal pit exists, debris or MEC should be encountered within $10 \mathrm{ft}$ bgs. In the case that buried debris is encountered within the anomalous area at an elevation shallower than $10 \mathrm{ft}$ bgs, the area will be defined as a disposal pit.

The primary CSM assumes that upon detonation of the bomblets (high-order detonation), any hazardous constituents (i.e., high explosives) would be spent and would not impact the surrounding soil. In the case of low-order detonations (e.g., dud fires) or damaged intact bomblets, the potential for COPCs in soil increases. However, due to the limited live tests conducted at the CAU 408 targets, COPCs are not expected in soil above FALs. Physical hazards from unexploded bomblets are of concern. The majority of the tests used inert filler and no fuzing, or inert filler and live fuzing. Some tests involved live filler (high explosives) and live fuzing.

At the South Antelope Lake bomblet area, submunition tests containing DU are known to have been conducted; however, the specific test locations have not been documented. A radiological survey of the southern portion of the lake bed was conducted on South Antelope Lake to identify the presence 
of DU, and the site boundaries were delineated to define the lateral extent. Several areas containing DU rings and fragments were identified, excavated, and clean closed under CAU 484 (NNSA/NSO, 2007). Corrective Action Site RG-52-007-TAML (Davis Gun Penetrator Test) was closed in place and use restricted at four locations. These areas are outside the scope of CAU 408. If any DU remains in the South Antelope Lake target area, it is expected to be found in discrete surface areas with minimal soil impact or present within a disposal pit where the volume of DU-impacted soil is expected to be more extensive.

If additional elements that are outside the scope of the CSM are identified during remediation, the situation will be reviewed, and a recommendation will be made as to how to proceed. In such cases, NDEP will be notified and given the opportunity to comment on, or concur with, the recommendation. The CSM describes the most probable scenario for current conditions at the site and defines the assumptions that are the basis for identifying the future land use, contaminant sources, release mechanisms, migration pathways, exposure points, and exposure routes. The CSM is also used to support appropriate sampling strategies and data collection methods. The CSM has been developed for CAU 408 using information from the physical setting, potential contaminant sources, release information, historical background information, knowledge from similar sites, and physical and chemical properties of the potentially affected media and COPCs. Figure 3-4 depicts a tabular representation of the conceptual pathways to receptors from CAU 408 sources. If evidence of contamination not consistent with the CSM is identified during investigation activities, the situation will be reviewed, the CSM will be revised, the DQOs will be reassessed, and a recommendation will be made as to how best to proceed. In such cases, the DQO process participants will be notified and given the opportunity to comment on and/or concur with the recommendation.

The target areas were used to perform submunitions-related tests for the DOE. The scope of CAU 408 is limited to submunitions released from DOE activities. However, it is recognized that the presence of other types of UXO and munitions may be present within the target areas due to the activities of other government organizations. 


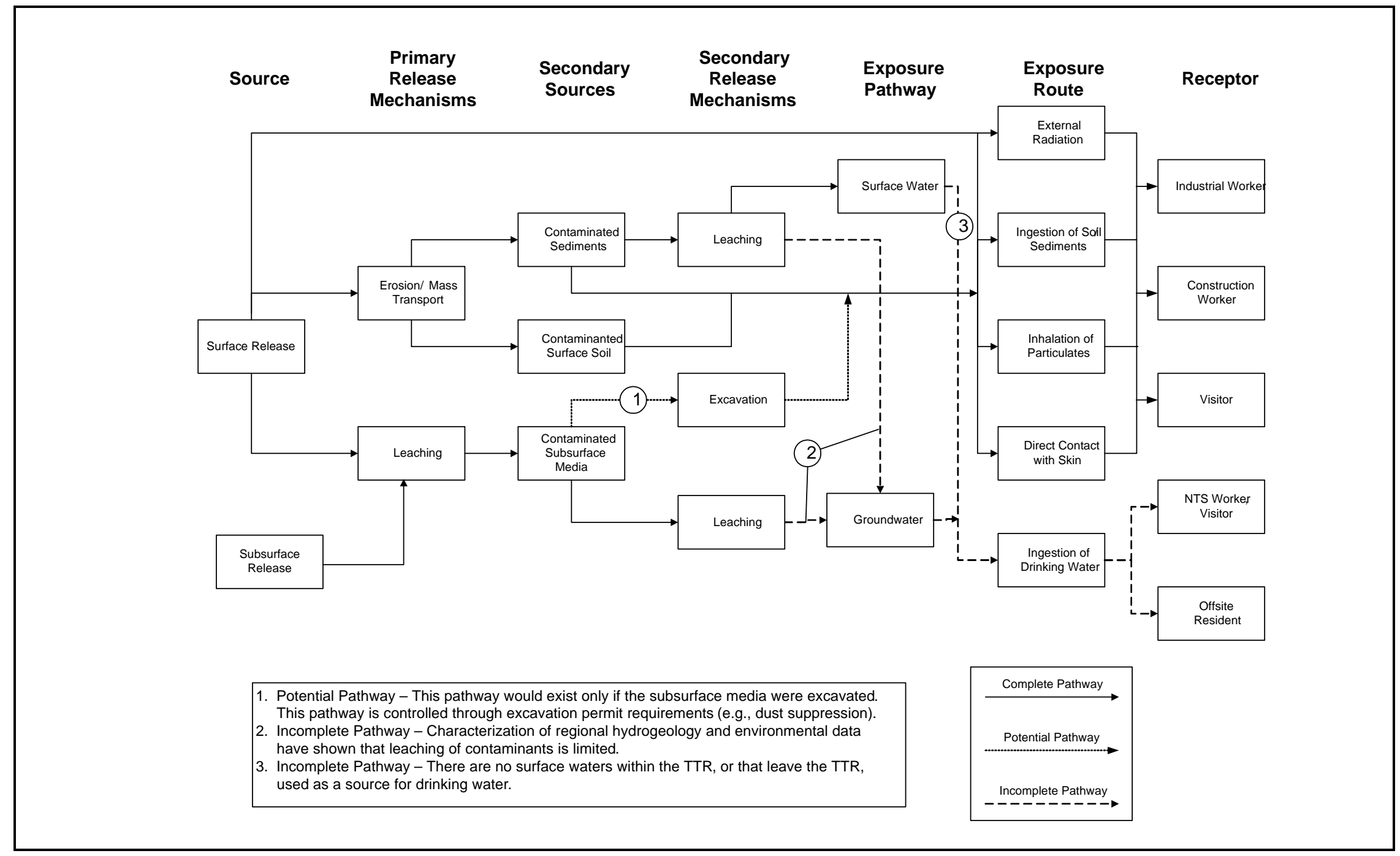

Figure 3-4

Potential Conceptual Site Model Diagram 
Appendix B

MEC Closure Activities 


\section{B.1.0 MEC Closure Activities}

This appendix provides additional detailed information regarding investigation of the 25 original anomalies located on Antelope Lake and SAC Target 1, including the six additional disposal pits discovered during Mag and Dig activities (Table B.1-1). A total of eight disposal pits were identified during the CAU 408 investigation, consisting of the following:

- Two of the original 25 anomalies (G156_95 and D006_002)

- Six additional burial areas identified on South Antelope Lake (one) and Mid Target (five)

Tables B.1-2 through B.1-7 are the grid tracking tables for each of the seven target areas. The tables provide information regarding start and completion dates, QC and seeding information, and types of MEC recovered on each grid. The grid tracking tables are organized as follows:

- $\quad$ Mid Target (Table B.1-2)

- $\quad$ Flightline Target (Table B.1-3)

- $\quad$ SAC Targets 1 and 2 (Table B.1-4)

- $\quad$ South Antelope Lake Target Area (Table B.1-5)

- Tomahawk Target 1 (Table B.1-6)

- Tomahawk Target 2 (Table B.1-7)

Attachments 1 and 2 of this appendix include the After-Action Reports for the investigation of the disposal pits and Mag and Dig clearance surveys within each of the seven target areas, including the buffer zone visual sweep. To meet the project schedule, work scope was segregated and performed by two UXO-qualified subcontractors. Both subcontractors provided qualified UXO-trained personnel to safely accomplish the CAU 408 scope of work. Attachment 1 describes the activities performed by Weston Solutions, Inc. Attachment 2 describes the activities performed by EOD Technology, Inc. 
Table B.1-1

Disposal Pit Status

(Page 1 of 3)

\begin{tabular}{|c|c|c|c|c|c|}
\hline Location & $\begin{array}{c}\text { Date } \\
\text { Excavation } \\
\text { Initiated }\end{array}$ & Debris & MEC & $\begin{array}{c}\text { Date } \\
\text { Excavation } \\
\text { Completed }\end{array}$ & $\begin{array}{c}\text { Final } \\
\text { Inspection }^{\mathrm{a}}\end{array}$ \\
\hline Anomaly G157_21 & 07/30/2009 & Metal, nails $\sim 0.0$ to 10.0 in. bgs & None & 07/31/2009 & N/A \\
\hline Anomaly G156_95 & 08/03/2009 & $\begin{array}{l}\text { Disposal pit, } \sim 40 \mathrm{yd}^{3} \text {, construction-type debris } \\
\text { (wood, wire, cable, concrete) }\end{array}$ & Inert MD & 09/09/2009 & N/A \\
\hline Anomaly G104_08 & 09/10/2009 & Spikes, nails & None & 09/10/2009 & 09/11/2009 \\
\hline Anomaly B117_91 & 09/10/2009 & Spikes, nails & None & 09/10/2009 & 09/11/2009 \\
\hline Anomaly B118_67 & 09/11/2009 & None & None & 09/11/2009 & 09/11/2009 \\
\hline Anomaly B118_07 & 09/11/2009 & None & None & 09/11/2009 & 09/11/2009 \\
\hline Anomaly B116_53 & 09/14/2009 & Spikes, nails of volume $\sim 2.5 \mathrm{gal}$ in buckets & None & 09/14/2009 & 09/15/2009 \\
\hline Anomaly B102_107 & 09/15/2009 & $\begin{array}{l}\text { Spikes, miscellaneous debris-identified } \\
\text { as former demolition area, not a disposal pit }\end{array}$ & $\begin{array}{l}\text { Five BLU-49s + } \\
\text { fragments }\end{array}$ & 09/16/2009 & 09/16/2009 \\
\hline Anomaly B101_023 & 09/17/2009 & $\begin{array}{l}\text { Street sign, nails, metal spikes of volume } \\
\qquad 3 \text { gal in buckets }\end{array}$ & None & 09/17/2009 & 09/17/2009 \\
\hline Anomaly B114_122 & 09/17/2009 & Nails of volume $\sim 2 \mathrm{gal}$ in buckets & None & 09/17/2009 & 09/17/2009 \\
\hline Anomaly B113_61 & 09/18/2009 & Metal nails & None & 09/18/2009 & 09/18/2009 \\
\hline Anomaly B075_038 & 09/21/2009 & Metal, nails of volume $\sim 2.5 \mathrm{gal}$ in buckets & None & 09/21/2009 & 09/21/2009 \\
\hline Anomaly B075_089 & 09/21/2009 & Metal, nails of volume $\sim 3.5 \mathrm{gal}$ in buckets & None & 09/21/2009 & 09/21/2009 \\
\hline Anomaly B099_070 & 09/28/2009 & None & None & 09/28/2009 & 09/28/2009 \\
\hline
\end{tabular}


Table B.1-1

Disposal Pit Status

(Page 2 of 3 )

\begin{tabular}{|c|c|c|c|c|c|}
\hline Location & $\begin{array}{c}\text { Date } \\
\text { Excavation } \\
\text { Initiated }\end{array}$ & Debris & MEC & $\begin{array}{c}\text { Date } \\
\text { Excavation } \\
\text { Completed }\end{array}$ & $\begin{array}{c}\text { Final } \\
\text { Inspection }^{\mathrm{a}}\end{array}$ \\
\hline Anomaly B090_174 & 09/23/2009 & Metal spikes & None & 09/23/2009 & 09/24/2009 \\
\hline Anomaly B074_056 & 09/22/2009 & Surface metal debris only & None & 09/22/2009 & 09/22/2009 \\
\hline Anomaly B106_071 & 09/24/2009 & Surface debris only & None & 09/24/2009 & 09/24/2009 \\
\hline Anomaly B083_32 & 09/28/2009 & None & None & 09/28/2009 & 09/28/2009 \\
\hline Anomaly B090_80 & 09/23/2009 & Metal spikes & None & 09/23/2009 & 09/24/2009 \\
\hline Anomaly D006_002 & 09/24/2009 & Disposal pits at points \#1 \&\#3, scrap metal & $\begin{array}{l}\text { Live M424A1 spotting } \\
\text { round, joint test } \\
\text { assembly unit }\end{array}$ & 09/25/2009 & 09/25/2009 \\
\hline Anomaly D043_01 & 09/22/2009 & Nails on surface, wood, spikes, metal rings & None & 09/22/2009 & 09/22/2009 \\
\hline Anomaly D053_01 & 09/28/2009 & None & None & 09/28/2009 & 09/28/2009 \\
\hline Anomaly D058_01 & 09/22/2009 & Nails on surface, wood, spikes, metal rings & None & 09/22/2009 & 09/22/2009 \\
\hline Anomaly D059_01 & 09/22/2009 & Nails on surface, wood, spikes, metal rings & None & 09/22/2009 & 09/22/2009 \\
\hline Anomaly SAC Target 1 & 08/28/2009 & Nails, battery parts, and metallic debris on surface & Inert MD & $10 / 12 / 2009$ & $10 / 12 / 2009$ \\
\hline South Antelope Lake Grid 94/701 & $11 / 23 / 2009$ & Disposal pit, MD & None & $11 / 23 / 2009$ & $12 / 01 / 2009$ \\
\hline Mid Target Grid 53/815 & 02/19/2010 & Disposal pit, MD & $\begin{array}{c}\text { BLU-63s, BLU-61s, } \\
\text { BLU-97s }\end{array}$ & $02 / 22 / 2010$ & 03/16/2010 \\
\hline
\end{tabular}


Table B.1-1

Disposal Pit Status

(Page 3 of 3)

\begin{tabular}{|c|c|c|c|c|c|}
\hline Location & $\begin{array}{c}\text { Date } \\
\text { Excavation } \\
\text { Initiated }\end{array}$ & Debris & MEC & $\begin{array}{c}\text { Date } \\
\text { Excavation } \\
\text { Completed }\end{array}$ & $\begin{array}{c}\text { Final } \\
\text { Inspection }^{a}\end{array}$ \\
\hline Mid Target Grid 53/814 & 02/19/2010 & Disposal pit, MD & $\begin{array}{l}\text { BLU-63s, BLU-61s, } \\
\text { BLU-97s, fuse }\end{array}$ & $02 / 23 / 2010$ & 03/16/2010 \\
\hline Mid Target Grid 52/817 & $02 / 24 / 2010$ & Disposal pit \#1, MD & $\begin{array}{c}\text { BLU-63, BLU-61, } \\
\text { BLU-97, BLU-26, fuses }\end{array}$ & 03/17/2010 & 03/17/2010 \\
\hline Mid Target Grid 52/817 & $02 / 24 / 2010$ & Disposal pit \#2, MD & $\begin{array}{c}\text { BLU-63, BLU-61, } \\
\text { BLU-97, BLU-26, fuses }\end{array}$ & $03 / 17 / 2010$ & 03/17/2010 \\
\hline Mid Target Grid 52/817 & $02 / 24 / 2010$ & Disposal pit \#3, MD & $\begin{array}{c}\text { BLU-63, BLU-61, } \\
\text { BLU-97, BLU-26, fuses }\end{array}$ & 03/17/2010 & 03/17/2010 \\
\hline
\end{tabular}

${ }^{\text {a}}$ Final inspection at each location was performed using an EM-61 survey, magnetometer survey, or visual inspection.

$\mathrm{yd}^{3}=$ Cubic yard 
Table B.1-2

Page B-5 of B-44

\section{Mid Target}

(Page 1 of 11)

\begin{tabular}{|c|c|c|c|c|c|c|c|c|c|c|c|c|}
\hline 은 $\frac{5}{\frac{5}{2}}$ & 은 方 & 这 & Status/Notes & MEC Items & $\begin{array}{l}\text { MD } \\
\text { (Ib) }\end{array}$ & $\begin{array}{l}\text { CD } \\
\text { (lb) }\end{array}$ & $\begin{array}{l}\text { Date } \\
\text { Started }\end{array}$ & $\begin{array}{c}\text { Date } \\
\text { Completed }\end{array}$ & $\begin{array}{l}\text { Date QC } \\
\text { Survey } \\
\text { Complete }\end{array}$ & $\begin{array}{l}\text { Percent } \\
\text { of Grid } \\
\text { Surveyed } \\
\text { for QC }\end{array}$ & $\begin{array}{l}\text { Number } \\
\text { of Blind } \\
\text { Seeds } \\
\text { Placed } \\
\text { in Grid }\end{array}$ & $\begin{array}{l}\text { Number of } \\
\text { Blind } \\
\text { Seeds } \\
\text { Recovered }\end{array}$ \\
\hline 50 & 810 & Yes & $100 \%$ & None & 0.5 & 0.0 & 02/08/2010 & 02/08/2010 & 02/11/2010 & 10 & -- & -- \\
\hline 49 & 811 & Yes & $100 \%$ & None & 0.0 & 0.0 & 02/08/2010 & 02/08/2010 & 02/11/2010 & 10 & -- & -- \\
\hline 50 & 811 & Yes & $100 \%$ & None & 10.0 & 0.0 & 02/08/2010 & 02/08/2010 & 02/11/2010 & 10 & -- & -- \\
\hline 51 & 811 & Yes & $100 \%$ & None & 0.0 & 0.0 & 02/09/2010 & 02/09/2010 & 02/11/2010 & 10 & -- & -- \\
\hline 52 & 811 & Yes & $100 \%$ & None & 0.5 & 0.0 & 02/10/2010 & 02/10/2010 & 02/11/2010 & 10 & 1 & 1 \\
\hline 53 & 811 & Yes & $100 \%$ & None & 2.0 & 0.0 & 02/10/2010 & 02/10/2010 & $02 / 12 / 2010$ & 10 & -- & -- \\
\hline 54 & 811 & Yes & $100 \%$ & None & 0.0 & 0.0 & $02 / 11 / 2010$ & 02/11/2010 & $02 / 12 / 2010$ & 10 & -- & -- \\
\hline 49 & 812 & Yes & $100 \%$ & None & 0.0 & 0.0 & 02/08/2010 & $02 / 08 / 2010$ & 02/11/2010 & 10 & -- & -- \\
\hline 50 & 812 & Yes & $100 \%$ & None & 0.0 & 0.0 & 02/08/2010 & 02/08/2010 & 02/11/2010 & 10 & 1 & 1 \\
\hline 51 & 812 & Yes & $100 \%$ & None & 0.0 & 0.0 & $02 / 09 / 2010$ & 02/09/2010 & 02/11/2010 & 10 & -- & -- \\
\hline 52 & 812 & Yes & $100 \%$ & None & 0.5 & 0.0 & 02/10/2010 & 02/10/2010 & $02 / 11 / 2010$ & 10 & -- & -- \\
\hline 53 & 812 & Yes & $100 \%$ & None & 10.0 & 0.0 & 02/10/2010 & 02/10/2010 & $02 / 12 / 2010$ & 10 & -- & -- \\
\hline 54 & 812 & Yes & $100 \%$ & None & 40.0 & 0.0 & $02 / 11 / 2010$ & $02 / 11 / 2010$ & $02 / 12 / 2010$ & 10 & 1 & 1 \\
\hline 55 & 812 & Yes & $100 \%$ & None & 5.0 & 0.0 & $02 / 11 / 2010$ & 02/11/2010 & $02 / 12 / 2010$ & 10 & -- & -- \\
\hline 56 & 812 & Yes & $100 \%$ & None & 0.0 & 0.0 & 02/11/2010 & 02/11/2010 & 02/12/2010 & 10 & -- & -- \\
\hline 57 & 812 & Yes & $100 \%$ & None & 0.0 & 0.0 & $02 / 11 / 2010$ & 02/11/2010 & $02 / 12 / 2010$ & 10 & -- & -- \\
\hline
\end{tabular}

\section{UNCONTROLLED When Printed}


Table B.1-2

Page B-6 of B-44

\section{Mid Target}

(Page 2 of 11)

\begin{tabular}{|c|c|c|c|c|c|c|c|c|c|c|c|c|}
\hline 은 $\frac{\text { ํ }}{\frac{2}{0}}$ & :은 & 这 & Status/Notes & MEC Items & $\begin{array}{l}\text { MD } \\
\text { (Ib) }\end{array}$ & $\begin{array}{l}\text { CD } \\
\text { (lb) }\end{array}$ & $\begin{array}{l}\text { Date } \\
\text { Started }\end{array}$ & $\begin{array}{c}\text { Date } \\
\text { Completed }\end{array}$ & $\begin{array}{l}\text { Date QC } \\
\text { Survey } \\
\text { Complete }\end{array}$ & $\begin{array}{l}\text { Percent } \\
\text { of Grid } \\
\text { Surveyed } \\
\text { for QC }\end{array}$ & $\begin{array}{l}\text { Number } \\
\text { of Blind } \\
\text { Seeds } \\
\text { Placed } \\
\text { in Grid }\end{array}$ & $\begin{array}{l}\text { Number of } \\
\text { Blind } \\
\text { Seeds } \\
\text { Recovered }\end{array}$ \\
\hline 49 & 813 & Yes & $100 \%$ & None & 0.0 & 0.0 & 02/08/2010 & 02/08/2010 & 02/11/2010 & 10 & -- & -- \\
\hline 50 & 813 & Yes & $100 \%$ & None & 0.0 & 0.0 & 02/08/2010 & 02/08/2010 & 02/11/2010 & 10 & -- & -- \\
\hline 51 & 813 & Yes & $100 \%$ & None & 30.0 & 0.0 & 02/09/2010 & 02/09/2010 & 02/11/2010 & 10 & 1 & 1 \\
\hline 52 & 813 & Yes & $100 \%$ & None & 0.5 & 0.0 & 02/10/2010 & 02/10/2010 & 02/11/2010 & 10 & -- & -- \\
\hline 53 & 813 & Yes & $100 \%$ & $2 \mathrm{BLU}-63 \mathrm{~s}$ & 15.0 & 0.0 & 02/10/2010 & 02/10/2010 & $02 / 12 / 2010$ & 10 & -- & -- \\
\hline 54 & 813 & Yes & $100 \%$ & None & 80.0 & 0.0 & $02 / 11 / 2010$ & 02/11/2010 & $02 / 12 / 2010$ & 10 & -- & -- \\
\hline 55 & 813 & Yes & $100 \%$ & None & 0.0 & 0.0 & $02 / 11 / 2010$ & 02/11/2010 & $02 / 12 / 2010$ & 10 & 1 & 1 \\
\hline 56 & 813 & Yes & $100 \%$ & None & 0.5 & 0.0 & $02 / 11 / 2010$ & 02/11/2010 & $02 / 12 / 2010$ & 10 & -- & -- \\
\hline 57 & 813 & Yes & $100 \%$ & None & 0.0 & 0.0 & $02 / 11 / 2010$ & 02/11/2010 & $02 / 12 / 2010$ & 10 & -- & -- \\
\hline 49 & 814 & Yes & $100 \%$ & 1 BLU-63 & 0.0 & 0.0 & 03/01/2010 & 03/01/2010 & 03/02/2010 & 10 & -- & -- \\
\hline 50 & 814 & Yes & $100 \%$ & None & 0.0 & 0.0 & 03/02/2010 & 03/02/2010 & 03/05/2010 & 10 & 1 & 1 \\
\hline 51 & 814 & Yes & $100 \%$ & None & 0.5 & 0.0 & 03/02/2010 & 03/03/2010 & 03/05/2010 & 10 & -- & -- \\
\hline 52 & 814 & Yes & $100 \%$ & $\begin{array}{l}3 \text { BLU-63s, } \\
8 \text { BLU-97s }\end{array}$ & 25.0 & 0.0 & 02/23/2010 & 02/26/2010 & 03/02/2010 & 10 & -- & -- \\
\hline
\end{tabular}


Table B.1-2

Page B-7 of B-44

\section{Mid Target}

(Page 3 of 11)

\begin{tabular}{|c|c|c|c|c|c|c|c|c|c|c|c|c|}
\hline -은 $\frac{5}{\frac{5}{3}}$ & 은 & 产 & Status/Notes & MEC Items & $\begin{array}{l}\text { MD } \\
\text { (lb) }\end{array}$ & $\begin{array}{l}C D \\
\text { (lb) }\end{array}$ & $\begin{array}{l}\text { Date } \\
\text { Started }\end{array}$ & $\begin{array}{c}\text { Date } \\
\text { Completed }\end{array}$ & $\begin{array}{l}\text { Date QC } \\
\text { Survey } \\
\text { Complete }\end{array}$ & $\begin{array}{l}\text { Percent } \\
\text { of Grid } \\
\text { Surveyed } \\
\text { for QC }\end{array}$ & $\begin{array}{l}\text { Number } \\
\text { of Blind } \\
\text { Seeds } \\
\text { Placed } \\
\text { in Grid }\end{array}$ & $\begin{array}{l}\text { Number of } \\
\text { Blind } \\
\text { Seeds } \\
\text { Recovered }\end{array}$ \\
\hline 53 & 814 & Yes & Disposal pit & $\begin{array}{c}18 \text { BLU-63s, } \\
16 \text { BLU-61s, } \\
1 \text { BLU-97, } 2 \text { fuses }\end{array}$ & 700.0 & 0.0 & 02/19/2010 & $02 / 23 / 2010$ & 03/16/2010 & 10 & -- & -- \\
\hline 54 & 814 & Yes & $100 \%$ & 2 BLU-63s & 25.0 & 0.0 & $02 / 17 / 2010$ & $02 / 18 / 2010$ & $02 / 19 / 2010$ & 10 & 1 & 1 \\
\hline 55 & 814 & Yes & $100 \%$ & None & 0.0 & 0.0 & 02/16/2010 & $02 / 16 / 2010$ & 02/19/2010 & 10 & -- & -- \\
\hline 56 & 814 & Yes & $100 \%$ & None & 0.0 & 0.0 & $02 / 12 / 2010$ & $02 / 12 / 2010$ & $02 / 12 / 2010$ & 10 & -- & -- \\
\hline 57 & 814 & Yes & $100 \%$ & None & 0.0 & 0.0 & $02 / 12 / 2010$ & $02 / 12 / 2010$ & $02 / 12 / 2010$ & 10 & -- & -- \\
\hline 49 & 815 & Yes & $100 \%$ & 2 BLU-63s & 0.0 & 0.0 & 03/01/2010 & 03/01/2010 & $03 / 02 / 2010$ & 10 & -- & -- \\
\hline 50 & 815 & Yes & $100 \%$ & None & 0.0 & 0.0 & 03/02/2010 & 03/02/2010 & 03/05/2010 & 10 & 1 & 1 \\
\hline 51 & 815 & Yes & $100 \%$ & None & 0.0 & 0.0 & 03/02/2010 & 03/03/2010 & 03/05/2010 & 10 & 1 & 1 \\
\hline 52 & 815 & Yes & $100 \%$ & 8 BLU-97s & 0.5 & 0.0 & $02 / 23 / 2010$ & $03 / 12 / 2010$ & $03 / 12 / 2010$ & 10 & -- & -- \\
\hline 53 & 815 & Yes & $\begin{array}{l}\text { Potential disposal pit, } \\
\text { to be sampled }\end{array}$ & $\begin{array}{l}63 \text { BLU-63s, } \\
7 \text { BLU-61s, } \\
5 \text { BLU-97s }\end{array}$ & 800.0 & 0.0 & 02/19/2010 & $02 / 22 / 2010$ & 03/16/2010 & 10 & -- & -- \\
\hline 54 & 815 & Yes & $100 \%$ & $\begin{array}{l}5 \text { BLU-63s, } \\
3 \text { BLU-97s }\end{array}$ & 25.0 & 0.0 & 02/17/2010 & 02/18/2010 & 02/19/2010 & 10 & -- & -- \\
\hline 55 & 815 & Yes & $100 \%$ & 1 BLU-63 & 0.0 & 0.0 & 02/16/2010 & 02/16/2010 & 02/19/2010 & 10 & 1 & 1 \\
\hline
\end{tabular}

\section{UNCONTROLLED When Printed}


Table B.1-2

Page B-8 of B-44

\section{Mid Target}

(Page 4 of 11)

\begin{tabular}{|c|c|c|c|c|c|c|c|c|c|c|c|c|}
\hline 은 $\frac{5}{\frac{5}{0}}$ & 은 方 & 苍 & Status/Notes & MEC Items & $\begin{array}{l}\text { MD } \\
\text { (lb) }\end{array}$ & $\begin{array}{l}C D \\
\text { (lb) }\end{array}$ & $\begin{array}{l}\text { Date } \\
\text { Started }\end{array}$ & $\begin{array}{c}\text { Date } \\
\text { Completed }\end{array}$ & $\begin{array}{l}\text { Date QC } \\
\text { Survey } \\
\text { Complete }\end{array}$ & $\begin{array}{l}\text { Percent } \\
\text { of Grid } \\
\text { Surveyed } \\
\text { for QC }\end{array}$ & $\begin{array}{l}\text { Number } \\
\text { of Blind } \\
\text { Seeds } \\
\text { Placed } \\
\text { in Grid }\end{array}$ & $\begin{array}{l}\text { Number of } \\
\text { Blind } \\
\text { Seeds } \\
\text { Recovered }\end{array}$ \\
\hline 56 & 815 & Yes & $100 \%$ & None & 0.0 & 0.0 & $02 / 12 / 2010$ & $02 / 12 / 2010$ & $02 / 12 / 2010$ & 10 & -- & -- \\
\hline 57 & 815 & Yes & $100 \%$ & None & 0.0 & 0.0 & $02 / 12 / 2010$ & $02 / 12 / 2010$ & $02 / 12 / 2010$ & 10 & -- & -- \\
\hline 48 & 816 & Yes & $100 \%$ & None & 0.0 & 0.0 & 03/01/2010 & 03/01/2010 & 03/02/2010 & 10 & -- & -- \\
\hline 49 & 816 & Yes & $100 \%$ & None & 0.0 & 0.0 & 03/01/2010 & 03/01/2010 & $03 / 02 / 2010$ & 10 & 1 & 1 \\
\hline 50 & 816 & Yes & $100 \%$ & None & 0.5 & 0.0 & 03/02/2010 & $03 / 02 / 2010$ & $03 / 05 / 2010$ & 10 & -- & -- \\
\hline 51 & 816 & Yes & $100 \%$ & None & 0.0 & 0.0 & 03/02/2010 & 03/03/2010 & 03/05/2010 & 10 & -- & -- \\
\hline 52 & 816 & Yes & $100 \%$ & $\begin{array}{l}\text { Disposal pit } \\
\text { requires excavation, } \\
34 \text { BLU-63s }\end{array}$ & 45.0 & 0.0 & $02 / 23 / 2010$ & 03/15/2010 & 03/16/2010 & 10 & -- & -- \\
\hline 53 & 816 & Yes & $100 \%$ & 10 BLU-63s, M117A & 0.0 & 0.0 & $02 / 19 / 2010$ & $02 / 19 / 2010$ & 03/16/2010 & 10 & 1 & 1 \\
\hline 54 & 816 & Yes & $100 \%$ & 15 BLU-63s & 100.0 & 0.0 & $02 / 17 / 2010$ & $02 / 18 / 2010$ & $02 / 19 / 2010$ & 10 & -- & -- \\
\hline 55 & 816 & Yes & $100 \%$ & 1 BLU-63, 1 BLU-97 & 0.0 & 0.0 & $02 / 16 / 2010$ & $02 / 16 / 2010$ & $02 / 19 / 2010$ & 10 & -- & -- \\
\hline 56 & 816 & Yes & $100 \%$ & 1 BLU-61 & 5.0 & 0.0 & $02 / 12 / 2010$ & $02 / 12 / 2010$ & $02 / 12 / 2010$ & 10 & -- & -- \\
\hline 57 & 816 & Yes & $100 \%$ & None & 0.0 & 0.0 & $02 / 12 / 2010$ & $02 / 12 / 2010$ & $02 / 12 / 2010$ & 10 & -- & -- \\
\hline 48 & 817 & Yes & $100 \%$ & None & 0.0 & 0.0 & $03 / 01 / 2010$ & 03/01/2010 & 03/02/2010 & 10 & -- & -- \\
\hline 49 & 817 & Yes & $100 \%$ & 1 BLU-63 & 0.5 & 0.0 & $03 / 01 / 2010$ & 03/01/2010 & 03/02/2010 & 10 & -- & -- \\
\hline
\end{tabular}

\section{UNCONTROLLED When Printed}


Table B.1-2

Page B-9 of B-44

\section{Mid Target}

(Page 5 of 11)

\begin{tabular}{|c|c|c|c|c|c|c|c|c|c|c|c|c|}
\hline 은 $\frac{\frac{5}{5}}{0}$ & 은 方 & 这 & Status/Notes & MEC Items & $\begin{array}{l}\text { MD } \\
\text { (Ib) }\end{array}$ & $\begin{array}{l}\text { CD } \\
\text { (lb) }\end{array}$ & $\begin{array}{l}\text { Date } \\
\text { Started }\end{array}$ & $\begin{array}{c}\text { Date } \\
\text { Completed }\end{array}$ & $\begin{array}{l}\text { Date QC } \\
\text { Survey } \\
\text { Complete }\end{array}$ & $\begin{array}{l}\text { Percent } \\
\text { of Grid } \\
\text { Surveyed } \\
\text { for QC }\end{array}$ & $\begin{array}{l}\text { Number } \\
\text { of Blind } \\
\text { Seeds } \\
\text { Placed } \\
\text { in Grid }\end{array}$ & $\begin{array}{l}\text { Number of } \\
\text { Blind } \\
\text { Seeds } \\
\text { Recovered }\end{array}$ \\
\hline 50 & 817 & Yes & $100 \%$ & $18 \mathrm{BLU}-63 \mathrm{~s}$ & 0.5 & 0.0 & 03/02/2010 & $03 / 02 / 2010$ & 03/05/2010 & 10 & -- & -- \\
\hline 51 & 817 & Yes & $100 \%$ & 1 BLU-63, 1 BLU-97 & 0.5 & 0.0 & 03/02/2010 & 03/03/2010 & 03/05/2010 & 10 & -- & -- \\
\hline 52 & 817 & Yes & $100 \%$ & $\begin{array}{c}23 \text { BLU-61s, } \\
8 \text { BLU-26s, } \\
3 \text { bomblet fuses, } \\
91 \text { BLU-63s, } \\
1 \text { BLU-97, 3 MK118, } \\
\text { disposal pit }\end{array}$ & 850.0 & 100.0 & $02 / 23 / 2010$ & 03/17/2010 & 03/19/2010 & 10 & -- & -- \\
\hline 53 & 817 & Yes & $100 \%$ & $\begin{array}{l}16 \text { BLU-63s, } \\
2 \text { BLU-61s }\end{array}$ & 10.0 & 0.0 & 02/19/2010 & 02/19/2010 & 03/16/2010 & 10 & -- & -- \\
\hline 54 & 817 & Yes & $100 \%$ & $3 \mathrm{BLU}-63 \mathrm{~s}$ & 50.0 & 0.0 & $02 / 17 / 2010$ & $02 / 18 / 2010$ & 02/19/2010 & 10 & 1 & 1 \\
\hline 55 & 817 & Yes & $100 \%$ & None & 0.0 & 0.0 & $02 / 17 / 2010$ & $02 / 17 / 2010$ & 02/19/2010 & 10 & -- & -- \\
\hline 56 & 817 & Yes & $100 \%$ & 1 40-mm TP & 5.0 & 0.0 & $02 / 12 / 2010$ & $02 / 12 / 2010$ & $02 / 12 / 2010$ & 10 & -- & -- \\
\hline 48 & 818 & Yes & $100 \%$ & 14 BLU-63s & 0.5 & 0.0 & 03/12/2010 & 03/12/2010 & 03/16/2010 & 10 & -- & -- \\
\hline 49 & 818 & Yes & $100 \%$ & 85 BLU-63s & 0.0 & 0.0 & 03/10/2010 & 03/11/2010 & 03/16/2010 & 10 & -- & -- \\
\hline 50 & 818 & Yes & $100 \%$ & 40 BLU-63s & 0.5 & 0.0 & 03/15/2010 & 03/15/2010 & 03/16/2010 & 10 & -- & -- \\
\hline 51 & 818 & Yes & $100 \%$ & $4 \mathrm{BLU}-63 \mathrm{~s}$ & 60.0 & 0.0 & $03 / 16 / 2010$ & 03/16/2010 & 03/16/2010 & 10 & 1 & 1 \\
\hline
\end{tabular}


Table B.1-2

Page B-10 of B-44

\section{Mid Target}

(Page 6 of 11)

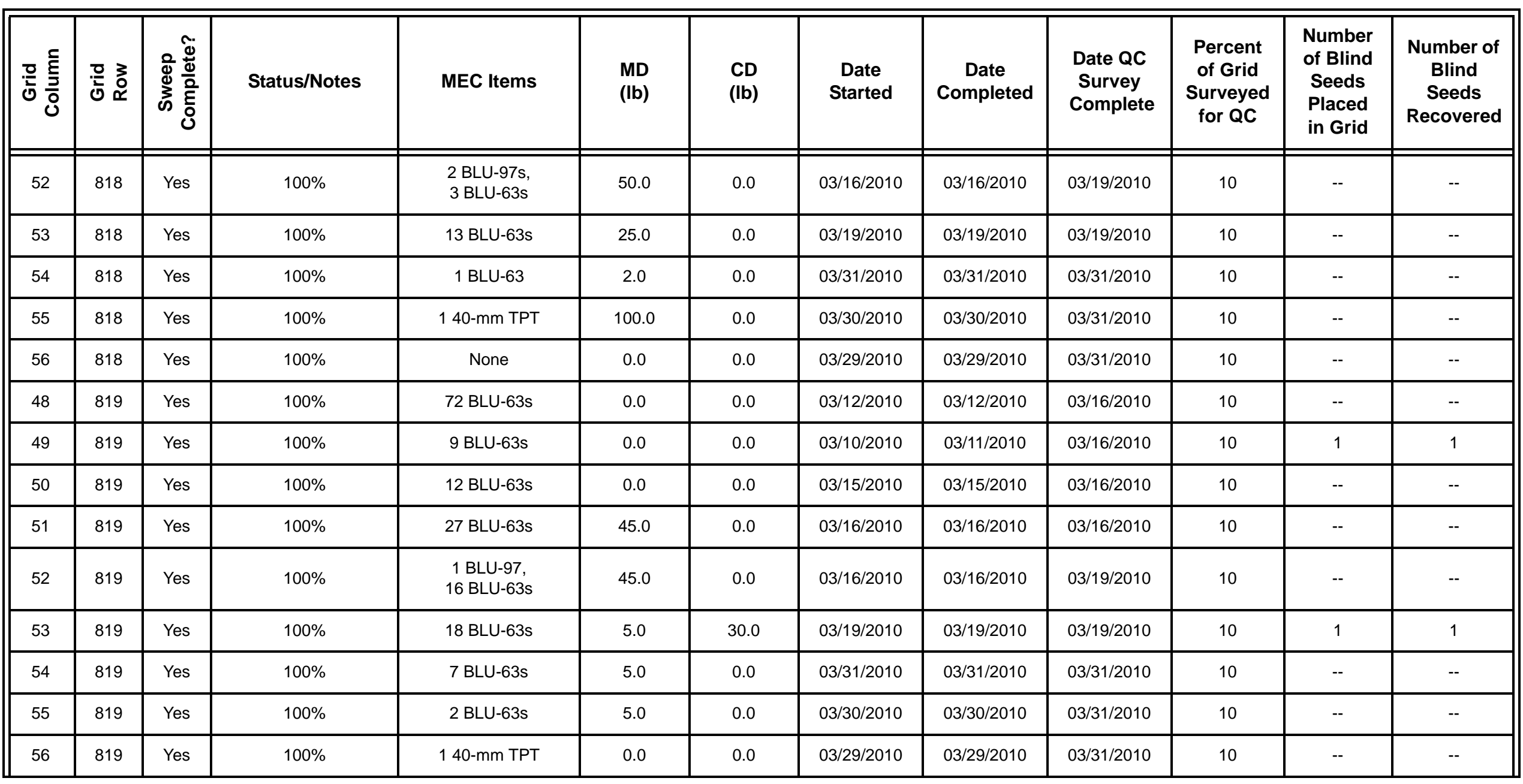

\section{UNCONTROLLED When Printed}


Table B.1-2

Page B-11 of B-44

\section{Mid Target}

(Page 7 of 11)

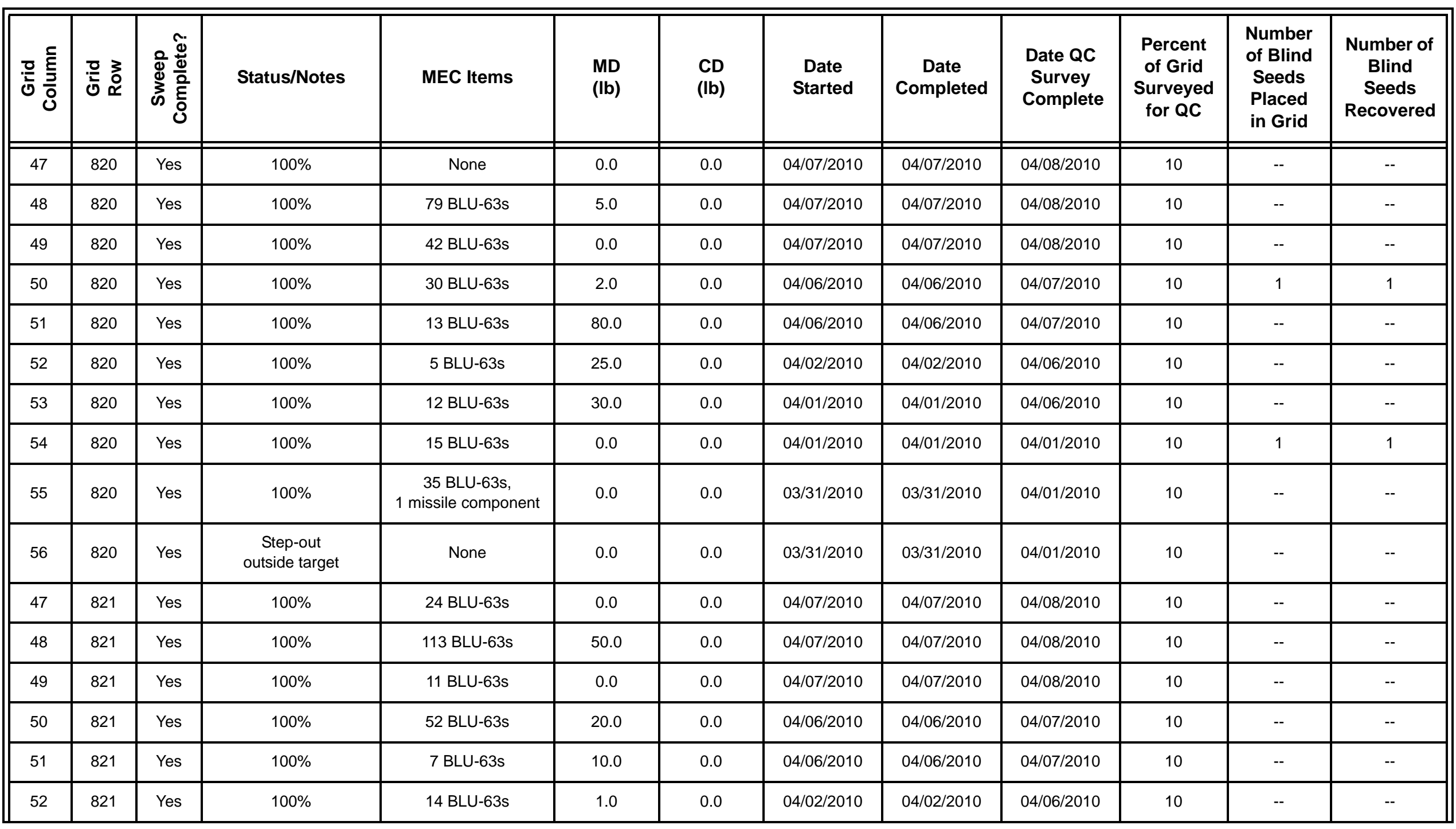

\section{UNCONTROLLED When Printed}


Table B.1-2

Page B-12 of B-44

\section{Mid Target}

(Page 8 of 11)

\begin{tabular}{|c|c|c|c|c|c|c|c|c|c|c|c|c|}
\hline 은 $\frac{5}{\frac{5}{0}}$ & 은 궁 & 这 & Status/Notes & MEC Items & $\begin{array}{l}\text { MD } \\
\text { (lb) }\end{array}$ & $\begin{array}{l}\text { CD } \\
\text { (lb) }\end{array}$ & $\begin{array}{c}\text { Date } \\
\text { Started }\end{array}$ & $\begin{array}{c}\text { Date } \\
\text { Completed }\end{array}$ & $\begin{array}{l}\text { Date QC } \\
\text { Survey } \\
\text { Complete }\end{array}$ & $\begin{array}{l}\text { Percent } \\
\text { of Grid } \\
\text { Surveyed } \\
\text { for QC }\end{array}$ & $\begin{array}{l}\text { Number } \\
\text { of Blind } \\
\text { Seeds } \\
\text { Placed } \\
\text { in Grid }\end{array}$ & $\begin{array}{l}\text { Number of } \\
\text { Blind } \\
\text { Seeds } \\
\text { Recovered }\end{array}$ \\
\hline 53 & 821 & Yes & $100 \%$ & 16 BLU-63s & 0.0 & 0.0 & 04/01/2010 & 04/01/2010 & 04/06/2010 & 10 & -- & -- \\
\hline 54 & 821 & Yes & $100 \%$ & 13 BLU-63 & 0.0 & 0.0 & 04/01/2010 & $04 / 01 / 2010$ & 04/01/2010 & 10 & -- & -- \\
\hline 55 & 821 & Yes & Step-out & 22 BLU-63s & 25.0 & 0.0 & 03/31/2010 & 03/31/2010 & 04/01/2010 & 10 & -- & -- \\
\hline 47 & 822 & Yes & $100 \%$ & None & 0.0 & 0.0 & 04/08/2010 & 04/08/2010 & 04/09/2010 & 10 & -- & -- \\
\hline 48 & 822 & Yes & $100 \%$ & 29 BLU-63s & 200.0 & 0.0 & 04/08/2010 & 04/08/2010 & 04/09/2010 & 10 & -- & -- \\
\hline 49 & 822 & Yes & $100 \%$ & 48 BLU-63s & 1.0 & 0.0 & 04/09/2010 & 04/09/2010 & 04/09/2010 & 10 & -- & -- \\
\hline 50 & 822 & Yes & $100 \%$ & 33 BLU-63s & 0.0 & 0.0 & $04 / 12 / 2010$ & $04 / 12 / 2010$ & $04 / 13 / 2010$ & 10 & 1 & 1 \\
\hline 52 & 822 & Yes & $100 \%$ & 26 BLU-63s & 5.0 & 0.0 & $04 / 13 / 2010$ & 04/13/2010 & $04 / 14 / 2010$ & 10 & -- & -- \\
\hline 53 & 822 & Yes & $100 \%$ & 8 BLU-63s & 10.0 & 0.0 & $04 / 13 / 2010$ & 04/13/2010 & $04 / 14 / 2010$ & 10 & -- & -- \\
\hline 54 & 822 & Yes & $100 \%$ & 20 BLU-63s & 0.0 & 0.0 & $04 / 14 / 2010$ & $04 / 14 / 2010$ & $04 / 14 / 2010$ & 10 & 1 & 1 \\
\hline 55 & 822 & Yes & Step-out & 4 BLU-63s & 0.0 & 0.0 & $04 / 14 / 2010$ & $04 / 14 / 2010$ & $04 / 14 / 2010$ & 10 & -- & -- \\
\hline 47 & 823 & Yes & $100 \%$ & None & 0.0 & 0.0 & 04/08/2010 & 04/08/2010 & 04/09/2010 & 10 & -- & -- \\
\hline 48 & 823 & Yes & $100 \%$ & 1 BLU-63 & 0.0 & 0.0 & 04/08/2010 & 04/08/2010 & 04/09/2010 & 10 & -- & -- \\
\hline 49 & 823 & Yes & $100 \%$ & 33 BLU-63s & 5.0 & 0.0 & 04/08/2010 & 04/09/2010 & 04/09/2010 & 10 & 1 & 1 \\
\hline 50 & 823 & Yes & $100 \%$ & $41 \mathrm{BLU}-63 \mathrm{~s}$ & 10.0 & 0.0 & $04 / 12 / 2010$ & $04 / 12 / 2010$ & $04 / 13 / 2010$ & 10 & -- & -- \\
\hline 51 & 823 & Yes & $100 \%$ & 9 BLU-63s & 20.0 & 0.0 & $04 / 12 / 2010$ & $04 / 12 / 2010$ & 04/13/2010 & 10 & -- & -- \\
\hline
\end{tabular}

\section{UNCONTROLLED When Printed}


Table B.1-2

Page B-13 of B-44

\section{Mid Target}

(Page 9 of 11)

\begin{tabular}{|c|c|c|c|c|c|c|c|c|c|c|c|c|}
\hline ·은 $\frac{c}{\frac{\varepsilon}{\partial}}$ & 은 方 & 高 & Status/Notes & MEC Items & $\begin{array}{l}\text { MD } \\
\text { (Ib) }\end{array}$ & $\begin{array}{l}C D \\
\text { (lb) }\end{array}$ & $\begin{array}{l}\text { Date } \\
\text { Started }\end{array}$ & $\begin{array}{c}\text { Date } \\
\text { Completed }\end{array}$ & $\begin{array}{l}\text { Date QC } \\
\text { Survey } \\
\text { Complete }\end{array}$ & $\begin{array}{l}\text { Percent } \\
\text { of Grid } \\
\text { Surveyed } \\
\text { for QC }\end{array}$ & $\begin{array}{l}\text { Number } \\
\text { of Blind } \\
\text { Seeds } \\
\text { Placed } \\
\text { in Grid }\end{array}$ & $\begin{array}{l}\text { Number of } \\
\text { Blind } \\
\text { Seeds } \\
\text { Recovered }\end{array}$ \\
\hline 52 & 823 & Yes & $100 \%$ & 14 BLU-63s & 0.0 & 0.0 & 04/13/2010 & $04 / 13 / 2010$ & $04 / 14 / 2010$ & 10 & 1 & 1 \\
\hline 53 & 823 & Yes & $100 \%$ & 12 BLU-63s & 0.0 & 0.0 & $04 / 13 / 2010$ & $04 / 13 / 2010$ & $04 / 14 / 2010$ & 10 & -- & -- \\
\hline 54 & 823 & Yes & $100 \%$ & $\begin{array}{c}4 \text { BLU-63s, } \\
1 \text { 40-mm TPT }\end{array}$ & 0.0 & 0.0 & $04 / 14 / 2010$ & $04 / 14 / 2010$ & $04 / 14 / 2010$ & 10 & -- & -- \\
\hline 55 & 823 & Yes & Step-out & 2 BLU-63s & 0.0 & 0.0 & $04 / 14 / 2010$ & $04 / 14 / 2010$ & $04 / 14 / 2010$ & 10 & -- & -- \\
\hline 47 & 824 & Yes & $100 \%$ & None & 0.0 & 0.0 & $04 / 21 / 2010$ & $04 / 21 / 2010$ & $04 / 26 / 2010$ & 10 & -- & -- \\
\hline 48 & 824 & Yes & $100 \%$ & None & 0.0 & 0.0 & 04/20/2010 & 04/20/2010 & $04 / 26 / 2010$ & 10 & -- & -- \\
\hline 50 & 824 & Yes & $100 \%$ & 73 BLU-63s & 25.0 & 0.0 & 04/19/2010 & 04/19/2010 & $04 / 21 / 2010$ & 10 & 1 & 1 \\
\hline 51 & 824 & Yes & $100 \%$ & 37 BLU-63s & 0.0 & 0.0 & $04 / 16 / 2010$ & 04/16/2010 & 04/19/2010 & 10 & -- & -- \\
\hline 52 & 824 & Yes & $100 \%$ & 21 BLU-63s & 1100.0 & 0.0 & $04 / 16 / 2010$ & 04/16/2010 & 04/19/2010 & 10 & -- & -- \\
\hline 53 & 824 & Yes & $100 \%$ & 11 BLU-63s & 0.0 & 0.0 & $04 / 15 / 2010$ & $04 / 15 / 2010$ & $04 / 16 / 2010$ & 10 & -- & -- \\
\hline 54 & 824 & Yes & $100 \%$ & 10 BLU-63 & 0.0 & 0.0 & $04 / 15 / 2010$ & $04 / 15 / 2010$ & $04 / 16 / 2010$ & 10 & 1 & 1 \\
\hline 55 & 824 & Yes & Step-out & 1 BLU-63 & 0.0 & 0.0 & $04 / 14 / 2010$ & $04 / 14 / 2010$ & $04 / 14 / 2010$ & 10 & -- & -- \\
\hline 46 & 825 & Yes & $100 \%$ & None & 0.0 & 0.0 & $04 / 21 / 2010$ & $04 / 21 / 2010$ & 04/26/2010 & 10 & -- & -- \\
\hline 47 & 825 & Yes & $100 \%$ & None & 0.0 & 0.0 & $04 / 21 / 2010$ & $04 / 21 / 2010$ & 04/26/2010 & 10 & 1 & 1 \\
\hline 48 & 825 & Yes & $100 \%$ & None & 0.0 & 0.0 & 04/20/2010 & 04/20/2010 & 04/26/2010 & 10 & -- & -- \\
\hline
\end{tabular}

\section{UNCONTROLLED When Printed}


Table B.1-2

Page B-14 of B-44

\section{Mid Target}

(Page 10 of 11)

\begin{tabular}{|c|c|c|c|c|c|c|c|c|c|c|c|c|}
\hline 은 $\frac{\frac{5}{E}}{0}$ & 음 & 这 & Status/Notes & MEC Items & $\begin{array}{l}\text { MD } \\
\text { (lb) }\end{array}$ & $\begin{array}{l}\text { CD } \\
\text { (lb) }\end{array}$ & $\begin{array}{l}\text { Date } \\
\text { Started }\end{array}$ & $\begin{array}{c}\text { Date } \\
\text { Completed }\end{array}$ & $\begin{array}{l}\text { Date QC } \\
\text { Survey } \\
\text { Complete }\end{array}$ & $\begin{array}{l}\text { Percent } \\
\text { of Grid } \\
\text { Surveyed } \\
\text { for QC }\end{array}$ & $\begin{array}{l}\text { Number } \\
\text { of Blind } \\
\text { Seeds } \\
\text { Placed } \\
\text { in Grid }\end{array}$ & $\begin{array}{l}\text { Number of } \\
\text { Blind } \\
\text { Seeds } \\
\text { Recovered }\end{array}$ \\
\hline 49 & 825 & Yes & $100 \%$ & None & 0.0 & 0.0 & 04/19/2010 & 04/19/2010 & $04 / 21 / 2010$ & 10 & -- & -- \\
\hline 50 & 825 & Yes & $100 \%$ & 3 BLU-63s, 1 MK83 & 30.0 & 0.0 & 04/19/2010 & 04/19/2010 & $04 / 21 / 2010$ & 10 & -- & -- \\
\hline 51 & 825 & Yes & $100 \%$ & 68 BLU-63s & 0.0 & 0.0 & 04/16/2010 & $04 / 16 / 2010$ & $04 / 19 / 2010$ & 10 & 1 & 1 \\
\hline 52 & 825 & Yes & $100 \%$ & 62-BLU-63s & 10.0 & 0.0 & 04/16/2010 & 04/16/2010 & 04/19/2010 & 10 & -- & -- \\
\hline 53 & 825 & Yes & $100 \%$ & 56 BLU-63s & 0.0 & 0.0 & 04/15/2010 & 04/15/2010 & $04 / 16 / 2010$ & 10 & -- & -- \\
\hline 54 & 825 & Yes & Step-out & $9 \mathrm{BLU}-63 \mathrm{~s}$ & 2.0 & 0.0 & 04/15/2010 & $04 / 15 / 2010$ & $04 / 16 / 2010$ & 10 & -- & -- \\
\hline 46 & 826 & Yes & $100 \%$ & None & 0.0 & 0.0 & $04 / 27 / 2010$ & $04 / 27 / 2010$ & $04 / 28 / 2010$ & 10 & -- & -- \\
\hline 47 & 826 & Yes & $100 \%$ & None & 25.0 & 0.0 & $04 / 27 / 2010$ & $04 / 27 / 2010$ & $04 / 28 / 2010$ & 10 & -- & -- \\
\hline 48 & 826 & Yes & $100 \%$ & None & 0.0 & 0.0 & $04 / 28 / 2010$ & $04 / 28 / 2010$ & 04/30/2010 & 10 & -- & -- \\
\hline 49 & 826 & Yes & $100 \%$ & None & 0.0 & 0.0 & 04/29/2010 & 04/29/2010 & 04/30/2010 & 10 & 1 & 1 \\
\hline 50 & 826 & Yes & $100 \%$ & 1 BLU-63 & 0.0 & 0.0 & 04/29/2010 & 04/29/2010 & 04/30/2010 & 10 & -- & -- \\
\hline 51 & 826 & Yes & $100 \%$ & None & 0.0 & 0.0 & 04/30/2010 & 04/30/2010 & 05/04/2010 & 10 & -- & -- \\
\hline 52 & 826 & Yes & $100 \%$ & 2 BLU-63s & 0.0 & 0.0 & 05/03/2010 & 05/03/2010 & 05/04/2010 & 10 & -- & -- \\
\hline 53 & 826 & Yes & $100 \%$ & $\begin{array}{c}140-\mathrm{mm} \text { TPT, } \\
3 \mathrm{BLU}-63 \mathrm{~s}\end{array}$ & 0.0 & 0.0 & 05/03/2010 & 05/03/2010 & 05/04/2010 & 10 & 1 & 1 \\
\hline 54 & 826 & Yes & Step-out & 1 BLU-63 & 0.0 & 0.0 & 05/03/2010 & 05/03/2010 & 05/04/2010 & 10 & -- & -- \\
\hline 46 & 827 & Yes & $100 \%$ & None & 0.0 & 0.0 & $04 / 27 / 2010$ & 04/27/2010 & $04 / 28 / 2010$ & 10 & -- & -- \\
\hline
\end{tabular}

\section{UNCONTROLLED When Printed}


Table B.1-2

Page B-15 of B-44

Mid Target

(Page 11 of 11)

\begin{tabular}{|c|c|c|c|c|c|c|c|c|c|c|c|c|}
\hline 은 兄 & 은 方 & 这 & Status/Notes & MEC Items & $\begin{array}{l}\text { MD } \\
\text { (Ib) }\end{array}$ & $\begin{array}{l}\text { CD } \\
\text { (lb) }\end{array}$ & $\begin{array}{l}\text { Date } \\
\text { Started }\end{array}$ & $\begin{array}{c}\text { Date } \\
\text { Completed }\end{array}$ & $\begin{array}{l}\text { Date QC } \\
\text { Survey } \\
\text { Complete }\end{array}$ & $\begin{array}{l}\text { Percent } \\
\text { of Grid } \\
\text { Surveyed } \\
\text { for QC }\end{array}$ & $\begin{array}{l}\text { Number } \\
\text { of Blind } \\
\text { Seeds } \\
\text { Placed } \\
\text { in Grid }\end{array}$ & $\begin{array}{l}\text { Number of } \\
\text { Blind } \\
\text { Seeds } \\
\text { Recovered }\end{array}$ \\
\hline 47 & 827 & Yes & $100 \%$ & None & 0.5 & 0.0 & $04 / 27 / 2010$ & $04 / 27 / 2010$ & $04 / 28 / 2010$ & 10 & 1 & 1 \\
\hline 48 & 827 & Yes & $100 \%$ & None & 0.0 & 0.0 & $04 / 28 / 2010$ & $04 / 28 / 2010$ & 04/30/2010 & 10 & -- & -- \\
\hline 49 & 827 & Yes & $100 \%$ & None & 0.0 & 0.0 & $04 / 29 / 2010$ & $04 / 29 / 2010$ & 04/30/2010 & 10 & -- & -- \\
\hline 50 & 827 & Yes & $100 \%$ & None & 0.0 & 0.0 & 04/29/2010 & $04 / 29 / 2010$ & 04/30/2010 & 10 & -- & -- \\
\hline 51 & 827 & Yes & $100 \%$ & None & 0.0 & 0.0 & 04/30/2010 & 04/30/2010 & 05/04/2010 & 10 & 1 & 1 \\
\hline 52 & 827 & Yes & $100 \%$ & None & 0.0 & 0.0 & 05/03/2010 & 05/03/2010 & 05/04/2010 & 10 & -- & -- \\
\hline 53 & 827 & Yes & $100 \%$ & None & 0.0 & 0.0 & 05/03/2010 & 05/03/2010 & 05/04/2010 & 10 & -- & -- \\
\hline 54 & 827 & Yes & $100 \%$ & None & 0.0 & 0.0 & 05/03/2010 & 05/03/2010 & 05/04/2010 & 10 & -- & -- \\
\hline 50 & 828 & Yes & $100 \%$ & None & 0.0 & 0.0 & 04/29/2010 & 04/29/2010 & 04/30/2010 & 10 & -- & -- \\
\hline 51 & 828 & Yes & $100 \%$ & None & 0.0 & 0.0 & 04/30/2010 & 04/30/2010 & 05/04/2010 & 10 & -- & -- \\
\hline 52 & 828 & Yes & $100 \%$ & None & 0.0 & 0.0 & 05/03/2010 & 05/03/2010 & 05/04/2010 & 10 & 1 & 1 \\
\hline 53 & 828 & Yes & $100 \%$ & None & 0.0 & 0.0 & 05/03/2010 & 05/03/2010 & 05/04/2010 & 10 & -- & -- \\
\hline 54 & 828 & Yes & $100 \%$ & None & 0.0 & 0.0 & 05/03/2010 & 05/03/2010 & 05/04/2010 & 10 & & \\
\hline \multicolumn{13}{|c|}{ Totals } \\
\hline 158 & & 158 & & & $4,882.0$ & 130.0 & & & & 158 & 31 & 31 \\
\hline
\end{tabular}

$\mathrm{CD}=$ Construction debris

TP $=$ Target practice

$\mathrm{TPT}=$ Target practice tracer 
Table B.1-3

Page B-16 of B-44

\section{Flightline}

(Page 1 of 2)

\begin{tabular}{|c|c|c|c|c|c|c|c|c|c|c|c|c|}
\hline 은 $\frac{\text { s }}{\frac{5}{0}}$ & 은 方 & 高 & Status/Notes & MEC Items & $\begin{array}{l}\text { MD } \\
\text { (lb) }\end{array}$ & $\begin{array}{l}\text { CD } \\
\text { (lb) }\end{array}$ & $\begin{array}{c}\text { Date } \\
\text { Started }\end{array}$ & $\begin{array}{c}\text { Date } \\
\text { Completed }\end{array}$ & $\begin{array}{c}\text { Date QC } \\
\text { Survey } \\
\text { Complete }\end{array}$ & $\begin{array}{l}\text { Percent } \\
\text { of Grid } \\
\text { Surveyed } \\
\text { for QC }\end{array}$ & $\begin{array}{l}\text { Number } \\
\text { of Blind } \\
\text { Seeds } \\
\text { Placed } \\
\text { in Grid }\end{array}$ & $\begin{array}{l}\text { Number of } \\
\text { Blind } \\
\text { Seeds } \\
\text { Recovered }\end{array}$ \\
\hline 65 & 767 & Yes & $100 \%$ & None & 0.0 & 0.0 & $01 / 27 / 2010$ & 01/29/2010 & 01/29/2010 & 10 & -- & -- \\
\hline 66 & 767 & Yes & $100 \%$ & None & 0.0 & 10.0 & $01 / 29 / 2010$ & 01/29/2010 & 01/29/2010 & 10 & -- & -- \\
\hline 62 & 766 & Yes & $100 \%$ & 1 BLU-63 & 0.0 & 0.0 & $01 / 25 / 2010$ & 01/29/2010 & 01/29/2010 & 10 & -- & -- \\
\hline 63 & 766 & Yes & $100 \%$ & 13 BLU-63s & 5.0 & 0.0 & $01 / 25 / 2010$ & 01/29/2010 & 01/29/2010 & 10 & -- & -- \\
\hline 64 & 766 & Yes & $100 \%$ & $4 \mathrm{BLU}-63 \mathrm{~s}$ & 5.0 & 0.5 & $01 / 26 / 2010$ & 01/29/2010 & 01/29/2010 & 10 & -- & -- \\
\hline 65 & 766 & Yes & $100 \%$ & 1 BLU-63 & 0.0 & 0.0 & $01 / 27 / 2010$ & 01/29/2010 & 01/29/2010 & 10 & 1 & 1 \\
\hline 66 & 766 & Yes & $100 \%$ & 2 BLU-63s & 1.0 & 10.0 & 01/29/2010 & 01/29/2010 & 01/29/2010 & 10 & -- & -- \\
\hline 62 & 765 & Yes & $100 \%$ & 36 BLU-63s & 0.0 & 0.0 & $01 / 25 / 2010$ & 01/29/2010 & 01/29/2010 & 10 & -- & -- \\
\hline 63 & 765 & Yes & $100 \%$ & 319 BLU-63s & 2.0 & 1.0 & $01 / 25 / 2010$ & 01/29/2010 & 01/29/2010 & 10 & -- & -- \\
\hline 64 & 765 & Yes & $100 \%$ & 14 BLU-63s & 2.0 & 2.0 & 01/26/2010 & 01/29/2010 & 01/29/2010 & 10 & 1 & 1 \\
\hline 65 & 765 & Yes & $100 \%$ & $10 \mathrm{BLU}-63 \mathrm{~s}$ & 0.0 & 0.0 & 01/27/2010 & 01/29/2010 & 01/29/2010 & 10 & -- & -- \\
\hline 66 & 765 & Yes & $100 \%$ & None & 0.5 & 0.0 & 01/29/2010 & 01/29/2010 & 01/29/2010 & 10 & -- & -- \\
\hline 62 & 764 & Yes & $100 \%$ & 43 BLU-63s & 0.0 & 0.0 & $01 / 25 / 2010$ & 01/29/2010 & 01/29/2010 & 10 & -- & -- \\
\hline 63 & 764 & Yes & $100 \%$ & $58 \mathrm{BLU}-63 \mathrm{~s}$ & 2.0 & 10.0 & $01 / 25 / 2010$ & 01/29/2010 & 01/29/2010 & 10 & 1 & 1 \\
\hline 64 & 764 & Yes & $100 \%$ & 7 BLU-63s & 1.0 & 5.0 & $01 / 26 / 2010$ & 01/29/2010 & 01/29/2010 & 10 & -- & -- \\
\hline 65 & 764 & Yes & $100 \%$ & 2 BLU-63s & 0.0 & 0.0 & $01 / 27 / 2010$ & 01/29/2010 & 01/29/2010 & 10 & -- & -- \\
\hline 66 & 764 & Yes & $100 \%$ & 1 BLU-63 & 1.0 & 0.0 & 01/29/2010 & 01/29/2010 & 01/29/2010 & 10 & -- & -- \\
\hline
\end{tabular}

\section{UNCONTROLLED When Printed}


Table B.1-3

Page B-17 of B-44

\section{Flightline}

(Page 2 of 2)

\begin{tabular}{|c|c|c|c|c|c|c|c|c|c|c|c|c|}
\hline 은 $\frac{5}{\frac{5}{2}}$ & 은 方 & ن & Status/Notes & MEC Items & $\begin{array}{l}\text { MD } \\
\text { (lb) }\end{array}$ & $\begin{array}{l}\text { CD } \\
\text { (lb) }\end{array}$ & $\begin{array}{c}\text { Date } \\
\text { Started }\end{array}$ & $\begin{array}{c}\text { Date } \\
\text { Completed }\end{array}$ & $\begin{array}{l}\text { Date QC } \\
\text { Survey } \\
\text { Complete }\end{array}$ & $\begin{array}{l}\text { Percent } \\
\text { of Grid } \\
\text { Surveyed } \\
\text { for QC }\end{array}$ & $\begin{array}{l}\text { Number } \\
\text { of Blind } \\
\text { Seeds } \\
\text { Placed } \\
\text { in Grid }\end{array}$ & $\begin{array}{l}\text { Number of } \\
\text { Blind } \\
\text { Seeds } \\
\text { Recovered }\end{array}$ \\
\hline 62 & 763 & Yes & $100 \%$ & 1 BLU-63 & None & 0.0 & $01 / 25 / 2010$ & $01 / 29 / 2010$ & 01/29/2010 & 10 & -- & -- \\
\hline 63 & 763 & Yes & $100 \%$ & 1 BLU-63 & None & 0.0 & $01 / 25 / 2010$ & $01 / 29 / 2010$ & $01 / 29 / 2010$ & 10 & -- & -- \\
\hline \multicolumn{13}{|c|}{ Totals: } \\
\hline 19 & & 19 & & & 19.5 & 38.5 & & & & 19 & 3 & 3 \\
\hline
\end{tabular}


Table B.1-4

Page B-18 of B-44

\section{SAC 1 and 2}

(Page 1 of 3 )

\begin{tabular}{|c|c|c|c|c|c|c|c|c|c|c|c|c|}
\hline 은 $\frac{5}{0}$ & 은 方 & ڤัญ & Status/Notes & $\begin{array}{l}\text { MEC } \\
\text { Items }\end{array}$ & $\begin{array}{l}\text { MD } \\
\text { (lb) }\end{array}$ & $\begin{array}{l}\text { CD } \\
\text { (lb) }\end{array}$ & $\begin{array}{l}\text { Date } \\
\text { Started }\end{array}$ & $\begin{array}{c}\text { Date } \\
\text { Completed }\end{array}$ & $\begin{array}{l}\text { Date QC } \\
\text { Survey } \\
\text { Complete }\end{array}$ & $\begin{array}{l}\text { Percent } \\
\text { of Grid } \\
\text { Surveyed } \\
\text { for QC }\end{array}$ & $\begin{array}{l}\text { Number } \\
\text { of Blind } \\
\text { Seeds } \\
\text { Placed } \\
\text { in Grid }\end{array}$ & $\begin{array}{l}\text { Number of } \\
\text { Blind } \\
\text { Seeds } \\
\text { Recovered }\end{array}$ \\
\hline 72 & 727 & Yes & $100 \%$ & None & 0.5 & 2.0 & $11 / 02 / 2009$ & $11 / 02 / 2009$ & $11 / 06 / 2009$ & 10 & -- & -- \\
\hline 73 & 727 & Yes & $100 \%$ & None & 0.0 & 1.0 & $11 / 02 / 2009$ & $11 / 02 / 2009$ & $11 / 06 / 2009$ & 10 & -- & -- \\
\hline 74 & 727 & Yes & $100 \%$ & None & 0.5 & 5.0 & $11 / 02 / 2009$ & $11 / 02 / 2009$ & $11 / 10 / 2009$ & 10 & -- & -- \\
\hline 72 & 728 & Yes & $100 \%$ & None & 2.0 & 50.0 & $11 / 02 / 2009$ & $11 / 02 / 2009$ & $11 / 06 / 2009$ & 10 & -- & -- \\
\hline 73 & 728 & Yes & $100 \%$ & None & 5.0 & 0.5 & $11 / 05 / 2009$ & $11 / 06 / 2009$ & $11 / 09 / 2009$ & 10 & -- & -- \\
\hline 74 & 728 & Yes & $100 \%$ & None & 50.0 & 0.5 & $11 / 09 / 2009$ & $11 / 09 / 2009$ & $11 / 10 / 2009$ & 10 & -- & -- \\
\hline 75 & 728 & Yes & $100 \%$ & None & 10.0 & 0.5 & $11 / 09 / 2009$ & $11 / 09 / 2009$ & $11 / 10 / 2009$ & 10 & -- & -- \\
\hline 71 & 729 & Yes & $\begin{array}{l}\text { 11/13/2009 soil sample } \\
\text { collected from soil pile }\end{array}$ & None & 75.5 & 5.0 & $11 / 05 / 2009$ & $11 / 10 / 2009$ & $11 / 10 / 2009$ & 10 & -- & -- \\
\hline 72 & 729 & Yes & $100 \%$ & None & 0.5 & 5.0 & $11 / 02 / 2009$ & $11 / 03 / 2009$ & $11 / 09 / 2009$ & 10 & -- & -- \\
\hline 73 & 729 & Yes & $100 \%$ & None & 5.0 & 0.5 & $11 / 05 / 2009$ & $11 / 06 / 2009$ & $11 / 09 / 2009$ & 10 & -- & -- \\
\hline 74 & 729 & Yes & $100 \%$ & None & 20.0 & 1.0 & $11 / 09 / 2009$ & $11 / 09 / 2009$ & $11 / 10 / 2009$ & 10 & -- & -- \\
\hline 75 & 729 & Yes & $100 \%$ & None & 10.0 & 0.5 & $11 / 09 / 2009$ & $11 / 09 / 2009$ & $11 / 10 / 2009$ & 10 & -- & -- \\
\hline 71 & 730 & Yes & $100 \%$ & None & 0.5 & 0.5 & $11 / 05 / 2009$ & $11 / 05 / 2009$ & $11 / 09 / 2009$ & 10 & -- & -- \\
\hline 72 & 730 & Yes & $100 \%$ & None & 5.0 & 0.5 & $11 / 03 / 2009$ & $11 / 03 / 2009$ & $11 / 11 / 2009$ & 10 & -- & -- \\
\hline 73 & 730 & Yes & $100 \%$ & None & 100.0 & 5.0 & $11 / 06 / 2009$ & $11 / 06 / 2009$ & $11 / 09 / 2009$ & 10 & -- & -- \\
\hline 74 & 730 & Yes & $100 \%$ & None & 2.0 & 0.5 & $11 / 09 / 2009$ & $11 / 09 / 2009$ & $11 / 10 / 2009$ & 10 & -- & -- \\
\hline
\end{tabular}

\section{UNCONTROLLED When Printed}


Table B.1-4

Page B-19 of B-44

\section{SAC 1 and 2}

(Page 2 of 3 )

\begin{tabular}{|c|c|c|c|c|c|c|c|c|c|c|c|c|}
\hline 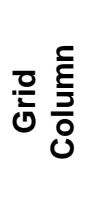 & 은 交 & ڤั & Status/Notes & $\begin{array}{l}\text { MEC } \\
\text { Items }\end{array}$ & $\begin{array}{l}\text { MD } \\
\text { (lb) }\end{array}$ & $\begin{array}{l}\text { CD } \\
\text { (lb) }\end{array}$ & $\begin{array}{c}\text { Date } \\
\text { Started }\end{array}$ & $\begin{array}{c}\text { Date } \\
\text { Completed }\end{array}$ & $\begin{array}{l}\text { Date QC } \\
\text { Survey } \\
\text { Complete }\end{array}$ & $\begin{array}{l}\text { Percent } \\
\text { of Grid } \\
\text { Surveyed } \\
\text { for QC }\end{array}$ & $\begin{array}{l}\text { Number } \\
\text { of Blind } \\
\text { Seeds } \\
\text { Placed } \\
\text { in Grid }\end{array}$ & $\begin{array}{l}\text { Number of } \\
\text { Blind } \\
\text { Seeds } \\
\text { Recovered }\end{array}$ \\
\hline 71 & 731 & Yes & $100 \%$ & None & 0.5 & 5.0 & $11 / 05 / 2009$ & $11 / 05 / 2009$ & $11 / 11 / 2009$ & 10 & -- & -- \\
\hline 72 & 731 & Yes & $100 \%$ & None & 0.5 & 20.0 & $11 / 03 / 2009$ & $11 / 03 / 2009$ & $11 / 11 / 2009$ & 10 & -- & -- \\
\hline 73 & 731 & Yes & $100 \%$ & None & 10.0 & 5.0 & $11 / 06 / 2009$ & $11 / 06 / 2009$ & $11 / 11 / 2009$ & 10 & 1 & 1 \\
\hline 74 & 731 & Yes & $100 \%$ & None & 0.5 & 0.5 & $11 / 09 / 2009$ & $11 / 09 / 2009$ & $11 / 10 / 2009$ & 10 & -- & -- \\
\hline 71 & 732 & Yes & $100 \%$ & None & 2.0 & 10.0 & $11 / 05 / 2009$ & $11 / 05 / 2009$ & $11 / 11 / 2009$ & 10 & 2 & 2 \\
\hline 72 & 732 & Yes & $100 \%$ & None & 5.0 & 15.0 & $11 / 03 / 2009$ & $11 / 03 / 2009$ & $11 / 11 / 2009$ & 10 & -- & -- \\
\hline 73 & 732 & Yes & $100 \%$ & None & 10.0 & 1.0 & $11 / 09 / 2009$ & $11 / 10 / 2009$ & $11 / 11 / 2009$ & 10 & 1 & 1 \\
\hline 74 & 732 & Yes & $100 \%$ & None & 0.5 & 0.5 & $11 / 10 / 2009$ & $11 / 10 / 2009$ & $11 / 11 / 2009$ & 10 & -- & -- \\
\hline 70 & 733 & Yes & $100 \%$ & None & 0.0 & 0.0 & $11 / 06 / 2009$ & $11 / 06 / 2009$ & $11 / 12 / 2009$ & 10 & -- & -- \\
\hline 71 & 733 & Yes & $100 \%$ & None & 10.0 & 0.5 & $11 / 05 / 2009$ & $11 / 05 / 2009$ & $11 / 12 / 2009$ & 10 & -- & -- \\
\hline 72 & 733 & Yes & $100 \%$ & None & 10.0 & 0.5 & $11 / 03 / 2009$ & $11 / 03 / 2009$ & $11 / 12 / 2009$ & 10 & -- & -- \\
\hline 73 & 733 & Yes & $100 \%$ & None & 10.0 & 5.0 & $11 / 09 / 2009$ & $11 / 10 / 2009$ & $11 / 16 / 2009$ & 10 & 1 & 1 \\
\hline 74 & 733 & Yes & $100 \%$ & None & 0.0 & 0.0 & $11 / 10 / 2009$ & $11 / 10 / 2009$ & $11 / 12 / 2009$ & 10 & -- & -- \\
\hline 70 & 734 & Yes & $100 \%$ & 1.50 caliber & 0.0 & 40.0 & $11 / 04 / 2009$ & $11 / 04 / 2009$ & $11 / 16 / 2009$ & 10 & -- & -- \\
\hline 71 & 734 & Yes & $100 \%$ & None & 10.0 & 10.0 & $11 / 04 / 2009$ & $11 / 04 / 2009$ & $11 / 16 / 2009$ & 10 & -- & -- \\
\hline 72 & 734 & Yes & $100 \%$ & None & 1.0 & 15.0 & $11 / 04 / 2009$ & $11 / 04 / 2009$ & $11 / 16 / 2009$ & 10 & 2 & 2 \\
\hline 73 & 734 & Yes & $100 \%$ & None & 5.0 & 5.0 & $11 / 10 / 2009$ & $11 / 10 / 2009$ & $11 / 16 / 2009$ & 10 & 1 & 1 \\
\hline
\end{tabular}

\section{UNCONTROLLED When Printed}


Table B.1-4

Page B-20 of B-44

\section{SAC 1 and 2}

(Page 3 of 3 )

\begin{tabular}{|c|c|c|c|c|c|c|c|c|c|c|c|c|}
\hline 은 苞 & 은 궁 & 递苍 & Status/Notes & $\begin{array}{l}\text { MEC } \\
\text { Items }\end{array}$ & $\begin{array}{l}\text { MD } \\
\text { (lb) }\end{array}$ & $\begin{array}{l}\text { CD } \\
\text { (lb) }\end{array}$ & $\begin{array}{c}\text { Date } \\
\text { Started }\end{array}$ & $\begin{array}{c}\text { Date } \\
\text { Completed }\end{array}$ & $\begin{array}{l}\text { Date QC } \\
\text { Survey } \\
\text { Complete }\end{array}$ & $\begin{array}{l}\text { Percent } \\
\text { of Grid } \\
\text { Surveyed } \\
\text { for QC }\end{array}$ & $\begin{array}{l}\text { Number } \\
\text { of Blind } \\
\text { Seeds } \\
\text { Placed } \\
\text { in Grid }\end{array}$ & $\begin{array}{l}\text { Number of } \\
\text { Blind } \\
\text { Seeds } \\
\text { Recovered }\end{array}$ \\
\hline 70 & 735 & Yes & $100 \%$ & None & 1.0 & 5.0 & $11 / 04 / 2009$ & $11 / 05 / 2009$ & $11 / 17 / 2009$ & 10 & -- & -- \\
\hline 71 & 735 & Yes & $100 \%$ & None & 0.5 & 10.0 & $11 / 04 / 2009$ & $11 / 05 / 2009$ & $11 / 17 / 2009$ & 10 & -- & -- \\
\hline 72 & 735 & Yes & $100 \%$ & None & 2.0 & 20.0 & $11 / 04 / 2009$ & $11 / 04 / 2009$ & $11 / 17 / 2009$ & 10 & -- & -- \\
\hline 73 & 735 & Yes & $100 \%$ & None & 0.5 & 0.5 & $11 / 10 / 2009$ & $11 / 10 / 2009$ & $11 / 17 / 2009$ & 10 & -- & -- \\
\hline 70 & 736 & Yes & $100 \%$ & None & 0.5 & 0.0 & $11 / 11 / 2009$ & $11 / 12 / 2009$ & $11 / 18 / 2009$ & 10 & -- & -- \\
\hline 71 & 736 & Yes & $100 \%$ & None & 50.0 & 0.5 & $11 / 11 / 2009$ & $11 / 12 / 2009$ & $11 / 18 / 2009$ & 10 & 1 & 1 \\
\hline 72 & 736 & Yes & $100 \%$ & None & 200.0 & 100.0 & $11 / 11 / 2009$ & $11 / 12 / 2009$ & $11 / 18 / 2009$ & 10 & 1 & 1 \\
\hline 73 & 736 & Yes & $100 \%$ & None & 0.5 & 0.0 & $11 / 10 / 2009$ & $11 / 10 / 2009$ & $11 / 18 / 2009$ & 10 & -- & -- \\
\hline 70 & 737 & Yes & $100 \%$ & None & 0.0 & 0.5 & $11 / 12 / 2009$ & $11 / 12 / 2009$ & $11 / 18 / 2009$ & 10 & -- & -- \\
\hline 71 & 737 & Yes & $100 \%$ & None & 0.5 & 0.0 & $11 / 12 / 2009$ & $11 / 12 / 2009$ & $11 / 18 / 2009$ & 10 & -- & -- \\
\hline 72 & 737 & Yes & $100 \%$ & None & 1.0 & 2.0 & $11 / 12 / 2009$ & $11 / 12 / 2009$ & $11 / 18 / 2009$ & 10 & -- & -- \\
\hline 73 & 737 & Yes & $100 \%$ & None & 0.0 & 0.0 & $11 / 10 / 2009$ & $11 / 10 / 2009$ & $11 / 18 / 2009$ & 10 & -- & -- \\
\hline \multicolumn{13}{|c|}{ Totals: } \\
\hline 45 & & 45 & & & 618.0 & 349.5 & & & & 45 & 10 & 10 \\
\hline
\end{tabular}

\section{UNCONTROLLED When Printed}


Table B.1-5

Page B-21 of B-44

\section{South Antelope Lake}

(Page 1 of 22)

\begin{tabular}{|c|c|c|c|c|c|c|c|c|c|c|c|c|}
\hline 은 $\frac{\text { ㅎ }}{\frac{5}{0}}$ & 은 궁 & 这 & Status/Notes & MEC Items & $\begin{array}{l}\text { MD } \\
\text { (lb) }\end{array}$ & $\begin{array}{l}\text { CD } \\
\text { (lb) }\end{array}$ & $\begin{array}{c}\text { Date } \\
\text { Started }\end{array}$ & $\begin{array}{c}\text { Date } \\
\text { Completed }\end{array}$ & $\begin{array}{l}\text { Date QC } \\
\text { Survey } \\
\text { Complete }\end{array}$ & $\begin{array}{l}\text { Percent } \\
\text { of Grid } \\
\text { Surveyed } \\
\text { for QC }\end{array}$ & $\begin{array}{l}\text { Number } \\
\text { of Blind } \\
\text { Seeds } \\
\text { Placed } \\
\text { in Grid }\end{array}$ & $\begin{array}{c}\text { Number } \\
\text { of Blind } \\
\text { Seeds } \\
\text { Recovered }\end{array}$ \\
\hline 90 & 688 & Yes & $\begin{array}{l}\text { Extended surface } \\
\text { clearance } 200 \mathrm{ft} \text { beyond } \\
\text { boundary due to } \\
\text { discovery of BLU-26 }\end{array}$ & BLU-63, BLU-26 & 2.0 & 15.0 & $01 / 22 / 2010$ & $04 / 28 / 2010$ & 04/28/2010 & 10 & -- & -- \\
\hline 91 & 688 & Yes & $100 \%$ & None & 3.0 & 1.0 & $01 / 21 / 2010$ & $04 / 28 / 2010$ & $04 / 28 / 2010$ & 10 & -- & -- \\
\hline 92 & 688 & Yes & $100 \%$ & None & 2.0 & 1.0 & 01/20/2010 & 04/28/2010 & 04/28/2010 & 10 & 1 & 1 \\
\hline 93 & 688 & Yes & $100 \%$ & None & 0.0 & 1.0 & 01/19/2010 & 04/28/2010 & 04/28/2010 & 10 & 1 & 1 \\
\hline 94 & 688 & Yes & DU debris found & None & 1.0 & 1.0 & 01/18/2010 & $04 / 28 / 2010$ & 04/28/2010 & 10 & -- & -- \\
\hline 95 & 688 & Yes & $100 \%$ & None & 1.0 & 1.5 & $02 / 25 / 2010$ & $04 / 28 / 2010$ & $04 / 28 / 2010$ & 10 & 1 & 1 \\
\hline 96 & 688 & Yes & $100 \%$ & None & 1.0 & 1.0 & $02 / 25 / 2010$ & $04 / 28 / 2010$ & 04/28/2010 & 10 & -- & -- \\
\hline 97 & 688 & Yes & DU debris found, $100 \%$ & None & 2.0 & 1.5 & $02 / 24 / 2010$ & $04 / 27 / 2010$ & $04 / 27 / 2010$ & 10 & 1 & 1 \\
\hline 98 & 688 & Yes & $100 \%$ & None & 1.5 & 1.0 & $02 / 24 / 2010$ & $04 / 27 / 2010$ & $04 / 27 / 2010$ & 10 & -- & -- \\
\hline 99 & 688 & Yes & $100 \%$ & None & 2.0 & 2.5 & $02 / 25 / 2010$ & $04 / 27 / 2010$ & $04 / 27 / 2010$ & 10 & 1 & 1 \\
\hline 00 & 688 & Yes & $100 \%$ & None & 1.0 & 2.5 & $02 / 24 / 2010$ & $04 / 27 / 2010$ & $04 / 27 / 2010$ & 10 & 1 & 1 \\
\hline 01 & 688 & Yes & $100 \%$ & None & 2.0 & 1.0 & $02 / 17 / 2010$ & $04 / 27 / 2010$ & $04 / 27 / 2010$ & 25 & 1 & 1 \\
\hline 02 & 688 & Yes & $100 \%$ & None & 4.0 & 2.0 & $04 / 27 / 2010$ & $04 / 27 / 2010$ & $04 / 27 / 2010$ & 10 & -- & -- \\
\hline 89 & 689 & Yes & $100 \%$ & None & 0.0 & 0.0 & $1 / 22 / 2010$ & $04 / 28 / 2010$ & 04/28/2010 & 10 & -- & -- \\
\hline 90 & 689 & Yes & $100 \%$ & None & 0.0 & 10.0 & $01 / 22 / 2010$ & $04 / 28 / 2010$ & 04/28/2010 & 10 & -- & -- \\
\hline
\end{tabular}

\section{UNCONTROLLED When Printed}


Table B.1-5

\section{South Antelope Lake}

(Page 2 of 22)

\begin{tabular}{|c|c|c|c|c|c|c|c|c|c|c|c|c|}
\hline 은 $\frac{\frac{5}{5}}{0}$ & 은 交 & 这 & Status/Notes & MEC Items & $\begin{array}{l}\text { MD } \\
\text { (lb) }\end{array}$ & $\begin{array}{l}\text { CD } \\
\text { (lb) }\end{array}$ & $\begin{array}{l}\text { Date } \\
\text { Started }\end{array}$ & $\begin{array}{c}\text { Date } \\
\text { Completed }\end{array}$ & $\begin{array}{l}\text { Date QC } \\
\text { Survey } \\
\text { Complete }\end{array}$ & $\begin{array}{l}\text { Percent } \\
\text { of Grid } \\
\text { Surveyed } \\
\text { for QC }\end{array}$ & $\begin{array}{l}\text { Number } \\
\text { of Blind } \\
\text { Seeds } \\
\text { Placed } \\
\text { in Grid }\end{array}$ & $\begin{array}{c}\text { Number } \\
\text { of Blind } \\
\text { Seeds } \\
\text { Recovered }\end{array}$ \\
\hline 91 & 689 & Yes & $100 \%$ & None & 0.5 & 0.5 & 01/20/2010 & $01 / 21 / 2010$ & $01 / 25 / 2010$ & 10 & -- & -- \\
\hline 92 & 689 & Yes & $100 \%$ & None & 1.0 & 5.0 & 01/20/2010 & 01/20/2010 & $01 / 21 / 2010$ & 10 & -- & -- \\
\hline 93 & 689 & Yes & $100 \%$ & None & 1.0 & 0.5 & 01/19/2010 & 01/20/2010 & $01 / 21 / 2010$ & 10 & 1 & 1 \\
\hline 94 & 689 & Yes & $100 \%$ & None & 1.0 & 0.5 & 01/18/2010 & 01/18/2010 & 01/19/2010 & 10 & -- & -- \\
\hline 95 & 689 & Yes & $100 \%$ & None & 1.5 & 0.5 & $02 / 23 / 2010$ & $02 / 23 / 2010$ & $02 / 23 / 2010$ & 10 & -- & -- \\
\hline 96 & 689 & Yes & $100 \%$ & None & 0.0 & 0.5 & $02 / 23 / 2010$ & $02 / 23 / 2010$ & $02 / 23 / 2010$ & 10 & -- & -- \\
\hline 97 & 689 & Yes & $100 \%$ & None & 0.0 & 0.5 & $02 / 23 / 2010$ & $02 / 23 / 2010$ & $02 / 23 / 2010$ & 10 & 1 & 1 \\
\hline 98 & 689 & Yes & $100 \%$ & None & 0.0 & 0.0 & $02 / 23 / 2010$ & $02 / 23 / 2010$ & $02 / 23 / 2010$ & 10 & -- & -- \\
\hline 99 & 689 & Yes & $100 \%$ & None & 2.0 & 2.5 & $02 / 24 / 2010$ & $04 / 26 / 2010$ & $04 / 26 / 2010$ & 10 & -- & -- \\
\hline 00 & 689 & Yes & $100 \%$ & None & 4.0 & 1.5 & $02 / 24 / 2010$ & $04 / 26 / 2010$ & 04/26/2010 & 10 & -- & -- \\
\hline 01 & 689 & Yes & $100 \%$ & None & 2.0 & 1.0 & $02 / 16 / 2010$ & $04 / 26 / 2010$ & $04 / 26 / 2010$ & 25 & -- & -- \\
\hline 02 & 689 & Yes & $100 \%$ & None & 2.5 & 2.5 & 03/15/2010 & $04 / 26 / 2010$ & $04 / 26 / 2010$ & 10 & -- & -- \\
\hline 89 & 690 & Yes & $100 \%$ & None & 40.0 & 10.0 & $01 / 22 / 2010$ & $01 / 22 / 2010$ & $01 / 25 / 2010$ & 10 & -- & -- \\
\hline 90 & 690 & Yes & $100 \%$ & None & 0.0 & 0.0 & $01 / 22 / 2010$ & $01 / 22 / 2010$ & $01 / 25 / 2010$ & 10 & -- & -- \\
\hline 91 & 690 & Yes & $100 \%$ & None & 2.0 & 0.5 & 01/20/2010 & $01 / 21 / 2010$ & $01 / 25 / 2010$ & 10 & 1 & 1 \\
\hline 92 & 690 & Yes & $100 \%$ & None & 20.0 & 1.0 & 01/20/2010 & 01/20/2010 & $01 / 21 / 2010$ & 10 & -- & -- \\
\hline 93 & 690 & Yes & $100 \%$ & None & 0.5 & 0.5 & 01/19/2010 & $01 / 20 / 2010$ & $01 / 21 / 2010$ & 10 & -- & -- \\
\hline
\end{tabular}

\section{UNCONTROLLED When Printed}


Table B.1-5

\section{South Antelope Lake}

(Page 3 of 22)

\begin{tabular}{|c|c|c|c|c|c|c|c|c|c|c|c|c|}
\hline 은 $\frac{\text { ㅎ }}{\frac{5}{0}}$ & 은 交 & 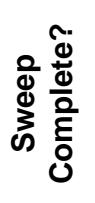 & Status/Notes & MEC Items & $\begin{array}{l}\text { MD } \\
\text { (lb) }\end{array}$ & $\begin{array}{l}\text { CD } \\
\text { (lb) }\end{array}$ & $\begin{array}{c}\text { Date } \\
\text { Started }\end{array}$ & $\begin{array}{c}\text { Date } \\
\text { Completed }\end{array}$ & $\begin{array}{l}\text { Date QC } \\
\text { Survey } \\
\text { Complete }\end{array}$ & $\begin{array}{l}\text { Percent } \\
\text { of Grid } \\
\text { Surveyed } \\
\text { for QC }\end{array}$ & $\begin{array}{l}\text { Number } \\
\text { of Blind } \\
\text { Seeds } \\
\text { Placed } \\
\text { in Grid }\end{array}$ & $\begin{array}{c}\text { Number } \\
\text { of Blind } \\
\text { Seeds } \\
\text { Recovered }\end{array}$ \\
\hline 94 & 690 & Yes & $100 \%$ & None & 0.5 & 2.0 & 01/18/2010 & $01 / 18 / 2010$ & 01/19/2010 & 10 & -- & -- \\
\hline 95 & 690 & Yes & $100 \%$ & None & 0.5 & 1.0 & $02 / 23 / 2010$ & $02 / 23 / 2010$ & $02 / 23 / 2010$ & 10 & -- & -- \\
\hline 96 & 690 & Yes & $100 \%$ & None & 0.0 & 0.0 & $02 / 22 / 2010$ & $02 / 22 / 2010$ & $02 / 22 / 2010$ & 10 & -- & -- \\
\hline 97 & 690 & Yes & $100 \%$ & None & 0.0 & 0.5 & $02 / 22 / 2010$ & $02 / 22 / 2010$ & $02 / 22 / 2010$ & 10 & -- & -- \\
\hline 98 & 690 & Yes & $100 \%$ & None & 0.0 & 0.0 & $02 / 22 / 2010$ & $02 / 22 / 2010$ & $02 / 22 / 2010$ & 10 & -- & -- \\
\hline 99 & 690 & Yes & $100 \%$ & None & 0.5 & 0.0 & $02 / 22 / 2010$ & $02 / 22 / 2010$ & $02 / 22 / 2010$ & 10 & -- & -- \\
\hline 00 & 690 & Yes & $100 \%$ & None & 0.0 & 0.5 & $02 / 22 / 2010$ & $02 / 22 / 2010$ & $02 / 22 / 2010$ & 10 & -- & -- \\
\hline 01 & 690 & Yes & $100 \%$ & None & 0.0 & 0.0 & $02 / 17 / 2010$ & $02 / 17 / 2010$ & $02 / 17 / 2010$ & 25 & -- & -- \\
\hline 02 & 690 & Yes & $100 \%$ & None & 1 & 1.5 & 03/30/2010 & $04 / 26 / 2010$ & $04 / 26 / 2010$ & 10 & 1 & 1 \\
\hline 03 & 690 & Yes & $100 \%$ & 1 20-mm TP & 0.5 & 0.5 & 03/15/2010 & $03 / 15 / 2010$ & $03 / 15 / 2010$ & 10 & -- & -- \\
\hline 88 & 691 & Yes & $100 \%$ & None & 0.0 & 1.0 & $01 / 22 / 2010$ & $01 / 22 / 2010$ & $01 / 25 / 2010$ & 10 & -- & -- \\
\hline 89 & 691 & Yes & $100 \%$ & None & 5.0 & 1.0 & $01 / 22 / 2010$ & $01 / 22 / 2010$ & $01 / 25 / 2010$ & 10 & -- & -- \\
\hline 90 & 691 & Yes & $100 \%$ & None & 0.5 & 0.0 & $01 / 22 / 2010$ & $01 / 22 / 2010$ & $01 / 25 / 2010$ & 10 & 1 & 1 \\
\hline 91 & 691 & Yes & $100 \%$ & None & 0.5 & 0.5 & $01 / 21 / 2010$ & $01 / 22 / 2010$ & $01 / 25 / 2010$ & 10 & -- & -- \\
\hline 92 & 691 & Yes & $100 \%$ & None & 5.0 & 2.0 & 01/20/2010 & 01/20/2010 & $01 / 21 / 2010$ & 10 & -- & -- \\
\hline 93 & 691 & Yes & $100 \%$ & None & 5.0 & 0.5 & 01/19/2010 & 01/20/2010 & $01 / 21 / 2010$ & 10 & -- & -- \\
\hline 94 & 691 & Yes & $100 \%$ & None & 0.5 & 0.0 & $01 / 18 / 2010$ & $01 / 18 / 2010$ & 01/19/2010 & 10 & 1 & 1 \\
\hline
\end{tabular}

\section{UNCONTROLLED When Printed}


Table B.1-5

\section{South Antelope Lake}

(Page 4 of 22)

\begin{tabular}{|c|c|c|c|c|c|c|c|c|c|c|c|c|}
\hline 은 $\frac{\text { ㅎ }}{\frac{5}{0}}$ & 은 交 & 造 & Status/Notes & MEC Items & $\begin{array}{l}\text { MD } \\
\text { (lb) }\end{array}$ & $\begin{array}{l}\text { CD } \\
\text { (lb) }\end{array}$ & $\begin{array}{c}\text { Date } \\
\text { Started }\end{array}$ & $\begin{array}{c}\text { Date } \\
\text { Completed }\end{array}$ & $\begin{array}{l}\text { Date QC } \\
\text { Survey } \\
\text { Complete }\end{array}$ & $\begin{array}{l}\text { Percent } \\
\text { of Grid } \\
\text { Surveyed } \\
\text { for QC }\end{array}$ & $\begin{array}{l}\text { Number } \\
\text { of Blind } \\
\text { Seeds } \\
\text { Placed } \\
\text { in Grid }\end{array}$ & $\begin{array}{c}\text { Number } \\
\text { of Blind } \\
\text { Seeds } \\
\text { Recovered }\end{array}$ \\
\hline 95 & 691 & Yes & $100 \%$ & None & 0.0 & 0.5 & $02 / 25 / 2010$ & $02 / 25 / 2010$ & $02 / 25 / 2010$ & 10 & -- & -- \\
\hline 96 & 691 & Yes & $100 \%$ & None & 10.0 & 5.0 & $04 / 26 / 2010$ & $04 / 26 / 2010$ & $04 / 26 / 2010$ & 10 & -- & -- \\
\hline 97 & 691 & Yes & $100 \%$ & None & 6.0 & 2.0 & $04 / 26 / 2010$ & $04 / 26 / 2010$ & $04 / 26 / 2010$ & 10 & 1 & 1 \\
\hline 98 & 691 & Yes & $100 \%$ & None & 5.0 & 2.0 & $04 / 15 / 2010$ & $04 / 15 / 2010$ & $04 / 15 / 2010$ & 10 & 1 & 1 \\
\hline 99 & 691 & Yes & $100 \%$ & None & 7.0 & 4.0 & $04 / 15 / 2010$ & $04 / 15 / 2010$ & $04 / 15 / 2010$ & 10 & -- & -- \\
\hline 00 & 691 & Yes & $100 \%$ & None & 0.0 & 0.0 & $02 / 19 / 2010$ & 02/19/2010 & 02/19/2010 & 10 & -- & -- \\
\hline 01 & 691 & Yes & $100 \%$ & None & 0.0 & 0.5 & $02 / 17 / 2010$ & $02 / 18 / 2010$ & $02 / 18 / 2010$ & 25 & -- & -- \\
\hline 02 & 691 & Yes & $100 \%$ & None & 1.0 & 1.0 & 03/30/2010 & 03/30/2010 & 03/30/2010 & 10 & -- & -- \\
\hline 03 & 691 & Yes & $100 \%$ & None & 0.5 & 0.5 & 03/30/2010 & 03/30/2010 & 03/30/2010 & 10 & -- & -- \\
\hline 04 & 691 & Yes & $100 \%$ & None & 0.5 & 0.5 & 03/15/2010 & 03/15/2010 & $03 / 15 / 2010$ & 10 & -- & -- \\
\hline 87 & 692 & Yes & $100 \%$ & None & 0.0 & 0.0 & $01 / 13 / 2010$ & $01 / 13 / 2010$ & $01 / 14 / 2010$ & 10 & -- & -- \\
\hline 88 & 692 & Yes & $100 \%$ & None & 0.0 & 0.5 & $01 / 13 / 2010$ & $01 / 13 / 2010$ & $01 / 14 / 2010$ & 10 & -- & -- \\
\hline 89 & 692 & Yes & $100 \%$ & None & 1.0 & 0.5 & 01/13/2010 & $01 / 13 / 2010$ & $01 / 15 / 2010$ & 10 & -- & -- \\
\hline 90 & 692 & Yes & $100 \%$ & None & 0.0 & 0.0 & 01/13/2010 & $01 / 14 / 2010$ & $01 / 15 / 2010$ & 10 & -- & -- \\
\hline 91 & 692 & Yes & $100 \%$ & None & 1.0 & 10.0 & 01/13/2010 & $01 / 14 / 2010$ & $01 / 15 / 2010$ & 10 & 1 & 1 \\
\hline 92 & 692 & Yes & $100 \%$ & None & 10.0 & 0.5 & 01/13/2010 & $01 / 14 / 2010$ & $01 / 15 / 2010$ & 10 & -- & -- \\
\hline 93 & 692 & Yes & $100 \%$ & None & 5.0 & 0.5 & $01 / 13 / 2010$ & $01 / 14 / 2010$ & $01 / 15 / 2010$ & 10 & -- & -- \\
\hline
\end{tabular}

\section{UNCONTROLLED When Printed}


Table B.1-5

Page B-25 of B-44

\section{South Antelope Lake}

(Page 5 of 22)

\begin{tabular}{|c|c|c|c|c|c|c|c|c|c|c|c|c|}
\hline 은 $\frac{5}{\frac{5}{0}}$ & 은 궁 & 造 & Status/Notes & MEC Items & $\begin{array}{l}\text { MD } \\
\text { (lb) }\end{array}$ & $\begin{array}{l}\text { CD } \\
\text { (lb) }\end{array}$ & $\begin{array}{l}\text { Date } \\
\text { Started }\end{array}$ & $\begin{array}{c}\text { Date } \\
\text { Completed }\end{array}$ & $\begin{array}{l}\text { Date QC } \\
\text { Survey } \\
\text { Complete }\end{array}$ & $\begin{array}{l}\text { Percent } \\
\text { of Grid } \\
\text { Surveyed } \\
\text { for QC }\end{array}$ & $\begin{array}{c}\text { Number } \\
\text { of Blind } \\
\text { Seeds } \\
\text { Placed } \\
\text { in Grid }\end{array}$ & $\begin{array}{c}\text { Number } \\
\text { of Blind } \\
\text { Seeds } \\
\text { Recovered }\end{array}$ \\
\hline 94 & 692 & Yes & $100 \%$ & None & 5.0 & 1.0 & $01 / 15 / 2010$ & $01 / 15 / 2010$ & 01/19/2010 & 10 & -- & -- \\
\hline 95 & 692 & Yes & $100 \%$ & None & 0.0 & 0.0 & $02 / 25 / 2010$ & $02 / 25 / 2010$ & $02 / 25 / 2010$ & 10 & -- & -- \\
\hline 96 & 692 & Yes & $\begin{array}{l}\text { 1.5-by-1.5 DU alloy } \\
\text { recovered }\end{array}$ & None & 5.0 & 2.0 & $04 / 26 / 2010$ & $04 / 26 / 2010$ & 04/26/2010 & 10 & 1 & 1 \\
\hline 97 & 692 & Yes & $100 \%$ & None & 50.0 & 10.0 & $04 / 26 / 2010$ & $04 / 26 / 2010$ & $04 / 26 / 2010$ & 10 & -- & -- \\
\hline 98 & 692 & Yes & $100 \%$ & None & 12.0 & 4.0 & $04 / 15 / 2010$ & $04 / 15 / 2010$ & $04 / 15 / 2010$ & 10 & -- & -- \\
\hline 99 & 692 & Yes & $100 \%$ & None & 8.0 & 2.0 & $04 / 14 / 2010$ & $04 / 14 / 2010$ & $04 / 14 / 2010$ & 10 & -- & -- \\
\hline 00 & 692 & Yes & $100 \%$ & None & 0.0 & 0.5 & 02/19/2010 & 02/19/2010 & $02 / 19 / 2010$ & 10 & 1 & 1 \\
\hline 01 & 692 & Yes & $100 \%$ & None & 0.0 & 0.5 & $02 / 18 / 2010$ & $02 / 18 / 2010$ & $02 / 18 / 2010$ & 10 & 1 & 1 \\
\hline 02 & 692 & Yes & $100 \%$ & None & 2.0 & 1.0 & 03/31/2010 & 03/31/2010 & 03/31/2010 & 10 & -- & -- \\
\hline 03 & 692 & Yes & $100 \%$ & None & 0.5 & 1.0 & 03/30/2010 & 03/30/2010 & 03/30/2010 & 10 & -- & -- \\
\hline 04 & 692 & Yes & $100 \%$ & None & 4.0 & 2.0 & $04 / 26 / 2010$ & $04 / 26 / 2010$ & $04 / 26 / 2010$ & 10 & -- & -- \\
\hline 86 & 693 & Yes & $100 \%$ & None & 1.0 & 0.0 & $01 / 12 / 2010$ & $01 / 13 / 2010$ & $01 / 14 / 2010$ & 10 & -- & -- \\
\hline 87 & 693 & Yes & $100 \%$ & None & 0.5 & 0.0 & $01 / 12 / 2010$ & $01 / 13 / 2010$ & $01 / 14 / 2010$ & 10 & 1 & 1 \\
\hline 88 & 693 & Yes & $100 \%$ & None & 0.5 & 0.5 & $01 / 12 / 2010$ & 01/13/2010 & $01 / 15 / 2010$ & 10 & -- & -- \\
\hline 89 & 693 & Yes & $100 \%$ & None & 0.5 & 0.5 & $01 / 12 / 2010$ & $01 / 13 / 2010$ & $01 / 15 / 2010$ & 10 & -- & -- \\
\hline 90 & 693 & Yes & $100 \%$ & None & 1.0 & 15.0 & $01 / 14 / 2010$ & $01 / 15 / 2010$ & $01 / 15 / 2010$ & 10 & 1 & 1 \\
\hline
\end{tabular}

\section{UNCONTROLLED When Printed}


Table B.1-5

\section{South Antelope Lake}

(Page 6 of 22)

\begin{tabular}{|c|c|c|c|c|c|c|c|c|c|c|c|c|}
\hline 은 $\frac{\text { ㅎ }}{\frac{5}{0}}$ & 은 交 & 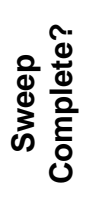 & Status/Notes & MEC Items & $\begin{array}{l}\text { MD } \\
\text { (lb) }\end{array}$ & $\begin{array}{l}\text { CD } \\
\text { (lb) }\end{array}$ & $\begin{array}{c}\text { Date } \\
\text { Started }\end{array}$ & $\begin{array}{c}\text { Date } \\
\text { Completed }\end{array}$ & $\begin{array}{l}\text { Date QC } \\
\text { Survey } \\
\text { Complete }\end{array}$ & $\begin{array}{l}\text { Percent } \\
\text { of Grid } \\
\text { Surveyed } \\
\text { for QC }\end{array}$ & $\begin{array}{l}\text { Number } \\
\text { of Blind } \\
\text { Seeds } \\
\text { Placed } \\
\text { in Grid }\end{array}$ & $\begin{array}{c}\text { Number } \\
\text { of Blind } \\
\text { Seeds } \\
\text { Recovered }\end{array}$ \\
\hline 91 & 693 & Yes & $100 \%$ & None & 5.0 & 2.0 & $01 / 14 / 2010$ & $01 / 14 / 2010$ & $01 / 15 / 2010$ & 10 & -- & -- \\
\hline 92 & 693 & Yes & $100 \%$ & None & 0.5 & 1.0 & $01 / 14 / 2010$ & $01 / 14 / 2010$ & $01 / 15 / 2010$ & 10 & -- & -- \\
\hline 93 & 693 & Yes & $100 \%$ & None & 0.5 & 2.0 & $01 / 14 / 2010$ & $01 / 14 / 2010$ & $01 / 15 / 2010$ & 10 & -- & -- \\
\hline 94 & 693 & Yes & $100 \%$ & None & 1.0 & 1.0 & $01 / 15 / 2010$ & $01 / 15 / 2010$ & $01 / 18 / 2010$ & 10 & 1 & 1 \\
\hline 95 & 693 & Yes & $100 \%$ & None & 1.0 & 2.5 & $02 / 26 / 2010$ & $02 / 26 / 2010$ & $02 / 26 / 2010$ & 10 & 1 & 1 \\
\hline 96 & 693 & Yes & $100 \%$ & None & 1.0 & 0.5 & 03/08/2010 & 03/08/2010 & 03/08/2010 & 10 & -- & -- \\
\hline 97 & 693 & Yes & $100 \%$ & None & 5.0 & 2.0 & $04 / 21 / 2010$ & $04 / 21 / 2010$ & $04 / 21 / 2010$ & 10 & -- & -- \\
\hline 98 & 693 & Yes & $100 \%$ & None & 15.0 & 5.0 & $04 / 15 / 2010$ & $04 / 15 / 2010$ & $04 / 15 / 2010$ & 10 & 1 & 1 \\
\hline 99 & 693 & Yes & $100 \%$ & None & 8.0 & 2.0 & $04 / 14 / 2010$ & $04 / 14 / 2010$ & $04 / 14 / 2010$ & 10 & 1 & 1 \\
\hline 00 & 693 & Yes & $100 \%$ & None & 0.5 & 0.0 & 02/19/2010 & 02/19/2010 & 02/19/2010 & 10 & -- & -- \\
\hline 01 & 693 & Yes & $100 \%$ & None & 0.0 & 0.0 & $02 / 18 / 2010$ & $02 / 18 / 2010$ & $02 / 18 / 2010$ & 10 & -- & -- \\
\hline 02 & 693 & Yes & $100 \%$ & None & 1.0 & 2.0 & 03/31/2010 & 03/31/2010 & 03/31/2010 & 10 & 1 & 1 \\
\hline 03 & 693 & Yes & $100 \%$ & None & 1.0 & 1.0 & 03/29/2010 & 03/29/2010 & 03/29/2010 & 10 & -- & -- \\
\hline 04 & 693 & Yes & $100 \%$ & None & 1.0 & 1.0 & $03 / 22 / 2010$ & $03 / 22 / 2010$ & $03 / 22 / 2010$ & 10 & -- & -- \\
\hline 05 & 693 & Yes & $100 \%$ & None & 0.5 & 0.5 & $03 / 22 / 2010$ & $03 / 22 / 2010$ & $03 / 22 / 2010$ & 10 & -- & -- \\
\hline 85 & 694 & Yes & $100 \%$ & None & 0.0 & 0.0 & $01 / 07 / 2010$ & $01 / 07 / 2010$ & $01 / 08 / 2010$ & 10 & -- & -- \\
\hline 86 & 694 & Yes & $100 \%$ & None & 2.0 & 0.5 & 010/7/2010 & $01 / 07 / 2010$ & 01/08/2010 & 10 & -- & -- \\
\hline
\end{tabular}

\section{UNCONTROLLED When Printed}


Table B.1-5

\section{South Antelope Lake}

(Page 7 of 22)

\begin{tabular}{|c|c|c|c|c|c|c|c|c|c|c|c|c|}
\hline 은 $\frac{\text { ㅎ }}{\frac{5}{0}}$ & 은 旁 & 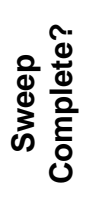 & Status/Notes & MEC Items & $\begin{array}{l}\text { MD } \\
\text { (lb) }\end{array}$ & $\begin{array}{l}\text { CD } \\
\text { (lb) }\end{array}$ & $\begin{array}{c}\text { Date } \\
\text { Started }\end{array}$ & $\begin{array}{c}\text { Date } \\
\text { Completed }\end{array}$ & $\begin{array}{l}\text { Date QC } \\
\text { Survey } \\
\text { Complete }\end{array}$ & $\begin{array}{l}\text { Percent } \\
\text { of Grid } \\
\text { Surveyed } \\
\text { for QC }\end{array}$ & $\begin{array}{l}\text { Number } \\
\text { of Blind } \\
\text { Seeds } \\
\text { Placed } \\
\text { in Grid }\end{array}$ & $\begin{array}{c}\text { Number } \\
\text { of Blind } \\
\text { Seeds } \\
\text { Recovered }\end{array}$ \\
\hline 87 & 694 & Yes & $100 \%$ & None & 1.0 & 0.5 & 01/07/2010 & 01/07/2010 & 01/08/2010 & 10 & -- & -- \\
\hline 88 & 694 & Yes & $100 \%$ & None & 2.0 & 0.0 & 01/07/2010 & 01/08/2010 & $01 / 11 / 2010$ & 10 & -- & -- \\
\hline 89 & 694 & Yes & $100 \%$ & None & 0.5 & 0.5 & 01/07/2010 & 01/08/2010 & $01 / 11 / 2010$ & 10 & -- & -- \\
\hline 90 & 694 & Yes & $100 \%$ & None & 1.0 & 0.5 & 01/07/2010 & 01/08/2010 & $01 / 11 / 2010$ & 10 & 1 & 1 \\
\hline 91 & 694 & Yes & $100 \%$ & None & 10.0 & 5.0 & $01 / 12 / 2010$ & $01 / 12 / 2010$ & $01 / 14 / 2010$ & 10 & -- & -- \\
\hline 92 & 694 & Yes & $100 \%$ & None & 0.0 & 2.0 & $01 / 12 / 2010$ & $01 / 12 / 2010$ & $01 / 14 / 2010$ & 10 & -- & -- \\
\hline 93 & 694 & Yes & $100 \%$ & None & 5.0 & 0.5 & $01 / 12 / 2010$ & $01 / 12 / 2010$ & $01 / 14 / 2010$ & 10 & 1 & 1 \\
\hline 94 & 694 & Yes & $100 \%$ & None & 15.0 & 2.0 & $01 / 15 / 2010$ & $01 / 15 / 2010$ & $01 / 18 / 2010$ & 10 & -- & -- \\
\hline 95 & 694 & Yes & $100 \%$ & None & 1.0 & 0.05 & $02 / 26 / 2010$ & $02 / 26 / 2010$ & $02 / 26 / 2010$ & 10 & -- & -- \\
\hline 96 & 694 & Yes & $100 \%$ & None & 10.0 & 5.0 & 03/08/2010 & 03/08/2010 & 03/8/2010 & 10 & 1 & 1 \\
\hline 97 & 694 & Yes & $100 \%$ & None & 5.0 & 20.0 & $04 / 21 / 2010$ & $04 / 21 / 2010$ & $04 / 21 / 2010$ & 10 & -- & -- \\
\hline 98 & 694 & Yes & $100 \%$ & None & 10.0 & 20.0 & $04 / 15 / 2010$ & $04 / 15 / 2010$ & $04 / 15 / 2010$ & 10 & -- & -- \\
\hline 99 & 694 & Yes & $100 \%$ & None & 5.0 & 2.0 & $04 / 14 / 2010$ & $04 / 14 / 2010$ & $04 / 14 / 2010$ & 10 & -- & -- \\
\hline 00 & 694 & Yes & $100 \%$ & None & 0.0 & 0.5 & $02 / 18 / 2010$ & $02 / 18 / 2010$ & $02 / 18 / 2010$ & 10 & -- & -- \\
\hline 01 & 694 & Yes & $100 \%$ & None & 0.0 & 0.5 & $02 / 18 / 2010$ & 02/18/2010 & $02 / 18 / 2010$ & 10 & -- & -- \\
\hline 02 & 694 & Yes & $100 \%$ & None & 6.0 & 4.0 & 03/31/2010 & 03/031/2010 & 03/31/2010 & 10 & -- & -- \\
\hline 03 & 694 & Yes & $100 \%$ & None & 2.0 & 1.0 & 03/29/2010 & 03/29/2010 & 03/29/2010 & 10 & 1 & 1 \\
\hline
\end{tabular}

\section{UNCONTROLLED When Printed}


Table B.1-5

\section{South Antelope Lake}

(Page 8 of 22)

\begin{tabular}{|c|c|c|c|c|c|c|c|c|c|c|c|c|}
\hline 은 $\frac{\text { 듬 }}{0}$ & 은 交 & 造 & Status/Notes & MEC Items & $\begin{array}{l}\text { MD } \\
\text { (lb) }\end{array}$ & $\begin{array}{l}\text { CD } \\
\text { (lb) }\end{array}$ & $\begin{array}{c}\text { Date } \\
\text { Started }\end{array}$ & $\begin{array}{c}\text { Date } \\
\text { Completed }\end{array}$ & $\begin{array}{l}\text { Date QC } \\
\text { Survey } \\
\text { Complete }\end{array}$ & $\begin{array}{l}\text { Percent } \\
\text { of Grid } \\
\text { Surveyed } \\
\text { for QC }\end{array}$ & $\begin{array}{l}\text { Number } \\
\text { of Blind } \\
\text { Seeds } \\
\text { Placed } \\
\text { in Grid }\end{array}$ & $\begin{array}{c}\text { Number } \\
\text { of Blind } \\
\text { Seeds } \\
\text { Recovered }\end{array}$ \\
\hline 04 & 694 & Yes & $100 \%$ & None & 1.5 & 1.0 & $03 / 23 / 2010$ & 03/23/2010 & 03/23/2010 & 10 & -- & -- \\
\hline 05 & 694 & Yes & $100 \%$ & None & 2.0 & 1.0 & $03 / 22 / 2010$ & $03 / 22 / 2010$ & $03 / 22 / 2010$ & 10 & 1 & 1 \\
\hline 06 & 694 & Yes & $100 \%$ & None & 0.5 & 0.5 & 03/18/2010 & 03/18/2010 & 03/18/2010 & 10 & -- & -- \\
\hline 85 & 695 & Yes & $100 \%$ & None & 0.0 & 0.0 & $01 / 06 / 2010$ & 01/07/2010 & 01/8/2010 & 10 & -- & -- \\
\hline 86 & 695 & Yes & $100 \%$ & None & 1.0 & 0.5 & $01 / 06 / 2010$ & 01/07/2010 & 01/8/2010 & 10 & -- & -- \\
\hline 87 & 695 & Yes & $100 \%$ & None & 0.5 & 1.0 & $01 / 06 / 2010$ & 01/07/2010 & $01 / 11 / 2010$ & 10 & -- & -- \\
\hline 88 & 695 & Yes & $100 \%$ & None & 10.0 & 1.0 & 01/08/2010 & 01/08/2010 & $01 / 11 / 2010$ & 10 & -- & -- \\
\hline 89 & 695 & Yes & $100 \%$ & None & 5.0 & 2.0 & 01/08/2010 & 01/08/2010 & $01 / 11 / 2010$ & 10 & -- & -- \\
\hline 90 & 695 & Yes & $100 \%$ & None & 10.0 & 0.5 & 01/08/2010 & 01/08/2010 & 01/11/2010 & 10 & 1 & 1 \\
\hline 91 & 695 & Yes & $100 \%$ & None & 200.0 & 15.0 & $01 / 11 / 2010$ & 01/11/2010 & 01/14/2010 & 10 & 1 & 1 \\
\hline 92 & 695 & Yes & $100 \%$ & None & 50.0 & 10.0 & 01/11/2010 & $01 / 11 / 2010$ & $01 / 14 / 2010$ & 10 & -- & -- \\
\hline 93 & 695 & Yes & $100 \%$ & None & 10.0 & 5.0 & $01 / 11 / 2010$ & $01 / 11 / 2010$ & $01 / 14 / 2010$ & 10 & -- & -- \\
\hline 94 & 695 & Yes & $\begin{array}{c}\text { DU plate found/moved to } \\
\text { RMA } 100 \%\end{array}$ & BLU-26 & 10.0 & 0.5 & $01 / 15 / 2010$ & $01 / 15 / 2010$ & $01 / 18 / 2010$ & 10 & -- & -- \\
\hline 95 & 695 & Yes & $100 \%$ & None & 3.0 & 1.0 & 03/01/2010 & 03/01/2010 & 03/01/2010 & 10 & -- & -- \\
\hline 96 & 695 & Yes & $100 \%$ & 1-BDU 33 & 1.0 & 18.0 & 03/05/2010 & 03/05/2010 & 03/05/2010 & 10 & -- & -- \\
\hline 97 & 695 & Yes & $100 \%$ & None & 15.0 & 120.0 & $04 / 21 / 2010$ & 04/21/2010 & $04 / 21 / 2010$ & 10 & -- & -- \\
\hline
\end{tabular}

\section{UNCONTROLLED When Printed}


Table B.1-5

\section{South Antelope Lake}

(Page 9 of 22)

\begin{tabular}{|c|c|c|c|c|c|c|c|c|c|c|c|c|}
\hline 은 $\frac{\text { ㅎ }}{\frac{5}{0}}$ & 은 交 & 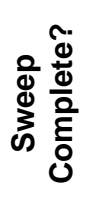 & Status/Notes & MEC Items & $\begin{array}{l}\text { MD } \\
\text { (lb) }\end{array}$ & $\begin{array}{l}\text { CD } \\
\text { (lb) }\end{array}$ & $\begin{array}{c}\text { Date } \\
\text { Started }\end{array}$ & $\begin{array}{c}\text { Date } \\
\text { Completed }\end{array}$ & $\begin{array}{l}\text { Date QC } \\
\text { Survey } \\
\text { Complete }\end{array}$ & $\begin{array}{l}\text { Percent } \\
\text { of Grid } \\
\text { Surveyed } \\
\text { for QC }\end{array}$ & $\begin{array}{l}\text { Number } \\
\text { of Blind } \\
\text { Seeds } \\
\text { Placed } \\
\text { in Grid }\end{array}$ & $\begin{array}{c}\text { Number } \\
\text { of Blind } \\
\text { Seeds } \\
\text { Recovered }\end{array}$ \\
\hline 98 & 695 & Yes & $100 \%$ & None & 10.0 & 3.0 & $04 / 16 / 2010$ & $04 / 16 / 2010$ & 04/16/2010 & 10 & -- & -- \\
\hline 99 & 695 & Yes & $100 \%$ & None & 5.0 & 2.0 & $04 / 13 / 2010$ & $04 / 13 / 2010$ & $04 / 13 / 2010$ & 10 & -- & -- \\
\hline 00 & 695 & Yes & $100 \%$ & None & 3.0 & 2.0 & 04/13/2010 & $04 / 13 / 2010$ & 04/13/2010 & 10 & -- & -- \\
\hline 01 & 695 & Yes & $100 \%$ & None & 10.0 & 5.0 & $04 / 14 / 2010$ & $04 / 14 / 2010$ & $04 / 14 / 2010$ & 10 & -- & -- \\
\hline 02 & 695 & Yes & $100 \%$ & None & 1.0 & 2.0 & $04 / 01 / 2010$ & $04 / 01 / 2010$ & 04/1/2010 & 10 & -- & -- \\
\hline 03 & 695 & Yes & $100 \%$ & None & 2.0 & 1.0 & 03/29/2010 & 03/29/2010 & 03/29/2010 & 10 & -- & -- \\
\hline 04 & 695 & Yes & $100 \%$ & None & 2.0 & 1.5 & 03/23/2010 & $03 / 23 / 2010$ & $03 / 23 / 2010$ & 10 & -- & -- \\
\hline 05 & 695 & Yes & $100 \%$ & None & 1.0 & 1.0 & 03/22/2010 & $03 / 22 / 2010$ & $03 / 22 / 2010$ & 10 & -- & -- \\
\hline 06 & 695 & Yes & $100 \%$ & None & 0.5 & 0.5 & 03/8/2010 & 03/08/2010 & 03/08/2010 & 10 & -- & -- \\
\hline 07 & 695 & Yes & $100 \%$ & None & 0.5 & 0.5 & 03/11/2010 & 03/11/2010 & 03/11/2010 & 10 & -- & -- \\
\hline 84 & 696 & Yes & $100 \%$ & None & 0.5 & 0.0 & $01 / 05 / 2010$ & $01 / 06 / 2010$ & $01 / 07 / 2010$ & 10 & -- & -- \\
\hline 85 & 696 & Yes & $100 \%$ & None & 0.5 & 0.0 & $01 / 05 / 2010$ & $01 / 06 / 2010$ & $01 / 07 / 2010$ & 10 & 1 & 1 \\
\hline 86 & 696 & Yes & $100 \%$ & None & 1.0 & 0.0 & $01 / 05 / 2010$ & $01 / 06 / 2010$ & $01 / 07 / 2010$ & 10 & -- & -- \\
\hline 87 & 696 & Yes & $100 \%$ & None & 0.5 & 1.0 & $01 / 05 / 2010$ & 01/06/2010 & $01 / 07 / 2010$ & 10 & 1 & 1 \\
\hline 88 & 696 & Yes & $100 \%$ & None & 5.0 & 0.5 & $12 / 16 / 2009$ & $01 / 04 / 2010$ & $01 / 07 / 2010$ & 10 & -- & -- \\
\hline 89 & 696 & Yes & $100 \%$ & None & 150.0 & 0.5 & $12 / 16 / 2009$ & $01 / 04 / 2010$ & $01 / 06 / 2010$ & 10 & -- & -- \\
\hline 90 & 696 & Yes & $100 \%$ & None & 1.0 & 1.0 & $12 / 16 / 2009$ & $01 / 04 / 2010$ & $01 / 06 / 2010$ & 10 & -- & -- \\
\hline
\end{tabular}

\section{UNCONTROLLED When Printed}


Table B.1-5

Page B-30 of B-44

\section{South Antelope Lake}

(Page 10 of 22)

\begin{tabular}{|c|c|c|c|c|c|c|c|c|c|c|c|c|}
\hline 은 $\frac{\text { ㅎ }}{\frac{5}{0}}$ & 은 交 & 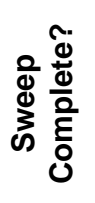 & Status/Notes & MEC Items & $\begin{array}{l}\text { MD } \\
\text { (lb) }\end{array}$ & $\begin{array}{l}\text { CD } \\
\text { (lb) }\end{array}$ & $\begin{array}{c}\text { Date } \\
\text { Started }\end{array}$ & $\begin{array}{c}\text { Date } \\
\text { Completed }\end{array}$ & $\begin{array}{l}\text { Date QC } \\
\text { Survey } \\
\text { Complete }\end{array}$ & $\begin{array}{l}\text { Percent } \\
\text { of Grid } \\
\text { Surveyed } \\
\text { for QC }\end{array}$ & $\begin{array}{l}\text { Number } \\
\text { of Blind } \\
\text { Seeds } \\
\text { Placed } \\
\text { in Grid }\end{array}$ & $\begin{array}{c}\text { Number } \\
\text { of Blind } \\
\text { Seeds } \\
\text { Recovered }\end{array}$ \\
\hline 91 & 696 & Yes & $100 \%$ & None & 0.50 & 0.5 & $12 / 16 / 2009$ & $01 / 04 / 2010$ & $01 / 06 / 2010$ & 10 & -- & -- \\
\hline 92 & 696 & Yes & $100 \%$ & None & 1.0 & 0.0 & $12 / 15 / 2009$ & $12 / 16 / 2009$ & $12 / 17 / 2010$ & 10 & 1 & 1 \\
\hline 93 & 696 & Yes & $100 \%$ & None & 5.0 & 0.5 & $12 / 15 / 2009$ & $12 / 16 / 2009$ & $12 / 17 / 2010$ & 10 & -- & -- \\
\hline 94 & 696 & Yes & $100 \%$ & None & 2.0 & 5.0 & $12 / 15 / 2009$ & $12 / 16 / 2009$ & $12 / 17 / 2010$ & 10 & -- & -- \\
\hline 95 & 696 & Yes & $100 \%$ & None & 0.5 & 1.0 & 03/01/2010 & 03/01/2010 & 03/01/2010 & 10 & 1 & 1 \\
\hline 96 & 696 & Yes & $100 \%$ & $\begin{array}{l}1 \text { 155-mm } \\
\text { projectile }\end{array}$ & 1.0 & 1.0 & $03 / 05 / 2010$ & 03/05/2010 & 03/05/2010 & 10 & 1 & 1 \\
\hline 97 & 696 & Yes & $100 \%$ & None & 10.0 & 20.0 & $04 / 21 / 2010$ & $04 / 21 / 2010$ & $04 / 21 / 2010$ & 10 & 1 & 1 \\
\hline 98 & 696 & Yes & $100 \%$ & None & 5.0 & 15.0 & $04 / 12 / 2010$ & $04 / 12 / 2010$ & $04 / 12 / 2010$ & 10 & -- & -- \\
\hline 99 & 696 & Yes & $100 \%$ & None & 3.0 & 2.0 & $04 / 12 / 2010$ & $04 / 12 / 2010$ & $04 / 12 / 2010$ & 10 & -- & -- \\
\hline 00 & 696 & Yes & $100 \%$ & None & 6.0 & 3.0 & $04 / 13 / 2010$ & $04 / 13 / 2010$ & 04/13/2010 & 10 & -- & -- \\
\hline 01 & 696 & Yes & $100 \%$ & $\begin{array}{c}140-\mathrm{mm} \text { smoke } \\
\text { expended }\end{array}$ & 10.0 & 6.0 & $04 / 14 / 2010$ & $04 / 14 / 2010$ & $04 / 14 / 2010$ & 10 & 1 & 1 \\
\hline 02 & 696 & Yes & $100 \%$ & None & 1.0 & 1.0 & 04/01/2010 & $04 / 01 / 2010$ & $04 / 1 / 2010$ & 10 & -- & -- \\
\hline 03 & 696 & Yes & $100 \%$ & None & 1.0 & 2.0 & 03/29/2010 & $03 / 29 / 2010$ & 03/29/2010 & 10 & -- & -- \\
\hline 04 & 696 & Yes & $100 \%$ & None & 1.0 & 0.5 & 03/23/2010 & 03/23/2010 & 03/23/2010 & 10 & 1 & 1 \\
\hline 05 & 696 & Yes & $100 \%$ & None & 1.0 & 0.5 & 03/22/2010 & $03 / 22 / 2010$ & $03 / 22 / 2010$ & 10 & -- & -- \\
\hline 06 & 696 & Yes & $100 \%$ & None & 0.5 & 0.5 & 03/08/2010 & 03/08/2010 & 03/08/2010 & 10 & -- & -- \\
\hline
\end{tabular}

\section{UNCONTROLLED When Printed}


Table B.1-5

Page B-31 of B-44

\section{South Antelope Lake}

(Page 11 of 22)

\begin{tabular}{|c|c|c|c|c|c|c|c|c|c|c|c|c|}
\hline 은 $\frac{\text { 듬 }}{0}$ & 은 궁 & 造 & Status/Notes & MEC Items & $\begin{array}{l}\text { MD } \\
\text { (lb) }\end{array}$ & $\begin{array}{l}\text { CD } \\
\text { (lb) }\end{array}$ & $\begin{array}{c}\text { Date } \\
\text { Started }\end{array}$ & $\begin{array}{c}\text { Date } \\
\text { Completed }\end{array}$ & $\begin{array}{l}\text { Date QC } \\
\text { Survey } \\
\text { Complete }\end{array}$ & $\begin{array}{l}\text { Percent } \\
\text { of Grid } \\
\text { Surveyed } \\
\text { for QC }\end{array}$ & $\begin{array}{l}\text { Number } \\
\text { of Blind } \\
\text { Seeds } \\
\text { Placed } \\
\text { in Grid }\end{array}$ & $\begin{array}{c}\text { Number } \\
\text { of Blind } \\
\text { Seeds } \\
\text { Recovered }\end{array}$ \\
\hline 07 & 696 & Yes & $100 \%$ & None & 0.5 & 0.5 & 03/08/2010 & 03/08/2010 & 03/08/2010 & 10 & -- & -- \\
\hline 84 & 697 & Yes & $100 \%$ & None & 1.0 & 0.0 & $01 / 06 / 2010$ & 01/06/2010 & 01/07/2010 & 10 & -- & -- \\
\hline 85 & 697 & Yes & $100 \%$ & None & 0.5 & 0.0 & 01/06/2010 & 01/06/2010 & 01/07/2010 & 10 & -- & -- \\
\hline 86 & 697 & Yes & $100 \%$ & None & 0.5 & 0.0 & 01/06/2010 & 01/06/2010 & 01/07/2010 & 10 & 1 & 1 \\
\hline 87 & 697 & Yes & $100 \%$ & None & 2.0 & 0.5 & 01/06/2010 & 01/06/2010 & $01 / 07 / 2010$ & 10 & -- & -- \\
\hline 88 & 697 & Yes & $100 \%$ & None & 0.5 & 0.5 & $01 / 04 / 2010$ & $01 / 05 / 2010$ & 01/06/2010 & 10 & -- & -- \\
\hline 89 & 697 & Yes & $\begin{array}{c}\text { DU found and removed to } \\
\text { RMA } 100 \%\end{array}$ & None & 200.0 & 0.5 & 01/04/2010 & $01 / 05 / 2010$ & 01/06/2010 & 10 & -- & -- \\
\hline 90 & 697 & Yes & $100 \%$ & None & 10.0 & 0.5 & 01/04/2010 & $01 / 05 / 2010$ & 01/06/2010 & 25 & 1 & 1 \\
\hline 91 & 697 & Yes & $100 \%$ & None & 15.0 & 0.5 & $01 / 04 / 2010$ & $01 / 05 / 2010$ & $01 / 06 / 2010$ & 10 & -- & -- \\
\hline 92 & 697 & Yes & $100 \%$ & None & 10.0 & 20.0 & $12 / 14 / 2009$ & $12 / 15 / 2009$ & $12 / 17 / 2009$ & 10 & -- & -- \\
\hline 93 & 697 & Yes & $100 \%$ & None & 120.0 & 10.0 & $12 / 14 / 2009$ & $12 / 15 / 2009$ & $12 / 17 / 2009$ & 10 & 1 & 1 \\
\hline 94 & 697 & Yes & $100 \%$ & None & 50.0 & 10.0 & $12 / 14 / 2009$ & $12 / 15 / 2009$ & $12 / 17 / 2009$ & 10 & -- & -- \\
\hline 95 & 697 & Yes & $100 \%$ & None & 0.5 & 0.5 & 03/01/2010 & $03 / 01 / 2010$ & 03/01/2010 & 10 & -- & -- \\
\hline 96 & 697 & Yes & $100 \%$ & None & 2.0 & 1.0 & $03 / 05 / 2010$ & $03 / 05 / 2010$ & $03 / 05 / 2010$ & 10 & -- & -- \\
\hline 97 & 697 & Yes & $100 \%$ & None & 5.0 & 4.0 & $04 / 21 / 2010$ & $04 / 21 / 2010$ & $04 / 21 / 2010$ & 10 & -- & -- \\
\hline 98 & 697 & Yes & $100 \%$ & None & 8.0 & 4.0 & $04 / 12 / 2010$ & $04 / 12 / 2010$ & $04 / 12 / 2010$ & 10 & 1 & 1 \\
\hline
\end{tabular}

\section{UNCONTROLLED When Printed}


Table B.1-5

\section{South Antelope Lake}

(Page 12 of 22)

\begin{tabular}{|c|c|c|c|c|c|c|c|c|c|c|c|c|}
\hline 은 $\frac{\text { ㅎ }}{\frac{5}{0}}$ & 은 交 & 造 & Status/Notes & MEC Items & $\begin{array}{l}\text { MD } \\
\text { (lb) }\end{array}$ & $\begin{array}{l}\text { CD } \\
\text { (lb) }\end{array}$ & $\begin{array}{c}\text { Date } \\
\text { Started }\end{array}$ & $\begin{array}{c}\text { Date } \\
\text { Completed }\end{array}$ & $\begin{array}{l}\text { Date QC } \\
\text { Survey } \\
\text { Complete }\end{array}$ & $\begin{array}{l}\text { Percent } \\
\text { of Grid } \\
\text { Surveyed } \\
\text { for QC }\end{array}$ & $\begin{array}{l}\text { Number } \\
\text { of Blind } \\
\text { Seeds } \\
\text { Placed } \\
\text { in Grid }\end{array}$ & $\begin{array}{c}\text { Number } \\
\text { of Blind } \\
\text { Seeds } \\
\text { Recovered }\end{array}$ \\
\hline 99 & 697 & Yes & $100 \%$ & None & 4.0 & 2.0 & $04 / 12 / 2010$ & $04 / 12 / 2010$ & $04 / 12 / 2010$ & 10 & 1 & 1 \\
\hline 00 & 697 & Yes & $100 \%$ & None & 4.0 & 2.0 & $04 / 13 / 2010$ & $04 / 13 / 2010$ & $04 / 13 / 2010$ & 10 & -- & -- \\
\hline 01 & 697 & Yes & $100 \%$ & None & 5.0 & 10.0 & 04/07/2010 & 04/07/2010 & 04/07/2010 & 10 & -- & -- \\
\hline 02 & 697 & Yes & $100 \%$ & None & 3.0 & 1.0 & 04/01/2010 & 04/01/2010 & 04/01/2010 & 10 & 1 & 1 \\
\hline 03 & 697 & Yes & $100 \%$ & None & 3.0 & 1.0 & 03/29/2010 & 03/29/2010 & 03/29/2010 & 10 & -- & -- \\
\hline 04 & 697 & Yes & $100 \%$ & None & 1.5 & 2.5 & 03/23/2010 & 03/23/2010 & 03/23/2010 & 10 & -- & -- \\
\hline 05 & 697 & Yes & $100 \%$ & None & 1.0 & 1.0 & 03/19/2010 & 03/19/2010 & 03/19/2010 & 10 & -- & -- \\
\hline 06 & 697 & Yes & $100 \%$ & None & 1.0 & 1.0 & $03 / 22 / 2010$ & $03 / 22 / 2010$ & $03 / 22 / 2010$ & 10 & -- & -- \\
\hline 07 & 697 & Yes & $100 \%$ & None & 0.5 & 0.5 & $03 / 11 / 2010$ & $03 / 11 / 2010$ & $03 / 11 / 2010$ & 10 & -- & -- \\
\hline 83 & 698 & Yes & $\begin{array}{l}\text { 100-m-wide step-out } \\
\text { performed beyond } \\
\text { BLU-26 }\end{array}$ & BLU-26 & 5.0 & 0.5 & $12 / 07 / 2009$ & $12 / 7 / 2009$ & $12 / 14 / 2009$ & 10 & -- & -- \\
\hline 84 & 698 & Yes & $100 \%$ & None & 0.5 & 0.5 & $12 / 07 / 2009$ & $12 / 07 / 2009$ & $12 / 14 / 2009$ & 10 & -- & -- \\
\hline 85 & 698 & Yes & $100 \%$ & None & 0.5 & 0.5 & $12 / 07 / 2009$ & $12 / 07 / 2009$ & $12 / 14 / 2009$ & 10 & -- & -- \\
\hline 86 & 698 & Yes & $100 \%$ & None & 0.5 & 1.0 & $12 / 07 / 2009$ & $12 / 07 / 2009$ & $12 / 14 / 2009$ & 10 & -- & -- \\
\hline 87 & 698 & Yes & $100 \%$ & None & 0.5 & 1.0 & $12 / 07 / 2009$ & $12 / 07 / 2009$ & $12 / 14 / 2009$ & 10 & -- & -- \\
\hline 88 & 698 & Yes & $100 \%$ & None & 10.0 & 15.0 & $12 / 07 / 2009$ & $12 / 08 / 2009$ & $12 / 14 / 2009$ & 10 & -- & -- \\
\hline 89 & 698 & Yes & $100 \%$ & None & 5.0 & 0.5 & $12 / 09 / 2009$ & $12 / 10 / 2009$ & $12 / 14 / 2009$ & 10 & -- & -- \\
\hline
\end{tabular}

\section{UNCONTROLLED When Printed}


Table B.1-5

\section{South Antelope Lake}

(Page 13 of 22)

\begin{tabular}{|c|c|c|c|c|c|c|c|c|c|c|c|c|}
\hline 은 $\frac{\text { ㅎ }}{\frac{5}{0}}$ & 은 旁 & 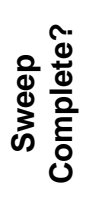 & Status/Notes & MEC Items & $\begin{array}{l}\text { MD } \\
\text { (lb) }\end{array}$ & $\begin{array}{l}\text { CD } \\
\text { (lb) }\end{array}$ & $\begin{array}{c}\text { Date } \\
\text { Started }\end{array}$ & $\begin{array}{c}\text { Date } \\
\text { Completed }\end{array}$ & $\begin{array}{l}\text { Date QC } \\
\text { Survey } \\
\text { Complete }\end{array}$ & $\begin{array}{l}\text { Percent } \\
\text { of Grid } \\
\text { Surveyed } \\
\text { for QC }\end{array}$ & $\begin{array}{l}\text { Number } \\
\text { of Blind } \\
\text { Seeds } \\
\text { Placed } \\
\text { in Grid }\end{array}$ & $\begin{array}{c}\text { Number } \\
\text { of Blind } \\
\text { Seeds } \\
\text { Recovered }\end{array}$ \\
\hline 90 & 698 & Yes & $100 \%$ & None & 0.5 & 10.0 & $12 / 09 / 2009$ & $12 / 10 / 2009$ & $12 / 14 / 2009$ & 10 & 1 & 1 \\
\hline 91 & 698 & Yes & $100 \%$ & None & 0.5 & 5.0 & $12 / 09 / 2009$ & $12 / 10 / 2009$ & $12 / 14 / 2009$ & 10 & -- & -- \\
\hline 92 & 698 & Yes & $100 \%$ & None & 1.0 & 2.0 & $12 / 10 / 2009$ & $12 / 11 / 2009$ & $12 / 14 / 2009$ & 10 & -- & -- \\
\hline 93 & 698 & Yes & $100 \%$ & BLU-49 & 50.0 & 0.5 & $12 / 10 / 2009$ & $12 / 11 / 2009$ & $12 / 14 / 2009$ & 10 & -- & -- \\
\hline 94 & 698 & Yes & $100 \%$ & BLU-49 & 10.0 & 0.5 & $12 / 10 / 2009$ & $12 / 11 / 2009$ & $12 / 14 / 2009$ & 10 & 1 & 1 \\
\hline 95 & 698 & Yes & $100 \%$ & None & 1.0 & 2.0 & 03/01/2010 & 03/01/2010 & 03/01/2010 & 10 & -- & -- \\
\hline 96 & 698 & Yes & $100 \%$ & None & 1.0 & 0.5 & 03/03/2010 & 03/03/2010 & 030/3/2010 & 10 & 1 & 1 \\
\hline 97 & 698 & Yes & $100 \%$ & None & 6.0 & 4.0 & $04 / 21 / 2010$ & $04 / 21 / 2010$ & $04 / 21 / 2010$ & 10 & -- & -- \\
\hline 98 & 698 & Yes & $100 \%$ & None & 8.0 & 2.0 & $04 / 16 / 2010$ & $04 / 16 / 2010$ & $04 / 16 / 2010$ & 10 & -- & -- \\
\hline 99 & 698 & Yes & $100 \%$ & None & 5.0 & 2.0 & $04 / 12 / 2010$ & $04 / 12 / 2010$ & $04 / 12 / 2010$ & 10 & -- & -- \\
\hline 00 & 698 & Yes & $100 \%$ & None & 145.0 & 5.0 & $05 / 05 / 2010$ & $05 / 05 / 2010$ & $05 / 05 / 2010$ & 10 & 1 & 1 \\
\hline 01 & 698 & Yes & $100 \%$ & None & 12.0 & 15.0 & $04 / 07 / 2010$ & $04 / 07 / 2010$ & $04 / 07 / 2010$ & 10 & -- & -- \\
\hline 02 & 698 & Yes & $100 \%$ & None & 2.0 & 2.0 & $04 / 01 / 2010$ & $04 / 01 / 2010$ & $04 / 01 / 2010$ & 10 & -- & -- \\
\hline 03 & 698 & Yes & $100 \%$ & None & 1.0 & 1.0 & $03 / 25 / 2010$ & $03 / 25 / 2010$ & $03 / 25 / 2010$ & 10 & -- & -- \\
\hline 04 & 698 & Yes & $100 \%$ & None & 2.0 & 2.0 & 03/23/2010 & 03/23/2010 & 03/23/2010 & 10 & -- & -- \\
\hline 05 & 698 & Yes & $100 \%$ & None & 0.5 & 0.5 & 03/19/2010 & 03/19/2010 & 03/19/2010 & 10 & -- & -- \\
\hline 06 & 698 & Yes & $100 \%$ & None & 0.5 & 1.0 & 03/17/2010 & 03/17/2010 & 03/17/2010 & 10 & -- & -- \\
\hline
\end{tabular}

\section{UNCONTROLLED When Printed}


Table B.1-5

\section{South Antelope Lake}

(Page 14 of 22)

\begin{tabular}{|c|c|c|c|c|c|c|c|c|c|c|c|c|}
\hline 은 $\frac{\text { ㅎ }}{\frac{5}{0}}$ & 은 交 & 造 & Status/Notes & MEC Items & $\begin{array}{l}\text { MD } \\
\text { (lb) }\end{array}$ & $\begin{array}{l}\text { CD } \\
\text { (lb) }\end{array}$ & $\begin{array}{c}\text { Date } \\
\text { Started }\end{array}$ & $\begin{array}{c}\text { Date } \\
\text { Completed }\end{array}$ & $\begin{array}{l}\text { Date QC } \\
\text { Survey } \\
\text { Complete }\end{array}$ & $\begin{array}{l}\text { Percent } \\
\text { of Grid } \\
\text { Surveyed } \\
\text { for QC }\end{array}$ & $\begin{array}{l}\text { Number } \\
\text { of Blind } \\
\text { Seeds } \\
\text { Placed } \\
\text { in Grid }\end{array}$ & $\begin{array}{c}\text { Number } \\
\text { of Blind } \\
\text { Seeds } \\
\text { Recovered }\end{array}$ \\
\hline 07 & 698 & Yes & $100 \%$ & None & 0.5 & 0.5 & 03/18/2010 & 03/18/2010 & 03/18/2010 & 10 & -- & -- \\
\hline 08 & 698 & Yes & $100 \%$ & None & 0.5 & 0.5 & $03 / 11 / 2010$ & $03 / 11 / 2010$ & $03 / 11 / 2010$ & 10 & -- & -- \\
\hline 82 & 699 & Yes & $100 \%$ & None & 0.0 & 0.5 & $12 / 04 / 2009$ & $12 / 04 / 2009$ & $12 / 10 / 2009$ & 10 & -- & -- \\
\hline 83 & 699 & Yes & $100 \%$ & None & 5.0 & 1.0 & $12 / 03 / 2009$ & $12 / 07 / 2009$ & $12 / 15 / 2009$ & 10 & -- & -- \\
\hline 84 & 699 & Yes & $100 \%$ & None & 5.0 & 0.5 & $12 / 03 / 2009$ & $12 / 07 / 2009$ & $12 / 15 / 2009$ & 10 & 1 & 1 \\
\hline 85 & 699 & Yes & $100 \%$ & None & 2.0 & 5.0 & $12 / 03 / 2009$ & $12 / 07 / 2009$ & $12 / 15 / 2009$ & 10 & -- & -- \\
\hline 86 & 699 & Yes & $100 \%$ & None & 5.0 & 5.0 & $12 / 08 / 2009$ & $12 / 08 / 2009$ & $12 / 15 / 2009$ & 10 & -- & -- \\
\hline 87 & 699 & Yes & $100 \%$ & None & 15.0 & 0.5 & $12 / 08 / 2009$ & $12 / 08 / 2009$ & $12 / 15 / 2009$ & 10 & -- & -- \\
\hline 88 & 699 & Yes & $100 \%$ & None & 5.0 & 5.0 & $12 / 08 / 2009$ & $12 / 08 / 2009$ & $12 / 15 / 2009$ & 10 & -- & -- \\
\hline 89 & 699 & Yes & $100 \%$ & None & 10.0 & 5.0 & $12 / 08 / 2009$ & $12 / 09 / 2009$ & $12 / 15 / 2009$ & 10 & -- & -- \\
\hline 90 & 699 & Yes & $100 \%$ & None & 1.0 & 20.0 & $12 / 08 / 2009$ & $12 / 09 / 2009$ & $12 / 15 / 2009$ & 10 & -- & -- \\
\hline 91 & 699 & Yes & $100 \%$ & None & 5.0 & 10.0 & $12 / 08 / 2009$ & $12 / 09 / 2009$ & $12 / 15 / 2009$ & 10 & 1 & 1 \\
\hline 92 & 699 & Yes & $100 \%$ & None & 10.0 & 0.5 & $12 / 11 / 2009$ & $12 / 14 / 2009$ & $12 / 15 / 2009$ & 10 & -- & -- \\
\hline 93 & 699 & Yes & $100 \%$ & None & 5.0 & 0.5 & $12 / 11 / 2009$ & $12 / 14 / 2009$ & $12 / 15 / 2009$ & 10 & -- & -- \\
\hline 94 & 699 & Yes & $100 \%$ & None & 5.0 & 0.5 & $12 / 11 / 2009$ & $12 / 14 / 2009$ & $12 / 15 / 2009$ & 10 & 1 & 1 \\
\hline 95 & 699 & Yes & $100 \%$ & None & 0.5 & 0.5 & 03/01/2010 & 03/01/2010 & $03 / 01 / 2010$ & 10 & -- & -- \\
\hline 96 & 699 & Yes & $100 \%$ & None & 1.5 & 1.0 & 03/03/2010 & 03/03/2010 & 03/03/2010 & 10 & -- & -- \\
\hline
\end{tabular}

\section{UNCONTROLLED When Printed}


Table B.1-5

\section{South Antelope Lake}

(Page 15 of 22)

\begin{tabular}{|c|c|c|c|c|c|c|c|c|c|c|c|c|}
\hline 은 $\frac{\text { ㅎ }}{\frac{5}{0}}$ & 은 交 & 造苍 & Status/Notes & MEC Items & $\begin{array}{l}\text { MD } \\
\text { (lb) }\end{array}$ & $\begin{array}{l}\text { CD } \\
\text { (lb) }\end{array}$ & $\begin{array}{c}\text { Date } \\
\text { Started }\end{array}$ & $\begin{array}{c}\text { Date } \\
\text { Completed }\end{array}$ & $\begin{array}{l}\text { Date QC } \\
\text { Survey } \\
\text { Complete }\end{array}$ & $\begin{array}{l}\text { Percent } \\
\text { of Grid } \\
\text { Surveyed } \\
\text { for QC }\end{array}$ & $\begin{array}{l}\text { Number } \\
\text { of Blind } \\
\text { Seeds } \\
\text { Placed } \\
\text { in Grid }\end{array}$ & $\begin{array}{c}\text { Number } \\
\text { of Blind } \\
\text { Seeds } \\
\text { Recovered }\end{array}$ \\
\hline 97 & 699 & Yes & $100 \%$ & None & 3.0 & 3.0 & $04 / 20 / 2010$ & 04/020/2010 & 04/20/2010 & 10 & -- & -- \\
\hline 98 & 699 & Yes & $100 \%$ & None & 10.0 & 3.0 & $04 / 16 / 2010$ & $04 / 16 / 2010$ & $04 / 16 / 2010$ & 10 & 1 & 1 \\
\hline 99 & 699 & Yes & $100 \%$ & None & 10.0 & 4.0 & 04/09/2010 & 04/09/2010 & 04/09/2010 & 10 & -- & -- \\
\hline 00 & 699 & Yes & $100 \%$ & None & 5.0 & 4.0 & $04 / 13 / 2010$ & $04 / 13 / 2010$ & 04/13/2010 & 10 & -- & -- \\
\hline 01 & 699 & Yes & $100 \%$ & 40-mm smoke & 10.0 & 15.0 & 04/07/2010 & $04 / 07 / 2010$ & 04/07/2010 & 10 & -- & -- \\
\hline 02 & 699 & Yes & $100 \%$ & None & 2.0 & 20.0 & $04 / 01 / 2010$ & $04 / 01 / 2010$ & 04/01/2010 & 10 & -- & -- \\
\hline 03 & 699 & Yes & $100 \%$ & None & 1.0 & 1.0 & $03 / 25 / 2010$ & 03/25/2010 & $03 / 25 / 2010$ & 10 & 1 & 1 \\
\hline 04 & 699 & Yes & $100 \%$ & None & 1.0 & 1.0 & 03/24/2010 & 03/24/2010 & $03 / 24 / 2010$ & 10 & 1 & 1 \\
\hline 05 & 699 & Yes & $100 \%$ & None & 1.0 & 1.0 & 03/19/2010 & 03/19/2010 & 03/19/2010 & 10 & 1 & 1 \\
\hline 06 & 699 & Yes & $100 \%$ & None & 1.0 & 0.5 & 03/17/2010 & 03/17/2010 & $03 / 17 / 2010$ & 10 & -- & -- \\
\hline 07 & 699 & Yes & $100 \%$ & None & 0.5 & 0.0 & 03/16/2010 & 03/16/2010 & 03/16/2010 & 10 & -- & -- \\
\hline 08 & 699 & Yes & $100 \%$ & None & 0.0 & 0.5 & 03/11/2010 & 03/11/2010 & 03/11/2010 & 10 & -- & -- \\
\hline 82 & 700 & Yes & $100 \%$ & None & 3.0 & 0.0 & $12 / 01 / 2009$ & $12 / 02 / 2009$ & $12 / 10 / 2009$ & 10 & -- & -- \\
\hline 83 & 700 & Yes & $100 \%$ & None & 40.0 & 0.5 & $12 / 01 / 2009$ & $12 / 07 / 2009$ & $12 / 07 / 2009$ & 10 & -- & -- \\
\hline 84 & 700 & Yes & $100 \%$ & None & 0.5 & 1.0 & $12 / 01 / 2009$ & $12 / 02 / 2009$ & $12 / 10 / 2009$ & 10 & -- & -- \\
\hline 85 & 700 & Yes & $100 \%$ & None & 0.5 & 5.0 & $12 / 01 / 2009$ & $12 / 02 / 2009$ & $12 / 10 / 2009$ & 10 & 0 & 0 \\
\hline 86 & 700 & Yes & $100 \%$ & None & 2.0 & 20.0 & $12 / 01 / 2009$ & $12 / 02 / 2009$ & $12 / 10 / 2009$ & 10 & -- & -- \\
\hline
\end{tabular}

\section{UNCONTROLLED When Printed}


Table B.1-5

\section{South Antelope Lake}

(Page 16 of 22)

\begin{tabular}{|c|c|c|c|c|c|c|c|c|c|c|c|c|}
\hline 은 $\frac{\text { ㅎ }}{\frac{5}{0}}$ & 은 交 & 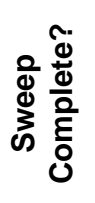 & Status/Notes & MEC Items & $\begin{array}{l}\text { MD } \\
\text { (lb) }\end{array}$ & $\begin{array}{l}\text { CD } \\
\text { (lb) }\end{array}$ & $\begin{array}{c}\text { Date } \\
\text { Started }\end{array}$ & $\begin{array}{c}\text { Date } \\
\text { Completed }\end{array}$ & $\begin{array}{l}\text { Date QC } \\
\text { Survey } \\
\text { Complete }\end{array}$ & $\begin{array}{l}\text { Percent } \\
\text { of Grid } \\
\text { Surveyed } \\
\text { for QC }\end{array}$ & $\begin{array}{l}\text { Number } \\
\text { of Blind } \\
\text { Seeds } \\
\text { Placed } \\
\text { in Grid }\end{array}$ & $\begin{array}{c}\text { Number } \\
\text { of Blind } \\
\text { Seeds } \\
\text { Recovered }\end{array}$ \\
\hline 87 & 700 & Yes & $100 \%$ & None & 0.5 & 0.0 & $11 / 30 / 2009$ & $12 / 01 / 2009$ & $12 / 10 / 2009$ & 10 & -- & -- \\
\hline 88 & 700 & Yes & $100 \%$ & None & 0.0 & 0.5 & $11 / 30 / 2009$ & $12 / 01 / 2009$ & $12 / 10 / 2009$ & 10 & -- & -- \\
\hline 89 & 700 & Yes & $100 \%$ & None & 0.0 & 0.5 & $11 / 30 / 2009$ & $12 / 01 / 2009$ & $12 / 09 / 2009$ & 10 & 1 & 1 \\
\hline 90 & 700 & Yes & $100 \%$ & None & 0.5 & 2.0 & $11 / 23 / 2009$ & $11 / 24 / 2009$ & $12 / 01 / 2009$ & 10 & -- & -- \\
\hline 91 & 700 & Yes & $100 \%$ & None & 0.5 & 0.5 & $11 / 23 / 2009$ & $11 / 24 / 2009$ & $12 / 01 / 2009$ & 10 & -- & -- \\
\hline 92 & 700 & Yes & $100 \%$ & None & 202.0 & 5.0 & $11 / 23 / 2009$ & $11 / 30 / 2009$ & $12 / 07 / 2009$ & 10 & -- & -- \\
\hline 93 & 700 & Yes & $100 \%$ & None & 5.0 & 0.5 & $11 / 22 / 2009$ & $11 / 23 / 2009$ & $11 / 24 / 2009$ & 10 & -- & -- \\
\hline 94 & 700 & Yes & $100 \%$ & None & 0.5 & 5.0 & $11 / 21 / 2009$ & $11 / 22 / 2009$ & $11 / 24 / 2009$ & 10 & -- & -- \\
\hline 95 & 700 & Yes & $100 \%$ & None & 2.0 & 3.0 & $03 / 02 / 2010$ & 03/02/2010 & $03 / 02 / 2010$ & 10 & 1 & 1 \\
\hline 96 & 700 & Yes & $100 \%$ & None & 1.0 & 1.0 & 03/03/2010 & 03/03/2010 & 03/03/2010 & 10 & -- & -- \\
\hline 97 & 700 & Yes & $100 \%$ & None & 4.0 & 2.0 & $04 / 20 / 2010$ & 04/20/2010 & $04 / 20 / 2010$ & 10 & 1 & 1 \\
\hline 98 & 700 & Yes & $100 \%$ & None & 5.0 & 4.0 & $04 / 16 / 2010$ & $04 / 16 / 2010$ & $04 / 16 / 2010$ & 10 & -- & -- \\
\hline 99 & 700 & Yes & $100 \%$ & None & 15.0 & 2.0 & 04/09/2010 & 04/09/2010 & 04/09/2010 & 10 & -- & -- \\
\hline 00 & 700 & Yes & $100 \%$ & None & 8.0 & 4.0 & 04/08/2010 & 04/08/2010 & $04 / 08 / 2010$ & 10 & -- & -- \\
\hline 01 & 700 & Yes & $100 \%$ & None & 12.0 & 10.0 & 04/06/2010 & 04/06/2010 & $04 / 06 / 2010$ & 10 & -- & -- \\
\hline 02 & 700 & Yes & $100 \%$ & None & 2.0 & 2.0 & 04/02/2010 & $04 / 02 / 2010$ & $04 / 02 / 2010$ & 10 & -- & -- \\
\hline 03 & 700 & Yes & $100 \%$ & 1 BLU-63 & 2.0 & 2.0 & $03 / 25 / 2010$ & $03 / 25 / 2010$ & $03 / 25 / 2010$ & 10 & -- & -- \\
\hline
\end{tabular}

\section{UNCONTROLLED When Printed}


Table B.1-5

\section{South Antelope Lake}

(Page 17 of 22)

\begin{tabular}{|c|c|c|c|c|c|c|c|c|c|c|c|c|}
\hline 은 $\frac{\text { ㅎ }}{\frac{5}{0}}$ & 은 交 & 造 & Status/Notes & MEC Items & $\begin{array}{l}\text { MD } \\
\text { (lb) }\end{array}$ & $\begin{array}{l}\text { CD } \\
\text { (lb) }\end{array}$ & $\begin{array}{c}\text { Date } \\
\text { Started }\end{array}$ & $\begin{array}{c}\text { Date } \\
\text { Completed }\end{array}$ & $\begin{array}{l}\text { Date QC } \\
\text { Survey } \\
\text { Complete }\end{array}$ & $\begin{array}{l}\text { Percent } \\
\text { of Grid } \\
\text { Surveyed } \\
\text { for QC }\end{array}$ & $\begin{array}{l}\text { Number } \\
\text { of Blind } \\
\text { Seeds } \\
\text { Placed } \\
\text { in Grid }\end{array}$ & $\begin{array}{c}\text { Number } \\
\text { of Blind } \\
\text { Seeds } \\
\text { Recovered }\end{array}$ \\
\hline 04 & 700 & Yes & $100 \%$ & None & 3.0 & 2.0 & 03/24/2010 & $03 / 24 / 2010$ & $03 / 24 / 2010$ & 10 & -- & -- \\
\hline 05 & 700 & Yes & $100 \%$ & 1 20-mm TP & 1.5 & 2.0 & 03/18/2010 & 03/18/2010 & 03/18/2010 & 10 & -- & -- \\
\hline 06 & 700 & Yes & $100 \%$ & None & 0.5 & 0.5 & 03/17/2010 & 03/17/2010 & 03/17/2010 & 10 & -- & -- \\
\hline 07 & 700 & Yes & $100 \%$ & None & 0.5 & 0.5 & 03/16/2010 & 03/16/2010 & 03/16/2010 & 10 & -- & -- \\
\hline 08 & 700 & Yes & $100 \%$ & None & 0.0 & 0.5 & 03/11/2010 & $03 / 11 / 2010$ & $03 / 11 / 2010$ & 10 & -- & -- \\
\hline 81 & 701 & Yes & $100 \%$ & None & 0.5 & 0.0 & $12 / 03 / 2009$ & $12 / 03 / 2009$ & $12 / 10 / 2009$ & 10 & -- & -- \\
\hline 82 & 701 & Yes & $100 \%$ & None & 2.0 & 0.0 & $12 / 03 / 2009$ & $12 / 03 / 2009$ & $12 / 10 / 2009$ & 10 & 1 & 1 \\
\hline 83 & 701 & Yes & $100 \%$ & None & 10.0 & 0.0 & $12 / 03 / 2009$ & $12 / 03 / 2009$ & $12 / 10 / 2009$ & 10 & -- & -- \\
\hline 84 & 701 & Yes & $100 \%$ & None & 5.0 & 0.5 & $12 / 03 / 2009$ & $12 / 03 / 2009$ & $12 / 10 / 2009$ & 10 & -- & -- \\
\hline 85 & 701 & Yes & $100 \%$ & None & 350.0 & 15.0 & $12 / 03 / 2009$ & $12 / 04 / 2009$ & $12 / 07 / 2009$ & 10 & -- & -- \\
\hline 86 & 701 & Yes & $100 \%$ & None & 10.0 & 5.0 & $12 / 03 / 2009$ & $12 / 04 / 2009$ & $12 / 09 / 2009$ & 10 & 1 & 1 \\
\hline 87 & 701 & Yes & $100 \%$ & None & 0.5 & 0.0 & $12 / 01 / 2009$ & $12 / 01 / 2009$ & $12 / 09 / 2009$ & 10 & -- & -- \\
\hline 88 & 701 & Yes & $100 \%$ & None & 0.5 & 0.0 & $12 / 01 / 2009$ & $12 / 01 / 2009$ & $12 / 09 / 2009$ & 10 & -- & -- \\
\hline 89 & 701 & Yes & $100 \%$ & None & 0.5 & 0.0 & $12 / 01 / 2009$ & $12 / 01 / 2009$ & $12 / 09 / 2009$ & 10 & -- & -- \\
\hline 90 & 701 & Yes & $100 \%$ & None & 0.5 & 0.5 & $11 / 24 / 2009$ & $11 / 24 / 2009$ & $12 / 01 / 2009$ & 10 & 1 & 1 \\
\hline 91 & 701 & Yes & $100 \%$ & None & 5.0 & 2.0 & $11 / 24 / 2009$ & $11 / 24 / 2009$ & $12 / 01 / 2009$ & 10 & -- & -- \\
\hline 92 & 701 & Yes & $100 \%$ & None & 0.5 & 5.0 & $11 / 24 / 2009$ & $11 / 24 / 2009$ & $11 / 30 / 2009$ & 10 & -- & -- \\
\hline
\end{tabular}

\section{UNCONTROLLED When Printed}


Table B.1-5

Page B-38 of B-44

\section{South Antelope Lake}

(Page 18 of 22)

\begin{tabular}{|c|c|c|c|c|c|c|c|c|c|c|c|c|}
\hline 은 $\frac{\text { ㅎ }}{\frac{2}{0}}$ & 은 궁 & 这 & Status/Notes & MEC Items & $\begin{array}{l}\text { MD } \\
\text { (lb) }\end{array}$ & $\begin{array}{l}\text { CD } \\
\text { (lb) }\end{array}$ & $\begin{array}{l}\text { Date } \\
\text { Started }\end{array}$ & $\begin{array}{c}\text { Date } \\
\text { Completed }\end{array}$ & $\begin{array}{l}\text { Date QC } \\
\text { Survey } \\
\text { Complete }\end{array}$ & $\begin{array}{l}\text { Percent } \\
\text { of Grid } \\
\text { Surveyed } \\
\text { for QC }\end{array}$ & $\begin{array}{l}\text { Number } \\
\text { of Blind } \\
\text { Seeds } \\
\text { Placed } \\
\text { in Grid }\end{array}$ & $\begin{array}{c}\text { Number } \\
\text { of Blind } \\
\text { Seeds } \\
\text { Recovered }\end{array}$ \\
\hline 93 & 701 & Yes & $100 \%$ & None & 10.0 & 5.0 & $11 / 22 / 2009$ & $11 / 23 / 2009$ & $11 / 30 / 2009$ & 10 & 1 & 1 \\
\hline 94 & 701 & Yes & $\begin{array}{l}\text { Soil samples } 408 \mathrm{~A} 021 \\
\text { through } 408 \mathrm{~A} 027 \text { were } \\
\text { collected from the four } \\
\text { sidewalls, bottom, and } \\
\text { spoils pile from the } \\
\text { excavation at grid 94/701; } \\
1 \text { QC field blank was } \\
\text { collected at same location } \\
\text { (408A301) }\end{array}$ & None & 305.0 & 10.0 & $11 / 21 / 2009$ & $11 / 23 / 2009$ & $12 / 01 / 2009$ & 10 & 1 & 1 \\
\hline 95 & 701 & Yes & $100 \%$ & None & 3.0 & 10.0 & 03/02/2010 & 03/02/2010 & 03/02/2010 & 10 & -- & -- \\
\hline 96 & 701 & Yes & $100 \%$ & None & 0.5 & 1.0 & 03/03/2010 & 03/03/2010 & 03/03/2010 & 10 & -- & -- \\
\hline 97 & 701 & Yes & $100 \%$ & None & 5.0 & 1.0 & 04/19/2010 & 04/19/2010 & 04/19/2010 & 10 & -- & -- \\
\hline 98 & 701 & Yes & $100 \%$ & None & 5.0 & 2.0 & 04/19/2010 & 04/19/2010 & 04/19/2010 & 10 & -- & -- \\
\hline 99 & 701 & Yes & $100 \%$ & None & 16.0 & 2.0 & 04/09/2010 & 04/09/2010 & 04/09/2010 & 10 & -- & -- \\
\hline 00 & 701 & Yes & $100 \%$ & None & 5.0 & 4.0 & 04/08/2010 & 04/08/2010 & 04/08/2010 & 10 & -- & -- \\
\hline 01 & 701 & Yes & $100 \%$ & None & 21.0 & 12.0 & 04/06/2010 & 04/06/2010 & 04/06/2010 & 10 & 1 & 1 \\
\hline 02 & 701 & Yes & $100 \%$ & 2 BLU-63s & 2.0 & 75.0 & $04 / 02 / 2010$ & $04 / 02 / 2010$ & $04 / 02 / 2010$ & 10 & 1 & 1 \\
\hline 03 & 701 & Yes & $100 \%$ & 2 BLU-63s & 7.0 & 5.0 & 03/25/2010 & $03 / 25 / 2010$ & 03/25/2010 & 10 & -- & -- \\
\hline 04 & 701 & Yes & $100 \%$ & 2 BLU-63s & 10.0 & 2.0 & 03/24/2010 & 03/24/2010 & 03/24/2010 & 10 & -- & -- \\
\hline 05 & 701 & Yes & $100 \%$ & None & 1.5 & 2.0 & 03/18/2010 & 03/18/2010 & 03/18/2010 & 10 & -- & -- \\
\hline
\end{tabular}


Table B.1-5

\section{South Antelope Lake}

(Page 19 of 22)

\begin{tabular}{|c|c|c|c|c|c|c|c|c|c|c|c|c|}
\hline 은 $\frac{\text { ㅎ }}{\frac{5}{0}}$ & 은 交 & 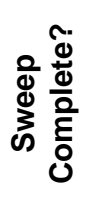 & Status/Notes & MEC Items & $\begin{array}{l}\text { MD } \\
\text { (lb) }\end{array}$ & $\begin{array}{l}\text { CD } \\
\text { (lb) }\end{array}$ & $\begin{array}{c}\text { Date } \\
\text { Started }\end{array}$ & $\begin{array}{c}\text { Date } \\
\text { Completed }\end{array}$ & $\begin{array}{l}\text { Date QC } \\
\text { Survey } \\
\text { Complete }\end{array}$ & $\begin{array}{l}\text { Percent } \\
\text { of Grid } \\
\text { Surveyed } \\
\text { for QC }\end{array}$ & $\begin{array}{l}\text { Number } \\
\text { of Blind } \\
\text { Seeds } \\
\text { Placed } \\
\text { in Grid }\end{array}$ & $\begin{array}{c}\text { Number } \\
\text { of Blind } \\
\text { Seeds } \\
\text { Recovered }\end{array}$ \\
\hline 06 & 701 & Yes & $100 \%$ & None & 1.0 & 1.0 & $03 / 17 / 2010$ & $03 / 17 / 2010$ & $03 / 17 / 2010$ & 10 & -- & -- \\
\hline 07 & 701 & Yes & $100 \%$ & None & 0.5 & 0.5 & 03/16/2010 & 03/16/2010 & 03/16/2010 & 10 & -- & -- \\
\hline 08 & 701 & Yes & $100 \%$ & None & 0.5 & 0.5 & 03/15/2010 & 03/15/2010 & 03/15/2010 & 10 & -- & -- \\
\hline 81 & 702 & Yes & $100 \%$ & None & 505.0 & 12.0 & $10 / 20 / 2009$ & $11 / 12 / 2009$ & $11 / 13 / 2009$ & 25 & -- & -- \\
\hline 82 & 702 & Yes & $100 \%$ & None & 0.0 & 5.0 & $10 / 13 / 2009$ & $10 / 13 / 2009$ & $11 / 02 / 2009$ & 25 & -- & -- \\
\hline 83 & 702 & Yes & $100 \%$ & None & 0.0 & 5.0 & $10 / 13 / 2009$ & $10 / 14 / 2009$ & $11 / 02 / 2009$ & 25 & -- & -- \\
\hline 84 & 702 & Yes & $100 \%$ & None & 1.0 & 0.5 & $10 / 21 / 2009$ & $10 / 22 / 2009$ & $11 / 03 / 2009$ & 25 & 2 & 2 \\
\hline 85 & 702 & Yes & $100 \%$ & None & 0.0 & 5.0 & $10 / 22 / 2009$ & $10 / 26 / 2009$ & $11 / 03 / 2009$ & 25 & 2 & 2 \\
\hline 86 & 702 & Yes & $100 \%$ & None & 0.0 & 2.0 & $10 / 26 / 2009$ & $10 / 26 / 2009$ & $11 / 05 / 2009$ & 10 & -- & -- \\
\hline 87 & 702 & Yes & $100 \%$ & None & 0.5 & 0.5 & $10 / 27 / 2009$ & $10 / 28 / 2009$ & $11 / 042009$ & 25 & -- & -- \\
\hline 88 & 702 & Yes & $100 \%$ & None & 0.5 & 0.5 & $10 / 28 / 2009$ & $10 / 29 / 2009$ & $11 / 19 / 2009$ & 10 & -- & -- \\
\hline 89 & 702 & Yes & $100 \%$ & None & 0.5 & 2.0 & $10 / 29 / 2009$ & 10/30/2009 & $11 / 05 / 2009$ & 10 & -- & -- \\
\hline 90 & 702 & Yes & $100 \%$ & None & 10.0 & 0.5 & $11 / 18 / 2009$ & $11 / 19 / 2009$ & $11 / 22 / 2009$ & 10 & -- & -- \\
\hline 91 & 702 & Yes & $100 \%$ & None & 5.0 & 0.5 & $11 / 18 / 2009$ & $11 / 19 / 2009$ & $11 / 23 / 2009$ & 10 & -- & -- \\
\hline 92 & 702 & Yes & $100 \%$ & None & 5.0 & 0.5 & $11 / 18 / 2009$ & $11 / 19 / 2009$ & $11 / 24 / 2009$ & 10 & 1 & 1 \\
\hline 93 & 702 & Yes & $100 \%$ & None & 0.5 & 5.0 & $11 / 19 / 2009$ & $11 / 21 / 2009$ & $11 / 24 / 2009$ & 10 & 1 & 1 \\
\hline 94 & 702 & Yes & $100 \%$ & None & 0.5 & 0.5 & $11 / 19 / 2009$ & $11 / 21 / 2009$ & $11 / 24 / 2009$ & 10 & 1 & 1 \\
\hline
\end{tabular}

\section{UNCONTROLLED When Printed}


Table B.1-5

\section{South Antelope Lake}

(Page 20 of 22)

\begin{tabular}{|c|c|c|c|c|c|c|c|c|c|c|c|c|}
\hline 은 $\frac{\text { ㅎ }}{\frac{5}{0}}$ & 은 交 & 造苍 & Status/Notes & MEC Items & $\begin{array}{l}\text { MD } \\
\text { (lb) }\end{array}$ & $\begin{array}{l}\text { CD } \\
\text { (lb) }\end{array}$ & $\begin{array}{c}\text { Date } \\
\text { Started }\end{array}$ & $\begin{array}{c}\text { Date } \\
\text { Completed }\end{array}$ & $\begin{array}{l}\text { Date QC } \\
\text { Survey } \\
\text { Complete }\end{array}$ & $\begin{array}{l}\text { Percent } \\
\text { of Grid } \\
\text { Surveyed } \\
\text { for QC }\end{array}$ & $\begin{array}{l}\text { Number } \\
\text { of Blind } \\
\text { Seeds } \\
\text { Placed } \\
\text { in Grid }\end{array}$ & $\begin{array}{c}\text { Number } \\
\text { of Blind } \\
\text { Seeds } \\
\text { Recovered }\end{array}$ \\
\hline 95 & 702 & Yes & $100 \%$ & None & 1.0 & 3.0 & $03 / 02 / 2010$ & $03 / 02 / 2010$ & $03 / 02 / 2010$ & 10 & -- & -- \\
\hline 96 & 702 & Yes & $100 \%$ & None & 1.0 & 0.5 & 03/03/2010 & 03/03/2010 & 03/03/2010 & 10 & -- & -- \\
\hline 97 & 702 & Yes & $100 \%$ & None & 4.0 & 2.0 & 04/19/2010 & 04/19/2010 & 04/19/2010 & 10 & -- & -- \\
\hline 98 & 702 & Yes & $100 \%$ & None & 4.0 & 2.0 & 04/19/2010 & 04/19/2010 & 04/19/2010 & 10 & -- & -- \\
\hline 99 & 702 & Yes & $100 \%$ & None & 7.0 & 3.0 & 04/08/2010 & 04/08/2010 & 04/08/2010 & 10 & -- & -- \\
\hline 00 & 702 & Yes & $100 \%$ & None & 5.0 & 2.0 & 04/07/2010 & 04/07/2010 & 04/07/2010 & 10 & -- & -- \\
\hline 01 & 702 & Yes & $100 \%$ & None & 2.0 & 1.0 & 04/06/2010 & $04 / 06 / 2010$ & $04 / 06 / 2010$ & 10 & -- & -- \\
\hline 02 & 702 & Yes & $100 \%$ & None & 2.0 & 2.0 & 04/06/2010 & 04/06/2010 & $04 / 06 / 2010$ & 10 & -- & -- \\
\hline 03 & 702 & Yes & $100 \%$ & 2 BLU-63s & 5.0 & 3.0 & 03/25/2010 & $03 / 25 / 2010$ & $03 / 25 / 2010$ & 10 & -- & -- \\
\hline 04 & 702 & Yes & $100 \%$ & None & 1.5 & 1.0 & 03/24/2010 & $03 / 24 / 2010$ & $03 / 24 / 2010$ & 10 & -- & -- \\
\hline 05 & 702 & Yes & $100 \%$ & None & 1.0 & 1.5 & 03/18/2010 & 03/18/2010 & 03/18/2010 & 10 & -- & -- \\
\hline 06 & 702 & Yes & $100 \%$ & None & 1.5 & 1.0 & 03/17/2010 & 03/17/2010 & 03/17/2010 & 10 & -- & -- \\
\hline 07 & 702 & Yes & $100 \%$ & None & 0.5 & 0.5 & 03/16/2010 & 03/16/2010 & 03/16/2010 & 10 & -- & -- \\
\hline 08 & 702 & Yes & $100 \%$ & None & 0.5 & 0.0 & 03/15/2010 & $03 / 15 / 2010$ & $03 / 15 / 2010$ & 10 & -- & -- \\
\hline 09 & 702 & Yes & $100 \%$ & None & 0.5 & 0.5 & 03/15/2010 & 03/15/2010 & 03/15/2010 & 10 & -- & -- \\
\hline 80 & 703 & Yes & $100 \%$ & None & 0.0 & 0.0 & $11 / 17 / 2009$ & $11 / 17 / 2009$ & $11 / 19 / 2009$ & 10 & -- & -- \\
\hline 81 & 703 & Yes & $100 \%$ & None & 0.0 & 15.0 & $11 / 16 / 2009$ & $11 / 16 / 2009$ & $11 / 19 / 2009$ & 10 & -- & -- \\
\hline
\end{tabular}

\section{UNCONTROLLED When Printed}


Table B.1-5

\section{South Antelope Lake}

(Page 21 of 22)

\begin{tabular}{|c|c|c|c|c|c|c|c|c|c|c|c|c|}
\hline 은 $\frac{\text { ㅎ }}{\frac{5}{0}}$ & 은 交 & 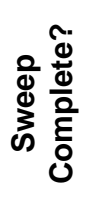 & Status/Notes & MEC Items & $\begin{array}{l}\text { MD } \\
\text { (lb) }\end{array}$ & $\begin{array}{l}\text { CD } \\
\text { (lb) }\end{array}$ & $\begin{array}{c}\text { Date } \\
\text { Started }\end{array}$ & $\begin{array}{c}\text { Date } \\
\text { Completed }\end{array}$ & $\begin{array}{l}\text { Date QC } \\
\text { Survey } \\
\text { Complete }\end{array}$ & $\begin{array}{l}\text { Percent } \\
\text { of Grid } \\
\text { Surveyed } \\
\text { for QC }\end{array}$ & $\begin{array}{l}\text { Number } \\
\text { of Blind } \\
\text { Seeds } \\
\text { Placed } \\
\text { in Grid }\end{array}$ & $\begin{array}{c}\text { Number } \\
\text { of Blind } \\
\text { Seeds } \\
\text { Recovered }\end{array}$ \\
\hline 82 & 703 & Yes & $100 \%$ & None & 0.5 & 5.0 & $11 / 16 / 2009$ & $11 / 16 / 2009$ & $11 / 19 / 2009$ & 10 & -- & -- \\
\hline 83 & 703 & Yes & $100 \%$ & 1 20-mm TP & 5.0 & 0.5 & $11 / 16 / 2009$ & $11 / 16 / 2009$ & $11 / 19 / 2009$ & 10 & 1 & 1 \\
\hline 84 & 703 & Yes & $100 \%$ & None & 5.0 & 5.0 & $11 / 16 / 2009$ & $11 / 16 / 2009$ & $11 / 19 / 2009$ & 10 & -- & -- \\
\hline 85 & 703 & Yes & $100 \%$ & None & 0.5 & 5.0 & $11 / 16 / 2009$ & $11 / 16 / 2009$ & $11 / 19 / 2009$ & 10 & -- & -- \\
\hline 86 & 703 & Yes & $100 \%$ & None & 5.0 & 0.5 & $11 / 17 / 2009$ & $11 / 17 / 2009$ & $11 / 19 / 2009$ & 10 & -- & -- \\
\hline 87 & 703 & Yes & $100 \%$ & None & 15.0 & 5.0 & $11 / 17 / 2009$ & $11 / 17 / 2009$ & $11 / 19 / 2009$ & 10 & -- & -- \\
\hline 88 & 703 & Yes & $100 \%$ & None & 200 & 0.5 & $11 / 17 / 2009$ & $11 / 17 / 2009$ & $11 / 22 / 2009$ & 10 & -- & -- \\
\hline 89 & 703 & Yes & $100 \%$ & None & 5.0 & 10.0 & $11 / 17 / 2009$ & $11 / 17 / 2009$ & $11 / 22 / 2009$ & 10 & -- & -- \\
\hline 90 & 703 & Yes & $100 \%$ & None & 10.0 & 0.5 & $11 / 18 / 2009$ & $11 / 18 / 2009$ & $11 / 22 / 2009$ & 10 & 1 & 1 \\
\hline 91 & 703 & Yes & $100 \%$ & None & 15.0 & 1.0 & $11 / 18 / 2009$ & $11 / 18 / 2009$ & $11 / 23 / 2009$ & 10 & 1 & 1 \\
\hline 92 & 703 & Yes & $100 \%$ & None & 5.0 & 10.0 & $11 / 18 / 2009$ & $11 / 18 / 2009$ & $11 / 23 / 2009$ & 10 & -- & -- \\
\hline 93 & 703 & Yes & $100 \%$ & None & 0.5 & 5.0 & $11 / 21 / 2009$ & $11 / 21 / 2009$ & $11 / 23 / 2009$ & 10 & -- & -- \\
\hline 94 & 703 & Yes & $100 \%$ & None & 1.0 & 25.0 & $11 / 21 / 2009$ & $11 / 21 / 2009$ & $11 / 23 / 2009$ & 10 & -- & -- \\
\hline 95 & 703 & Yes & $100 \%$ & None & 0.5 & 2.0 & 03/02/2010 & $03 / 02 / 2010$ & $03 / 02 / 2010$ & 10 & -- & -- \\
\hline 96 & 703 & Yes & $100 \%$ & None & 1.0 & 1.0 & 03/02/2010 & $03 / 02 / 2010$ & 03/02/2010 & 10 & -- & -- \\
\hline 97 & 703 & Yes & $100 \%$ & None & 3.0 & 3.0 & 04/19/2010 & 04/19/2010 & 04/19/2010 & 10 & -- & -- \\
\hline 98 & 703 & Yes & $100 \%$ & None & 2.0 & 2.0 & 04/19/2010 & 04/19/2010 & 04/19/2010 & 10 & 1 & 1 \\
\hline
\end{tabular}

\section{UNCONTROLLED When Printed}


Table B.1-5

\section{South Antelope Lake}

(Page 22 of 22)

\begin{tabular}{|c|c|c|c|c|c|c|c|c|c|c|c|c|}
\hline 은 $\frac{\text { 듬 }}{0}$ & 은 궁 & 造 & Status/Notes & MEC Items & $\begin{array}{l}\text { MD } \\
\text { (lb) }\end{array}$ & $\begin{array}{l}\text { CD } \\
\text { (lb) }\end{array}$ & $\begin{array}{c}\text { Date } \\
\text { Started }\end{array}$ & $\begin{array}{c}\text { Date } \\
\text { Completed }\end{array}$ & $\begin{array}{l}\text { Date QC } \\
\text { Survey } \\
\text { Complete }\end{array}$ & $\begin{array}{l}\text { Percent } \\
\text { of Grid } \\
\text { Surveyed } \\
\text { for QC }\end{array}$ & $\begin{array}{l}\text { Number } \\
\text { of Blind } \\
\text { Seeds } \\
\text { Placed } \\
\text { in Grid }\end{array}$ & $\begin{array}{c}\text { Number } \\
\text { of Blind } \\
\text { Seeds } \\
\text { Recovered }\end{array}$ \\
\hline 99 & 703 & Yes & $100 \%$ & None & 2.0 & 2.0 & 04/08/2010 & 04/08/2010 & $04 / 08 / 2010$ & 10 & 1 & 1 \\
\hline 00 & 703 & Yes & $100 \%$ & None & 5.0 & 1.0 & $04 / 07 / 2010$ & 04/07/2010 & 04/07/2010 & 10 & 1 & 1 \\
\hline 01 & 703 & Yes & $100 \%$ & None & 1.0 & 0.5 & 04/06/2010 & 04/06/2010 & 04/06/2010 & 10 & -- & -- \\
\hline 02 & 703 & Yes & $100 \%$ & None & 1.0 & 2.0 & $04 / 02 / 2010$ & 04/20/2010 & $04 / 02 / 2010$ & 10 & -- & -- \\
\hline 03 & 703 & Yes & $100 \%$ & None & 0.5 & 2.0 & $03 / 24 / 2010$ & $03 / 24 / 2010$ & $03 / 24 / 2010$ & 10 & -- & -- \\
\hline 04 & 703 & Yes & $100 \%$ & None & 1.0 & 1.0 & $03 / 24 / 2010$ & $03 / 24 / 2010$ & $03 / 24 / 2010$ & 10 & -- & -- \\
\hline 05 & 703 & Yes & $100 \%$ & None & 1.5 & 1.0 & 03/18/2010 & 03/18/2010 & 03/18/2010 & 10 & -- & -- \\
\hline 06 & 703 & Yes & $100 \%$ & None & 0.5 & 0.5 & 03/16/2010 & 03/16/2010 & 03/16/2010 & 10 & -- & -- \\
\hline 07 & 703 & Yes & $100 \%$ & None & 0.0 & 0.5 & 03/16/2010 & 03/16/2010 & 03/16/2010 & 10 & -- & -- \\
\hline 08 & 703 & Yes & $100 \%$ & None & 0.0 & 0.5 & 03/15/2010 & $03 / 15 / 2010$ & $03 / 15 / 2010$ & 10 & -- & -- \\
\hline 09 & 703 & Yes & $100 \%$ & None & 0.0 & 0.5 & 03/15/2010 & 03/15/2010 & 03/15/2010 & 10 & -- & -- \\
\hline \multicolumn{13}{|c|}{ Totals: } \\
\hline 357 & & 357 & & & $3,713.0$ & $1,156.5$ & & & & 357 & 81 & 81 \\
\hline
\end{tabular}

$\mathrm{RMA}=$ Radioactive material area 
Table B.1-6

Page B-43 of B-44

Tomahawk 1

\begin{tabular}{|c|c|c|c|c|c|c|c|c|c|c|c|c|}
\hline 은 $\frac{5}{\frac{5}{\partial}}$ & 은 궁 & 递衣 & Status/Notes & $\begin{array}{l}\text { MEC } \\
\text { Items }\end{array}$ & $\begin{array}{l}\text { MD } \\
\text { (Ib) }\end{array}$ & $\begin{array}{l}\text { CD } \\
\text { (lb) }\end{array}$ & $\begin{array}{c}\text { Date } \\
\text { Started }\end{array}$ & $\begin{array}{c}\text { Date } \\
\text { Completed }\end{array}$ & $\begin{array}{l}\text { Date QC } \\
\text { Survey } \\
\text { Complete }\end{array}$ & $\begin{array}{l}\text { Percent } \\
\text { of Grid } \\
\text { Surveyed } \\
\text { for QC }\end{array}$ & $\begin{array}{l}\text { Number } \\
\text { of Blind } \\
\text { Seeds } \\
\text { Placed } \\
\text { in Grid }\end{array}$ & $\begin{array}{l}\text { Number of } \\
\text { Blind } \\
\text { Seeds } \\
\text { Recovered }\end{array}$ \\
\hline 83 & 658 & Yes & $100 \%$ & None & 0.0 & 0.0 & $11 / 13 / 2009$ & $11 / 13 / 2009$ & $11 / 13 / 2009$ & 10 & -- & -- \\
\hline 84 & 658 & Yes & $100 \%$ & None & 0.5 & 0.0 & $11 / 13 / 2009$ & $11 / 13 / 2009$ & $11 / 13 / 2009$ & 10 & 1 & 1 \\
\hline 83 & 659 & Yes & $100 \%$ & None & 0.0 & 0.0 & $11 / 13 / 2009$ & $11 / 13 / 2009$ & $11 / 13 / 2009$ & 10 & -- & -- \\
\hline 84 & 659 & Yes & $100 \%$ & None & 0.0 & 0.5 & $11 / 13 / 2009$ & $11 / 13 / 2009$ & $11 / 13 / 2009$ & 10 & -- & -- \\
\hline \multicolumn{13}{|l|}{ Totals: } \\
\hline 4 & & 4 & & & 0.5 & 0.5 & & & & 4 & 1 & 1 \\
\hline
\end{tabular}


Table B.1-7

\section{Tomahawk 2}

\begin{tabular}{|c|c|c|c|c|c|c|c|c|c|c|c|c|}
\hline 은 $\frac{\mathfrak{c}}{\frac{5}{0}}$ & 은 方 & 这 & Status/Notes & $\begin{array}{l}\text { MEC } \\
\text { Items }\end{array}$ & $\begin{array}{l}\text { MD } \\
\text { (lb) }\end{array}$ & $\begin{array}{l}\text { CD } \\
\text { (lb) }\end{array}$ & $\begin{array}{l}\text { Date } \\
\text { Started }\end{array}$ & $\begin{array}{c}\text { Date } \\
\text { Completed }\end{array}$ & $\begin{array}{l}\text { Date QC } \\
\text { Survey } \\
\text { Complete }\end{array}$ & $\begin{array}{l}\text { Percent } \\
\text { of Grid } \\
\text { Surveyed } \\
\text { for QC }\end{array}$ & $\begin{array}{l}\text { Number } \\
\text { of Blind } \\
\text { Seeds } \\
\text { Placed } \\
\text { in Grid }\end{array}$ & $\begin{array}{l}\text { Number of } \\
\text { Blind } \\
\text { Seeds } \\
\text { Recovered }\end{array}$ \\
\hline 89 & 630 & Yes & $100 \%$ & None & 0.0 & 0.0 & $11 / 13 / 2009$ & 11/13/2009 & 11/18/2009 & 10 & -- & -- \\
\hline 90 & 630 & Yes & $100 \%$ & None & 0.0 & 0.5 & $11 / 13 / 2009$ & 11/13/2009 & 11/18/2009 & 10 & 1 & 1 \\
\hline 91 & 630 & Yes & $100 \%$ & None & 0.0 & 0.0 & $11 / 13 / 2009$ & 11/13/2009 & $11 / 18 / 2009$ & 10 & -- & -- \\
\hline 89 & 631 & Yes & $100 \%$ & None & 0.0 & 0.0 & $11 / 13 / 2009$ & $11 / 13 / 2009$ & $11 / 18 / 2009$ & 10 & -- & -- \\
\hline 90 & 631 & Yes & $100 \%$ & None & 0.0 & 0.0 & $11 / 13 / 2009$ & $11 / 13 / 2009$ & $11 / 18 / 2009$ & 10 & -- & -- \\
\hline 91 & 631 & Yes & $100 \%$ & None & 0.0 & 0.0 & $11 / 13 / 2009$ & $11 / 13 / 2009$ & $11 / 18 / 2009$ & 10 & -- & -- \\
\hline \multicolumn{13}{|c|}{ Totals: } \\
\hline 6 & & 6 & & & 0.0 & 0.5 & & & & 6 & 1 & 1 \\
\hline
\end{tabular}




\section{Attachment 1}

\section{Final After-Action Report: \\ Munitions and Explosives of Concern (MEC) \\ Disposal Pit Investigation and Sub-Munition Clearance \\ Corrective Action Unit 408 \\ Tonopah Test Range \\ Prepared by Weston Solutions, Inc.}

(56 Pages) 
FinAl AfTER ACTION REPORT

Munitions AND EXPlosives OF CONCERN (MEC)

\author{
DISPOSAL PIT INVESTIGATION \\ AND SUB-MUNITION CLEARANCE
}

\title{
CORRECTIVE ACTION UNIT 408 TONOPAH TEST RANGE
}

CONTRACT No.: DE-AC52-09NA28091

\author{
PREPARED FOR: \\ Navarro Nevada Environmental Services \\ 669 Emory Valley Road \\ Oak Ridge, Tennessee 37830 \\ The S. M. Stoller Corporation \\ 105 Technology Drive \\ Broomfield, Colorado 80021
}

PREPARED BY:

Weston Solutions, Inc.

4801 University Square, Suite 13

Huntsville, Alabama 35816

JULY 2010 


\section{MUNITIONS AND EXPLOSIVES OF CONCERN (MEC) DisPosal PIT InVESTIGATION AND SUb-MuNition CLEARANCE}

Tonopah Test Range, NeVADA

CONTRACT No.: DE-AC52-09NA28091

/s/ William T. Phelps

Phelps, William T., "Troy" 27 July 2010

WESTON - Site Manager

/s/ Betty J. Humphrey

Humphrey, Betty J.

WESTON - Project Manager

/s/ Eugene F. Richardson

Richardson, Eugene F., "Sonny"

WESTON - UXO Director
27 July 2010

Date 


\section{TABLE OF CONTENTS}

Section

Page

EXECUTIVE SUMMARY ES-1

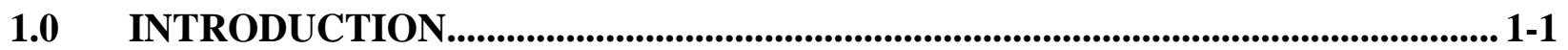

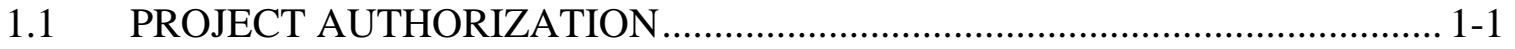

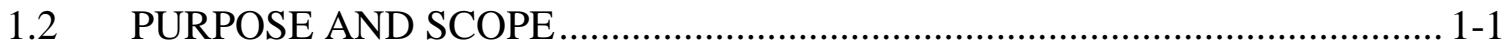

1.3 REPORT ORGANIZATION................................................................ 1-1

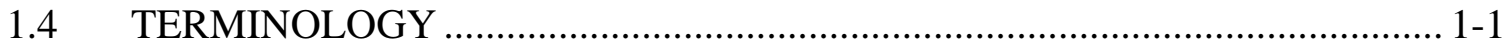

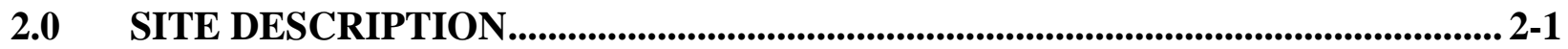

2.1 SITE LOCATION AND PHYSICAL SETTING ......................................... 2-1

2.2 SITE CHARACTERISTICS ...................................................................... 2-1

2.2.1 Corrective Action Unit (CAU) 408.................................................. 2-1

3.0 GEOPHYSICAL DETECTION TECHNIQUES .................................................. 3-1

3.1 CHRONOLOGY OF GEOPHYSICAL ACTIVITY AT TTR .......................... 3-1

3.2 GEOPHYSICAL INVESTIGATION ......................................................... 3-1

3.2.1 Disposal Pit Investigations.............................................................. 3-1

3.2.2 Target Area Surface Clearance ..................................................... 3-2

3.3 DATA PROCESSING ............................................................................ $3-3$

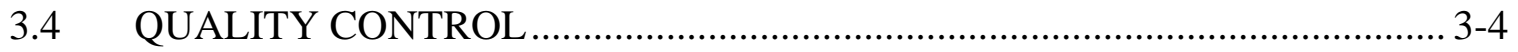

3.4.1 Surface Clearance QC Operations .................................................. 3-4

4.0 MEC REMOVAL ........................................................................................................ 4-1

4.1 SURFACE CLEARANCE PROCEDURES ............................................... 4-1

4.2 DEMOLITION PROCEDURES …....................................................... 4-2

4.3 MANAGEMENT OF SCRAP AND MUNITIONS DEBRIS........................... 4-2

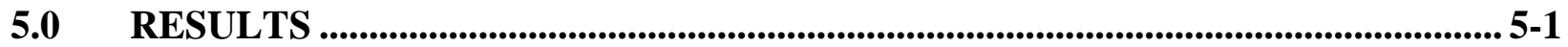

5.1 SUMMARY AND CONCLUSIONS ........................................................ 5-2

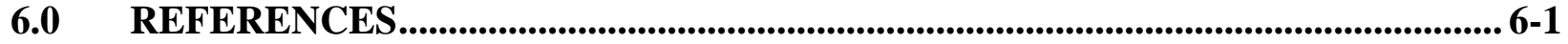

APPENDIX A MEC TERMINOLOGY AND MEC DATA SHEETS

APPENDIX B EXPLOSIVES ACCOUNTABILITY RECORDS 


\section{LIST OF FIGURES}

Figure

Page

Figure 2-1 TTR and CAU 408 - Site Location Map ................................................................. 2-2

Figure 2-2 CAU 408 Clearance Sites.................................................................................. 2-3

Figure 2-3 Disposal Pits - Grid Coverage and MEC Items ...................................................... 2-4

Figure 2-4 Tomahawk I - Grid Coverage and MEC Items ......................................................... 2-5

Figure 2-5 Tomahawk II - Grid Coverage and MEC Items ........................................................ 2-6

Figure 2-6 SAC 1 \& 2 - Grid Coverage and MEC Items............................................................... 2-7

Figure 2-7 South Antelope Lake - Grid Coverage and MEC Items ..........................................2-8

Figure 2-8 Flightline - Grid Coverage and MEC Items ............................................................. 2-9

Figure 2-9 Mid Target - Grid Coverage and MEC Items ....................................................... 2-10

Figure 2-10 Buffer Zone ............................................................................................. 2-12

\section{LIST OF TABLES}

Table

Page

Table 3-1 Chronology of Activities for MEC Clearance, TTR ………................................... 3-1

Table 5-1 MEC Summary Table............................................................................................... 5-1

\section{LIST OF PHOTOS}

Photo

Page

Photo 3-1 Technician Performing Sweep with Schonstedt............................................................ 3-2

Photo 3-2 Technician Performing Sweep with Schiebel ................................................................ 3-3 


\section{LIST OF ACRONYMS}

\begin{tabular}{|c|c|}
\hline AEDA & Ammunition, Explosives and Dangerous Articles \\
\hline bgs & below ground surface \\
\hline $\mathrm{BDU}$ & Bomblet Dummy Unit \\
\hline BIP & Blown-in-Place \\
\hline BLU & Bomb Live Unit \\
\hline CAS & Corrective Action Site \\
\hline CAU & Corrective Action Unit \\
\hline CBU & Cluster Bomb Unit \\
\hline CD & Cultural Debris \\
\hline DGM & digital geophysical mapping \\
\hline DMM & Discarded Military Munitions \\
\hline DOE & Department of Energy \\
\hline DQO & Data Quality Objectives \\
\hline DU & Depleted Uranium \\
\hline EMS & Emergency Medical Services \\
\hline EOD & Explosive Ordnance Disposal \\
\hline GIS & Geographic Information System \\
\hline GPO & geophysical prove-out \\
\hline GPS & Global Positioning System \\
\hline MD & Munitions Debris \\
\hline MDAS & material documented as safe \\
\hline MEC & Munitions and Explosives of Concern \\
\hline MPPEH & Material Potentially Presenting an Explosive Hazard \\
\hline MR & Munitions Responses \\
\hline NNES & Navarro Nevada Environmental Services \\
\hline NNSA & National Nuclear Safety Administration \\
\hline NTP & Notice to Proceed \\
\hline TTR & Tonopah Test Range \\
\hline PPE & Personal Protective Equipment \\
\hline QC & Quality Control \\
\hline RTK & Real-Time Kinematic \\
\hline SNJV & Stoller-Navarro Joint Venture \\
\hline SOP & Standard Operating Procedures \\
\hline SOW & scope of work \\
\hline SUXOS & Senior UXO Supervisor \\
\hline
\end{tabular}




$\begin{array}{ll}\text { TDY } & \text { Temporary Duty } \\ \text { TTR } & \text { Tonapah Test Range } \\ \text { USAF } & \text { United States Air Force } \\ \text { UTV } & \text { Utility Terrain Vehicle } \\ \text { UXO } & \text { unexploded ordnance } \\ \text { UXOSO/QC } & \text { UXO Safety Officer /Quality Control } \\ \text { WESTON } & \text { Weston Solutions, Inc. }\end{array}$




\section{EXECUTIVE SUMMARY}

Weston Solutions, Inc. $\left(\right.$ WESTON ${ }^{\circledR}$ ) performed a Munitions and Explosives of Concern (MEC) clearance action at selected portions of Corrective Action Unit (CAU) 408, Tonopah Test Range, NV, between 20 July 2009 and 15 May 2010. The CAU 408 effort was divided into two parts:

1. Investigating predetermined disposal pits

2. Target areas along Flightline Road.

The goal of the investigative digs were to prove the existence, or lack thereof, of MEC or Discarded Military Munitions (DMM) to depth. A final check was made with the same instrument with which the original anomalies were located. The work on the target areas was accomplished by one Team Leader and team members utilizing Schiebel instruments (all metals detector) to locate any sub-munitions and/ or unexploded ordnance (UXO). The Schiebel was the best instrument based on the prove-out grid (test strip) that included the worst case scenario of sub-munitions at one foot maximum depth (surface clearance).

\section{Disposal Pits}

Geophysical data was analyzed for the burial pits by both the client and WESTON to determine the areas most probable to contain DMM or MEC. Once determined, a UXO Team Leader and team would reacquire the location and begin an investigation with heavy equipment. Where areas were too contaminated to discriminate between soil and possible ordnance, the team employed a manual sifting method to separate soil from anything larger than one inch, as limited by spacing, on an expanded metal screen.

Of 25 disposal pits, four yielded a total of 13 MEC items and all pits produced several thousands of pounds of Cultural Debris (CD).

\section{Target Areas}

There were six target areas requiring remediation: Tomahawk I, Tomahawk II, SAC I \& II, South Antelope Lake, Flightline, and Mid Target:

- $\quad$ SAC I \& II Targets contained forty-five (45) 100m x 100m grids. The munitions debris (MD) was 617.5 pounds and there were 350 pounds of CD.

- Tomahawk I Target contained 4 grids yielding no MEC, 0.5 pounds of MD, and 0.5 pounds of CD.

- Tomahawk II Target contained 6 grids with no MEC, no MD and 0.5 pounds of CD.

- The western portion of South Antelope Lake Target was comprised of 154 grids and contained 5 MEC items, 3,335 pounds of MD, and 1,104.55 pounds of CD.

- $\quad$ Flightline Target contained 19 grids with 513 MEC items, 19.5 pounds of MD, and 38.5 pounds of CD. There were seventeen (17) 200 foot expansion grids added to Flightline, with two additional MEC found.

- Mid Target was comprised of 158 grids resulting in 1867 MEC items, 4,882 pounds of MD, and 130 pounds of CD. There were twenty-six (26) 200 foot expansion grids added to Mid Target when MEC was found close to the Target border, 90 additional MEC items were located. 


\section{Buffer Zone}

WESTON was additionally tasked to perform a visual sweep within a Buffer Zone that encompassed all target areas. WESTON, using Real-Time Kinematic Global Positioning System (RTK GPS), installed zone boundary stakes to demark that area. The "Buffer Zone" was, by direction, initially covered by "visual sweep". Of the three acres of Buffer Zone covered by WESTON, the team located thirty-five (35) M42 sub-munitions during the sweep. WESTON returned to the already swept Buffer Zone area and used the centers of sub-munitions piles as center points for a 200' radius around each until all were encompassed within a radius. The subsequent mag and dig effort located 34 more M42s.

The remaining acreage of the Buffer Zone was completed by others. 


\subsection{INTRODUCTION}

\subsection{PROJECT AUTHORIZATION}

Technical Services for Unexploded Ordnance (UXO)/Disposal Pit Investigation and Submunition Clearance, Tonopah Test Range, Corrective Action Unit (CAU) 408: Bomblet Target Area was originally awarded to Weston Solutions, Inc. $\left(\right.$ WESTON $\left.^{\circledR}\right)$ by Stoller-Navarro Joint Venture (SNJV) under SNJV Prime Contract DE-AC52-03NA99205 and subsequently Navarro Nevada Environmental Services (NNES) under NNES contract DE-AC52-09NA28091 with the United States Department of Energy (DOE), National Nuclear Security Administration (NNSA), Nevada Site Office.

\subsection{PURPOSE AND SCOPE}

The purpose of this Munitions and Explosives of Concern (MEC) Disposal Pit Investigation and Sub-munition Clearance Final Report for CAU 408 is to document the results of the MEC investigation services provided to NNES under the Task Order Scope of Work (SOW), dated May 2009. This Final MEC Clearance After Action Report identifies the work procedures, processes executed by WESTON and identifies the results related to identification, removal and destruction/ detonation of MEC items, including UXO.

\subsection{REPORT ORGANIZATION}

This Final MEC Clearance After Action Report summarizes the field activities and results of the geophysical surveys and MEC clearances activities conducted at CAU 408 sites covered under the MEC Clearance Work Plan and Task Order SOW. Section 1 presents an overview of the project requirements, organization and terminology. Section 2 presents the site background information. Section 3 of this report presents a discussion on the geophysical mapping and target selection and anomaly reacquisition processes used to identify and locate subsurface MEC items. Section 4 presents a discussion of the MEC recovery, demolition, and scrap management procedures. Section 5 presents the results of the MEC Clearance activities, including the type and number of recovered MEC items. Section 6 presents a summary and conclusions. The Appendices include: MEC Terminology and Recovered MEC Data Sheets; Geophysical Mapping Data (electronic files); Dig Sheet Database (electronic files); and, Explosives Accountability Records.

\subsection{TERMINOLOGY}

MEC terminology used throughout this report adheres to standard definitions established on 28 October 2003 by the Deputy Assistant Secretary of the Army for Installations and Environment. This memorandum provided standard definitions to be used in Munitions Responses (MR). The purpose was to ensure clarity and consistency in the use of terms for an MR. Discussions contained herein will adhere to the terminology as set forth in the memorandum (U.S. Army, 2003). While most of the terminology in the memorandum is well established, several terms are a departure from the traditional terminology. Specific terminology used throughout this report is defined in Appendix A. 


\subsection{SITE DESCRIPTION}

\subsection{SITE LOCATION AND PHYSICAL SETTING}

CAU 408 is located at the Tonopah Test Range (TTR), Nevada. The TTR is approximately 235 miles (mi) northwest of Las Vegas, Nevada. CAU 408 includes several areas where bomblet drops were conducted from the late 1960s to 1985 as part of testing and development programs for improved sub-munition dispersion coverage and cluster bomb unit (CBU) accuracy. Submunitions consist of various types of small spherical and cylindrical ordnance that range in size from two to four inches. A sub-munition bomblet is defined as an intact ordnance item that was dispersed from a CBU. After release from the aircraft, the CBUs would open and disperse the bomblets over the target areas. The bomblets used were mainly inert; however, several live tests (containing high explosives) were also conducted (see Figure 2-1).

The site has level to rolling topography, and supports limited growth of low vegetation due to the arid climate. The weather at the TTR is generally cool to mild and arid in the winter months and hot and arid in the summer months. Winter months average daytime highs are approximately 55 to 60 degrees Fahrenheit, while summer months have average daytime high temperatures approximately 95 to 100 degrees Fahrenheit. Rainfall is limited to approximately six (6) inches per year, with January being the wettest month, with an average precipitation of approximately one (1) inch.

\subsection{SITE CHARACTERISTICS}

The following is a brief description of this site.

\subsubsection{Corrective Action Unit (CAU) 408}

The majority of TTR, including NEDS Lake, Brownes Lake, Pedro Lake, and Antelope Lake, is located in Cactus Flat. Cactus Flat is an intermontane basin, typical of the Basin and Range Physiographic Province, surrounded by the Cactus Range to the southwest, the northern portion of Kawich Range to the east and to the north. Cactus Flat is made up of Quaternary-aged alluvium eroded from the surrounding volcanic highlands. The alluvium can be divided into local landslide and talus, fan alluvium, valley-filled alluvium, and lake and shoreline deposits; each division differs in grain size, locality, and/or degree of compaction and cementation (United States Geological Survey, 1971).

CAU 408, Bomblet Target Areas, includes one Corrective Action Site (CAS, TA-55-002-TAB2) consisting of seven identified target areas which required further investigation (see Figure 2-2). 


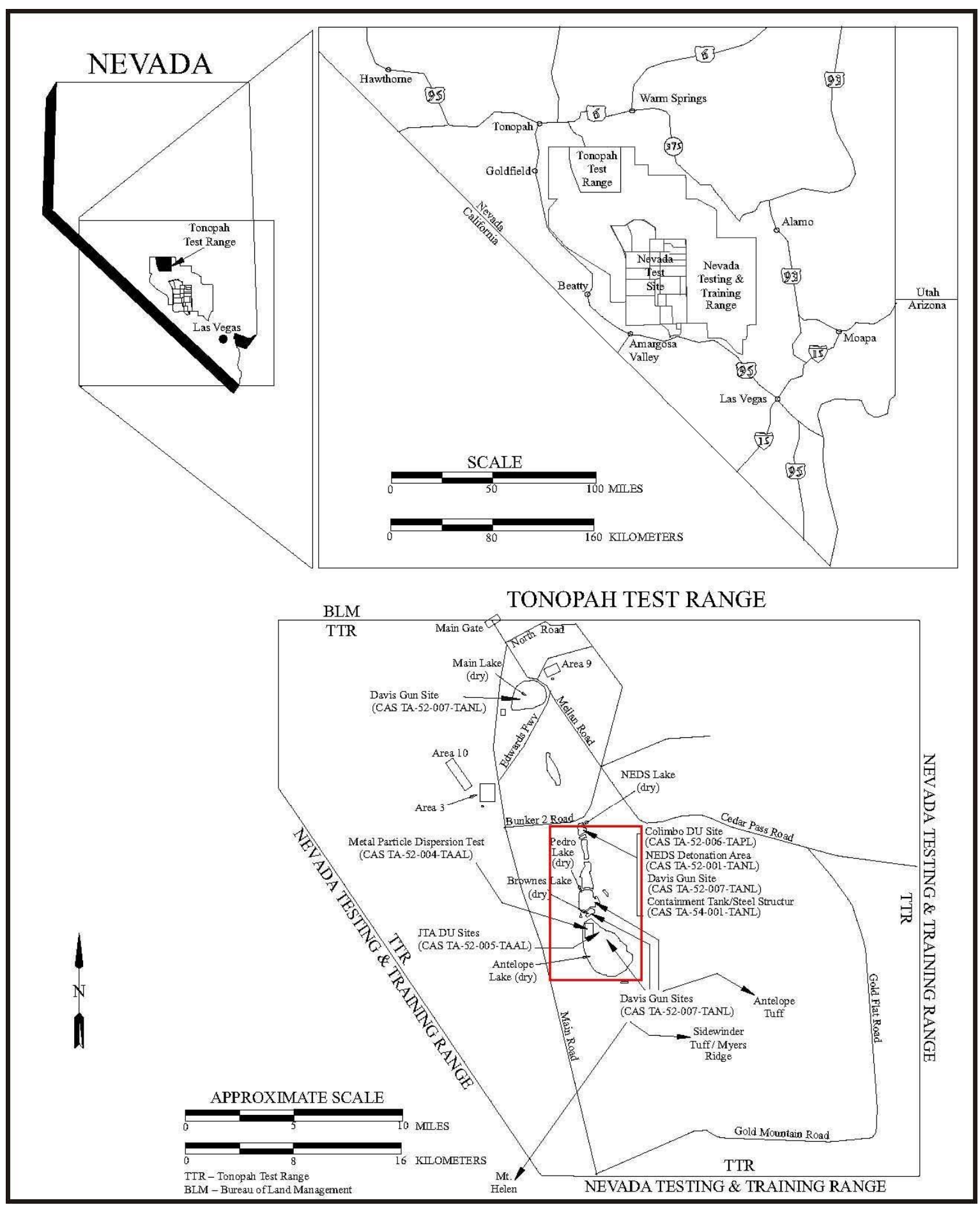

Figure 2-1 TTR and CAU 408 - Site Location Map 


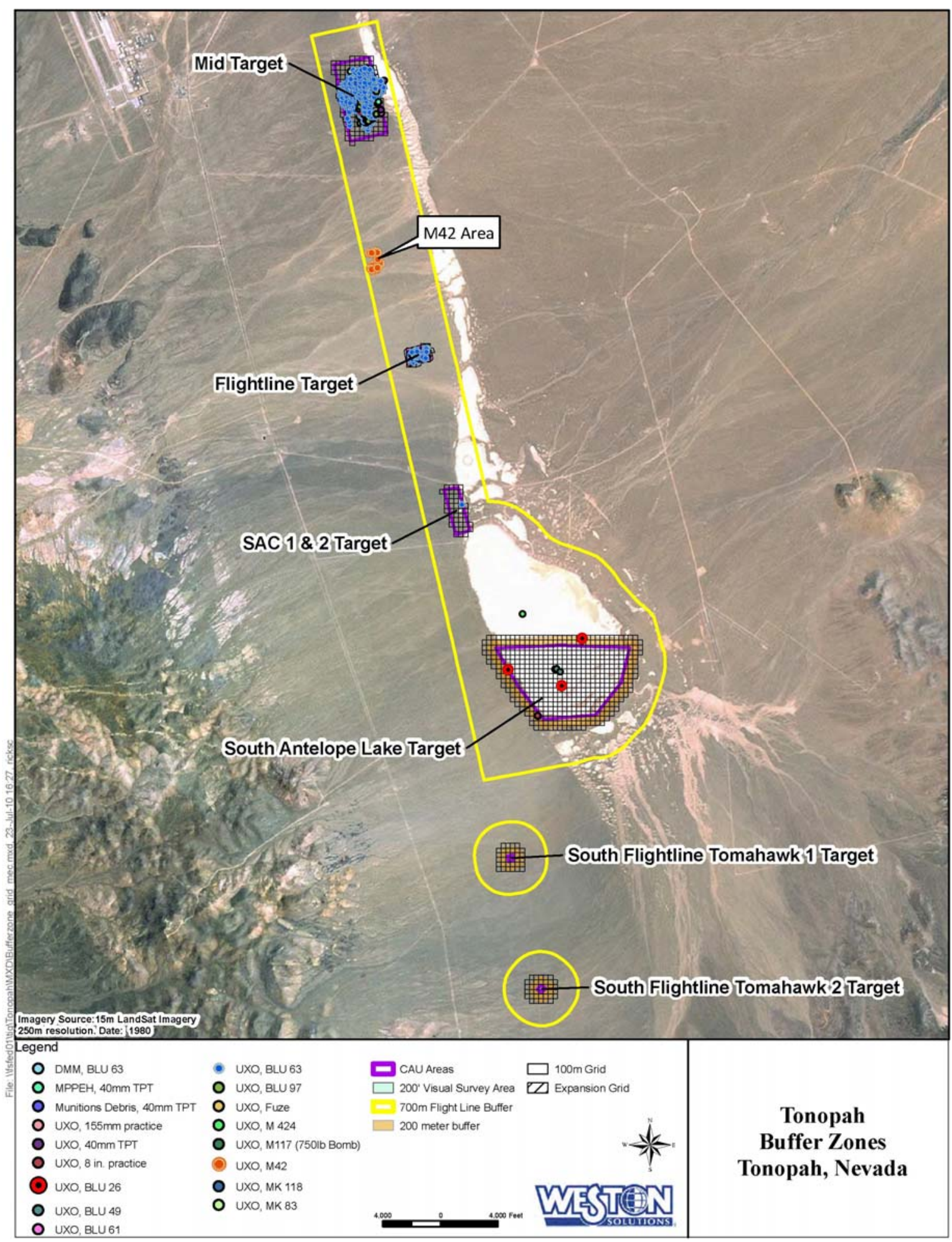

Figure 2-2 CAU 408 Clearance Sites 
The following are descriptions of each CAU 408 site assigned to WESTON:

\subsubsection{Disposal Pit areas}

Burial pits containing munitions debris (MD) from the target areas were located in the target areas (see Figure 2-3).

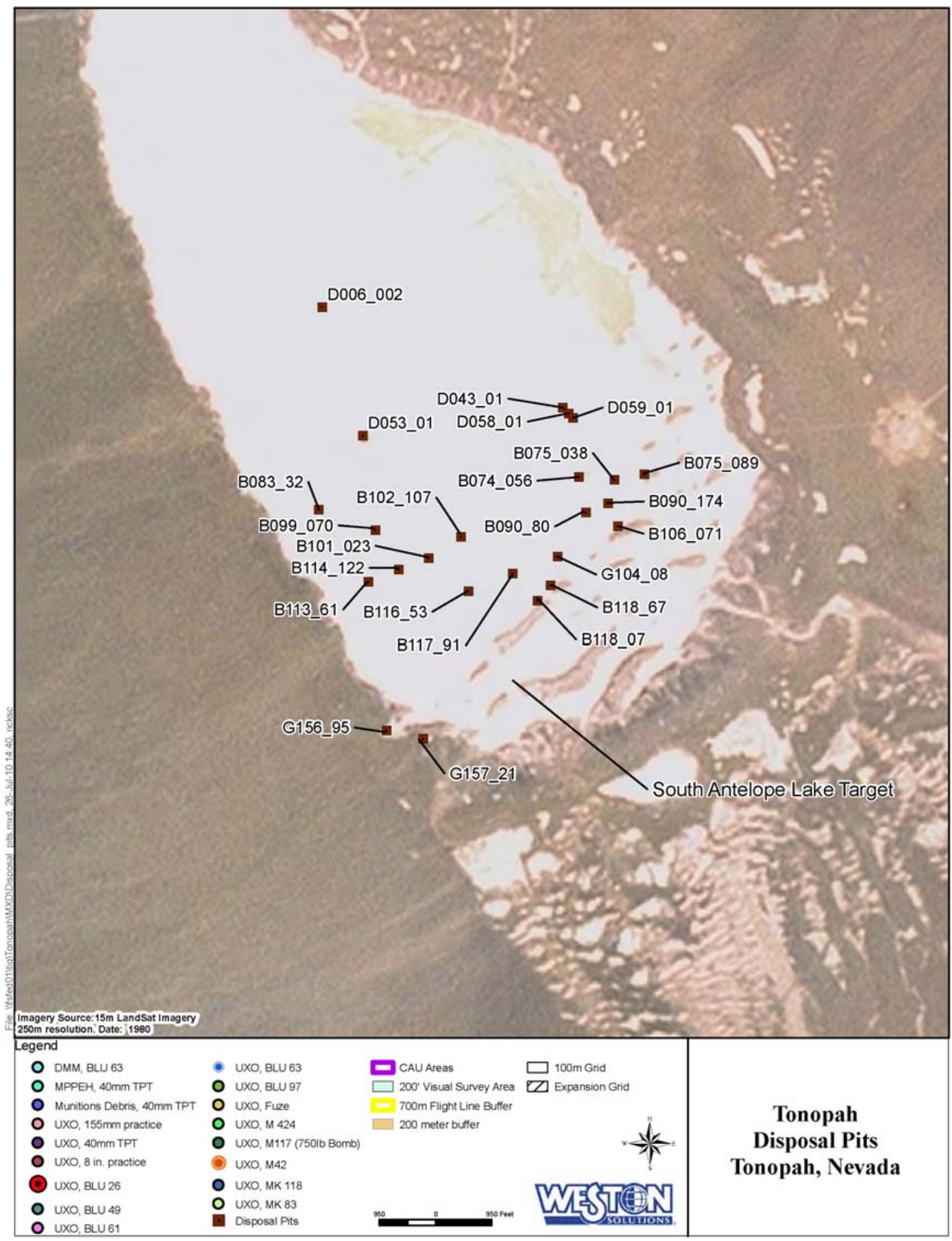

Figure 2-3 Disposal Pits - Grid Coverage and MEC Items 


\subsubsection{Tomahawk I and Tomahawk II}

The South Flightline Tomahawk Target Areas consist of two locations where sub-munitions were deployed from Tomahawk cruise missiles from 1983 to 1985 (see Figures 2-4 and 2-5).

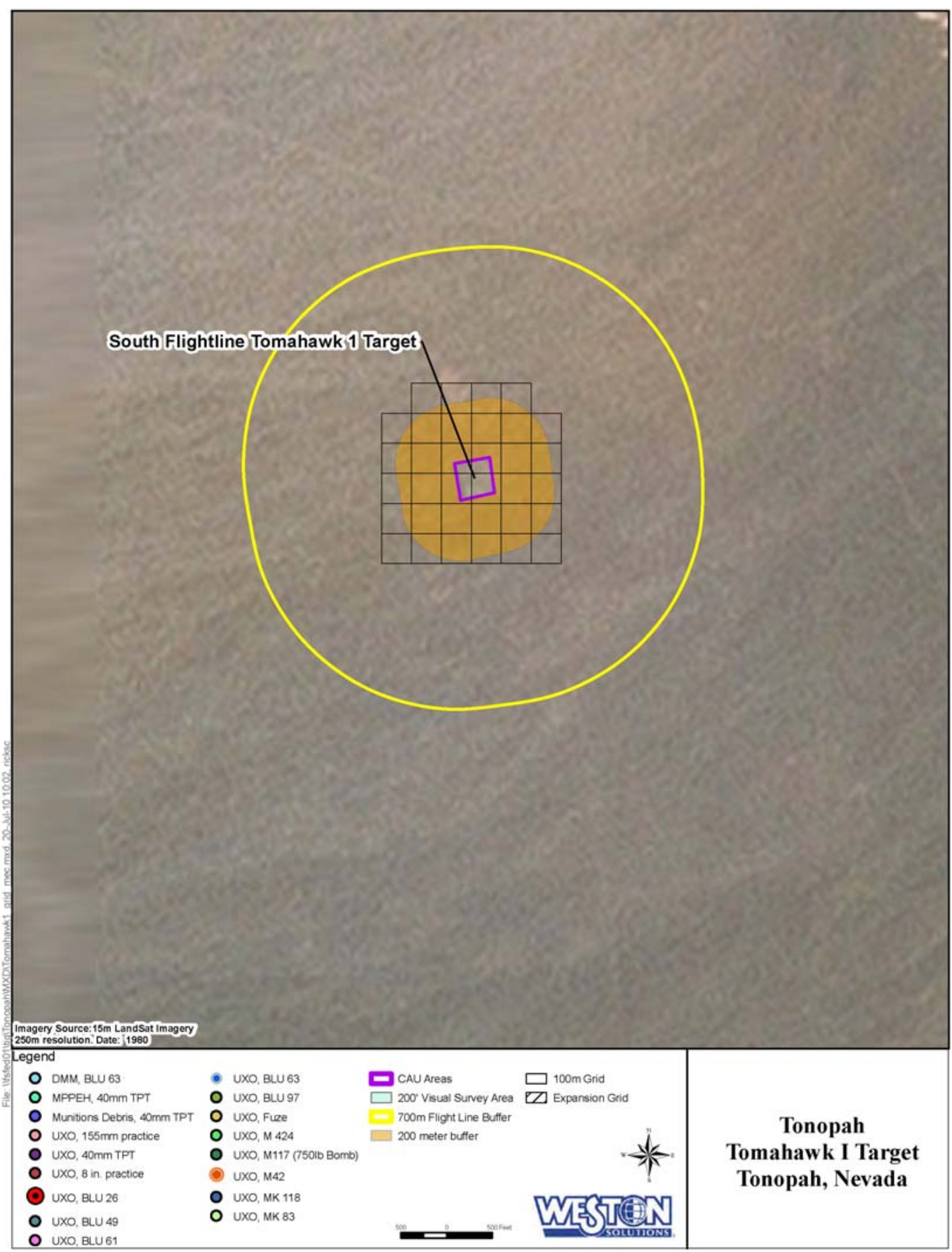

Figure 2-4 Tomahawk I - Grid Coverage and MEC Items

Based upon visual inspections, personnel interviews, and research of United States Air Force (USAF) documents, the initial boundaries for the South Flightline Tomahawk locations encompassed an area of approximately eight acres. Each target location is approximately four acres in size (NNSA, 2009). 


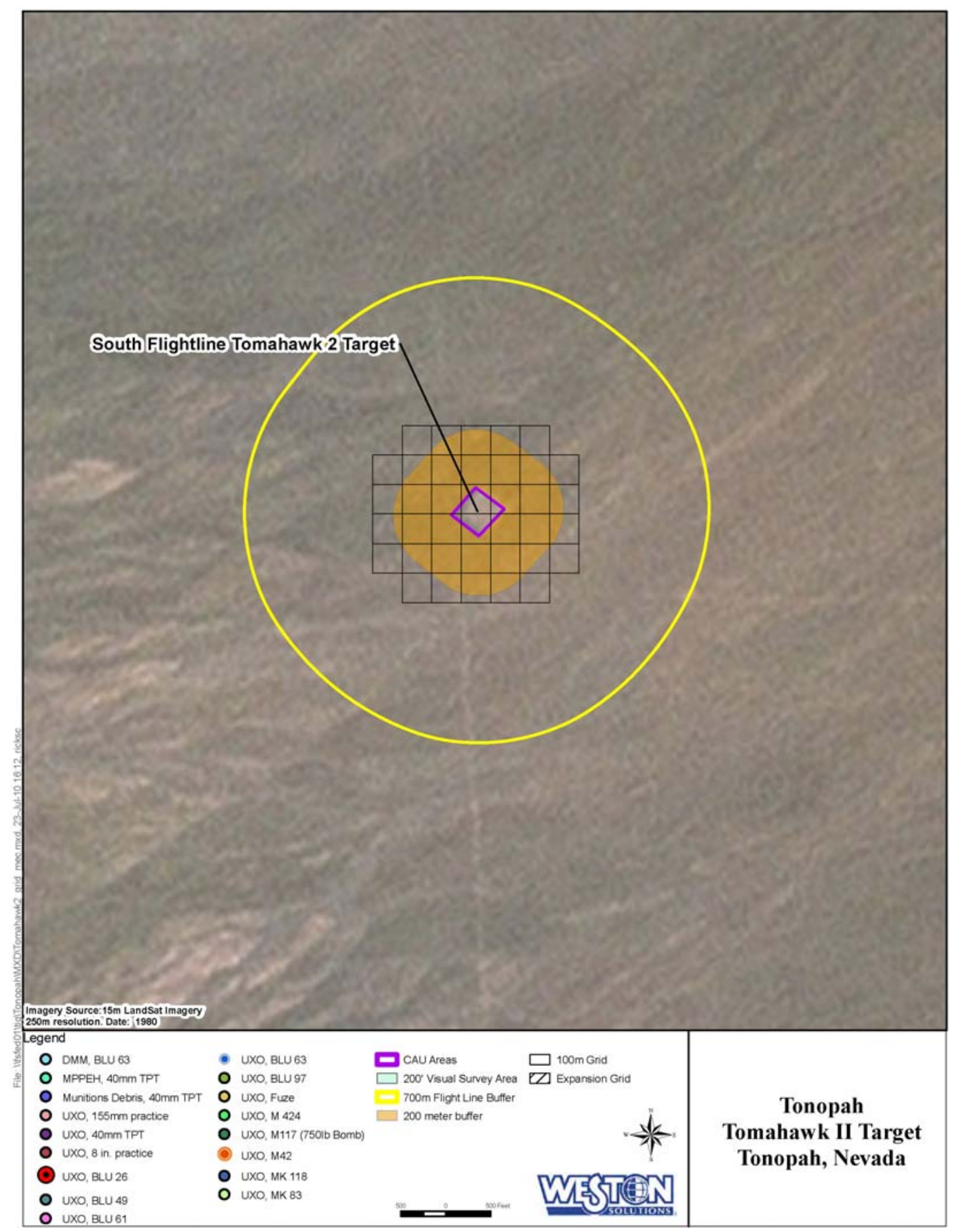

Figure 2-5 Tomahawk II - Grid Coverage and MEC Items

Tomahawk 1 Visual sweep efforts began 17 December 2009 with emplacement of 21 boundary stakes using Navarro Nevada Environmental Services (RTK GPS). A sweep was conducted at 30 $\mathrm{ft}$ separation over the entire area. During the visual sweep, spacing was maintained to ensure adequate coverage and effort efficiency. Coverage was marked by the team leader to ensure completeness. This target was completed on the same date started. No MD, Cultural Debris (CD) or MEC was recovered. 


\subsubsection{SACI\& II}

The SAC Targets are two of several locations at TTR where cruise-missile-dispensed bomblets were tested.

The SAC Target 1 consists of an area of disturbed ground as well as a subsurface geophysical anomaly, possibly indicating an area of buried debris. The SAC Target 2 contains an unknown prototype bomblet or dispensing mechanism on the ground surface. Based upon visual inspections, personnel interviews, and research of USAF documents, the boundary for the SAC Target locations encompassed an area of approximately 72 acres (see Figure 2-6).

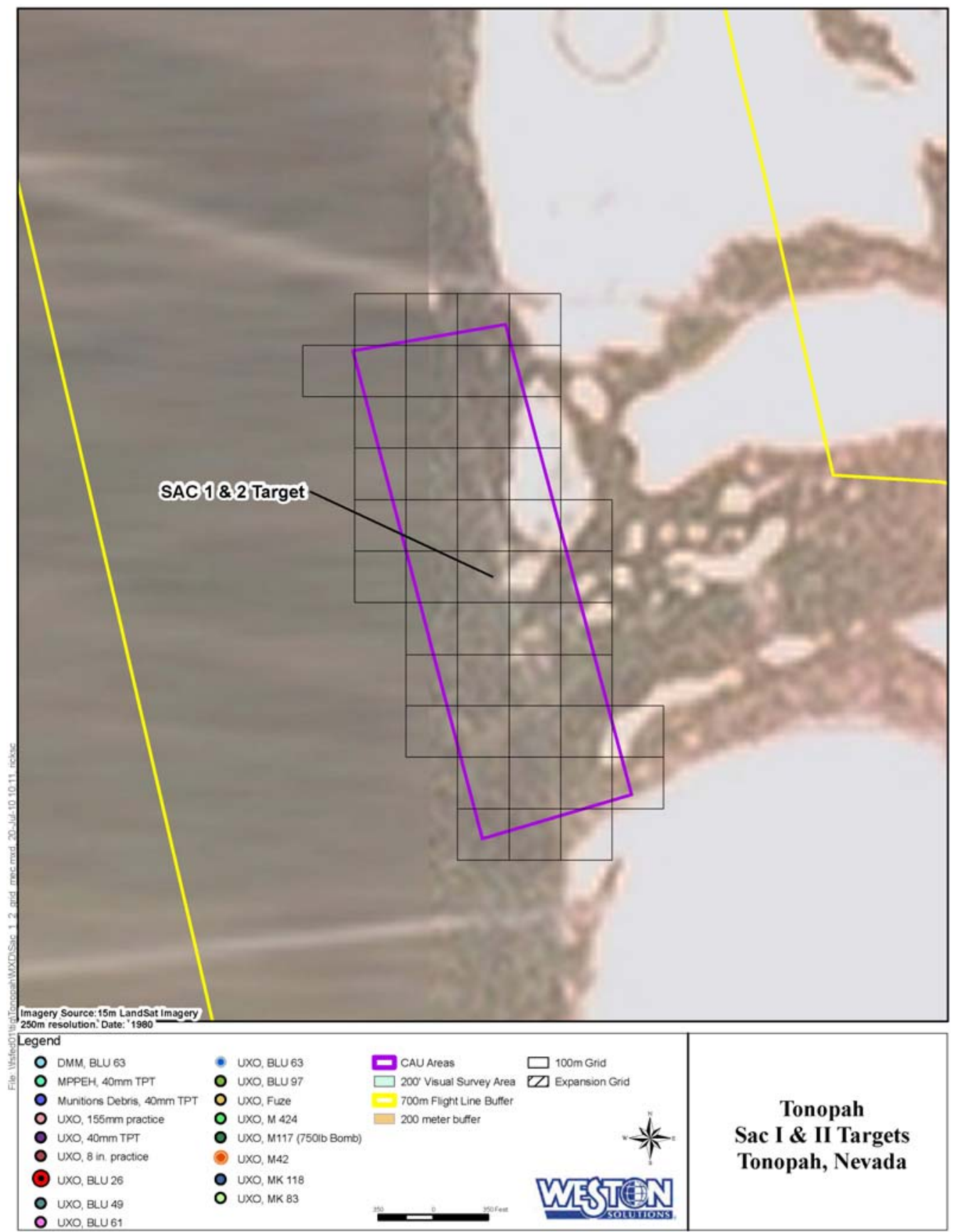

Figure 2-6 SAC 1 \& 2 - Grid Coverage and MEC Items 
Historical documentation regarding the sub-munitions used at these target areas is limited; it is assumed that the bomblets at these two locations are similar in properties to bomblets at the other Target Areas (NNSA, 2009).

\subsubsection{South Antelope Lake}

South Antelope Lake was the identified location of numerous tests involving Bomb Live Unit (BLU)-26, BLU-49, BLU-63, BLU-97, MK-118, and prototype munitions/sub-munitions. At least one of the tests involved full-scale live bomblet tests on test vehicles. A prototype munition containing depleted uranium (DU) bomblets was also tested on South Antelope Lake; however, the exact location of the test is unknown. Bomblets referred to as Bomblet Dummy Unit (BDU) 63s and bomblets resembling the BLU-59 were dropped over the mid-lake and the southern portion of Antelope Lake. Buried ordnance debris may also be present on or around the lake as indicated by the geophysical data (see Figure 2-7).

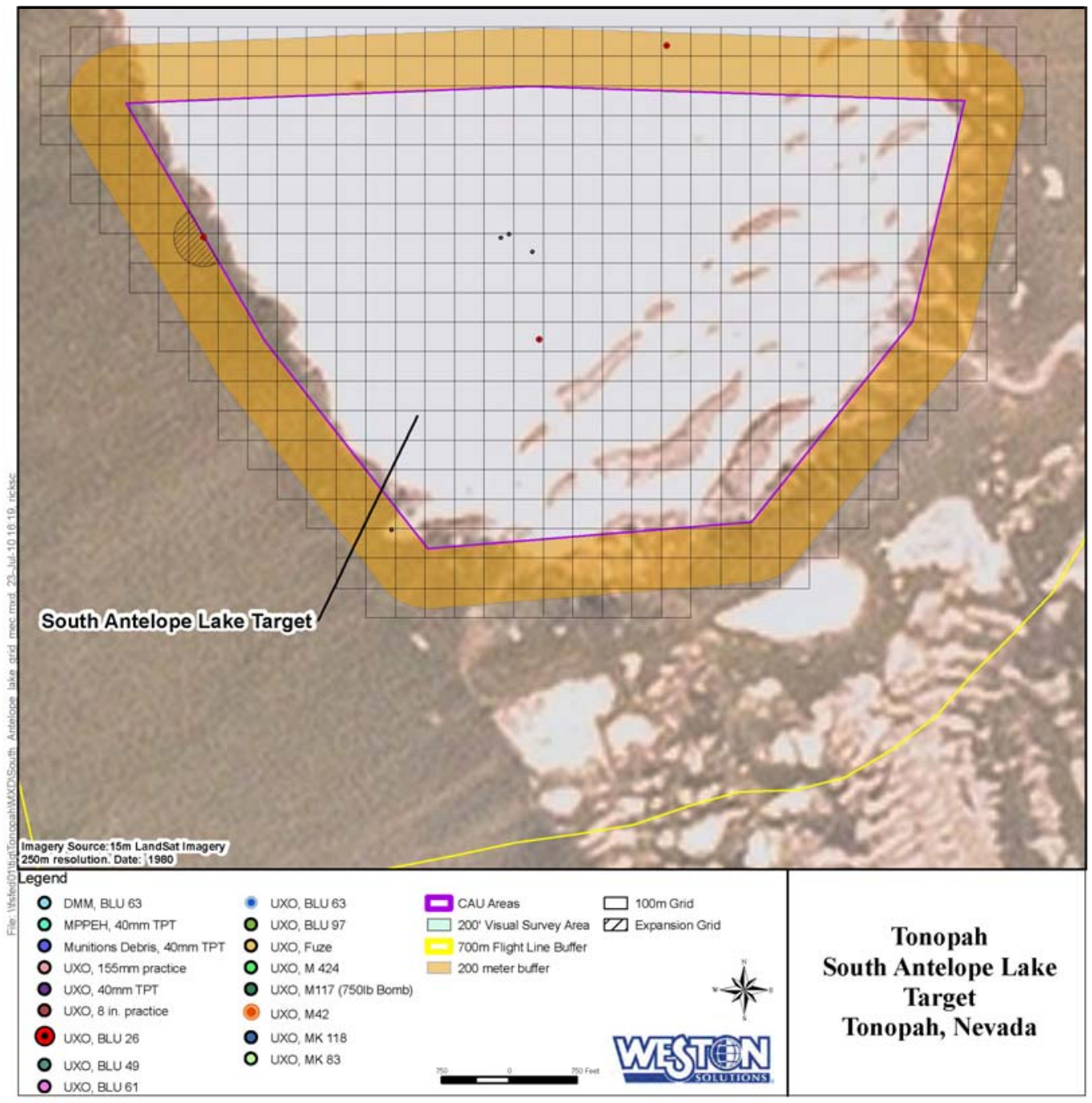

Figure 2-7 South Antelope Lake - Grid Coverage and MEC Items

Based upon visual inspections, personnel interviews, and research of USAF documents, the boundary for the South Antelope Lake Target location encompasses an area of approximately 877 acres (NNSA, 2009) 


\subsubsection{Flightline}

The Flightline Bomblet Location is located on the flightline between NEDS Lake and Pedro Lake, and contains BLU-63 bomblets. Some previous cleanup was evident from field observations (i.e., piles of bomblets). This target was identified during a UXO evaluation of the flightline (see Figure 2-8).

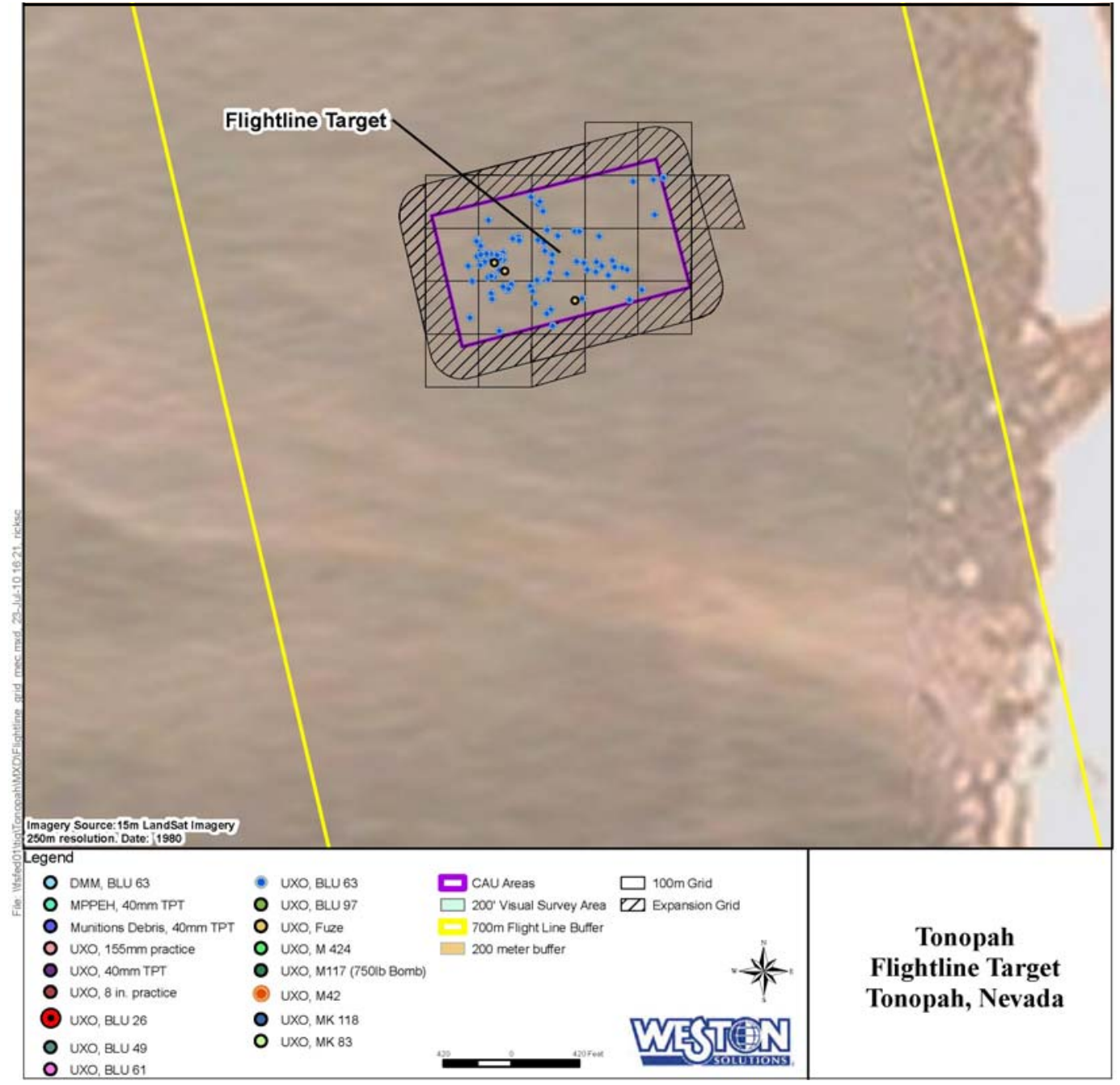

Figure 2-8 Flightline - Grid Coverage and MEC Items

WESTON began Flightline expansion grids on 7 May 2010. The Team measured $200 \mathrm{ft}$ beyond the existing target boundary line and established grid corners with stakes. The Team then began normal mag and dig procedures by lining up at the north boundary and setting adequate instrument overlap. They proceeded at a comfortable pace for the instrument efficiency. The Team Leader followed and visibly marked the team's area of coverage. If a grid was completed with no MEC found, WESTON did not expand coverage from that grid. However, if MEC was found, then the team would extend coverage out another grid and repeat the process until a grid was completed with no discovered MEC.

Field evaluation suggested a single drop of two CBUs at this location. Based upon visual inspections, personnel interviews, and research of USAF documents, the boundary for the Flightline Bomblet Target location encompassed an area of approximately 28 acres. The area of 
the Flightline Bomblet Location was expanded as defined in Revision 0 of the CAU 408 SAFER Plan beyond the observed piles of bomblets due to uncertainties in the actual target location (NNSA, 2009).

\subsubsection{Mid Target}

Mid Target consisted of a 1,000 by 1,500-ft CBU grid and was the primary location of bomblet testing at TTR. Based upon visual inspections, personnel interviews, and research of USAF documents, the boundary for Mid Target encompassed an area of approximately 320 acres (see Figure 2-9).

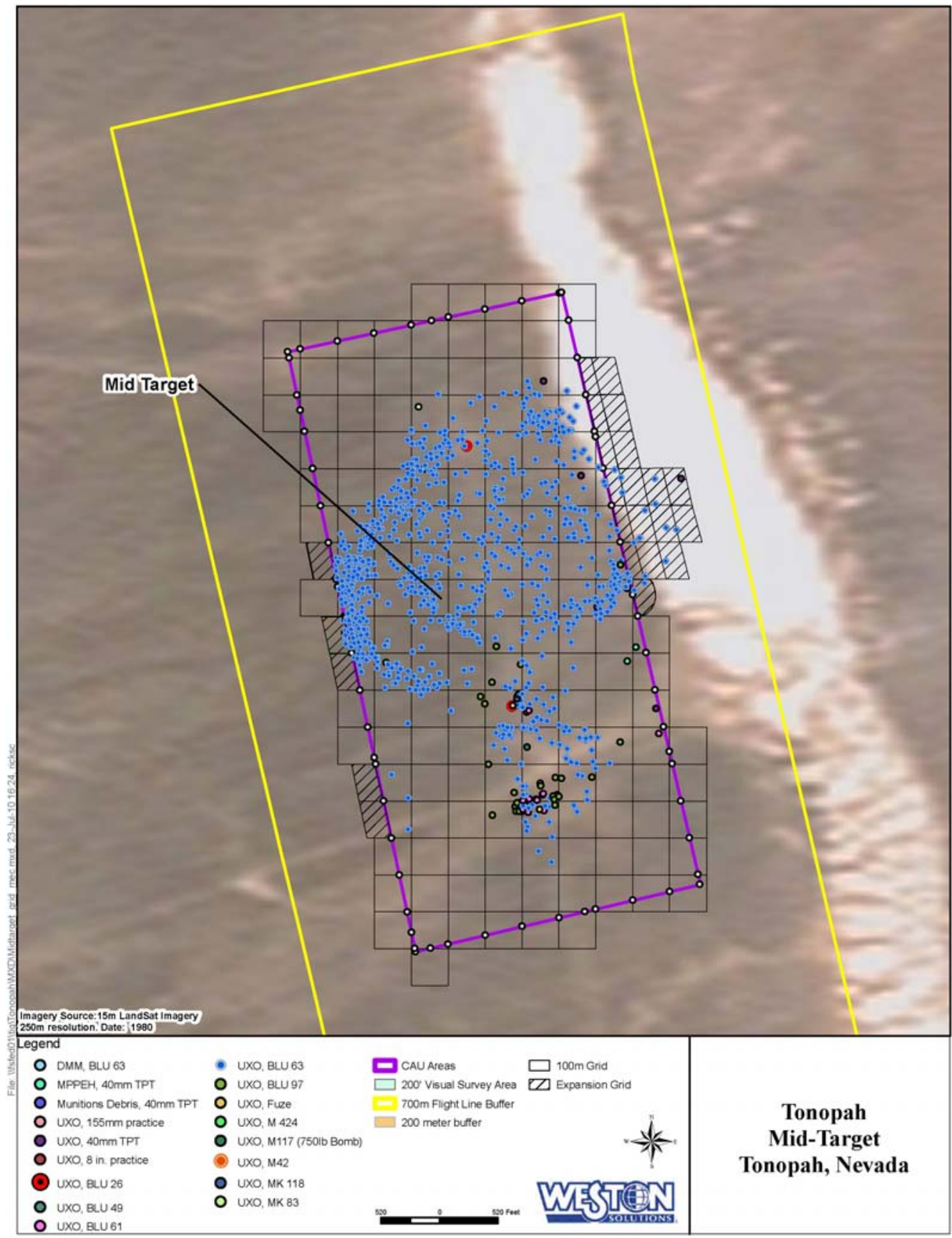

Figure 2-9 Mid Target - Grid Coverage and MEC Items 
WESTON began Mid Target expansion grids on 4 May 2010. The team measured $200 \mathrm{ft}$ beyond the existing target boundary line and established grid corners with stakes. Team then began normal mag and dig procedures by lining up at the north boundary and setting adequate instrument overlap. They proceeded at a comfortable pace for the instrument efficiency. The team leader followed and visibly marked the team's area of coverage. If a grid was completed with no MEC found, WESTON did not expand coverage from that grid. However, if MEC was found, then the team would extend coverage out another grid and repeat the process until a grid was completed with no discovered MEC.

Known sub-munitions used at Mid Target include BLU-61, BLU-63, BLU-97, and MK-118. One live test is known to have been conducted at Mid Target involving a sub-munition containing fuel-air explosive device (BLU-72). A previous investigation included excavation and removal of a disposal pit located west of Mid Target (NNSA, 2009).

\subsubsection{Buffer Zone}

Between the remediation efforts of Flightline Target and Mid Target, WESTON was tasked with initiating a surface only "visual sweep" of a Buffer Zone surrounding all Target Areas. The team spent one work-week on this task and cleared 3.1 acres before moving on to Mid Target. During the visual sweep the team utilized utility terrain vehicles (UTVs), separated by a modest distance to ensure the most efficient, yet best visual coverage possible. The team located thirty-five (35) M42 sub-munitions during the sweep. The MEC items were geo-referenced and flagged. The MEC items were subsequently blown-in-place (BIP). There was no MD or CD collected from this task (see Figure 2-10).

Upon completion of Mid Target, and Mid Target and Flightline expansion grids, WESTON returned to the already swept Buffer Zone area and conducted "surface clearance" within the union of all 200' radii based on centers of concentration of the sub-munitions. WESTON located 34 additional M42s and prepared them for demolition. 


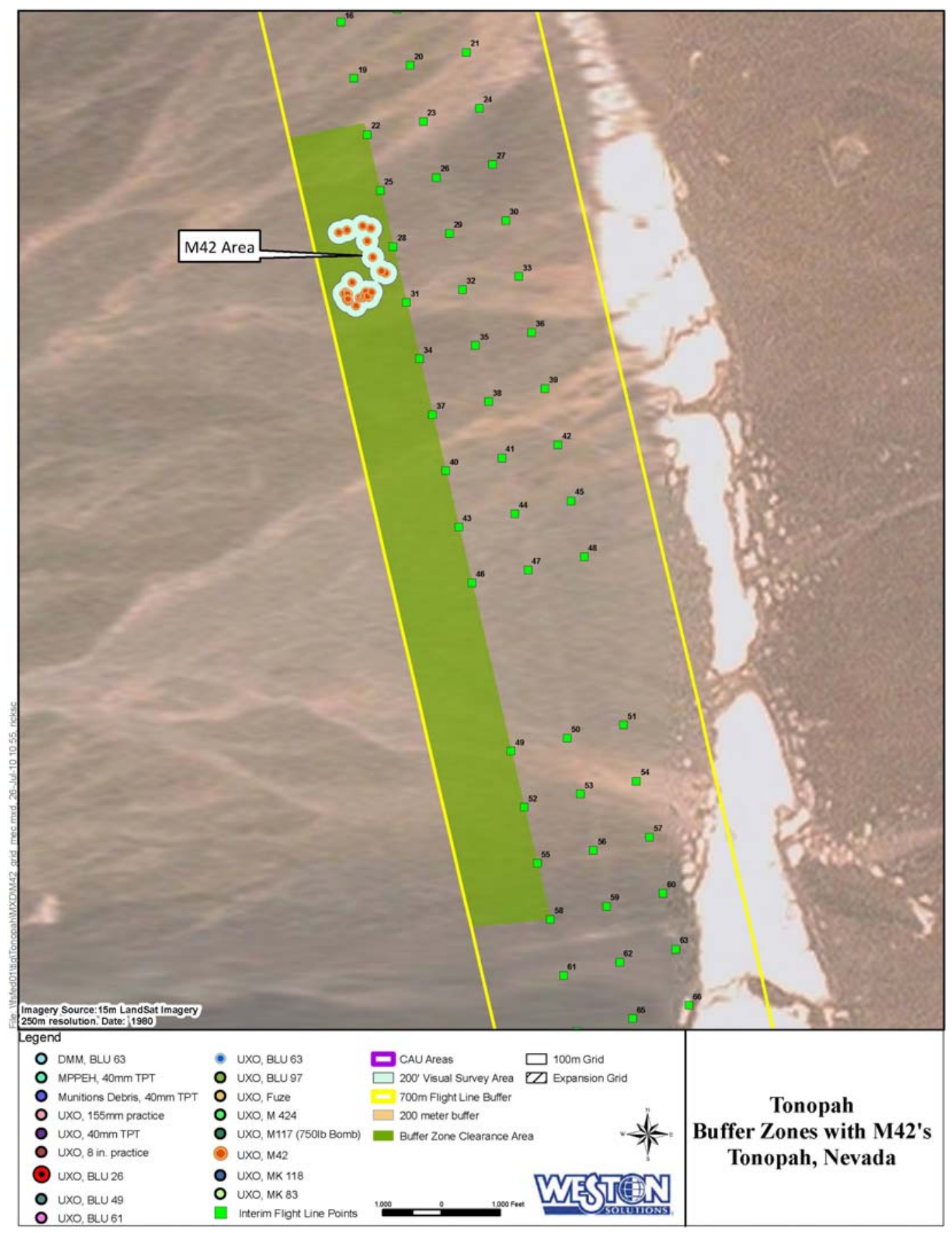

Figure 2-10 Buffer Zone 


\subsection{GEOPHYSICAL DETECTION TECHNIQUES}

\subsection{CHRONOLOGY OF GEOPHYSICAL ACTIVITY AT TTR}

WESTON performed geophysical surveys to identify the locations of anomalies that may represent MEC items, including UXO, Material Potentially Presenting an Explosive Hazard (MPPEH), DMM and MD, in support of the clearance activities at the CAU 408 sites. A chronology of activities performed at TTR is provided in Table 3-1.

Table 3-1 Chronology of Activities for MEC Clearance, TTR

\begin{tabular}{|l|c|c|l|}
\hline \multicolumn{1}{|c|}{ Action } & Dates & Location & \multicolumn{1}{c|}{ Comments } \\
\hline Mobilization & 20JUL09 & NNES, South Las Vegas & $\begin{array}{l}\text { Pre-Field Training - RAD Worker II, } \\
\text { Security Briefings }\end{array}$ \\
\hline GPO & 27JUL09 & TTR Area 3 & $\begin{array}{l}\text { Geophysical Prove-out - Background } \\
\text { and Seeded Grid Survey }\end{array}$ \\
\hline Burial Pits & $\begin{array}{c}\text { 27JUL09 - } \\
\text { 22NOV09 }\end{array}$ & Antelope Lake, TTR & $\begin{array}{l}\text { Investigation to extinction, MEC } \\
\text { disposal, MD and scrap stockpile }\end{array}$ \\
\hline SAC I\&II Targets & $\begin{array}{c}\text { 02NOV09- } \\
\text { 12NOV09 }\end{array}$ & West of Flightline Road & Surface sweep, 45 grids (100m x 100m) \\
\hline Tomahawk I Target & 13NOV09 & West of Flightline Road & Surface sweep, 4 grids \\
\hline Tomahawk II Target & 13NOV09 & West of Flightline Road & Surface sweep, 6 grids \\
\hline South Antelope Lake & $\begin{array}{c}\text { 16NOV09- } \\
\text { Target }\end{array}$ & Antelope Lake & Surface sweep, 154 grids \\
\hline Flightline Target & $\begin{array}{c}\text { 26JAN10 - } \\
\text { 29JAN10 }\end{array}$ & West of Flightline Road & $\begin{array}{l}\text { Surface sweep, 19 grids plus expansion } \\
\text { grids }\end{array}$ \\
\hline Mid Target & $\begin{array}{c}\text { 08FEB10 - } \\
\text { 03MAY10 }\end{array}$ & West of Flightline Road & $\begin{array}{l}\text { Surface sweep, 158 grids plus expansion } \\
\text { grids }\end{array}$ \\
\hline Demobilization & 16MAY10 & & \\
\hline
\end{tabular}

\subsection{GEOPHYSICAL INVESTIGATION}

\subsubsection{Disposal Pit Investigations}

Geophysical data was analyzed for the burial pits by both the client and WESTON to determine areas most probable to contain DMM or MEC. Zapata Incorporated had previously identified several anomalies that they interpreted as potential pits. The centers of these anomalies were provided in a report. The WESTON geophysicist used this data and the position of the "pit like" anomalies to create grid maps. A WESTON developed script was used to extract a 40x40 meter grid centered on each potential pit location. If there was a feature that looked like a potential pit, it was delineated with (polygon) waypoints for reacquisition and investigation. If there was no feature that could be defined as a potential pit, the geophysicist selected a variety of individual point source anomalies to investigate.

The reacquisition teams used an EM61-MK2 to help delineate pit boundaries on the ground. Once determined, the UXO Team Leader and team began investigation with heavy equipment. When areas were too contaminated to easily discriminate between soil and possible ordnance, the 
team would employ a manual sifting method that would separate soil from anything larger than one inch, as limited by the spacing of the expanded metal screen. The screened soil was further subjected to investigation using a Schonstedt GA-52C.

\subsubsection{Disposal Pit Instrumentation}

\section{Reacquisition}

WESTON used a Geonics, Ltd. EM61-MK2 ${ }^{\mathrm{TM}}$ instrument to assist with delineation of disposal pits. The EM61-MK2 ${ }^{\mathrm{TM}}$ high-sensitivity metal detector uses electromagnetic induction technology to detect both ferrous and non-ferrous metals. The system generates a pulsed magnetic field that induces eddy currents in conductive objects within the subsurface. These currents are proportional to the conductive nature of the material below the instrument. When a conductive object is located below the instrument, the amplitude and decay time of the induced eddy currents vary in response to the size, mass, depth and orientation of the object. Using the amplitude and duration of response of the object with respect to different time gates, the relative size and depth of the object can be estimated. The EM61-MK2 ${ }^{\mathrm{TM}}$ utilized four time gates which recorded at 261, 376, 527, and $727 \mu$ sec (microsecond) after initial termination of the signal. The effective detection depth for the EM61-MK2 ${ }^{\mathrm{TM}}$ towed-array is a function of target characteristic (i.e., composition, mass, and orientation) and local terrain noise.

\section{Screening}

Schonstedt handheld magnetometers were used for screening soil removed from the disposal pits. The Schonstedt GA-52Cx ordnance locator identifies magnetic field variations between two sensors spaced $20 \mathrm{~cm}$ apart. An audible signal is used to identify any variation in the magnetic field as the sensor is passed over or near a ferromagnetic source (see Photo 3-1). The volume and frequency of the signal changes as the sensor pinpoints the center of the source body. Similar to the Schiebel, the instrument sensitivity can be adjusted to increase or decrease detection capability of small metallic material.

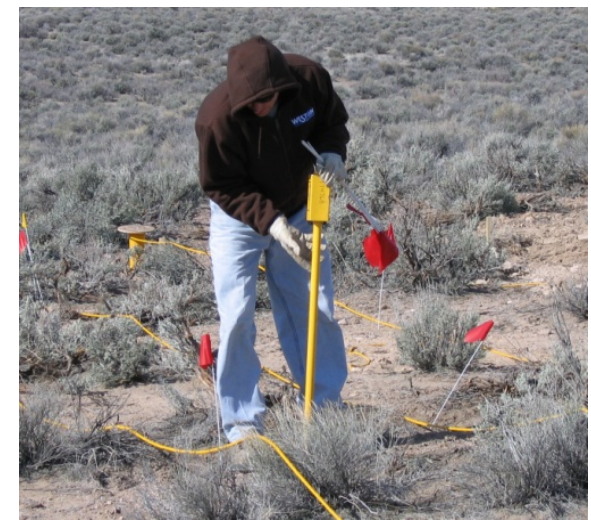

\section{Photo 3-1 Technician Performing Sweep with Schonstedt}

\subsubsection{Target Area Surface Clearance}

To mark surface clearance grids, the grid corner data was generated and then preloaded in the (Trimble) RTK GPS. WESTON utilized on site personnel to employ RTK GPS to navigate to and establish grid stakes for their assigned areas. 
To accomplish the clearance, team members lined up side by side and conducted a sweep ensuring there was adequate overlap. The Team Leader walked behind to supervise, ensure overlap and mark the area covered. The team swept the grid from North to South and then returned, starting the next lane over, in the opposite direction. They investigated any anomaly, and marked discovered ordnance with plastic pin flags for further investigation.

Most ordnance was found within the first few inches of the surface. On many occasions it was discovered that some of the piles were consolidation points that were never dealt with in the past, or a demolition shot that was never cleaned up or inspected after detonation. There was evidence of demolition shots on Flightline and Mid Target on both sub-munitions and some of the air dropped ordnance.

\subsubsection{Surface Clearance Instrumentation}

Schiebel Instruments (all metals detector) was used to locate any sub-munitions and/or UXO. The Schiebel was the best instrument based on the geophysical prove-out results. The geophysical prove-out (GPO) included the worst case scenario of sub-munitions at maximum depth of the surface clearance to one foot.

The Schiebel All-Metals instruments proved to be the most effective instruments for surface clearance investigations of the Target Areas. These instruments were also used for reacquisition of digital geophysical mapping (DGM) anomalies, and as screening and avoidance tools by MEC-qualified personnel.

The Schiebel AN-19/2 consists of a hand-held two-coil design, which utilized the electromagnetic method to detect both ferrous and non-ferrous metals. As the UXO Technician sweeps a lane (see Photo 3-2) an audible signal will sound when the sensors are swept over conductive material. The volume and frequency of the signal changes as the sensor pinpoints the center of the source body. The instrument sensitivity can be adjusted to increase or decrease detection capability of small metallic material.

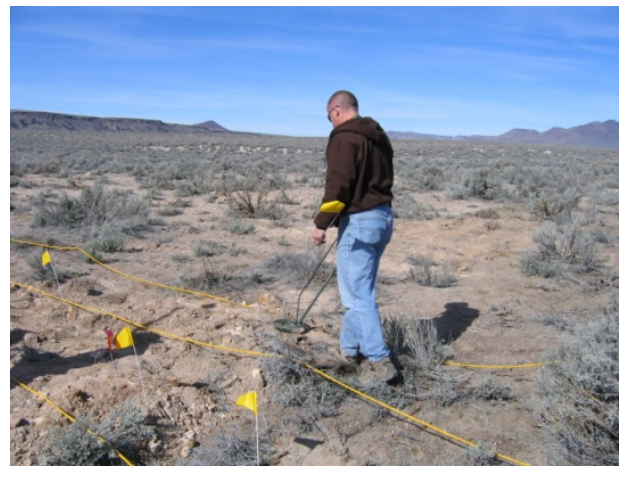

Photo 3-2 Technician Performing Sweep with Schiebel

\subsection{DATA PROCESSING}

WESTON generated several reports daily, all were shared with NNES. The Senior UXO Supervisor (SUXOS) reported on the team's daily progress and other issues that may have impacted the effort. The UXO Safety Officer (UXOSO) reported daily on his observation of the team working in a safe manner and wearing proper personal protective equipment (PPE). The 
Quality Control (QC) report included observations and noted the team's efficiency and included QC complete grids, outcome, seeded grids, and recovery of QC seeds. Team Leaders kept a daily hand written log noting start and finish time as well as grid completion status and quantity and disposition of MD, CD, and MEC found.

The SUXOS contributed to a spreadsheet generated by NNES that listed grid start/ completion dates, MD and CD weights, MEC items per grid, QC date and seeds planted and recovered.

\subsection{QUALITY CONTROL}

Quality Control was performed on two levels including;

- QC (by others) intrinsic to the DGM process; to ensure that all aspects of field data acquisition, data processing and analyses were consistent with the Data Quality Objectives (DQO) metrics.

- QC on the surface clearance anomaly removal operations to confirm that MEC items had been located and removed to the specified clearance depth of one foot.

\subsubsection{Surface Clearance QC Operations}

The following section details WESTON's Team QC Operations for this Task Order, including roles and responsibilities that were performed for surface clearance field work and documentation.

\subsubsection{Field Supervision Responsibilities}

The WESTON SUXOS was the senior subject matter expert for MEC issues in the field during the execution of WESTON's Task Order. The SUXOS had stop work authority, as well as responsibility to:

- Planning, coordinating, and supervising all on-site MEC and MEC- related activities.

- Implementing standard operating procedures (SOPs) for MEC operations (ensuring compliance with NNES and DOE NTS directives and federal, state, and local statutes and codes).

- Certifying Ammunition, Explosives, and Dangerous Articles (AEDA) and/ or range scrap was ready for turn-in, disposal, or recycling.

- Maintaining administrative records of the project.

- Supervising multiple project teams performing MEC clearance and MEC-related activities.

The UXOSO/QC was on-site at all times during MEC-related work. The UXOSO/QC reported directly to the WESTON Corporate Safety \& Health Manager, and indirectly to the WESTON Project Manager. He was responsible for coordinating and supervising all site quality and safety activities, which include but are not limited to supervision of WESTON subcontractor personnel, and submission of daily reports, QC data, and any subcontractor reports. The UXOSO/QC had stop work authority. The UXOSO/QC's responsibilities included: 
- Implementing the approved MEC safety program in compliance with all federal, state, and local regulations;

- Analyzing MEC and explosives operational risks, hazards, and safety requirements.

- Enforcing personnel limits and safety exclusion zones for MEC clearance operations.

- Overseeing MEC and explosives transportation, storage, and destruction.

- Conducting safety inspections to ensure compliance with MEC safety codes.

- Implementing the QC Program for this project.

- Performing QC of initial geophysical surveys.

- Directing and approving corrective actions to ensure that work complies with contractual requirements.

- Performing other quality-related duties, as required.

\subsubsection{Daily Magnetometer Calibration}

Prior to starting work each day, a calibration was conducted on all hand held detection instruments being used in the field for Surface Clearance operations. A simulated item the size of the smallest know ordnance items (BLU-26 and 40mm grenade) was placed at depths of one foot, six inches and on the surface and marked with a stake indicating the location of the calibration item. Each instrument was passed over to detect each of the items and under no circumstances was a defective magnetometer allowed to proceed to field use.

\subsubsection{Blind Seeding}

Blind seed items were placed at an interval of at least one seed per four grids within the Surface Clearance areas planned for investigation. The project UXOSO/QC, in consultation with the NNES Site Supervisor, determined the locations of the seed items.

The blind seed items were placed in the Surface Clearance/ Mag and Dig grids as a quality indicator. The UXOSO/QC and the NNES Site Supervisor employed bias when placing the seed items in selected removal grids, based upon professional experience. The location of the seed items were within specifications required by the SOW and were recorded in the QC log based on $\mathrm{X} / \mathrm{Y}$ position and Grid ID. The seed item location was revisited by the UXOSO/QC following surface clearance operations in each seeded grid to ensure the seed item was detected and removed by the UXO Teams.

\subsubsection{Grid Inspections}

Initially, the QC inspections performed by the UXOSO/QC required a surface sweep to a depth of one foot over $25 \%$ of each grid for heightened confidence. Upon satisfactorily acquiring $100 \%$ of the blind seeds (if planted) in four consecutive grids, and all MEC related items, the 25\% inspection was reduced to $10 \%$ of each grid.

If any number of blind seeds and/or MEC related items had not been detected by the sweep personnel, the grid was to be returned to the SUXOS for reinvestigation of the entire grid. Additionally, in such case, the grid inspection percentage was to be resumed at $25 \%$ as 
established in the initial confidence protocol and was not to be reduced until successful clearance of $100 \%$ of all seeds and MEC related items were successfully detected in four consecutive grids. This created a cyclical quality process. In the event that grids were continually being returned for rework, a Root Cause Analysis was to be performed to identify the cause for diminished quality and a Corrective Action was to be implemented to ensure all grids were cleared as determined by the SOW.

\subsubsection{QC Reporting}

Daily QC and weekly status reports were made available to the Project Team via the NNES Site Supervisor. These reports included daily and weekly work-related activities, in addition to progress reports and MEC statistics (including recovered items, MD cumulative weight, and QC status). 


\subsection{MEC REMOVAL}

During the Surface Clearance activities, all anomalies detected with the hand held Schiebel were investigated to a depth of one foot. If the anomaly was determined to be a potential MEC item it was be marked for disposal and recorded with a GPS coordinate for future entry into the Geographic Information System (GIS) data base.

During the Surface Clearance phase of this project, anomalies deeper than one foot were reported to the NNES Site Supervisor. The location was excavated over the entire anomaly to characterize if the anomaly represented an impact area, disposal pit, or burial pit. Once determined, NNES would decide if further action was required. The excavation was photographed, geo-referenced (RTK GPS), and then backfilled. All excavations were done with trained excavator operators and an OSHA 29 CFR 1926 Excavation and Trenching - Competent Person on site. Excavation resulted in NNES identifying six of the anomalies as disposal pits.

WESTON identified, cleared, and segregated MEC and metal debris within the seven sites. Identified items were excavated to a maximum depth of one foot below ground surface (bgs), and staged for disposal. In general, excavation was conducted by hand to depths of one foot bgs. Deeper excavations at the disposal pits required an excavator.

WESTON provided the necessary equipment and material to safely execute all activities; with the exception of the items and services provided by NNES and listed in the Subsection 3.2 of the Work Plan.

All excavated debris was segregated into appropriate categories (i.e., scrap and MD, MPPEH, and MEC) and staged separately for final disposal by NNES. Scrap material and MD was staged in an area identified by NNES, and certified by the WESTON SUXOS, UXOSO/QC, and the Team Leader as being MEC-free. MD was staged in a separate area and certified to be nonreactive before being handled. MPPEH and MEC were identified and a determination made as to whether the item could be safely moved to a detonation area or required to be BIP. WESTON was responsible for the destruction of recovered MPPEH and MEC items.

As discussed in Section 3, WESTON performed analog geophysical surveying (Surface Clearance) identifying the locations of anomalies that may represent MEC items in support of the clearance activities at the Target Area sites. Analog geophysical surveying was performed in accordance with industry standard practices. The geophysical survey performed during clearance activities included the following equipment:

- Schonstedt Ordnance Locator- utilizes passive vertical magnetic fluxgate gradiometer detection technology to identify ferrous materials (soil screening at the disposal pits).

- Schiebel All-Metals Ordnance Locator - utilizes digital electromagnetic pulse induction technology to identify both ferrous and non-ferrous metals (surface clearance in target areas).

\subsection{SURFACE CLEARANCE PROCEDURES}

Qualified UXO personnel performed surface removal and excavations so that identification procedures could be conducted. The UXO Team assessed all MEC-like ordnance items to determine their condition and potential hazards. MEC items were identified. The MEC item was 
visually examined for markings and other external features such as shape, size, and external fittings. If an unknown MEC item was encountered, the NNES Site Supervisor was to be notified immediately. No fuzed UXO was moved in an attempt to make a definitive identification. Fuzed MEC was detonated in the original position found (BIP).

Only UXO-qualified personnel handled MEC items, and only during daylight hours. UXO items were marked with a pin flag for subsequent demolition and disposal. Each UXO item had its condition and identification determined by qualified UXO personnel. All access, excavation and detonation holes were backfilled with local soils as directed by NNES Personnel.

\subsection{DEMOLITION PROCEDURES}

Demolition safety and operations were conducted in accordance with industry standard practices, the procedures outlined in Explosive Ordnance Disposal (EOD) publication 60A-1-1-31 and the appropriate specific 60 Series EOD publications. The designated demolition supervisor was responsible for all aspects of conducting demolition operations. The anomaly would be excavated until the entire hole was free from metal.

All recovered MEC items were detonated at the completion of each Target Area that had items to be destroyed. An electrical demolition system was used to allow positive control of the demolition activities. Non-electric firing systems were used on the remaining demolition shots because of the ease of set up for non-electric and distance for evacuation for the shot was further than effective range of firing device. The Fire Department, Wackenhut Security Group and Emergency Medical Services (EMS) personnel were present during all demolition operations to ensure the exclusion zone was secure and medical attention was readily available in case of an explosive accident. Based on the secure nature of the TTR, and the remote locations of the seven sites, recovered MEC-demolition operations took place at the end of the each target areas clearance. This one-time demolition operational practice allowed clearance activities to proceed in a safe, effective, and efficient manner; without the continuing interruptions of arranging for demolition materials to be delivered to the remote site(s). WESTON ordered explosives on two separate occasions and the delivery of the explosives was arranged through NNES support staff. The delivery of explosives onto the TTR, and to the magazine storage area, was coordinated through NNES project staff and the Sandia National Laboratories support personnel. Explosives delivery and transport on the TTR project site was conducted in accordance with DOE M440.1 Explosive Safety Manual. Explosive documentation records are provided in Appendix B.

The WESTON SUXOS, in consultation with the WESTON UXOSO/QC, determined if a recovered ordnance item was safe-to-move, or had to be left in-place for BIP operations. All safe-to-move MEC items were relocated to a consolidation point located on site. During the demolition operations all MPPEH items were explosively destroyed. Only the demolition team, SUXOS, and UXOSO/QC were permitted in the area where charges were being assembled and demolition operations were being conducted. Other non-demolition team UXO personnel left the demolition area and were staged outside the exclusion zone entry point.

\subsection{MANAGEMENT OF SCRAP AND MUNITIONS DEBRIS}

During the execution of this project, MD and scrap metal were recovered from CAU 408 sites and staged in piles adjacent to Flightline Road. No minimum size of scrap is specified for 
collection and segregation in the Task Order SOW. All recovered MPPEH items were visually inspected for the presence of explosive or other hazardous material and if cleared then it was classified as material documented as safe (MDAS). Additionally, the UXOSO/QC inspected the $\mathrm{MD}$ and scrap to verify the process and insure that only $\mathrm{CD}$ items were contained in the scrap pile. A final visual inspection was conducted on each recovered MD item immediately prior to release of the MD container to NNES. NNES managed the disposal of all recovered CD and MD.

Non-MEC scrap metal was collected, segregated, and staged at the location specified by NNES. The types, amounts and location of surface scrap was recorded and reported. The non-MEC subsurface scrap items recovered during anomaly investigations were removed from their location, catalogued, and consolidated with surface scrap metal. NNES assumed responsibility for the proper disposal of all recovered scrap and MD items. 


\subsection{RESULTS}

The results of the clearance operations on the seven CAU 408 sites are presented in this section. Table 5-1 shows a summary table of all MEC items found at each of the areas.

Table 5-1 MEC Summary Table

\begin{tabular}{|c|c|c|c|}
\hline Corrective Action Site & QTY of MEC & Description & Quantity \\
\hline \multirow{5}{*}{ Burial Pits } & \multirow{5}{*}{12} & 155 mm Projectile & 3 \\
\hline & & 8 in Projectile & 3 \\
\hline & & M424A1 spotting charge & 1 \\
\hline & & BLU 49 & 5 \\
\hline & & .50 cal bullet & 0 \\
\hline SAC I\&II Targets & 1 & .50 cal bullet & 1 \\
\hline Tomahawk I Target & 0 & & \\
\hline Tomahawk II Target & 0 & & \\
\hline \multirow{2}{*}{ South Antelope Lake Target } & \multirow{2}{*}{5} & BLU 49 & 2 \\
\hline & & BLU 26 & 3 \\
\hline Flightline Target & 513 & BLU 63 & 513 \\
\hline Flightline expanded grids & 2 & BLU 63 & 2 \\
\hline \multirow{8}{*}{ Mid Target } & \multirow{8}{*}{1867} & BLU 63 & 1772 \\
\hline & & BLU 26 & 8 \\
\hline & & BLU 61 & 41 \\
\hline & & Misc bomblet fuzes & 14 \\
\hline & & 40mm TPТ & 4 \\
\hline & & BLU 97 & 23 \\
\hline & & $\begin{array}{l}100 \mathrm{lb} \text { practice with spotting } \\
\text { charge }\end{array}$ & 2 \\
\hline & & Mark 118 & 3 \\
\hline \multirow{2}{*}{ Mid Target expanded grids } & \multirow{2}{*}{90} & BLU 63 & 88 \\
\hline & & 40mm TPT & 2 \\
\hline Buffer Zone & 69 & M 42 & 69 \\
\hline Total & 2559 & & 2559 \\
\hline
\end{tabular}




\subsection{SUMMARY AND CONCLUSIONS}

WESTON performed a MEC Clearance on CAU 408, TTR, Nye County, Nevada, between 20 July 2009 and 15 May 2010. The objective of this project was to safely locate, identify and dispose of MEC items to a depth of one foot bgs and investigation to extinction in burial pits. This work was originally performed for NNES under NNES Prime Contract DE-AC5203NA99205 and subsequently under DE-AC52-09NA28091 with the DOE, NNSA, Nevada Site Office. The Task Order was authorized with a notice to proceed (NTP) under a costreimbursement Temporary Duty (TDY) Work Authorization. WESTON mobilized on 20 July 2010.

The primary tasks of this project were to 1) excavate (to extinction) disposal pits in the Antelope Lake Area 2) provide Surface Clearance over directed portions of seven Target Areas that had formerly been used as bombing areas 3) identify and remove anomalies that are, or could represent, MEC. WESTON was additionally tasked to conduct a visual sweep of portions of the Buffer Zone - an activity which evolved into a surface clearance and removal in an area where M42 sub-munitions were discovered.

DGM was accomplished by others prior to WESTON mobilization to the project site. The DGM provided data for polygon mapping of anomaly areas to focus investigation and identification of potential MEC and MD within CAU 408. The DGM database was provided to WESTON's UXO team, which in-turn carried out investigation and removal actions at the seven sites. Grids, polygons and disposal pit boundaries were reacquired using a survey-grade RTK GPS, and Schiebel all metal detectors, or, in the case of the disposal pits, an EM 61 MK2 instrument.

A total of 2,559 MEC items were removed (See Table 5-1). 


\subsection{REFERENCES}

DOE (U.S. Department of Energy). 2004. Draft Corrective Action Investigation Plan for Corrective Action Unit 511: Waste Dumps (Piles \& Debris), Tonopah Test Range, Nevada. July 2004.

National Nuclear Security Administration (NNSA), August 2009, Streamlined Approach for Environmental Restoration (SAFER) Plan for Corrective Action Unit 408: Bomblet Target Area (TTR) Tonopah Test Range, Nevada.

U.S. Army Engineering and Support Center (USACE). 2001. Geophysical Investigation Plan. USACE DID OE-005-07.01. Huntsville, AL. revised 2001.

U.S. Army. 2003. Memorandum dated 28 October 2003 establishing standard definitions of MEC terminology by the Deputy Assistant Secretary of the Army for Installations and Environment.

WESTON (Weston Solutions, Inc.). 2009. Munitions and Explosives of Concern (MEC) Disposal Pit Investigation \& Submunition Clearance Work Plan, Corrective Action Unit 408 UXO Sites, Tonopah Test Range, July 2009. 


\section{APPENDIX A}

MEC TERMINOLOGY AND MEC DATA 


\section{A1.0 MEC TERMINOLOGY AND MEC DATA}

On 18 December 2003, the Office of the Secretary of Defense (OSD) issued a memorandum providing new and standardized definitions for Munitions Response Actions for Military Munitions Response Program (MMRP). This memorandum eliminated several previously used definitions, most notably OE - ordnance and explosives, and defined several new categories for munitions. The new categories are defined as Munitions and Explosives of Concern (MEC) and Munitions Constituents (MC). The definitions included in the OSD memorandum are paraphrased below and used throughout this report.

\section{A1.1 ORDNANCE TERMINOLOGY}

Military Munitions- Military munitions means all ammunition products and components produced for, or used by, the Armed Forces for National Defense and Security, including ammunition products or components under the control of the Department of Defense, the Coast Guard, the Department of Energy, and the National Guard. The term includes confined gaseous, liquid, and solid propellants, explosives, pyrotechnics, chemical and riot control agents, smokes, and incendiaries, bulk explosives and chemical warfare agents, chemical munitions, rockets, guided and ballistic missiles, bombs, warheads, mortar rounds, artillery ammunition, small arms ammunition, grenades, mines, torpedoes, depth charges, cluster munitions and dispensers, demolition charges, and devices and components thereof.

The term Military Munitions does not include wholly inert items, improvised explosive devices, nuclear weapons, nuclear devices, and nuclear components, except that the term does include non-nuclear components of nuclear devices that are managed under the nuclear weapons program of the Department of Energy after all required sanitization operations under the Atomic Energy Act of 1954 (42 U.S.C. §2011 et seq.) have been completed. (10 U.S.C. §2710 (e) (3) (A) and (B))

\section{A1.1.1 Munitions and Explosives of Concern (MEC):}

The MEC category includes military munitions that may pose unique explosive safety risks. The following are included in this category.

\section{A1.1.1.1 Unexploded Ordnance (UXO)}

Unexploded ordnance is defined as: a) military munitions that have been primed, fuzed armed or otherwise prepared for action; b) have been fired, dropped, launched, projected or placed in such a manner as to constitute a hazard to operations, installations, personnel or material; and, c) remained unexploded either through malfunction, design, or any other cause.

\section{A1.1.1.2 Discarded Military Munitions (DMM)}

Discarded military munitions are defined as munitions that have been abandoned without proper disposal, or removed from storage in a military magazine or other storage area for the purpose of disposal. The term does not include unexploded ordnance, military munitions that are being held for future use or planned disposal, or military munitions that have been properly disposed of consistent with applicable environmental laws and regulations. 


\section{A1.1.2 Munitions Constituents (MC)}

Munitions constituents are defined as any materials originating from unexploded ordnance, discarded military munitions, or other military munitions, including explosive and non-explosive materials, and emission, degradation, or breakdown elements of such ordnance or munitions. The materials are present in sufficient concentration to constitute an explosive hazard (e.g. TNT greater than $10 \%$ in soils). This category is further defined as:

- Material Potentially Presenting an Explosive Hazard (MPPEH): Material potentially containing explosives or munitions, (including containers, packing materials, munitions debris and range-related debris) or materials potentially contaminated with sufficient concentration of explosives such that the material presents an explosive hazard (e.g. holding tanks, piping, settling basin drainage systems).

- Munitions Debris (MD): Remnants of military munitions remaining after munitions use, demilitarization or disposal.

\section{A1.2 RECOVERED MEC}

The results of the clearance operations on the seven CAU 408 sites were presented in Table 5-1 of the CAU 408 After Action Report and show the quantity and type of MEC items found at each of the areas.

Table 5-1 MEC Summary Table

\begin{tabular}{|c|c|c|c|}
\hline Corrective Action Site & QTY of MEC & $\begin{array}{r}\text { Description } \\
\end{array}$ & Quantity \\
\hline \multirow{5}{*}{ Burial Pits } & \multirow{5}{*}{12} & 155 mm Projectile & 3 \\
\hline & & 8 in Projectile & 3 \\
\hline & & M424A1 spotting charge & 1 \\
\hline & & BLU 49 & 5 \\
\hline & & .50 cal bullet & 0 \\
\hline SAC I\&II Targets & 1 & .50 cal bullet & 1 \\
\hline Tomahawk I Target & 0 & & \\
\hline Tomahawk II Target & 0 & & \\
\hline \multirow{2}{*}{ South Antelope Lake Target } & \multirow[b]{2}{*}{5} & BLU 49 & 2 \\
\hline & & BLU 26 & 3 \\
\hline Flightline Target & 513 & BLU 63 & 513 \\
\hline Flightline expanded grids & 2 & BLU 63 & 2 \\
\hline \multirow{8}{*}{ Mid Target } & \multirow{8}{*}{1867} & BLU 63 & 1772 \\
\hline & & BLU 26 & 8 \\
\hline & & BLU 61 & 41 \\
\hline & & Misc bomblet fuzes & 14 \\
\hline & & 40mm TPT & 4 \\
\hline & & BLU 97 & 23 \\
\hline & & $100 \mathrm{lb}$ practice with spotting charge & 2 \\
\hline & & Mark 118 & 3 \\
\hline \multirow{2}{*}{ Mid Target expanded grids } & \multirow{2}{*}{90} & BLU 63 & 88 \\
\hline & & 40mm TPT & 2 \\
\hline Buffer Zone & 69 & M 42 & 69 \\
\hline Total & 2559 & & 2559 \\
\hline
\end{tabular}




\section{A1.2.1 BLU-49 - Munition with Greatest Fragmentation Distance}

BLU-49s were recovered in the Burial Pits and at the South Antelope Lake Target. The BLU-49 is the munition with the greatest fragmentation distance (MGFD). Recent guidance from the U.S. Army Corps of Engineers (USACE) and the Department of Defense Explosive Safety Board has indicated that the Hazardous Fragment Distance (1/600 rule is the new guidance for unintentional detonation of known MEC. The hazardous fragment distance for the BLU-49 was be established as 395' which is the greater of the two hazardous fragment distances listed in Tables 4-1 and 4-2 of the Department of Defense Explosive Safety Board (DDESB) Technical Publication (TP) 16. As such, the safety exclusion zone for non-EOD qualified or non-essential personnel will be set as 395' feet outside the work area during investigation activities.

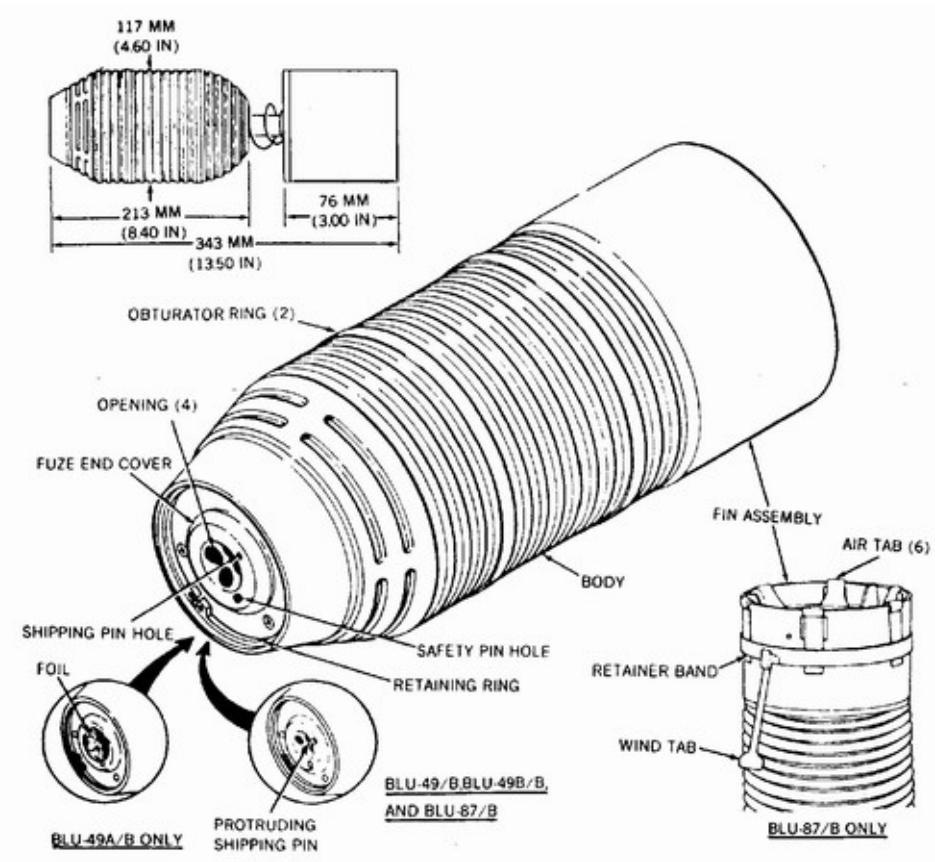

\section{BLU-49}

\section{A1.2.2 155mm Projectile}

The 155MM projectile's were recovered from a burial pit and found to be unfuzed and wax filled.

\section{A1.2.3 8 in Projectile}

The 8 in projectile's were recovered from a burial pit and found to be unfuzed and wax filled. 


\section{A1.2.4 M424A1 Spotting Charge}

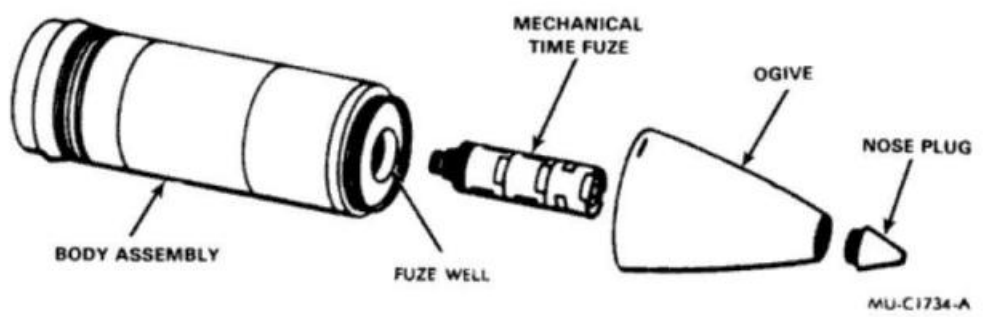

\section{A1.2.5 $50 \mathrm{Cal}$ Bullet}

The caliber .50 cartridge consists of a cartridge case, primer, propelling charge, and the bullet. See TM 9-1300-200. The term bullet refers only to the small-arms projectile. There are eight types of ammunition issued for use in the caliber .50 machine gun. The tips of the various rounds are color-coded to indicate their type. The ammunition is linked with the M2 or M9 metallic links for use in the machine gun. (FM 23-65)

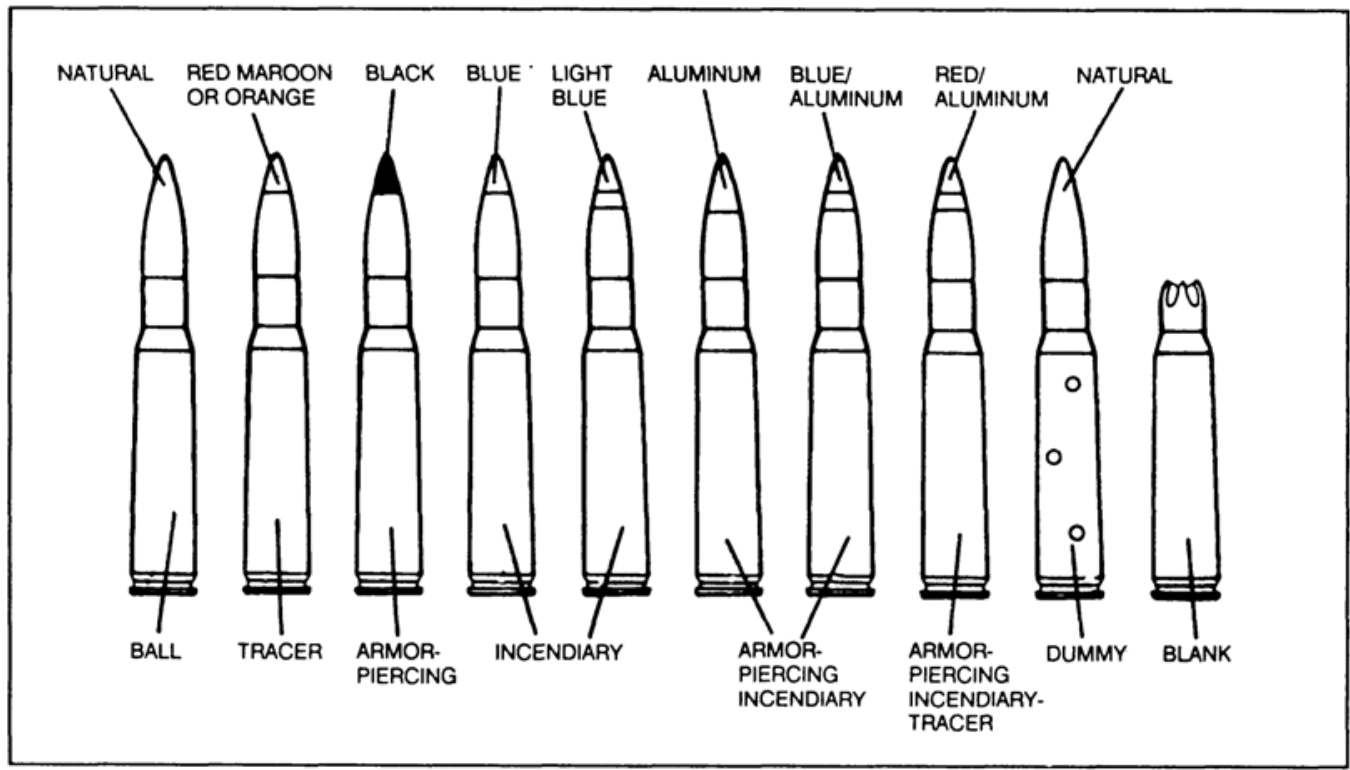

50 CAL Ammunition

\section{A1.2.6 BLU 26 Air-dispensed APAM}

The BLU-26/B "Guava" was an air-dispensed APAM (anti-personnel/anti-material) fragmentation bomblet with 600 embedded steel fragments. The BLU-26/B had three different

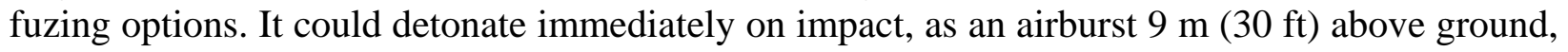
or after a selectable but fixed time after impact. The BLU-26/B was used as payload in cluster bombs. 

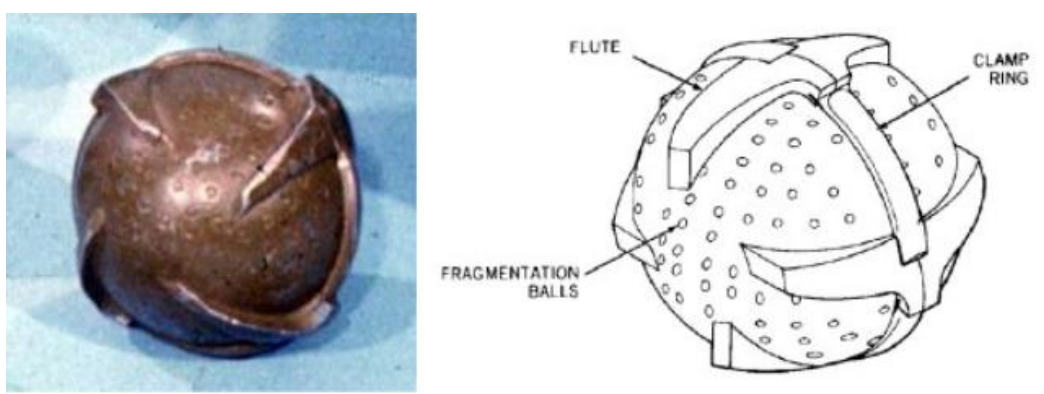

BLU-26

\section{A1.2.7 BLU 63 Cluster Bomblet}

The BLU-63/B was an aerially dispensed, centrifugally-armed, impact-fired anti-personnel/antimaterial fragmentation bomblet. It contained $113 \mathrm{~g}(0.25 \mathrm{lb})$ of Cyclotol. There was also a BLU$63 \mathrm{~A} / \mathrm{B}$ version, but confirmed information about the differences is not available (the 63A/B possibly had a secondary incendiary effect). The BLU-63( )/B was used as payload in a cluster bombs.

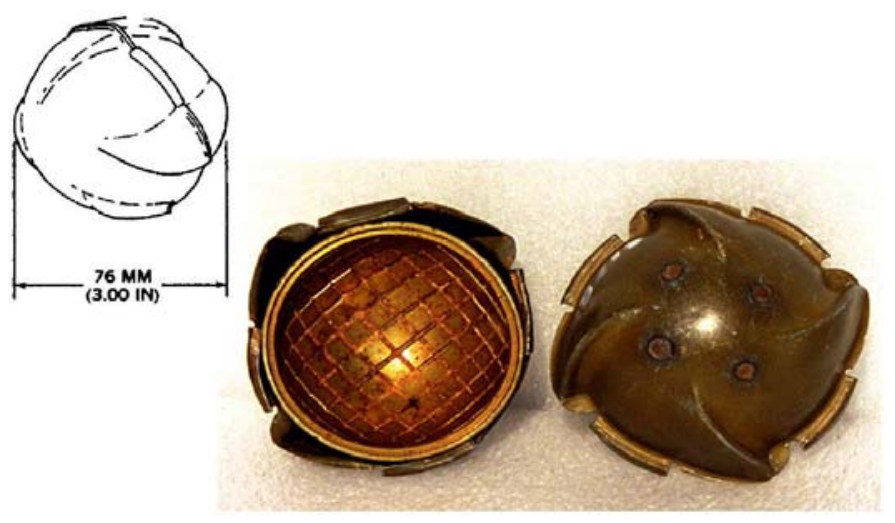

BLU-63

\section{A1.2.8 BLU 61 Anti-Material Fragmentation and Incendiary Bomblet}

The BLU-61/B was an aerially dispensed anti-material fragmentation and incendiary bomblet. It was spin-armed and detonated on impact. The bomblet consisted of two hemispheres, both with a fragmentation liner of coined steel and a liner for zirconium-tin for the incendiary effect. Contained $277 \mathrm{~g}(0.61 \mathrm{lb})$ of Octol. There was also a BLU-61A/B version, but information about the differences is not available. The BLU-61A/B was apparently the primary (and possibly only) variant used in service. The BLU-61A/B was used as payload in cluster bombs. 

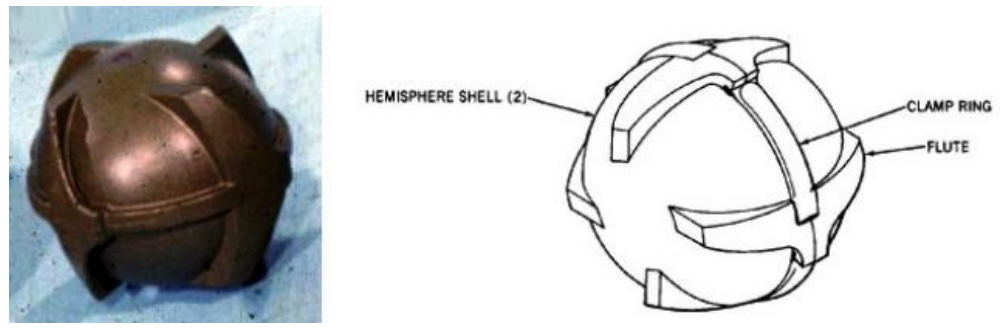

BLU-61A/B

\section{A1.2.9 Miscellaneous Bomblet Fuzes}

The miscellaneous bomblet fuzes recovered were identified as M219E1 and are functioned by impact inertia. If they could not be identified as being functioned, then they were treated as live and disposed. They are used in a variety of sub-munitions to include the BLU 63, BLU 61 and the BLU 26, all of which were found CAU 408.

\section{A1.2.10 40MM TPT}

The projectile is a $40 \mathrm{~mm}$ tracer (target practice tracer). The weapons system is either single or multi- barreled anti-aircraft.

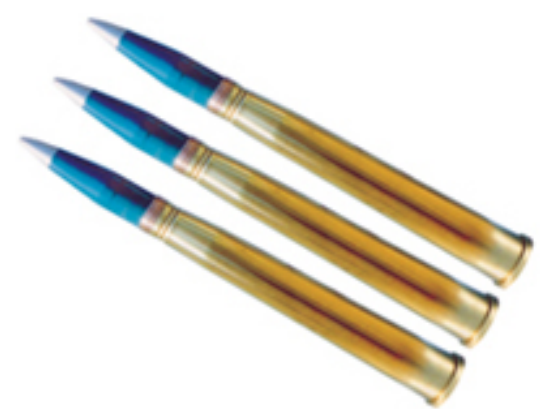

\section{$40 \mathrm{~mm}$ Target Practice Tracers (shown in full rounds)}

\section{A1.2.11 BLU-97/B Combined Effects Bomb}

The BLU-97/B Combined Effects Bomb (CEB) is deployed against armor, personnel and material. It is configured as a shaped charge, scored steel casing, and zirconium ring for antiarmor, fragmentation, and incendiary effects. The case is made of scored steel designed to break into approximately 300 preformed fragments. The bright yellow body of the sub-munition is cylindrical and approximately 20 centimeters long with a 6 centimeter diameter. The original Cyclotol explosive was later replaced with PBXN-107 explosive in the improved BLU-97. 


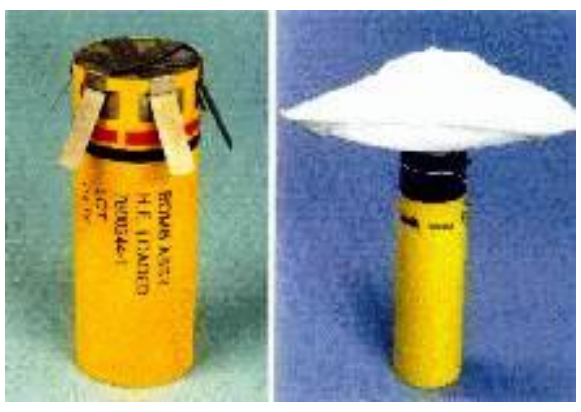

BLU-97

\section{A1.2.12 100LB PRACTICE BOMB WITH SPOTTING CHARGE}

The $100 \mathrm{lb}$ practice bomb constructed of light 22 ga sheet metal rolled into an 8 in. $(20 \mathrm{~cm})$ cylinder and spot welded at the seam. The rounded nose and tail are fabricated from the same metal as the body. The spotting charge is located at the base of the bomb, within the fin box. The bomb is 47.5 in long. When empty, the bomb body weighs approximately 14 pounds but when completely loaded with sand and spotting charge, the bomb weighs 100 lbs.

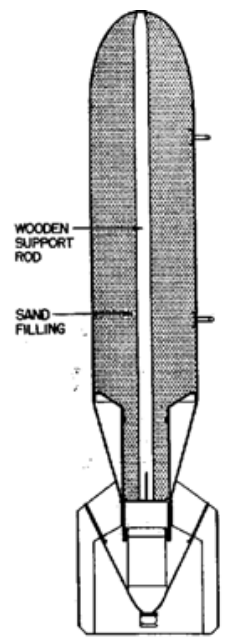

\section{Ib Practice Bomb}

\section{A1.2.13 MARK 118 ROCKEYE}

The Mk118 Rockeye has a cylindrical body incorporating a standoff initiated HEAT warhead with a rear-mounted fuze and fixed plastic fins. When the bomblet strikes a hard object nosefirst, the detonator at the rear of the shaped charge is initiated to produce an anti-armor effect. Most also produce anti-personnel/anti-materiel fragmentation as the body is shattered, and many are scored or notched to enhance the effect. The bomblet weighs 1.32 pounds and has a 0.4pound shaped-charge warhead of high explosives 


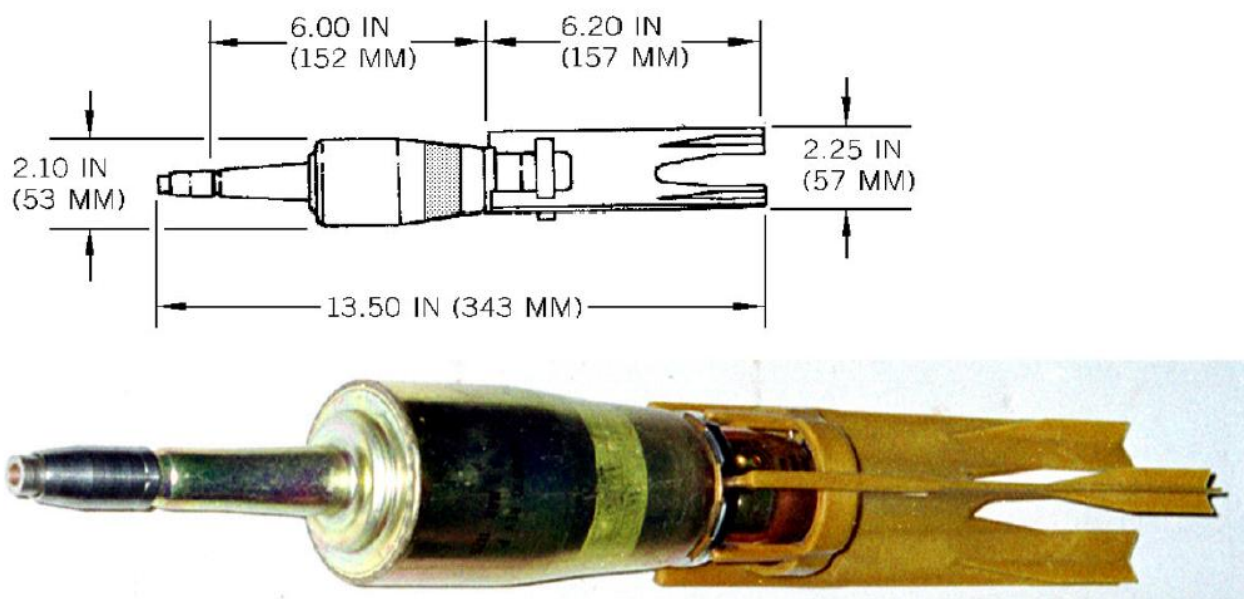

Mark 118 Rockeye

\section{A1.2.14 M42 DUAL PURPOSE SUBMUNITION}

The M42 is a dual purpose sub-munitions in the category of DPICM (Dual Purpose Improved Conventional Munition). The dual purposes are anti-amour and anti-personnel. The outer sleeve of the munition is its anti-personnel fragmentation. The interior has a small amount of high explosive above an armor-piercing shaped charge. The end opposite the ribbon is empty and provides a "standoff" that allows the shaped charge to form and achieve its armor-piercing properties.

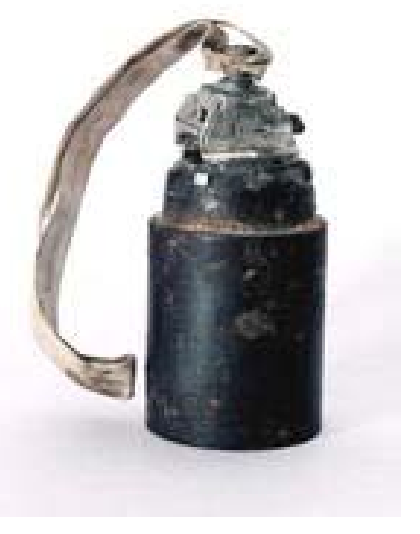

M42 Dual Purpose Sub-munition 


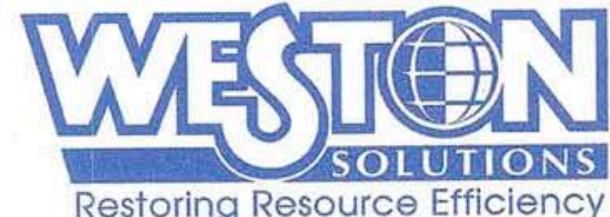

Restoring Resource Efficiency
Weston Solutions, Inc.

4801 University Square

Suite 25

Huntsville, AL 35816

256-430-3781 • Fax 256-430-3784

www.westonsolutions.com

\section{Memorandum for the Record}

17 May 2010

\section{Subject: Expenditure of Commercially Procured Explosives}

From: E. F. "Sonny" Richardson

1. I certify that Weston Solutions, Inc. personnel expended the following company-procured explosive materials during the period of 12 Jan 2010 and 15 May 2010 to destroy Munitions and Explosives of Concern (MEC) found during the performance of work at the Tonopah Test Range, Nevada. The explosives were ordered from Omni Explosives and Halliburton Industries. Copies of ordering invoices are attached as a matter of record.

Item Description
Electric Blasting Caps
Non Electric Ignitors
Jet Perforators (Shaped Charges)
C-4 Plastic Explosives
80 gr Det Cord (Prima Cord)
Time Fuze

\section{Quantity \\ 200 Each \\ 100 Each \\ 200 Each \\ 400 Pounds \\ 2000 Feet \\ 500 Feet}

2. The commercially procured explosives were stored during Weston Solutions Inc. operations in Department of Energy provided explosive storage magazines. Upon completion of demolition operations all packaging materials were carefully inspected for the presence of explosive materials prior to being discarded.

\section{/s/ E. F. Richardson}

E. F. "Sonny" Richardson

Senior UXO Technical Manager

Encl: (1) Omni Explosives invoice No. 19899

Encl: (2) Omni Explosives invoice No. 20081

Encl: (3) Halliburton Explosives invoice No. 96673011

Encl: (4) Halliburton Explosives invoice No. 96814692 
REMIT TO:

OMNI DISTRIBUTION, INC.

\section{PO Box 69}

\section{Marion, AR 72364}

\section{Bill To:}

WESTON SOLUTIONS

SONNY RICHARDSON

4801 UNIVERSITY SQUARE SUITE 13

HUNTSVILLE AL 35816
Optional REMIT TO:

PO Box 171154

Memphis TN 38187-1154
CAGE: 072V3

DUNS: 177096906

PHONE: 800-277-6664

FAX: 800-508-8534

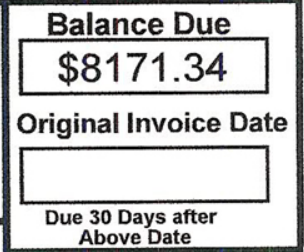

Ship To:

Weston Solutions/Navarro Nevada Environmental Services C/O SANDIA NATIONAL LABORATORIES WILLIAMS PHELPS

Tonopah Test Range

702-295-8108

Tonopah NV 89049

\begin{tabular}{|rrr|}
\hline P.O. Number: & $\begin{array}{r}\text { Ship Complete Date: } \\
\text { Order Date }\end{array}$ 1/15/2010 16:10:38 & $\begin{array}{l}\text { F.O.B.: Memphis, TN } \\
\text { Terms: }\end{array}$ \\
\hline
\end{tabular}

These items may be covered by the United States Munitions List (USML) and if so, therefore, subject to control by the US Dept of State. Export requires an export license, or other approval, issued by the US Dept of State.

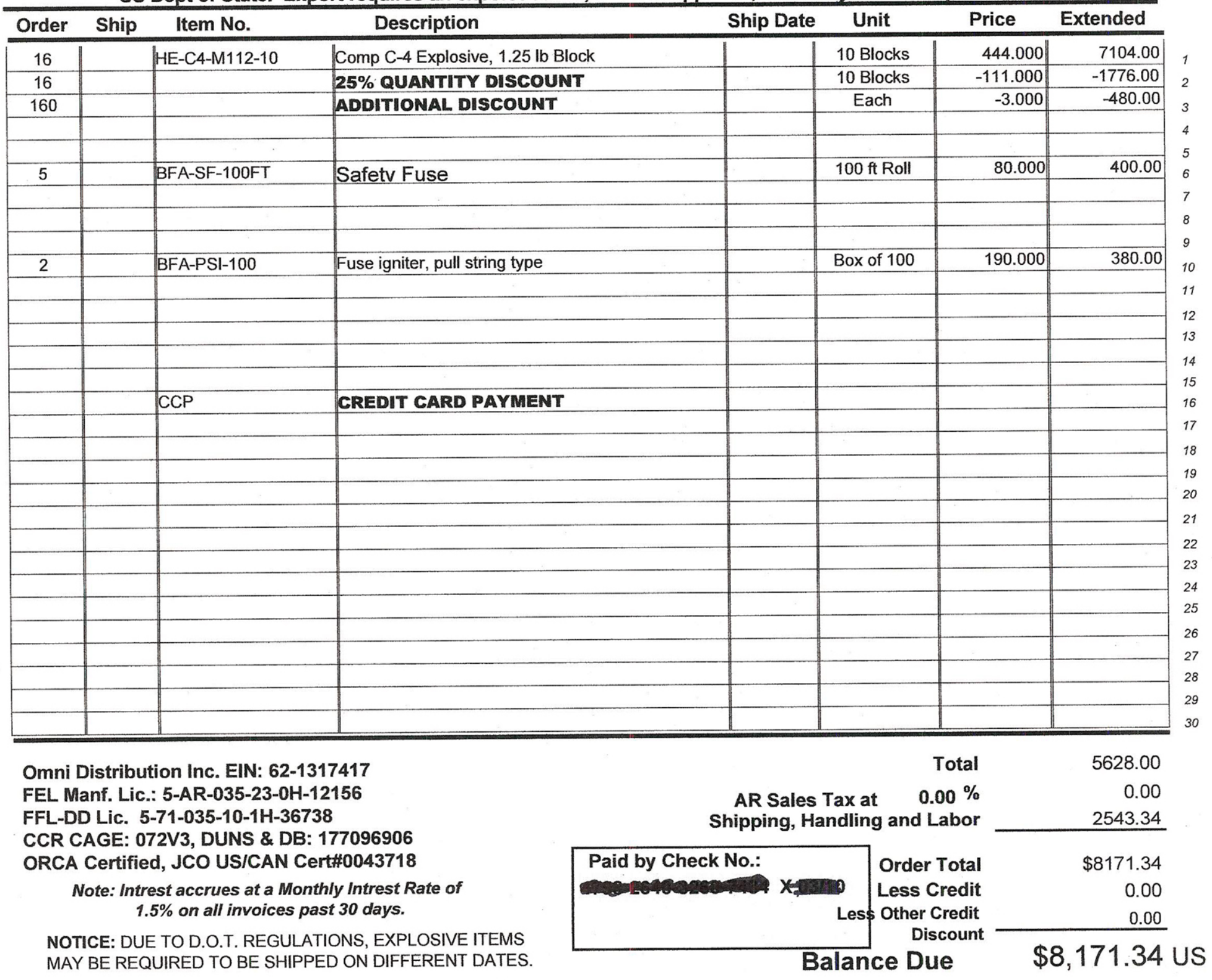


REMIT TO: OMNI DISTRIBUTION, INC. PO Box 69

Marion, AR 72364

\section{Bill To:}

WESTON SOLUTIONS

SONNY RICHARDSON

4801 UNIVERSITY SQUARE SUITE 13

HUNTSVILLE AL 35816
Optional REMIT TO:

PO Box 171154

Memphis TN $38187-1154$
CAGE: 072V3

DUNS: 177096906

PHONE: 800-277-6664

FAX: 800-508-8534
Balance Due $\$ 0.00$ Original Invoice Date

\begin{tabular}{|c|}
\hline $4 / 8 / 2010$ \\
\hline $\begin{array}{c}\text { Due } 30 \text { Days after } \\
\text { Above Date }\end{array}$ \\
\hline
\end{tabular}

Ship To:

Weston Solutions/Navarro NV Environmental Serv C/O SANDIA NATIONAL LABORATORIES

\section{WILLIAMS PHELPS}

Tonopah Test Range

702-295-8108

Tonopah NV 89049

\begin{tabular}{|c|c|c|c|c|}
\hline P.O. Number: & $\begin{array}{c}\text { Ship Complete Date: } \\
\text { Order Date }\end{array}$ & $\begin{array}{l}4 / 9 / 2010 \\
3 / 30 / 2010 \text { 13:49:52 }\end{array}$ & $\begin{array}{l}\text { F.O.B.: } \\
\text { Terms: }\end{array}$ & $\begin{array}{l}\text { Memphis, TN } \\
\text { Upon Receipt }\end{array}$ \\
\hline
\end{tabular}

F.O.B.: Memphis, TN
Terms: Upon Receipt

These items may be covered by the United States Munitions List (USML) and if so, therefore, subject to control by the US Dept of State. Export requires an export license, or other approval, issued by the US Dept of State.

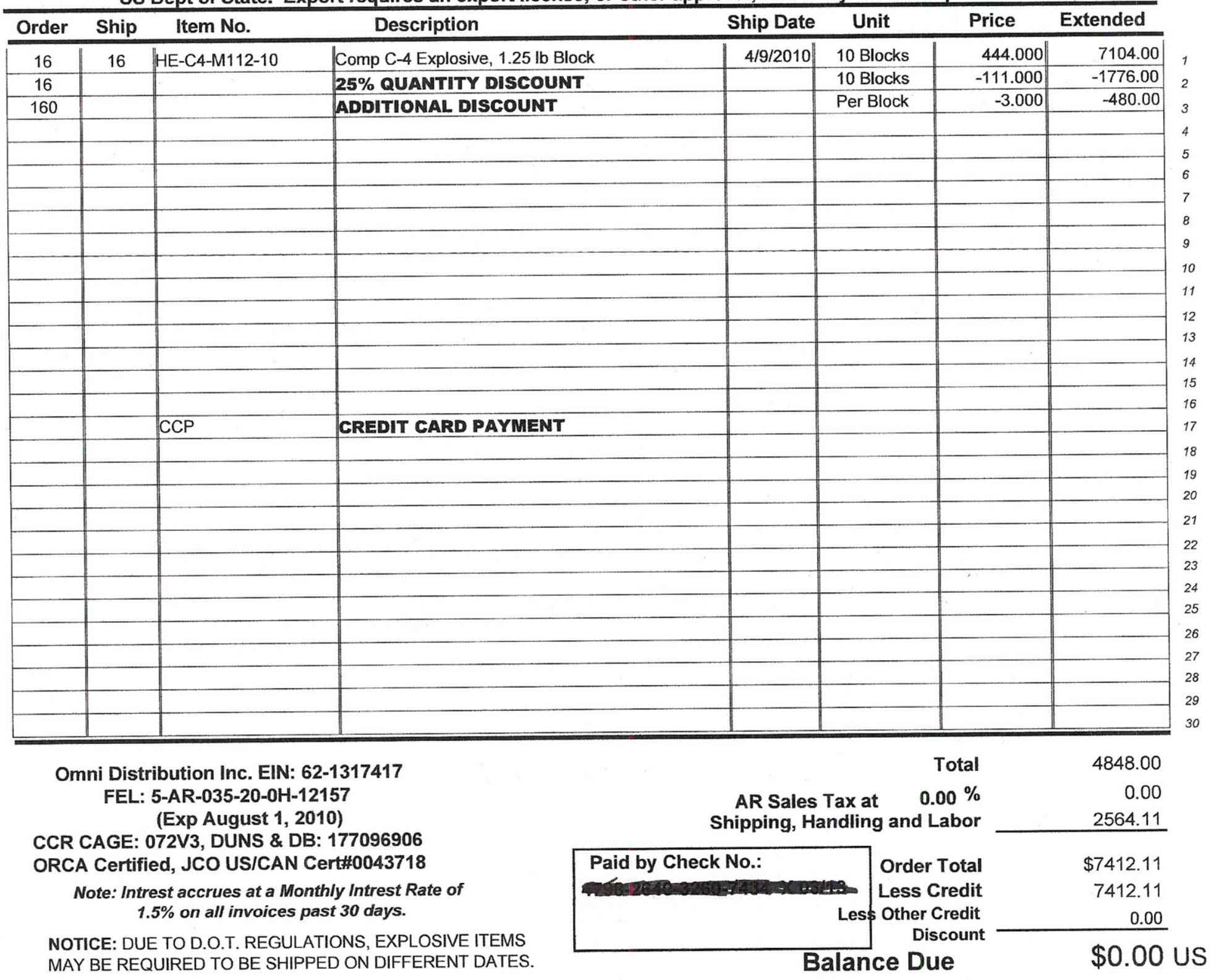


INVOICE

\begin{tabular}{|l|}
\hline \multicolumn{1}{|c|}{ Remit payment to: } \\
\hline Remit To: P.O. Box 203143 \\
Houston, TX $77216-3143$ \\
\\
\end{tabular}

\section{HALLIBURTON}

Halliburton Energy Services, Inc.

\begin{tabular}{|l|c|}
\hline \multicolumn{2}{|c|}{ Wire Transfer to be made to: } \\
\hline Halliburton Energy Services & Account No. \\
\cline { 2 - 2 } Citibank N.A. & 00032969 \\
\hline One Penn's Way & ABA Routing No. \\
Attn: Ops 2, 2nd Fioor & 021000089 \\
\hline New Casule. DE 19720 & \\
\hline
\end{tabular}

Invoice No: 96673011

Registration Number: NIF 73-0271280

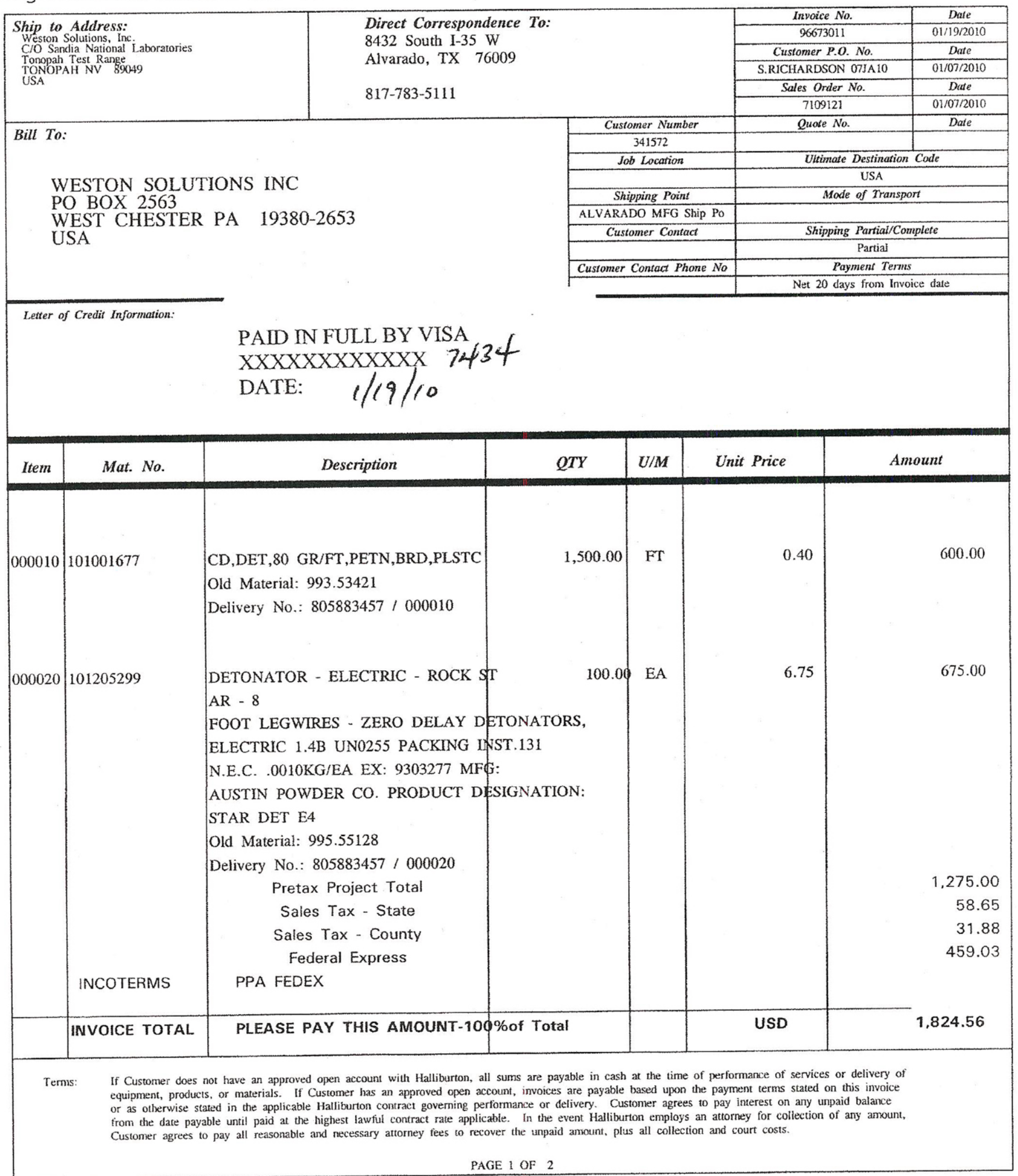




\section{INVOICE}

\begin{tabular}{|l|}
\hline \multicolumn{1}{|c|}{ Remit payment to: } \\
\hline Remit To: P.O. Box 203143 \\
Houston. TX $77216-3143$ \\
\\
\hline
\end{tabular}

\section{HALLIBURTON}

Halliburton Energy Services, Inc.

\begin{tabular}{|l|c|}
\hline \multicolumn{2}{|c|}{ Wire Transfer to be made to: } \\
\hline Halliburton Energy Services & Account No. \\
\cline { 2 - 2 } Citibank N.A. & 00032969 \\
\hline One Penn's Way & ABA Routing No. \\
Attn: Ops 2, 2nd Floor & 021000089 \\
\hline New Castle. DE 19720 & \\
\hline
\end{tabular}

\section{Invoice No: 96814692}

Registration Number: NIF 73-0271280

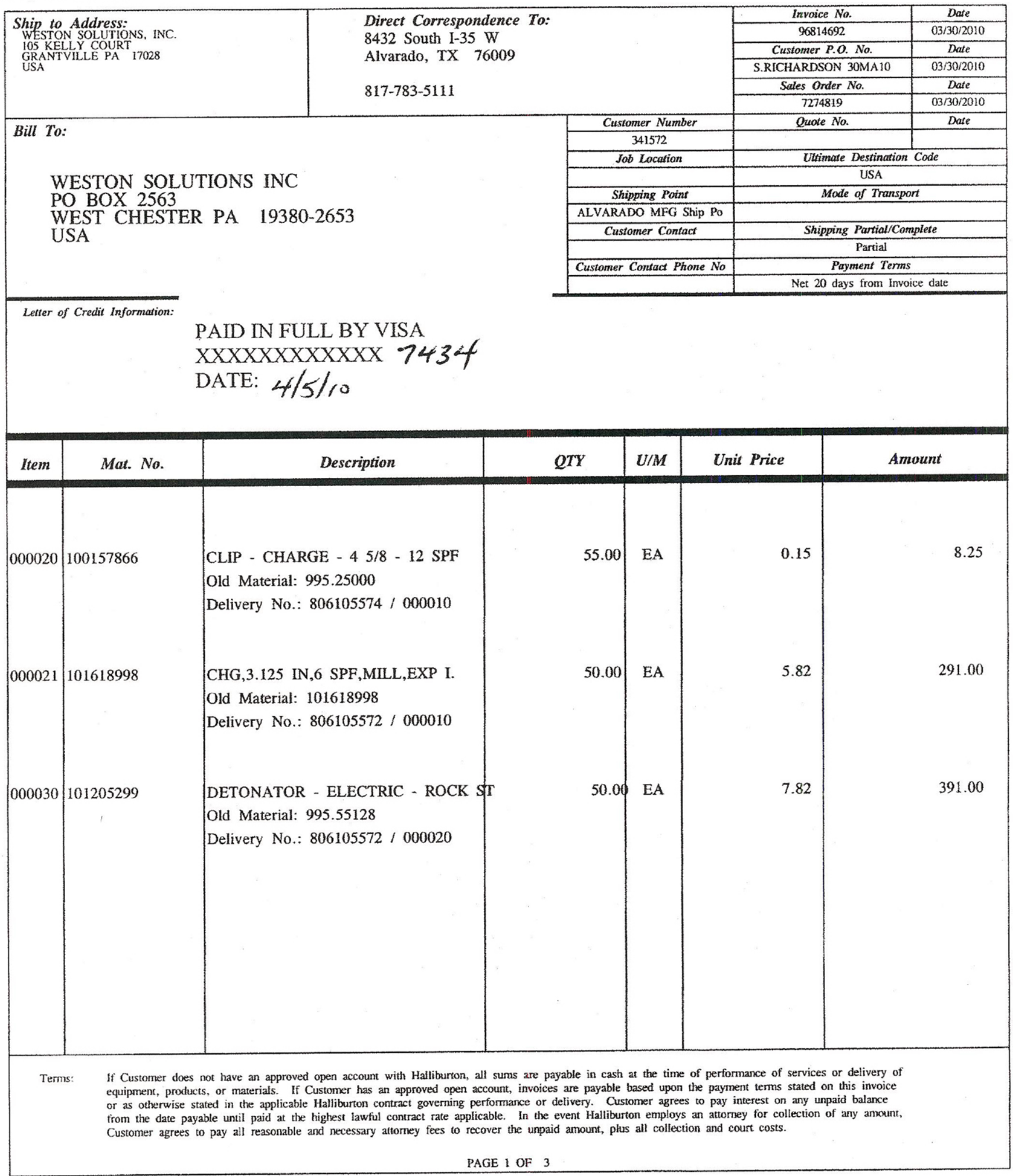


Halliburton Energy Services, Inc.

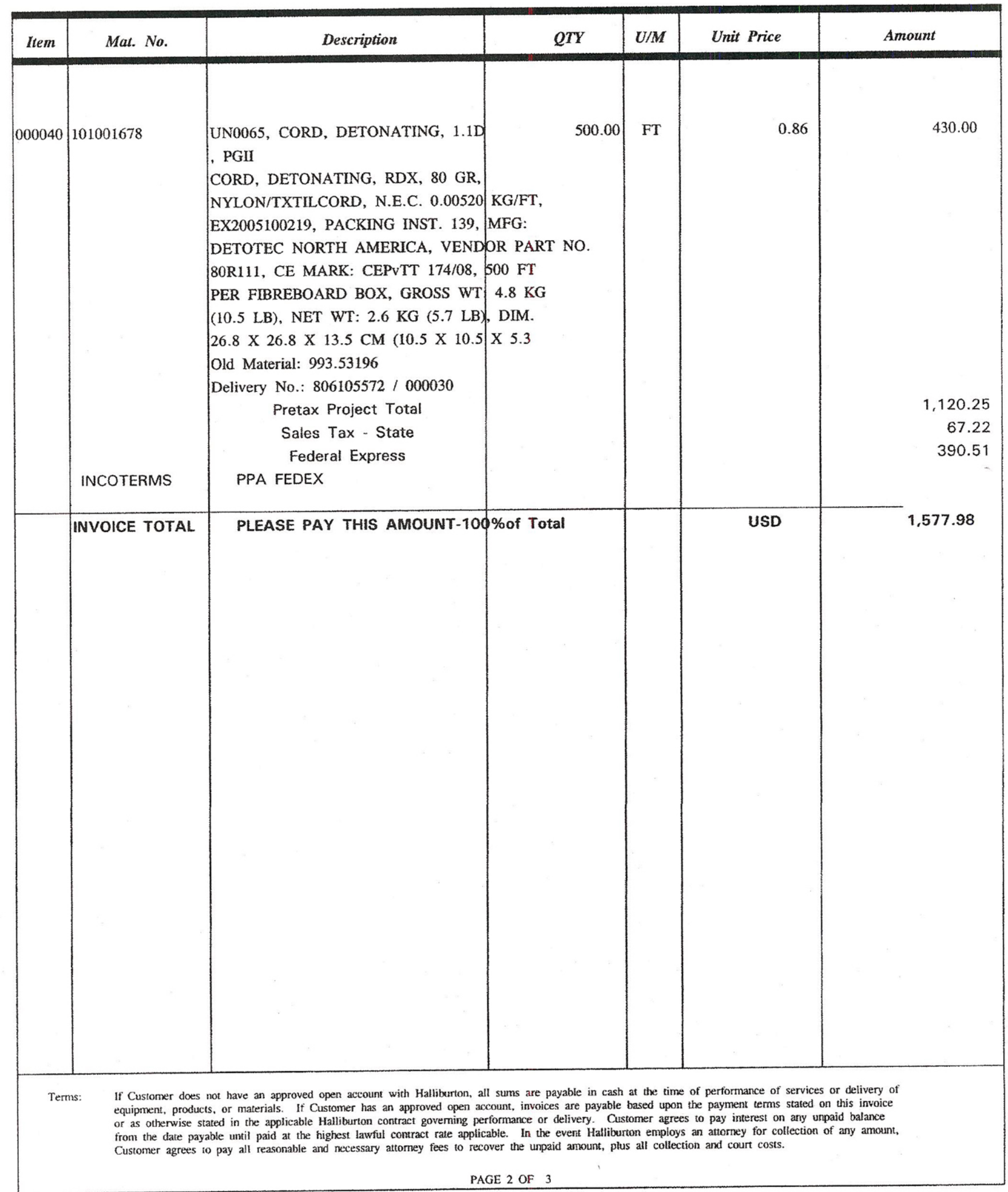




\section{Weston Solutions Magazine Data Card}

\begin{tabular}{|c|c|c|c|c|c|c|}
\hline Description: & Jon- Electric Blasting Caps & & & Location: & Area 9 Igloo \# 3 & \\
\hline Lot: $\quad 263$ & & & & & & \\
\hline Date & Purpose & Gain & Loss & Balance & Name & \\
\hline 13-Oct-09 & Received from Vern Hermansen & 494 & - & 494 & Durapue Fremeh & \\
\hline 210901 & INVeu Gory & - & - & ify & Dhaver Frong h & \\
\hline 780409 & INVE" Tory & - & - & 4,4 & Divaper Frem h & \\
\hline 4 NOUOS & Fnvergory & - & $=$ & 494 & Divarar Fene 5 & \\
\hline $11 \mathrm{NOY} O \mathrm{~S}$ & Inventory & - & - & 494 & Darour frears & \\
\hline $18 \mathrm{NaN} 09$ & Frllen Tory & - & - & 494 & Dorayer French & \\
\hline $24 \mathrm{Nov} 09$ & InilenTory & c & $=$ & 494 & Divar ne foruet. & \\
\hline $212 \times 29$ & INVon Ta & 2 & $=$ & 4Q9 & 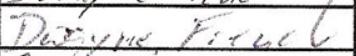 & \\
\hline $9 \operatorname{DEC} 0^{4}$ & INventory & - & - & 494 & Phelos/mcconneld & $S=A L H$ \\
\hline HWDEC OQ9 & LNventory & - & - & 494 & Phelos / stebelske & 006972530 \\
\hline $26.7 e n d 0^{6.14}$ & iNV & - & - & 494 & Pheis/siepeis & र \\
\hline $12 \sin 10$ & INV & - & $=$ & 494 & Phelps/stebeis & 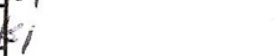 \\
\hline 19.) Dan 10 & loventory & - & - & 494 & Phelps/stebelsk & \\
\hline 27 JAN 10 & iNventory & - & $=$ & 499 & Pre Nos/stebels & ki \\
\hline $03 \mathrm{FEB} 10$ & inventory & $=$ & - & 494 & pue 1ps/steves & Sh. \\
\hline 10 FEB is & iNv & $=$ & - & 494 & Pnelps/stebels & i \\
\hline $15 F E B 10$ & DEMD Draw/1NV & - & $82 i$ & 486 & Phelps/stebel & $k i$ \\
\hline $23 F E B 10$ & $\operatorname{lng}$ & - & - & 486 & Phelps/stebel & $\$ k i$ \\
\hline OSMAR IO & INV & $=$ & - & 486 & Phelps/stebels & k! \\
\hline$D 8 M A R$ U & INV/DEmo D.R.AW & - & 2 & 484 & Phelos/steneis & k: \\
\hline $16 M A R 10$ & $\ln V$ & - & - & 484 & Pneles/stebclsi & \\
\hline 1 Apr 10 & INV & - & - & 484 & Pnelps/stewers & ki \\
\hline 8AP: iv & ind & $=$ & - & 484 & Pnatps/stesolsk & \\
\hline$\angle 3 A P R 10$ & $\operatorname{cNo}$ & - & - & 484 & Phelps/Stebeiski & \\
\hline Lu AfR 10 & inV & - & - & 484 & Phelps/S+el & $e l s k i$ \\
\hline 28 Apr 10 & DEMnO DRAW/INV & - & 11 & 473 & Pnelps/stebels & $k i$ \\
\hline SMAn 10 & $\mathrm{NV}$ & - & - & 473 & Pheles/stebcisk & \\
\hline 12 MAy 10 & Nir & $=$ & - & 473 & Phelps/stebeis & Gi \\
\hline $15 \mathrm{MA} / \mathrm{L}$ & Demo & $=$ & 473 & $\theta$ & pnelps/scheil & \\
\hline & & & & & & \\
\hline & & & & & & \\
\hline & & & & & & \\
\hline & & & & & & \\
\hline & & & & & & \\
\hline & & & & & & \\
\hline & & & & & & \\
\hline & & & & & & \\
\hline & & & & & & \\
\hline & & & & & & \\
\hline & & & & & & \\
\hline & & & & & & \\
\hline & & & & & & \\
\hline & & & & & & \\
\hline & & & & & & \\
\hline & & & & & & \\
\hline
\end{tabular}




\section{Weston Solutions Magazine Data Card}

\begin{tabular}{|c|c|c|c|c|c|c|}
\hline Description: El & ctric Blasting Caps & & & Location: & Area 9 Igloo \# 3 & \\
\hline Lot:17AU0951 & & & & & & \\
\hline Date & Purpose & Gain & Loss & Balance & Name & \\
\hline 12-Jan-10 & Received & 100 & - & 100 & phelps/stebelski & \\
\hline 19-Jan-10 & Inventory & $2-$ & $=$ & 100 & phelps/stebelski & \\
\hline $25 \mathrm{NANiO}$ & RECAVE & 100 & $=$ & 260 & Pnelps/stebe & $15 \mathrm{kl}$ \\
\hline 27 UAN 10 & $\ln V$ & $=$ & - & 200 & Phe $105 / 5+2 b 2$ & sk, \\
\hline 03 FEBIC & INV & - & - & 200 & Pnalps/stebelsk & \\
\hline$\angle O F E B I O$ & INV & - & - & 200 & Pheles/stebels & $k i$ \\
\hline $15 F E B 10$ & DEMO DRAW / INV & - & 2 & 198 & Pnelps/steb/sk & \\
\hline 2350310 & iNV & - & 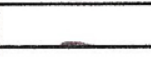 & 198 & Phe/ps/stebels & ki \\
\hline D BMAR IO & $\mathrm{INV}$ & - & $=$ & 198 & Phelps/stebels & ki \\
\hline $08 \mathrm{mar} w$ & NV WDEMU DRAw & $=$ & 4 & 194 & Pheles/stabe & sic ${ }^{3}$ \\
\hline 16 MAR 10 & inv & $=$ & - & 194 & Pnelps/ stebets & Ki SEAC 9909 \\
\hline $1 \mathrm{APB} 10$ & $\operatorname{IN} 4$ & - & - & 194 & Prelps/stebersk & \\
\hline QAPr 10 & INV & - & - & 194 & Prueles/Stebelsk & \\
\hline 13 APR 10 & iNV & $=$ & - & 194 & Pheips/stebe/ski & \\
\hline 20 APR 10 & inV & - & - & 124 & lheles Stebelsis & \\
\hline 28 APR 10 & INV & - & $=$ & 104 & Pnelps/stebalse & is \\
\hline 5 MAI 10 & INV & - & - & 174 & Phelps/stebeisk & \\
\hline 12 MAY 10 & INV & - & - & 104 & Phelps/stebeiste & \\
\hline 15 MAY 10 & Drino & $=$ & 194 & $\theta$ & Phelps/schen & \\
\hline & & & & & & \\
\hline & & & & & & \\
\hline & & & & & & \\
\hline & & & & & & \\
\hline & & & & & & \\
\hline & & & & & & \\
\hline & & & & & & \\
\hline & & & & & & \\
\hline & & & & & & \\
\hline & & & & & & \\
\hline & & & & & & \\
\hline & & & & & & \\
\hline & & & & & & \\
\hline & & & & & & \\
\hline & & & & & & \\
\hline & & & & & & \\
\hline & & & & & & \\
\hline & & & & & & \\
\hline & & & & & & \\
\hline & & & & & & \\
\hline & & & & & & \\
\hline & & & & & & \\
\hline & & & & & & \\
\hline & & & & & & \\
\hline & & & & & & \\
\hline & & & & & & \\
\hline
\end{tabular}




\begin{tabular}{|c|c|c|c|c|c|c|}
\hline Description: Tir & Fuse & & & Location: & Area 9 Igloo \# 8 & \\
\hline Lot: EX920 109 & & & & & & \\
\hline Date & Purpose & Gain & Loss & Balance & Name & \\
\hline 25-Jan-10 & Received & 500 & - & 500 & phelps/stebelski & \\
\hline 27.1900 & INV & - & - & 500 & Phelps/siebels & \\
\hline OSFEBID & $2 N \mathrm{~V}$ & $=$ & - & 500 & Pheles/stebed & $k$ \\
\hline 10 Ferio & INV & - & - & 500 & Phelos/stebel & skei \\
\hline $15 \% E$ ESH & DEMD / NV & - & 32 & 468 & Pheils/steb & eisk. \\
\hline 23 FEB 70 & INV & $=$ & - & 468 & Pnelps stebel & ski \\
\hline o3 MAR 10 & INV & - & $=$ & 468 & Pnelps/stebels & $\mathrm{Ki}$ \\
\hline $08 \mathrm{mnv}=10$ & $I N V$ & - & - & 468 & Thelps/ste batski & \\
\hline I6 Mar io & iniv & - & $=$ & 468 & fueles/stepotski & $56 x+9908$ \\
\hline 1 APr 10 & iNV & $=$ & - & 468 & Pheles stebusk & \\
\hline 8 APr 10 & inv & - & $=$ & 468 & phelps/stebelsk: & \\
\hline$\angle 3 A P R 10$ & NV & - & - & 468 & Pneles/stebeisk & \\
\hline 20 AOR 10 & INV & - & - & 468 & Thelps stebelsk & \\
\hline 28 AfR 10 & Devas / INV & - & 70 & 398 & Phelps/stebelsk & \\
\hline $\sin 4 y 10$ & inV & - & - & 398 & Phelps/stebels & W \\
\hline $12 m+y 10$ & INV & - & $=$ & 398 & Phelps/stebels & $k^{\prime}$ \\
\hline $15 \mathrm{MAy} 10$ & DE ML & - & 398 & $\theta$ & Aveles/sche & 11 \\
\hline & & & & & & \\
\hline & & & & & & \\
\hline & & & & & & \\
\hline & & & & & & \\
\hline & & & & & & \\
\hline & & & & & & \\
\hline & & & & & & \\
\hline & & & & & & \\
\hline & & & & & & \\
\hline & & & & & & \\
\hline & & & & & & \\
\hline & & & & & & \\
\hline & & & & & & \\
\hline & & & & & & \\
\hline & & & & & & \\
\hline & & & & & & \\
\hline & & & & & & \\
\hline & & & & & & \\
\hline & & & & & & \\
\hline & & & & & & \\
\hline & & & & & & \\
\hline & & & & & & \\
\hline & & & & & & \\
\hline & & & & & & \\
\hline & & & & & & \\
\hline & & & & & & \\
\hline & & & & & & \\
\hline & & & & & & \\
\hline & & & & & & \\
\hline
\end{tabular}




\begin{tabular}{|c|c|c|c|c|c|}
\hline \multicolumn{4}{|l|}{ Description: C-4 } & \multicolumn{2}{|c|}{ Location: Area 9 Igloo \# 8} \\
\hline \multicolumn{6}{|c|}{ Lot:BAE09C059-082 } \\
\hline \begin{tabular}{l|l} 
Date & \\
\end{tabular} & Purpose & Gain & Loss & Balance & Name \\
\hline 25-Jan-10 & Received & 200 & - & \begin{tabular}{|r|}
200 \\
\end{tabular} & phelps/stebelski \\
\hline $27 \operatorname{Jan} 10$ & INJ & -1 & - & 200 & Pheles/Stebels \\
\hline DSFES10 & iNV & $=$ & - & 200 & Pwales/stebels \\
\hline 18 FRBio & INV & $=$ & - & 200 & Pulps) stebels \\
\hline $\mid 5 P=310$ & $D$ EraO/ INV & $=$ & 125 & 75 & Phelps/stebe \\
\hline 23 FEB 10 & INV & - & - & 75 & Phelps/stebel \\
\hline 03 MAR 10 & INV & - & - & 75 & Phelps/stebels \\
\hline DQMAR 10 & $10 \mathrm{~V} / \mathrm{Dence}$ DRAon & - & 5 & 70 & phelos/stoweisk \\
\hline 16 MAR 10 & inv & - & $=$ & 70 & fheips/stebeisk \\
\hline 1 Apr 10 & INV & - & - & 70 & Phelps/stebelsk \\
\hline Q Apr 10 & INV & $=$ & - & 70 & Phelas/stebelsk \\
\hline laAR 10 & INV/RECEIV & 208 & - & 270 & Pueles/stebeisi \\
\hline 20 AfR 10 & $\mathrm{INV}$ & - & - & 270 & Pheles stebelsk \\
\hline 28 APE 10 & Demo/inv & - & 1175 & 152.5 & lnelos/stenels \\
\hline 5 mAy 10 & inV & - & - & 152.5 & Pnelps/5tebeiski \\
\hline 12 May 10 & INV & - & - & 152.5 & Drelps stebeisk \\
\hline 15 MAtg 10 & Desno & - & 152.5 & $\theta$ & Puelps/scinell \\
\hline & & & & & \\
\hline & & & & & \\
\hline & & & & & \\
\hline & & & & & \\
\hline & & & & & \\
\hline & & & & & \\
\hline & & & & & \\
\hline & & & & & \\
\hline & & & & & \\
\hline & & & & & \\
\hline & & & & & \\
\hline & & & & & \\
\hline & & & & & \\
\hline & & & & & \\
\hline & & & & & \\
\hline & & & & & \\
\hline & & & & & \\
\hline & & & & & \\
\hline & & & & & \\
\hline & & & & & \\
\hline & & & & & \\
\hline & & & & & \\
\hline & & & & & \\
\hline & & & & & \\
\hline & & & & & \\
\hline & & & & & \\
\hline & & & & & \\
\hline & & & & & \\
\hline & & & & & \\
\hline
\end{tabular}




\section{Weston Solutions Magazine Data Card}

\begin{tabular}{|c|c|c|c|c|c|}
\hline Description: De & rd $80 \mathrm{gpf}$ & & & Location: A & rea 9, Igloo 8 \\
\hline Lot: $80 \mathrm{P} 113$ & & & & & \\
\hline Date & Purpose & Gain & Loss & Balance & Name \\
\hline 12-Jan-10 & receive & 500 & - & 500 & phelps/stebelski \\
\hline 19-Jan-10 & Inventory & $=$ & - & 500 & phelps/stebelski \\
\hline 20-Jan-10 & receive & 1500 & - & 2000 & phelps/stebelski \\
\hline 27:JAN10 & INV & - & - & 2000 & Phelps/stebelsk \\
\hline DSFEB 10 & $I N V$ & - & - & 2000 & Pulps/Stebelsk \\
\hline 10 FEB:O & INV & - & - & 2000 & Phelps/stebel \\
\hline $15 F E B 18$ & DEMO/ INV & 2 & 205 & 1795 & Pnel ps/stebe \\
\hline $23 \mathrm{FEB} 10$ & INV & - & - & 1795 & Phelps/stebe \\
\hline 03 MAR 10 & INV & - & - & 1775 & Pheles/stebelsk \\
\hline $09 \mathrm{MARM}$ & INV/DEMVDRAu & - & 20 & 1775 & fuelps/stebe \\
\hline 16 MAR ID & INV & $=$ & - & 1775 & Pneles/Stebcisk \\
\hline 1 Afr 10 & iNV & - & - & 1775 & Phelps/Stebeish \\
\hline 8 APr 10 & inv & - & - & 1775 & Phelps/stebelsk \\
\hline 13 APR 10 & iNV & - & $=$ & 1775 & Phelyostebelski \\
\hline 20 AfR 10 & $\mathrm{NNW}$ & - & - & 1775 & Prueles/stabels \\
\hline $28 \wedge P R ~ 10$ & DEAMC/ INV & $=$ & 43 & 1732 & Phelos stebeis \\
\hline 5 maty 10 & INV & - & - & 1732 & Phelps/stebelsk \\
\hline 12 MAY 10 & INV & - & - & 1732 & enelps/stebe/ski \\
\hline $15 \mathrm{maty} 10$ & DEMO & $=$ & 1732 & $-\theta$ & Puedes/schein \\
\hline & & & & & \\
\hline & & & & & \\
\hline & & & & & \\
\hline & & & & & \\
\hline & & & & & \\
\hline & & & & & \\
\hline & & & & & \\
\hline & & & & & \\
\hline & & & & & \\
\hline & & & & & \\
\hline & & & & & \\
\hline & & & & & \\
\hline & & & & & \\
\hline & & & & & \\
\hline & & & & & \\
\hline & & & & & \\
\hline & & & & & \\
\hline & & & & & \\
\hline & & & & & \\
\hline & & & & & \\
\hline & & & & & \\
\hline & & & & & \\
\hline & & & & & \\
\hline & & & & & \\
\hline & & & & & \\
\hline & & & & & \\
\hline & & & & & \\
\hline & & & & & \\
\hline
\end{tabular}




\section{Weston Solutions Magazine Data Card}

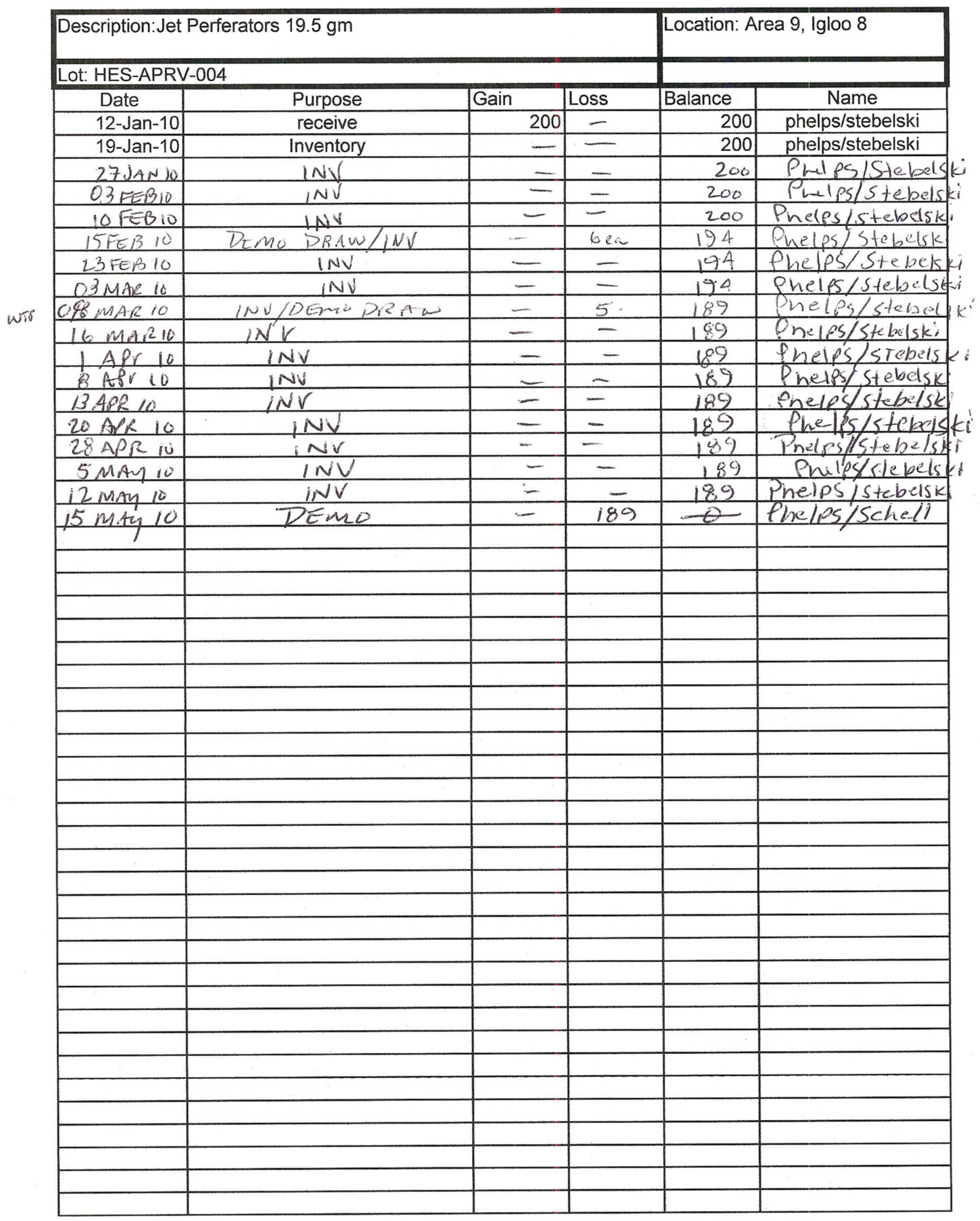




\begin{tabular}{|c|c|c|c|c|c|}
\hline Description: Ig & & & & Location: & Area 9 Igloo \# 8 \\
\hline Lot: 430 UG AJ & & & & & \\
\hline Date & Purpose & Gain & Loss & Balance & Name \\
\hline 25-Jan-10 & Received & 200 & $\infty$ & \begin{tabular}{r|}
200 \\
\end{tabular} & phelps/stebelski \\
\hline 27 JAN M & in & $\ldots$ & - & 200 & Phos/stenels \\
\hline 02 FEBDO & inv & - & - & 200 & Phelps/stebeis \\
\hline -O FEB & $\operatorname{lng}$ & $=$ & - & 200 & Pheips/STEBzes \\
\hline $15 F E B$ & DEMO PRAW/INV & - & 10 & 190 & Phelos/stebel \\
\hline $23 \operatorname{sen} 10$ & inV & - & - & 190 & Phelpsistebels \\
\hline $03 M A R 10$ & INV & - & - & 190 & Phelps/stebels \\
\hline $08 M A R 10$ & INV/DFM- PreAm & - & - & 190 & Phelos/stebel \\
\hline 16 MAR 10 & iNV & - & - & 190 & lneles/stebiski \\
\hline 1 Apr 10 & $1 N V^{\prime}$ & - & - & 190 & Phelps/stebelst \\
\hline 8 Apr 10 & NV & - & - & 120 & Pnelps/stebelski \\
\hline 13 APR 10 & WV & $=$ & - & 190 & Phipistebelski \\
\hline $20 A P R 10$ & iNV & - & - & 90 & Pheips/stepelsk \\
\hline $28 A f R ~ N$ & Denc/iNV & - & 7 & 183 & Phelpls/stebels \\
\hline 5 MAy 10 & inv & - & - & 183 & Phelps/stebeist \\
\hline 12 may 10 & inV & - & - & 183 & Pmelps/stebelski \\
\hline $15 \mathrm{MAy} 10$ & DEMO & - & 183 & $\theta$ & Pheifs/scinell \\
\hline & & & & & \\
\hline & & & & & \\
\hline & & & & & \\
\hline & & & & & \\
\hline & & & & & \\
\hline & & & & & \\
\hline & & & & & \\
\hline & & & & & \\
\hline & & & & & \\
\hline & & & & & \\
\hline & & & & & \\
\hline & & & & & \\
\hline & & & & & \\
\hline & & & & & \\
\hline & & & & & \\
\hline & & & & & \\
\hline & & & & & \\
\hline & & & & & \\
\hline & & & & & \\
\hline & & & & & \\
\hline & & & & & \\
\hline & & & & & \\
\hline & & & & & \\
\hline & & & & & \\
\hline & & & & & \\
\hline & & & & & \\
\hline & & & & & \\
\hline & & & & & \\
\hline & & & & & \\
\hline & & & & & \\
\hline
\end{tabular}




\section{Attachment 2}

Excerpts from

After-Action Report for the

Corrective Action Unit (CAU) 408 Bomblet Target Area

Munitions and Explosives of Concern

Surface Clearance

Tonopah Test Range, Nevada

Prepared by EOD Technology, Inc.

$$
\text { (46 Pages) }
$$




\title{
AFTER ACTION REPORT
}

FOR THE

\section{CORRECTIVE ACTION UNIT (CAU) 408 BOMBLET TARGET AREA MUNITIONS AND EXPLOSIVES OF CONCERN SURFACE CLEARANCE TONOPAH TEST RANGE, NEVADA}

PREPARED FOR:

\author{
Navarro Nevada Environmental Services, LLC, a Joint Venture \\ Attn: Mark Burmeister \\ 232 Energy Way \\ N. Las Vegas, NV 89030
}

Subcontract Number: NNES-ECRS 09

Under Contract Number: CE-AC52-09NA28091

PREPARED BY:

\section{EODT \\ RANGEX CHANGE}

2229 Old Highway 95

Lenoir City, Tennessee 37771

September 2010 


\section{AFTER ACTION REPORT}

FOR THE

\section{CORRECTIVE ACTION UNIT (CAU) 408 \\ BOMBLET TARGET AREA \\ MUNITIONS AND EXPLOSIVES OF CONCERN \\ SURFACE CLEARANCE \\ TONOPAH TEST RANGE, NEVADA}

PREPARED FOR:

Navarro Nevada Environmental Services, LLC, a Joint Venture

Attn: Mark Burmeister

232 Energy Way

N. Las Vegas, NV 89030

Subcontract Number: NNES-ECRS 09

Under Contract Number: CE-AC52-09NA28091

PREPARED BY:

\section{EODT \\ EOD TECHNOL.OGY, INC \\ RANGE $\mathbf{Y}$ CHANGE}

2229 Old Highway 95

Lenoir City, Tennessee 37771

/s/ William R. Brown

William (Bill) R. Brown, Jr., Ed.S. Project Manager

/s/ Signature on file for

Kevin Corbett, Corporate Quality Manager

/s/ Matthew G. Hughs

Matthew G. Hughs, RangeXchange ${ }^{(\mathbb{R}}$ Program Manager

September 2010 


\section{TABLE OF CONTENTS}

SECTION

PAGE

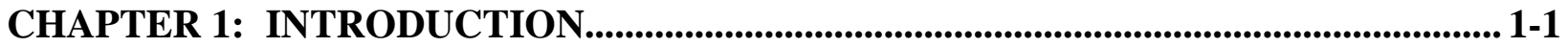

1.1 GENERAL PROJECT DESCRIPTION AND OBJECTIVE ............................ 1-1

1.1.1 Description/Authorization................................................................ 1-1

1.1.2 General Statement of Work ......................................................... 1-1

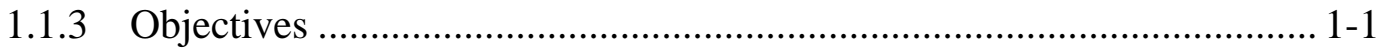

1.1.4 Report Organization...................................................................... 1-2

1.2 BACKGROUND INFORMATION …....................................................... 1-2

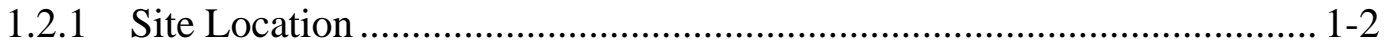

1.2.2 Current Site Use ............................................................................... 1-2

1.3 STATEMENT OF PROBABILITY OF SOLUTION …................................... 1-4

CHAPTER 2: TECHNICAL APPROACH...................................................................... 2-1

2.1 GENERAL INFORMATION .................................................................. 2-1

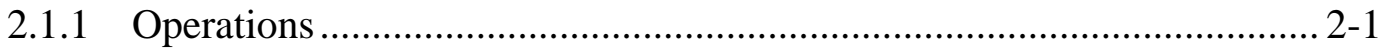

2.1.2 Phase One: Production and Approval of the Work Plan......................... 2-2

2.1.3 Phase Two: Mobilization of Personnel and Equipment......................... 2-2

2.1.4 Phase Three: Surface and/or Subsurface Clearance of Four Sites.......... 2-2

2.1.4.1 South Flight-line Tomahawk 1 Target Buffer Zone ................. 2-2

2.1.4.2 South Antelope Lark Target Area.......................................... 2-3

2.1.4.3 CAU-408 Buffer Area.......................................................... 2-3

2.1.4.4 Buffer Zone Step-Out Area.................................................... 2-3

2.1.4.5 CAU 400 Bomblet Pit.......................................................... 2-4

2.1.4.6 MEC Related Items ........................................................... 2-4

2.2 DEMOLITION OPERATIONS................................................................ 2-5

2.3 ARCHAELOGICAL SITES AND ENVIRONMENTALY SENSITIVE

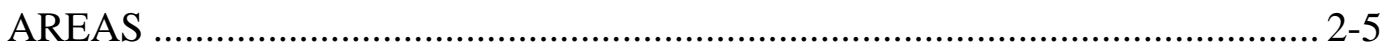

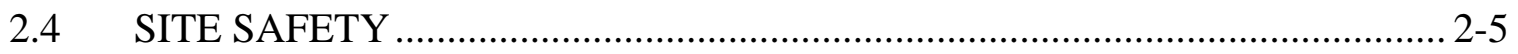

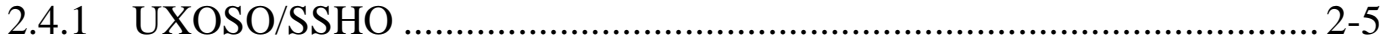

2.4.2 UXOQCS .................................................................................. 2-5

2.4.2.1 Preparatory Phase Oversight............................................... 2-5

2.4.2.2 Initial Phase Oversight ...................................................... 2-6

2.4.2.3 Follow-up QC Oversight.................................................... 2-6

2.4.2.4 Personnel Qualifications ..................................................... 2-7

2.4.3 Safety Training and Briefing ........................................................... 2-7 
2.4.3.1 Daily General Briefing........................................................ 2-7

2.4.3.2 Daily Tailgate Briefing ………………………..................... 2-8

2.4.3.3 Additional Training............................................................. 2-8

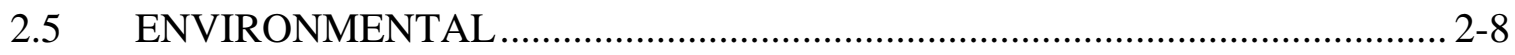

2.5.1 Environmental Awareness .............................................................. 2-8

2.5.2 Safety and Environmental Violations ................................................. 2-8

2.6 COMPLANCE WITH PLANS AND PROCEDURES ………........................ 2-9

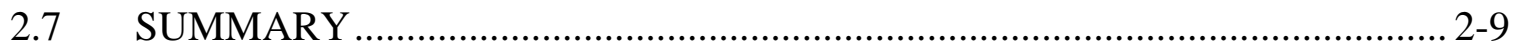

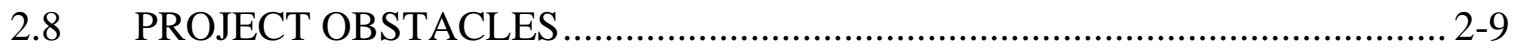

\section{LIST OF TABLES}

Table 2-1: $\quad$ Field Work On-Site. 2-9

\section{LIST OF FIGURES}

Figure 1-1: General Site Location $1-3$

\section{APPENDICES}

Appendix A Scope of Work

Appendix B Site Maps

Appendix C Site Photos

Appendix D SUXOS Log Appendix E Quality Control Documents Appendix F. Grid Tracking Log Appendix G Daily Production Report Appendix $\mathrm{H}$ Munitions and Explosives of Concern Inventory List Appendix I Demolition Operations Documentation 


\section{ACRONYMS AND ABBREVIATIONS}

$\begin{array}{ll}\text { CAU } & \text { Corrective Action Unit } \\ \text { CBU } & \text { Cluster Bomb Unit } \\ \text { DDESB } & \text { Department of Defense Explosive Safety Board } \\ \text { DID } & \text { Data Item Description } \\ \text { DoD } & \text { Department of Defense } \\ \text { DOE } & \text { Department of Energy } \\ \text { EM } & \text { Engineering Manual } \\ \text { EODT } & \text { EOD Technology, Inc. } \\ \text { FCR } & \text { Field Change Request } \\ \text { GPS } & \text { global positioning system } \\ \text { GTL } & \text { grid tracking log } \\ \text { HE } & \text { High Explosives } \\ \text { MD } & \text { Munitions Debris } \\ \text { MEC } & \text { Munitions and Explosives of Concern } \\ \text { MMPEH } & \text { material potentially presenting explosive hazard } \\ \text { NNES } & \text { Navarro Nevada Environmental Service, LLC } \\ \text { NTP } & \text { notice to proceed } \\ \text { OSHA } & \text { Occupational Safety and Health Administration } \\ \text { PM } & \text { Project Manager } \\ \text { PWS } & \text { Performance Work Statement } \\ \text { QA } & \text { quality assurance } \\ \text { QC } & \text { quality control } \\ \text { QCM } & \text { Quality Control Manager } \\ \text { QCP } & \text { Quality Control Plan } \\ \text { RRD } & \text { Range Related Debris } \\ \text { SNJV } & \text { Stoller Navarro Joint Venture } \\ \text { SOP } & \text { standard operating procedure } \\ \text { SOW } & \text { Statement of Work } \\ \text { SSFR } & \text { Site Specific Final Report } \\ \text { SSHASP } & \text { Site Specific Health and Safety Plan } \\ \text { SSHO } & \text { Site Safety and Health Officer } \\ \text { SUXOS } & \text { Senior Unexploded Ordnance Supervisor } \\ \text { TM } & \text { Technical Manual } \\ \text { TTR } & \text { Tonopah Test Range } \\ \text { UXO } & \text { Unexploded Ordnance } \\ \text { UXOSO } & \text { Unexploded Ordnance Safety Officer } \\ \text { UXOQCS } & \text { Unexploded Ordnance Quality Control Specialist } \\ & \end{array}$




\section{CHAPTER 1 INTRODUCTION}

\subsection{GENERAL PROJECT DESCRIPTION AND OBJECTIVE}

\subsubsection{Description/Authorization}

EOD Technology, Inc. (EODT) conducted an Unexploded Ordnance (UXO)/Disposal Pit Investigation and Sub-munition Clearance, Tonopah Test Range (TTR), Corrective Action Unit (CAU) 408 Bomblet Target Area. Authorization for performance of this work is contained in Contract NNES-ECRS 09 which was issued from Navarro Nevada Environmental Services, LLC (NNES) 22 January 2010 under Stoller-Navarro Joint Venture (SNJV) Prime Contract DEAC52-03NA99205 with the United States Department of Energy (DOE), National Nuclear Security Administration Nevada Site Office.

\subsubsection{General Statement of Work}

EODT accomplished the following:

- $\quad$ Attended training as required by prime contractor

- $\quad$ South Antelope Lake Target Area was surface cleared to a depth of 1 foot below ground for munitions and explosives of concern (MEC) using geophysical detection equipment

- $\quad$ Additional buffer zone surrounding the target areas was surface swept without geophysical instrumentation

- $\quad$ South Flight-line Tomahawk 1 Target Buffer Zone was surface swept without geophysical instrumentation

\subsubsection{Objectives}

The objective of this Munitions and Explosives of Concern (MEC) surface clearance was to use "Mag and Dig" surveys as the selected method for surveying and detect surface and shallow (up to $1.0 \mathrm{ft}$ below grade) anomalies that may represent MEC. This After Action Report identifies the work procedures and processes that were executed by EODT to accomplish the Statement of Work (SOW).

- $\quad$ Prepare a comprehensive Work Plan and a Site Specific Health and Safety Plan (SSHASP). Both clearly state the procedures used to complete the project and fulfill the requirements of the Occupational Safety and Health Administration (OSHA), Department of Defense (DoD) Demilitarization Manual (DoD 4160.21-M-1), and the applicable rules and regulations governing Range Related Debris (RRD) and scrap disposal actions. 
- Use fully qualified UXO personnel in accordance with the Performance Work Statement (PWS), EODT will conduct surface and subsurface clearance as necessary.

- Inspect, certify, and dispose of Munitions Debris (MD), and RRD in accordance with the DoD 4160.21-M-1.

- $\quad$ Properly stage trash, non-recyclable scrap, and range residue for disposal at a later date.

\subsubsection{Report Organization}

This report has been organized in a manner that is consistent with the requirements of the SOW.

\subsection{BACKGROUND INFORMATION}

\subsubsection{Site Location}

CAU 408 is located at TTR, Nevada. TTR is approximately 235 miles (mi) northwest of Las Vegas, Nevada. CAU 408 includes several areas where bomblet drops were conducted from the late 1960s to 1985 as part of testing and development programs for improved sub-munition dispersion coverage and Cluster Bomb Unit (CBU) accuracy. Sub-munitions consist of various types of small spherical and cylindrical ordnance that range in size from two (2) to four (4) inches. A sub-munition bomblet is defined as an intact ordnance item that was dispersed from a CBU. After release from the aircraft, the CBUs would open and disperse the bomblets over the target areas. The bomblets used were mainly inert; however, several live tests (containing high explosives [HEs]) were also conducted. The TTR site is shown on Figure 1-1.

\subsubsection{Current Site Use}

TTR is currently an active military installation.

(This space intentionally left blank.) 


\section{FIGURE 1-1: GENERAL SITE LOCATION}

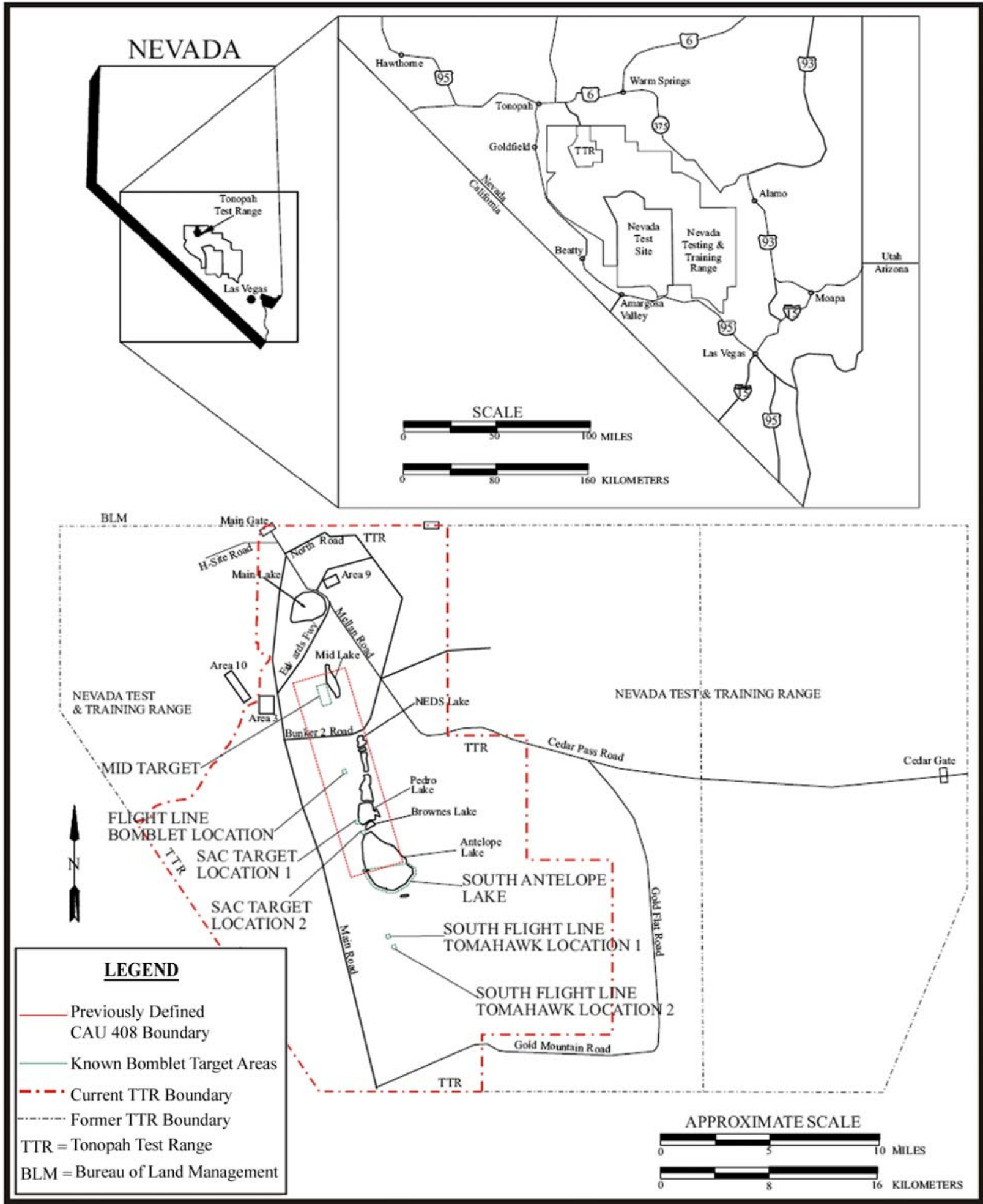

Contract Number: NNES-ECRS 09 


\subsection{STATEMENT OF PROBABILITY OF SOLUTION}

EODT is confident that all requirements for completion of this task order have been met at

Tonopah Test Range, Nevada. 


\section{CHAPTER 2 TECHNICAL APPROACH}

\subsection{GENERAL INFORMATION}

All project associated activities were conducted in full compliance with DOE, Nevada Navarro Environmental Services work safety and health program (10 CFR 851), CAU 408 SSHASP, and EODT requirements regarding personnel, equipment and procedures. As a minimum, the explosive safety requirements and criteria pertaining to the detection, identification, handling and marking of MEC located in the clearance area were govern by the following reference documents:

- $\quad$ DOE Manual 440.1-1A, DOE Explosive Safety Manual
- $\quad$ Engineering Manual (EM) 385-1-1
- $\quad$ CAU 408 Site-Specific Health And Safety Plan
- $\quad$ Technical Manual (TM) 60A-1-1-31
- $\quad$ DoD Explosive Safety Board (DDESB) Technical Paper (TP) 16
- $\quad$ EODT Standard Operating Procedures (SOPs)

\subsubsection{Operations}

Initial clearance area was 500 acres of the 1900 acre CAU-408. Clearance area was divided into $100 \mathrm{~m} \times 100 \mathrm{~m}$ grids for the South Antelope Lake Target Area. Maps and global position system (GPS) coordinates for the clearance area were provided by the customer. Clearance operations consisted of four, two- man sweep teams using a mag and dig technique to identify MEC to a depth of 1'. All anomalies or detections on the White's XLT magnetometers greater than 1' bgs were investigated. Sweep teams cleared grids by dividing grids into sweep lanes and operating GPS with track log initiated. These track logs were downloaded each day to incorporate into a grid mapping system. See Appendix B and F. Sweep lanes usage ensures 100\% coverage of the grid being cleared. Once MEC was identified, it was conspicuously marked and the location logged into the Garmin GPS. Grid sheets were used to log all pertinent data for each grid.

Sweep lanes were identified by spray painting the ground. The sweep teams consisted of one person operating the White's XLT magnetometer and a second person using a shovel to uncover the anomaly detected by the locator operator. The White's XLT magnetometer was chosen because of its all metal capability and the XLT is a machine that is simple to use and has different combinations of settings. The White's XLT's flexibility in adjusting to any soil conditions makes the detector an outstanding multi-purpose magnetometer. Each White's XLT magnetometer was validated each day through a function check in a predetermined anomaly 
field. Anomalies were unearthed by digging from the side of the item until a positive identification can be made. Anomalies determined to be MEC were categorized as either consolidate for disposal or blow in place. The Senior Unexploded Ordnance Supervisor (SUXOS) made this determination. Non-MEC items were consolidated in a designated area.

The SUXOS provided the customer with a grid tracking log (GTL) containing grid status consisting of grid name, MEC quantity, non-MEC quantity, MEC nomenclature, MEC status, MEC totals, burial pit information, and Seed information. In addition, Garmin GPS files were provided for inclusion in the database.

Visual sweeps were conducted in the buffer zone which included step-out mag and dig surveys of a 200-ft radius if MEC items were found. This step-out process was conducted in all directions until a $200-\mathrm{ft}$ radius was established without discovering MEC items.

The overall TTR CAU-408 Project was broken down into three manageable phases to ensure mission accomplishment of all the requirements within the SOW. These phases allowed EODT and the DOE representatives to track progress and efficiency of all the work to be conducted on TTR. The phases also provided milestones for EODT accounting and prevented any back logged invoices for the government. The following is a brief description of the phases and the work completed during each phase.

\subsubsection{Phase One: Production and Approval of the Work Plan}

On 4 February 2010 EODT completed and e-mailed the Draft Work Plan to Mark Burmeister (NNES PM) for review. On 5 February 2010, EODT received a response from Mark Burmeister approving the Draft Work Plan as Final.

\subsubsection{Phase Two: Mobilization of Personnel and Equipment}

Upon receiving the notice to proceed (NTP) from DOE, EODT immediately implemented a 2 stage plan. Stage one consisted of mobilization of the main work crew to TTR on 1 February, 2010. On 2 February, 2010, EODT personnel commenced stage two, which included site specific training at DOE facilities located in Las Vegas, NV. EODT completed site specific training on 5 February, 2010 and commenced field operations on 8 February 2010 at 0600.

\subsubsection{Phase Three: Surface and/or Subsurface Clearance of Four Sites}

\subsubsection{South Flight-line Tomahawk 1 Target Buffer Zone}

The first major task to be completed was the surface clearance of the South Flight-line Tomahawk 1 Target Buffer Zone consisting of 463 acres. One team was used to perform the clearance operations. This surface clearance was accomplished utilizing visual sweeps on foot 
and in Universal Terrain Vehicles (UTVs). All Munitions and Explosives of Concern (MEC) items deemed safe and acceptable to move were either marked and left in place or moved to a central location. All routes and buffer areas were clearly marked with orange spray paint to ensure the safety of down range personnel. No step-out mag and dig surveys were performed. On 16 February 2010, EODT completed the clearance of all south flight-line Tomahawk 1 target buffer areas. See Appendix B for site map.

\subsubsection{South Antelope Lake Target Area}

The second major task to be completed was the surface and subsurface clearance of the South Antelope Lake Target Area consisting of 494 acres. One team was used to perform the clearance operations. All Munitions and Explosives of Concern (MEC) items deemed safe and acceptable to move were either marked and left in place or moved to a central location. All routes and buffer areas were clearly marked with orange spray paint to ensure the safety of down range personnel. Step-out mag and dig surveys were performed around the MEC found in grid 90/68. On 12 March, 2010, EODT completed the clearance of all South Antelope Lake Target Areas. See Appendix B for site map.

\subsubsection{CAU-408 Buffer Area}

The third major task to be completed was the "visual sweep" and then surface clearance of any MEC items found in the CAU-408 Buffer Area consisting of 5,700 acres. One team was used to perform the "visual sweep" and clearance operations. All MEC items deemed safe and acceptable to move were either marked and left in place or moved to a central location. If Submunitions were located, a 200 foot step-out procedure was initiated. This process was utilized on all Submunition found until a clear 200 foot radius was achieved as shown in Appendix B for the BLU-63 found in grid 90/688.. All routes and buffer areas were clearly marked with orange spray paint to ensure the safety of down range personnel. See Appendix B for site map.

\subsubsection{Buffer Zone Step-Out Area}

The fourth major task to be completed was the mag and dig clearance of all MEC items found in the CAU-408 Buffer Area. The overall acreage that was mag and dug was 171 acres. One team was used to perform the mag and dig clearance operations. All MEC items deemed safe and acceptable to move were either marked and left in place or moved to a central location. If Submunitions were located, a 200 foot step-out procedure was initiated. This process was utilized on all Sub-munitions and MEC found until a clear 200 foot radius was achieved, as indicated in Appendix B where MEC items are indicated, the 200 foot step-out procedure was accomplished. All routes and buffer areas were clearly marked with orange spray paint to ensure the safety of down range personnel. On 13 July 2010, EODT completed the mag and dig clearance of the step-out area. See Appendix B for site map. 


\subsubsection{CAU 400 Bomblet Pit}

A Mag and Dig clearance survey was completed in and around the former CAU 400 Bomblet Pit. The CAU 400 Bomblet Pit is located just outside the eastern edge of the CAU 408 Buffer Zone, and was included within the scope of CAU 408 as a Best Management Practice. The Mag and Dig survey encompassed the area inside the fenced area, and extended out approximately 100 meters in 15 grids (see figure in Appendix B of this document). A supplemental visual inspection was conducted outside the grids extending 100 meters beyond the grid. Eighteen MEC items (six BLU-63s, sic MK118 fuses, one M219E1 fuse, and one 8” projectile), and approximately 900 pounds of munitions debris was recovered from this location.

\subsubsection{MEC Related Items}

MEC items and their weights, which were removed from South Flight-line Tomahawk 1 Target, South Antelope Lake Target Area CAU-408 buffer and Buffer Zone Step-out area can be found in Appendix H. In order to accomplish this objective EODT followed the following process:

1. During the course of range related debris processing and removal, any MEC-related items found were inspected using Chapter 14 of Engineering Manual (EM) 1110-1-4009 as described in the SOW to positively confirm the presence or absence of explosives. Live ordnance items were found and either marked and left in place or moved for demolition at a later date. MD was removed from the range.

2. No operational photographs displaying demilitarization activities were authorized for EODT personnel. Daily activities are documented in the SUXOS Log contained in Appendix D.

3. Upon completion of processing, all materials were re-inspected for the presence of material potentially presenting explosive hazard (MPPEH) as part of ongoing quality surveillance and audit activities and to certify the material as "free from MPPEH." This process was performed by the onsite UXO Safety Officer/Site Safety and Health Officer (UXOSO/SSHO) to ensure strict compliance with EODT SOPs and the Work Plan. Appendix E contains quality control (QC) documents.

4. EODT moved all range related debris removed from the TTR ranges and piled the debris in predetermined areas. Appendix F contains the grid tracking logs.

5. EODT used White's XLT Detectors to identify items up to one foot depth in areas that were subsurface cleared. Daily QC checks were performed to ensure instruments were performing properly. 


\subsection{DEMOLITION OPERATIONS}

Six demolition operations were performed on 16 August, 2010 to countercharge recovered MEC items within the TTR complex (See Appendix I).

\subsection{ARCHEOLOGICAL SITES AND ENVIRONMENTALLY SENSISITIVE AREAS}

EODT encountered no archeological sites or environmentally sensitive areas

\subsection{SITE SAFETY}

\subsubsection{UXOSO/SSHO}

EODT's UXOSO/SSHO monitored site safety on a continual basis to verify procedures and ensure compliance with the Work Plan, SSHP, and applicable OSHA regulations. Each morning prior to the start of work, a site-specific safety briefing was conducted and attended by all personnel working at the site. EODT personnel experienced no accidents or incidents during the duration of the CAU-408 project.

\subsubsection{UXOQCS}

The UXO Quality Control Specialist (UXOQCS) had the responsibility and authority to enforce the site-specific Quality Control Plan (QCP) procedures. The UXOQCS responsibilities were:

- Coordinating with the DOE quality assurance (QA) representative to ensure that QA/QC objectives appropriate to the project are established and that all personnel are aware of these objectives

- Conducting periodic QC surveillance of site work processes IAW DOE requirements and recording the results on the appropriate documents for submission to DOE representatives

- Recommending and implementing actions to be taken in the event of a QC deviation to include "stop-work" authority

- Reporting noncompliance with QC criteria to the Field Quality Control Manager (QCM) and Project Manager (PM)

The UXOQCS utilized the "three phases of control" for QC oversight purposes. The UXOQCS oversaw the preparatory, initial, and follow up activities for all field operations.

\subsubsection{Preparatory Phase Oversight}

The Preparatory Phase of QC oversight was used during the pre-operational training step of project operations and was performed by the UXOQCS. This phase of QC oversight was used by the UXOQCS to ensure all pre-operational actions were met and that each field team was properly prepared to conduct field operations. All deficiencies were corrected on the spot or brought to the attention of the SUXOS for immediate attention. 
Work plans and operating procedures were reviewed by the PM to ensure they describe prequalifying requirements or conditions, equipment and materials, appropriate sequence, methodology, and QC provisions. The UXOQCS verified the following:

- All plans and submittals were prepared and approved, and were available to field personnel.

- Appropriate field equipment was available, functional, and properly calibrated.

- Responsibilities were assigned and communicated.

- The job hazards in the Accident Prevention Plan were communicated and the necessary safety measures were in place.

- Field personnel had the necessary knowledge, expertise, and information to perform their duties.

- Arrangements for support services were made and the prerequisite site work was completed.

- Discrepancies between existing conditions and approved plans/procedures would be resolved and corrective actions taken for unsatisfactory and nonconforming conditions identified during the preparatory phase.

\subsubsection{Initial Phase Oversight}

An initial phase of QC oversight was performed by the UXOQCS the first time selected tasks were performed. This phase of QC oversight included:

- Check the preliminary work for compliance with procedures and contract specifications.

- Verify inspection and testing

- Establish the acceptable level of proficiency

- Check and upgrade safety compliance.

- Review the Preparatory Phase QC oversight observations to ensure that any required changes have been incorporated into site activities.

- Check for omissions and resolve differences in interpretation.

- The PM and UXOQCS will ensure discrepancies between site practices and approved specifications that have been identified are resolved before granting approval to proceed.

\subsubsection{Follow-up QC Oversight}

A follow-up phase of QC oversight was performed on project processes periodically during operations. This ongoing oversight ensured continued compliance and quality. The UXOQCS monitored the practices and operations and verified continued compliance with approved project plans. No Stop Work Orders were completed or issued. 
The UXOQCS oversaw and observed the same activities as under the initial phase. Discrepancies between site practices and the approved plans/procedures were resolved and no corrective actions for unsatisfactory and nonconforming conditions or practices was issued. QC Operations included:

- Daily checks of detection equipment in established test grids. If an instrument failed the detection test the instrument was removed from service, checked for defects, and repaired or tagged and removed from service.

- $10 \%$ QC of Tomahawk One Target area visual sweep.

- $25 \%$ of each grid completed was the initial requirement until 4 consecutive grids passed QC inspection. Per the WP, after the first 4 grids passed QC inspection the requirement then was reduced to checking $10 \%$ of each grid completed. If any of the $10 \%$ of grids checked did not pass the QC process, then the $25 \%$ grid requirement would be reinstated. During the entire CAU-408 project no seeds were missed during the $10 \%$ grid process.

- QC seed program of South Antelope grid area consisted of one seed per 4 grids, per instructions from DOE representatives. A seed program for visual sweep areas, step-out areas, etc., was demonstrated to be impractical.

- $10 \%+$ QC of all visual sweeps conducted.

- $10 \%+$ QC conducted on all added subsurface sweeps and associated step-out areas.

- QC of daily and weekly reports, data, and documentation. No major findings were reported during the CAU-408 UXO project.

\subsubsection{Personnel Qualifications}

Personnel qualifications were in accordance DoD Explosive Safety Board (DDESB) Technical Paper (TP) 16. The initial composition of the EODT UXO team consisted of a Senior Unexploded Ordnance Supervisor (SUXOS), UXOSO/SSHO, UXO Technician III, and five UXO Technician II personnel. EODT provided qualified UXO Technicians that were Explosive Ordnance Disposal (EOD) School trained and had at least five years military EOD and/or civilian experience. This requirement provided a team of well trained and experienced UXO personnel for the TTR project.

\subsubsection{Safety Training/Briefing}

EODT conducted two distinct safety meetings and briefings:

- $\quad$ Daily general briefing

- Daily tailgate safety briefing

\subsubsection{Daily General Briefing}

The daily general briefing was conducted for all personnel prior to beginning daily operations. A written record of this training and the signatures of personnel attending the training were 
maintained. The briefing covered general hazards for the project and any new safety, security, and intelligence issues or hazards that were identified since the last briefing. This briefing was conducted by the UXOSO/QCS and the Senior Security Specialist. The SUXOS discussed the operations scheduled for the day.

\subsubsection{Daily Tailgate Briefing}

The NNES Supervisor conducted tailgate safety briefings with input from all team members. The training focused on the specific hazards anticipated at each work site during that day's operations and the safety measures that were used to eliminate or mitigate those hazards. The training also referred to other operations within the area whose proximity may have safety ramifications. As work progressed and team locations changed within the site, or from site-tosite, any corresponding changes in ingress/egress routes and emergency evacuation routes were also reviewed during this tailgate briefing. Communications procedures for access to response forces and medical support were briefed and a readily available list was located at appropriate locations, i.e. in personnel notebooks, near communications gear and SUXOS/Team Leader logbook.

\subsubsection{Additional Training}

Initial site training was provided by personnel representing DOE in Las Vegas, NV and once onsite at TTR. Radiological worker I and II training was provided to all EODT personnel.

\subsection{ENVIRONMENTAL}

\subsubsection{Environmental Awareness}

Environmental concerns and issues were discussed as part of safety and operational briefs, with the objective of minimizing impact to the surrounding environment. During the CAU-408 project, the UXO team encountered extreme winter conditions such as snow and frigid cold temperatures. As the project progressed they also experienced extreme summer conditions such as high winds and temperatures approaching 100 degrees.

\subsubsection{Safety and Environmental Violations}

There were no safety violations or unsafe acts during the CAU-408 project phase. Additionally, there were no reckless interference with sensitive species or blatant disregard for environmental issues.

\subsection{COMPLIANCE WITH PLANS AND PROCEDURES}

EODT conducted operations in a systematic manner using proven operating methods and techniques. All activities were conducted under the direction, supervision, and observation of the SUXOS, UXOSO/QC, and UXO Technician III. All personnel strictly adhered to approved 
plans and established procedures. When operational parameters changed and there was a corresponding requirement to change procedures or routines, careful evaluation of such changes were conducted by on-site supervisory personnel.

\subsection{SUMMARY}

DOE representatives have provided outstanding over site on a project that had many weather related problems such as wind, snow, cold and extreme heat. Both companies have been very supportative of EODT personnel requirements, both on a personal and professional level. The TTR site manager has handled each situation in an extremely professional manner. His knowledge of the site, base personnel, and his support in providing needed assets has been invaluable. In support of this contract, see Table 2-1 for personnel exposure data.

TABLE 2-1: FIELD WORK ON SITE

\begin{tabular}{|c|c|c|c|}
\hline $\begin{array}{c}\text { Total Days of } \\
\text { Field Work }\end{array}$ & $\begin{array}{c}\text { EODT Man-Hours } \\
\text { Worked On Site }\end{array}$ & $\begin{array}{c}\text { On-the-Job } \\
\text { Accident }\end{array}$ & $\begin{array}{c}\text { Lost Work Days Resulting from } \\
\text { On-the-Job Accident }\end{array}$ \\
\hline 112 & 7,970 & 0 & 0 \\
\hline
\end{tabular}

\subsection{PROJECT OBSTACLES}

EODT had plans in place to seek approval from DOE to make adjustments that benefit the DOE, the Government and EODT in the event that unforeseen circumstances arose that could result in a modification of the Work Plan. During every task performed at TTR, EODT's original plan fit all the situations encountered on the ground and a Field Change Request (FCR) was not required. 


\title{
APPENDIX A \\ STATEMENT OF WORK
}

FOR THE

\section{CORRECTIVE ACTION UNIT (CAU) 408 BOMBLET TARGET AREA MUNITIONS AND EXPLOSIVES OF CONCERN SURFACE CLEARANCE TONOPAH TEST RANGE, NEVADA}

\author{
PREPARED FOR:

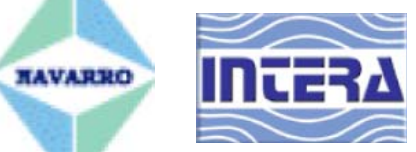 \\ Navarro Nevada Environmental Services, LLC, a Joint Venture \\ Attn: Mark Burmeister \\ 232 Energy Way \\ N. Las Vegas, NV 89030
}

Subcontract Number: NNES-ECRS 09

Under Contract Number: CE-AC52-09NA28091

PRePARed BY:

\section{EODT}

EOD TECHNOLLOGY,INC

RANGE 2 CHANCE

2229 Old Highway 95

Lenoir City, Tennessee 37771

July 2010 
This appendix is not included in the CAU 408 Closure Report due to size constraints.

UNCONTROLLED When Printed 


\title{
APPENDIX B SITE MAPS
}

FOR THE

\section{CORRECTIVE ACTION UNIT (CAU) 408 BOMBLET TARGET AREA MUNITIONS AND EXPLOSIVES OF CONCERN SURFACE CLEARANCE TONOPAH TEST RANGE, NEVADA}

\author{
PREPARED FOR: \\ mayane \\ Intras \\ Navarro Nevada Environmental Services, LLC, a Joint Venture \\ Attn: Mark Burmeister \\ 232 Energy Way \\ N. Las Vegas, NV 89030
}

Subcontract Number: NNES-ECRS 09

Under Contract Number: CE-AC52-09NA28091

PRePARed BY:

\section{$E O D T$}

EOD TECHNOLLOGY,

RANGE 2 CHANCE

2229 Old Highway 95

Lenoir City, Tennessee 37771

July 2010 


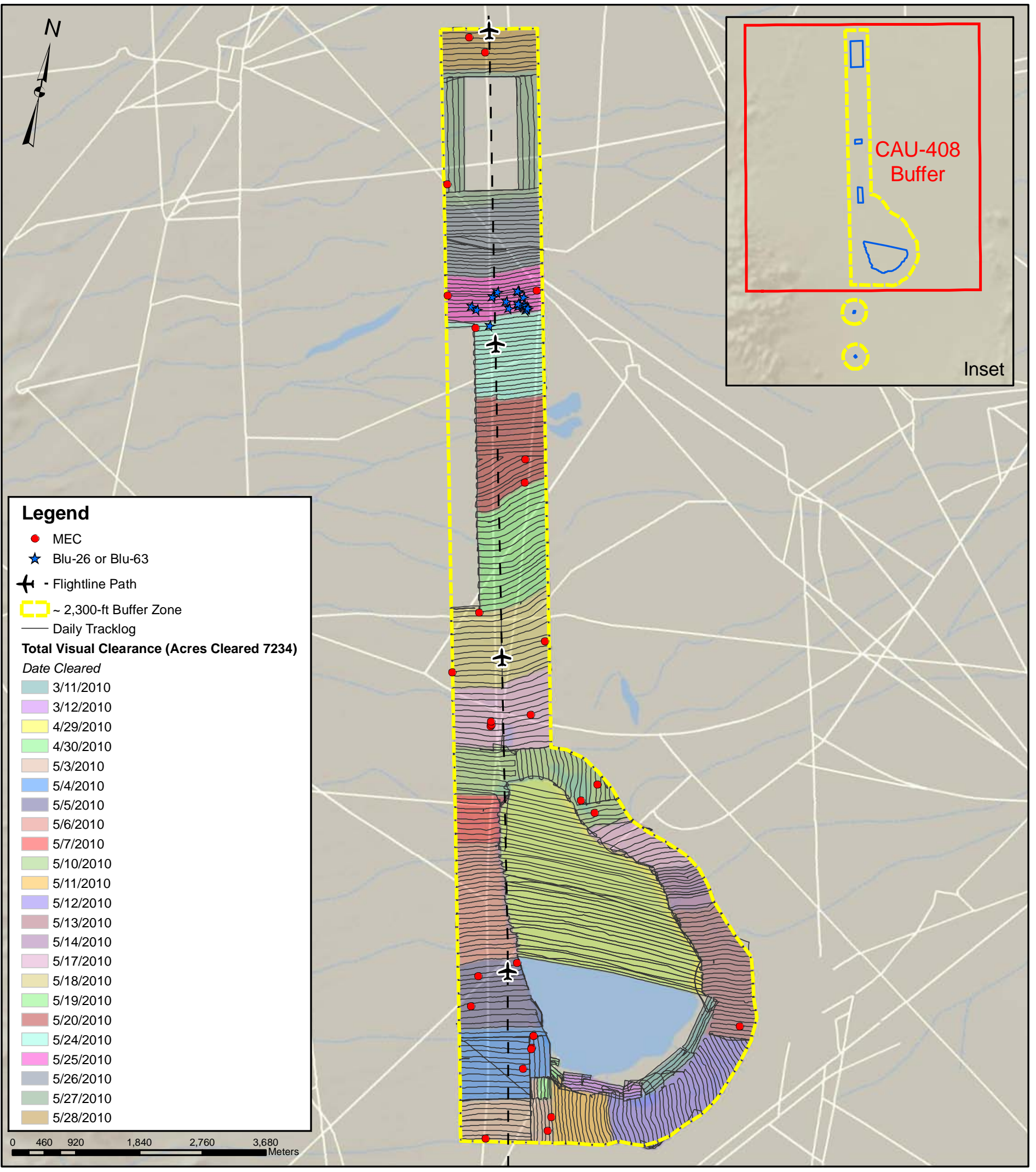

CORRECTIVE ACTION UNIT (CAU-408) BUFFER 


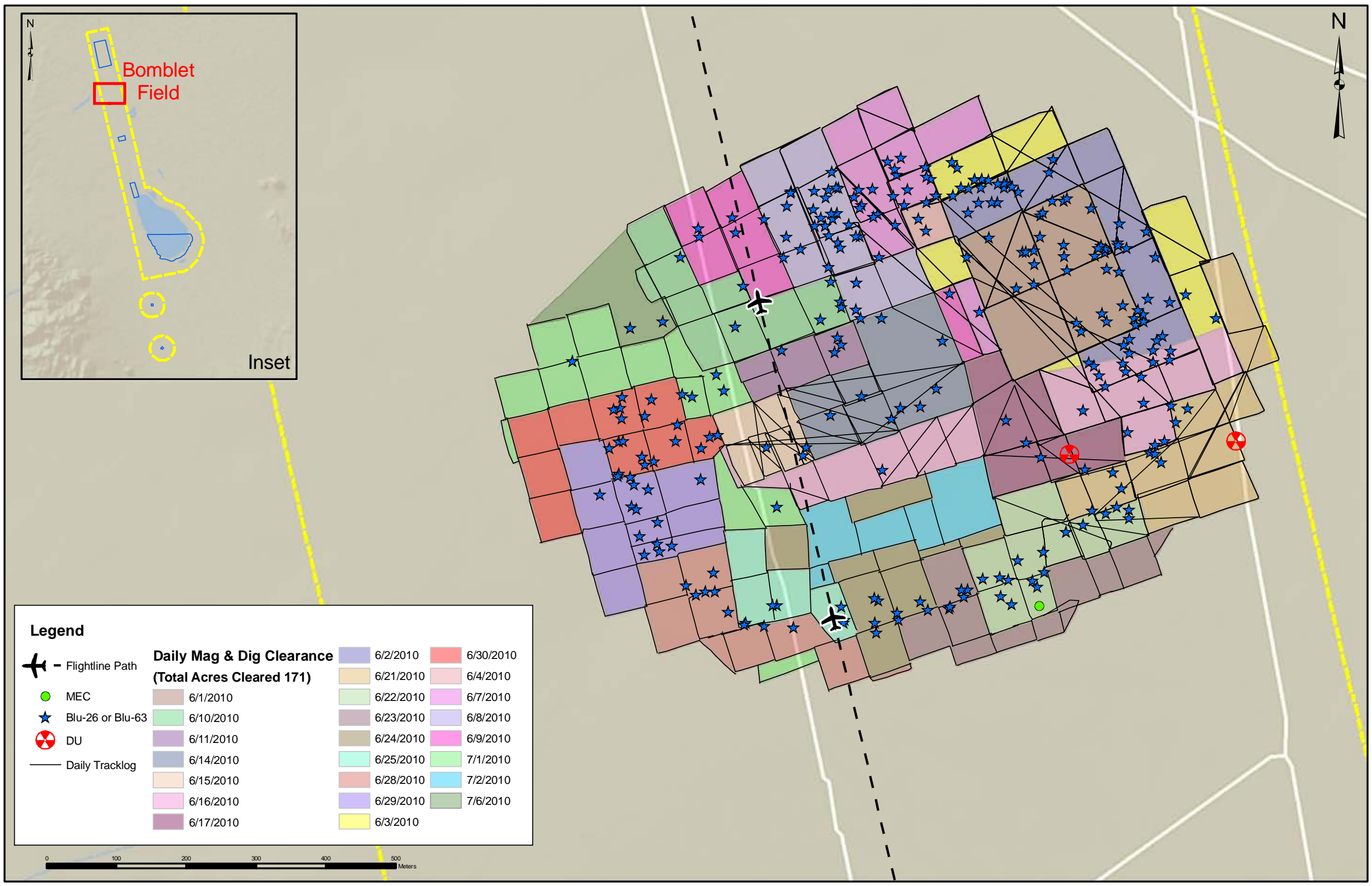

CAU-408 BUFFER ZONE BOMBLET FIELD

Contract Number: NNES-ECRS 09 


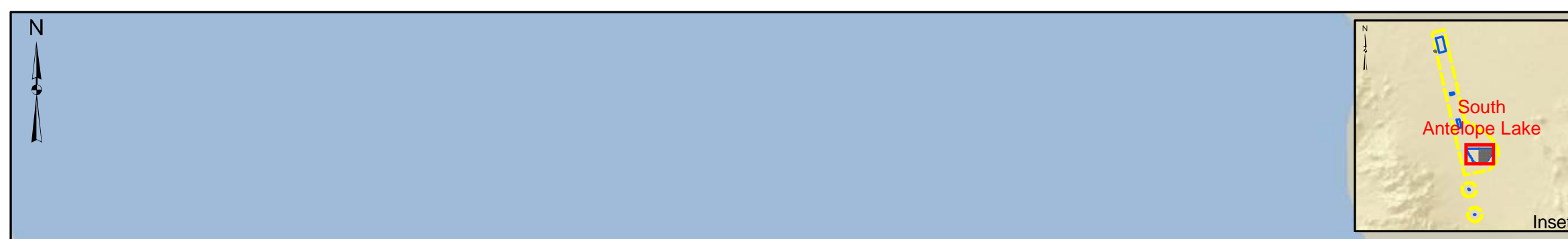

Inset

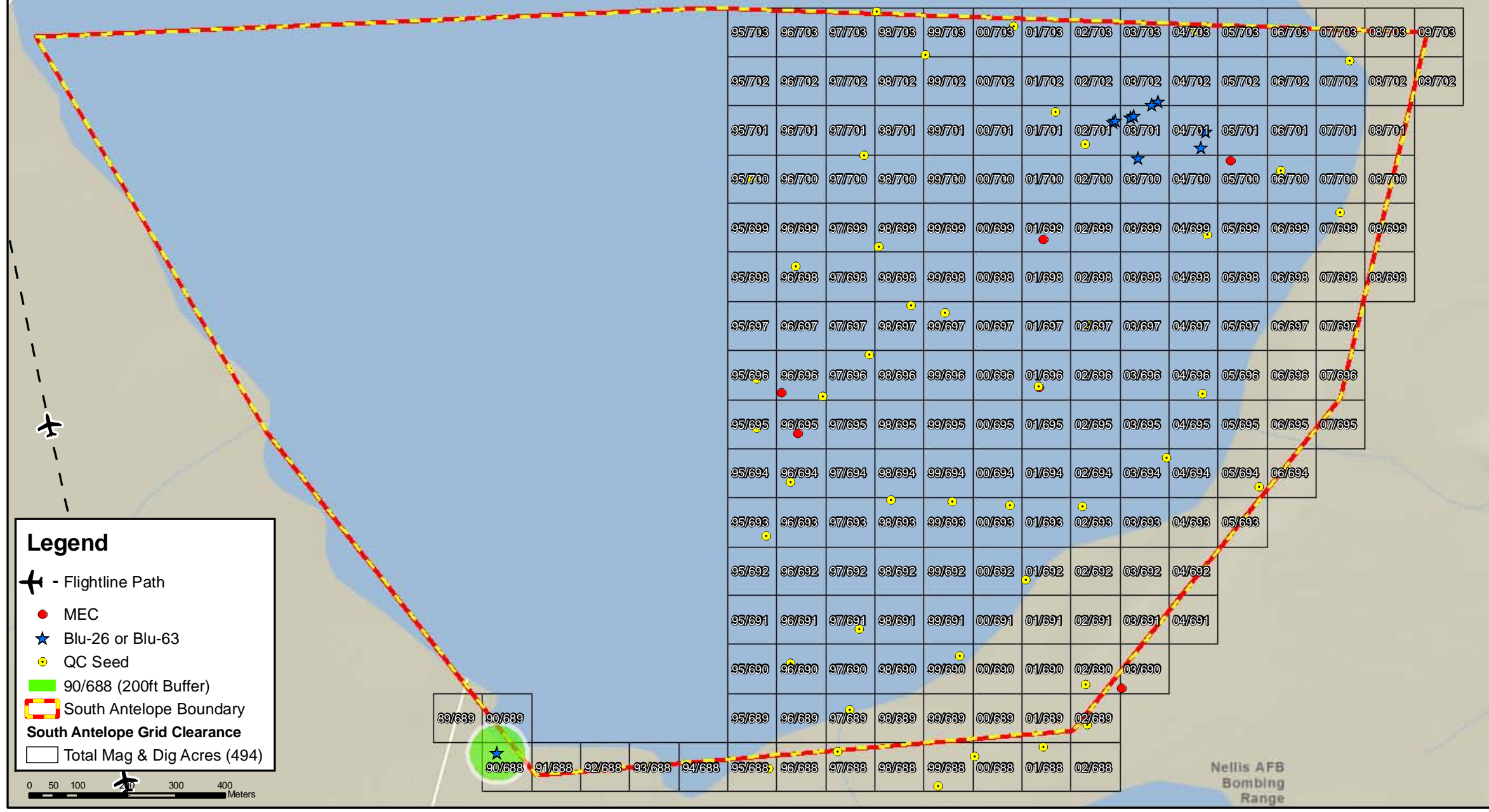

\section{SOUTH ANTELOPE LAKE TARGET AREA}




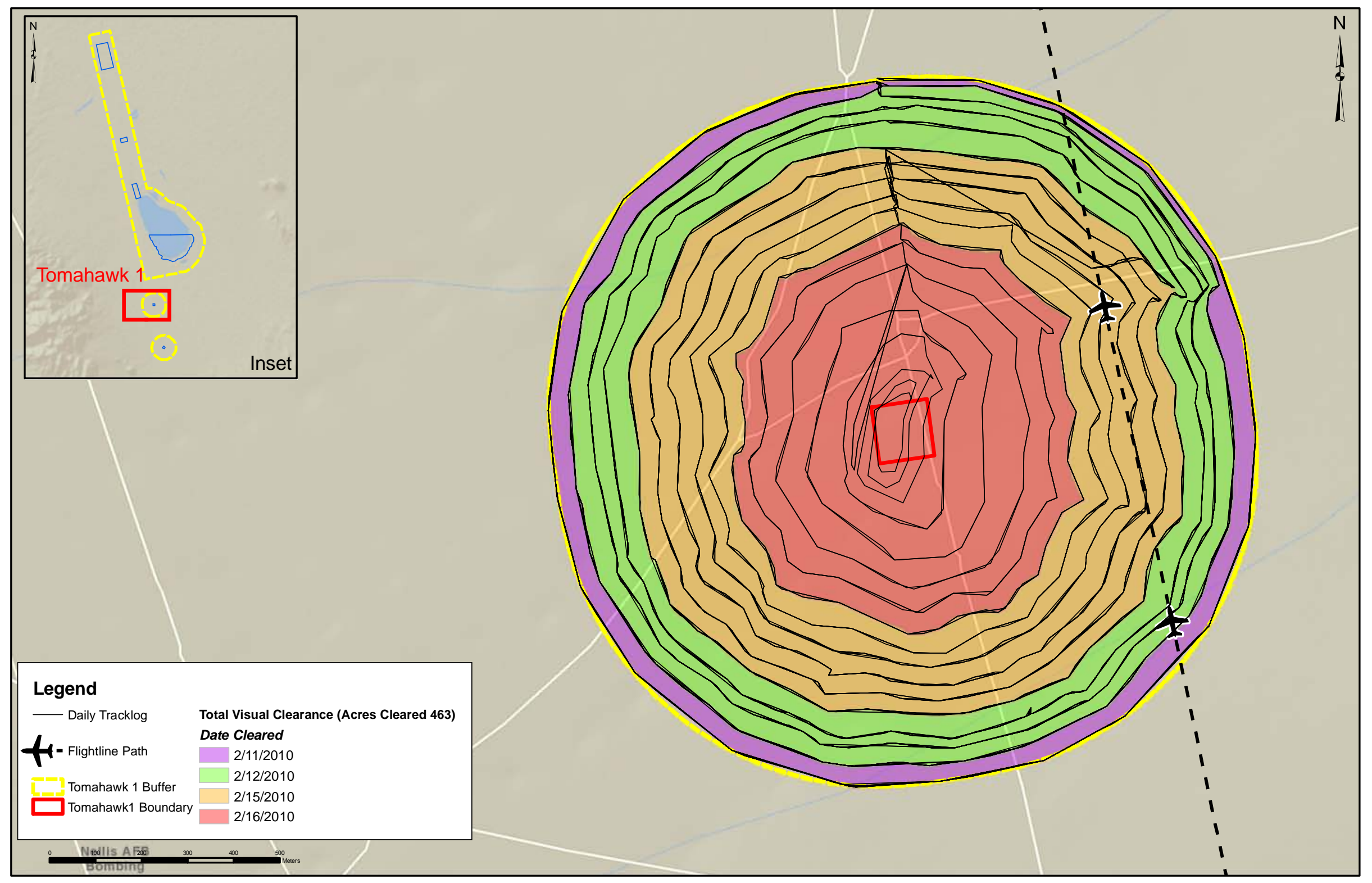

SOUTH FLIGHT-LINE TOMAHAWK 1 TARGET BUFFER ZONE

Contract Number: NNES-ECRS 09 


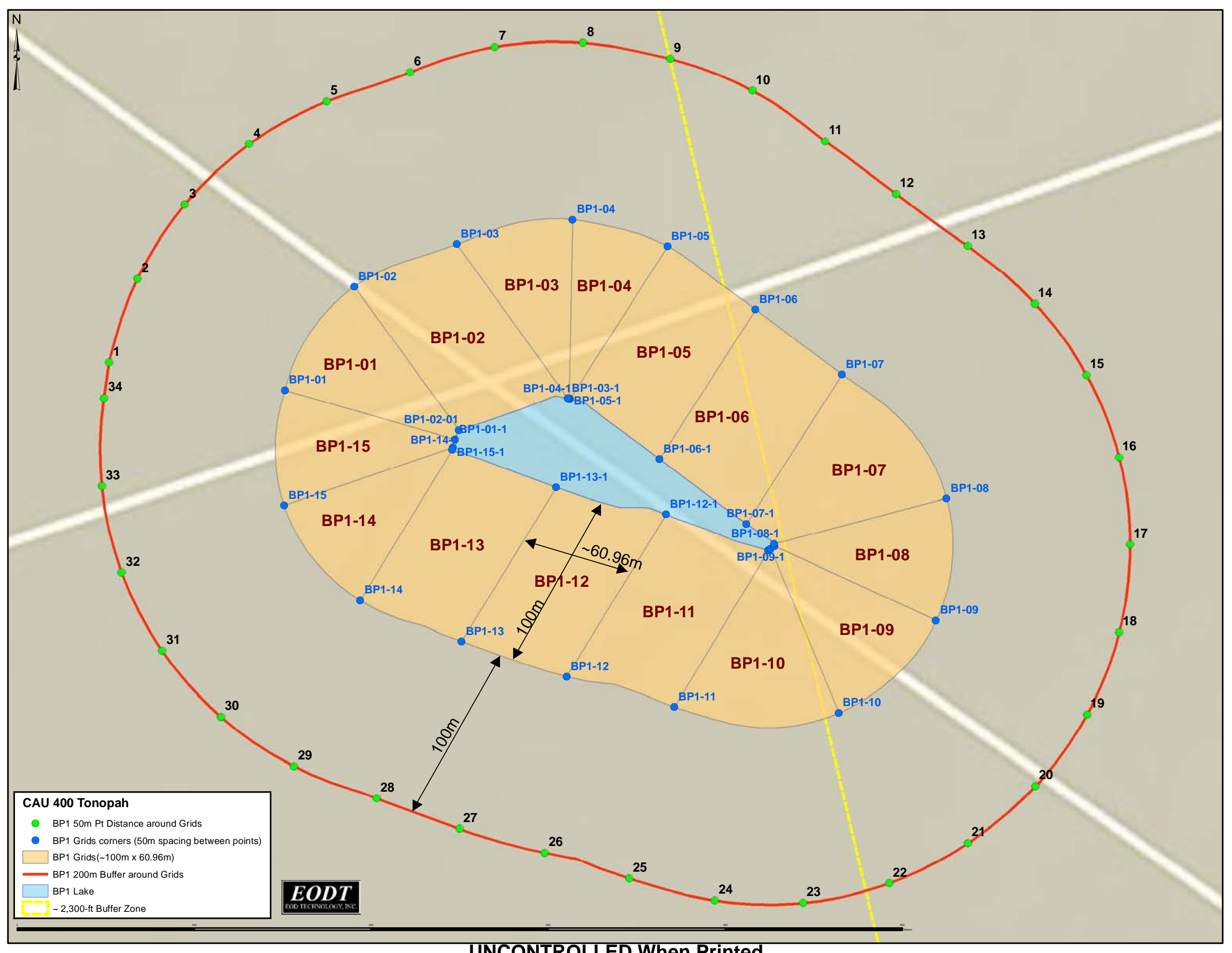

UNCONTROLLED When Printed 


\title{
APPENDIX C \\ PHOTOS
}

FOR THE

\section{CORRECTIVE ACTION UNIT (CAU) 408 BOMBLET TARGET AREA MUNITIONS AND EXPLOSIVES OF CONCERN SURFACE CLEARANCE TONOPAH TEST RANGE, NEVADA}

\author{
PREPARED FOR:

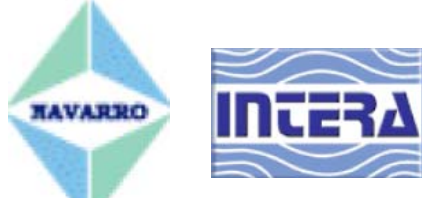 \\ Navarro Nevada Environmental Services, LLC, a Joint Venture \\ Attn: Mark Burmeister \\ 232 Energy Way \\ N. Las Vegas, NV 89030 \\ Subcontract Number: NNES-ECRS 09 \\ Under Contract Number: CE-AC52-09NA28091
}

Prepared by:

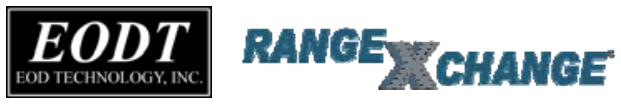

2229 Old Highway 95

Lenoir City, Tennessee 37771

July 2010 


\section{APPENDIX C \\ PHOTOS}

This appendix is not required for this project. 


\title{
APPENDIX D SUXOS LOG
}

гов тит

\section{CORRECTIVE ACTION UNIT (CAU) 408 BOMBLET TARGET AREA MUNITIONS AND EXPLOSIVES OF CONCERN SURFACE CLEARANCE TONOPAH TEST RANGE, NEVADA}

\author{
PREPARED FOR:

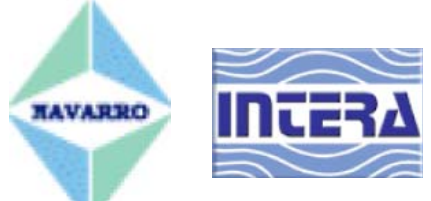 \\ Navarro Nevada Environmental Services, LLC, a Joint Venture \\ Attn: Mark Burmeister \\ 232 Energy Way \\ N. Las Vegas, NV 89030
}

Subcontract Number: NNES-ECRS 09

Under Contract Number: CE-AC52-09NA28091

Prepared by:

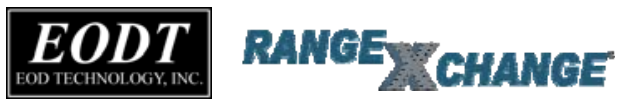

2229 Old Highway 95

Lenoir City, Tennessee 37771

July 2010 
This appendix is not included in the CAU 408 Closure Report due to size constraints.

UNCONTROLLED When Printed 


\title{
APPENDIX E \\ QUALITY CONTROL DOCUMENTS
}

FOR THE

\section{CORRECTIVE ACTION UNIT (CAU) 408 BOMBLET TARGET AREA MUNITIONS AND EXPLOSIVES OF CONCERN SURFACE CLEARANCE TONOPAH TEST RANGE, NEVADA}

\author{
PREPARED FOR:

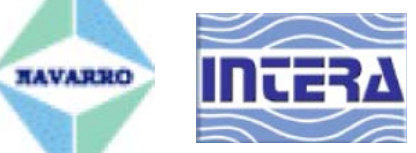 \\ Navarro Nevada Environmental Services, LLC, a Joint Venture \\ Attn: Mark Burmeister \\ 232 Energy Way \\ N. Las Vegas, NV 89030
}

Subcontract Number: NNES-ECRS 09

Under Contract Number: CE-AC52-09NA28091

PRePARed BY:

\section{EODT}

EOD TECHNOLLOGY,N

RANGE 2 CHANCE

2229 Old Highway 95

Lenoir City, Tennessee 37771

July 2010 
This appendix is not included in the CAU 408 Closure Report due to size constraints.

UNCONTROLLED When Printed 


\title{
APPENDIX F \\ GRID TRACKING LOG
}

FOR THE

\section{CORRECTIVE ACTION UNIT (CAU) 408 BOMBLET TARGET AREA MUNITIONS AND EXPLOSIVES OF CONCERN SURFACE CLEARANCE TONOPAH TEST RANGE, NEVADA}

\author{
PREPARED FOR:

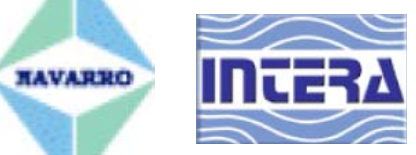 \\ Navarro Nevada Environmental Services, LLC, a Joint Venture \\ Attn: Mark Burmeister \\ 232 Energy Way \\ N. Las Vegas, NV 89030
}

Subcontract Number: NNES-ECRS 09

Under Contract Number: CE-AC52-09NA28091

PRePARed BY:

\section{EODT}

EOD TECHNOLLOGY,TSE

RANGE 2 CHANCE

2229 Old Highway 95

Lenoir City, Tennessee 37771

July 2010 
GRID / ORDNANCE TRACKING LOG

Subcontract Number: NNES-ECRS09

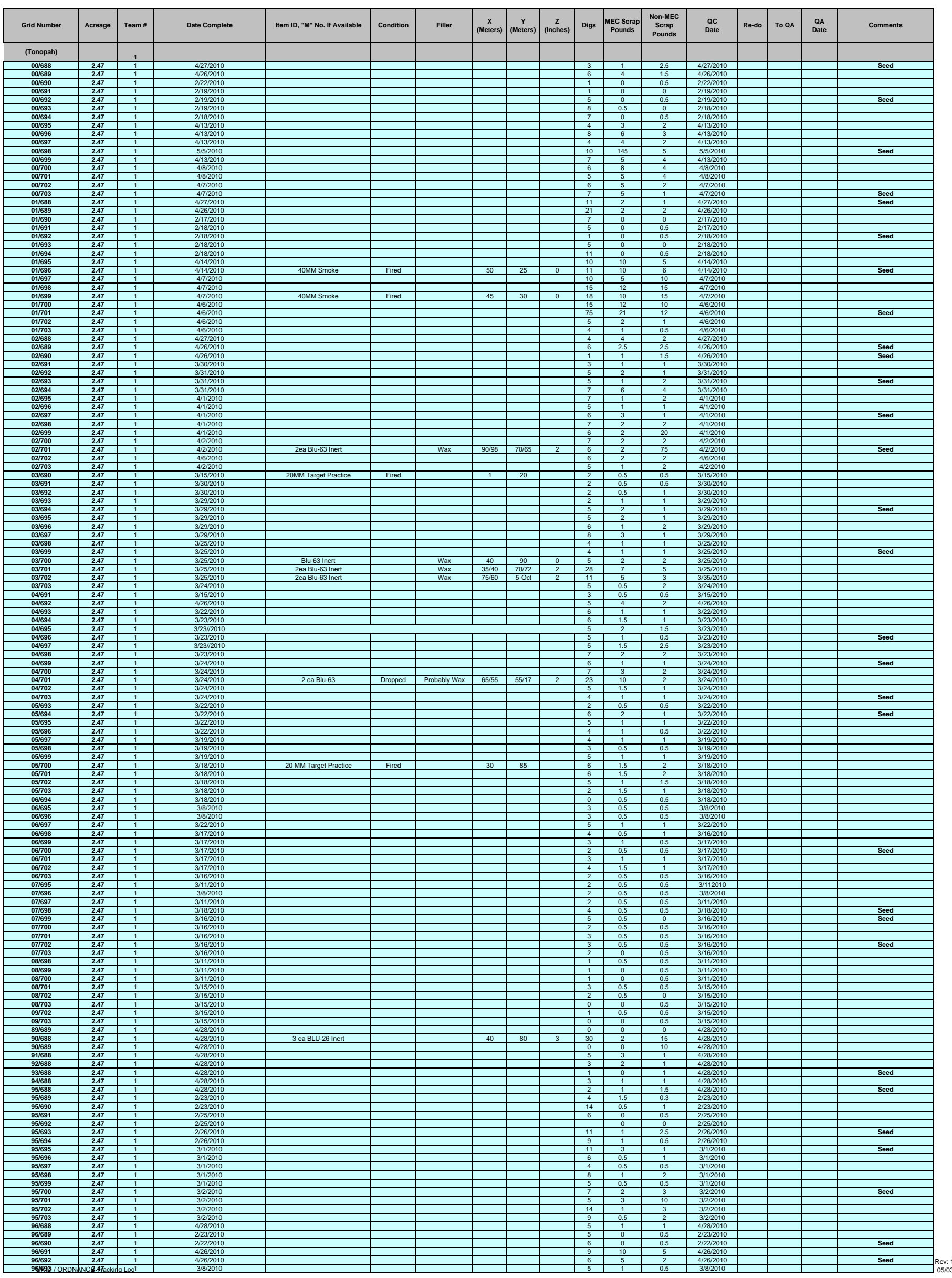




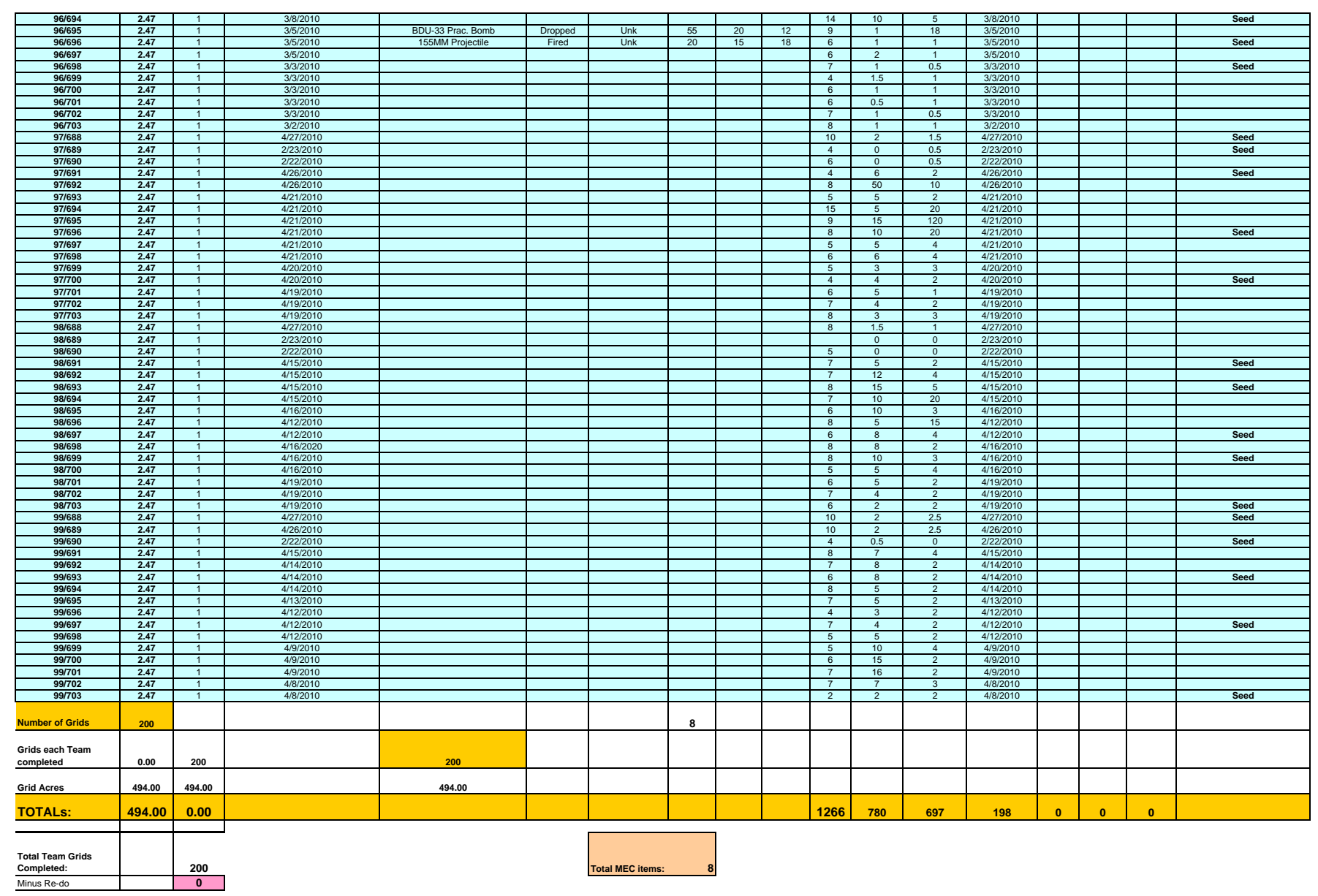


GRID / ORDNANCE TRACKING LOG

Job Title: CAU-400 NNES, Tonopah, NV
Subcontract Number: NNES-ECRSO9

\begin{tabular}{|c|c|c|c|c|c|c|c|c|c|c|c|c|c|c|c|c|c|}
\hline Grid Number & Acreage & Team \# & Date Complete & Item ID, "M" No. If Available & Condition & Filler & $\begin{array}{c}\mathrm{x} \\
\text { (Meters) }\end{array}$ & \begin{tabular}{|c}
$Y$ \\
(Meters)
\end{tabular} & $\begin{array}{c}z \\
z \\
\text { (inches) }\end{array}$ & Digs & $\begin{array}{c}\text { MEC } \\
\text { Scrap } \\
\text { Pounds }\end{array}$ & $\begin{array}{l}\text { Non-MEC } \\
\text { Scrap } \\
\text { Pounds }\end{array}$ & $\begin{array}{l}\text { QC } \\
\text { Date }\end{array}$ & Re-do & To QA & $\begin{array}{c}\text { QA } \\
\text { Date }\end{array}$ & Comments \\
\hline (Tonopah) & & 1 & & & & & & & & & & & & & & & \\
\hline BP1-01 & 0.96 & $\frac{1}{1}$ & $7 / 9 / 2010$ & & & & & & & 84 & 35 & 0 & $7 / 9 / 2010$ & & & & \\
\hline BP1-02 & 1.56 & & $\begin{array}{ll}719 / 2010 \\
77 / 192010\end{array}$ & & & & & & & 186 & 42 & 0 & $7 / 9 / 2010$ & & & & \\
\hline BP1-03 & 0.87 & 1 & $\begin{array}{l}7 / 8 / 2010 \\
7782010\end{array}$ & & & & & & & 118 & 28 & 0 & $7 / 8 / 2010$ & & & & \\
\hline$\frac{\text { BP1-04 }}{\text { BP1-05 }}$ & $\frac{0.70}{1.51}$ & & $\begin{array}{ll}7 / 8 / 2010 \\
778 / 2010\end{array}$ & & fired & detonator & 30 & & & $\frac{109}{238}$ & $\frac{45}{90}$ & 0 & $\begin{array}{l}7 / 8 / 2010 \\
7 / 8 / 2010 \\
\end{array}$ & & & & \\
\hline $\begin{array}{l}\frac{B}{B} 1-05 \\
\mathrm{P} 1-06\end{array}$ & $\frac{1.51}{1.51}$ & & $7 / 7 / 7 / 201010$ & $\frac{\text { M219E1 Fuze }}{\text { 6 MK-118 fuzes }}$ & $\begin{array}{l}\text { firifed } \\
\text { fired }\end{array}$ & $\begin{array}{l}\text { detonator } \\
\text { HE }\end{array}$ & 30 & 25 & 0 & $\frac{238}{109}$ & $\frac{90}{40}$ & $\frac{0}{0}$ & $\frac{78 / 1 / 2010}{777 / 2010}$ & & & & \\
\hline BP1-07 & 1.40 & & $77 / 72010$ & 2 Blu-63 & fired & Inert & & & & $\frac{105}{101}$ & 28 & 0 & $7 / 7 / 72010$ & & & & \\
\hline BP1-08 & 0.89 & 1 & 77772010 & None & & & & & & 78 & 35 & 0 & $7 / 7 / 2010$ & & & & \\
\hline $\begin{array}{l}\text { BP1-09 } \\
B \text { P1-10 }\end{array}$ & 0.99 & & $7 / 7 / 2010$ & Blu-63 & fired & Inert & & & & 91 & 65 & 0 & $7 / 7 / 2010$ & & & & \\
\hline 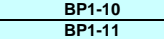 & $\frac{1.20}{1.54}$ & $\frac{1}{1}$ & & & & & & & & & & & & & & & \\
\hline $\begin{array}{l}\mathrm{BP} 1 \mathrm{11} \\
\mathrm{BP} 1-12 \\
\end{array}$ & $\frac{1.54}{1.57}$ & $\frac{1}{1}$ & & & & & & & & & & & & & & & \\
\hline $\begin{array}{l}\text { BP1-13 } \\
\text { BP1.14 }\end{array}$ & 1.53 & 1 & & & & & & & & & $\bar{E}$ & & & & & & \\
\hline $\begin{array}{l}\text { BP1-14 } \\
\text { BP1-15 }\end{array}$ & 0.88 & 1 & $\begin{array}{l}7 / 9 / 2010 \\
7 / 9 / 2010\end{array}$ & 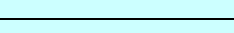 & 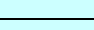 & 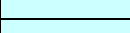 & & & & $\frac{112}{92}$ & 36 & & $7 / 9 / 2010$ & & & & 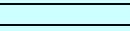 \\
\hline $\begin{array}{l}\text { BP1-15 } \\
\text { BP1-Fenced Area }\end{array}$ & 0.88 & $\begin{array}{l}1 \\
1 \\
\end{array}$ & $\begin{array}{l}79 / 2010 \\
779 / 2010 \\
\end{array}$ & Blu-63 & fired & Inert & & & & $\begin{array}{r}92 \\
90 \\
\end{array}$ & $\begin{array}{r}36 \\
20\end{array}$ & & $\begin{array}{l}7 / 9 / 2010 \\
7 / 9 / 2010 \\
\end{array}$ & & & & $30 \%$ completed \\
\hline Number of Grids & 16 & & & & & & 1 & & & & & & & & & & \\
\hline $\begin{array}{l}\text { Grids each Team } \\
\text { completed }\end{array}$ & 1.00 & 15 & & 15 & & & & & & & & & & & & & \\
\hline Grid Acres & 18.01 & 18.01 & & 18.01 & & & & & & & & & & & & & \\
\hline TOTALs: & 18.01 & 0.00 & & & & & & & & 1408 & 480 & 0 & 11 & 0 & 0 & 0 & \\
\hline $\begin{array}{l}\text { Total Team Grids } \\
\text { Completed: }\end{array}$ & & 15 & & & & Total MEC items & & & & & & & & & & & \\
\hline \begin{tabular}{|l|} 
Minus Re-do \\
\end{tabular} & & 0 & & & & & & & & & & & & & & & \\
\hline Total Grids & & 15 & & & & & & & & & & & & & & & \\
\hline
\end{tabular}




\title{
APPENDIX G DAILY PRODUCTION REPORTS
}

FOR THE

\section{CORRECTIVE ACTION UNIT (CAU) 408 BOMBLET TARGET AREA}

MUNITIONS AND EXPLOSIVES OF CONCERN SURFACE CLEARANCE TONOPAH TEST RANGE, NEVADA

\author{
PREPARED FOR:

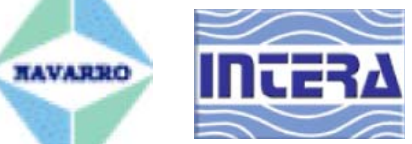 \\ Navarro Nevada Environmental Services, LLC, a Joint Venture \\ Attn: Mark Burmeister \\ 232 Energy Way \\ N. Las Vegas, NV 89030
}

Subcontract Number: NNES-ECRS 09

Under Contract Number: CE-AC52-09NA28091

PRePARED BY:

\section{$E O D T$}

EOD TECHNOLLGYY,

RANGE 2 CHANCE

2229 Old Highway 95

Lenoir City, Tennessee 37771

July 2010 
This appendix is not included in the CAU 408 Closure Report due to size constraints.

UNCONTROLLED When Printed 


\title{
APPENDIX H \\ MEC INVENTORY LIST
}

FOR THE

\section{CORRECTIVE ACTION UNIT (CAU) 408 BOMBLET TARGET AREA} MUNITIONS AND EXPLOSIVES OF CONCERN SURFACE CLEARANCE TONOPAH TEST RANGE, NEVADA

\author{
PREPARED FOR:

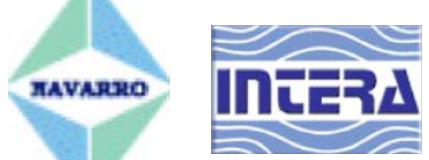 \\ Navarro Nevada Environmental Services, LLC, a Joint Venture \\ Attn: Mark Burmeister \\ 232 Energy Way \\ N. Las Vegas, NV 89030 \\ Subcontract Number: NNES-ECRS 09 \\ Under Contract Number: CE-AC52-09NA28091
}

Prepared by:

\section{EODT RANGE}

2229 Old Highway 95

Lenoir City, Tennessee 37771

July 2010 


\begin{tabular}{|c|c|c|c|c|c|c|c|c|}
\hline \multicolumn{9}{|c|}{ MEC INVENTORY LIST AS OF 8-16-2010 } \\
\hline ITEM & Condition & Filler & Date Identified & QUANTITY & LOCATION & STATUS & DISPOSED & COMMENTS \\
\hline 155mm Projo & Fired & Inert & $3 / 3 / 2010$ & 1 & Demo Site & Awaiting Disposal & & \\
\hline BDU-33 & Dropped & Spotting Charge & $3 / 5 / 2010$ & 1 & NTS/U10C & Off-Site & $5 / 15 / 2010$ & \\
\hline Blu-63 & Dropped & Inert w/ Fuze & $3 / 24 / 2010$ & 1 & NTS/U10C & Off-Site & $5 / 15 / 2010$ & \\
\hline Blu-63 & Dropped & Inert w/ Fuze & $3 / 24 / 2010$ & 1 & NTS/U10C & Off-Site & $5 / 15 / 2010$ & \\
\hline Blu-63 & Dropped & Inert w/ Fuze & $3 / 25 / 2010$ & 1 & NTS/U10C & Off-Site & $5 / 15 / 2010$ & \\
\hline Blu-63 & Dropped & Inert w/ Fuze & $3 / 25 / 2010$ & 1 & NTS/U10C & Off-Site & $5 / 15 / 2010$ & \\
\hline Blu-63 & Dropped & Inert w/ Fuze & $3 / 25 / 2010$ & 1 & NTS/U10C & Off-Site & $5 / 15 / 2010$ & \\
\hline Blu-63 & Dropped & Inert w/ Fuze & $3 / 25 / 2010$ & 1 & NTS/U10C & Off-Site & $5 / 15 / 2010$ & \\
\hline Blu-63 & Dropped & Inert w/ Fuze & $3 / 25 / 2010$ & 1 & NTS/U10C & Off-Site & $5 / 15 / 2010$ & \\
\hline Blu-63 & Dropped & Inert w/ Fuze & $4 / 2 / 2010$ & 1 & NTS/U10C & Off-Site & $5 / 15 / 2010$ & \\
\hline Blu-63 & Dropped & Inert w/ Fuze & $4 / 2 / 2010$ & 1 & NTS/U10C & Off-Site & $5 / 15 / 2010$ & \\
\hline 40mm Smoke & Fired & Empty & $4 / 7 / 2010$ & 1 & NTS/U10C & Off-Site & $5 / 15 / 2010$ & \\
\hline 40mm Smoke & Fired & Empty & $4 / 14 / 2010$ & 1 & NTS/U10C & Off-Site & $5 / 15 / 2010$ & \\
\hline Blu-26 & Dropped & Inert w/ Fuze & $4 / 28 / 2010$ & 3 & NTS/U10C & Off-Site & $5 / 15 / 2010$ & \\
\hline 8" Projo & Fired & Inert & $5 / 3 / 2010$ & 1 & Demo Site & Awaiting Off-Site transport & $8 / 16 / 2010$ & \\
\hline 8" Projo & Fired & Inert & $5 / 3 / 2010$ & 1 & Demo Site & Awaiting Off-Site transport & $8 / 16 / 2010$ & \\
\hline $155 \mathrm{~mm}$ Projo & Fired & Inert & $5 / 3 / 2010$ & 1 & Demo Site & Awaiting Off-Site transport & $8 / 16 / 2010$ & \\
\hline 8" Projo & Fired & Inert & $5 / 4 / 2010$ & 1 & Demo Site & Awaiting Off-Site transport & $8 / 16 / 2010$ & \\
\hline 8" Projo & Fired & Inert & $5 / 4 / 2010$ & 1 & Demo Site & Awaiting Off-Site transport & $8 / 16 / 2010$ & \\
\hline 8" Projo & Fired & Inert & $5 / 4 / 2010$ & 1 & Demo Site & Awaiting Off-Site transport & $8 / 16 / 2010$ & \\
\hline MJU-23 Flare & Fired & Flare mixture & $5 / 5 / 2010$ & 1 & & Disposed & $8 / 16 / 2010$ & \\
\hline M-38 Spotting charge & Dropped & Black Powder & $5 / 7 / 2010$ & 1 & NTS/U10C & Off-Site & $5 / 15 / 2010$ & \\
\hline $155 \mathrm{~mm}$ Projo & Fired & Inert & $5 / 11 / 2010$ & 1 & Demo Site & Awaiting Off-Site transport & $8 / 16 / 2010$ & \\
\hline $155 \mathrm{~mm}$ Projo & Fired & Inert & $5 / 11 / 2010$ & 1 & Demo Site & Awaiting Off-Site transport & $8 / 16 / 2010$ & \\
\hline Mk-82 Inert & Dropped & Concrete & $5 / 10 / 2010$ & 1 & GPS & Awaiting Off-Site transport & $8 / 16 / 2010$ & \\
\hline 5" Projo & Fired & Unk & $5 / 10 / 2010$ & 1 & GPS & Awaiting Off-Site transport & $8 / 16 / 2010$ & \\
\hline MK40Mod0 w/h & Fired & Unk & $5 / 10 / 2010$ & 1 & GPS & Awaiting Off-Site transport & $8 / 16 / 2010$ & \\
\hline .50 Cal Ball & Unfired & Smokeless Powder & $5 / 13 / 2010$ & 59 & NTS/U10C & Off-Site & $5 / 15 / 2010$ & \\
\hline MJU-23 Flare & Fired & Flare mixture & $5 / 13 / 2010$ & 1 & & Disposed & $8 / 16 / 2010$ & \\
\hline M451 MLRS fuze & Fired & Empty & $5 / 17 / 2010$ & 1 & Demo Site & Awaiting Off-Site transport & $8 / 16 / 2010$ & \\
\hline BDU-33 & Dropped & Spotting Charge & $5 / 17 / 2010$ & 1 & NTS/U10C & Off-Site & $5 / 15 / 2010$ & \\
\hline M451 MLRS fuze & Fired & Empty & $5 / 17 / 2010$ & 1 & Demo Site & Awaiting Off-Site transport & $8 / 16 / 2010$ & \\
\hline M451 MLRS fuze & Fired & Empty & $5 / 17 / 2010$ & 1 & Demo Site & Awaiting Off-Site transport & $8 / 16 / 2010$ & \\
\hline BDU-33 & Dropped & Spotting Charge & $5 / 18 / 2010$ & 1 & Demo Site & Awaiting Off-Site transport & $8 / 16 / 2010$ & \\
\hline 2.75 Rocket w/h & Fired & $\mathrm{HE}$ & $5 / 18 / 2010$ & 1 & GPS & Awaiting Off-Site transport & $8 / 16 / 2010$ & \\
\hline BDU-33 & Dropped & Spotting Charge & $5 / 18 / 2010$ & 1 & Demo Site & Awaiting Off-Site transport & $8 / 16 / 2010$ & \\
\hline MJU-7 Flare & Fired & Flare mixture & $5 / 18 / 2010$ & 1 & & Disposed & $8 / 16 / 2010$ & \\
\hline 155mm Projo Empty & Fired & Empty & $5 / 20 / 2010$ & 1 & Demo Site & Awaiting Off-Site transport & $8 / 16 / 2010$ & \\
\hline 155mm Projo Empty & Fired & Empty & $5 / 20 / 2010$ & 1 & Demo Site & Awaiting Off-Site transport & $8 / 16 / 2010$ & \\
\hline Blu-63 & Dropped & Inert w/ Fuze & $5 / 24 / 2010$ & 1 & Demo Site & Awaiting Off-Site transport & $8 / 16 / 2010$ & \\
\hline MJU-7 Flare & Fired & Flare mixture & $5 / 24 / 2010$ & 1 & & Disposed & $8 / 16 / 2010$ & \\
\hline Blu-63 & Dropped & Inert w/ Fuze & $5 / 25 / 2010$ & 16 & Demo Site & Awaiting Off-Site transport & $8 / 16 / 2010$ & \\
\hline Blu-26 & Dropped & Inert w/ Fuze & $5 / 25 / 2010$ & 1 & Demo Site & Awaiting Off-Site transport & $8 / 16 / 2010$ & \\
\hline Mk-82 Inert & Dropped & Concrete & $5 / 25 / 2010$ & 1 & GPS & Awaiting Off-Site transport & $8 / 16 / 2010$ & \\
\hline 155mm Projo & Fired & Inert & $5 / 25 / 2010$ & 1 & Demo Site & Awaiting Off-Site transport & $8 / 16 / 2010$ & \\
\hline M-206 Flare & Fired & Flare mixture & $5 / 27 / 2010$ & 1 & & Disposed & $8 / 16 / 2010$ & \\
\hline MK-84 Inert Bomb & Dropped & \begin{tabular}{|l|} 
Concrete \\
\end{tabular} & $5 / 28 / 2010$ & 1 & GPS & Awaiting Off-Site transport & $8 / 16 / 2010$ & \\
\hline .50 Cal Ball & Unfired & Smokeless Powder & $5 / 28 / 2010$ & 80 & & Disposed & $8 / 16 / 2010$ & \\
\hline Blu-63 & Dropped & Inert w/ Fuze & $6 / 1 / 2010$ & 32 & Demo Site & Awaiting Off-Site transport & $8 / 16 / 2010$ & \\
\hline Blu-63 & Dropped & Inert w/ Fuze & $6 / 2 / 2010$ & 40 & Demo Site & Awaiting Off-Site transport & $8 / 16 / 2010$ & \\
\hline Blu-26 & Dropped & Inert w/ Fuze & $6 / 2 / 2010$ & 1 & Demo Site & Awaiting Off-Site transport & $8 / 16 / 2010$ & \\
\hline Blu-63 & Dropped & Inert w/ Fuze & $6 / 3 / 2010$ & 11 & Demo Site & Awaiting Off-Site transport & $8 / 16 / 2010$ & \\
\hline Blu-63 & Dropped & Inert w/ Fuze & $6 / 4 / 2010$ & 9 & Demo Site & Awaiting Off-Site transport & $8 / 16 / 2010$ & \\
\hline Blu-63 & Dropped & Inert w/ Fuze & $6 / 7 / 2010$ & 19 & Demo Site & Awaiting Off-Site transport & $8 / 16 / 2010$ & \\
\hline Blu-63 & Dropped & Inert w/ Fuze & $6 / 8 / 2010$ & 29 & Demo Site & Awaiting Off-Site transport & $8 / 16 / 2010$ & \\
\hline Blu-63 & Dropped & Inert w/ Fuze & $6 / 92010$ & 7 & Demo Site & Awaiting Off-Site transport & $8 / 16 / 2010$ & \\
\hline Blu-26 & Dropped & Inert w/ Fuze & $6 / 9 / 2010$ & 1 & Demo Site & Awaiting Off-Site transport & $8 / 16 / 2010$ & \\
\hline Blu-63 & Dropped & Inert w/ Fuze & $6 / 10 / 2010$ & 7 & Demo Site & Awaiting Off-Site transport & $8 / 16 / 2010$ & \\
\hline Blu-63 & Dropped & Inert w/ Fuze & $6 / 11 / 2010$ & 4 & Demo Site & Awaiting Off-Site transport & $8 / 16 / 2010$ & \\
\hline Blu-63 & Dropped & Inert w/ Fuze & $6 / 14 / 2010$ & 5 & Demo Site & Awaiting Off-Site transport & $8 / 16 / 2010$ & \\
\hline Blu-63 & Dropped & Inert w/ Fuze & $6 / 15 / 2010$ & 6 & Demo Site & Awaiting Off-Site transport & $8 / 16 / 2010$ & \\
\hline Blu-63 & Dropped & Inert w/ Fuze & $6 / 16 / 2010$ & 1 & Demo Site & Awaiting Off-Site transport & $8 / 16 / 2010$ & \\
\hline Blu-63 & Dropped & Inert w/ Fuze & $6 / 17 / 2010$ & 3 & Demo Site & Awaiting Off-Site transport & $8 / 16 / 2010$ & \\
\hline Blu-63 & Dropped & Inert w/ Fuze & $6 / 21 / 2010$ & 10 & Demo Site & Awaiting Off-Site transport & $8 / 16 / 2010$ & \\
\hline Blu-63 & Dropped & Inert w/ Fuze & $6 / 22 / 2010$ & 14 & Demo Site & Awaiting Off-Site transport & $8 / 16 / 2010$ & \\
\hline Blu-63 & Dropped & Inert w/ Fuze & $6 / 23 / 2010$ & 7 & Demo Site & Awaiting Off-Site transport & $8 / 16 / 2010$ & \\
\hline Blu-63 & Dropped & Inert w/ Fuze & $6 / 24 / 2010$ & 8 & Demo Site & Awaiting Off-Site transport & $8 / 16 / 2010$ & \\
\hline Blu-63 & Dropped & Inert w/ Fuze & $6 / 25 / 2010$ & 7 & Demo Site & Awaiting Off-Site transport & $8 / 16 / 2010$ & \\
\hline Blu-63 & Dropped & Inert w/ Fuze & $6 / 28 / 2010$ & 8 & Demo Site & Awaiting Off-Site transport & $8 / 16 / 2010$ & \\
\hline Blu-63 & Dropped & Inert w/ Fuze & $6 / 29 / 2010$ & 13 & Demo Site & Awaiting Off-Site transport & $8 / 16 / 2010$ & \\
\hline Blu-63 & Dropped & Inert w/ Fuze & $6 / 30 / 2010$ & 19 & Demo Site & Awaiting Off-Site transport & $8 / 16 / 2010$ & \\
\hline Blu-63 & Dropped & Inert w/ Fuze & $7 / 1 / 2010$ & 4 & Demo Site & Awaiting Off-Site transport & $8 / 16 / 2010$ & \\
\hline Blu-26 & Dropped & Inert w/ Fuze & $7 / 1 / 2010$ & 1 & Demo Site & Awaiting Off-Site transport & $8 / 16 / 2010$ & \\
\hline Blu-63 & Dropped & Inert w/ Fuze & $7 / 2 / 2010$ & 1 & Demo Site & Awaiting Off-Site transport & $8 / 16 / 2010$ & \\
\hline Blu-63 & Dropped & Inert w/ Fuze & $7 / 6 / 2010$ & 2 & \begin{tabular}{|l|} 
Demo Site \\
\end{tabular} & Awaiting Off-Site transport & $8 / 16 / 2010$ & \\
\hline Blu-63 & Dropped & Inert w/ Fuze & $7 / 7 / 2010$ & 6 & Demo Site & Awaiting Off-Site transport & $8 / 16 / 2010$ & \\
\hline MK-118 Fuzes & Dropped & Detonator & $7 / 7 / 2010$ & 6 & Demo Site & Awaiting Off-Site transport & $8 / 16 / 2010$ & \\
\hline M219E1 Fuze & Dropped & Detonator & $7 / 8 / 2010$ & 1 & Demo Site & Awaiting Off-Site transport & $8 / 16 / 2010$ & \\
\hline Blu-63 & Dropped & Inert w/ Fuze & $7 / 9 / 2010$ & 1 & Demo Site & Awaiting Off-Site transport & $8 / 16 / 2010$ & \\
\hline Blu-63 & Dropped & Inert w/ Fuze & $7 / 12 / 2010$ & 1 & \begin{tabular}{|l|} 
Demo Site \\
\end{tabular} & Awaiting Off-Site transport & $8 / 16 / 2010$ & \\
\hline Blu-63 & Dropped & Inert w/ Fuze & $7 / 13 / 2010$ & 1 & \begin{tabular}{|l|} 
Demo Site \\
\end{tabular} & Awaiting Off-Site transport & \begin{tabular}{|l|}
$8 / 16 / 2010$ \\
\end{tabular} & \\
\hline Blu-63 & Dropped & Inerrt w/Fuze & $7 / 26 / 2010$ & 1 & \begin{tabular}{|l|} 
Demo Site \\
\end{tabular} & Awaiting Off-Site transport & $8 / 16 / 2010$ & \\
\hline 8" Proj & Fired & Inert & $7 / 26 / 2010$ & 1 & Demo Site & Awaiting Off-Site transport & $8 / 16 / 2010$ & \\
\hline
\end{tabular}

ITEMS TO DEMO

$155 \mathrm{~mm}$

8" Projos

MJU-23 Flare

Blu-63

Blu-26

MK-82 Inert

Mk-84 Inert

MLRS Fuzes M451

MK-118 Fuzes

M219E1

.50 Cal. Ball

M-206 Flare

BDU-33

5" Mk41 projo

MK40Mod0

2.75" W/H

M38 100lb Prac. Bomb Spot 


\title{
APPENDIX I \\ DEMOLITION OPERATIONS \\ DOCUMENTATION
}

FOR THE

CORRECTIVE ACTION UNIT (CAU) 408

BOMBLET TARGET AREA

MUNITIONS AND EXPLOSIVES OF CONCERN

SURFACE CLEARANCE

TONOPAH TEST RANGE, NEVADA

\author{
PREPARED FOR: \\ Navarro Nevada Environmental Services, LLC, a Joint Venture \\ Attn: Mark Burmeister \\ 232 Energy Way \\ N. Las Vegas, NV 89030 \\ Subcontract Number: NNES-ECRS 09 \\ Under Contract Number: CE-AC52-09NA28091
}

PRepared by:

\begin{tabular}{|l|}
\hline EOD TECHOLLOCY,NC. \\
\hline
\end{tabular}

2229 Old Highway 95

Lenoir City, Tennessee 37771

September 2010 


\section{APPENDIX I \\ DEMOLITION OPERATIONS DOCUMENTATION \\ (8-16-2010 DEMO OPERATION)}

\begin{tabular}{|c|ll|}
\hline & 7 EA 155 MM PROJOS & 1 EA 1000' SHOCK TUBE \\
& 6 EA 8” PROJOS & 4 EA NON EL CAPS \\
& 303 EA BLU-63 & 20' TIME FUZE \\
3 EA M451 MLRS FUZES & 3 FUZE IGNITER \\
SHOT 1 & 6 EA MK-118 FUZES & 10 EA 80' SHOCK TUBE \\
(Demo Area) & EA M219E1 FUZES & 36 JET PERFORATORS \\
& 1 EA .50 CAL. BALL & 63 LBS C-4 \\
& 2 EA M-206 FLARE & 50' DET. CORD \\
& 2 EA BJU-7 FLARE & \\
& 1 EA M38 100LB PRAC. SPOT & \\
\hline
\end{tabular}

\begin{tabular}{|c|c|c|}
\hline $\begin{array}{c}\text { SHOT } 2 \\
\text { (West) }\end{array}$ & 1 EA MJU-23 FLARE & $\begin{array}{l}1 \text { EA 1000' SHOCK TUBE } \\
2 \text { EA NON EL CAPS } \\
\text { 20’ TIME FUZE } \\
3 \text { FUZE IGNITERS } \\
2 \text { EA 80' SHOCK TUBE } \\
4 \text { LBS C-4 }\end{array}$ \\
\hline $\begin{array}{c}\text { SHOT } 3 \\
\text { (East) }\end{array}$ & 1 EA MJU-23 FLARE & $\begin{array}{l}1 \text { EA 1000' SHOCK TUBE } \\
2 \text { EA NON EL CAPS } \\
\text { 20’ TIME FUZE } \\
3 \text { FUZE IGNITERS } \\
2 \text { EA 80' SHOCK TUBE } \\
4 \text { LBS C-4 }\end{array}$ \\
\hline SHOT 4 & $\begin{array}{l}1 \text { EA MK-41 5” PROJO } \\
2 \text { EA MK-82 INERT BOMB } \\
1 \text { EA MK-84 INERT BOMB } \\
\text { 1EA MK-40 MOD 0 BULLPUP C W/H }\end{array}$ & $\begin{array}{l}4 \text { EA 1000' SHOCK TUBE } \\
1 \text { EA 500' SHAOCK TUBE } \\
4 \text { EA NON EL CAPS } \\
\text { 20' TIME FUZE } \\
3 \text { FUZE IGNITERS } \\
4 \text { EA 80' SHOCK TUBE } \\
\text { 10 LBS C-4 } \\
2 \text { EA JET PERFORATORS } \\
\text { 100' DET. CORD }\end{array}$ \\
\hline
\end{tabular}




\begin{tabular}{|c|c|c|}
\hline SHOT 5 & 1 EA 2.75” RKT W/H & $\begin{array}{l}1 \text { EA 1000' SHOCK TUBE } \\
2 \text { EA NON EL CAPS } \\
\text { 20’ TIME FUZE } \\
3 \text { FUZE IGNITERS } \\
2 \text { EA 80' SHOCK TUBE } \\
4 \text { LBS C-4 }\end{array}$ \\
\hline $\begin{array}{c}\text { CLEAN-UP } \\
\text { SHOT }\end{array}$ & & $\begin{array}{l}8 \text { EA 1000' SHOCK TUBE } \\
15 \text { EA 500' SHOCK TUBE } \\
36 \text { EA NON EL CAPS } \\
2969.5 M \text { TIME FUZE } \\
5 \text { FUZE IGNITERS } \\
\text { 25 EA 80' SHOCK TUBE } \\
\text { 35 LBS C-4 } \\
2 \text { EA JET PERFORATORS } \\
\text { 2350' DET. CORD }\end{array}$ \\
\hline
\end{tabular}


EOD TECHNOLOG , INC.

P.O. BOX 24173

ATTN : ACCTS PAYABLE

KNOXVILLE, TN 37933-2173

Order TO: ALPHA EXPLOSIVES

PO BOX 310

3400 NADER RD

LINCOLN, CA 95648
Purchase Order: 0000011403

Date Printed: $08 / 10 / 2010$

102324 Ship To: Navaro levada Emronmental Sevice

co Sand:a llationa! Laboratories

Tonosah iest Range

DELIVER TO: Robert Prosper

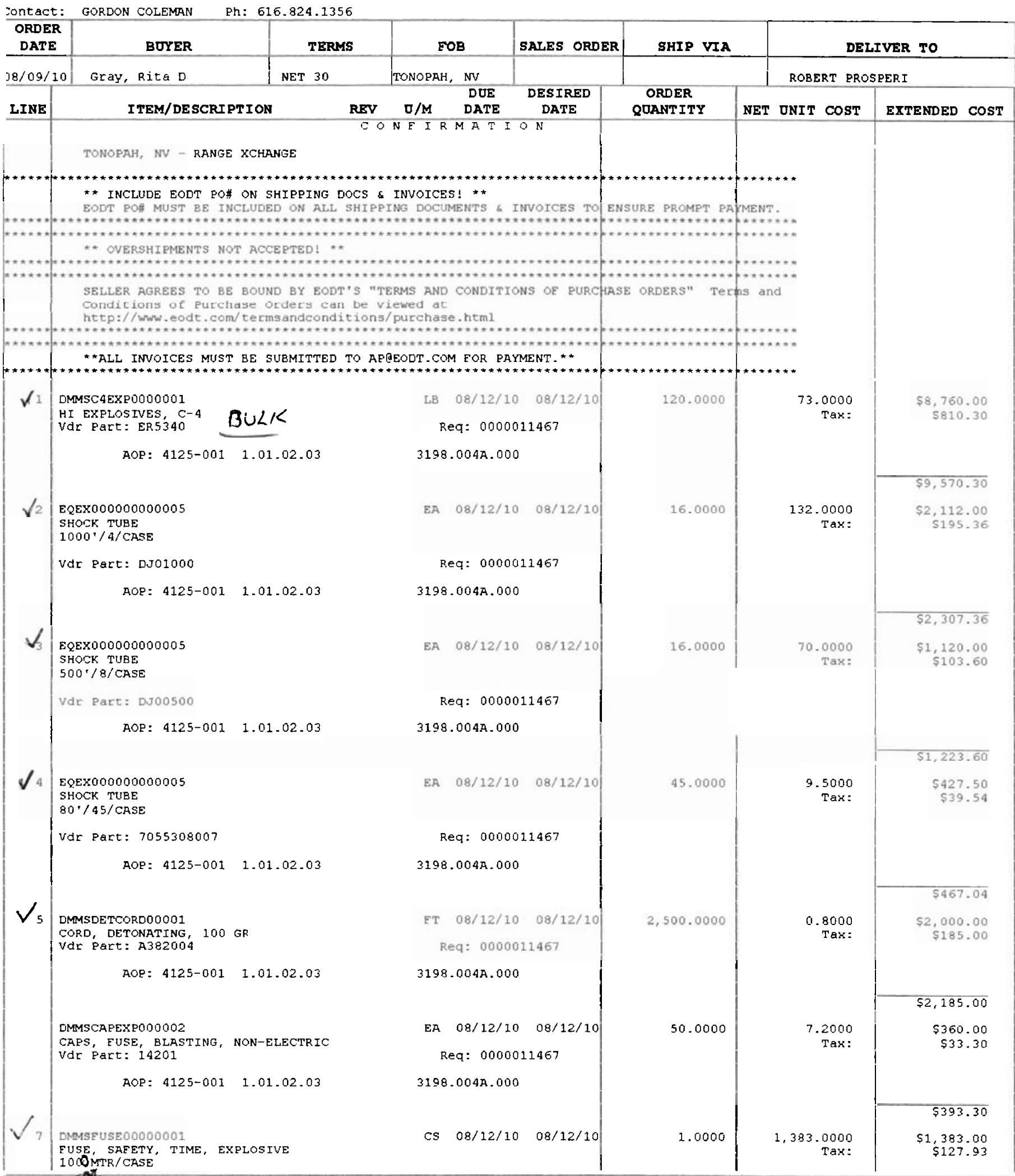

Bux $x$, niles

1000 m.tRs 
EOD TECHNOLOGY, INC.

P.O. BOX 24173

ATTN: ACCTS PAYABLE

KNOXVILLE, TN 37933-2173

Order TO: ALPHA EXPLOSIVES

PO BOX 310

3400 NADER RD

LINCOLN, CA. 95648
Purchase Order: 0000011403

Page: 2 of 2 Date Printed: $08 / 10 / 2010$

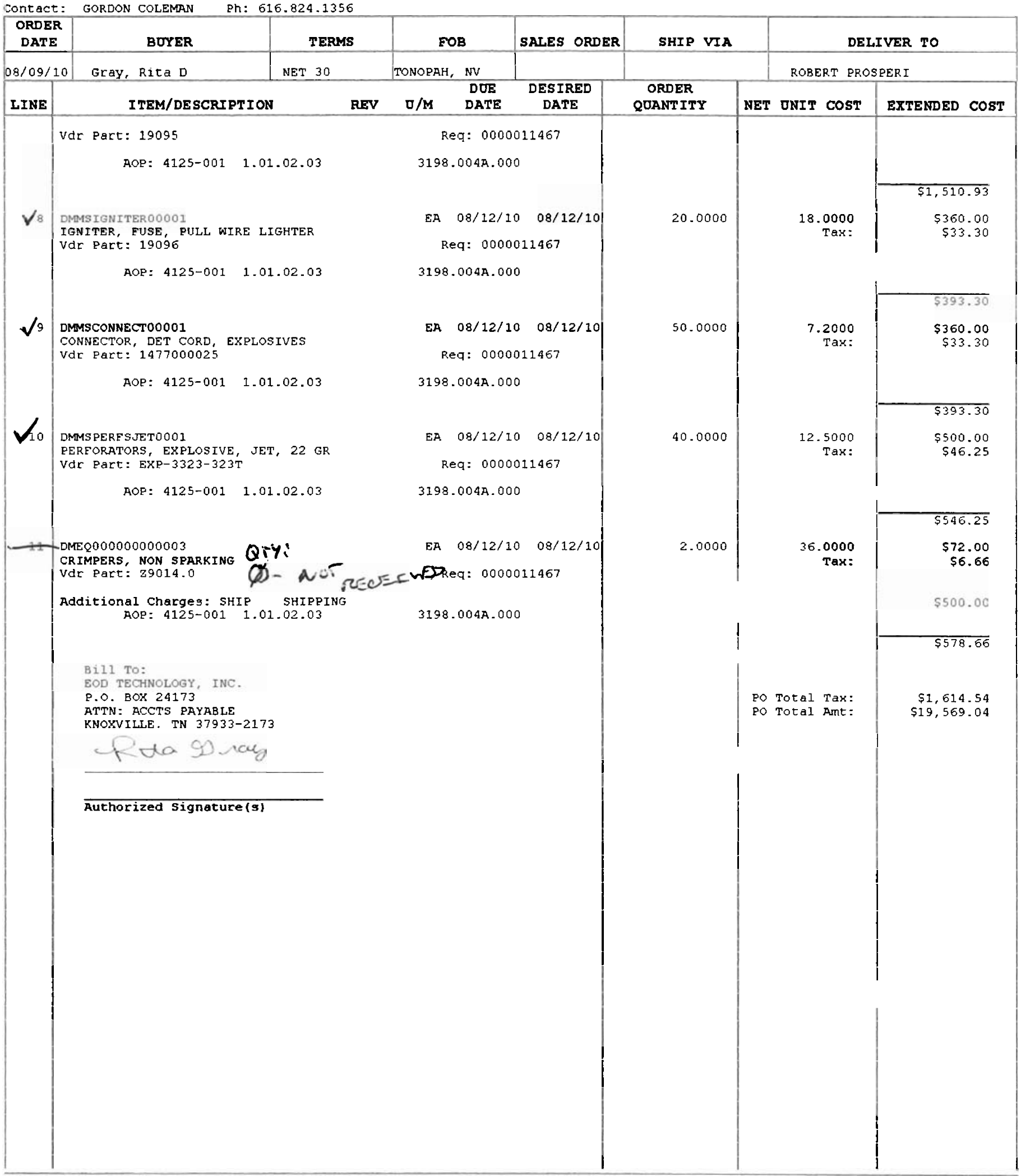




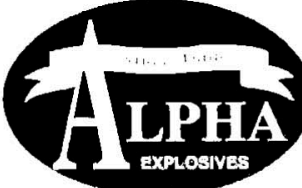

A Dvno Nobel Distributor
ALPHA EXPLOSIVES

P.O. BOX 310

LINCOLN, CALIFORNIA 95648

TELEPHONE (916) 645-3377

FAX (916) 645-8512

\section{$08 / 11 / 2010$ 23225}

STRAIGHT

BILL OF LADING

NON-NEGOTIABLE $\begin{array}{cl}\text { SOLD } & \text { EOD TECHNOLOGY INC } \\ \text { TO } & \text { PO BOX } 24173 \\ & \text { KNOXVILLE, TN 37933-2173 }\end{array}$

ATF \#

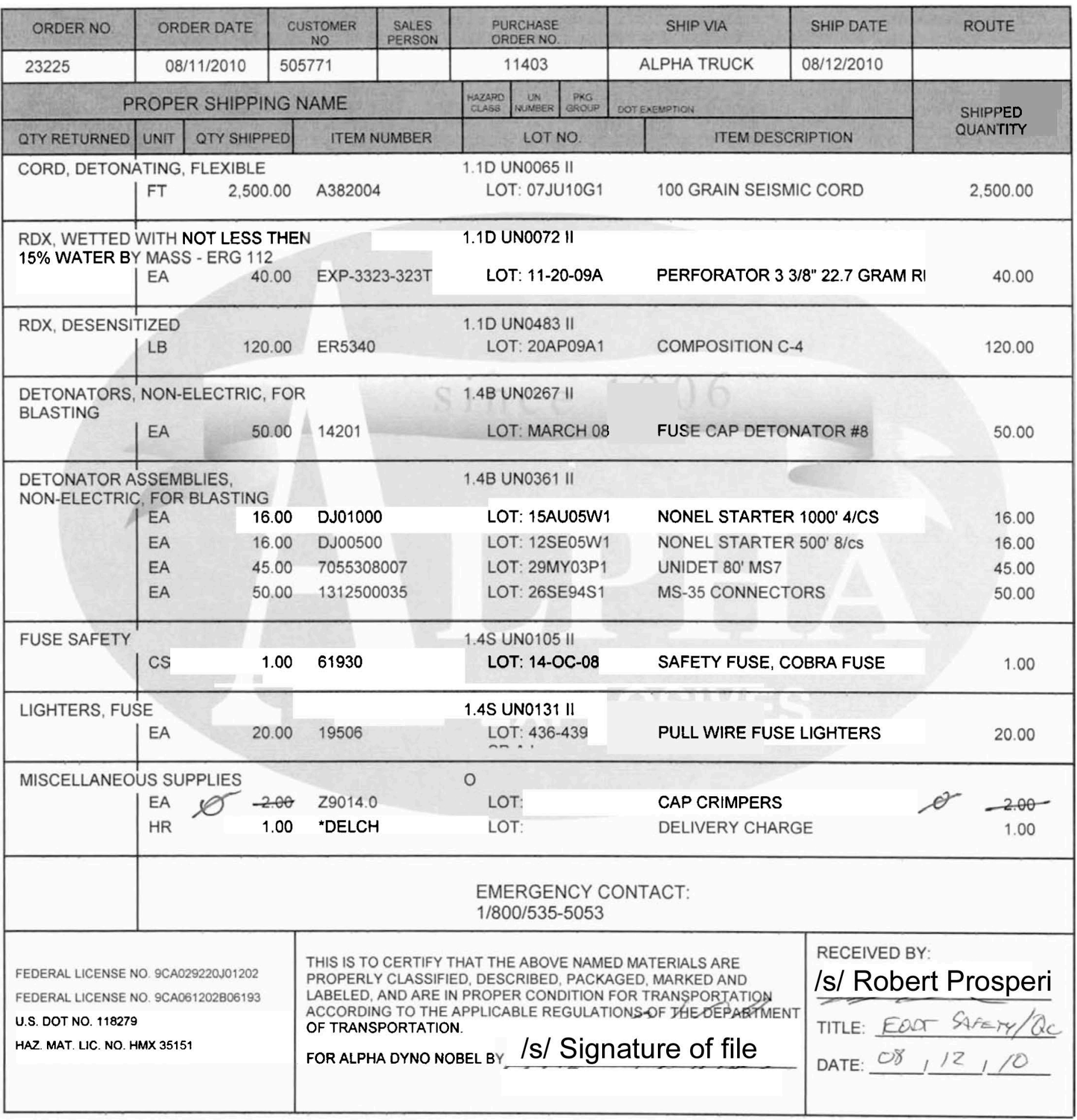




\section{Appendix C}

\section{Confirmation Sampling Test Results}


This appendix presents the verification analytical results for CAU 408, which is located at the TTR, Nevada, and is composed of one CAS: TA-55-002-TAB2, Bomblet Target Areas.

The following sections describe the verification sampling activities that took place at CAU 408. The After-Action Reports included in Appendix B describe the MEC/UXO clearance and demilitarization activities that were performed by qualified UXO personnel. The results of the MEC clearance activities will not be repeated elsewhere in this appendix.

\section{C.1.1 Project Objectives}

The primary objective of the investigation was to provide sufficient information to validate the assumptions used to select the corrective actions and to verify that closure objectives were met for CAS TA-55-002-TAB2 in CAU 408. This objective was achieved by conducting MEC response actions consisting of identifying and removing MEC, and determining the presence of COCs and the vertical and lateral extent of the COCs, if present.

The selection of verification soil sample locations samples was based on site conditions, identification of disposal pits, and the strategy developed during the DQO process (Appendix A) as presented in the CAU 408 SAFER Plan (NNSA/NSO, 2010b). The soil sampling strategy involved biased verification sample locations from beneath and/or adjacent to areas indicating the potential for explosives and/or DU contamination.

\section{C.1.2 Contents}

This appendix contains information and data in sufficient detail to justify that no further corrective action is required at CAU 408. The contents of this appendix are as follows:

- Section C.1.0 describes the investigation background, objectives, and content.

- $\quad$ Section C.2.0 provides an investigation overview.

- Sections C.3.0 provide CAS-specific information regarding the field sampling activities, sampling methods, and laboratory analytical results from investigation sampling. 
- Section C.4.0 summarizes waste management activities.

- Section C.5.0 discusses the QA and QC procedures followed and results of the QA/QC activities.

- Section C.6.0 is a summary of the investigation results.

- Section C.7.0 lists the cited references.

The complete field documentation and laboratory data—including field activity daily logs, sample collection logs, analysis request/chain-of-custody forms, soil sample descriptions, laboratory certificates of analyses, analytical results, and surveillance results—-are retained in project files as hard copy files or electronic media. 


\section{C.2.0 Investigation Overview}

Field investigation and sampling activities for the CAU 408 CAI were conducted from July 22, 2009, through July 6, 2010.

The investigation and sampling program was managed in accordance with the requirements set forth in the CAU 408 SAFER Plan (NNSA/NSO, 2010b). Field activities were performed in compliance with safety documents that are consistent with the DOE Integrated Safety Management System. Samples were collected and documented following approved protocols and procedures. Quality control samples (e.g., field blanks and duplicate samples) were collected as required by the Industrial Sites QAPP (NNSA/NV, 2002) and the CAU 408 SAFER Plan (NNSA/NSO, 2010b). During field activities, waste minimization practices were followed according to approved procedures, including segregation of waste by waste stream.

Weather conditions at the site varied to include sun (moderate to low temperatures), snow, heavy rainfall, intermittent cloudiness, and light to strong winds. Rain and snow suspended site operations on several occasions due to the concern for health and safety of personnel (Figures C.2-1 and C.2-2). Strong wind gusts delayed site operations due to the potential for airborne debris and dust particles.

Sections C.2.1 through C.2.3 provide the investigation methodology and laboratory analytical information.

\section{C.2.1 Investigation Activities}

The investigation activities performed at CAU 408 were based on field investigation activities discussed in the CAU 408 SAFER Plan (NNSA/NSO, 2010b). Clean closure was demonstrated by performing magnetometer and visual surveys of target areas and buffer zones, conducting radiological surface screening and surveys, and collecting verification surface and subsurface soils.

\section{C.2.1.1 Field Screening}

Field-screening activities for alpha and beta/gamma radiation, and gamma-emitting radionuclides were performed on soil samples as specified in the CAU 408 SAFER Plan (NNSA/NSO, 2010b). 


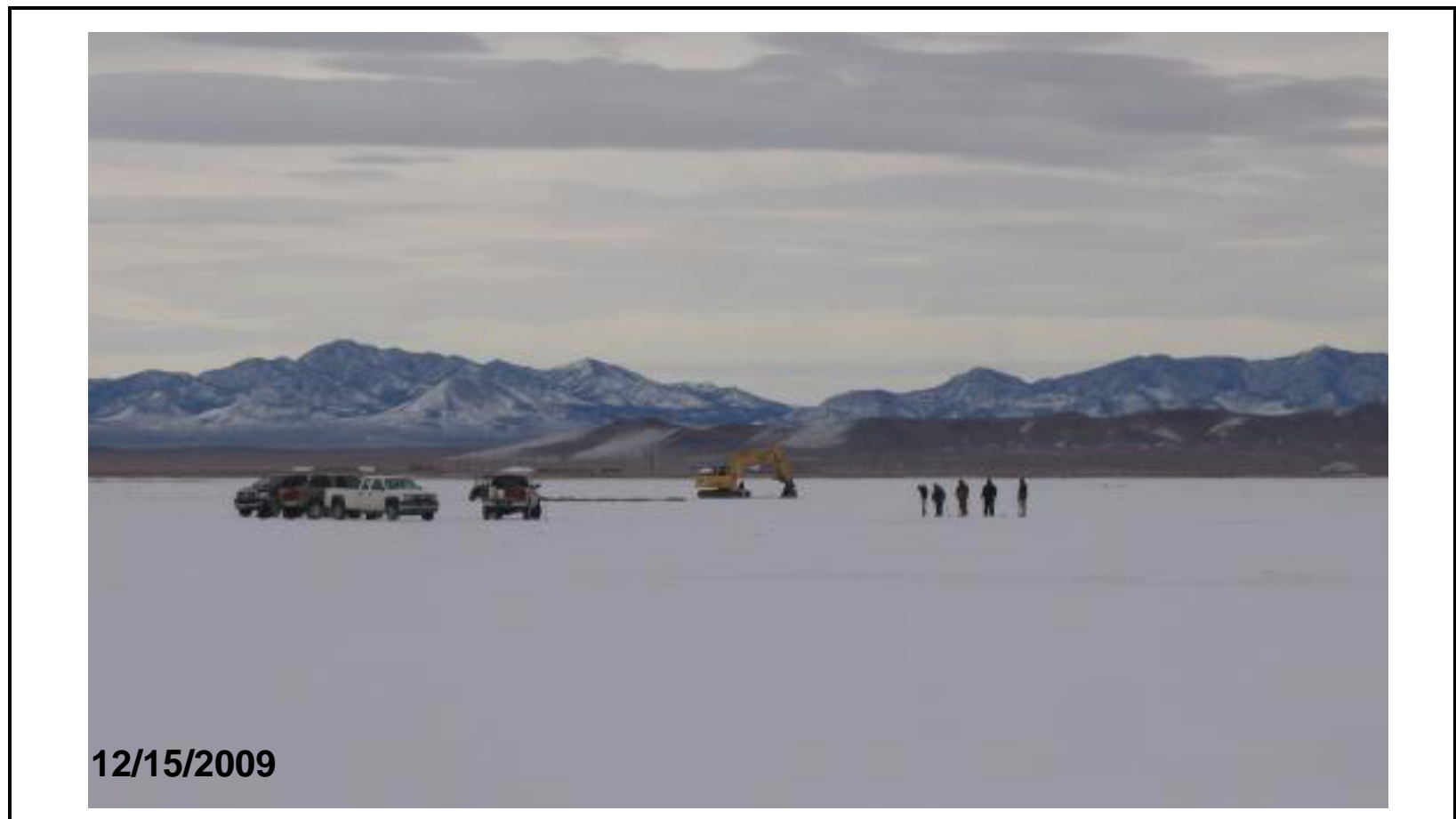

Figure C.2-1

South Antelope Lake Covered with Snow

$03 / 16 / 2010$

Figure C.2-2

South Antelope Lake after Heavy Rainfall 
Site-specific field-screening levels (FSLs) for alpha and beta/gamma radiation were defined as the mean background activity level plus two times the standard deviation. The radiation FSLs are instrument-specific and were established for each instrument and target area before use.

During MEC clearance activities and the buffer zone visual sweep activities, RCTs were present to perform field-screening on debris recovered due to the known and suspected presence of DU. Several pieces of metal debris were identified as being impacted with DU and were removed for disposal (Table 2-2). All pieces of DU-impacted metal and debris discovered during CAU 408 CAI activities were discrete fragments found on the surface.

\section{C.2.1.2 Verification Soil Sampling}

Surface soil samples were collected using "scoop and trowel" (surface hand-grab sampling) and were collected from 0.0 to $0.5 \mathrm{ft}$ bgs at biased locations focusing on presence of MD, stained soil, or areas with elevated radiological measurements. Subsurface verification samples were collected from the bottom and sides of excavations using an excavator following the removal of disposal pit contents (e.g., MD and/or waste). Field screening was conducted during sample collection to guide the investigation and serve as a health and safety control to protect the sampling team. Soil was transferred into an aluminum pan, homogenized, and field screened for alpha and beta/gamma radiation before filling sample containers. Excess soil was returned to its original location and the sample containers appropriately disposed (based on field-screening results [FSRs] and/or analytical results).

\section{C.2.1.3 Waste Characterization Sampling}

Specific waste characterization sampling and analysis was conducted on the containerized DU-impacted soil and lead battery waste to confirm the regulatory status of this remediation waste. All analytical data and radiological surveys were reviewed to determine a waste disposal path for the waste streams present (i.e., construction debris and MD). Specific analytical results for waste characterization samples are provided in Section C.4.0 and all analytical data are compared to the federal limits for hazardous waste, landfill acceptance criteria, and the limits in the NTS performance objective criteria (POC) (BN, 1995). The POC limits have been established for NTS hazardous waste generators to ensure that all hazardous waste being shipped off site contains no "added radioactivity." 


\section{C.2.2 Laboratory Analytical Information}

Radiological and chemical analyses were performed by ALS Laboratory Group (Paragon) of Fort Collins, Colorado, and GEL Laboratories of Charleston, South Carolina. The analytical suites and laboratory analytical methods used to analyze investigation samples are listed in Table C.2-1. Analytical results are reported in this appendix if they were detected above the minimum detectable concentrations (MDCs). The complete laboratory data packages are available in the project files.

Table C.2-1

Laboratory Analyses and Methods, CAU 408 Investigation Samples $^{\text {a }}$

\begin{tabular}{|c|c|}
\hline Analysis & Analytical Method $^{\mathbf{b}}$ \\
\hline \hline Explosives & All - EPA SW-846 8330 \\
\hline Metals & All - EPA SW-846 6010 \\
\hline Isotopic U & All - DOE EML HASL-300 ${ }^{\mathrm{d}}$ \\
\hline Mercury & $\begin{array}{c}\text { Aqueous - EPA SW-846 } 7470 \\
\text { Non-aqueous - EPA SW-846 } 7471\end{array}$ \\
\hline Gamma Spectroscopy & $\begin{array}{c}\text { Aqueous - EPA } 901.1^{\mathrm{e}} \\
\text { Non-aqueous - DOE EML HASL-300 }\end{array}$ \\
\hline TCLP Metals (waste samples only) & EPA SW-846 $1311 / 6010 / 7470$ \\
\hline
\end{tabular}

anvestigation samples include both environmental and waste characterization samples and associated QC samples.

${ }^{\mathrm{b}}$ The most current EPA, DOE, ASTM, NIOSH, or equivalent accepted analytical method may be used, including Laboratory Standard Operating Procedures approved by SNJV in accordance with industry standards and the SNJV/NNES Statement of Work requirements (SNJV, 2006; NNES, 2009).

${ }^{\mathrm{c}}$ Test Methods for Evaluating Solid Waste, Physical/Chemical Methods (EPA, 2008).

${ }^{\mathrm{d}}$ The Procedures Manual of the Environmental Measurements Laboratory (DOE, 1997).

${ }^{\mathrm{e}}$ Prescribed Procedures for Measurement of Radioactivity in Drinking Water (EPA, 1980).

Note: The term "modified" indicates modifications of approved methods. All modifications have been approved by the SNJV/NNES Analytical Services Department.

ASTM = American Society for Testing and Materials

$\mathrm{EML}=$ Environmental Measurements Laboratory

EPA = U.S. Environmental Protection Agency

HASL = Health and Safety Laboratory
$\mathrm{NIOSH}=$ National Institute for Occupational Safety and Health NNES = Navarro Nevada Environmental Services, LLC SNJV = Stoller-Navarro Joint Venture

Validated analytical data for CAU 408 investigation samples have been compiled and evaluated to confirm the presence of contamination and define the extent of contamination, if present. The analytical results for CAS TA-55-002-TAB2 are presented in Section C.3.0.

The analytical parameters are CAS-specific and were selected through the application of site process knowledge according to the DQOs. 


\section{C.2.3 Comparison to Action Levels}

A COC is defined as any contaminant present in environmental media exceeding a FAL. A COC may also be defined as a contaminant that, in combination with other like contaminants, is determined to jointly pose an unacceptable risk based on a multiple constituent analysis (NNSA/NSO, 2006).

If COCs are present, corrective action must be considered for the CAS. The FALs for the CAU 408 investigation are defined for each CAS in Appendix E. Results that are equal to or greater than FALs are identified by bold text in the CAS-specific results tables (see Section C.3.0). 


\section{C.3.0 CAS TA-55-002-TAB2, Bomblet Target Areas, Investigation Results}

This section addresses the investigation results of verification soil sampling performed at CAS TA-55-002-TAB2 to achieve clean closure and waste characterization results.

\section{C.3.1 Verification Sampling Activities}

A total of 68 characterization samples (including 5 field duplicates [FDs], and 1 field blank) were collected during investigation activities at CAS TA-55-002-TAB2. The sample identifications (IDs), locations, types, and analyses are listed in Table C.3-1. The specific CAI activities conducted to satisfy the SAFER Plan (NNSA/NSO, 2010b) requirements at this CAS are described in the following sections.

\section{C.3.2 Soil Verification Investigations}

The information necessary to satisfy the closure criteria for verification sampling was generated at specific target areas and disposal pit locations by collecting and analyzing soil samples. Verification samples were collected from soil beneath and/or adjacent to areas indicating the potential for explosives and/or DU contamination. For disposal pit excavations, samples were collected from the bottom and sides of excavations after waste and MEC removal was conducted.

A total of 64 soil samples were collected from the eight disposal pits. One biased composite soil sample was collected from the small soil mound investigated at grid 71/729 at SAC Target 2 based on biasing factors (i.e., presence of MD in the mound).

\section{C.3.2.1 Field Screening}

Field-screening activities for alpha and beta/gamma radiation, and gamma-emitting radionuclides were performed on soil samples as specified in the CAU 408 SAFER Plan (NNSA/NSO, 2010b). Site-specific FSLs for alpha and beta/gamma radiation were defined as the mean background activity level plus two times the standard deviation. The radiation FSLs are instrument-specific and were established for each instrument and target area before use. 
Table C.3-1

Samples Collected at CAS TA-55-002-TAB2, Bomblet Target Areas

(Page 1 of 5 )

\begin{tabular}{|c|c|c|c|c|c|c|c|c|c|}
\hline Sample Location & $\begin{array}{l}\text { Sample } \\
\text { Number }\end{array}$ & $\begin{array}{l}\text { Depth } \\
\text { (ft bgs) }\end{array}$ & Matrix & Purpose & $\begin{array}{l}y \\
\frac{a}{n} \\
\frac{0}{2} \\
\frac{x}{x}\end{array}$ & 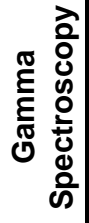 & $\frac{\frac{\omega}{\pi}}{\frac{\Phi}{\Sigma}}$ & 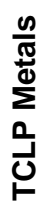 & 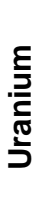 \\
\hline South Wall, East End Anomaly G156_95 & 408A001 & $6.0-8.0$ & Soil & Environmental & $\mathrm{x}$ & $\mathrm{x}$ & $\mathrm{x}$ & -- & $\mathrm{x}$ \\
\hline Bottom, East End Anomaly G156_95 & 408A002 & $12.0-14.0$ & Soil & Environmental & $\mathrm{x}$ & $\mathrm{x}$ & $x$ & -- & $x$ \\
\hline North Wall, East End Anomaly G156_95 & 408A003 & $6.0-8.0$ & Soil & Environmental & $x$ & $x$ & $x$ & -- & $x$ \\
\hline North Wall, Center Anomaly G156_95 & 408A004 & $6.0-8.0$ & Soil & Environmental & $x$ & $x$ & $x$ & -- & $x$ \\
\hline North Wall, West End Anomaly G156_95 & 408A005 & $6.0-8.0$ & Soil & Environmental & $x$ & $\mathrm{x}$ & $x$ & -- & $x$ \\
\hline Bottom, West End Anomaly G156_95 & 408A006 & $12.0-14.0$ & Soil & Environmental & $x$ & $x$ & $x$ & -- & $\mathrm{x}$ \\
\hline South Wall, East End Anomaly G156_95 & 408A007 & $6.0-8.0$ & Soil & Environmental & $\mathrm{x}$ & $\mathrm{x}$ & $x$ & -- & $\mathrm{x}$ \\
\hline South Wall, Center Anomaly G156_95 & 408A008 & $6.0-8.0$ & Soil & Environmental & $x$ & $x$ & $x$ & -- & $\mathrm{x}$ \\
\hline Bottom, Center Anomaly G156_95 & 408A009 & $12.0-14.0$ & Soil & Environmental & $\mathrm{x}$ & $\mathrm{x}$ & $x$ & -- & $\mathrm{x}$ \\
\hline North Wall, Small Excavation Anomaly G156_95 & 408A010 & $1.0-2.0$ & Soil & Environmental & $\mathrm{x}$ & $x$ & $\mathrm{x}$ & -- & $\mathrm{x}$ \\
\hline \multirow{2}{*}{ South Wall, Small Excavation Anomaly G156_95 } & 408A011 & $1.0-2.0$ & Soil & Environmental & $\mathrm{x}$ & $x$ & $x$ & -- & $\mathrm{x}$ \\
\hline & 408A012 & $1.0-2.0$ & Soil & FD of \#408A011 & $x$ & $x$ & $x$ & -- & $\mathrm{x}$ \\
\hline West Wall, Small Excavation Anomaly G156_95 & 408A013 & $1.0-2.0$ & Soil & Environmental & $\mathrm{x}$ & $x$ & $x$ & -- & $\mathrm{x}$ \\
\hline East Wall, Small Excavation Anomaly G156_95 & 408A014 & $1.0-2.0$ & Soil & Environmental & $\mathrm{x}$ & $x$ & $x$ & -- & $x$ \\
\hline Bottom, West End Small Excavation Anomaly G156_95 & 408A015 & $3.0-4.0$ & Soil & Environmental & $\mathrm{x}$ & $x$ & $x$ & -- & $x$ \\
\hline Bottom, South Side Anomaly G156_95 & 408A016 & $3.0-4.0$ & Soil & Environmental & $x$ & $x$ & $x$ & -- & $\mathrm{x}$ \\
\hline Soil Stock Pile, West Side Anomaly G156_95 & 408A017 & N/A & Soil & Environmental & $\mathrm{x}$ & $x$ & $\mathrm{x}$ & -- & $\mathrm{x}$ \\
\hline Soil Stock Pile, East Side Anomaly G156_95 & 408A018 & N/A & Soil & Environmental & $\mathrm{x}$ & $\mathrm{X}$ & $\mathrm{X}$ & -- & $\mathrm{x}$ \\
\hline
\end{tabular}


Table C.3-1

Samples Collected at CAS TA-55-002-TAB2, Bomblet Target Areas

(Page 2 of 5 )

\begin{tabular}{|c|c|c|c|c|c|c|c|c|c|}
\hline Sample Location & $\begin{array}{l}\text { Sample } \\
\text { Number }\end{array}$ & $\begin{array}{l}\text { Depth } \\
\text { (ft bgs) }\end{array}$ & Matrix & Purpose & 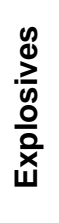 & 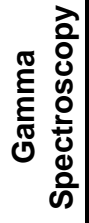 & $\frac{\frac{\omega}{\pi}}{\frac{\Phi}{\Sigma}}$ & $\begin{array}{l}\frac{n}{\pi} \\
\sum_{0}^{0} \\
\frac{1}{0} \\
0\end{array}$ & 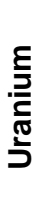 \\
\hline Large Screened Stock Pile Anomaly G156_95 & 408A019 & N/A & Soil & Environmental & $\mathrm{x}$ & $\mathrm{x}$ & $\mathrm{x}$ & -- & $\mathrm{X}$ \\
\hline Small Stock Pile Anomaly G156_95 & 408A020 & N/A & Soil & Environmental & $\mathrm{x}$ & $\mathrm{x}$ & $x$ & -- & $\mathrm{x}$ \\
\hline North Wall Grid 94/701, South Antelope Lake & 408A021 & $0.0-0.5$ & Soil & Environmental & $x$ & $x$ & $x$ & -- & $\mathrm{x}$ \\
\hline \multirow{2}{*}{ East Wall Grid 94/701, South Antelope Lake } & 408A022 & $0.0-0.5$ & Soil & Environmental & $\mathrm{x}$ & $x$ & $x$ & -- & $x$ \\
\hline & 408A023 & $0.0-0.5$ & Soil & FD of \#408A022 & $x$ & $x$ & $x$ & -- & $\mathrm{x}$ \\
\hline South Wall Grid 94/701, South Antelope Lake & 408A024 & $0.0-0.5$ & Soil & Environmental & $x$ & $x$ & $x$ & -- & $\mathrm{x}$ \\
\hline West Wall Grid 94/701, South Antelope Lake & $408 \mathrm{~A} 025$ & $0.0-0.5$ & Soil & Environmental & $\mathrm{x}$ & $x$ & $\mathrm{x}$ & -- & $\mathrm{x}$ \\
\hline Bottom Center Grid 94/701, South Antelope Lake & 408A026 & $0.0-0.5$ & Soil & Environmental & $x$ & $x$ & $x$ & -- & $\mathrm{x}$ \\
\hline Spoils Pile Grid 94/701, South Antelope Lake & 408A027 & $0.0-0.5$ & Soil & Environmental & $\mathrm{x}$ & $\mathrm{X}$ & $x$ & -- & $\mathrm{x}$ \\
\hline Grid 94/701, South Antelope Lake & 408A301 & N/A & Water & Field Blank & $x$ & $x$ & $\mathrm{x}$ & -- & $\mathrm{x}$ \\
\hline 3-Sided Concrete Bunker & 408A501 & N/A & Soil & Waste Management & $x$ & -- & -- & $x$ & -- \\
\hline Container 408A02 SAA-TTR-09-02 & 408A502 & N/A & Solid & Waste Management & -- & -- & -- & $x$ & -- \\
\hline Center West Wall, Pit 1 Anomaly D006_002 & 408B001 & $3.0-4.0$ & Soil & Environmental & $x$ & $x$ & $x$ & -- & $x$ \\
\hline Center Bottom, Pit 1 Anomaly D006_002 & 408B002 & $6.0-7.0$ & Soil & Environmental & $x$ & $x$ & $x$ & -- & $x$ \\
\hline \multirow{2}{*}{ North Wall, Pit 1 Anomaly D006_002 } & 408B003 & $3.0-4.0$ & Soil & Environmental & $\mathrm{X}$ & $x$ & $x$ & -- & $x$ \\
\hline & 408B004 & $3.0-4.0$ & Soil & FD of \#408B003 & $x$ & $x$ & $x$ & -- & $x$ \\
\hline East Wall, Pit 1 Anomaly D006_002 & 408B005 & $3.0-4.0$ & Soil & Environmental & $\mathrm{x}$ & $x$ & $x$ & -- & $\mathrm{x}$ \\
\hline South Wall, Pit 1 Anomaly D006_002 & 408B006 & $3.0-4.0$ & Soil & Environmental & $\mathrm{x}$ & $\mathrm{X}$ & $\mathrm{X}$ & -- & $\mathrm{x}$ \\
\hline
\end{tabular}


Table C.3-1

Samples Collected at CAS TA-55-002-TAB2, Bomblet Target Areas

(Page 3 of 5 )

\begin{tabular}{|c|c|c|c|c|c|c|c|c|c|}
\hline Sample Location & $\begin{array}{l}\text { Sample } \\
\text { Number }\end{array}$ & $\begin{array}{c}\text { Depth } \\
\text { (ft bgs) }\end{array}$ & Matrix & Purpose & $\begin{array}{l}y \\
\frac{a}{n} \\
\frac{0}{2} \\
\frac{x}{x}\end{array}$ & 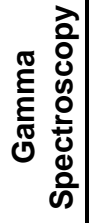 & $\frac{\frac{\omega}{\pi}}{\frac{\Phi}{\Sigma}}$ & $\begin{array}{l}\frac{n}{\pi} \\
\sum_{0}^{0} \\
\frac{1}{0} \\
0\end{array}$ & 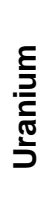 \\
\hline South Wall, Pit 3 Anomaly D006_002 & 408B007 & $4.0-5.0$ & Soil & Environmental & $\mathrm{x}$ & $x$ & $\mathrm{x}$ & -- & $\mathrm{x}$ \\
\hline East Wall, Pit 3 Anomaly D006_002 & 408B008 & $4.0-5.0$ & Soil & Environmental & $\mathrm{x}$ & $x$ & $x$ & -- & $x$ \\
\hline North Wall, Pit 3 Anomaly D006_002 & 408B009 & $4.0-5.0$ & Soil & Environmental & $x$ & $x$ & $x$ & -- & $x$ \\
\hline West Wall, Pit 3 Anomaly D006_002 & 408B010 & $4.0-5.0$ & Soil & Environmental & $x$ & $x$ & $x$ & -- & $x$ \\
\hline Center Bottom, Pit 3 Anomaly D006_002 & 408B011 & $8.0-9.0$ & Soil & Environmental & $x$ & $x$ & $x$ & -- & $x$ \\
\hline Spoils Pile, Pit 1 Anomaly D006_002 & 408B012 & $0.0-1.0$ & Soil & Environmental & $x$ & $x$ & $x$ & -- & $x$ \\
\hline Spoils Pile, Pit 3 Anomaly D006_002 & 408B013 & $0.0-1.0$ & Soil & Environmental & $x$ & $x$ & $x$ & -- & $x$ \\
\hline Soil Mound Grid 71/729, SAC Target 2 & 408D001 & $0.0-1.0$ & Soil & Environmental & $x$ & $x$ & $x$ & -- & $x$ \\
\hline South Wall Grid 53/815, Mid Target & 408G001 & $0.0-2.0$ & Soil & Environmental & $\mathrm{x}$ & $x$ & $x$ & -- & $x$ \\
\hline \multirow{2}{*}{ West Wall Grid 53/815, Mid Target } & 408G002 & $0.0-2.0$ & Soil & Environmental & $x$ & $x$ & $x$ & -- & $x$ \\
\hline & 408G003 & $0.0-2.0$ & Soil & FD of \#408G002 & $x$ & $x$ & $x$ & -- & $\mathrm{x}$ \\
\hline North Wall Grid 53/815, Mid Target & 408G004 & $0.0-2.0$ & Soil & Environmental & $x$ & $x$ & $x$ & -- & $x$ \\
\hline East Wall Grid 53/815, Mid Target & $408 G 005$ & $0.0-2.0$ & Soil & Environmental & $x$ & $x$ & $x$ & -- & $x$ \\
\hline \multirow{2}{*}{ Bottom of Excavation Grid 53/815, Mid Target } & 408G006 & $0.0-4.0$ & Soil & Environmental & $x$ & $x$ & $x$ & -- & $x$ \\
\hline & 408G007 & $0.0-4.0$ & Soil & Environmental & $x$ & $x$ & $x$ & -- & $x$ \\
\hline East Wall Grid 53/814, Mid Target & 408G008 & $0.0-1.5$ & Soil & Environmental & $x$ & $x$ & $x$ & -- & $x$ \\
\hline South Wall Grid 53/814, Mid Target & 408G009 & $0.0-1.5$ & Soil & Environmental & $\mathrm{x}$ & $x$ & $x$ & -- & $x$ \\
\hline West Wall Grid 53/814, Mid Target & $408 G 010$ & $0.0-1.5$ & Soil & Environmental & $\mathrm{X}$ & $\mathrm{X}$ & $x$ & -- & $\mathrm{x}$ \\
\hline
\end{tabular}


Table C.3-1

Samples Collected at CAS TA-55-002-TAB2, Bomblet Target Areas

(Page 4 of 5 )

\begin{tabular}{|c|c|c|c|c|c|c|c|c|c|}
\hline Sample Location & $\begin{array}{l}\text { Sample } \\
\text { Number }\end{array}$ & $\begin{array}{c}\text { Depth } \\
\text { (ft bgs) }\end{array}$ & Matrix & Purpose & 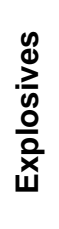 & 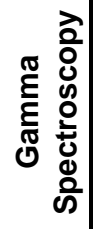 & $\begin{array}{l}\frac{n}{\pi} \\
\stackrel{\mathbb{d}}{\Sigma}\end{array}$ & $\begin{array}{l}\frac{\infty}{\pi} \\
\frac{\pi}{0} \\
\sum \\
0 \\
0 \\
1\end{array}$ & $\frac{\underline{5}}{\frac{5}{c}}$ \\
\hline North Wall Grid 53/814, Mid Target & 408G011 & $0.0-1.0$ & Soil & Environmental & $\mathrm{X}$ & $x$ & $\mathrm{x}$ & -- & $\mathrm{x}$ \\
\hline \multirow{2}{*}{ Bottom of Excavation Grid 53/814, Mid Target } & $408 G 012$ & $0.0-3.0$ & Soil & Environmental & $x$ & $x$ & $x$ & -- & $x$ \\
\hline & $408 \mathrm{G} 013$ & $0.0-3.0$ & Soil & Environmental & $x$ & $x$ & $x$ & -- & $x$ \\
\hline East Wall Grid 52/817, Mid Target & $408 G 014$ & $0.0-2.0$ & Soil & Environmental & $\mathrm{x}$ & $x$ & $x$ & -- & $x$ \\
\hline South Wall Grid 52/817, Mid Target & $408 \mathrm{G} 015$ & $1.0-2.0$ & Soil & Environmental & $x$ & $x$ & $x$ & -- & $\mathrm{x}$ \\
\hline West Wall Grid 52/817, Mid Target & 408G016 & $0.0-2.0$ & Soil & Environmental & $x$ & $x$ & $x$ & -- & $x$ \\
\hline North Wall Grid 52/817, Mid Target & 408G017 & $0.0-1.5$ & Soil & Environmental & $x$ & $x$ & $x$ & -- & $\mathrm{x}$ \\
\hline \multirow{2}{*}{ Bottom of Excavation Grid 52/817, Mid Target } & 408G018 & $0.0-3.5$ & Soil & Environmental & $x$ & $\mathrm{x}$ & $x$ & -- & $x$ \\
\hline & 408G019 & $0.0-3.5$ & Soil & Environmental & $\mathrm{x}$ & $\mathrm{x}$ & $x$ & -- & $x$ \\
\hline South Wall Excavation 2 Grid 52/817, Mid Target & $408 \mathrm{G} 020$ & $2.0-3.0$ & Soil & Environmental & $\mathrm{x}$ & $x$ & $x$ & -- & $\mathrm{x}$ \\
\hline West Wall Excavation 2 Grid 52/817, Mid Target & 408G021 & $2.0-3.0$ & Soil & Environmental & $\mathrm{x}$ & $x$ & $x$ & -- & $\mathrm{x}$ \\
\hline North Wall Excavation 2 Grid 52/817, Mid Target & $408 G 022$ & $2.0-3.0$ & Soil & Environmental & $x$ & $x$ & $x$ & -- & $x$ \\
\hline East Wall Excavation 2 Grid 52/817, Mid Target & $408 G 023$ & $2.0-3.0$ & Soil & Environmental & $x$ & $x$ & $x$ & -- & $\mathrm{x}$ \\
\hline \multirow{2}{*}{ Bottom South End Excavation 2 Grid 52/817, Mid Target } & 408G024 & $4.0-5.0$ & Soil & Environmental & $\mathrm{x}$ & $x$ & $x$ & -- & $\mathrm{X}$ \\
\hline & $408 G 025$ & $4.0-5.0$ & Soil & FD of $\# 408 \mathrm{G} 024$ & $x$ & $x$ & $x$ & -- & $\mathrm{x}$ \\
\hline Bottom North End Excavation 2 Grid 52/817, Mid Target & $408 \mathrm{G} 026$ & $4.0-5.0$ & Soil & Environmental & $\mathrm{x}$ & $x$ & $x$ & -- & $\mathrm{x}$ \\
\hline South Wall Excavation 3 Grid 52/817, Mid Target & $408 \mathrm{G} 027$ & $2.0-3.0$ & Soil & Environmental & $x$ & $x$ & $\mathrm{x}$ & -- & $\mathrm{x}$ \\
\hline West Wall Excavation 3 Grid 52/817, Mid Target & $408 G 028$ & $2.0-3.0$ & Soil & Environmental & $X$ & $x$ & $x$ & -- & $x$ \\
\hline
\end{tabular}


Table C.3-1

Samples Collected at CAS TA-55-002-TAB2, Bomblet Target Areas

(Page 5 of 5 )

\begin{tabular}{|c|c|c|c|c|c|c|c|c|c|}
\hline Sample Location & $\begin{array}{l}\text { Sample } \\
\text { Number }\end{array}$ & $\begin{array}{c}\text { Depth } \\
\text { (ft bgs) }\end{array}$ & Matrix & Purpose & $\begin{array}{l}\frac{y}{d} \\
\frac{1}{w} \\
\frac{0}{2} \\
\frac{x}{x}\end{array}$ & 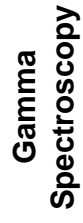 & $\frac{\frac{n}{\pi}}{\frac{d}{2}}$ & 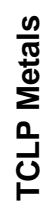 & 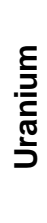 \\
\hline North Wall Excavation 3 Grid 52/817, Mid Target & $408 G 029$ & $2.0-3.0$ & Soil & Environmental & $\mathrm{X}$ & $\mathrm{x}$ & $\mathrm{x}$ & -- & $\mathrm{x}$ \\
\hline East Wall Excavation 3 Grid 52/817, Mid Target & $408 \mathrm{G} 030$ & $2.0-3.0$ & Soil & Environmental & $\mathrm{x}$ & $\mathrm{x}$ & $\mathrm{X}$ & -- & $x$ \\
\hline Bottom South End Excavation 3 Grid 52/817, Mid Target & $408 \mathrm{G} 031$ & $3.0-4.0$ & Soil & Environmental & $x$ & $\mathrm{X}$ & $\mathrm{x}$ & -- & $\mathrm{x}$ \\
\hline Bottom North End Excavation 3 Grid 52/817, Mid Target & 408G032 & $3.0-4.0$ & Soil & Environmental & $\mathrm{x}$ & $\mathrm{x}$ & $\mathrm{x}$ & -- & $\mathrm{x}$ \\
\hline
\end{tabular}

$-=$ Not required 


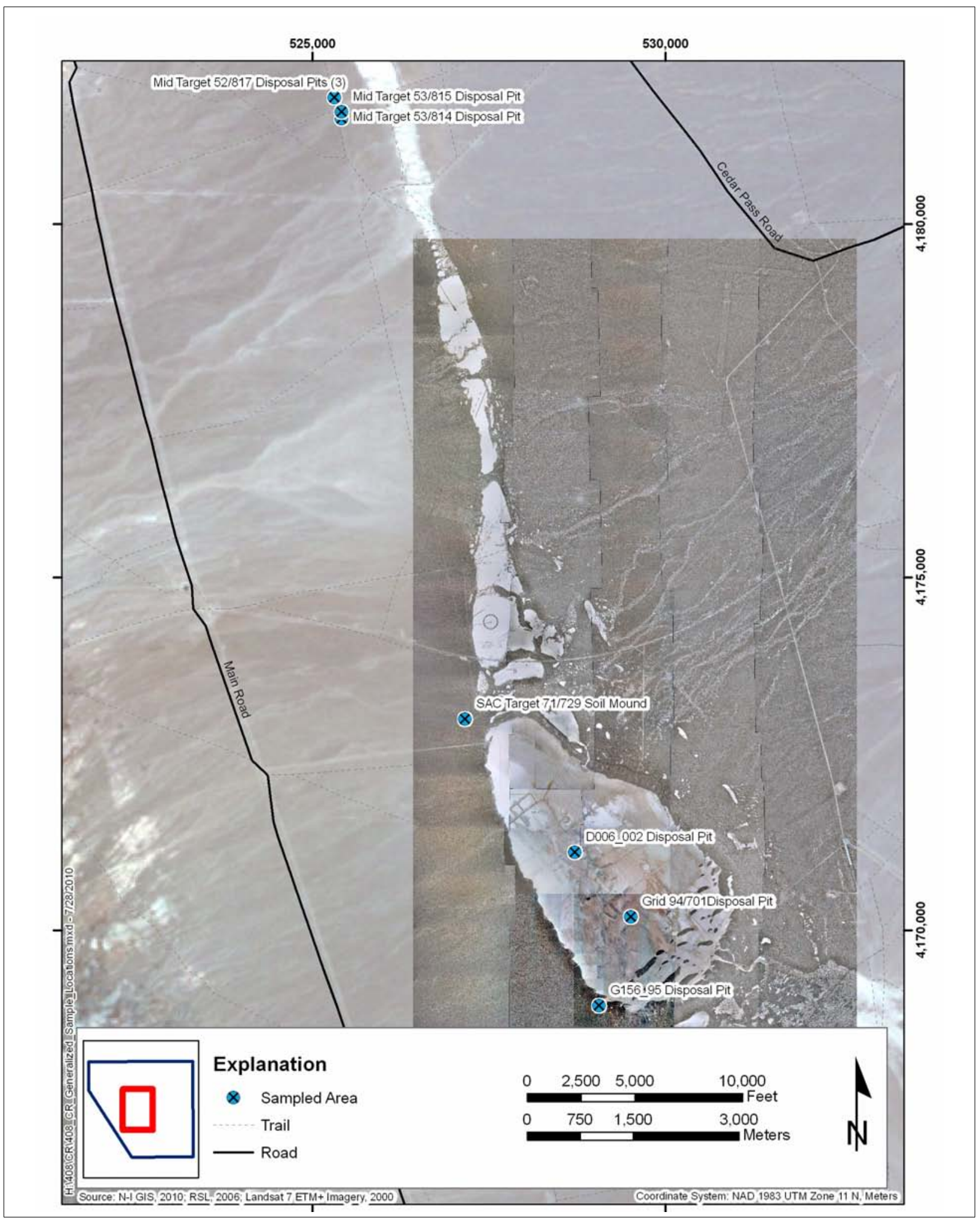

Figure C.3-1

Sample Locations at CAS TA-55-002-TAB2, Bomblet Target Areas 


\section{C.3.2.2 Visual Inspections}

Visual inspections were performed before excavation activities at each identified geophysical anomaly and/or during MEC clearance activities to identify additional sample locations based on biasing factors (i.e., staining). No additional biased sample locations were identified before disposal pit excavations nor during MEC clearance activities based on biasing factors other than the presence of MD.

\section{C.3.2.3 Sample Collection}

Anomaly G156_95 located at the south end of Antelope Lake had two disposal pit trenches excavated and remediated for construction-type debris and MD. The first, and largest, of all disposal pits identified was excavated to a depth of $14.0 \mathrm{ft}$ bgs. A second adjacent trench was excavated to a depth of approximately $4.0 \mathrm{ft}$ bgs. A total of 16 verification samples (408A001 through 408A016) were collected from the two trenches and submitted for analysis (Figure C.3-2). An additional four samples (408A017 through 408A020) were collected from the stockpiled soil before backfilling. Anomaly D006_002 had four trenches excavated to investigate potential disposal pits. Two of the four trenches were identified as disposal pit \# 1 and disposal pit \#3 and excavated to depths of 7.0 and $9.0 \mathrm{ft}$ bgs, respectively. The two pits were remediated of scrap metal and MEC, and verification samples 408B001 through 408B011 were collected from the sides and bottom of each pit (Figure C.3-3). Samples 408B012 and 408B013 were collected from the pit \#1 and pit \#3 soil stockpiles, respectively. During Mag and Dig surveys, one location in grid 94/701 was identified as a disposal pit based on high concentration of debris deeper than $1.0 \mathrm{ft}$ bgs. This location was excavated and remediated, and verification samples 408A022 through 408A026 were collected and submitted for analysis (Figure C.3-4). Verification sample 408A027 was a soil stockpile sample.

Five additional locations at Mid Target were identified as disposal pits during Mag and Dig surveys in grids 53/815, 53/814, and 52/817. In grid 53/815, one trench was excavated to a depth of $4.0 \mathrm{ft} \mathrm{bgs,}$ waste was remediated, and verification samples 408G001 through 408G007 were collected. In grid 53/814, one trench was excavated to a depth of $3.0 \mathrm{ft}$ bgs, waste was remediated, and verification samples 408G008 through 408G013 were collected and submitted for analysis. In grid 52/817, three trenches were excavated to depths ranging from 3.5 to $5.0 \mathrm{ft}$ bgs. Munitions debris waste was 


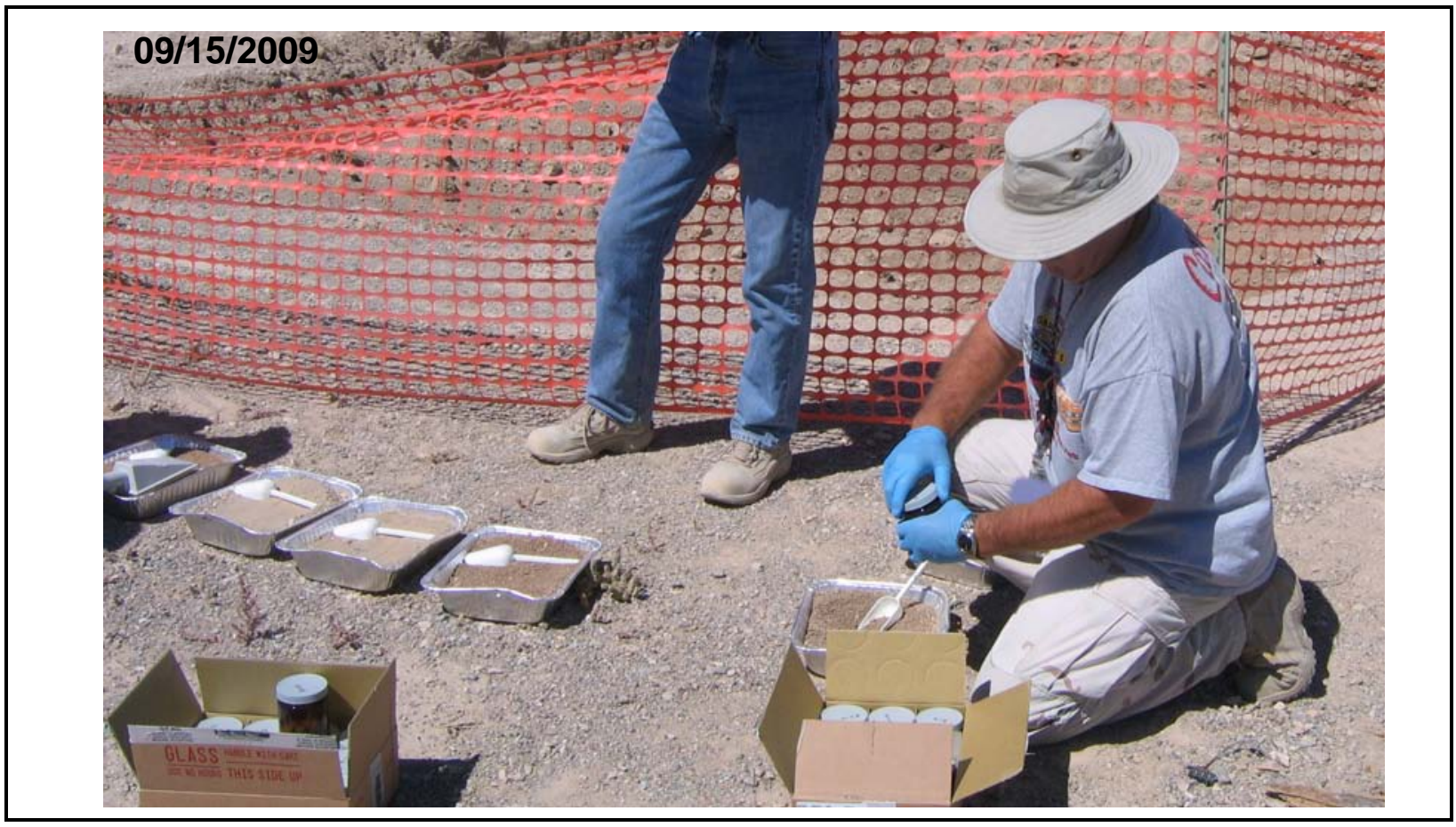

Figure C.3-2

Disposal Pit G156_95 Soil Sampling

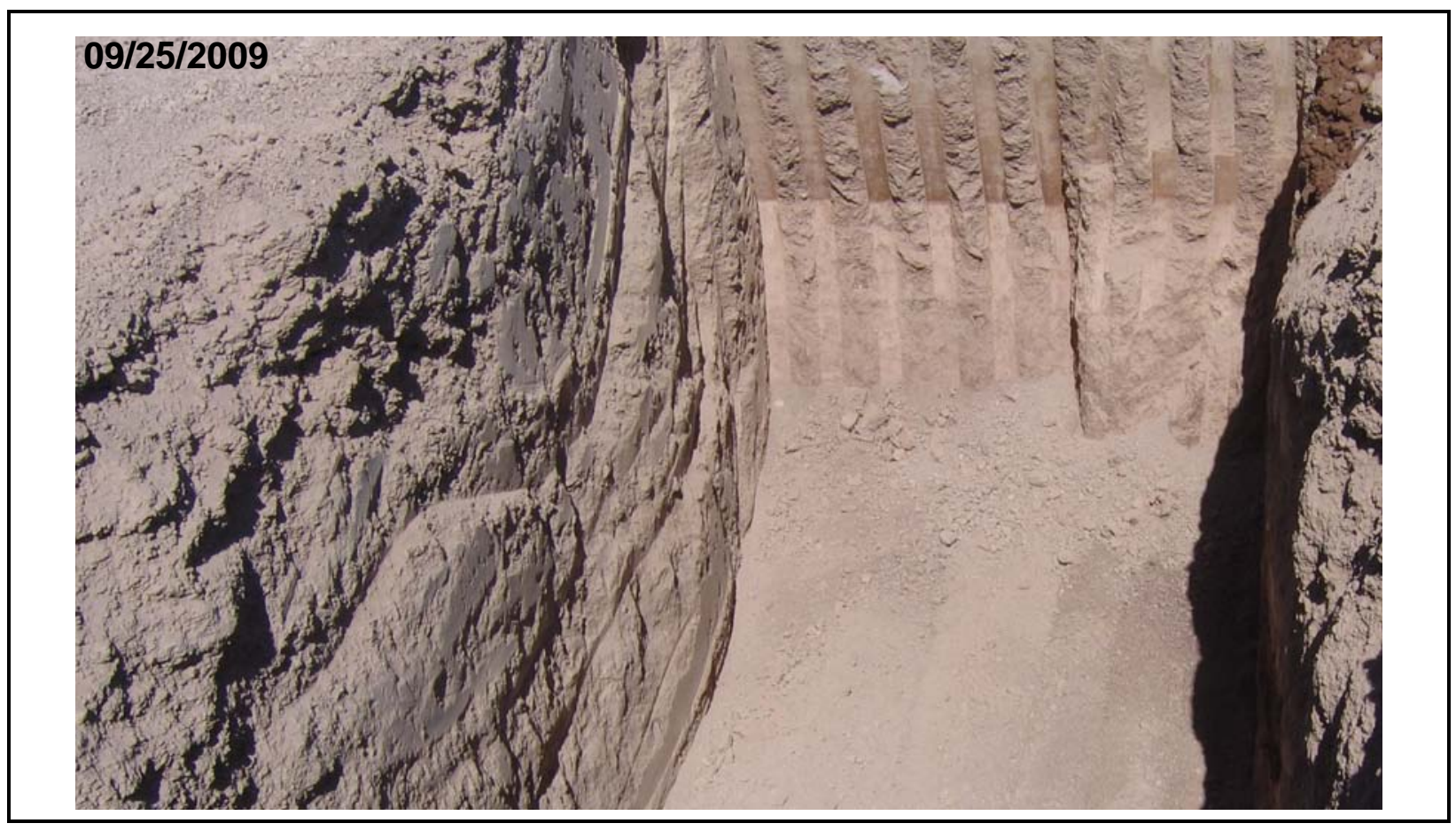

Figure C.3-3

Disposal Pit D006_002 Sampled Trench 


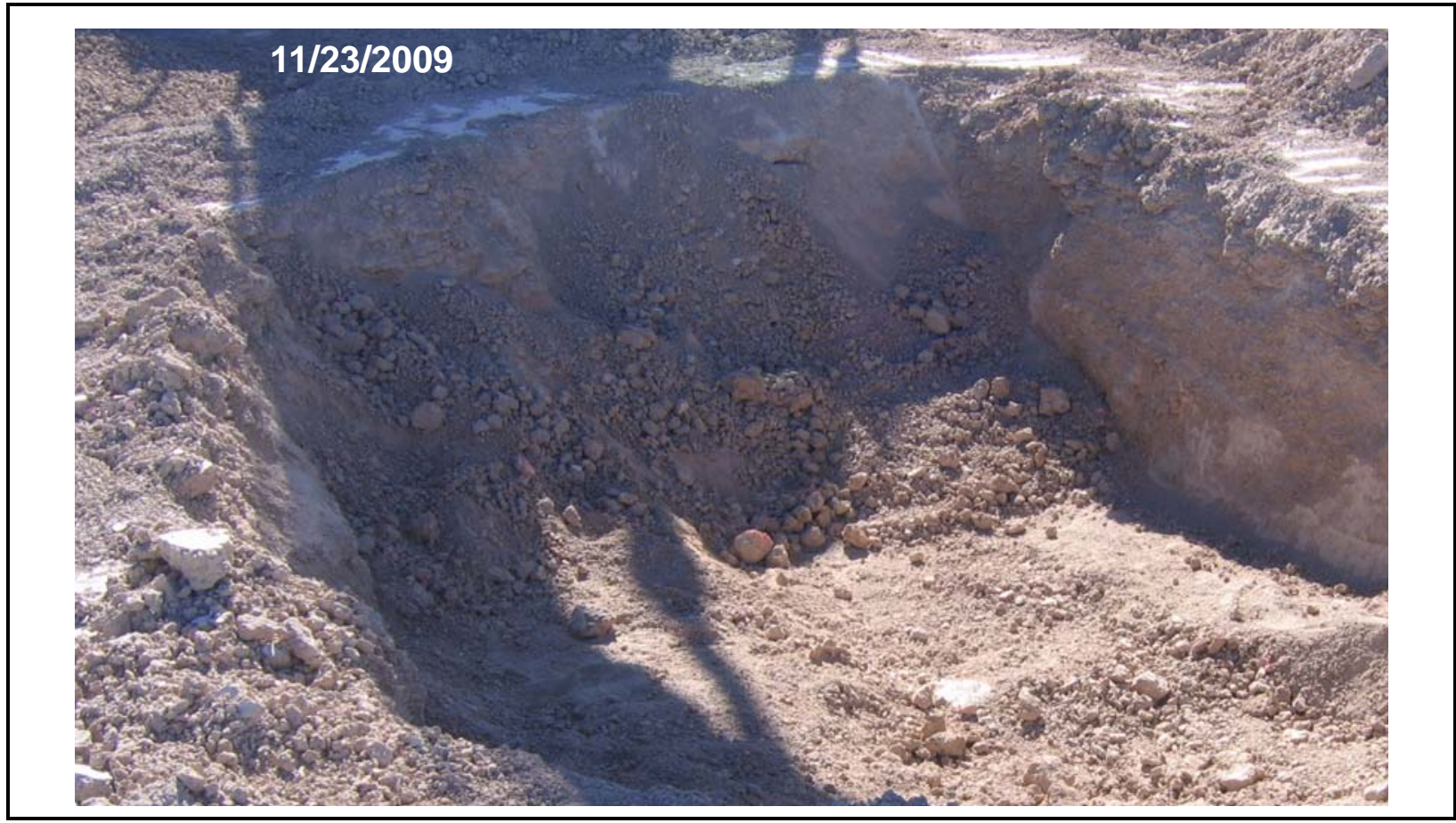

Figure C.3-4

\section{Grid 94/701 Post-excavation and Remediation}

remediated, and verification samples 408G014 through 408G032 were collected between the three trenches.

At SAC Target 2, an aboveground soil mound and associated depression was investigated to determine whether MEC was present. An excavator was used to spread out the soil mound to a thickness of about $1.0 \mathrm{ft}$ for a Mag and Dig clearance, and one trench was excavated in the depression. The depression trench encountered native soil at the surface (Figure C.3-5). The soil mound contained pieces of residual MD (e.g., rocket fragments); therefore, a biased composite sample (408D001) was collected from several locations within the thinned-out soil mound.

All sample locations are shown on Figure C.3-1.

\section{C.3.3 Deviations}

Investigation samples were collected as outlined in the CAU 408 SAFER Plan (NNSA/NSO, 2010b) and submitted for laboratory analysis. There were no deviations from the SAFER Plan. 


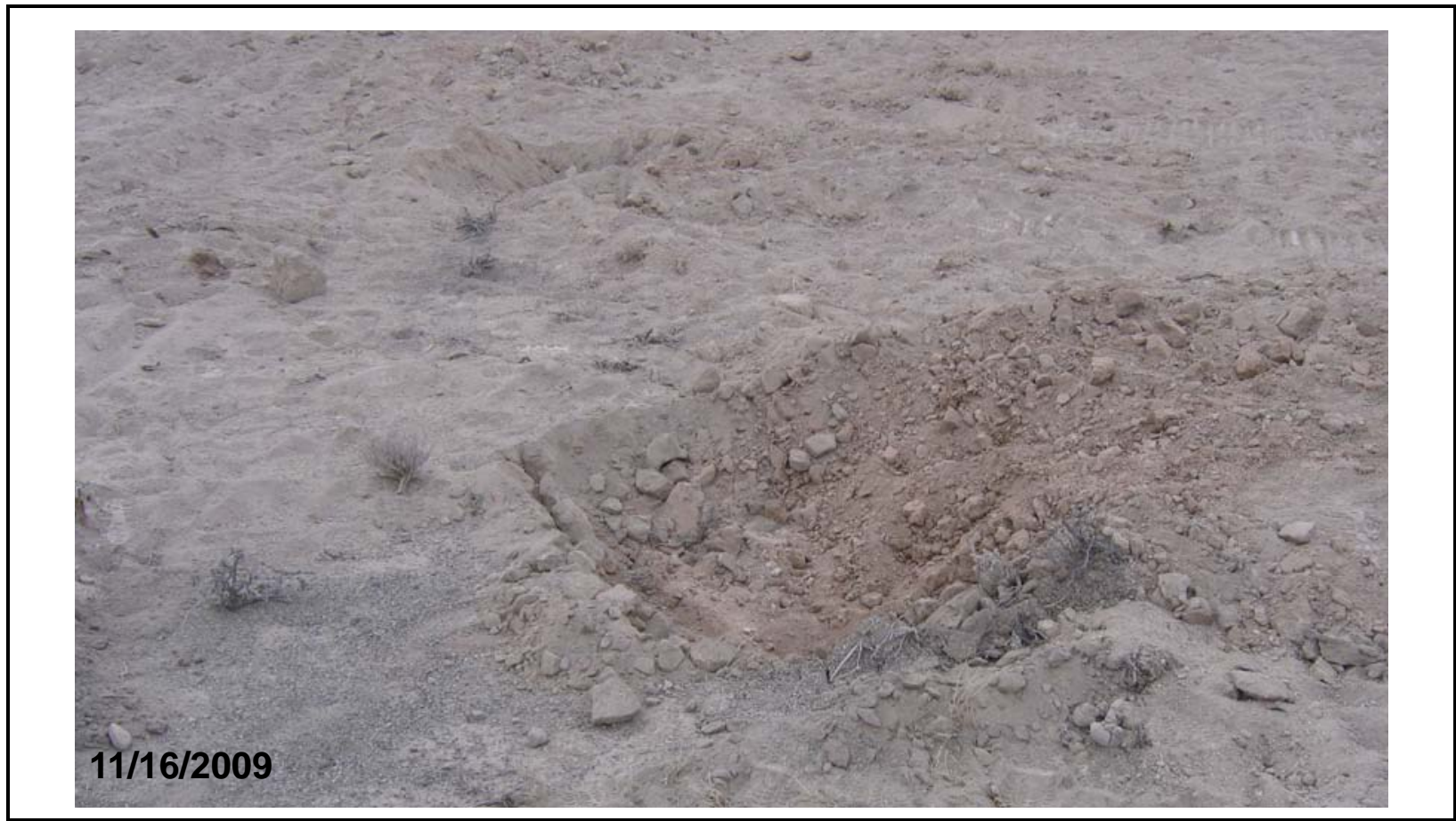

Figure C.3-5

SAC Target, Grid 71/729 Soil Mound after MEC Inspection

\section{C.3.4 Investigation Results}

The following sections provide analytical results from the samples collected to complete investigation activities as outlined in the SAFER Plan (NNSA/NSO, 2010b). Investigation samples were analyzed for the SAFER Plan-specified COPCs, which included high explosives, RCRA metals, gamma-emitting radionuclides, and isotopic $\mathrm{U}$. The analytical parameters and laboratory methods used to analyze the investigation samples are listed in Table C.2-1. Table C.3-1 lists the sample-specific analytical suite. The waste characterization analytical results are discussed in Section C.4.0.

Analytical results from the soil samples with concentrations exceeding MDCs are summarized in the following sections. An evaluation was conducted on all contaminants detected above MDCs by comparing individual concentration or activity results against the FALs. Establishment of the FALs is presented in Appendix E. The FALs were established as the corresponding PAL concentrations or activities if the contaminant concentrations were below their respective PALs. 


\section{C.3.4.1 High Explosives}

No concentrations of high explosives were detected above MDCs. The FAL was established at the corresponding PAL concentrations.

\section{C.3.4.2 RCRA Metals and Beryllium}

Analytical results for RCRA metals in soil samples collected at this CAS that were detected above MDCs are presented in Table C.3-2. Except for one lead sample and two arsenic samples, all other metals were detected at concentrations below their respective PALs. For all metals except lead, the FALs were established at the PAL concentrations. Lead in sample 408D001 was detected at a concentration exceeding the PAL. Lead was moved on to a Tier 2 evaluation, and a FAL was established using site-specific parameters. The FAL of 1,872 mg/kg was not exceeded; therefore, lead is not considered a COC. The calculation of the FAL for lead is presented in Appendix E.

Arsenic is present in native minerals and soils throughout the avid southwestern portion of the United States. Where surface waters accumulate in seasonal lake water (such as Antelope Lake), the arsenic and other soluble salts concentrate in the evaporating lake water and are deposited in the underlying soils in a process referred to as evapoconcentration (Gao et al., 2006; Ryu et al., 2002). It is not unexpected that a sample from the dry lake bed where soluble salts have concentrated would have a naturally elevated concentration of arsenic. Consequently, it is determined that the arsenic concentrations of 24 and $27 \mathrm{mg} / \mathrm{kg}$ in Antelope Lake (samples 408A001 and 408A008) is consistent with natural concentrations, and arsenic is not a contaminant released from DOE activities at the site. Therefore, a Tier 2 site-specific target level (SSTL) was not developed for arsenic (see Appendix E).

\section{C.3.4.3 Gamma-Emitting Radionuclides}

Analytical results for gamma-emitting radionuclides in soil samples collected at this CAS that were detected above MDCs are presented in Table C.3-3. No gamma-emitting radionuclide concentrations exceeded their respective PALs. The FALs were established at the PAL concentrations. 
Table C.3-2

Sample Results for Metals Detected above MDCs at CAS TA-55-002-TAB2, Bomblet Target Areas (Page 1 of 5)

\begin{tabular}{|c|c|c|c|c|c|c|c|c|c|}
\hline \multirow[b]{2}{*}{$\begin{array}{l}\text { Sample } \\
\text { Location }\end{array}$} & \multirow[b]{2}{*}{$\begin{array}{l}\text { Sample } \\
\text { Number }\end{array}$} & \multirow[b]{2}{*}{$\begin{array}{c}\text { Depth } \\
\text { (ft bgs) }\end{array}$} & \multicolumn{7}{|c|}{ COPCs (mg/kg) } \\
\hline & & & 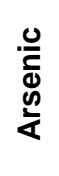 & 占 & 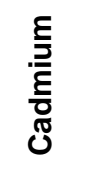 & 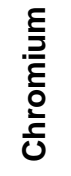 & ర్ర్త & $\begin{array}{l}\frac{\lambda}{2} \\
\frac{0}{d} \\
\sum\end{array}$ & 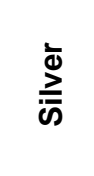 \\
\hline \multicolumn{3}{|l|}{ FAL } & 23 & 190,000 & 800 & 450 & 1,872 & 34 & 5,100 \\
\hline South Wall, East End Anomaly G156_95 & 408A001 & $6.0-8.0$ & 24 & $290(\mathrm{~J})$ & 0.26 & 13 & 17 & -- & -- \\
\hline Bottom, East End Anomaly G156_95 & 408A002 & $12.0-14.0$ & 17 & $270(\mathrm{~J})$ & 0.27 & 14 & 17 & -- & -- \\
\hline North Wall, East End Anomaly G156_95 & 408A003 & $6.0-8.0$ & 11 & $170(\mathrm{~J})$ & 0.2 & 12 & 16 & -- & -- \\
\hline North Wall, Center Anomaly G156_95 & 408A004 & $6.0-8.0$ & 14 & $270(\mathrm{~J})$ & 0.21 & 12 & 17 & -- & -- \\
\hline North Wall, West End Anomaly G156_95 & 408A005 & $6.0-8.0$ & 11 & $180(\mathrm{~J})$ & 0.22 & 12 & 15 & -- & -- \\
\hline Bottom, West End Anomaly G156_95 & 408A006 & $12.0-14.0$ & 21 & $240(\mathrm{~J})$ & 0.23 & 12 & 17 & -- & -- \\
\hline South Wall, East End Anomaly G156_95 & 408A007 & $6.0-8.0$ & 17 & $220(\mathrm{~J})$ & 0.27 & 13 & 18 & -- & -- \\
\hline South Wall, Center Anomaly G156_95 & 408A008 & $6.0-8.0$ & 27 & $750(\mathrm{~J})$ & 0.22 & 13 & 21 & -- & -- \\
\hline Bottom, Center Anomaly G156_95 & 408A009 & $12.0-14.0$ & 14 & $170(\mathrm{~J})$ & 0.31 & 14 & 18 & -- & -- \\
\hline North Wall, Small Excavation Anomaly G156_95 & 408A010 & $1.0-2.0$ & 8.2 & $130(\mathrm{~J})$ & 0.22 & 13 & 17 & -- & -- \\
\hline \multirow{2}{*}{ South Wall, Small Excavation Anomaly G156_95 } & 408A011 & $1.0-2.0$ & 5.1 & $130(\mathrm{~J})$ & 0.072 & 4.1 & 8.3 & -- & -- \\
\hline & 408A012 & $1.0-2.0$ & 6.1 & $130(\mathrm{~J})$ & 0.045 & 4.5 & 8.2 & $0.0054(\mathrm{~J}-)$ & -- \\
\hline West Wall, Small Excavation Anomaly G156_95 & $408 A 013$ & $1.0-2.0$ & 5.4 & $120(\mathrm{~J})$ & 0.11 & 5.5 & 9.1 & $0.0051(\mathrm{~J}-)$ & -- \\
\hline East Wall, Small Excavation Anomaly G156_95 & 408A014 & $1.0-2.0$ & 9.9 & $130(\mathrm{~J})$ & 0.16 & 9.6 & 13 & -- & -- \\
\hline Bottom, West End Small Excavation Anomaly G156_95 & 408A015 & $3.0-4.0$ & 9.5 & $170(\mathrm{~J})$ & 0.22 & 12 & 42 & -- & -- \\
\hline Bottom, South Side Anomaly G156_95 & 408A016 & $3.0-4.0$ & 7.2 & $120(\mathrm{~J})$ & 0.16 & 6.9 & 12 & -- & -- \\
\hline Soil Stock Pile, West Side Anomaly G156_95 & 408A017 & N/A & 16 & $210(\mathrm{~J})$ & 0.38 & 12 & 17 & -- & -- \\
\hline
\end{tabular}

\section{UNCONTROLLED When Printed}


Table C.3-2

Sample Results for Metals Detected above MDCs at CAS TA-55-002-TAB2, Bomblet Target Areas

(Page 2 of 5 )

\begin{tabular}{|c|c|c|c|c|c|c|c|c|c|}
\hline \multirow[b]{2}{*}{$\begin{array}{c}\text { Sample } \\
\text { Location }\end{array}$} & \multirow[b]{2}{*}{$\begin{array}{l}\text { Sample } \\
\text { Number }\end{array}$} & \multirow[b]{2}{*}{$\begin{array}{c}\text { Depth } \\
\text { (ft bgs) }\end{array}$} & \multicolumn{7}{|c|}{ COPCs (mg/kg) } \\
\hline & & & 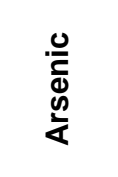 & 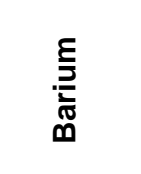 & 高 & 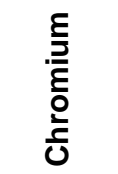 & ర్త్ర & $\begin{array}{l}\frac{\lambda}{J} \\
\frac{d}{d} \\
\sum\end{array}$ & $\frac{\grave{̀}}{\bar{c}}$ \\
\hline \multicolumn{3}{|l|}{ FAL } & 23 & 190,000 & 800 & 450 & 1,872 & 34 & 5,100 \\
\hline Soil Stock Pile, East Side Anomaly G156_95 & 408A018 & $\mathrm{N} / \mathrm{A}$ & 16 & $230(\mathrm{~J})$ & 0.23 & 12 & 16 & -- & -- \\
\hline Large Screened Stock Pile Anomaly G156_95 & 408A019 & $\mathrm{N} / \mathrm{A}$ & 13 & $250(\mathrm{~J})$ & 0.42 & 12 & 35 & $0.005(\mathrm{~J}-)$ & -- \\
\hline Small Stock Pile Anomaly G156_95 & $408 A 020$ & $\mathrm{~N} / \mathrm{A}$ & 12 & $230(\mathrm{~J})$ & 0.2 & 12 & 15 & $0.0033(\mathrm{~J}-)$ & -- \\
\hline North Wall Grid 94/701, South Antelope Lake & 408A021 & $0.0-0.5$ & 10.3 & 216 & $0.267(\mathrm{~J})$ & $13.7(\mathrm{~J})$ & $17.5(\mathrm{~J})$ & -- & 0.751 \\
\hline \multirow{2}{*}{ East Wall Grid 94/701, South Antelope Lake } & 408A022 & $0.0-0.5$ & 10.2 & 208 & $0.309(\mathrm{~J})$ & $13.8(\mathrm{~J})$ & $17.3(\mathrm{~J})$ & $0.0057(\mathrm{~J})$ & 0.719 \\
\hline & $408 A 023$ & $0.0-0.5$ & 9.46 & 220 & $0.342(\mathrm{~J})$ & $13.9(\mathrm{~J})$ & $16.8(\mathrm{~J})$ & -- & 0.668 \\
\hline South Wall Grid 94/701, South Antelope Lake & 408A024 & $0.0-0.5$ & 9.8 & 242 & $0.327(\mathrm{~J})$ & $14.7(\mathrm{~J})$ & $16.7(\mathrm{~J})$ & $0.00569(\mathrm{~J})$ & 0.665 \\
\hline West Wall Grid 94/701, South Antelope Lake & $408 A 025$ & $0.0-0.5$ & 9.81 & 235 & $0.328(\mathrm{~J})$ & $14.6(\mathrm{~J})$ & $17.8(J)$ & $0.0081(\mathrm{~J})$ & 0.647 \\
\hline Bottom Center Grid 94/701, South Antelope Lake & 408A026 & $0.0-0.5$ & 9.81 & 448 & $0.548(\mathrm{~J})$ & $15.5(\mathrm{~J})$ & $18.1(\mathrm{~J})$ & $0.00943(\mathrm{~J})$ & 0.629 \\
\hline Spoils Pile Grid 94/701, South Antelope Lake & 408A027 & $0.0-0.5$ & 10.7 & 2,370 & 1.11 & $39.8(\mathrm{~J})$ & $32.9(\mathrm{~J})$ & $0.0111(\mathrm{~J})$ & 0.786 \\
\hline Center West Wall, Pit 1 Anomaly D006_002 & 408B001 & $3.0-4.0$ & $10.9(\mathrm{~J})$ & $218(\mathrm{~J}+)$ & $0.437(\mathrm{~J})$ & $16.2(\mathrm{~J})$ & 17.9 & $0.0181(\mathrm{~J}-)$ & $0.479(\mathrm{~J})$ \\
\hline Center Bottom, Pit 1 Anomaly D006_002 & 408B002 & $6.0-7.0$ & $11.8(\mathrm{~J})$ & $169(\mathrm{~J}+)$ & $0.333(\mathrm{~J})$ & $16.8(\mathrm{~J})$ & 17 & $0.00948(\mathrm{~J}-)$ & $0.659(\mathrm{~J})$ \\
\hline \multirow{2}{*}{ North Wall, Pit 1 Anomaly D006_002 } & 408B003 & $3.0-4.0$ & $11.3(\mathrm{~J})$ & $189(\mathrm{~J}+)$ & $0.467(\mathrm{~J})$ & $17.1(\mathrm{~J})$ & 17.7 & $0.00626(\mathrm{~J}-)$ & $0.258(\mathrm{~J})$ \\
\hline & 408B004 & $3.0-4.0$ & $11.5(\mathrm{~J})$ & $214(\mathrm{~J}+)$ & $0.426(\mathrm{~J})$ & $16.6(\mathrm{~J})$ & 18.1 & $0.0111(\mathrm{~J}-)$ & $0.35(\mathrm{~J})$ \\
\hline East Wall, Pit 1 Anomaly D006_002 & 408B005 & $3.0-4.0$ & $10.1(\mathrm{~J})$ & $234(\mathrm{~J}+)$ & $0.475(\mathrm{~J})$ & $17.6(\mathrm{~J})$ & 17.3 & $0.0149(\mathrm{~J}-)$ & $0.406(\mathrm{~J})$ \\
\hline South Wall, Pit 1 Anomaly D006_002 & 408B006 & $3.0-4.0$ & $11.1(\mathrm{~J})$ & $219(\mathrm{~J}+)$ & $0.417(\mathrm{~J})$ & $16.6(\mathrm{~J})$ & 18.2 & $0.0129(\mathrm{~J}-)$ & $0.425(\mathrm{~J})$ \\
\hline South Wall, Pit 3 Anomaly D006_002 & 408B007 & $4.0-5.0$ & $11.9(\mathrm{~J})$ & $174(\mathrm{~J}+)$ & $0.472(\mathrm{~J})$ & $16.7(\mathrm{~J})$ & 17.7 & $0.00973(\mathrm{~J}-)$ & $0.188(\mathrm{~J})$ \\
\hline
\end{tabular}


Table C.3-2

Sample Results for Metals Detected above MDCs at CAS TA-55-002-TAB2, Bomblet Target Areas

(Page 3 of 5)

\begin{tabular}{|c|c|c|c|c|c|c|c|c|c|}
\hline \multirow[b]{2}{*}{$\begin{array}{l}\text { Sample } \\
\text { Location }\end{array}$} & \multirow[b]{2}{*}{$\begin{array}{l}\text { Sample } \\
\text { Number }\end{array}$} & \multirow[b]{2}{*}{$\begin{array}{c}\text { Depth } \\
\text { (ft bgs) }\end{array}$} & \multicolumn{7}{|c|}{ COPCs (mg/kg) } \\
\hline & & & $\begin{array}{l}\frac{0}{c} \\
\frac{0}{d} \\
\frac{\omega}{\alpha}\end{array}$ & 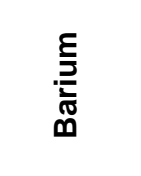 & 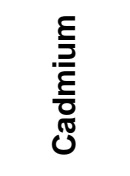 & 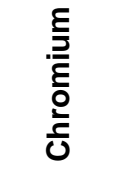 & ర్త్ర & 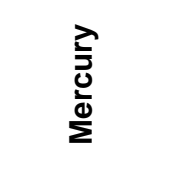 & 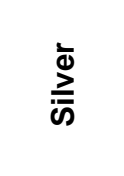 \\
\hline \multicolumn{3}{|l|}{ FAL } & 23 & 190,000 & 800 & 450 & 1,872 & 34 & 5,100 \\
\hline East Wall, Pit 3 Anomaly D006_002 & 408B008 & $4.0-5.0$ & $11.5(\mathrm{~J})$ & $243(\mathrm{~J}+)$ & $0.442(\mathrm{~J})$ & $17.6(\mathrm{~J})$ & 18.6 & $0.0115(\mathrm{~J}-)$ & $0.493(\mathrm{~J})$ \\
\hline North Wall, Pit 3 Anomaly D006_002 & 408B009 & $4.0-5.0$ & $12.6(\mathrm{~J})$ & $210(\mathrm{~J}+)$ & $0.403(\mathrm{~J})$ & $17.1(\mathrm{~J})$ & 18.1 & $0.0118(\mathrm{~J}-)$ & $0.373(\mathrm{~J})$ \\
\hline West Wall Pit 3 Anomaly D006_002 & 408B010 & $4.0-5.0$ & $12.7(\mathrm{~J})$ & $204(J+)$ & $0.448(J)$ & $16.9(\mathrm{~J})$ & 17.9 & $0.0072(\mathrm{~J}-)$ & $0.404(\mathrm{~J})$ \\
\hline Center Bottom, Pit 3 Anomaly D006_002 & 408B011 & $8.0-9.0$ & $14(\mathrm{~J})$ & $149(\mathrm{~J}+)$ & $0.412(\mathrm{~J})$ & $16.2(\mathrm{~J})$ & 18.5 & $0.00635(\mathrm{~J}-)$ & $0.501(\mathrm{~J})$ \\
\hline Spoils Pile, Pit 1 Anomaly D006_002 & 408B012 & $0.0-1.0$ & $11.4(\mathrm{~J})$ & $232(\mathrm{~J}+)$ & $0.372(\mathrm{~J})$ & $16.3(\mathrm{~J})$ & 18.2 & $0.01(\mathrm{~J}-)$ & $0.502(\mathrm{~J})$ \\
\hline Spoils Pile, Pit 3 Anomaly D006_002 & 408B013 & $0.0-1.0$ & $13(\mathrm{~J})$ & $416(\mathrm{~J}+)$ & 0.782 & $17.8(\mathrm{~J})$ & 18.4 & $0.00885(\mathrm{~J}-)$ & $0.492(\mathrm{~J})$ \\
\hline Soil Mound Grid 71/729 SAC Target 2 & 408D001 & $0.0-1.0$ & $4.73(\mathrm{~J})$ & 130 & 9.42 & 9.03 & $945(\mathrm{~J})$ & 0.35 & $8.28(\mathrm{~J})$ \\
\hline South Wall Grid 53/815, Mid Target & 408G001 & $0.0-2.0$ & 2.49 & 71.7 & -- & 3.89 & $6.08(\mathrm{~J})$ & -- & -- \\
\hline \multirow{2}{*}{ West Wall Grid 53/815, Mid Target } & 408G002 & $0.0-2.0$ & 2.23 & 90 & -- & 5.28 & $6.79(\mathrm{~J})$ & $0.00439(\mathrm{~J})$ & -- \\
\hline & 408G003 & $0.0-2.0$ & 2.55 & 92.6 & -- & 5.1 & $7.44(J)$ & $0.00493(\mathrm{~J})$ & -- \\
\hline North Wall Grid 53/815, Mid Target & $408 G 004$ & $0.0-2.0$ & 1.95 & 61.8 & -- & 3.7 & $5.32(\mathrm{~J})$ & -- & -- \\
\hline East Wall Grid 53/815, Mid Target & 408G005 & $0.0-2.0$ & 2.6 & 55.7 & -- & 4.43 & $6.91(\mathrm{~J})$ & -- & -- \\
\hline \multirow{2}{*}{ Bottom of Excavation Grid 53/815, Mid Target } & 408G006 & $0.0-4.0$ & 3.53 & 76.7 & -- & 6.15 & $8.34(\mathrm{~J})$ & $0.00788(\mathrm{~J})$ & -- \\
\hline & $408 \mathrm{G} 007$ & $0.0-4.0$ & 2.92 & 88.2 & -- & 5.74 & $6.71(\mathrm{~J})$ & $0.00599(\mathrm{~J})$ & -- \\
\hline East Wall Grid 53/814, Mid Target & 408G008 & $0.0-1.5$ & 3.73 & 113 & -- & 7.74 & $8.97(\mathrm{~J})$ & $0.00937(\mathrm{~J})$ & -- \\
\hline South Wall Grid 53/814, Mid Target & 408G009 & $0.0-1.5$ & 3 & 138 & $0.109(\mathrm{~J})$ & 6.82 & $9.74(\mathrm{~J})$ & $0.00893(\mathrm{~J})$ & -- \\
\hline West Wall Grid 53/814, Mid Target & 408G010 & $0.0-1.5$ & 2.42 & 68.4 & -- & 5.34 & $7.28(\mathrm{~J})$ & $0.00555(\mathrm{~J})$ & -- \\
\hline
\end{tabular}

\section{UNCONTROLLED When Printed}


Table C.3-2

Sample Results for Metals Detected above MDCs at CAS TA-55-002-TAB2, Bomblet Target Areas (Page 4 of 5)

\begin{tabular}{|c|c|c|c|c|c|c|c|c|c|}
\hline \multirow[b]{2}{*}{$\begin{array}{l}\text { Sample } \\
\text { Location }\end{array}$} & \multirow[b]{2}{*}{$\begin{array}{c}\text { Sample } \\
\text { Number }\end{array}$} & \multirow[b]{2}{*}{$\begin{array}{c}\text { Depth } \\
\text { (ft bgs) }\end{array}$} & \multicolumn{7}{|c|}{ COPCs (mg/kg) } \\
\hline & & & 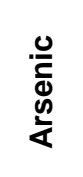 & $\frac{\underline{\varepsilon}}{\mathfrak{n}}$ & 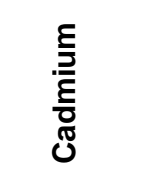 & 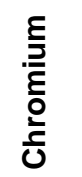 & ర్శ్త & $\begin{array}{l}\frac{\lambda}{J} \\
\frac{0}{d} \\
\sum\end{array}$ & $\stackrel{\grave{D}}{\bar{\omega}}$ \\
\hline \multicolumn{3}{|l|}{ FAL } & 23 & 190,000 & 800 & 450 & 1,872 & 34 & 5,100 \\
\hline North Wall Grid 53/814, Mid Target & $408 G 011$ & $0.0-1.0$ & 2.88 & 72.8 & -- & 5.68 & $7.42(\mathrm{~J})$ & $0.00957(\mathrm{~J})$ & -- \\
\hline \multirow{2}{*}{ Bottom of Excavation Grid 53/814, Mid Target } & $408 \mathrm{G} 012$ & $0.0-3.0$ & 4.52 & 107 & -- & 7.22 & $9.04(\mathrm{~J})$ & $0.00983(\mathrm{~J})$ & -- \\
\hline & $408 G 013$ & $0.0-3.0$ & 3.27 & 265 & $0.408(\mathrm{~J})$ & 6.99 & $8.51(\mathrm{~J})$ & $0.00814(\mathrm{~J})$ & -- \\
\hline East Wall Grid 52/817, Mid Target & $408 G 014$ & $0.0-2.0$ & 3.18 & 94.2 & -- & 5.49 & $6.61(\mathrm{~J})$ & $0.0052(\mathrm{~J})$ & -- \\
\hline South Wall Grid 52/817, Mid Target & $408 G 015$ & $1.0-2.0$ & 3.48 & 126 & -- & 8.18 & $9.95(\mathrm{~J})$ & 0.016 & -- \\
\hline West Wall Grid 52/817, Mid Target & 408G016 & $0.0-2.0$ & 4.2 & 94.2 & -- & 5.54 & $7.56(\mathrm{~J})$ & $0.00855(\mathrm{~J})$ & -- \\
\hline North Wall Grid 52/817, Mid Target & $408 \mathrm{G} 017$ & $0.0-1.5$ & 2.04 & 51.6 & -- & 4.32 & $5.29(\mathrm{~J})$ & $0.00429(\mathrm{~J})$ & -- \\
\hline \multirow{2}{*}{ Bottom of Excavation Grid 52/817, Mid Target } & 408G018 & $0.0-3.5$ & 4.58 & 122 & -- & 4.92 & $6.13(\mathrm{~J})$ & $0.00459(\mathrm{~J})$ & -- \\
\hline & 408G019 & $0.0-3.5$ & 2.85 & 116 & -- & 6.43 & $6.85(\mathrm{~J})$ & $0.00606(\mathrm{~J})$ & -- \\
\hline South Wall Excavation 2 Grid 52/817, Mid Target & 408G020 & $2.0-3.0$ & 3.5 & 70 & -- & 5.17 & 6.17 & $0.00995(\mathrm{~J})$ & -- \\
\hline West Wall Excavation 2 Grid 52/817, Mid Target & $408 G 021$ & $2.0-3.0$ & 3.17 & 58.7 & -- & 3.62 & 6.65 & -- & -- \\
\hline North Wall Excavation 2 Grid 52/817, Mid Target & 408G022 & $2.0-3.0$ & 3.96 & 106 & -- & 5.91 & 7.45 & -- & -- \\
\hline East Wall Excavation 2 Grid 52/817, Mid Target & 408G023 & $2.0-3.0$ & 3.44 & 105 & -- & 4.69 & 7.1 & -- & -- \\
\hline \multirow{2}{*}{ Bottom South End Excavation 2 Grid 52/817, Mid Target } & 408G024 & $4.0-5.0$ & 4.14 & 116 & $0.178(\mathrm{~J})$ & 6.23 & 10.3 & $0.00871(\mathrm{~J})$ & -- \\
\hline & 408G025 & $4.0-5.0$ & 4.09 & 107 & -- & 5.67 & 8.55 & $0.00731(\mathrm{~J})$ & -- \\
\hline Bottom North End Excavation 2 Grid 52/817, Mid Target & $408 \mathrm{G} 026$ & $4.0-5.0$ & 5.41 & 64.9 & -- & 5.28 & 9.76 & $0.00776(\mathrm{~J})$ & -- \\
\hline South Wall Excavation 3 Grid 52/817, Mid Target & $408 G 027$ & $2.0-3.0$ & 3.43 & 89.4 & -- & 6.25 & 8.06 & $0.0119(\mathrm{~J})$ & -- \\
\hline
\end{tabular}

\section{UNCONTROLLED When Printed}


Table C.3-2

Sample Results for Metals Detected above MDCs at CAS TA-55-002-TAB2, Bomblet Target Areas

(Page 5 of 5 )

\begin{tabular}{|c|c|c|c|c|c|c|c|c|c|}
\hline \multirow[b]{2}{*}{$\begin{array}{l}\text { Sample } \\
\text { Location }\end{array}$} & \multirow[b]{2}{*}{$\begin{array}{l}\text { Sample } \\
\text { Number }\end{array}$} & \multirow[b]{2}{*}{$\begin{array}{c}\text { Depth } \\
\text { (ft bgs) }\end{array}$} & \multicolumn{7}{|c|}{ COPCs (mg/kg) } \\
\hline & & & 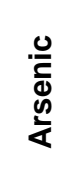 & $\frac{\underline{\Sigma}}{\mathfrak{D}}$ & 高 & 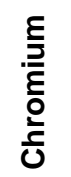 & శ్ర్త & $\begin{array}{l}\frac{\lambda}{0} \\
\frac{0}{d} \\
\sum\end{array}$ & 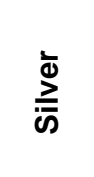 \\
\hline \multicolumn{3}{|l|}{ FAL } & 23 & 190,000 & 800 & 450 & 1,872 & 34 & 5,100 \\
\hline West Wall Excavation 3 Grid 52/817, Mid Target & $408 G 028$ & $2.0-3.0$ & 2.05 & 90.1 & -- & 4.58 & 6.49 & -- & -- \\
\hline North Wall Excavation 3 Grid 52/817, Mid Target & $408 G 029$ & $2.0-3.0$ & 2.97 & 113 & -- & 7.42 & 11 & $0.00727(\mathrm{~J})$ & -- \\
\hline East Wall Excavation 3 Grid 52/817, Mid Target & $408 G 030$ & $2.0-3.0$ & 2.1 & 74 & -- & 5.42 & 7.68 & $0.00607(\mathrm{~J})$ & -- \\
\hline Bottom South End Excavation 3 Grid 52/817, Mid Target & $408 G 031$ & $3.0-4.0$ & 3.65 & 79 & -- & 5.78 & 8.29 & $0.007(\mathrm{~J})$ & -- \\
\hline Bottom North End Excavation 3 Grid 52/817, Mid Target & 408G032 & $3.0-4.0$ & 5.01 & 104 & -- & 8.34 & 10.3 & $0.008(\mathrm{~J})$ & -- \\
\hline
\end{tabular}

-- = Not detected above MDCs.

$\mathrm{J}=$ Estimated value

$\mathrm{J}+=$ Result is an estimated quantity but may be biased high.

$\mathrm{J}$ - = Result is an estimated quantity but may be biased low.

Bold indicates the value is equal to or exceeds the FAL 
Table C.3-3

\section{Sample Results for Gamma-Emitting Radionuclides Detected above MDCs at CAS TA-55-002-TAB2, Bomblet Target Areas}

(Page 1 of 3)

\begin{tabular}{|c|c|c|c|c|c|}
\hline \multirow{2}{*}{$\begin{array}{c}\text { Sample } \\
\text { Location }\end{array}$} & \multirow{2}{*}{$\begin{array}{c}\text { Sample } \\
\text { Number }\end{array}$} & \multirow{2}{*}{$\begin{array}{l}\text { Depth } \\
\text { (ft bgs) }\end{array}$} & \multicolumn{3}{|c|}{ COPCs (pCi/g) } \\
\hline & & & \multirow{2}{*}{$\frac{A c-228}{5}$} & \multirow{2}{*}{$\frac{\text { Cs-137 }}{12.2}$} & \multirow{2}{*}{$\begin{array}{c}\text { Th-234 } \\
105\end{array}$} \\
\hline \multicolumn{3}{|l|}{ FAL } & & & \\
\hline South Wall, East End Anomaly G156_95 & 408A001 & $6.0-8.0$ & 2.15 & -- & -- \\
\hline Bottom, East End Anomaly G156_95 & 408A002 & $12.0-14.0$ & 1.93 & -- & -- \\
\hline North Wall, East End Anomaly G156_95 & 408A003 & $6.0-8.0$ & 2.14 & -- & -- \\
\hline North Wall, Center Anomaly G156_95 & 408A004 & $6.0-8.0$ & 2.12 & -- & -- \\
\hline North Wall, West End Anomaly G156_95 & 408A005 & $6.0-8.0$ & 2.26 & -- & -- \\
\hline Bottom, West End Anomaly G156_95 & 408A006 & $12.0-14.0$ & 1.97 & -- & -- \\
\hline South Wall, East End Anomaly G156_95 & 408A007 & $6.0-8.0$ & 2.54 & -- & $3.4(\mathrm{~J})$ \\
\hline South Wall, Center Anomaly G156_95 & 408A008 & $6.0-8.0$ & 2.1 & -- & -- \\
\hline Bottom, Center Anomaly G156_95 & 408A009 & $12.0-14.0$ & 1.91 & -- & $4.5(\mathrm{~J})$ \\
\hline North Wall, Small Excavation Anomaly G156_95 & 408A010 & $1.0-2.0$ & 2.02 & -- & -- \\
\hline \multirow{2}{*}{ South Wall, Small Excavation Anomaly G156_95 } & 408A011 & $1.0-2.0$ & 1.83 & -- & -- \\
\hline & 408A012 & $1.0-2.0$ & 1.82 & -- & -- \\
\hline West Wall, Small Excavation Anomaly G156_95 & 408A013 & $1.0-2.0$ & 1.92 & -- & -- \\
\hline East Wall, Small Excavation Anomaly G156_95 & 408A014 & $1.0-2.0$ & 1.89 & -- & -- \\
\hline Bottom, West End Small Excavation Anomaly G156_95 & 408A015 & $3.0-4.0$ & 1.73 & -- & -- \\
\hline Bottom, South Side Anomaly G156_95 & 408A016 & $3.0-4.0$ & 2.06 & -- & -- \\
\hline Soil Stock Pile, West Side Anomaly G156_95 & 408A017 & $\mathrm{N} / \mathrm{A}$ & 1.73 & -- & -- \\
\hline Soil Stock Pile, East Side Anomaly G156_95 & 408A018 & N/A & 1.78 & -- & $3.9(\mathrm{~J})$ \\
\hline Large Screened Stock Pile Anomaly G156_95 & 408A019 & N/A & 2.12 & -- & -- \\
\hline Small Stock Pile Anomaly G156_95 & 408A020 & N/A & 2.01 & -- & -- \\
\hline North Wall Grid 94/701, South Antelope Lake & 408A021 & $0.0-0.5$ & 2.11 & -- & -- \\
\hline \multirow{2}{*}{ East Wall Grid 94/701, South Antelope Lake } & 408A022 & $0.0-0.5$ & 2.23 & -- & -- \\
\hline & 408A023 & $0.0-0.5$ & 2.24 & -- & -- \\
\hline South Wall Grid 94/701, South Antelope Lake & 408A024 & $0.0-0.5$ & 2.27 & -- & -- \\
\hline West Wall Grid 94/701, South Antelope Lake & 408A025 & $0.0-0.5$ & 2.23 & -- & -- \\
\hline Bottom Center Grid 94/701, South Antelope Lake & 408A026 & $0.0-0.5$ & 1.93 & -- & -- \\
\hline
\end{tabular}


Table C.3-3

\section{Sample Results for Gamma-Emitting Radionuclides Detected above MDCs at CAS TA-55-002-TAB2, Bomblet Target Areas}

(Page 2 of 3 )

\begin{tabular}{|c|c|c|c|c|c|}
\hline \multirow{2}{*}{$\begin{array}{c}\text { Sample } \\
\text { Location }\end{array}$} & \multirow{2}{*}{$\begin{array}{l}\text { Sample } \\
\text { Number }\end{array}$} & \multirow{2}{*}{$\begin{array}{l}\text { Depth } \\
\text { (ft bgs) }\end{array}$} & \multicolumn{3}{|c|}{ COPCs (pCi/g) } \\
\hline & & & \multirow{2}{*}{$\frac{A c-228}{5}$} & \multirow{2}{*}{$\frac{\text { Cs-137 }}{12.2}$} & \multirow{2}{*}{$\begin{array}{c}\text { Th-234 } \\
105\end{array}$} \\
\hline \multicolumn{3}{|l|}{ FAL } & & & \\
\hline Spoils Pile Grid 94/701, South Antelope Lake & 408A027 & $0.0-0.5$ & 2.26 & -- & -- \\
\hline Center West Wall, Pit 1 Anomaly D006_002 & 408B001 & $3.0-4.0$ & 1.9 & 0.136 & -- \\
\hline Center Bottom, Pit 1 Anomaly D006_002 & 408B002 & $6.0-7.0$ & 2.29 & -- & -- \\
\hline \multirow{2}{*}{ North Wall, Pit 1 Anomaly D006_002 } & 408B003 & $3.0-4.0$ & 2.25 & -- & -- \\
\hline & 408B004 & $3.0-4.0$ & 1.99 & -- & -- \\
\hline East Wall, Pit 1 Anomaly D006_002 & 408B005 & $3.0-4.0$ & 2.13 & -- & -- \\
\hline South Wall, Pit 1 Anomaly D006_002 & 408B006 & $3.0-4.0$ & 2.27 & -- & -- \\
\hline South Wall, Pit 3 Anomaly D006_002 & 408B007 & $4.0-5.0$ & 2.22 & -- & -- \\
\hline East Wall, Pit 3 Anomaly D006_002 & 408B008 & $4.0-5.0$ & 2.05 & -- & -- \\
\hline North Wall, Pit 3 Anomaly D006_002 & 408B009 & $4.0-5.0$ & 2.05 & -- & -- \\
\hline West Wall Pit 3 Anomaly D006_002 & 408B010 & $4.0-5.0$ & 1.92 & -- & -- \\
\hline Center Bottom, Pit 3 Anomaly D006_002 & 408B011 & $8.0-9.0$ & 2.49 & -- & -- \\
\hline Spoils Pile, Pit 1 Anomaly D006_002 & 408B012 & $0.0-1.0$ & 2.25 & -- & -- \\
\hline Spoils Pile, Pit 3 Anomaly D006_002 & 408B013 & $0.0-1.0$ & 2.35 & -- & -- \\
\hline Soil Mound Grid 71/729 SAC Target 2 & 408D001 & $0.0-1.0$ & 1.66 & -- & -- \\
\hline South Wall Grid 53/815, Mid Target & 408G001 & $0.0-2.0$ & 2.3 & -- & $3.86(\mathrm{~J})$ \\
\hline \multirow{2}{*}{ West Wall Grid 53/815, Mid Target } & $408 G 002$ & $0.0-2.0$ & 1.76 & -- & -- \\
\hline & $408 G 003$ & $0.0-2.0$ & 1.8 & -- & -- \\
\hline North Wall Grid 53/815, Mid Target & $408 G 004$ & $0.0-2.0$ & 1.96 & -- & $1.3(\mathrm{~J})$ \\
\hline East Wall Grid 53/815, Mid Target & $408 G 005$ & $0.0-2.0$ & 2.04 & -- & $1.19(\mathrm{~J})$ \\
\hline \multirow{2}{*}{ Bottom of Excavation Grid 53/815, Mid Target } & $408 G 006$ & $0.0-4.0$ & 2.12 & -- & -- \\
\hline & $408 \mathrm{G} 007$ & $0.0-4.0$ & 1.84 & -- & -- \\
\hline East Wall Grid 53/814, Mid Target & $408 G 008$ & $0.0-1.5$ & 2.21 & -- & -- \\
\hline South Wall Grid 53/814, Mid Target & 408G009 & $0.0-1.5$ & 1.89 & -- & -- \\
\hline West Wall Grid 53/814, Mid Target & $408 G 010$ & $0.0-1.5$ & 2.02 & -- & -- \\
\hline North Wall Grid 53/814, Mid Target & $408 G 011$ & $0.0-1.0$ & 1.91 & -- & -- \\
\hline
\end{tabular}


Table C.3-3

\section{Sample Results for Gamma-Emitting Radionuclides Detected above MDCs at CAS TA-55-002-TAB2, Bomblet Target Areas}

(Page 3 of 3 )

\begin{tabular}{|c|c|c|c|c|c|}
\hline \multirow{2}{*}{$\begin{array}{c}\text { Sample } \\
\text { Location }\end{array}$} & \multirow{2}{*}{$\begin{array}{l}\text { Sample } \\
\text { Number }\end{array}$} & \multirow{2}{*}{$\begin{array}{l}\text { Depth } \\
\text { (ft bgs) }\end{array}$} & \multicolumn{3}{|c|}{ COPCs (pCi/g) } \\
\hline & & & \multirow{2}{*}{$\frac{A c-228}{5}$} & \multirow{2}{*}{$\frac{\text { Cs-137 }}{12.2}$} & \multirow{2}{*}{$\begin{array}{c}\text { Th-234 } \\
105\end{array}$} \\
\hline FAL & & & & & \\
\hline \multirow{2}{*}{ Bottom of Excavation Grid 53/814, Mid Target } & 408G012 & $0.0-3.0$ & 2 & -- & -- \\
\hline & $408 G 013$ & $0.0-3.0$ & 1.71 & -- & -- \\
\hline East Wall Grid 52/817, Mid Target & $408 G 014$ & $0.0-2.0$ & 1.55 & -- & -- \\
\hline South Wall Grid 52/817, Mid Target & 408G015 & $1.0-2.0$ & 1.86 & -- & -- \\
\hline West Wall Grid 52/817, Mid Target & 408G016 & $0.0-2.0$ & 1.92 & -- & -- \\
\hline North Wall Grid 52/817, Mid Target & $408 \mathrm{G} 017$ & $0.0-1.5$ & 1.65 & -- & -- \\
\hline \multirow{2}{*}{ Bottom of Excavation Grid 52/817, Mid Target } & 408G018 & $0.0-3.5$ & 2 & -- & -- \\
\hline & $408 G 019$ & $0.0-3.5$ & 2.12 & -- & -- \\
\hline South Wall Excavation 2 Grid 52/817, Mid Target & 408G020 & $2.0-3.0$ & 1.82 & -- & -- \\
\hline West Wall Excavation 2 Grid 52/817, Mid Target & $408 G 021$ & $2.0-3.0$ & 2.05 & -- & $3.07(\mathrm{~J})$ \\
\hline North Wall Excavation 2 Grid 52/817, Mid Target & $408 G 022$ & $2.0-3.0$ & 1.94 & -- & -- \\
\hline East Wall Excavation 2 Grid 52/817, Mid Target & $408 G 023$ & $2.0-3.0$ & 2.1 & -- & -- \\
\hline \multirow{2}{*}{ Bottom South End Excavation 2 Grid 52/817, Mid Target } & $408 G 024$ & $4.0-5.0$ & 1.74 & -- & -- \\
\hline & $408 G 025$ & $4.0-5.0$ & 1.75 & -- & -- \\
\hline Bottom North End Excavation 2 Grid 52/817, Mid Target & $408 G 026$ & $4.0-5.0$ & 1.95 & -- & -- \\
\hline South Wall Excavation 3 Grid 52/817, Mid Target & $408 \mathrm{G} 027$ & $2.0-3.0$ & 1.76 & -- & -- \\
\hline West Wall Excavation 3 Grid 52/817, Mid Target & $408 G 028$ & $2.0-3.0$ & 2.08 & -- & -- \\
\hline North Wall Excavation 3 Grid 52/817, Mid Target & $408 G 029$ & $2.0-3.0$ & 2.46 & -- & -- \\
\hline East Wall Excavation 3 Grid 52/817, Mid Target & $408 G 030$ & $2.0-3.0$ & 1.8 & -- & -- \\
\hline Bottom South End Excavation 3 Grid 52/817, Mid Target & $408 G 031$ & $3.0-4.0$ & 1.8 & -- & -- \\
\hline Bottom North End Excavation 3 Grid 52/817, Mid Target & $408 G 032$ & $3.0-4.0$ & 1.93 & -- & -- \\
\hline
\end{tabular}

\footnotetext{
Ac $=$ Actinium

$\mathrm{Cs}=$ Cesium

$\mathrm{Th}=$ Thorium

$--=$ Not detected above MDCs.

$\mathrm{J}=$ Estimated value.
} 


\section{C.3.4.4 Uranium Isotopes}

Analytical results for isotopic $U$ in soil samples collected at this CAS that were detected above MDCs are presented in Table C.3-4. No isotopic U concentrations exceeded the PALs. The FALs were established at the PAL concentrations.

\section{Table C.3-4 \\ Sample Results for Isotopic U Detected above MDCs at CAS TA-55-002-TAB2, Bomblet Target Areas}

(Page 1 of 4 )

\begin{tabular}{|c|c|c|c|c|c|}
\hline \multirow{2}{*}{$\begin{array}{c}\text { Sample } \\
\text { Location }\end{array}$} & \multirow{2}{*}{$\begin{array}{l}\text { Sample } \\
\text { Number }\end{array}$} & \multirow{2}{*}{$\begin{array}{l}\text { Depth } \\
\text { (ft bgs) }\end{array}$} & \multicolumn{3}{|c|}{ COPCs (pCi/g) } \\
\hline & & & \multirow{2}{*}{$\frac{U-234}{143}$} & \multirow{2}{*}{$\frac{U-235}{17.6}$} & \multirow{2}{*}{$\begin{array}{r}\text { U-238 } \\
105\end{array}$} \\
\hline \multicolumn{3}{|l|}{ FAL } & & & \\
\hline South Wall, East End Anomaly G156_95 & 408A001 & $6.0-8.0$ & 2.77 & 0.11 & 2.16 \\
\hline Bottom, East End Anomaly G156_95 & 408A002 & $12.0-14.0$ & 2.7 & 0.082 & 2.22 \\
\hline North Wall, East End Anomaly G156_95 & 408A003 & $6.0-8.0$ & 1.81 & 0.089 & 1.62 \\
\hline North Wall, Center Anomaly G156_95 & 408A004 & $6.0-8.0$ & 2.19 & 0.071 & 1.73 \\
\hline North Wall, West End Anomaly G156_95 & 408A005 & $6.0-8.0$ & 1.5 & 0.056 & 1.32 \\
\hline Bottom, West End Anomaly G156_95 & 408A006 & $12.0-14.0$ & 3.17 & 0.109 & 2.48 \\
\hline South Wall, East End Anomaly G156_95 & 408A007 & $6.0-8.0$ & 2.33 & 0.093 & 1.84 \\
\hline South Wall, Center Anomaly G156_95 & 408A008 & $6.0-8.0$ & 2.63 & 0.12 & 1.99 \\
\hline Bottom, Center Anomaly G156_95 & 408A009 & $12.0-14.0$ & 2.52 & 0.096 & 2.15 \\
\hline North Wall, Small Excavation Anomaly G156_95 & 408A010 & $1.0-2.0$ & 1.62 & 0.081 & 1.58 \\
\hline \multirow{2}{*}{ South Wall, Small Excavation Anomaly G156_95 } & 408A011 & $1.0-2.0$ & 1.33 & 0.084 & 1.28 \\
\hline & 408A012 & $1.0-2.0$ & 1.44 & -- & 1.47 \\
\hline West Wall, Small Excavation Anomaly G156_95 & 408A013 & $1.0-2.0$ & 1.37 & 0.059 & 1.43 \\
\hline East Wall, Small Excavation Anomaly G156_95 & 408A014 & $1.0-2.0$ & 1.46 & 0.061 & 1.29 \\
\hline Bottom, West End Small Excavation Anomaly G156_95 & 408A015 & $3.0-4.0$ & 1.22 & 0.077 & 1.16 \\
\hline Bottom, South Side Anomaly G156_95 & 408A016 & $3.0-4.0$ & 1.53 & 0.07 & 1.62 \\
\hline Soil Stock Pile, West Side Anomaly G156_95 & 408A017 & N/A & 2.23 & 0.078 & 1.95 \\
\hline Soil Stock Pile, East Side Anomaly G156_95 & 408A018 & N/A & 2.41 & 0.107 & 1.97 \\
\hline Large Screened Stock Pile Anomaly G156_95 & 408A019 & N/A & 2.02 & 0.126 & 1.75 \\
\hline Small Stock Pile Anomaly G156_95 & 408A020 & $\mathrm{N} / \mathrm{A}$ & 1.7 & 0.079 & 1.42 \\
\hline North Wall Grid 94/701, South Antelope Lake & 408A021 & $0.0-0.5$ & 1.24 & 0.0928 & 1.18 \\
\hline
\end{tabular}


Table C.3-4

\section{Sample Results for Isotopic U Detected above MDCs at CAS TA-55-002-TAB2, Bomblet Target Areas}

(Page 2 of 4)

\begin{tabular}{|c|c|c|c|c|c|}
\hline \multirow{2}{*}{$\begin{array}{c}\text { Sample } \\
\text { Location }\end{array}$} & \multirow{2}{*}{$\begin{array}{l}\text { Sample } \\
\text { Number }\end{array}$} & \multirow{2}{*}{$\begin{array}{l}\text { Depth } \\
\text { (ft bgs) }\end{array}$} & \multicolumn{3}{|c|}{ COPCs (pCi/g) } \\
\hline & & & \multirow{2}{*}{$\frac{U-234}{143}$} & \multirow{2}{*}{$\begin{array}{c}\text { U-235 } \\
17.6\end{array}$} & \multirow{2}{*}{$\begin{array}{r}\text { U-238 } \\
105\end{array}$} \\
\hline FAL & & & & & \\
\hline \multirow{2}{*}{ East Wall Grid 94/701, South Antelope Lake } & 408A022 & $0.0-0.5$ & 1.28 & 0.0759 & 1.06 \\
\hline & 408A023 & $0.0-0.5$ & 1.62 & -- & 0.976 \\
\hline South Wall Grid 94/701, South Antelope Lake & 408A024 & $0.0-0.5$ & 1.24 & -- & 1.13 \\
\hline West Wall Grid 94/701, South Antelope Lake & 408A025 & $0.0-0.5$ & 1.5 & 0.168 & 1.24 \\
\hline Bottom Center Grid 94/701, South Antelope Lake & 408A026 & $0.0-0.5$ & 1.27 & -- & 1.36 \\
\hline Spoils Pile Grid 94/701, South Antelope Lake & 408A027 & $0.0-0.5$ & 1.2 & -- & 1.32 \\
\hline Center West Wall, Pit 1 Anomaly D006_002 & 408B001 & $3.0-4.0$ & 1.37 & 0.0788 & 1.15 \\
\hline Center Bottom, Pit 1 Anomaly D006_002 & 408B002 & $6.0-7.0$ & 1.37 & -- & 1.41 \\
\hline \multirow{2}{*}{ North Wall, Pit 1 Anomaly D006_002 } & 408B003 & $3.0-4.0$ & 1.55 & 0.054 & 1.36 \\
\hline & 408B004 & $3.0-4.0$ & 1.62 & -- & 1.32 \\
\hline East Wall, Pit 1 Anomaly D006_002 & 408B005 & $3.0-4.0$ & 1.37 & -- & 1.34 \\
\hline South Wall, Pit 1 Anomaly D006_002 & 408B006 & $3.0-4.0$ & 1.43 & 0.0666 & 1.17 \\
\hline South Wall, Pit 3 Anomaly D006_002 & 408B007 & $4.0-5.0$ & 1.74 & 0.0722 & 1.43 \\
\hline East Wall, Pit 3 Anomaly D006_002 & 408B008 & $4.0-5.0$ & 1.5 & 0.0958 & 1.29 \\
\hline North Wall, Pit 3 Anomaly D006_002 & 408B009 & $4.0-5.0$ & 1.7 & 0.112 & 1.45 \\
\hline West Wall Pit 3 Anomaly D006_002 & 408B010 & $4.0-5.0$ & 1.6 & 0.114 & 1.51 \\
\hline Center Bottom, Pit 3 Anomaly D006_002 & 408B011 & $8.0-9.0$ & 1.8 & 0.125 & 1.59 \\
\hline Spoils Pile, Pit 1 Anomaly D006_002 & 408B012 & $0.0-1.0$ & 1.49 & 0.0869 & 1.26 \\
\hline Spoils Pile, Pit 3 Anomaly D006_002 & 408B013 & $0.0-1.0$ & 1.72 & 0.0932 & 1.46 \\
\hline Soil Mound Grid 71/729, SAC Target 2 & 408D001 & $0.0-1.0$ & 1.11 & 0.078 & 1.04 \\
\hline South Wall Grid 53/815, Mid Target & 408G001 & $0.0-2.0$ & 1.26 & -- & 1.19 \\
\hline \multirow{2}{*}{ West Wall Grid 53/815, Mid Target } & 408G002 & $0.0-2.0$ & 1.35 & 0.0625 & 1.34 \\
\hline & 408G003 & $0.0-2.0$ & 1.22 & -- & 1.23 \\
\hline North Wall Grid 53/815, Mid Target & 408G004 & $0.0-2.0$ & 1.07 & 0.0838 & 1.15 \\
\hline East Wall Grid 53/815, Mid Target & 408G005 & $0.0-2.0$ & 1.29 & 0.0644 & 1.24 \\
\hline
\end{tabular}


Table C.3-4

\section{Sample Results for Isotopic U Detected above MDCs at CAS TA-55-002-TAB2, Bomblet Target Areas}

(Page 3 of 4)

\begin{tabular}{|c|c|c|c|c|c|}
\hline \multirow{2}{*}{$\begin{array}{c}\text { Sample } \\
\text { Location }\end{array}$} & \multirow{2}{*}{$\begin{array}{l}\text { Sample } \\
\text { Number }\end{array}$} & \multirow{2}{*}{$\begin{array}{l}\text { Depth } \\
\text { (ft bgs) }\end{array}$} & \multicolumn{3}{|c|}{ COPCs (pCi/g) } \\
\hline & & & \multirow{2}{*}{$\frac{U-234}{143}$} & \multirow{2}{*}{$\begin{array}{c}\text { U-235 } \\
17.6\end{array}$} & \multirow{2}{*}{$\frac{\text { U-238 }}{105}$} \\
\hline FAL & & & & & \\
\hline \multirow{2}{*}{ Bottom of Excavation Grid 53/815, Mid Target } & 408G006 & $0.0-4.0$ & 1.61 & 0.107 & 1.53 \\
\hline & 408G007 & $0.0-4.0$ & 1.12 & 0.0534 & 1.04 \\
\hline East Wall Grid 53/814, Mid Target & 408G008 & $0.0-1.5$ & 1.25 & 0.0745 & 1.13 \\
\hline South Wall Grid 53/814, Mid Target & 408G009 & $0.0-1.5$ & 1.07 & -- & 1.02 \\
\hline West Wall Grid 53/814, Mid Target & 408G010 & $0.0-1.5$ & 1.35 & -- & 1.16 \\
\hline North Wall Grid 53/814, Mid Target & $408 G 011$ & $0.0-1.0$ & 1.2 & -- & 1.13 \\
\hline \multirow{2}{*}{ Bottom of Excavation Grid 53/814, Mid Target } & $408 G 012$ & $0.0-3.0$ & 1.14 & -- & 1.03 \\
\hline & $408 \mathrm{G} 013$ & $0.0-3.0$ & 1.12 & 0.0694 & 1.01 \\
\hline East Wall Grid 52/817, Mid Target & 408G014 & $0.0-2.0$ & 1.37 & 0.117 & 1.27 \\
\hline South Wall Grid 52/817, Mid Target & 408G015 & $1.0-2.0$ & 1.22 & 0.084 & 1.24 \\
\hline West Wall Grid 52/817, Mid Target & 408G016 & $0.0-2.0$ & 1.32 & 0.0794 & 1.23 \\
\hline North Wall Grid 52/817, Mid Target & 408G017 & $0.0-1.5$ & 1.16 & 0.0705 & 1.18 \\
\hline \multirow{2}{*}{ Bottom of Excavation Grid 52/817, Mid Target } & 408G018 & $0.0-3.5$ & 1.33 & 0.0928 & 1.24 \\
\hline & $408 G 019$ & $0.0-3.5$ & 1.42 & 0.0896 & 1.23 \\
\hline South Wall Excavation 2 Grid 52/817, Mid Target & 408G020 & $2.0-3.0$ & $1.3(\mathrm{~J})$ & 0.136 & 1.32 \\
\hline West Wall Excavation 2 Grid 52/817, Mid Target & $408 G 021$ & $2.0-3.0$ & $1.41(\mathrm{~J})$ & -- & 1.33 \\
\hline North Wall Excavation 2 Grid 52/817, Mid Target & $408 G 022$ & $2.0-3.0$ & $1.48(\mathrm{~J})$ & -- & $1.23(\mathrm{~J})$ \\
\hline East Wall Excavation 2 Grid 52/817, Mid Target & $408 G 023$ & $2.0-3.0$ & $1.32(\mathrm{~J})$ & -- & 1.52 \\
\hline \multirow{2}{*}{ Bottom South End Excavation 2 Grid 52/817, Mid Target } & $408 G 024$ & $4.0-5.0$ & $1.52(\mathrm{~J})$ & 0.0991 & 1.47 \\
\hline & $408 G 025$ & $4.0-5.0$ & $1.38(\mathrm{~J})$ & 0.0924 & 1.29 \\
\hline Bottom North End Excavation 2 Grid 52/817, Mid Target & 408G026 & $4.0-5.0$ & $2.15(\mathrm{~J})$ & 0.149 & 1.57 \\
\hline South Wall Excavation 3 Grid 52/817, Mid Target & $408 G 027$ & $2.0-3.0$ & $2.17(\mathrm{~J})$ & -- & $1.43(\mathrm{~J})$ \\
\hline West Wall Excavation 3 Grid 52/817, Mid Target & 408G028 & $2.0-3.0$ & $1.25(\mathrm{~J})$ & 0.0648 & 1.25 \\
\hline North Wall Excavation 3 Grid 52/817, Mid Target & $408 G 029$ & $2.0-3.0$ & $1.23(\mathrm{~J})$ & -- & 1.4 \\
\hline East Wall Excavation 3 Grid 52/817, Mid Target & $408 G 030$ & $2.0-3.0$ & $1.09(\mathrm{~J})$ & -- & 1.23 \\
\hline
\end{tabular}


Table C.3-4

\section{Sample Results for Isotopic U Detected above MDCs at CAS TA-55-002-TAB2, Bomblet Target Areas \\ (Page 4 of 4)}

\begin{tabular}{|c|c|c|c|c|c|}
\hline \multirow{2}{*}{$\begin{array}{c}\text { Sample } \\
\text { Location }\end{array}$} & \multirow{2}{*}{$\begin{array}{l}\text { Sample } \\
\text { Number }\end{array}$} & \multirow{2}{*}{$\begin{array}{l}\text { Depth } \\
\text { (ft bgs) }\end{array}$} & \multicolumn{3}{|c|}{ COPCs (pCi/g) } \\
\hline & & & U-234 & U-235 & U-238 \\
\hline \multicolumn{3}{|l|}{ FAL } & 143 & 17.6 & 105 \\
\hline Bottom South End Excavation 3 Grid 52/817, Mid Target & 408G031 & $3.0-4.0$ & $1.54(\mathrm{~J})$ & 0.0914 & 1.55 \\
\hline Bottom North End Excavation 3 Grid 52/817, Mid Target & $408 G 032$ & $3.0-4.0$ & $1.53(\mathrm{~J})$ & -- & $1.45(\mathrm{~J})$ \\
\hline
\end{tabular}

$--=$ Not detected above MDCs.

$\mathrm{J}=$ Estimated value.

\section{C.3.5 Nature and Extent of Contamination}

Based on the analytical results for soil samples collected within CAU 408, no COCs were identified. Lead was detected above the PAL in a soil sample collected at the SAC target soil mound but did not exceed the Tier II RBCA criteria. Therefore, it is not considered a COC. Arsenic was detected above the PAL in two soil samples collected in the large trench of anomaly G156_95 disposal pit. However, the concentrations are consistent with natural concentrations for Antelope Lake at TTR, and therefore arsenic is not considered a COC.

\section{C.3.6 Revised Conceptual Site Model}

The SAFER Plan requirements (NNSA/NSO, 2010b) were met at this CAS, and no revisions were necessary to the CSM. 


\section{C.4.0 Waste Management}

The following sections describe the waste management activities completed during closure activities at CAU 408 and the final disposition of the waste. For regulated waste, waste management areas were established and managed as specified in the CAU 408 SAFER Plan (NNSA/NSO, 2010b). A description of the type, amount, and source of the waste was recorded on the waste container logbook for each waste container at the time of generation. A summary of the wastes generated, managed, and disposed for CAU 408 is provided in Table 3-1.

\section{C.4.1 Waste Minimization}

In an effort to reduce the amount of waste generated during the closure activities, waste minimization techniques were integrated into the field activities. The waste minimization controls included waste segregation, substitution of nonhazardous materials (e.g., water-based marking paint versus solvent-based marking paint) or minimizing the use of hazardous materials to avoid the unnecessary generation of hazardous and/or mixed waste. Recycling techniques were also incorporated into waste disposal activities for CAU 408. Decontamination activities were planned and executed to minimize the volume of rinsate generated.

\section{C.4.2 Waste Characterization}

Waste characterization and disposal were based on process knowledge, radiological field surveys, site samples, and direct samples of the waste, as applicable. Characterization and disposal for all waste streams were completed in accordance with state and federal regulations, DOE Orders, and the waste acceptance criteria of the applicable disposal site. The load verification and shipping documentation for CAU 408 are provided in Appendix D.

\section{C.4.3 Sanitary Waste}

Sanitary waste included office trash and discarded packaging materials. The office waste and lunch trash were disposed of in designated sanitary waste bins allocated for disposal at the TTR sanitary landfill. Surplus packaging materials (e.g., cardboard boxes, plastic) leftover from equipment/supply deliveries were disposed of in designated sanitary waste bins located in Area 3 of the TTR. 


\section{C.4.4 Investigation-Derived Waste}

Investigation-derived waste (IDW) includes disposable PPE and sampling equipment, and nonhazardous construction debris. Personal protective equipment and disposable sampling equipment generated during the site activities were determined to be nonhazardous waste based on visual inspection and radiological field screening. The waste was bagged, labeled, and placed in a designated sanitary waste bins located in Area 3 of the TTR.

The nonhazardous construction debris consisted of concrete, metal, wood, and plastic collected during investigation activities. The debris was visually inspected as generated to verify that it was free of MEC, MD, and other explosives components. All debris has been certified to be free of MEC, MD, and other explosives concern by a qualified SUXOS. The debris was also inspected to verify that it was free of staining or other evidence of hazardous/chemical contamination. Approximately $60,000 \mathrm{lb}$ of nonhazardous construction debris was disposed of at the PEOT Landfill at the TTR.

\section{C.4.5 Remediation Waste}

Remediation waste generated at CAU 408 included MEC (including RCRA-regulated MEC), MD, and remediated soil contaminated with DU.

\section{C.4.5.1 Munitions and Explosives of Concern}

The munitions and explosives of concern generated during CAU 408 closure activities were subdivided into two distinct waste streams: RCRA-regulated waste and non-RCRA-regulated waste.

- The RCRA-regulated MEC is defined as live munitions that were previously collected and disposed in a solid waste disposal site. These munitions were removed from the solid waste disposal site and managed in an SAA before treatment (Figure C.4-1).

- The non-RCRA-regulated MEC is defined as live munitions that were collected at the surface or near surface during range clearance activities. The non-RCRA-regulated MEC was collected "as found" and had not been previously disposed in a solid waste disposal site. The non-RCRA-regulated MEC was collected and managed in designated munitions collection areas before treatment (Figure C.4-2).

The live munitions were all treated in accordance with the 90-day Temporary Emergency Permit for treatment of UXO (Murphy, 2009 and 2010) before disposal. 


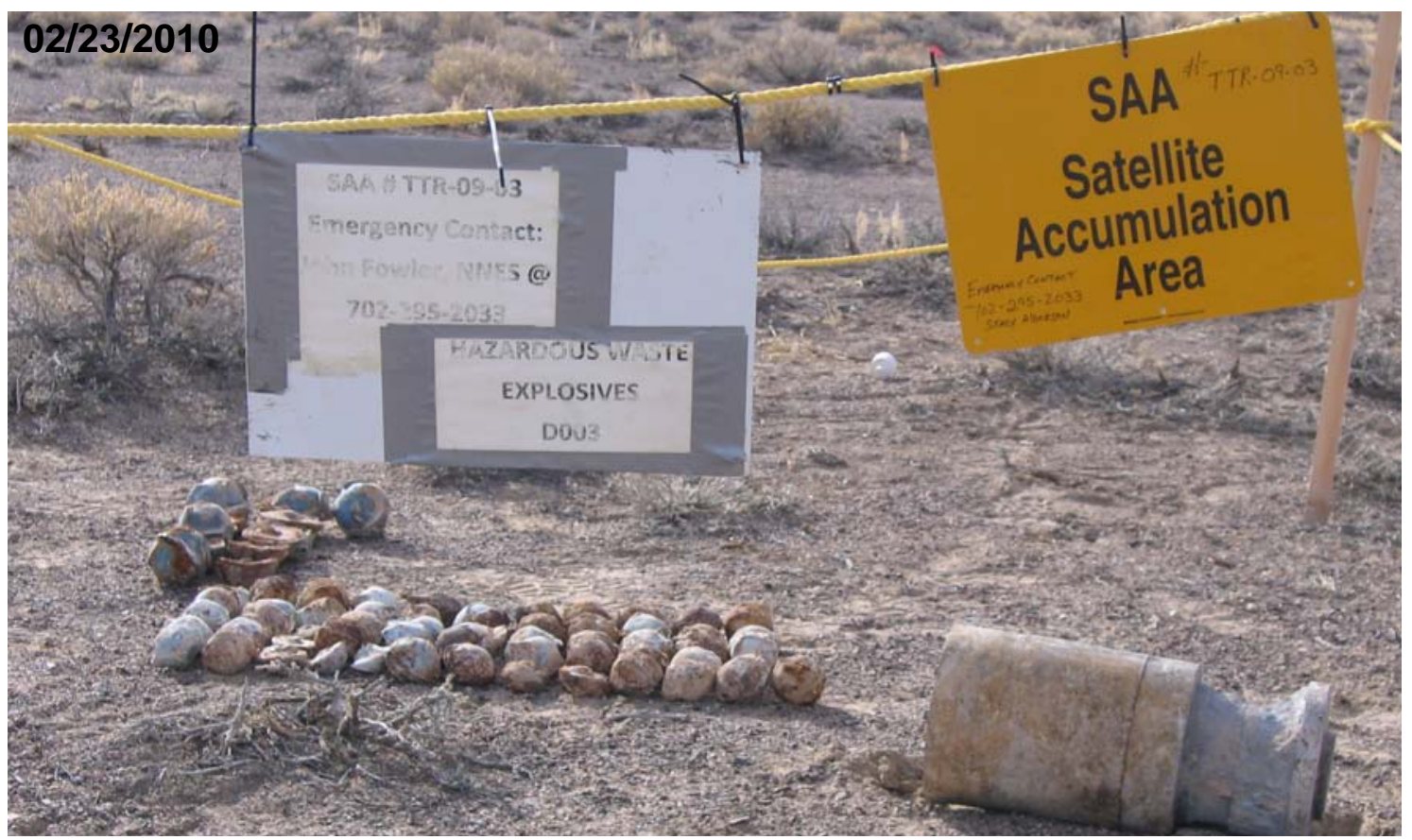

Figure C.4-1

RCRA-Regulated MEC inside an SAA in South Antelope Lake

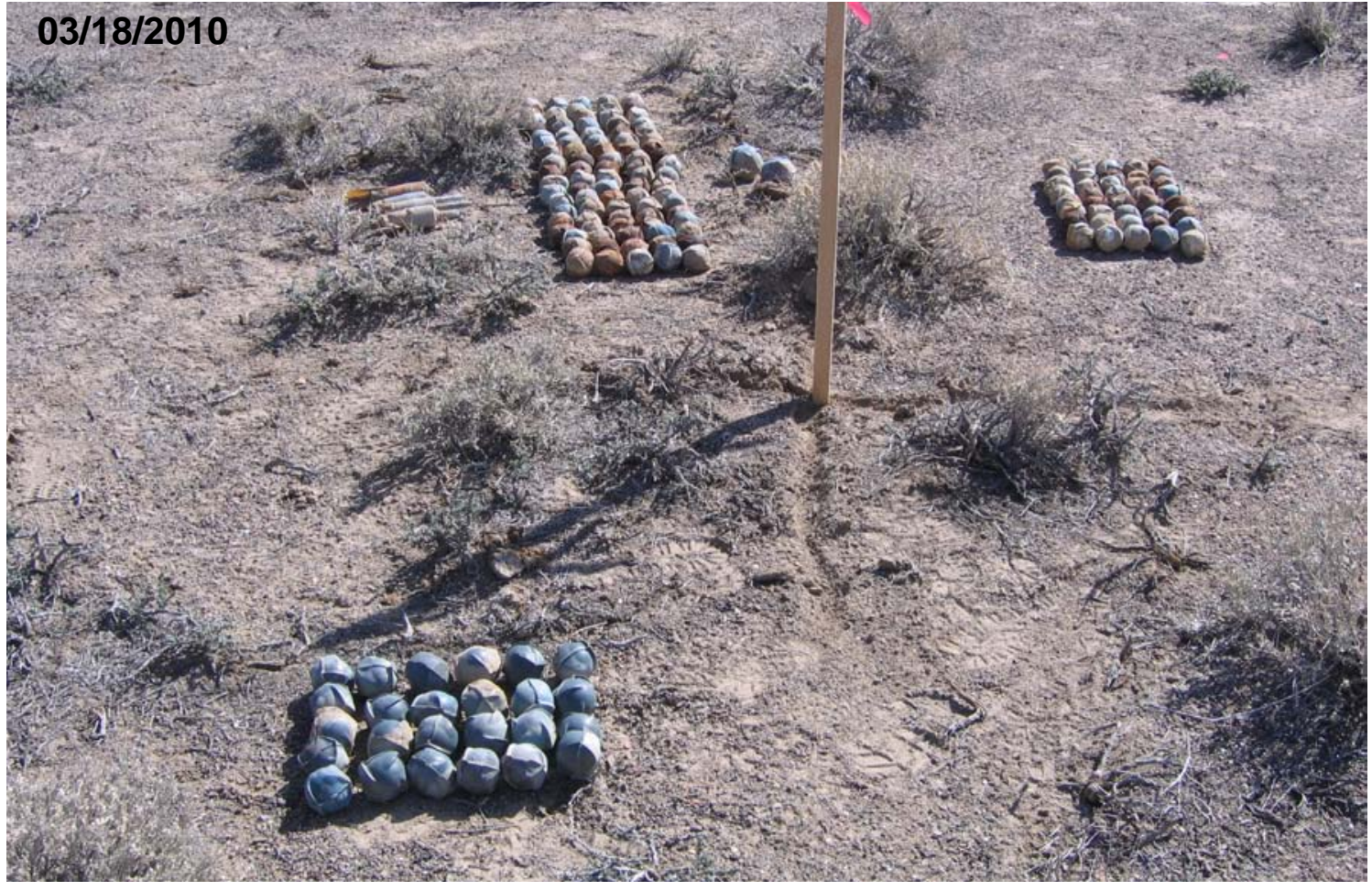

Figure C.4-2

Example of Non-RCRA-Regulated MEC before Treatment 


\section{C.4.5.2 Munitions Debris}

Inert MD is defined as munitions that have been rendered inert through treatment or that were visually inspected and certified to be inert. All inert MD has been certified to be free of MEC, MD, and other explosives of concern by a qualified SUXOS. The inert MD has been characterized as nonhazardous and nonradioactive. An estimated 100,380 lb of inert MD was transported and disposed at the Area 9 U10c Industrial Waste Landfill located at the NTS.

\section{C.4.5.3 Remediated Soil Waste}

Approximately $370 \mathrm{lb}$ of soil and metal fragments contaminated with DU were remediated during CAU 408 closure activities. The remediation waste was characterized as low-level radioactive waste using the analytical results from a direct sample of the soil (408A501) and radiological FSRs of the metal fragments. The waste was packaged into drum number 408A06 and will be disposed at the Area 5 RWMC located at the NTS. Results above MDCs for sample 408A501 are provided in Table C.4-1.

Table C.4-1

Waste Characterization Results Detected at CAS TA-55-002-TAB2, Bomblet Target Areas

\begin{tabular}{|c|c|c|c|c|c|c|}
\hline Sample Location & $\begin{array}{l}\text { Sample } \\
\text { Number }\end{array}$ & $\begin{array}{c}\text { Sample } \\
\text { Matrix }\end{array}$ & Parameter & $\begin{array}{c}\text { Regulatory } \\
\text { Criteria }^{\mathrm{a}} \\
\text { (mg/L) }\end{array}$ & Result & Unit \\
\hline \multirow{3}{*}{ 3-Sided Concrete Bunker } & \multirow{3}{*}{ 408A501 } & \multirow{3}{*}{ Soil } & TCLP Barium & 100.0 & 0.422 & $\mathrm{mg} / \mathrm{L}$ \\
\hline & & & TCLP Cadmium & 1.0 & $0.0146(\mathrm{~J})$ & $\mathrm{mg} / \mathrm{L}$ \\
\hline & & & TCLP Chromium & 5.0 & $0.011(\mathrm{~J})$ & $\mathrm{mg} / \mathrm{L}$ \\
\hline \multirow{3}{*}{ Container 408A02 SAA-TTR-09-02 } & \multirow{3}{*}{ 408A502 } & \multirow{3}{*}{ Solid } & TCLP Barium & 100.0 & 0.154 & $\mathrm{mg} / \mathrm{L}$ \\
\hline & & & TCLP Cadmium & 1.0 & $244(\mathrm{~J}+)$ & $\mathrm{mg} / \mathrm{L}$ \\
\hline & & & TCLP Lead & 5.0 & $0.0378(\mathrm{~J})$ & $\mathrm{mg} / \mathrm{L}$ \\
\hline
\end{tabular}

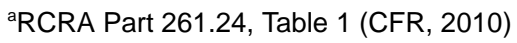

$\mathrm{mg} / \mathrm{L}=$ Milligrams per liter

$\mathrm{J}=$ Estimated value

$\mathrm{J}+=$ The result is an estimated quantity, but the result may be biased high. 


\section{C.4.5.4 Recycled Lead}

Approximately $50 \mathrm{lb}$ of elemental lead was collected and packaged into drum number 408A01 during CAU 408 closure activities. The material was identified as lead using process knowledge. The lead was surveyed as generated and subsequently released as nonradioactive according to the limits set forth in Table 4.2 of the Nevada Test Site Radiological Control Manual (NNSA/NSO, 2010a). Therefore, the material is characterized as nonradioactive. In accordance with 40 Code of Federal Regulations 261.2 (3)(1)(i) (CFR, 2010), this material is exempt from management as a RCRA-hazardous waste, if the material is recycled in its present form. This container will be transferred to the lead recycling accumulation area located at Building 23-153 at the NTS pending offsite recycling. Various other metallic debris contained in drum number 408A01 (e.g., battery plates, circuit boards) was sampled for waste characterization purposes (sample number 408A502). These waste materials, other than recyclable lead, were consumed during the sampling process. Results above MDCs for sample 408A502 are provided in Table C.4-1. 
This section contains a summary of QA/QC measures implemented during the sampling and analysis activities conducted in support of the CAU 408 CAI. The following sections discuss the data validation process, QC samples, and nonconformances. A detailed evaluation of the DQIs is presented in Section 4.4.

Laboratory analyses were conducted for samples used in the decision-making process to provide a quantitative measurement of any COPCs present. Rigorous QA/QC was implemented for all laboratory samples, including documentation, verification and validation of analytical results, and affirmation of DQI requirements related to laboratory analysis. Detailed information regarding the QA program is contained in the Industrial Sites QAPP (NNSA/NV, 2002).

\section{C.5.1 Data Validation}

Data validation was performed in accordance with the Industrial Sites QAPP (NNSA/NV, 2002) and approved protocols and procedures. All laboratory data from samples collected and analyzed for CAU 408 were evaluated for data quality in a tiered process described in Sections C.5.1.1 through C.5.1.3. Data were reviewed to ensure that samples were appropriately processed and analyzed, and the results were evaluated using validation criteria. Documentation of the data qualifications resulting from these reviews is retained in project files as a hard copy and electronic media.

One hundred percent of the data analyzed as part of this investigation were subjected to Tier I and Tier II evaluations. A Tier III evaluation was performed on approximately 5 percent of the data analyzed.

\section{C.5.1.1 Tier I Evaluation}

Tier I evaluation for chemical and radiochemical analysis examines, but is not limited to, the following:

- Sample count/type consistent with chain of custody.

- Analysis count/type consistent with chain of custody.

- Correct sample matrix. 
- Significant problems stated in cover letter or case narrative.

- Completeness of certificates of analysis.

- Completeness of Contract Laboratory Program (CLP) or CLP-like packages.

- Completeness of signatures, dates, and times on chain of custody.

- Condition-upon-receipt variance form included.

- Requested analyses performed on all samples.

- Date received/analyzed given for each sample.

- Correct concentration units indicated.

- Electronic data transfer supplied.

- Results reported for field and laboratory QC samples.

- Whether or not the deliverable met the overall objectives of the project.

\section{C.5.1.2 Tier II Evaluation}

Tier II evaluation for chemical analysis examines, but is not limited to, the following:

- Correct detection limits achieved.

- Sample date, preparation date, and analysis date for each sample.

- Holding time criteria met.

- Quality control batch association for each sample.

- Cooler temperature upon receipt.

- Sample pH for aqueous samples, as required.

- Detection limits properly adjusted for dilution, as required.

- Blank contamination evaluated and applied to sample results/qualifiers.

- Matrix spike/matrix spike duplicate (MSD) percent recoveries (\%R) and RPDs evaluated and qualifiers applied to laboratory results, as necessary.

- Field duplicate RPDs evaluated using professional judgment and qualifiers applied to laboratory results, as necessary.

- Laboratory duplicate RPDs evaluated and qualifiers applied to laboratory results, as necessary.

- Surrogate \%R evaluated and qualifiers applied to laboratory results, as necessary.

- Laboratory control sample \%R evaluated and qualifiers applied to laboratory results, as necessary.

- Initial and continuing calibration evaluated and qualifiers applied to laboratory results, as necessary.

- Internal standard evaluation. 
- Mass spectrometer tuning criteria.

- Organic compound quantitation.

- Inductively coupled plasma interference check sample evaluation.

- Graphite furnace atomic absorption QC.

- Inductively coupled plasma serial dilution effects.

- Recalculation of 10 percent of laboratory results from raw data.

Tier II evaluation for radiochemical analysis examines, but is not limited to, the following:

- Correct detection limits achieved.

- Blank contamination evaluated and, if significant, qualifiers are applied to sample results.

- Certificate of Analysis consistent with data package documentation.

- Quality control sample results (duplicates, LCSs, laboratory blanks) evaluated and used to determine laboratory result qualifiers.

- Sample results, uncertainty, and MDC evaluated.

- Detector system calibrated with National Institute of Standards and Technology (NIST)traceable sources.

- Calibration sources preparation was documented, demonstrating proper preparation and appropriateness for sample matrix, emission energies, and concentrations.

- Detector system response to daily or weekly background and calibration checks for peak energy, peak centroid, peak full-width half-maximum, and peak efficiency, depending on the detection system.

- Tracers NIST-traceable, appropriate for the analysis performed, and recoveries that met QC requirements.

- Documentation of all QC sample preparation complete and properly performed.

- Spectra lines, photon emissions, particle energies, peak areas, and background peak areas support the identified radionuclide and its concentration. 


\section{C.5.1.3 Tier III Evaluation}

The Tier III review is an independent examination of the Tier II evaluation. A Tier III review of 5 percent of the sample analytical data was performed by TLI, of Lakewood, Colorado. Tier II and Tier III results were compared and where differences are noted, data were reviewed and changes were made accordingly. This review included the following additional evaluations:

- Review:

- case narrative, chain of custody, and sample receipt forms,

- lab qualifiers (applied appropriately),

- method of analyses performed as dictated by the chain of custody,

- raw data, including chromatograms, instrument printouts, preparation logs, and analytical logs,

- manual integrations to determine whether the response is appropriate,

- data package for completeness.

- Determine sample results qualifiers through the evaluation of (but not limited to):

- tracers and QC sample results (e.g., duplicates, LCSs, blanks, MSs) evaluated and used to determine sample results qualifiers,

- sample preservation, sample preparation/extraction and run logs, sample storage, and holding time,

- instrument and detector tuning,

- initial and continuing calibrations,

- calibration verification (initial, continuing, second source),

- retention times,

- second column and/or second detector confirmation,

- mass spectra interpretation,

- interference check samples and serial dilutions, 
- post-digestion spikes and method of standard additions,

- breakdown evaluations.

- Perform calculation checks of:

- at least one analyte per QC sample and its recovery,

- at least one analyte per initial calibration curve, continuing calibration verification, and second source recovery,

- at least one analyte per sample that contains positive results (hits); radiochemical results only require calculation checks on activity concentrations (not error).

- Verify that target compound detects identified in the raw data are reported on the results form.

- Document any anomalies for the laboratory to clarify or rectify. The contractor should be notified of any anomalies.

\section{C.5.2 Field QC Samples}

Field QC samples consisted of one field blank and five FDs collected and submitted for analysis by the laboratory analytical methods shown in Table C.2-1. The QC samples were assigned individual sample numbers and sent to the laboratory "blind.” Additional samples were selected by the laboratory to be analyzed as laboratory duplicates.

Field blanks were analyzed for the applicable parameters listed in Table C.2-1. There were no detections above MDCs for the field blank sample.

During the CAI, five FDs were sent as blind samples to the laboratory to be analyzed for the investigation parameters listed in Table C.2-1. For these samples, the duplicate results precision (i.e., RPDs between the environmental sample results and their corresponding FD sample results) were evaluated.

\section{C.5.2.1 Laboratory QC Samples}

Analysis of QC preparation blanks (PBs) was performed on each sample delivery group (SDG) for inorganics. Analysis for surrogate spikes and method blanks were performed on each SDG for organics. Initial and continuing calibration and LCSs were performed for each SDG. The results of 
these analyses were used to qualify associated environmental sample results. Documentation of data qualifications resulting from the application of these guidelines is retained in project files as both hard copy and electronic media.

The laboratory included a PB, LCS, and laboratory duplicate sample with each batch of field samples analyzed for radionuclides.

\section{C.5.3 Field Nonconformances}

There were no field nonconformances identified for the CAI.

\section{C.5.4 Laboratory Nonconformances}

Laboratory nonconformances are generally due to inconsistencies in the analytical instrumentation operation, sample preparations, extractions, missed holding times, and fluctuations in internal standard and calibration results. Laboratory nonconformances have been accounted for and resolved during the data qualification process. 


\section{C.6.0 Summary}

Explosives, inorganics, and radionuclide contaminants detected in environmental samples during the CAI were evaluated against FALs to determine the nature and extent of COCs for CAU 408 at identified disposal pits and/or biased locations where MEC (i.e., MD) was identified. Assessment of the data generated from investigation activities indicates the FALs were not exceeded in surface and subsurface soil samples in CAS TA-55-002-TAB2. The following summarizes the results for each CAS.

\section{CAS TA-55-002-TAB2, Bomblet Target Areas}

Based on the observations made and the analytical results of the verification soil samples collected at this CAS, no contamination has been released to the soil at this CAS. Therefore, no further action is required at this CAS. 


\section{C.7.0 References}

BN, see Bechtel Nevada.

Bechtel Nevada. 1995. Nevada Test Site Performance Objective for Certification of Nonradioactive Hazardous Waste, Rev. 0, G-E11/96.01. Las Vegas, NV.

CFR, see Code of Federal Regulations.

Code of Federal Regulations. 2010. Title 40 CFR, "Protection of Environment,” Parts 260-282, "Hazardous Waste Management.” Washington, DC: U.S. Government Printing Office.

DOE, see U.S. Department of Energy.

DOE/NV, see U.S. Department of Energy, Nevada Operations Office.

EPA, see U.S. Environmental Protection Agency.

Gao, S., J. Ryu, K.K. Tanji, and M.J. Herbel. 2006. “Arsenic Speciation and Accumulation in Evapoconcentrating Waters of Agricultural Evaporation Basins.” In Chemosphere, Vol. 67: 862-871. Amsterdam, Netherlands: Elsevier B.V.

Landsat 7 ETM+ Imagery, see Landsat 7 Enhanced Thematic Mapper Plus Imagery.

Landsat 7 Enhanced Thematic Mapper Plus Imagery. 2000. Satellite Orthophotography. Reston, VA: U.S. Geological Survey.

Murphy, T., Bureau of Federal Facilities. 2009. Letter to K. Small (NNSA/NSO) entitled “Temporary Emergency Permits for Treatment of Unexploded Ordnance (UXO) Found During Remediation Activities for Corrective Action Unit (CAU) 484 on the Tonopah Test Range (TTR), while conducting a survey in the Cat Canyon area at the Nevada Test Site (NTS), and as accumulated during WSI activities on the NTS firing range,” 9 December. Las Vegas, NV.

Murphy, T., Bureau of Federal Facilities. 2010. Letter to K. Small (NNSA/NSO) entitled “Temporary Emergency Permit for Tonopah Test Range Unexploded Ordnance (UXO)," 16 April. Las Vegas, NV.

N-I GIS, see Navarro-Intera Geographic Information Systems.

NNES, see Navarro Nevada Environmental Services, LLC.

NNSA/NV, see U.S. Department of Energy, National Nuclear Security Administration Nevada Operations Office.

NNSA/NSO, see U.S. Department of Energy, National Nuclear Security Administration Nevada Site Office. 
Navarro-Intera Geographic Information Systems. 2010. ESRI ArcGIS Software.

Navarro Nevada Environmental Services, LLC. 2009. Statement of Work for Analytical Laboratories, Section C. Las Vegas, NV.

RSL, see Remote Sensing Laboratory.

Remote Sensing Laboratory. 2006. Tonopah Test Range Orthophotos, acquired 29 April. Las Vegas, NV.

Ryu, J., S. Gao, R.A. Dahlgren, and R.A. Zierenberg. 2002. “Arsenic Distribution, Speciation, and Solubility in Shallow Groundwater of Owens Dry Lake, California.” In Geochimica et Cosmochimica Acta, Vol. 66, Issue 17: 2981-2994. Amsterdam, Netherlands: Elsevier B.V.

SNJV, see Stoller-Navarro Joint Venture.

Stoller-Navarro Joint Venture. 2006. Model Statement of Work for Analytical Laboratories, Rev. 0. February. Las Vegas, NV.

U.S. Department of Energy. 1997. The Procedures Manual of the Environmental Measurements Laboratory, HASL-300. 28th Ed., Vol. I. February. New York, NY.

U.S. Department of Energy, National Nuclear Security Administration Nevada Operations Office. 2002. Industrial Sites Quality Assurance Project Plan, Nevada Test Site, Nevada, Rev. 3, DOE/NV--372. Las Vegas, NV.

U.S. Department of Energy, National Nuclear Security Administration Nevada Site Office. 2006. Industrial Sites Project Establishment of Final Action Levels, Rev. 0, DOE/NV--1107. Las Vegas, NV.

U.S. Department of Energy, National Nuclear Security Administration Nevada Site Office. 2010a. Nevada Test Site Radiological Control Manual, DOE/NV/25946--801, Rev. 1. Prepared by Radiological Control Managers’ Council. Las Vegas, NV.

U.S. Department of Energy, National Nuclear Security Administration Nevada Site Office. 2010b. Streamlined Approach for Environmental Restoration for Corrective Action Unit 408: Bomblet Target Area, Tonopah Test Range (TTR), Nevada, Rev. 1, DOE/NV--1171-Rev.1. Las Vegas, NV.

U.S. Environmental Protection Agency. 1980. Prescribed Procedures for Measurement of Radioactivity in Drinking Water, EPA 600/4-80-032. Cincinnati, OH: Environmental Monitoring and Support Laboratory Office of Research and Development.

U.S. Environmental Protection Agency. 2008. SW-846 On-Line, Test Methods for Evaluating Solid Waste, Physical/Chemical Methods. As accessed at http://www.epa.gov/epaoswer/hazwaste/test/main.htm on 15 July 2009. 


\title{
Appendix D
}

\section{Waste Disposition Documentation}

\author{
(13 Pages)
}




\begin{tabular}{|llllll}
\hline SWO USE (Select One) & AREA & $\square 23$ & $\square 6$ & $\square 9$ & $\square$ LANDFILL
\end{tabular}

For waste characterization, approval, and/or assistance, contact Solid Waste Operation (SWO) at 5.7898. REQUIRED: WASTE GERERATOR INFORMATION

(This form is for rolloffs, dump trucks, and other onsite disposal of materials.)

Waste Generator: Mark Heser (NNES, WO) (M/S - NSF176) (Fax 5-2241) Phone Number: (0)5-2124; (c)496-0150 Location / Origin: Tonapah Test Range, CAU 408 - Bulk Industrial Debris waste (Container \# 408A05). FAX 5-2Z4/ Waste Category: (check one) $\square$ Commercial $Q$ industrial

Waste Type: $\square$ NTS $\square$ Putrescrible $\square$ FFACO-onsite $\square$ WAC Exception

(check one) $\square$ Non-Putrescible $\square$ Asbestos Containing Material $\triangle$ FFACO-offsite $\square$ Historic DOE/NV Pollution Prevention Category: (check one) $\otimes$ Environmental management $\square$ Defense Projects $\square$ YMP Pollution Prevention Category: (check one) $\otimes$ Clean-Up $\square$ Routine Method of Characterization: (check one) $\otimes$ Sampling \& Analysis $\otimes$ Process Knowledge $\square$ Contents Prohibited Waste at all three Radioactive waste; RCRA waste; Hazardous waste; Free liquids, PCBs above TSCA regulatory NTS landfills: Additional Prohibited Waste
at the Area 9 U10C Landfill:

\section{REQUIRED: WASTE CONTENTS ALLOWABLE WASTES}

Check all allowable wastes that are contained within this load:

NOTE: Waste disposal at the Area 6 Hydrocarbon Landfill must have come into contact with petroleum hydrocarbons or coolants, such as: gasoline (no benzene, lead); jet fuel; diesel fuel; lubricants and hydraulics; kerosene; asphaltic petroleum bydrocarbon: and ethylene glycol.
Acceptable waste at any NTS landfill:
[] Paper
$\square$ Rocks / unaltered geologic materials
$\square$ soil
$\square$ Rubber (excluding tires)
$\square$ Insulation (non-Asbestosform)
$\square$ Empty containers
$\square$ Asphalt $\triangle$ Metal $\square$ Wood
$\square$ Cloth
Cable
$\bigotimes$ Manufactured items: (swamp coolers, furniture, rugs, carpet, electronic components. PPE, etc.)
Additional waste atcepted at the Area 23 Mercury Landfill: $\square$ Office Waste $\square$ Food Waste
$\square$ Demolition debris
$\square$ Cement \& concrete
Additional waste accepted at the Area 23 Mercury Landfill: $\square$ Office Waste
$\square$ Asbestos
$\square$ Friable
$\square$ Non-Friable (contact sWO if regulated load)
Quantity: Animal Carcasses

Additional waste accepted at the Area 9 U10c Landifil:

$\square$ Non-friable asbestos

$\square$ Drained automobiles and military vehicles

$\square$ Drained fuel filters (gas \& diesel)

Hydrocarbons (contact SwO) $\bigotimes$ Other Iner Munitions Debris

Additional waste accepted at the Area 6 Hydrocarbon Landfill:

$\square$ Septic sludge $\square$ Rags
$\square$ Plants
$\square$ Soil $\square$ Sludge from sand/oil/water separators
Solid fractions from sand/oil/water

Deconned Underground and Above Ground Tanks

Initials: (if initialed, no radiological clearance is necessary.)

The above mentioned waste was generated outside of a Controlled Waste Manageme knowledge, does not contain radiological materials.

To the best of my knowledge, the waste described above contains only those materia site. I have verified this through the waste characterization method identified above a prohibited and allowable waste items. I have contacted Property Management and ha is approved for disposal in the landfill.

Print Name: Mark Heser

Signature: /s/ Mark Heser Date: $5 / 17 / 10$ [] Crushed non-teme plated oil filters PCBs below 50 parts per million Note: "Food waste, office trash and animal carcasses do not require a radiological
must have signed removal certification statement with Load Verification." SWO USE ONLY Load Weight (net fron scale or estimate): $\frac{32680}{\text { shipmeat } 1 \text { of } 3}$ /s/ Donald Bickford Radiologlcal Survoy Relaase for Waste Olsposal RCT Initials This container/load meets the crlteria for no adided man-mado radloactive matorlal This contalner/load moots the criterla for Radcon Manual Table 4.2 raleaso litmits. This containerfload is exempt from survey due to process knowledge and origin. SIGNATURE: /s/ Harrold W. Anagnostopoulos DATE: $1 / 27.14$ QN.0600 1000 


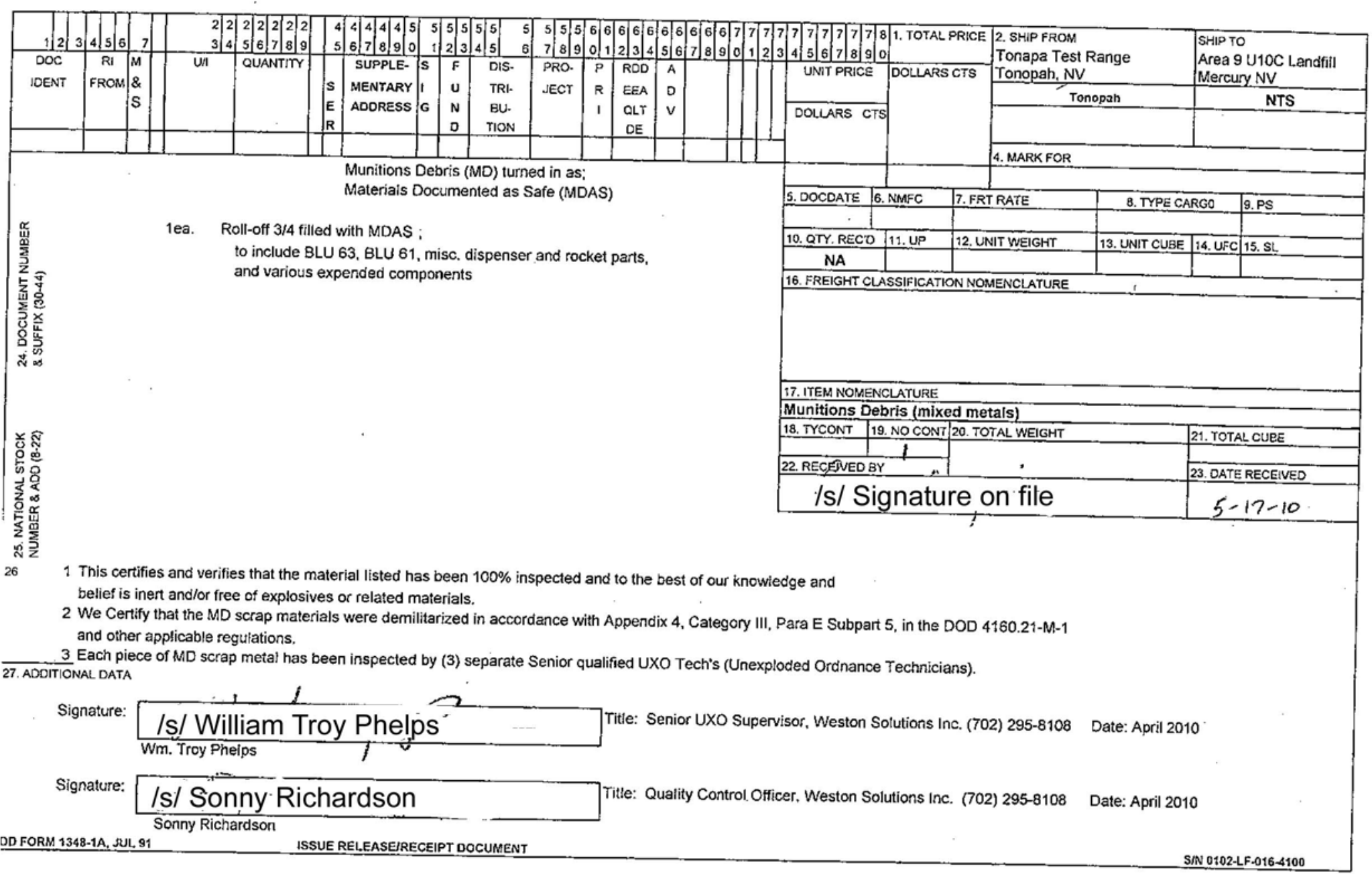


TRAILER/CAR NUMBER: EIO $7351 / 075029$ BILL DATE: $5-17-10$

TO

\begin{tabular}{|l|}
\hline Consignee: NSTec Solid Waste Operations \\
\hline Street: Mercury Highway \\
\hline Destination: Area 9, U10c Landfill \\
\hline City/State/Zip: Mercury, Nevada, \\
\hline Route: N/A \\
\hline
\end{tabular}

FOR PAYMENT, SEND BILL TO
FROM

Shipper: NNES for USDOE

Street: Building 101 Tonopah test Range

Origin: Tonopah Test Range

City/State/Zip: Tonopah, Nevada 89049

Special Instructions:

\begin{tabular}{|l|}
\hline Name: N/A \\
\hline Company: N/A \\
\hline Street: N/A \\
\hline City/State/Zip: N/A \\
\hline
\end{tabular}

SHIPPER'S INSTRUCTIONS

Exclusive use shipment - no stops

Shipment shall be covered with tarp

\begin{tabular}{|c|c|c|c|c|c|c|}
\hline NU. SHIPPING UNIIS & TIME & \multicolumn{2}{|c|}{$\begin{array}{l}\text { DESCRIPTION OF ARTICLES } \\
\text { SPECIAL MARKS \& EXCEPTIONS } \\
\end{array}$} & WEIGHT & RATE & CHARGES \\
\hline 1 Each & $15: 00$ & \multicolumn{2}{|c|}{$\begin{array}{l}\text { Non-Regulated shipment } \\
\text { Bulk Debris Waste }\end{array}$} & 70,000 & N/A & $N / A$ \\
\hline & & & & & & \\
\hline & & & & & & \\
\hline & & & & & & \\
\hline & & & & & & \\
\hline & & & & & & \\
\hline & & & & & & \\
\hline $\begin{array}{r}\text { REMIT C.O.D. } \\
\text { N/A }\end{array}$ & & & C.O.D. AMOUNT: \$ N/A & & $\begin{array}{l}\text { C.O.D. } \\
\text { PREPA } \\
\text { COLLE }\end{array}$ & $\begin{array}{ll}E E & \\
T & \square \\
\end{array}$ \\
\hline $\begin{array}{l}\text { TO: N/A } \\
\text { ADDRESS: N/A }\end{array}$ & 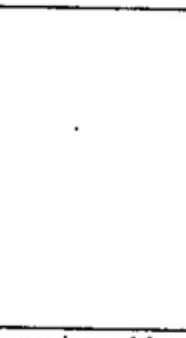 & & $\begin{array}{l}\text { If this shipment is to be de } \\
\text { the consignee without recc } \\
\text { consignor, the consignor s } \\
\text { following statement: The } \\
\text { not make delivery of this s } \\
\text { without payment of freight } \\
\text { other lawful charaes. } \\
\text { /s/ Mark Hes } \\
\text { (Signature of Consi }\end{array}$ & $\begin{array}{l}\text { vered to } \\
\text { urse on the } \\
\text { lall sign the } \\
\text { arrier shall } \\
\text { ipment } \\
\text { ind all } \\
\text { nor) } \\
\end{array}$ & $\begin{array}{l}\text { TOTAL } \\
\text { CHARG }\end{array}$ & S \$ N/A \\
\hline $\begin{array}{l}\text { NOTE: Where the rate is depe } \\
\text { required to state specifically in } \\
\text { value of the property. The agree } \\
\text { property is hereby specifically s } \\
\text { exceeding } \$ \text { N/A }\end{array}$ & $\begin{array}{l}\text { on value, shipp } \\
\text { the agreed or } \\
\text { eclared value } \\
\text { oy the shipper t } \\
\text { per: I }\end{array}$ & $\begin{array}{l}\text { ers are } \\
\text { leclared } \\
\text { f the } \\
\text { o be not } \\
\text { IIA }\end{array}$ & & & $\begin{array}{l}\text { Freight } \\
\text { market } \\
\text { CHECK }\end{array}$ & $\begin{array}{l}\text { harges are collect unless } \\
\text { epaid } \\
\text { 3OX IF PREPAID } \otimes\end{array}$ \\
\hline
\end{tabular}

RECEIVED subject to the classifications and tariffs in effect on the date of the issue of this Bill of Lading, the property described above in apparent (the word carrier being understood through this of packages unknown), marked consigned and destined as indicated above which said carrier agrees to carry to its usual place of delivery as said destination. If on any person or corporation in possession of the property under the contract) It is mutually agreed as to each carrier of all or any of caidon. If on its route, othenwise to deliver to another carrier on the route to said destination. time interested in all or any said property, that any of said property, over all or any portion of said route to destination and as to each party at any in the governing classification on the date of shipment. Shipper performed hereunder shall be subject to all the Bill of Lading terms and conditions the governing classjication and the said terms and conditions.

\begin{tabular}{|l|l|l} 
Shipper Is/ Mark Heser & Carrier /s/ Signature on file \\
\hline Per & Per & Date? $5-17-10$ \\
\hline Mark with " $X$ " or "RQ" if appropriate to desigate Hardo
\end{tabular}

governing the transportation of hazardous materials. The use of this s Substances as defined in the Department of Transportation Regulations Lading 172.201(a)(1) (iii) of Title 49 . Co prescribed in section 172.204(a) of the Federal Regulations, requirement is pro vided in the Regulation for a particular material. 


SWO USE (Select One) AREA $\square 23 \quad \square 6 \quad \square 90$ LANDFILL

For waste characterization, approval, and/or assistance, contact Solid Waste Operation (SWO) at 5-7898. REQUIRED: WASTE GERERATOR INFORMATION

(This form is for rolloffs, dump trucks, and other onsite disposal of materials.)

Waste Generator: Mark Heser (NNES, WO) (M/S - NSF176) (Fax 5-2241) Phone Number: (0)5-2124; (c) 496-0150

Location / Origin: Tonapah Test Range, CAU 408 - Bulk Industrial Debris waste (Container \# 408A05). TAX-S- 224)

\begin{tabular}{|c|c|c|c|}
\hline Waste Category: (eheck one) & \multirow{2}{*}{$\begin{array}{l}\square \text { Commercial } \\
\square \text { Putrescrible }\end{array}$} & \multicolumn{2}{|l|}{ Industrial } \\
\hline Waste Type: $\square$ NTS & & $\square$ FFACO-onsite & $\square$ WAC Exception \\
\hline (check one) $\quad \square$ Non-Putrescible & $\square$ Asbestos Containing Material & Q FFACO-offsite & Historic DOE/NV \\
\hline Pollution Prevention Category: (check one) & Environmental management & Q Defense Projects & $\square$ YMP \\
\hline Pollution Prevention Category: (check one) & $\triangle$ Clean-Up & $\square$ Routine & \\
\hline Method of Characterization: (check one) & ه Sampling \& Analysis & Q Process Knowledge & $\square$ Contents \\
\hline
\end{tabular}
Prohibited Waste at all three Radioactive waste; RCRA waste; Hazardous waste; Free liquids, PCBș above TSCA regulatory NTS landfills:

Additional Prohibited Wasto at the Area 9 U10C Landfill:

levels, and Medical wastes (needles, sharps, bloody clothing).

Sewage Sludge, Animal carcasses, Wet garbage (food waste); and Friable asbestos

\section{REQUIRED: WASTE CONTENTS ALLOWABLE WASTES}

Check all allowable wastes that are contained within this load:

NOTE: Waste disposal at the Area 6 Hydrocarbon Landfill must have come into contact with petroleum hydrocarbons or coolants, such as: gasoline (no benzene, lead); jet fuel; diesel fuel; lubricants and hydraulics; kerosene; asphaltic petroleum hydrocarbon; and ethylene glycol.
Acceptable waste at any NTS landfill:
$\square$ Paper
$\square$ Soil
$\square$ Cloth
$\square$ Rocks / unaltered geologic materials
$\square$ Asphalt
$\bigotimes$ Metal
$\square$ Wood
$\square$ Rubber (excluding tires)
$\square$ Insulation (non-Asbestosform)
Q Plastic
Wire
Cable
Q Manufactured items: (swamp coolers, furniture, rugs, carpet, electronic components, PPE, etc.)
Additional waste accepted at the Area 23 Mercury Landfil:
$\square$ Asbestos
$\square$ Friable
$\square$ Non-Friable (contact SWO if regulated load)
Quantity:
Additional waste accepted at the Area 9 U10 C Landfill:
$\square$ Non-friable asbestos
$\square$ Light ballasts (contact SWO)
$\square$ Hydrocarbons (contact SWO)
$\square$ Drained automobiles and military vehicles
$\square$ Drained fuel filters (gas \& diesel)
Other Inert Munitions Debris
Solid fractions from sand/oil/water
Deconned Underground and Above Ground Tanks

$\square$ Empty containers

$\square$ Demolition debris

$\square$ Cement \& concrete

Additional waste accepted at the Area 6 Hydrocarbon Landfiil: $\square$
$\square$ Septic sludge
$\square$ Rags
$\square$ Drained fuel filters (gas \& diesel)
Plants
Soil
$\square$ Sludge from sand/oil/water separators
Crushed non-teme plated oil filters REQUIRED: WASTE GENERATOR SIGNATURE

Initials: (if initialed, no radiological clearance is necessary.)

The above mentloned waste was generated outside of a Controlled Waste Manageme| knowledge, does not contain radiological materials.

To the best of my knowledge, the waste described above contains only those materia site. I have verified this through the waste characterization method Identified above a prohibited and allowable waste iterns. I have contacted Properte Management and ha is approved for disposal in the landfill.

Print Name: Mark Heser

Signature: /s/ Mark Heser Date: $2 / 2 / 10$
Radlological Survey Releaso for Waste Disposal RGT Initials

This contalner/load meets the critería for $r$ added man-mado radloactive material This container/load meots the criteria for Radeon Manual Table 4.2 raleaso limits. Thls containerlload is exempt from survey duo to proceges knowlodge and origin. SIGNATURE: /s/ Harold W. Anagnostopoulos DATE: $4 \underbrace{427}_{\text {BN-06A6(1) }}$

Note: "Food waste, office trash and animal carcasses do not require a radiological clearance. Freon-containing appliances must have signed removal certification statement with Load Verification."

SWO USE ONLY

Load Weight (net from scale dr estimate): 32600

$$
8-3-10
$$

Signature of Certifier:

$$
\text { shipment } 2 \text { of } 3
$$




\begin{tabular}{|l|l|}
\hline Consignee: NSTec Solid Waste Operations \\
\hline Street Mercury Highway & \\
\hline Destination: Area 9, U10c Landfill & \\
\hline City/State/Zip: Mercunf, Nevada, & \\
\hline Route: N/A & \\
\hline
\end{tabular}

\begin{tabular}{|l|}
\hline Shipper, NWES for USDOE \\
\hline Street Building 101 Tonopah Test Range \\
\hline Origin: Tonopah Test Range \\
\hline City/StatelZip: Tonopah; Nevada 89049 \\
\hline Special Instructions: Exclusive Use Shipment \\
\hline
\end{tabular}

\begin{tabular}{|c|c|}
\hline FOR PAYMENT, SEND BILI TQ & SHIPPER'S INSTRUCTIONS \\
\hline Name: N/A & Exclusive use shipment - no additional loads \\
\hline Company: N/A & Shipment shall be covered with tarp \\
\hline \multicolumn{2}{|l|}{ Street: N/A } \\
\hline City/State/Zip: N/A & \\
\hline
\end{tabular}

\section{NO. SHIPPING UNITS}

TIME

\begin{tabular}{|c|c|c|c|c|}
\hline 1 Each & $\div 1450$ & \multicolumn{2}{|c|}{$\begin{array}{l}\text { Non-Regulated shipment } \\
\text { Bulk Debris Waste }\end{array}$} & 35 , and \\
\hline & & & & \\
\hline & & & & \\
\hline & & & & \\
\hline & & & & \\
\hline & & & & \\
\hline $\begin{array}{c}\text { REMIT C.O.D. } \\
\text { N/A }\end{array}$ & & & C.O.D. AMOUNT: $\$$ & \\
\hline $\begin{array}{l}\text { TO: N/A } \\
\text { ADDRESS: N/A }\end{array}$ & . & & $\begin{array}{l}\text { If this shipment is to } \\
\text { the consignee withou } \\
\text { consignos, the consig } \\
\text { following statement } \\
\text { not make dervery of } \\
\text { without paymemt of f } \\
\text { other lawrul charges. } \\
* \text { /S/ Dan } \\
\text { SSignaturejof }\end{array}$ & $\begin{array}{l}\text { elivered to } \\
\text { course on the } \\
\text { shall sign the } \\
\text { camier shall } \\
\text { shipment } \\
\text { it and all } \\
\text { nign } \\
\text { signor) }\end{array}$ \\
\hline $\begin{array}{l}\text { NOTE: W here the } \\
\text { required to state s } \\
\text { value of the proper } \\
\text { property is hereby } \\
\text { exceeding }\end{array}$ & $\begin{array}{r}\text { int on value, shiph } \\
\text { ng the agreed of } \\
\text { r declared value } \\
\text { d by the shippes } \\
\text { pert }\end{array}$ & $\begin{array}{l}\text { ers ane } \\
\text { decalared } \\
\text { af the } \\
\text { o be not } \\
\text { i/A }\end{array}$ & . & \\
\hline
\end{tabular}

\section{Freight Charges are collect unless market prepaid CHECK BOX IF PREPAID}

RECEIVED subject to the classifications and tariff in effect on the date of the issue of this Bill of Lading, the property described above in apparent good order, except as noted (contents and condition of packages unknown), marked consigned and destined as indicated above which said carrier (the word carrier being underslood through this contract as meaning any person or corporation in possession of the property under the contract) agrees to camy to its usual place of delivery as said pestination. If on its route, ofherwise to deiver to another canier on the route to said destination. It is mutually agreed as to each carrer of all or ant of said property, over all or any portion of said route to destination and as to each pariy at any time interested in all or any said property, that eveng service ta be performed hereunder shats be subject to all the Bill of Lading terms and conditions in the governing classification on the date of shipm ent. Shipper hereby certifies that he is familiar wyith all the Bill of Lading terms and conditions in the goveming classification and the said terms and onditions.

Shipper is./s/ Dan Henry $8-z-10$

Per

$t$

Carrier /s/ Signature on file

Mark with ' $\mathrm{X}$ " or "RQ" if appropriate to designate Hazerdous Materials Substances as defined in the Department of Transportation Regulations goveming the transportation of hazardous material the use of thls column is an optional method for identifying hazardous materials on Bills of Lading 172.201 (a)(1) (iii) of Title 49 . Cade of Fede 2. Regulations. Also when shipping hazardous materials, the shipper's certification slatement prescribed in section 172.204(a) of the Federal Redu ations, as indicated on the Bill of Lading ooes apply, unless a.specific exception fiom the requirement is pro vided in the Regulation for a pa tipular material. 


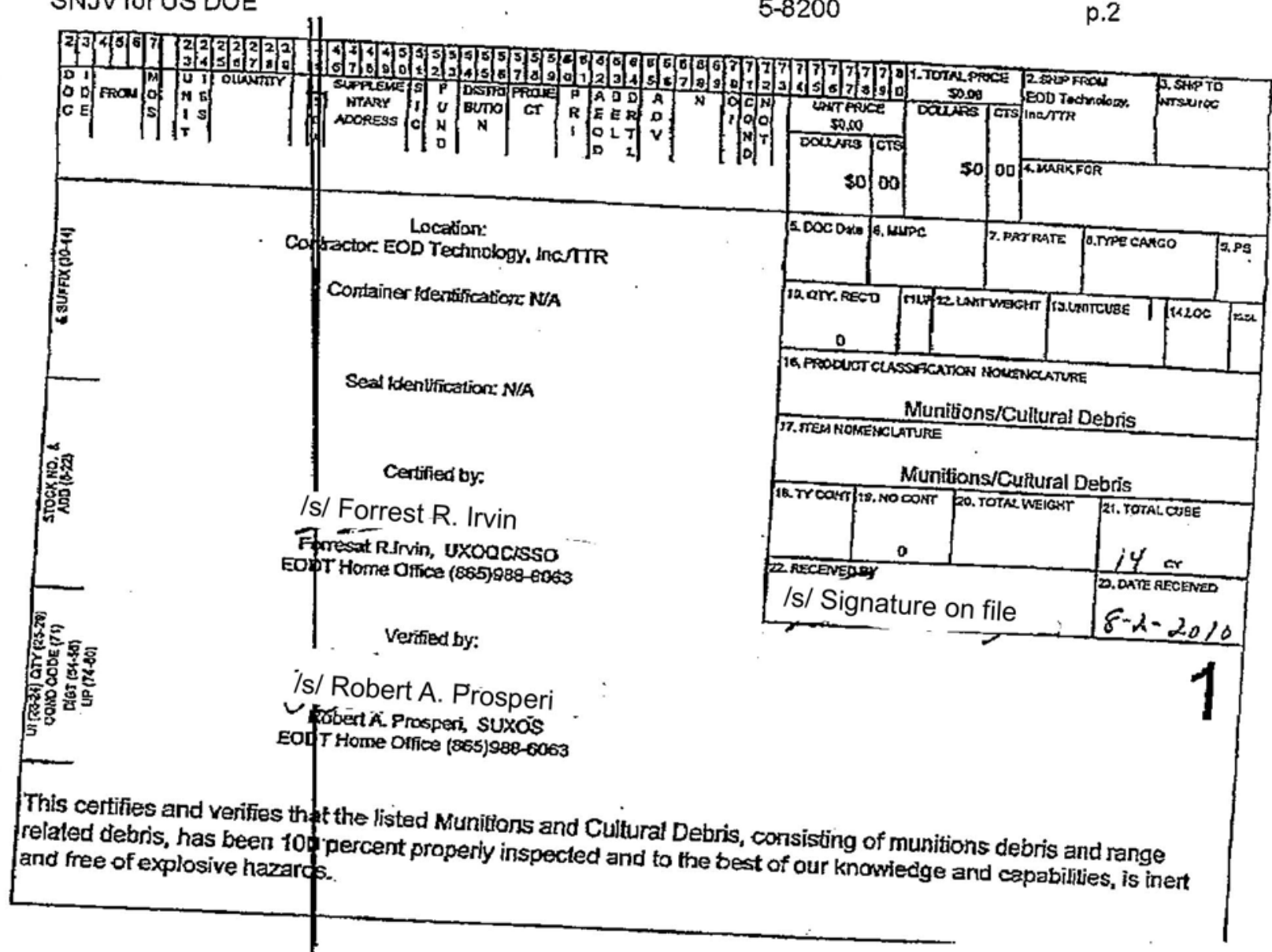


NSTec

Form

For waste characterization, approval, and/or assistance, contact Solid Waste Operation (SWO) at 5-7898. REQUIRED: WASTE GERERATOR INFORMATION

(This form is for rolloffs, dump trucks, and other onsite disposal of materials.)

Waste Generator: Mark Heser (NNES, WO) (M/S - NSF176) (Fax 5-2241) Phone Number: (0)5-2124: (c)496-0150 Location / Origin: Tonapah Test Range, CAL

Waste Type: $\square$ NTS (chack one) Non-Putrescible $\square$ Commercial

口 Putrescrible (Container \# 408A05). Fax 5-2241 Pollution Prevention Category: (check one) Pollution Prevention Category: (check one) Method of Characterization: (check one)

$\square$ Asbestos Containing Material

Q Industrial

Environmental management

$\triangle$ Clean-Up

Prohibited Wasto at all three NTS landfllis:

Additional Prohibited Waste at the Area 9 U $10 C$ Landfill: Radioactive waste: RCRA waste; Hazardous waste; Free liquids, PCBs above TSCA regulatory
levels, and Medical wastes (needles, sharps, bloody clothing). Sewage Sludge, Animal carcasses, Wet garbage (food waste); and Friable asbestos

\section{REQUIRED: WASTE CONTENTS ALLOWABLE WASTES}

Cheok all allowable wastes that are contained within this load:

NOTE: Waste disposal at the Area 6 Hydrocarbon Landfill must have come into contact with petroleum hydrocarbons or coolants, such as: gasoline (no benzeno, lead); jet fuel; diesel fuel; lubricants and hydraulics; kerosene; asphaltic petroleum hydrocarbon; and ethylene glycol.

Acceptable waste at any N'S landfill: $\square$ Paper

$\square$ Asphalt $\square$ Metal $\square$ Wood $\square$ Soil

$\bigotimes$ Plastic $\square$ Wire $\square$ Cable $\quad$ Cloth

$\square$ Rubber (excluding tires)

$\square$ Rocks / unaltered geologic materials

$\square$ insulation (non-Asbestosform)

$\bigotimes$ Manufactured items: (swamp coolers, furniture, fugs, carpet, electronic components, PPE, etc.)

Additional waste accepted at the Area 23 Mercury Landfil!: $\square$ Office Waste

$\square$ Asbestos $\square$ Friable

$\square$ Non-Friable (contact SWO if regulated load)

$\square$ Food Waste

Quantity:

Additional waste accepted at the Area 9 U10c Landfill:

$\square$ Non-friable asbestos

$\square$ Light ballasts (contact SWO)

$\square$ Drained automobiles and military vehicles

Hydrocarbons (contact SWO)

$\square$ Drained fuel filters (gas \& diesel)

$\bigotimes$ Other Inert Munitions Debris

Additional waste accepted at the Area 6 Hydrocarbon Landfill:
$\square$ Septic sludge
$\square$ Rags
Soil
$\square$ Drained fuel filters (gas \& diesel)
Plants

Q Sol
$\square$ Sludge from sand/oil/water separators
REQUIRED: WASTE GENERATOR SIGNATURE Crushed non-teme plated oil filters PCBs below 50 parts per million

Solid fractions from sand/oil water

Deconned Underground and Above Ground Tanks

Initials: (if initialed, no radiological clearance is necessary.) The above mentioned waste was generated outside of a Controlled Waste Manageme
knowledge, does not contain radlological materlals.

To the best of my knowledge, the waste described above contains only those materia site. I have verified this through the waste characterization mothod identified above । prohibited and allowable waste items. I have contacted Property Management and ha is approved for disposal in the landifill.

Print Name: Mark Heser

Signature: /s/ Mark Heser Date: $8 / 30 / 10$ :

$\square$ Empty container's Demolition debris Cement \& concrete

Note: "Food waste, office trash and animal carcasses do not require a radiological clear must have signed-removal certification statement with Load Verification."

LWO USE ONLY Signature of Certifier:

/s/ Donald Bickford

$$
\text { shipment } 3 \text { of } 3
$$

Radlological Survay Release for Waśte Dlaposal KCT Initlals

This container/load moots the criterla for added man-made radloactivo material Thls contalnorlioad meats the eritorla for X Radcon Manual Table 4.2 roloase IImItr. This contalnerlload is oxompt from aurves duo to procese knoyjledgo and origin. SIGNATURE: /s/ Harold W. Anagnostopoulos DATE: 4/2 arance. Freon-containing appliances बNन्OCQB 


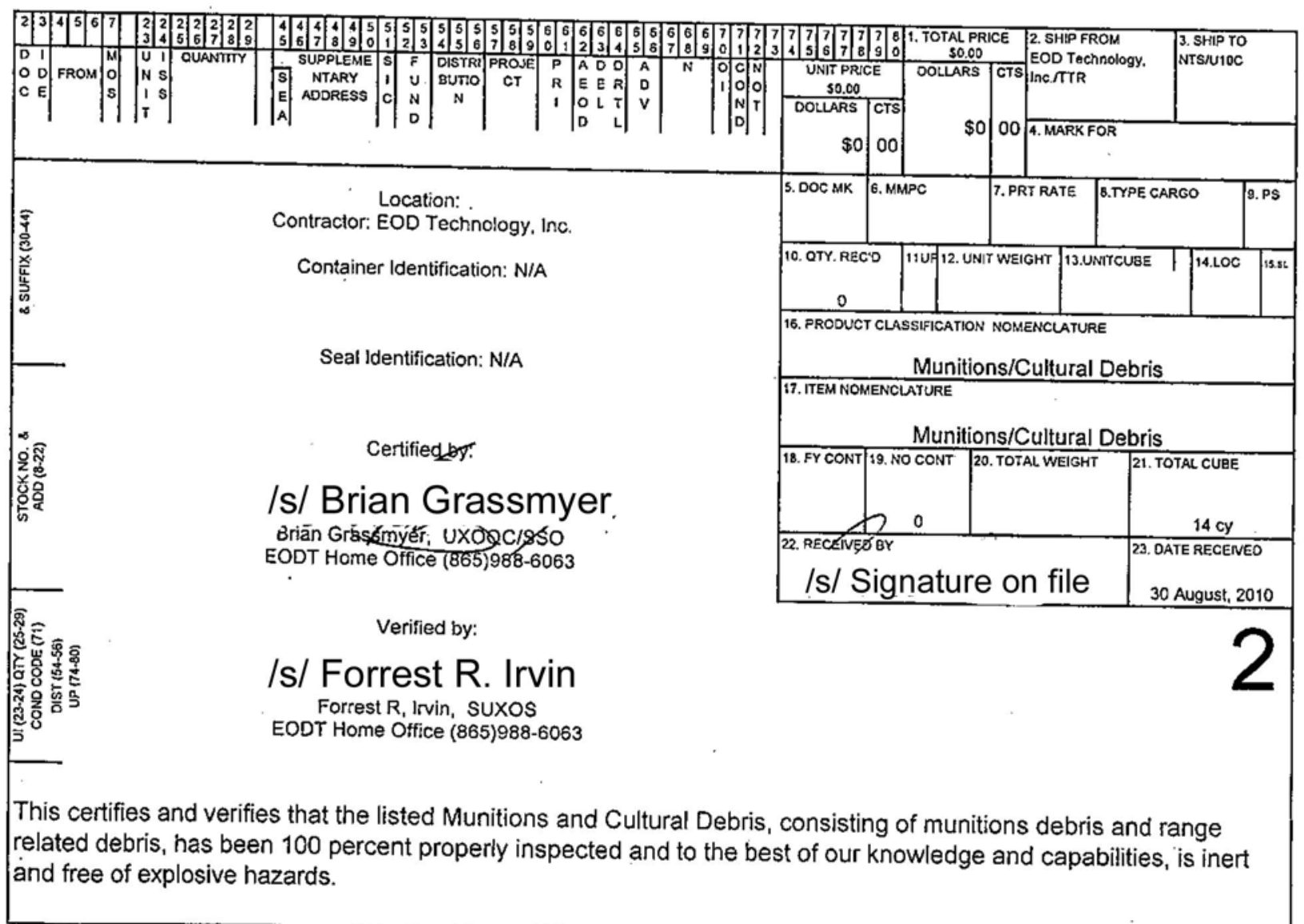


TRAILER/CAR NUMBER: $E / 07351$

BILL DATE: $8-30-10$

TO

\begin{tabular}{|l|}
\hline Consignee: NSTec Solid Waste Operations \\
\hline Street: Mercury Highway \\
\hline Destination: Area 9, U10c Landfill \\
\hline City/State/Zip: Mercury, Nevada, \\
\hline Route: N/A \\
\hline
\end{tabular}

FOR PAYMENT, SEND BILL TO
FROM

\begin{tabular}{|l|}
\hline Shipper: NNES for USDOE \\
\hline Street: Building 101 Tonopah test Range \\
\hline Origin: Tonopah Test Range \\
\hline City/State/Zip: Tonopah, Nevada 89049 \\
\hline Special Instructions: \\
\hline
\end{tabular}

SHIPPER'S INSTRUCTIONS

\begin{tabular}{|l|}
\hline Name: N/A \\
\hline Company: N/A \\
\hline Street: N/A \\
\hline City/State/Zip: N/A \\
\hline
\end{tabular}

Exclusive use shipment - no stops

Shipment shall be covered with tarp
TIME
DESCRIPTION OF ARTICLES SPECIAL MARKS \& EXCEPTIONS

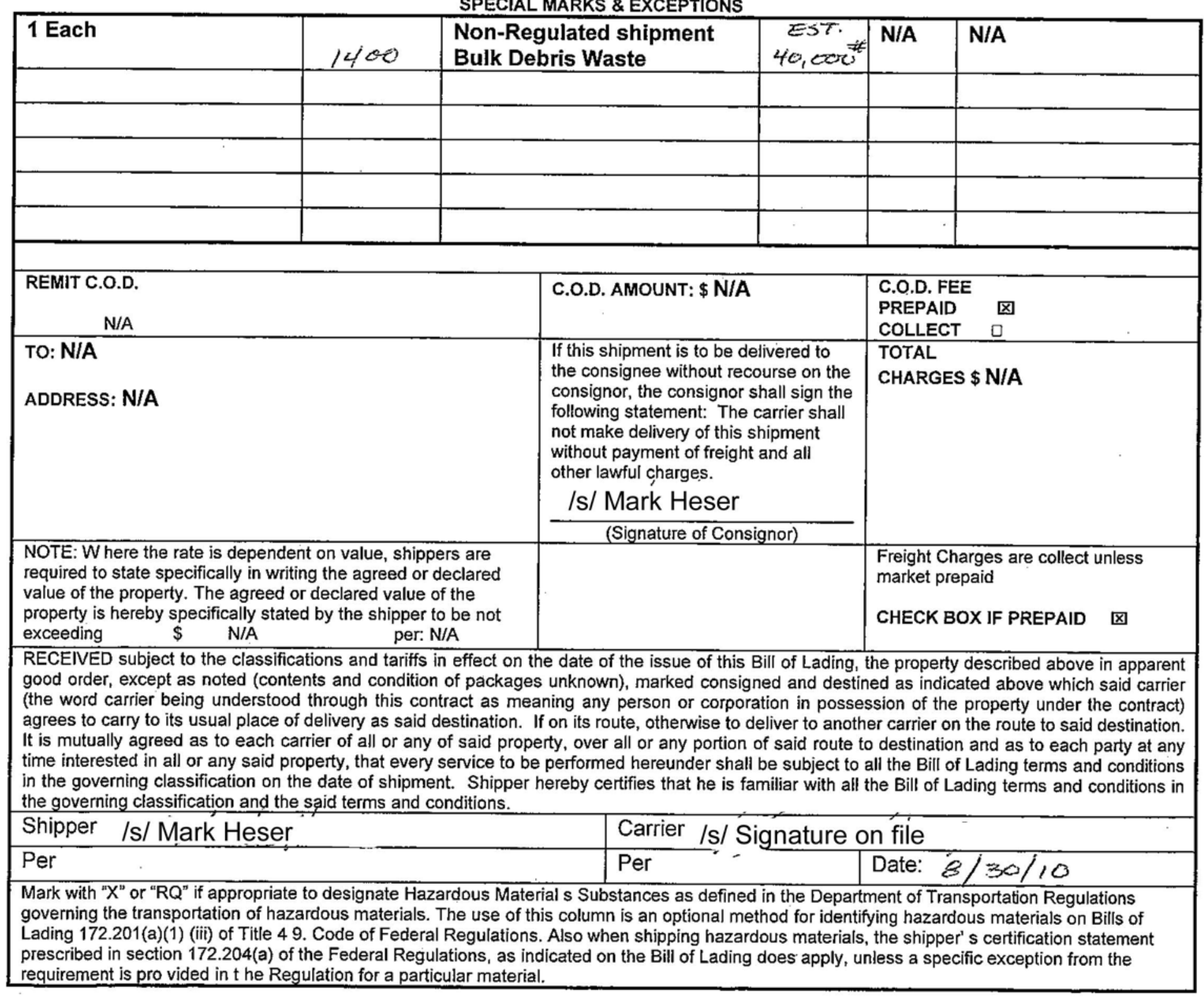




\section{Certificate of Disposal}

This is to cerfify that the Waste Stream No. LITN-000000006, Revision 13, shipment number ITL 10002 , with container numbers $408 \mathrm{~A} 06 ; 484004 ; 484012 ;$ and 484055 was shipped and received at the Nevada Test Site Radtoactive Waste Management Complex in Area 5 for disposal as stated below.

$\frac{\text { Mark Heser }}{\text { Shipped by }}$

/s/ Mark Heser

Signature

Ton TANAKA

Reccived by

/s/ Jon Tanaka

Ş̣ignature
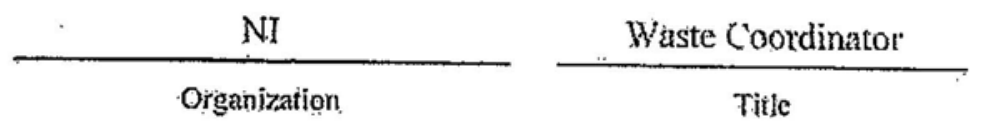

$4-7 \cdot 10$

Daite
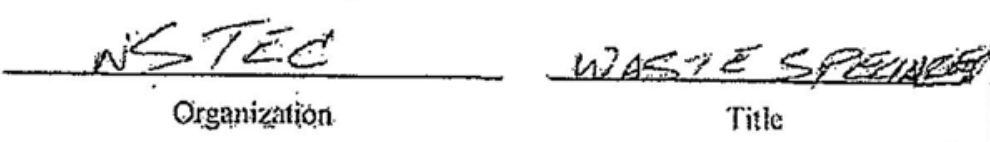

07.SEPT-2010

Date 


\section{DESCRIPTION OF WASTE:}

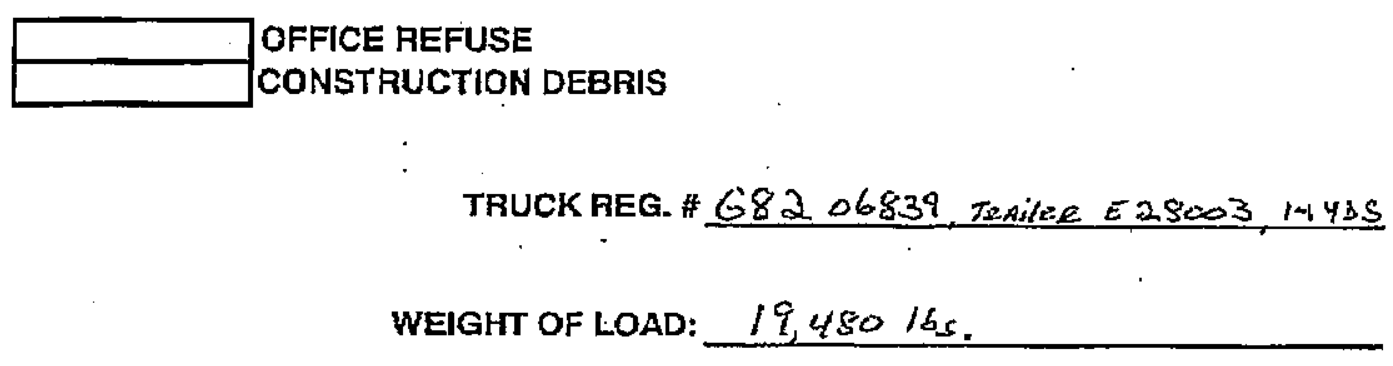

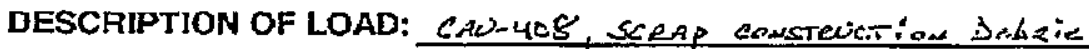

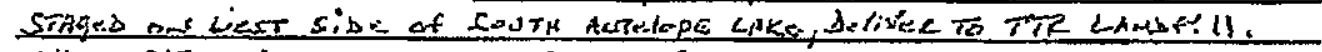

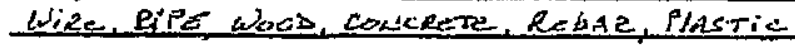

AREA: TTR LANSFill

COMPANY: WAshington GLOLP

NAME: Ton Wilsow

DATE: $3-3-10$.

Genecator. NNES

Daw Hersizy

$3-3-10$ 


\section{PEOT}

\section{NON-HAZARDOUS WASTE}

\section{DESCRIPTION OF WASTE:}

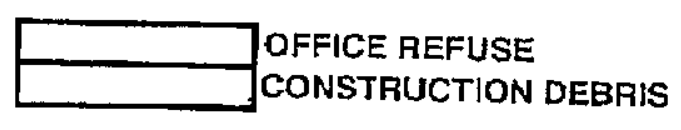

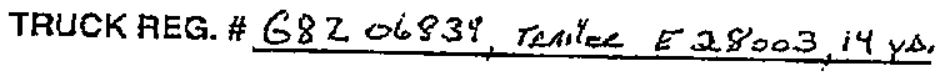

WEIGHT OF LOAD: 7360 its.

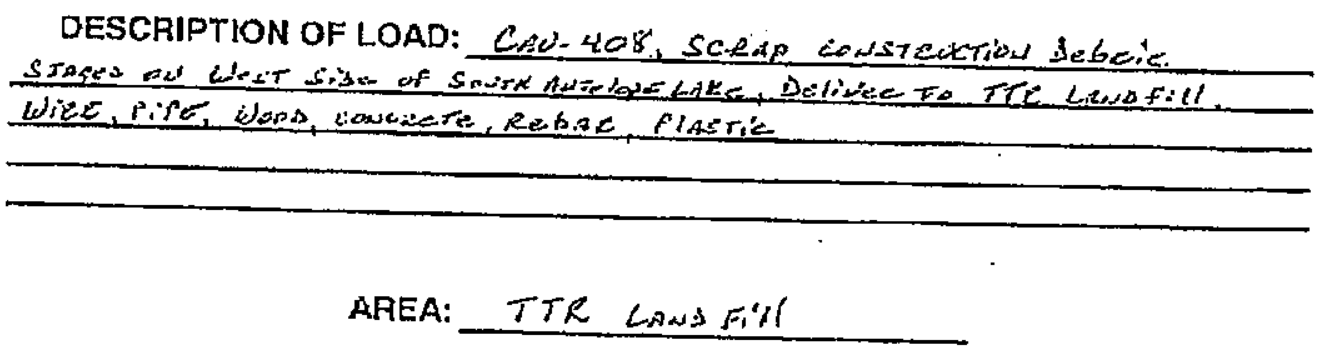

COMPANY: Whashiestiton Eaces

NAME: Trom witsod.

DATE: $\quad 3-3-10$

$$
\begin{aligned}
& \text { Genematoc - NNES } \\
& \text { DAN Heney } \\
&: \quad 3-3-10
\end{aligned}
$$




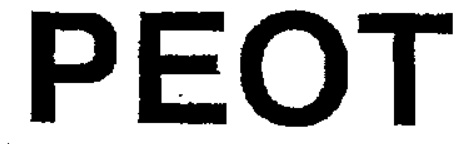

\section{NON-HAZARDOUS WASTE}

\section{DESCRIPTION OF WASTE:}

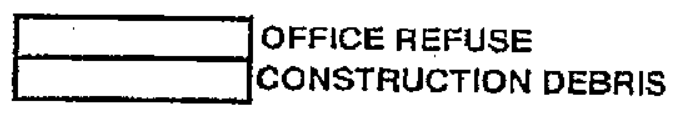

TRUCK REG. \# Q82 DL839, TRailes, E28003 14 yss

WEIGHT OF LOAD: $11,22016.5$

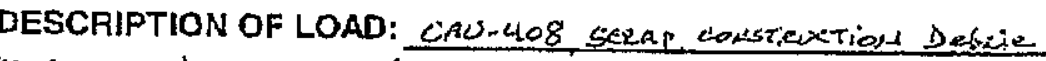

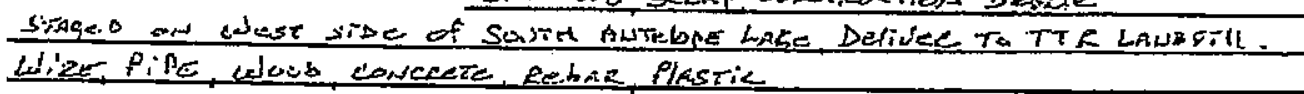

AREA: TTR La,b fill

COMPANY: LAShingTON GKOUP

NAME: Tom Wilson

DATE: $3-3-10$

Genceature hNES

DAN Heney

$3-3-10$ 


\section{Appendix E}

\section{Risk Evaluation}




\section{E.1.0 Risk Assessment}

This risk evaluation addresses the chemical and radiological contamination detected in CAU 408 verification soil samples. Part of this evaluation is to establish RBCA FALs as described in the Industrial Sites Project Establishment of Final Action Levels (NNSA/NSO, 2006). This process conforms with Nevada Administrative Code (NAC) Section 445A.227, which lists the requirements for sites with soil contamination (NAC, 2008a). For the evaluation of corrective actions, NAC Section 445A.22705 (NAC, 2008b) requires the use of ASTM Method E1739 (ASTM, 1995) to "conduct an evaluation of the site, based on the risk it poses to public health and the environment, to determine the necessary remediation standards (i.e., FALs) or to establish that corrective action is not necessary."

A site contaminant that is present at concentrations exceeding a FAL is defined as a COC. The presence of a COC requires that a corrective action be implemented. For verification samples collected following excavation of contaminated soils, the presence of a COC in a verification sample would require the removal of additional material to complete the corrective action of clean closure. If no COCs are present in any verification sample, the completion of the corrective action of clean closure will be verified.

This section contains documentation of the RBCA process used to establish FALs described in the Industrial Sites Project Establishment of Final Action Levels (NNSA/NSO, 2006). This process defines three tiers (or levels) to establish FALs used to evaluate DQO decisions:

- Tier 1 - Sample results from source areas (highest concentrations) compared to risk-based screening levels (RBSLs) (i.e., PALs) based on generic (non-site-specific) conditions.

- $\quad$ Tier 2 - Sample results from exposure points compared to SSTLs calculated using site-specific inputs and Tier 1 formulas.

- $\quad$ Tier 3 - Sample results from exposure points compared to SSTLs and points of compliance calculated using chemical fate/transport and probabilistic modeling.

The RBCA decision process stipulated in the Industrial Sites Project Establishment of Final Action Levels (NNSA/NSO, 2006) is summarized in Figure E.1-1. 


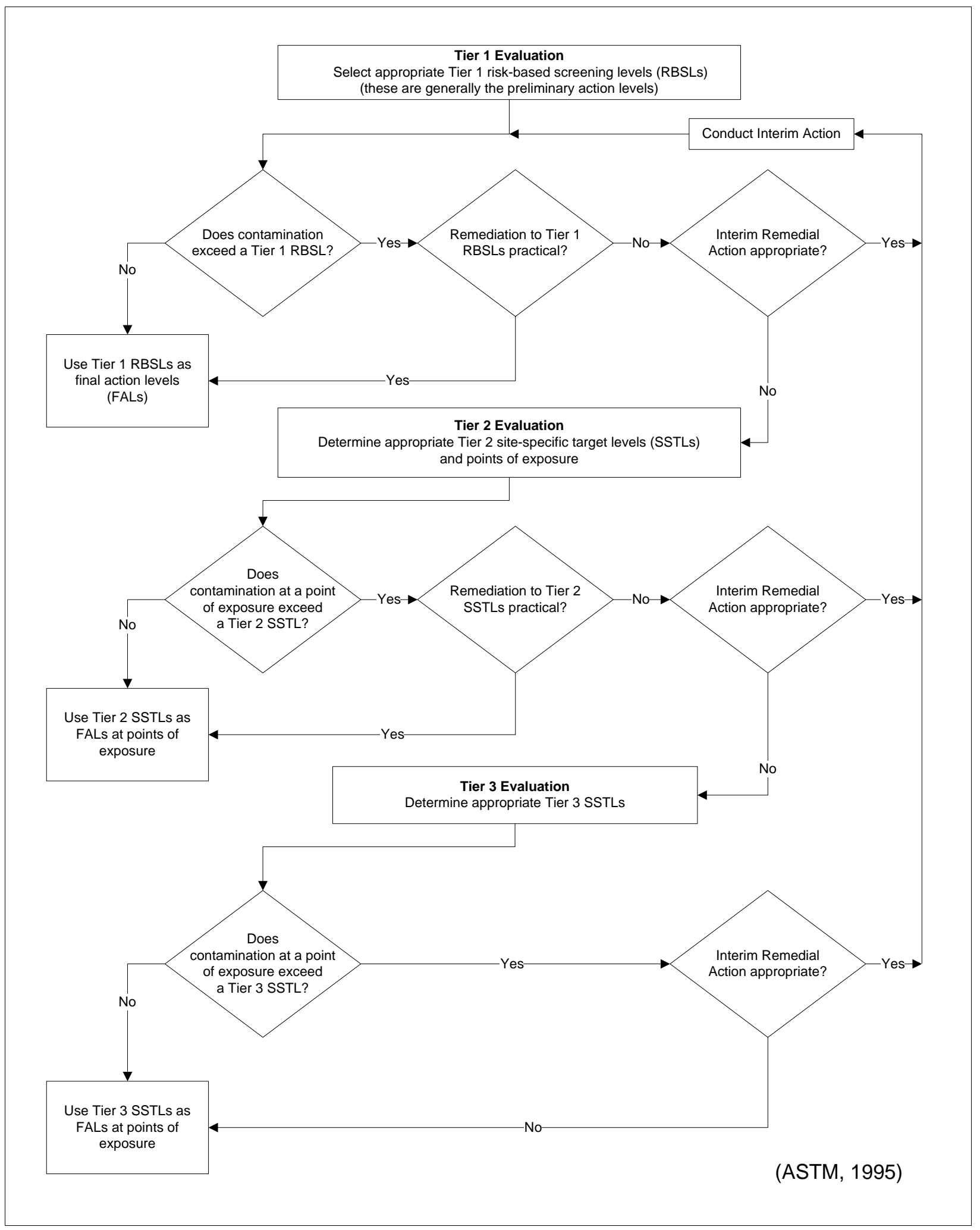

Figure E.1-1

Risk-Based Corrective Action Decision Process 


\section{E.1.1 A. Scenario}

Corrective Action Unit is located at the TTR, Nevada, and is composed of CAS TA-55-002-TAB2, Bomblet Target Areas. The CAU 408 Bomblet Target Area was originally identified as an approximately 19-mi area of bomblet drops from Mid Target to central Antelope Lake. Based upon document reviews, personnel interviews, and preliminary investigations in 2006 where UXO personnel walked the flight paths to identify areas that contain evidence of bomblet testing, the CAU boundary was redefined to consist of seven discrete target areas as defined in the SAFER Plan (NNSA/NSO, 2010). To account for possible inaccuracies in hitting intended targets, the CAU 408 investigation included a 2,300-ft buffer zone around each target and along Flightline Road. Additionally, geophysical survey results from SAC Target 1 and Antelope Lake identified up to 25 anomalies that could represent potential disposal pits with buried ordnance.

The target areas were used to perform submunitions-related tests for the DOE. The scope of CAU 408 was limited to submunitions (on the surface and disposal pits) released from DOE activities and potentially contaminated soil from those activities. However, it was recognized that the presence of other types of UXO and munitions might be present within the target areas and in the buffer zones due to the activities of other government organizations; these items (miscellaneous debris and MEC) were removed and dispositioned as a BMP.

\section{E.1.2 B. Site Assessment}

The CAI performed at CAS TA-55-002-TAB2 was completed by identification and removal of MEC within seven target areas, the buffer zone, and identified disposal pits. Clean closure was demonstrated by performing magnetometer and visual surveys of target areas and buffer zones, conducting radiological surface screening and surveys, and collecting verification surface and subsurface soil samples. The verification samples were collected from seven disposal pits and excavation of a small soil mound after remediation of MEC and/or waste materials. The verification samples indicate that lead and arsenic are present in soils above PALs. However, it was determined that arsenic is not a site contaminant as it is present in native mineralogy and is concentrated through natural evapoconcentration in dry lake beds (see Section E.1.10). 
Waste materials (e.g., wood, metal, wire) and MEC (including UXO and MD) were identified and removed such that no identified waste remains at the CAS that meet potential source material criteria.

The maximum concentration of each contaminant identified in verification samples, and their corresponding PALs, are presented in Table E.1-1.

Table E.1-1

Maximum Concentration of Detected Contaminants for CAS TA-55-002-TAB2, Bomblet Target Areas (Page 1 of 2)

\begin{tabular}{|c|c|c|c|c|c|c|}
\hline Contaminant & $\begin{array}{l}\text { Maximum } \\
\text { Result }\end{array}$ & $\begin{array}{l}\text { Sample } \\
\text { Number }\end{array}$ & $\begin{array}{l}\text { Depth } \\
\text { (ft bgs) }\end{array}$ & Location & PAL & Units \\
\hline Ac-228 & 2.54 & 408A007 & $6.0-8.0$ & $\begin{array}{l}\text { South Wall, West End } \\
\text { Anomaly G156_95 }\end{array}$ & 5 & $\mathrm{pCi} / \mathrm{g}$ \\
\hline Arsenic & 27 & 408A008 & $6.0-8.0$ & $\begin{array}{l}\text { South Wall, Center } \\
\text { Anomaly G156_95 }\end{array}$ & 23 & $\mathrm{mg} / \mathrm{kg}$ \\
\hline Barium & 2,370 & 408A027 & $0.0-0.5$ & $\begin{array}{c}\text { Spoils Pile } \\
\text { Grid } 94 / 701 \text { South Antelope Lake }\end{array}$ & 190,000 & $\mathrm{mg} / \mathrm{kg}$ \\
\hline Cadmium & 9.42 & 408D001 & $0.0-1.0$ & $\begin{array}{l}\text { Soil Mound Grid 71/729 } \\
\text { SAC Target } 2\end{array}$ & 800 & $\mathrm{mg} / \mathrm{kg}$ \\
\hline Chromium & $39.8(\mathrm{~J})$ & 408A027 & $0.0-0.5$ & $\begin{array}{c}\text { Spoils Pile } \\
\text { Grid } 94 / 701 \text { South Antelope Lake }\end{array}$ & 450 & $\mathrm{mg} / \mathrm{kg}$ \\
\hline Cs-137 & 0.136 & 408B001 & $3.0-4.0$ & $\begin{array}{l}\text { Center West Wall, Pit } 1 \\
\text { Anomaly D006 } 002\end{array}$ & 12.2 & $\mathrm{pCi} / \mathrm{g}$ \\
\hline Lead & $945(\mathrm{~J})$ & 408D001 & $0.0-1.0$ & $\begin{array}{l}\text { Soil Mound Grid 71/729 } \\
\text { SAC Target } 2\end{array}$ & 800 & $\mathrm{mg} / \mathrm{kg}$ \\
\hline Mercury & 0.35 & 408D001 & $0.0-1.0$ & $\begin{array}{l}\text { Soil Mound Grid 71/729 } \\
\text { SAC Target } 2\end{array}$ & 34 & $\mathrm{mg} / \mathrm{kg}$ \\
\hline Silver & $8.28(\mathrm{~J})$ & 408D001 & $0.0-1.0$ & $\begin{array}{l}\text { Soil Mound Grid 71/729 } \\
\text { SAC Target } 2\end{array}$ & 5,100 & $\mathrm{mg} / \mathrm{kg}$ \\
\hline Th-234 & $4.5(\mathrm{~J})$ & 408A009 & $12.0-14.0$ & $\begin{array}{c}\text { Bottom, Center } \\
\text { Anomaly G156_95 }\end{array}$ & 105 & $\mathrm{pCi} / \mathrm{g}$ \\
\hline U-234 & 3.17 & 408A006 & $12.0-14.0$ & $\begin{array}{l}\text { Bottom, West End } \\
\text { Anomaly G156_95 }\end{array}$ & 143 & $\mathrm{pCi} / \mathrm{g}$ \\
\hline
\end{tabular}


Table E.1-1

Maximum Concentration of Detected Contaminants for CAS TA-55-002-TAB2, Bomblet Target Areas

(Page 2 of 2)

\begin{tabular}{|c|c|c|c|c|c|c||}
\hline Contaminant & $\begin{array}{c}\text { Maximum } \\
\text { Result }\end{array}$ & $\begin{array}{c}\text { Sample } \\
\text { Number }\end{array}$ & $\begin{array}{c}\text { Depth } \\
\text { (ft bgs) }\end{array}$ & Location & PAL & Units \\
\hline \hline U-235 & 0.168 & 408 A025 & $0.0-0.5$ & Grid 94/701 South Antelope Lake & 17.6 & pCi/g \\
\hline U-238 & 2.48 & $408 A 006$ & $12.0-14.0$ & $\begin{array}{c}\text { Bottom, West End } \\
\text { Anomaly G156_95 }\end{array}$ & 105 & pCi/g \\
\hline
\end{tabular}

Bold indicates the value is equal to or exceeds the PAL.

$\mathrm{pCi} / \mathrm{g}=$ Picocuries per gram

$\mathrm{J}=$ Estimated value

\section{E.1.3 C. Site Classification and Initial Response Action}

The four major site classifications listed in Table 3 of the ASTM Standard are (1) immediate threat to human health, safety, and the environment; (2) short-term (0 to 2 years) threat to human health, safety, and the environment; (3) long-term (greater than 2 years) threat to human health, safety, or the environment; and (4) no demonstrated long-term threats.

Based on the CAI, the CAS in CAU 408 does not present an immediate threat to human health, safety, and the environment; therefore, no interim response actions are necessary at this site. Based on this information, the CAS is determined to be a Classification 4 site as defined by ASTM Method E1739 (ASTM, 1995) and poses no demonstrated near- or long-term threats.

\section{E.1.4 D. Development of Tier 1 Lookup Table of RBSLs}

Tier 1 RBSLs have been defined as the PALs established during the DQO process. The PALs are a tabulation of chemical-specific (but not site-specific) screening levels based on the type of media (soil) and potential exposure scenarios (industrial). These are very conservative estimates of risk, are preliminary in nature, and are used as action levels for site screening purposes. Although the PALs are not intended to be used as FALs, a FAL may be defined as the Tier 1 action level (i.e., PAL) value if individual contaminant analytical results are below the corresponding Tier 1 action level value. The FAL may also be established as the Tier 1 action level value if individual 
contaminant analytical results exceed the corresponding Tier 1 action level value and implementing a corrective action based on the FAL is practical. The PALs are defined as follows:

- The EPA Region 9 Risk-Based Preliminary Remediation Goals (PRGs) for Industrial Soils (EPA, 2008).

- Background concentrations for RCRA metals will be evaluated when natural background exceeds the PAL, as is often the case with arsenic. Background is considered the mean plus two times the standard deviation of the mean based on data published in Mineral and Energy Resource Assessment of the Nellis Air Force Range (NBMG, 1998; Moore, 1999).

- The concentrations of total petroleum hydrocarbons above the action level of $100 \mathrm{mg} / \mathrm{kg}$ per NAC 445A.2272 (NAC, 2008c).

- For COPCs without established PRGs, a protocol similar to EPA Region 9 will be used to establish an action level; otherwise, an established PRG from another EPA region may be chosen.

- The PALs for radiological contaminants (other than tritium) are based on the National Council on Radiation Protection and Measurement (NCRP) Report No. 129 recommended screening limits for construction, commercial, industrial land-use scenarios (NCRP, 1999) using a 25-millirem-per-year dose constraint (Murphy, 2004) and the generic guidelines for residual concentration of radionuclides in DOE Order 5400.5 (DOE, 1993). These PALs are based on the construction, commercial, and industrial land-use scenario provided in the guidance and are appropriate for the TTR based on future land uses.

The PALs were developed based on an industrial scenario. Because the CAU 408 target areas within CAS TA-55-002-TAB2 at the TTR are not assigned work stations and are considered to be in remote or occasional use areas, the use of industrial scenario based PALs is conservative. The Tier 1 lookup table is defined as the PAL concentrations or activities defined in the SAFER Plan (NNSA/NSO, 2010).

\section{E.1.5 E. Exposure Pathway Evaluation}

The DQOs (NNSA/NSO, 2010) stated that site workers would only be exposed to COCs through oral ingestion, inhalation, or dermal contact (absorption) due to exposure to potentially contaminated media (i.e., soil) at the CAS. The limited migration demonstrated by the analytical results, elapsed time since the suspected release, and depth to groundwater supports the selection 
and evaluation only surface and shallow subsurface contact as the complete exposure pathways. Groundwater is not considered to be a significant exposure pathway.

\section{E.1.6 F. Comparison of Site Conditions with Tier 1 RBSLs}

All analytical results from CAU 408 samples were less than corresponding Tier 1 action levels (i.e., PALs) except for those listed in Table E.1-2.

Table E.1-2

COPCs Detected above PALs (mg/kg)

\begin{tabular}{|c|c|c|}
\hline CAS & Lead & Arsenic \\
\hline \hline TA-55-002-TAB2 & 945 & 27 \\
\hline
\end{tabular}

\section{E.1.7 G. Evaluation of Tier 1 Results}

For all contaminants not listed in Table E.1-2, the FALs were established as the Tier 1 RBSLs. It was determined that no further action is required for these contaminants at the CAS.

It was determined by NNSA/NSO that remediation to the remaining contaminants listed in Table E.1-2 was not practical. Therefore, a Tier 2 SSTL will be calculated for these contaminants.

\section{E.1.8 H. Tier 1 Remedial Action Evaluation}

\section{Lead Evaluation}

No actions are proposed to remediate lead to Tier 1 action levels. Therefore, lead associated with the soil mound at the SAC Target was moved to a Tier 2 evaluation.

\section{Arsenic Evaluation}

No actions are proposed to remediate arsenic to Tier 1 action levels. Therefore, arsenic associated with the remediated disposal pit at Antelope Lake was moved to a Tier 2 evaluation.

\section{E.1.9 I. Tier 2 Evaluation}

No additional data were needed to complete a Tier 2 evaluation for lead. 


\section{E.1.10 J. Development of Tier 2 SSTLS}

\section{Development of Lead SSTLS}

The EPA's risk assessment for lead is unique because a reference dose (RfD) value for lead is not available. Because the toxicokinetics (the absorption, distribution, metabolism, and excretion of toxins in the body) of lead are well understood, lead is regulated based on blood lead concentration (PbB). The EPA and the Centers for Disease Control and Prevention (CDC) have determined that childhood PbBs at or above 10 micrograms per deciliter ( $\mu \mathrm{g} / \mathrm{dL}$ ) of blood present risks to children's health. The EPA risk reduction goal for contaminated sites is to limit the probability of a child's PbB exceeding $10 \mu \mathrm{g} / \mathrm{dL}$ to 5 percent or less after cleanup. The EPA's Adult Lead Methodology (ALM) has been developed to estimate the PbB of pregnant women and their developing fetuses who might be exposed to non-residential lead-contaminated soils (EPA, 2003).

In the commercial/industrial setting, the most sensitive receptor is the fetus of a worker who has a non-residential exposure to lead. Based on the available scientific data, a fetus is more sensitive to the adverse effects of lead than an adult (National Academy of Sciences, 1993). The EPA assumes that cleanup levels that are protective of a fetus will also afford protection for male or female adult workers. The ALM was developed to calculate cleanup goals such that there would be no more than a 5 percent probability that fetuses exposed to lead would exceed a PbB of $10 \mu \mathrm{g} / \mathrm{dL}$ of blood. This same approach also appears to be protective for lead's effect on blood pressure in adult males.

Therefore, EPA’s ALM was used to develop an SSTL for lead of 1,872 mg/kg.

\section{Development of Arsenic SSTLs}

Arsenic is present in native minerals and soils throughout the arid southwestern portion of the United States. Therefore, soluble salts of arsenic are commonly found at elevated concentrations (i.e., near or exceeding drinking water standards) in surface water and shallow groundwaters of this region. Where surface water (or shallow groundwater that percolates to the surface) accumulate in seasonal lakes (such as Antelope Lake), the arsenic and other soluble salts concentrate in the evaporating lake water and are deposited in the underlying soil. This process, referred to as evapoconcentration, has been shown to result in concentrations of arsenic of up to $42.6 \mathrm{mg} / \mathrm{kg}$ at Owens Dry Lake and up to 80 mg/kg in the San Juan Valley (Gao et al., 2007; Ryu et al., 2002). 
The maximum concentration of arsenic in any CAU 408 sample was $27 \mathrm{mg} / \mathrm{kg}$, which is only slightly above the PAL of $23 \mathrm{mg} / \mathrm{kg}$ for background soils at the TTR. It is not unexpected that a sample from the dry lake bed where soluble salts have concentrated would have a naturally elevated concentration of arsenic. Consequently, it is determined that the arsenic concentration of $27 \mathrm{mg} / \mathrm{kg}$ in the dry lake bed sample is consistent with natural concentrations of arsenic and is not a contaminant released from DOE activities at the site. Therefore, a Tier 2 SSTL will not be developed for arsenic as it is not considered to be a contaminant.

\section{E.1.11 K. Comparison of Site Conditions with Tier 2 SSTLs}

The Tier 2 action levels are typically compared to individual sample results from reasonable points of exposure (as opposed to the source areas as is done in Tier 1) on a point-by-point basis. Points of exposure are defined as those locations or areas at which an individual or population may come in contact with a COC originating from a CAS. For CAU 408, the Tier 2 action level for lead was compared to maximum contaminant concentrations from each sample location.

As shown in Table E.1-1, the maximum concentration for lead (945 mg/kg) is less than corresponding Tier 2 action level of 1,872 mg/kg. The FAL for lead was established as the Tier 2 SSTL.

\section{E.1.12 L. Tier 2 Remedial Action Evaluation}

Based on the Tier 2 evaluation of lead, the maximum lead concentration in verification samples does not exceed the FAL and does not pose an unacceptable risk to human health and the environment. Therefore, no further action concerning lead is required within CAU 408.

Based on the Tier 2 evaluation of arsenic, the maximum arsenic concentration does not exceed a value that would be expected for naturally evapoconcentrated arsenic in a dry lake bed and is therefore, not considered to be a site contaminant. Therefore, no further action concerning arsenic is required within CAU 408.

As all contaminant FALs were established as Tier 1 or Tier 2 action levels, a Tier 3 evaluation was not considered necessary. 


\section{E.2.0 Recommendations}

As all of the site contaminant concentrations from the analysis of CAU 408 verification samples were less than the corresponding FALs at all locations, it was determined that the corrective actions of clean closure was effective and complete. Therefore, no further corrective actions are required, and clean closure objectives have been met. 


\section{E.3.0 References}

ASTM, see American Society for Testing and Materials.

American Society for Testing and Materials. 1995 (reapproved 2002). Standard Guide for Risk-Based Corrective Action Applied at Petroleum Release Sites, ASTM E1739 - 95(2002). Philadelphia, PA.

DOE, see U.S. Department of Energy.

EPA, see U.S. Environmental Protection Agency.

Gao, S., J. Ryu, K.K. Tanji, and M.J. Herbel. 2006. "Arsenic Speciation and Accumulation in Evapoconcentrating Waters of Agricultural Evaporation Basins.” In Chemosphere, Vol. 67: 862-871. Amsterdam, Netherlands: Elsevier B.V.

Moore, J., Science Applications International Corporation. 1999. Memorandum to M. Todd (SAIC), "Background Concentrations for NTS and TTR Soil Samples," 3 February. Las Vegas, NV.

Murphy, T., Bureau of Federal Facilities. 2004. Letter to R. Bangerter (NNSA/NSO) titled "Review of Industrial Sites Project Document Guidance for Calculating Industrial Sites Project Remediation Goals for Radionuclides in Soil Using the Residual Radiation (RESRAD) Computer Code," 19 November. Las Vegas, NV.

NAC, see Nevada Administrative Code.

NBMG, see Nevada Bureau of Mines and Geology.

NCRP, see National Council on Radiation Protection and Measurements.

NNSA/NSO, see U.S. Department of Energy, National Nuclear Security Administration Nevada Site Office.

National Academy of Sciences. 1993. Measuring Lead Exposure in Infants, Children, and Other Sensitive Populations. Washington, DC: National Academy Press:

National Council on Radiation Protection and Measurements. 1999. Recommended Screening Limits for Contaminated Surface Soil and Review of Factors Relevant to Site-Specific Studies, NCRP Report No. 129. Bethesda, MD. 
Nevada Administrative Code. 2008a. NAC 445A.227, "Contamination of Soil: Order by Director for Corrective Action; Factors To Be Considered in Determining Whether Corrective Action Required.” Carson City, NV. As accessed at http://www.leg.state.nv.us/nac on 15 July 2009.

Nevada Administrative Code. 2008b. NAC 445A.22705, "Contamination of Soil: Evaluation of Site by Owner or Operator; Review of Evaluation by Division.” Carson City, NV. As accessed at http://www.leg.state.nv.us/nac on 15 July 2009.

Nevada Administrative Code. 2008c. NAC 445A.2272, "Contamination of Soil: Establishment of Action Levels.” Carson City, NV. As accessed at http://www.leg.state.nv.us/nac on 15 July 2009.

Nevada Bureau of Mines and Geology. 1998. Mineral and Energy Resource Assessment of the Nellis Air Force Range, Open-File Report 98-1. Reno, NV.

Ryu, J., S. Gao, R.A. Dahlgren, and R.A. Zierenberg. 2002. “Arsenic Distribution, Speciation, and Solubility in Shallow Groundwater of Owens Dry Lake, California.” In Geochimica et Cosmochimica Acta, Vol. 66, Issue 17: 2981-2994. Amsterdam, Netherlands: Elsevier B.V.

U.S. Department of Energy. 1993. Radiation Protection of the Public and the Environment, DOE Order 5400.5, Change 2. Washington, DC.

U.S. Department of Energy, National Nuclear Security Administration Nevada Site Office. 2006. Industrial Sites Project Establishment of Final Action Levels, Rev. 0, DOE/NV--1107. Las Vegas, NV.

U.S. Department of Energy, National Nuclear Security Administration Nevada Site Office. 2010. Streamlined Approach for Environmental Restoration for Corrective Action Unit 408: Bomblet Target Area, Tonopah Test Range (TTR), Nevada, Rev. 1, DOE/NV--1171-Rev. 1. Las Vegas, NV.

U.S. Environmental Protection Agency. 2003. Recommendations of the Technical Review Workgroup for Lead for an Approach to Assessing Risks Associated with Adult Exposures to Lead in Soil, EPA-540-R-03-001. As accessed at http://www.epa.gov/superfund/health/contaminants/lead/products.htm on 15 July 2009.

U.S. Environmental Protection Agency. 2008. SW-846 On-Line, Test Methods for Evaluating Solid Waste, Physical/Chemical Methods. As accessed at http://www.epa.gov/epaoswer/hazwaste/test/main.htm on 15 July 2009. 


\section{Appendix F}

Nevada Division of Environmental Protection Comment Responses

(2 Pages) 


\section{STATE OF NEVADA Im Gibous Gevenoror Department of Conservation \& Natural Resources Allen Bioggi, Director

August 10, 2010

Robert F. Boehlecke, Federal Project Director

Environmental Restoration Project

National Nuclear Security Administration

Nevada Site Office (NNSA/NSO)

P.O. Box 98518

Las Vegas, NV 89193-8518

RE: Review of Draft Closure Report for

Corrective Action Unit 408, Bomblet Target Area, Tonopah Test Range, Nevada

Federal Facility Agreement and Consent Order (FFACO)

Dear Mr. Boehlecke:

The Nevada Division of Environmental Protection, Bureau of Federal Facilities (NDEP) staff reviewed the draft Closure Report (CR) for Corrective Action Unit (CAU) 408, Bomblet Target Area, Tonopah Test Range (TTR). NDEP's review of this document did not indicate any deficiencies.

Address any questions regarding this matter to Ted Zaferatos at (702) 486-2850, ext. 234, or me at (702) 486-2850, ext. 233.

Sincerely,

\section{/s/ Jeff MacDougall}

Jeff MacDougall, Ph.D., C.P.M.

Supervisor

Bureau of Federal Facilities

$\mathrm{TZ}$ 
Page 2

August 10,2010

cc: $\quad$ K. J. Cabble, ERP, NNSANSO, Las Vegas, NV

E.F. DiSanza, WMP, NNSANSSO, Las Vegas, NV

FFACO Group, PSG, NNSA/NSO, Las Vegas, NV

J.T. Fraher, DTRA/CXTS, Kirtland AFB, NM

Roger Christensen, 98 RANW/XPL, NAFB, NV

D.J. Haarklau, 98 RANW/XPL, NAFB, NV

Cyndy Lang, 98 RANW/XPL, NAFB, NV

Robert Sherwood, SNL/TTR, Tonopah, NV

Dewey Gray, USAF Liason Office, Las Vegas, NV

D.C. Stockdale, USAF, Nellis AFB, NV

D.M. Rupp, NTS CAB, Las Vegas, NV

T. A. Thiele, NSTec, Las Vegas, NV

M. J. Krauss, N-I, Las Vegas, NV

J.M. Fowler, N-I, Las Vergas, NV

N.Y. Carson, N-I, Las Vegas, NV

T.D. Taylor, N-I, Las Vegas, NV

M.C. Burmeister, N-I, Las Vegas, NV 


\section{Library Distribution List}

\section{$\underline{\text { Copies }}$}

U.S. Department of Energy

1 (Uncontrolled, electronic copy)

National Nuclear Security Administration

Nevada Site Office

Technical Library

P.O. Box 98518, M/S 505

Las Vegas, NV 89193-8518

U.S. Department of Energy

1 (Uncontrolled, electronic copy)

Office of Scientific and Technical Information

1 (Uncontrolled, electronic copy)

P.O. Box 62

Oak Ridge, TN 37831-0062

Southern Nevada Public Reading Facility

2 (Uncontrolled, electronic copies)

c/o Nuclear Testing Archive

P.O. Box 98521, M/S 400

Las Vegas, NV 89193-8521

Manager, Northern Nevada FFACO

1 (Uncontrolled, electronic copy)

Public Reading Facility

c/o Nevada State Library \& Archives

100 N Stewart Street

Carson City, NV 89701-4285 